\title{
Roberto Arlt en los años treinta
}

\section{Índice}

Introducción p.3

1. El teatro p. 15

1. El Teatro del Pueblo y la propuesta dramática de Leónidas Barletta. p. 18

2. En torno al proyecto teatral de Roberto Arlt. p. 28

La simulación de Arlt: una teoría del teatro desde Saverio el Cruel. .p.53

2. Viaje y representación. p. 63

1. España: la mirada del viajero. p. 65

El color local y la tarjeta postal. p. 67

La construcción de "paisajes de la mirada" p. 83

Más allá de las ciudades "nerviosas". p. 96

2. África: el exotismo oriental p. 104

Otras visones, otras versiones p. 116

Aguafuertes sobre Marruecos. p. 116

Reescritura del viaje a África. p. 119

África, la pieza teatral. p. 126

\section{El modo fantástico}

1. Fantástico modernista e imaginario decadente p. 133

Un recorrido por los textos previos p. 133

El giro de los años treinta. p. 140

Los relatos finales de Arlt y las formas "modernistas decadentes" de lo fantástico. p. 141

2. Exotismo y fantástico-maravilloso en los cuentos africanos. p. 152 Arlt, lo maravilloso y Las mil y una noches, un caso peculiar. p. 160 


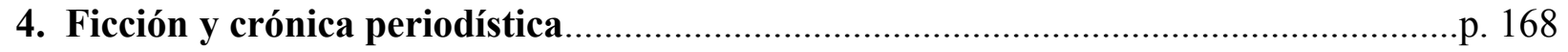

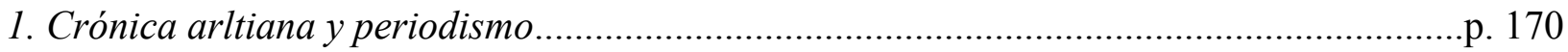

2. Crónica, ficción y representación ................................................................................. 179

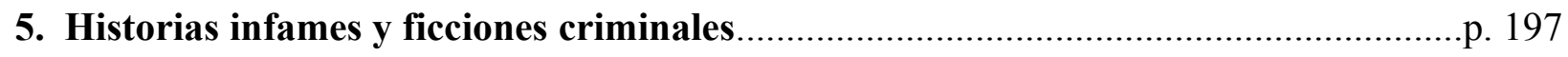

1.Historias infames................................................................................... 200

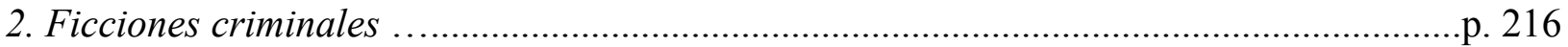

El policial de Arlt en los años treinta....................................................... 216

Narración policial y aventuras sobre espías................................................... 239

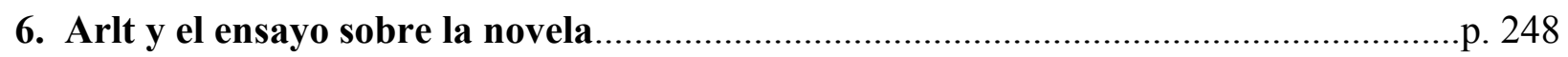

1. Arlt ensayista................................................................................................ 249

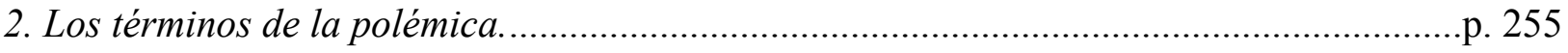

3. El ensayo arltiano sobre la novela.................................................................................. 263

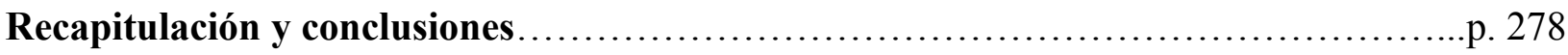

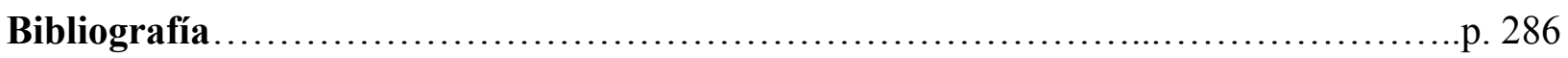





\section{Introducción}

Se dice que a un autor debemos buscarlo en sus obras mejores; podría replicarse [...] que si queremos conocerlo de veras, conviene interrogar las menos felices, pues en ellas —en lo injustificable, en lo imperdonable- está más el autor que en aquellas otras que nadie vacilaría en firmar. ${ }^{1}$

Jorge Luis Borges

En la década del treinta se abre un nuevo período para la literatura de Roberto Arlt. Así, puede considerarse el año 1932 como el punto clave del cambio pues constituye, en primer lugar, el momento en el que Arlt cierra el ciclo novelístico $-E l$ amor brujo (1932) es su última novela publicada-y ese mismo año es también el de su ingreso a la producción dramática por impulso de Leónidas Barletta. El 3 de marzo de 1932, Arlt se integra con una adaptación de "El humillado", fragmento de Los siete locos, al Teatro del Pueblo fundado por Barletta y desde entonces participa - con algunas disidencias como se verá más adelante- en este proyecto teatral alternativo que ofrece un lugar a los dramaturgos argentinos y que - orientado por una idea didáctica del teatro inspirada en el modelo de Romain Rolland-, intenta "realizar experiencias de teatro moderno para salvar el envilecido arte teatral y llevar a las masas el arte en general, con el objeto de propender a la elevación de nuestro pueblo". ${ }^{2}$ A partir, entonces, de 1932 y hasta 1942 el escritor se orienta de lleno al teatro, a la cuentística y continúa su colaboración con las notas que desde 1928 se publican en el diario El

\footnotetext{
${ }^{1}$ Borges, Jorge Luis. "Presencia de Miguel de Unamuno", en El Hogar, 29 de enero de 1937. Recopilado en Textos cautivos. Obras Completas, IV, Buenos Aires, Emecé, 1996, p. 284.

${ }^{2}$ La cita se refiere al acta de fundación del Teatro del Pueblo y está tomada de Marial, José, "El Teatro del Pueblo", en El teatro independiente, Buenos Aires, Alpe, 1955, p. 61. Véase además: Saítta, Sylvia. "6. La propuesta", en El escritor en el bosque de ladrillos. Una biografía de Roberto Arlt, Buenos Aires, Sudamericana, 2000, pp. 92-104; y "El Teatro del pueblo y sus puestas de los textos de Roberto Arlt", en Pelletieri, Osvaldo (Ed.). Roberto Arlt. Dramaturgia y Teatro Independiente, Buenos Aires, Galerna/Fundación Roberto Arlt, 2000.
} 
Mundo. Por otra parte, en esta etapa sus obras se modifican y aparecen nuevos modos de representación que, si bien en muchos casos están en germen en los textos previos, se distancian de los que, desde los años veinte y con "Las ciencias ocultas en la ciudad de Buenos Aires" (1920), El juguete rabioso (1926) y Los siete locos-Los Lanzallamas (1929-1931) Arlt venía ensayando. Lo fantástico, lo maravilloso, el relato de viajes y aventuras, el policial, y los cuentos de espionaje, son algunos de esos modos. Por lo tanto, en esta segunda etapa de su producción, la literatura de Arlt presenta una textualidad que problematiza su literatura previa y que cuestiona las afirmaciones de la crítica que se sostienen desplazando y subestimando este período en sus análisis. ${ }^{3}$ En este marco, las estrategias y los procesos que los textos llevan a cabo para delimitar su lugar en la literatura se modifican y reorganizan a la luz de los problemas culturales, políticos y, sobre todo, estéticos del período. Se intenta, entonces, demostrar que en los años treinta Arlt reestructura su proyecto literario, considerar las nuevas orientaciones que despliega en las ficciones, en las crónicas periodísticas y en las obras teatrales, y determinar el modo en que los textos del último Arlt introducen nuevas particularidades y establecen lineamientos distintivos en el campo cultural y literario de la época.

A lo largo de los años, en sus lecturas de la obra de Roberto Arlt, la crítica ha ejercido un proceso de recorte permanente por el que ciertos tramos de esa obra quedaron desplazados o apenas atisbados, y si bien existieron trabajos sobre su teatro, estos análisis no vincularon la producción teatral con el resto de la obra de Arlt. Esta tendencia llevó casi a dar por clausurada su narrativa de después de la novelística y al estancamiento del discurso crítico en torno a núcleos conceptuales cerrados a nuevas problematizaciones. Así, como puede verse en la bibliografía, abundan las consideraciones críticas, sociológicas, estéticas, ideológicas respecto de El juguete rabioso (1926), Los siete locos (1929) y Los lanzallamas (1931), mientras queda apenas explorado, y sólo delineado en algunas de sus características, el espacio de los textos

${ }^{3}$ Cabe destacar que también 1932 es el año que marca, como analiza Sylvia Saítta, su incorporación como colaborador en publicaciones vinculadas a la izquierda. Arlt, que anteriormente y en muchos casos por la censura de El Mundo, introduce sus opiniones sobre la política nacional aisladamente $\mathrm{y}$, cuando lo hace, con un tono predominantemente escéptico y burlón, a partir de este momento y de su presencia en Bandera Roja y Actualidad, interviene en algunos emprendimientos político-culturales ligados al Partido Comunista - como la formación de la Unión de Escritores Proletarios impulsada por él y Castelnuovo- y se desplaza hacia una postura esperanzada, y en cierto sentido comprometida. Saítta, Sylvia. "7. Ejercicio de artillería", en El escritor en el bosque de ladrillos. Una biografía de Roberto Arlt, Op. Cit., pp.105-135. 
posteriores a estas novelas, centro de interés de la presente tesis. Adolfo Prieto es uno de los pocos críticos que, muy tempranamente, señala un foco desatendido por los trabajos especializados en la obra de Arlt, pues es el primero y el único durante mucho tiempo, en prestar atención al período antes mencionado. ${ }^{4}$ Prieto enmarca la producción de Arlt en dos ciclos. El primero de ellos correspondería a la etapa realista, “...dominado... por la concepción de una literatura 'con la violencia de un cross a la mandíbula", 5 y el segundo, caracterizado por un abandono de la voluntad realista, por una búsqueda expresiva de lo imaginario por sí mismo e interés en expresar estados de conciencia individual y por un impulso estilístico tendiente a atenuar las críticas que Arlt había recibido acerca de su estilo. ${ }^{6}$

En alguna medida como continuación de los trabajos de Adolfo Prieto, puede decirse que, en los últimos años, el estado de la cuestión antes mencionado ha empezado a revertirse. En principio cabe destacar la labor de recopilación y edición de aguafuertes inéditas llevada a cabo por Sylvia Saítta desde hace algunos años ${ }^{7}$ y la biografía del autor que publica en abril del $2000,{ }^{8}$ texto que, además de cuestionar ciertos lugares comunes de la crítica en torno a la figura de Roberto Arlt, ofrece una visión del conjunto de la obra y focaliza muchos aspectos de su literatura en los años treinta, no estudiados antes, como las relaciones del escritor con los sectores de la izquierda o las

${ }^{4}$ En dos trabajos: Prieto, Adolfo. "La fantasía y lo fantástico en Roberto Arlt", en Boletín de literaturas hispánicas, Instituto de Letras de la Facultad de Filosofía y Letras de la Universidad del Litoral, Rosario, 1963; y también en su prólogo "Roberto Arlt. Los siete locos. Los lanzallamas", en Arlt Roberto. Los siete locos, Los lanzallamas, Caracas, Biblioteca Ayacucho, 1978.

${ }^{5}$ Prieto, Adolfo. Op. cit. (1978) p.xxvii

${ }^{6}$ Estas consideraciones, aunque insinúan un conjunto de problemáticas no logran resolverlas en su complejidad, y Prieto no va mucho más allá cuando intenta definir en qué consiste lo fantástico, pues lo ve como una forma de salida, escape, superación de lo real que, a causa de su fracaso, termina por afirmar la crudeza de esa realidad; dicha perspectiva, al seguir inscripta en una lectura social, no logra despejar los mecanismos textuales: lo fantástico, aunque opuesto a la crítica de la sociedad, termina ejerciéndola, propone Prieto, de modo más acabado.

${ }^{7}$ Véase: Arlt, Roberto. Aguafuertes porteñas: Buenos Aires, vida cotidiana, Selección y prólogo de Sylvia Saítta, Buenos Aires, Alianza, 1993; Arlt, Roberto. Aguafuertes porteñas: cultura y política, Selección y prólogo de Sylvia Saítta, Buenos Aires, Losada, 1994; Arlt, Roberto. Tratado de la delincuencia. Aguafuertes inéditas. Recopilación y prólogo de Sylvia Saítta, Buenos Aires, Biblioteca Página/12, 1996; Arlt, Roberto. En el país del viento. Viaje a la patagonia (1934), Edición y prólogo de Silvia Saítta, Buenos Aires, Simurg, 1997; Arlt, Roberto. Aguafuertes gallegas y asturianas, Compilación y prólogo Sylvia Saítta, Buenos Aires, Losada, 1999; Arlt, Roberto. Aguafuertes madrileñas. Presagios de una guerra civil, Compilación y prólogo Sylvia Saítta, Buenos Aires, Losada, 1999; Arlt, Roberto. Aguafuertes vascas, Prólogo, compilación y notas de Sylvia Saítta, Buenos Aires, 2005.

${ }^{8}$ Saítta, Sylvia. El escritor en el bosque de ladrillos. Una biografia de Roberto Arlt, Op. Cit. 
crónicas de la época. Deben mencionarse, asimismo los trabajos de Beatriz Sarlo sobre la excentricidad y lo "maravilloso técnico" en Arlt, "las investigaciones recientes sobre la rupturas del realismo en su novelística, ${ }^{10}$ y la recopilación en libro de algunas de las crónicas inéditas "Al margen del cable" realizada por Rose Corral. ${ }^{11}$ En los últimos años, también empiezan a publicarse nuevos trabajos sobre el teatro, ${ }^{12}$ y en octubre de 2000 se edita una compilación de ensayos de Osvaldo Pellettieri en torno a la obra dramática de Arlt. ${ }^{13}$

Si bien la tendencia que durante mucho tiempo redujo el estudio de la obra de Arlt a un sector de su producción, ha comenzado a modificarse, esto es, en varios sentidos, insuficiente. En primer lugar, porque queda todo un corpus de relatos casi inexplorado por la crítica, como las narraciones africanas (fantásticas y maravillosas), ${ }^{14}$

9 Sarlo, Beatriz. "Roberto Arlt, excéntrico". Liminar de Arlt, Roberto. Los siete locos-Los lanzallamas, edición crítica coordinada por Mario Goloboff, México, FCE, Colección Archivos, 2000; y Sarlo, Beatriz. "Arlt: la técnica en la ciudad", en La imaginación técnica, Buenos Aires, Nueva Visión, 1992.

10 Véase, a este respecto, entre otros trabajos: Renaud, Marise. "Los siete locos y Los Lanzallamas: audacia y candor del expresionismo", en Arlt, Roberto. Los siete locos-Los Lanzallamas, Op. Cit. Capdevila, Analía. "Las novelas de Arlt. Un realismo para la modernidad", en Gramuglio, María Teresa. (directora). El imperio realista. Historia crítica de la literatura argentina (dirigida por Noé Jitrik), Buenos Aires, Emecé, 2002. Amícola, José. "Fritz Lang, Alfred Döblin y Roberto Arlt", 2007, mimeo.

${ }^{11}$ Arlt, Roberto. Al margen del cable. Crónicas publicadas en El Nacional, México, 1937, 1941, Recopilación, introducción y notas de Rose Corral, Buenos Aires, Losada, 2001

${ }_{12}$ Castagnino es el precursor de los estudios sobre el teatro de Arlt con su libro de 1964. (Castagnino, Raúl. El teatro de Roberto Arlt, La Plata, UNLP, 1964.) Con respecto a los trabajos de los últimos años pueden mencionarse, entre otros, Carlos Correas ("Teatro", en Arlt literato. Buenos Aires, Atuel, 1995); Dubatti, Jorge. "Roberto Arlt y la escritura de Trescientos millones", en Espacio, n 12, 1992; Fernández, Graciela Beatriz. "La isla desierta: un espacio clausurado, una metáfora", en Estudios Filológicos, Valdivia, n 18, 1983; Foster, David W. "Popular Culture as Mediating Sign Between Fantasy and Reality in Arlt's Trescientos millones", en The Argentine Teatro Independiente 1930-1935, York, South Carolina, Spanish Literature Publishing Company, 1986; Ordaz, Luis. "Las máscaras dramáticas de Roberto Arlt", en Revista de estudios de teatro, VI, ${ }^{\circ}$ 15, 1987, pp. 3-14; Pellettieri, Osvaldo. "Relaciones textuales entre el teatro de Pirandello y la obra de Arlt", en Espacio, n' 5, año 3, abril de 1989; Rosa, Nicolás. "La ilusión cómica", en Revista de Letras, n 5, Rosario, 1997. pp. 5-10; Russi, David P. "Metatheatre: Roberto Arlt Vehicle toward the Awareness of an Art Form", en Latin American Theatre Review, 24/1, Fall 1990; Trastoy, Beatriz. "El fabricante de fantasmas de Roberto Arlt y su relación con el teatro de Lenormand", en De Sarah Bernhardt a Lavelli, O. Pellettieri (ed). Cuaderno del GETEA n ${ }^{\circ}$ 3, Buenos Aires, Galerna/Revista Espacio, 1993; Zaina, Alicia. "El proyecto teatral de Roberto Arlt", en El juguete rabioso, 1, n 1, 1990. También, en 2006 se ha publicado un tomo sobre el Teatro del Pueblo: Osvaldo Pellettieri (dir). Teatro del Pueblo: una utopía concentrada, Buenos Aires, Galerna, 2006.

${ }^{13}$ Pellettieri, Osvaldo (Ed.). Roberto Arlt. Dramaturgia y Teatro Independiente, Buenos Aires, Galerna/Fundación Roberto Arlt, 2000.

${ }^{14}$ Cabe citar, a este respecto: Dámaso Martínez, Carlos. "La irrupción de la dimensión 
los cuentos policiales, de aventuras y sobre todo los de espionaje, textos muy inusuales en la literatura argentina y prácticamente desconocidos respecto de Arlt. En segundo lugar, porque todavía es necesario un enfoque que determine los vínculos de su teatro con las expresiones teatrales de la época, con la literatura culta y la popular, con los otros textos de Arlt en los treinta y sus diferencias con las obras previas. Asimismo, porque hay toda una zona de la columna periodística de Arlt, —un nuevo diseño de crónica, más vinculada al presente y al cable de noticias, diferente de las aguafuertes porteñas-, que casi no ha sido trabajada y cuyos textos están, en su mayoría, inéditos en libro. ${ }^{15}$ Finalmente, porque falta profundizar sobre los cambios en su literatura y en su obra en esta segunda etapa de su producción y ahondar en las correlaciones de las piezas teatrales, relatos y crónicas periodísticas con las tendencias inscriptas en la época y con problemáticas presentes en el campo literario.

Si se atiende, entonces, a este corpus, puede formularse como hipótesis general que los textos que constituyen los últimos diez años de la obra de Roberto Arlt (19321942) redefinen y reestructuran su literatura, ensayan diferentes formas de legitimación, se aproximan a posiciones prestigiosas (o que Arlt percibe como prestigiosas, como el modernismo y cierto cuidado del estilo) y se acercan, asimismo, a los sectores que en esos años promovían las tendencias estéticas que en la década siguiente obtendrían la primacía en el campo de las letras. En ese movimiento, se conservan algunas de sus normas y preocupaciones anteriores, (la búsqueda de un público amplio, por ejemplo) pero éstas entran en una tensión que las reubica o transforma.

Así, por una parte, a lo largo de la década del treinta y fundamentalmente desde las páginas de la revista Sur, Borges -y también otros escritores que formaban un subgrupo con Borges, como Bioy Casares y Silvina Ocampo- intervienen polémicamente en el campo literario para disputar un espacio a las tendencias realistas y psicológicas dominantes en la narrativa, representadas, entre otros, por Eduardo Mallea,

\footnotetext{
fantástica", en Saítta, Sylvia. (directora). El oficio se afirma. Historia crítica de la literatura argentina (dirigida por Noé Jitrik), Buenos Aires, Emecé, 2004, pp. 171-194, que analiza algunos aspectos de lo fantástico en Arlt, junto con otros autores considerados; y Gasquet, Axel. "La ficción morisca y africana de Roberto Arlt", en Oriente al Sur. El orientalismo literario argentino de Esteban Echeverría a Roberto Arlt, Buenos Aires, Eudeba, 2007, pp. 269-290

${ }^{15}$ Cabe aclarar que la única compilación que existe sobre las notas "Al margen del cable" es la mencionada de Rose Corral, que agrupa poco más de 60 de las crónicas que son, en realidad, más de 250 .
} 
escritor central en Sur hasta cuando se impone la figura de Borges. ${ }^{16}$ Roberto Arlt, por ese entonces tenía una posición ganada dentro del público, sobre todo por sus aguafuertes. La inserción de Arlt en las letras se había producido alrededor de una definición antiesteticista de lo literario donde se privilegiaba la representación de las "crudezas de la realidad", ${ }^{17}$ la preocupación "por la sociedad que se desmorona", la "prepotencia del trabajo", el impacto sobre el lector como "un cross a la mandíbula" 18 y la importancia del mercado como forma de legitimación de la tarea del escritor. ${ }^{19}$ De esta manera, el antagonista Arlt intentaba construir un lugar de enunciación opuesto a lo establecido (el modernismo, por ejemplo, en los tempranos años veinte) y a la importancia del estilo como el fundamento del valor literario. ${ }^{20}$ Es así que en esta segunda etapa de su literatura se produce un distanciamiento de muchas de esas premisas y Arlt intenta la jerarquización de su obra, introduce nuevas tendencias,

${ }^{16}$ María Teresa Gramuglio, "Posiciones, transformaciones y debates en la literatura" en Crisis económica, avance del Estado e incertidumbre política (1930-1943), tomo VII de la Nueva Historia Argentina dirigido por Alejandro Cataruzza, Buenos Aires, Sudamericana, 2001, y, de la misma autora: Gramuglio, María Teresa. "Posiciones de Sur en el espacio literario. Una política de la cultura", en Saítta, Sylvia. (directora). El oficio se afirma. Historia crítica de la literatura argentina, Op. Cit., pp. 93- 122. Para estas cuestiones también véase: John King, Sur. Estudio de la revista argentina y de su papel en el desarrollo de una cultura. 1931-1970, México, Fondo de Cultura Económica, 1990; Stratta, Isabel. "Documentos para una poética del relato", en Saítta, Sylvia. (directora). El oficio se afirma. Historia crítica de la literatura argentina, Op. Cit., pp 39-63. Judith Podlubme, más recientemente, discute la centralidad de Borges en Sur desde los años cuarenta y sostiene que la figura central sigue siendo Mallea: Podlubne, Judith. Tesis doctoral, (en preparación), mimeo, 2007. A este respecto, puede considerarse que el "Desagravio a Borges", independientemente de cuáles fueran los argumentos con lo que se lo defendía (que para Podlubme ratificaban la poética de Mallea), implica un gesto muy fuerte de consagración local y el reconocimiento de sus pares en 1942. Véase: "Desagravio a Borges", en Sur n ${ }^{\circ}$ 94, Buenos Aires, julio 1942, pp. 7-34.

${ }^{17}$ Arlt, Roberto. "Las ciencias ocultas en la ciudad de Buenos Aires" en Tribuna libre, Buenos Aires, núm. 63, 28-1-1920. Reeditado en Obras completas, Buenos Aires, Carlos Lohlé, 1981, tomo II, pp. 30-31.

${ }^{18}$ Véase, a este respecto las palabras preliminares a Los lanzallamas que condensan, como un manifiesto estético escrito casi a posteriori, algunas de las fórmulas que permiten sintetizar los modos de la literatura de Arlt en la primera etapa de su producción. Arlt, Roberto. "Palabras del autor", en Los siete locos-Los Lanzallamas, Op. Cit. Véase, asimismo, "El conventillo de nuestra literatura", una aguafuerte en la que Arlt se opone al estilo de Lugones "que lo realiza cualquier estudiante aventajado" y defiende una literatura comprometida con lo social. (Arlt, Roberto. "El conventillo de nuestra literatura", en El Mundo, 21 de diciembre de 1928. Recopilada en Arlt, Roberto. Aguafuertes porteñas: cultura y política, Op. Cit., pp. 54-57).Para un análisis del prólogo a Los lanzallamas, véase: Drucaroff, Elsa. "El estilo, ese oscuro objeto de deseo", en Arlt. Profeta del miedo, Buenos Aires, Catálogos, 1998.

${ }^{19}$ Véase :Piglia, Ricardo. "Roberto Arlt: una crítica de la economía literaria" en Los libros, Buenos Aires, $n^{\circ} 29$, marzo-abril, 1973.

${ }^{20}$ Drucaroff también lee en el prólogo a Los lanzallamas, el estilo como "ese oscuro objeto de deseo". 
participa de los debates, y se acerca, siempre de modo complejo, problemático y selectivo, a posiciones que se venían delineando en la Argentina desde los años veinte con la vanguardia y que en los años treinta, son centrales en estos escritores de Sur. Es decir, la posición lograda para ese entonces le permite procurar una más alta, o, en otros términos, procurar una posición alta según algunas de las pautas de la elite y la atención a cierto cuidado del estilo (en un escritor criticado por escribir mal) y no solamente, como en los comienzos, por desafiante y rupturista. De este modo, en las polémicas en torno del realismo, —iniciadas por Macedonio Fernández y continuadas por Borges, Bianco, Silvina Ocampo y Bioy Casares, que privilegiaban lo fantástico y las tramas elaboradas del relato de aventuras o el policial contra la novela psicológica-, Arlt se acerca a estas definiciones tanto en sus declaraciones, ${ }^{21}$ — donde critica el realismo y la novela psicológica, y se inclina por la acción en tanto elemento fundamental de la narración-, como en sus ficciones, en las que predominan el relato fantástico y maravilloso, de viajes y aventuras, y el policial.

Por otro lado, hay que considerar que los criterios esteticistas de los escritores vinculados a la revista Sur — con sus polémicas internas - coexisten en la época con otra postura con respecto a la literatura, que es la que sostiene un sector de escritores e intelectuales de izquierda que en los años veinte estuvieron relacionados con el denominado grupo de Boedo. En este caso, los intelectuales de la izquierda incorporan en el debate literario nuevos temas y nuevos referentes sobre los cuales escribir — por ejemplo, la noción del compromiso en el arte-, actualizan la discusión en torno al rol del intelectual y dan respuestas a la pregunta acerca de los vínculos y la función del arte en la sociedad. ${ }^{2}$ Se intenta dar cuenta, a su vez, de la relación que, aunque refuncionalizada, Arlt mantiene asimismo con algunos grupos y escritores de la izquierda en el panorama de los años treinta, como en el caso del Teatro del Pueblo de Leónidas Barletta. Se estudia, entonces, la singularidad de la obra de Arlt en el cruce de estos textos del último período con las tendencias mencionadas y con los problemas

\footnotetext{
${ }^{21}$ Véase, Arlt, Roberto. Aguafuertes porteñas: cultura y política, Op. Cit..

${ }^{22}$ Sobre la izquierda en los años treinta véase, además de los trabajos sobre el teatro de Barletta que se citan en el capítulo 1, y entre otros que se pueden mencionar: Saítta, Sylvia. "Entre la cultura y la política: los escritores de izquierda", en Crisis económica, avance del Estado e incertidumbre politica (1930-1943), Op. Cit., pp. 383-428; Astutti, Adriana. "Elías Castelnuovo o las intenciones didácticas de la narrativa de Boedo", en Gramuglio, María Teresa. (directora). El imperio realista. Historia crítica de la literatura argentina, Op. Cit., pp. 417-446.
} 
sociales, culturales e ideológicos que en el tiempo que nos ocupa se introducen en el campo literario de modo evidente. Entre los problemas de orden histórico e ideológico consideramos el avance de los totalitarismos, la crisis europea, y la segunda guerra mundial como momento paradigmático de los cambios de la literatura de Arlt. $^{23}$

En este sentido, el primer capítulo se enfoca en el teatro de Arlt, en principio, en el contexto del Teatro del Pueblo de Leónidas Barletta. A este respecto, si lo que define la propuesta de Barletta se da en torno a la difusión cultural, literaria y artística, el desinterés económico, un proyecto de experimentación, o "teatro de arte", —como ellos proclamaban-, y una idea didáctica del teatro, con contenido social, que piensa el teatro como "escuela de la humanidad", la dramaturgia de Arlt, aunque cuestiona, como Barletta, las derivaciones del teatro comercial de la época, se separa de ese énfasis en lo pedagógico e intenta más bien provocar un efecto de "simpatía" en el espectador que lo introduzca y asimile a la "emoción" de lo representado. Por otra parte, Arlt cuestiona las formas de incidencia del orden de la ficción, la literatura, el arte y el género dramático en el orden de lo real, lo que lo aleja del optimismo social de Barletta y su confianza pedagógica en las potencialidades de la representación. Finalmente, se indaga la búsqueda literaria en el teatro de Arlt y especialmente el alejamiento estético en las piezas de contenido ideológico o de crítica política y los modos en que este alejamiento, que en muchos casos se orienta hacia lo fantástico, cuestiona algunas de las formas de la representación realista y abre en los textos otra dimensión de lectura posible más allá de la condicionada por la clave ideológica.

En el segundo capítulo se estudia la mirada cultural y literaria del viajero y se analiza el corpus completo de aguafuertes que Arlt publica como corresponsal del diario El Mundo con motivo de su viaje a España y África en 1935 y 1936, una instancia que significa un impacto tan fuerte en su literatura que sus efectos se traducen en los cuentos escritos a su regreso al país, en los cuales aparece otro modo de narrar y una espacialidad nueva en su literatura. Si puede sostenerse que en el viaje a España, tal como ha estudiado la crítica, ${ }^{24}$ aparece el cronista político y el testigo veraz de la tensa

\footnotetext{
${ }^{23}$ Para estudiar las relaciones de la obra de Arlt con el fascismo véase: Amícola, José. Astrología y fascismo en la obra de Arlt, Buenos Aires, Weimar ediciones, 1981.

${ }^{24}$ Véase, a este respecto: Saítta, Sylvia. "Nuevos viajeros, otras miradas: Roberto Arlt en España”, en Hispamérica. Revista de literatura, año XXVIII, $\mathrm{n}^{\circ}$ 82, 1999, y, de la misma autora, "Sueño del viaje", en El escritor en el bosque de ladrillos., Op. Cit., p. 136 y 145. También, pueden consultarse los prólogos de Saítta de las ediciones de las aguafuertes gallegas $\mathrm{y}$ asturianas, madrileñas y vascas.
} 
situación que se vivía en la península, en sus aguafuertes españolas, paralelamente y en crisis con el punto de vista de ese viajero testigo, aparece la fascinación de Arlt por lo nuevo -los escenarios, las costumbres, el paisaje urbano y natural- y en las crónicas puede verse también una búsqueda de lo exótico, lo típico y lo pintoresco, y escenarios de tarjeta postal que dialogan con otras representaciones sobre ese espacio (Gálvez, Larreta, Barrés, El Greco). El capítulo estudia, igualmente, las valoraciones, juicios y apreciaciones que asocian a este orden con un mundo de ensueño, lugar de la aventura y sitio de lo ideal, y examina los modos en que en las aguafuertes españolas, a diferencia de las porteñas y de lo que sucede en las novelas de Arlt, aparecen distintos modos de mirar los escenarios urbanos, suburbanos y el territorio natural. Si la mirada paisajística implica una perspectiva distanciada del todo ajena a una subjetividad en conflicto con el espacio del que surge y la rodea, ${ }^{25}$ el viaje también posibilita la construcción del paisaje en la literatura de Arlt. Se analiza, asimismo, el exotismo oriental que aparece en los textos africanos (las crónicas de viaje, El criador de gorilas y la pieza teatral Africa) y las distintas formas en que se muestra cómo es posible narrar de otro modo para Arlt en los años treinta. En el caso específico de El criador de gorilas se estudia, la búsqueda de la belleza y el estilo, la selección de lo pintoresco y la construcción escenográfica y colorista del sitio africano donde aparece un saber literario que remite al modernismo y al imaginario decadente. De esta manera, el espacio africano resulta ser, además del ámbito en que la literatura de Arlt se aleja del "edificio social que se desmorona" de sus primeras obras, la zona en que puede "pensar en bordados" e intentar realizar el deseo, expresado en los preliminares de Los lanzallamas, de componer un texto "de panorámicos lienzos" al modo flaubertiano.

Es en relación con ese saber literario modernista y decadentista que el tercer capítulo explora uno de los aspectos de lo fantástico en Roberto Arlt. Efectivamente, si los modos de lo fantástico y lo maravilloso que recorren la cuentística son centrales para considerar un giro en su textualidad en los años treinta y las formas en que su obra se modifica y reestructura en relación con problemáticas vigentes en el campo literario, se considera, en principio, cómo lo fantástico de Arlt se construye reiteradamente en relación con tópicos reescritos y retomados de esa estética, en un movimiento anacrónico que los acerca a relatos fantásticos de la literatura argentina bastante

${ }^{25}$ Tomo estas ideas de Silvestri, Graciela y Aliata, Fernando. El paisaje como cifra de armonía, Buenos Aires, Ediciones Nueva Visión, 2001. 
anteriores, como los de Leopoldo Lugones. Se examina, a su vez, de qué manera los rasgos decadentistas y modernistas se cruzan y conviven en los años treinta con otros elementos también presentes que remiten a las constantes más típicas de la ficción arltiana de la década del veinte. Asimismo, se analiza cómo el exotismo que aparece en muchos de estos textos y hace que todo pueda ser posible en el espacio de lo ajeno, genera una apertura que, en muchos casos, aproxima las narraciones al orden de lo maravilloso, y no siempre al de lo fantástico. El suceso extraordinario que tanto esperan los personajes arltianos tiene su lugar en un mundo alejado, en el sitio donde, como en varias manifestaciones del exotismo, se proyectan los deseos e ideales que se contraponen a la realidad. De esta manera, que las ficciones africanas y los textos de $E l$ criador de gorilas constituyen un fantástico-maravilloso o un tipo de relato que por introducir cierta forma de exotismo se aproxima más resueltamente a lo maravilloso. Se explora aquí, de igual forma, el acercamiento de Arlt y su reescritura de Las mil y una noches.

Pero además de cambios que se introducen en las ficciones de los años treinta y de su ingreso al teatro, en esta época también se modifica su columna periodística. A este respecto, en el cuarto capítulo se estudian las crónicas que Arlt publica en El Mundo entre 1937 y 1942, período en el que ya no aparecen en el diario las aguafuertes porteñas. Efectivamente, cuando Arlt vuelve del viaje que realiza durante un año (1935 a 1936) por España y Marruecos, su columna cambia de título y desde el 12 de marzo de 1937 empieza a denominarse "Tiempos presentes" y, desde el 8 de octubre de ese mismo año, “Al margen del cable". En el capítulo se consideran entonces, los modos en que se constituyen estas crónicas, y se analiza de qué manera, con qué procedimientos y recortes entra el registro del presente en estos textos. Asimismo, se examina cómo a partir de la ficción que generan los cables y las noticias, Arlt reflexiona sobre la guerra inminente, sus implicancias, agentes y consecuencias, y de qué modo estos artículos se transmutan, reiteradamente, en textos de aventuras y relatos ligados al policial, a la trama de espionaje y a la criminalidad, es decir, a las formas narrativas vinculadas con el tipo de cuentos que Arlt estaba publicando en ese momento. Por otra parte, se indaga el modo en que, a partir de la noticia, Arlt despliega en muchos casos piezas teatrales con personajes, diálogo y notación dramática. 
Dentro del conjunto de estas crónicas se inscribe una serie sobre el delito y la criminalidad, que se analiza en el quinto capítulo. En este sentido, si el interés por la delincuencia aparece desde los primeros textos de Arlt, en los años treinta se encuentra un modo diferente de incorporarlo, tanto en las notas de "Tiempos Presentes" y "Al margen del cable" como en los relatos policiales y de espionaje que aparecen hacia el final de su producción. En efecto, dentro del extenso corpus de la nueva columna periodística de Arlt, el capítulo reflexiona sobre las que pueden considerarse en muchos sentidos historias infames; es decir, crónicas narrativas sobre delincuentes singulares, personajes del delito, (simuladores, impostores, traidores, gangsters norteamericanos y orientales) que curiosamente se acercan a las biografías de la Historia universal de la infamia de Borges. Pero también en las ficciones el delito ingresa de otra manera, pues a partir de la segunda mitad de la década del treinta y hasta el año 1942, Arlt publica en las revistas El Hogar y Mundo Argentino cuentos de criminales y de espías, más cercanos al policial y a la literatura de espionaje desde el punto de vista de los modos de narrar y de los rasgos genéricos, inéditos en su producción anterior, que ponen en juego nuevas formas del relato. En el capítulo se indaga, entonces, este desplazamiento en el Arlt de los treinta, sus diferencias con los textos previos y sus vínculos con los modos de representación del crimen y la delincuencia en la época.

A partir de su propia experimentación narrativa y literaria en los años treinta, Arlt arriba en 1941 a una reflexión sistemática sobre la novela, que se estudia en el sexto capítulo. Este conjunto de textos, cercanos al ensayo, se edita igualmente en el diario El Mundo y participa de la polémica instalada a principios de la década del cuarenta, donde se discuten las "Ideas sobre la novela" que José Ortega y Gasset había publicado en su libro La deshumanización del arte en 1925 y en la que participaron intelectuales y escritores provenientes de distintos sectores, como Borges, Roger Caillois, y Héctor Agosti. En el capítulo se analizan las sucesivas intervenciones de Arlt como una zona de sus notas periodísticas en las que se inscriben ciertas "formas del ensayo". Se estudian, asimismo, los modos en que Arlt polemiza y discute algunas de las definiciones e ideas sobre la novela (Ortega) y se acerca a otras opiniones contemporáneas como las de Borges y los escritores que junto con él estaban confiriendo nuevos perfiles para la escritura de ficción en ese momento. Por ultimo, se proponen estas crónicas como el lugar de una búsqueda (como en todo ensayo), y el 
espacio en el que se intenta definir una nueva poética de la narración y una propuesta de arte dramático, en consonancia con el giro que hace la literatura de Arlt en 1932. Arlt ensaya, discurre sobre el arte de narrar y, a la vez intenta una puesta a prueba y explicitación de los desvíos de su propia obra.

Arlt en los treinta introduce, finalmente, el problema del valor literario de relatos, piezas teatrales y crónicas periodísticas que se han considerado "los menos felices" del autor. La tesis responde, en este punto acerca de la relevancia de la consideración de este período como clave para entender la obra de Arlt, no sólo en lo que respecta a su trayectoria de escritor, que, lejos de aparecer, como en sus textos previos, desafiante, agónico y rupturista, se muestra aquí atento e interesado por los avatares del funcionamiento del campo literario de su tiempo, sino también en lo que atañe a su importancia en el curso histórico de las prácticas y debates literarios, críticos, teatrales y culturales argentinos de esos años; años que la historia literaria pretende nada menos que decisivos para la consolidación de nuestras letras. 


\section{1 \\ El teatro}

El teatro marca una impronta muy fuerte y determina un cambio rotundo en la obra de Roberto Arlt en la década del treinta. Como ya se señaló, en 1932 aparece El amor brujo, ${ }^{1}$ su última novela aun cuando Arlt había proyectado escribir su continuidad en $E l$ pájaro de fuego. ${ }^{2}$ También en 1932 Arlt ingresa en la escena dramática por invitación de Leónidas Barletta, que no sólo adapta un fragmento de Los siete locos, titulado El humillado, sino que además estimula a Arlt a escribir una pieza para colaborar con el Teatro del Pueblo. En junio de ese año se estrena, entonces, Trescientos millones, su primer drama representado. Desde 1936, cuando Arlt regresa del viaje por España y África que realiza durante un año como cronista de El Mundo, y hasta el momento de su

\footnotetext{
${ }^{1}$ Es interesante destacar el modo en que en El amor brujo se inscriben algunos fragmentos netamente teatrales, con diálogo y notación dramática, que ya parecen indicar en la novela el interés de Arlt por el teatro. Así, por ejemplo, el capítulo "Cuando el amor avanza" se estructura con una descripción escénica al comienzo y luego se da paso a un diálogo entre los personajes, como puede verse en la cita: "Alcoba conyugal. Balder y su esposa Elena. Tinieblas. Palabras que chasquean rencorosas.

BALDER: Quiero a esa criatura y no la dejaré, ¿entendés? No la dejaré nunca.

ELENA: ¿Para qué me sacaste de mi casa?

BALDER: No te he sacado. Pero en el supuesto caso que lo hubiera hecho, ¿querés decirme qué me has dado? Vida gris...eso. Desde que nos casamos. Reproches. Luchas.

ELENA: Sos un perro, calláte.

BALDER: ¡Oh!, sí... un perro (tratando de ofenderla). Pero nunca al perro le has dado un beso como el que le dio la deliciosa criatura"

Véase: Arlt, Roberto. El amor brujo, en Novelas I, Ensayo preliminar de David Viñas, Buenos Aires, Losada, 1997, p. 755. A propósito de lo teatral en la novelística de Arlt, véase: Capdevila, Analía. "Sobre la teatralidad en la narrativa de Arlt", en Cuadernos Hispanoamericanos, $\mathrm{n}^{\circ} 11$, 1993, pp. 53-57.

${ }^{2}$ En la contratapa de Trescientos millones, Arlt había prometido también el lanzamiento de otra novela, El emboscado rojo, que tampoco llegó a redactar, como El bandido en el bosque de ladrillos, un proyecto, asimismo, trunco. Para estos datos véase: Omar Borré. Arlt y la crítica. 1926-1990, Buenos Aires, Ediciones América Libre, 1996, p. 205.
} 
muerte, participa en el Teatro del Pueblo. En agosto de 1936 estrena Saverio el cruel, La isla desierta en septiembre de 1937, África en marzo de 1938 y La fiesta del hierro en julio de 1940. Sólo una obra se pone en escena sin mucho éxito el 8 de octubre de 1936 en un teatro comercial, El fabricante de fantasmas, que se representa en el Teatro Argentino, con el elenco de Carlos Perelli y Milagros de la Vega. Debe mencionarse, a su vez, en este período su breve incursión en el diario El Mundo como cronista teatral, un tipo de ejercicio del que Arlt se había distanciado en aguafuertes previas en razón de los sus juicios parciales, la hipocresía y la irresponsabilidad elogiosa de los críticos del momento ante "bodrios" y representaciones que encarnaban el "acabóse" del teatro. ${ }^{3}$ Desde de abril de 1933 a junio de ese mismo año, Arlt escribe aguafuertes teatrales, un tipo de textos que, al estar vinculados a sus nuevos intereses, se convierten en un instrumento más en su ofensiva contra los espectáculos comerciales y las obras en cartelera. No obstante, después de algunas notas publicadas en la sección "Vida teatral" y “sin que medie ningún tipo de explicación”, Arlt vuelve a su página habitual, porque, como sostiene Sylvia Saítta, "un diario comercial y masivo como El Mundo no podía darse el lujo de perder los avisos publicitarios de los poderosos empresarios teatrales". ${ }^{4}$

De esta manera, la producción dramática de Arlt se inscribe, con interferencias que luego desarrollaremos, en el proyecto de jerarquización del teatro nacional que, iniciado con la escena independiente por Leónidas Barletta, intenta separarse de las derivaciones comerciales a que se había llegado por ese entonces. En este sentido, Arlt es considerado por la crítica como el autor más importante entre los que representaron sus obras en el Teatro del Pueblo, y el más significativo en el período ${ }^{5}$ entre aquellos que

\footnotetext{
${ }^{3}$ Arlt, Roberto. "Críticos teatrales", en El Mundo, 2 de junio de 1929. Reproducido en Arlt, Roberto. Aguafuertes porteñas: cultura y política, Compilación, prólogo y notas de Sylvia Saítta, Buenos Aires, Losada, 1994, pp. 66-69. En esta aguafuerte, a la vez que Arlt cuestiona a los críticos teatrales y los hace responsables de su complicidad complaciente en el deterioro y decadencia del teatro en ese momento, porque callan lo que no tendrían que ocultar (que las obras son malas, verdaderos "bodrios"), también ironiza sobre Elelín de Ricardo Rojas, estrenada en El Ateneo de Buenos Aires.

${ }^{4}$ Para un análisis de las aguafuertes teatrales, véase: Saítta, Sylvia. "Desde la butaca: Roberto Arlt, crítico teatral", en Pellettieri, Osvaldo (Ed.) Roberto Arlt. Dramaturgia y teatro independiente, Buenos Aires, Galerna/Fundación Roberto Arlt, pp. 111-125. La expresión citada está en las pp. 119-120.

${ }^{5}$ Véase, entre otros trabajos: Pellettieri, Osvaldo. "Algunos aspectos del 'teatro de arte' en Buenos Aires", en Osvaldo Pellettieri (dir). Teatro del Pueblo: una utopía concentrada, Buenos Aires, Galerna, 2006, pp. 69-157 y, también: Fischer, Patricia y Ogás Puga, Grisby. "El Teatro del Pueblo: período de culturización", en Osvaldo Pellettieri (dir). Teatro del Pueblo: una utopía concentrada, Buenos Aires, Galerna, 2006, pp. 159-212. Cabe considerar que Osvaldo
} 
llevaron a cabo en Argentina, un proceso latinoamericano de modernización del teatro en que se entabla una polémica con las convenciones finiseculares del teatro realistacostumbrista y sus elementos melodramáticos y se desarrollan nuevos esquemas que remiten a los modelos europeos y norteamericanos: ${ }^{6}$ Strindberg, Lenormand, O’Neill, el expresionismo y Pirandello, cuya repercusión en particular, sumada al éxito de las representaciones en Buenos Aires de Seis personajes en busca de un autor y sus dos visitas a la Argentina es reiteradamente mencionada en los estudios generales sobre los movimientos de quiebre con la tradición teatral nacional y, en particular, en el caso de Arlt. $^{7}$ Si la etapa comprendida entre 1932 y 1942 es un momento en que los textos de Arlt se modifican, introducen nuevos modos de representación, despliegan estrategias estetizantes y dibujan mecanismos destinados a establecer filiaciones que los jerarquicen, interesa ver cómo este proceso se inaugura en el teatro y para ello es atinado responder a una serie de interrogantes: ¿por qué el teatro?, ¿cuáles son las posibilidades y ventajas que lo convierten en uno de los ejes de la literatura de Arlt en los años treinta?, ¿qué intereses, qué imposiciones lo sitúan allí?, ¿cómo se inserta su teatro en el Teatro del Pueblo? Este capítulo se introduce, en primer lugar, en el marco del Teatro del Pueblo y en la propuesta dramática de Leónidas Barletta para estudiar luego, detenidamente, estas cuestiones.

Pellettieri marca tres períodos en la historia del teatro independiente: el primero, de 1930 a 1949; el segundo, de 1949 a 1959; y el tercero, de 1960 a 1967.

${ }^{6}$ Osvaldo Pelletieri retoma muchas de las opiniones críticas que han sostenido esto. Pelletieri, Osvaldo. Cien años de teatro argentino. De Moreira a teatro abierto, Buenos Aires, Galerna, 1990. Este autor también analiza lo que él considera un cruce entre "expresionismo subjetivo" y "tesis social" en el teatro de Arlt. Véase, a este respecto: "Algunos aspectos del 'teatro de arte' en Buenos Aires (1930-1975)", Op. Cit.

${ }^{7}$ La mayoría de los estudios sobre el teatro de Arlt marcan la influencia de Pirandello: Larra, Raúl. Roberto Arlt, el torturado, Buenos Aires, Talleres gráficos Cadel, 1956. Castagnino, Raúl. El teatro de Roberto Arlt, La Plata, UNLP, 1964. Blanco Amores de Pagella, A., Nuevos temas en el teatro argentino, Buenos Aires, Huemul, 1965. Gugliemini, H. El teatro del disconformismo, Buenos Aires, Minor Nova, 1967. Neglia, E. G. Pirandello y la dramaturgia rioplatense, Firenze, Valmartina, 1970. Troiano, J. L. "Pirandellism in the theatre of Roberto Arlt", en Latin American Theatre Review, 8/1, Fall 1974, pp. 37-44. Rela, W. "Argumentos renovadores de Roberto Arlt en el teatro argentino moderno", en Latin American Theatre Review, 13/2, Spring 1980, pp. 65-71. Arlt, Mirta. Prólogos a la obra de mi padre, Buenos Aires, Torres Agüero, 1984. Ordaz, Luis. "Las máscaras dramáticas de Roberto Arlt", Revista de estudios de teatro, VI, $\mathrm{n}^{\circ} 15,1987$, pp. 3-14. 


\section{El Teatro del Pueblo y la propuesta dramática de Leónidas Barletta}

$Y$ hemos descubierto que nuestro oficio tiene esa única finalidad, aventar la oscuridad del cerebro del hombre, excitar su sensibilidad, promover la vida del espíritu. ${ }^{8}$

Conducta.

En la década del treinta, con el movimiento teatral independiente se inicia una nueva etapa para la dramaturgia en la Argentina que tiene en el teatro de Leónidas Barletta una de sus manifestaciones privilegiadas. En 1929, después del alejamiento Barletta del grupo inicial de Claridad, la revista dirigida por Antonio Zamora y de la cual éste era uno de sus secretarios de redacción, surge en Buenos Aires el Teatro del Pueblo. Se trata en realidad de una verdadera empresa cultural que está montada en torno del teatro y en la cual se reúnen junto a Barletta algunos de los artistas, intelectuales y escritores que en 1920 conformaban el denominado grupo de Boedo. Así, si en los años veinte, como afirma Saítta, funcionaba la tranquilizadora dicotomía que al “arte social" de estos últimos, oponía el "arte por el arte" de los artistas de Florida, en la década siguiente, el panorama de la izquierda era considerablemente distinto porque "los escritores que años antes se habían agrupado en Boedo, en los treinta conformaron un mapa atravesado por dispersiones y enfrentamientos". Sin embargo, y pese a la dispersión, "Barletta intentó organizar, desde el Teatro del Pueblo, un espacio común para convocar a escritores que provenían de diferentes zonas del campo cultural de izquierda". ${ }^{9}$ Inaugurado el 30 de noviembre de 1930, el elenco se constituye —al igual que las otras agrupaciones independientes de la época-, en oposición al denominado en ese entonces "teatro comercial" o "teatro profesional". Según se asevera en el acta de fundación, sus miembros se proponen "realizar experiencias de teatro moderno para salvar el envilecido arte teatral y llevar a las masas el arte en general, con el objeto de

${ }^{8}$ Conducta, $\mathrm{n}^{\circ}$ 1, agosto de 1938, p. 1.

9 Saítta, Sylvia Saítta, Sylvia. "Entre la cultura y la política: los escritores de izquierda", en Crisis económica, avance del Estado e incertidumbre política (1930-1943), Tomo VII de la Nueva Historia Argentina, dirigido por Alejandro Cattaruzza, Buenos Aires, Sudamericana, 2001. 
propender a la elevación de[1] (nuestro) pueblo". ${ }^{10}$ Ya desde 1931 cuentan con una publicación: Metrópolis. De los que escriben para decir algo, (1931-1933) una revista que continúa el tono combativo de Boedo pero que incorpora al teatro entre sus preocupaciones principales. ${ }^{11}$

En sus comienzos la propuesta de Barletta se desarrolla en muy modestos escenarios, pero después de una lucha compleja y bastante accidentada por la que el grupo lucha por obtener un lugar en el campo intelectual, en 1937, y gracias a la adhesión de un centenar de artistas e intelectuales que reconocen su labor de "utilidad pública", ${ }^{12}$ la Municipalidad le cede el Teatro Corrientes (hoy Teatro General San Martín). Allí se constituye en un verdadero centro de cultura donde, además de otorgar un espacio muy importante a los nuevos dramaturgos argentinos (se representan las obras de Arlt, Raúl González Tuñón, Amado Villar, Nicolás Olivari, Eduardo González Lanuza, Arturo Capdevila, Roberto Mariani, Horacio Rega Molina, Álvaro Yunque, entre otros), se divulgan las clásicas y modernas piezas extranjeras (a lo largo de los años se escenificaron, entre otras, obras de Sófocles, Plauto, Gogol, Shakespeare, Cervantes, Tolstoi, Lope de Vega, Molière, Eugene O’Neill, Jean Cocteau, Andreiev). El Teatro del Pueblo, como la mayor parte de los elencos independientes del período, organiza, a su vez, conferencias, exposiciones de pintura y conciertos de música, y lleva

\footnotetext{
${ }^{10}$ La cita se refiere al acta de fundación del Teatro del Pueblo y está tomada de Marial, José. "El Teatro del Pueblo", en El teatro independiente, Buenos Aires, Alpe, 1955, p. 61. Sobre el Teatro del Pueblo, los elencos independientes del período y el proyecto cultural de Barletta véase además de los textos citados anteriormente, entre otros: Barletta, Leónidas. Viejo y nuevo teatro, Buenos Aires, Futuro, 1960; Larra, Raúl. Leónidas Barletta. El hombre de la campana, Buenos Aires, Edición Homenaje de Amigos de Aníbal Ponce, 1987; Pelletieri, Osvaldo. "El teatro independiente en la Argentina (1930-1965): intertexto europeo y norteamericano y realidad nacional", en F. de Toro (ed), Semiótica y teatro latinoamericano, Buenos Aires, Galerna, 1991; y Trastoy, Beatriz. "El movimiento teatral independiente y la modernización de la escena argentina", en María Teresa Gramuglio (dir.), El imperio realista. Historia crítica de la literatura argentina, Vol. 6, Buenos Aires, Emecé Editores, 2002, p. 490.

${ }^{11}$ Patricia Verónica Fischer y Grisby Ogás Puga sostienen que Metrópolis, definida en la contratapa como "revista de batalla" esclarece su finalidad combativa: y "mediante un lenguaje panfletista, [...] [estos intelectuales] ponían en un primer plano la confrontación polémica con la intención de denunciar un estado de cosas y marcar un posicionamiento claro y diferente desde el cual llevar adelante su práctica cultural." Véase: Fischer, Patricia y Ogás Puga, Grisby. "El Teatro del Pueblo: período de culturización”, Op. Cit., pp. 185-186. Véase, además: Lafleur, Héctor René, Sergio Provenzano y Fernando Alonso, Las revistas literarias argentinas, 18931967, Buenos Aires, Ceal, 1968, p. 125.

${ }^{12}$ Marial, José. El teatro independiente, Op. Cit.
} 
a cabo lo que se denominaron las funciones del "Teatro polémico", que consistían en debates con el público organizados por el propio Barletta, luego de la representación. ${ }^{13}$

Desde agosto de 1938 a diciembre de 1943, es decir, en el período que se ha considerado de apogeo en la larga trayectoria de esta agrupación, Barletta dirige y edita los veintisiete números de la revista que sucede a aquella Metrópolis de los tempranos años treinta: Conducta. Al servicio del Pueblo, publicación bimensual que funciona como un espacio donde se continúan, examinan, discuten, defienden y promueven las propuestas y las ideas de ese teatro. A diferencia de la primera, y de lo que podría preverse si nos atenemos al itinerario intelectual de su ideólogo y a las otras empresas editoriales en que participó, se trata de una revista cultural y sobre todo literaria, que se acerca a la modernidad estética, a la alta cultura y al saber consagrado, ${ }^{14}$ y en la que además participan escritores y colaboradores provenientes de diferentes sectores del campo literario, tales como Eduardo González Lanuza, Raúl González Tuñón, Nicolás Olivari, Marcelo Menasché, Octavio Rivas Rooney, Álvaro Yunque, Cayetano Córdoba Iturburu, Horacio Rega Molina, Roberto Mariani, Conrado Nalé Roxlo. ${ }^{15}$

Uno de los ejes principales que articulan el proyecto teatral, literario y artístico de Barletta es su propósito de divulgación cultural. Ciertamente, tal como figura en su estatuto: el Teatro del Pueblo se compromete a "experimentar, fomentar y difundir el buen teatro, clásico y moderno, antiguo y contemporáneo" y "Fomentar y difundir las artes en general, asumiendo la defensa de la cultura". ${ }^{16}$ Esto puede verse de modo muy

13 Para una información en lo que respecta a las distintas actividades y obras que se representaban en el Teatro del Pueblo, véase: Verzero, Lorena. "Actividades y Estrenos I" y "Actividades y Estrenos II", en Osvaldo Pellettieri (dir). Teatro del Pueblo: una utopía concentrada, Op. Cit., pp. 11-68.

${ }_{14}$ Julia Sagaseta afirma, en este sentido, que Conducta se abre a todas las instancias que la cultura moderna ofrece en Buenos Aires y se acerca a sectores de la alta cultura como Sur. Véase. Sagaseta, Julia Helena. "Conducta, la revista del Teatro del Pueblo: una mirada a la modernidad”, en Espacios de crítica y Producción, n 12, junio julio, 1993.

15 "En Conducta se nos revela un Barletta muy distinto del que conocimos en Dínamo, Extrema Izquierda, Izquierda, Los Pensadores, Claridad y Metrópolis", sostienen Lafleur, Provenzano y Alonso. (Lafleur, Héctor René, Sergio Provenzano y Fernando Alonso, Las revistas literarias argentinas, Op. Cit., p. 125).

${ }^{16}$ Un simple recorrido de la diagramación formal y del índice de contenido de Conducta explicita los modos en que en sus páginas se cumple con este objetivo. Las diferentes secciones en que se divide el material publicado responden a un interés difusionista: en todos los números se encuentran poemas o breves textos literarios y ficcionales, reseñas de cine, de la pintura del momento, de la música, de los dibujos animados, de las obras representadas en los distintos teatros independientes, del teatro polémico, de los libros recientemente publicados. De esta manera, la revista construye una configuración que designa cuidadosamente un apartado para 
claro, por ejemplo, en el número 2 de Conducta, de septiembre de 1938, donde se publica un fragmento del Sarmiento de Leopoldo Lugones. El texto, a la vez que hace un esbozo de la personalidad del "gran maestro" y civilizador, coincide y sintetiza los propósitos que esa revista ha señalado desde el primer número, y con la función de los intelectuales que promueve Barletta: "Había asumido la responsabilidad del país, considerándose un perpetuo representante suyo, [...] Vivió acarreando menesteres de civilizar, en el olvido más absoluto de su conveniencia propia, que es decir, desnudo y valeroso como la hormiga. [...] Su actividad excita al pueblo, indúcelo a andar más de prisa...." ${ }^{17}$ La trayectoria de Sarmiento, según la mirada de Lugones, ${ }^{18}$ concuerda con la propuesta de Conducta, que, toma para sí las palabras del poeta sobre el autor de Facundo y se coloca en la línea civilizadora de las minorías ilustradas, en un gesto próximo al que asume en ese mismo momento la revista Sur, que también edita un número en homenaje a Sarmiento y propone una "Defensa de la inteligencia". ${ }^{19}$ Porque efectivamente, si en los años treinta, a partir de la lucha antifascista, todos los intelectuales (menos los nacionalistas, los nazis y los fascistas) están del mismo lado, en contra de los regímenes totalitarios, no sorprende que Sur y Conducta sostengan las mismas ideas. Por otra parte, es la "vulgarización de la cultura" que lleva a cabo Sur lo que Conducta valora y destaca reiteradas veces de la revista de Victoria Ocampo. ${ }^{20}$

cada una de las ramas del arte.

${ }^{17}$ Véase: Conducta, ${ }^{\circ} 2$, septiembre de 1938, p. 3.

${ }_{18}$ A este respecto, interesa indagar, asimismo, las razones de la inclusión de un texto de Lugones en Conducta, lo que podría vincularse con su suicidio en febrero de ese mismo año, y con un posible intento de retomar al Lugones más "iluminista" de sus comienzos, y menos nacionalista que en los treinta.

${ }^{19}$ Efectivamente, el ejemplar de Sur número 47, de agosto de 1938, está dedicado enteramente a Sarmiento y el número anterior, de julio de 1938 desarrolla una "Defensa de la inteligencia", un tema propuesto por Erro y Mallea. Allí aparece, entre otros, un artículo de Victoria Ocampo sobre Sarmiento ("Con Sarmiento) y un trabajo de Eduardo Mallea titulado "Sentido de la inteligencia en la expresión de nuestro tiempo" que es reseñado muy elogiosamente en Conducta. El número 48 también publica "Aseveración sobre Sarmiento", texto de una conferencia de Mallea. Para estas cuestiones véase a propósito de Sur, Gramuglio, María Teresa. "'Sur' en la década del treinta: una revista política", en Punto de vista, Año IX, $\mathrm{n}^{\circ}$ 28, noviembre de 1986; y también, de la misma autora: "Las minorías y la defensa de la cultura. Proyecciones de un tópico de la crítica literaria inglesa en Sur", en Boletín/7, del Centro de Estudios de Teoría y Crítica Literaria, Facultad de Humanidades y Artes, Universidad Nacional de Rosario, octubre de 1999, y "Posiciones de Sur en el espacio literario. Una política de la cultura", en Saítta, Sylvia. (directora). El oficio se afirma. Historia crítica de la literatura argentina (dirigida por Noé Jitrik), Buenos Aires, Emecé, 2004, pp. 93- 122.

${ }^{20}$ En el número 3 de Conducta se valora la empresa de Victoria Ocampo que "ha puesto en manos del gran público, desconocido de los idiomas extranjeros, las obras capitales de la literatura actual", y esto "no es poco en un país como el nuestro, donde todo lo que se haga a 
En relación con esta idea de difusión artística y cultural que puede parangonarse, además, como una continuación, con la empresa de divulgación literaria de la izquierda y con lo que sucedía en los veinte entre los intelectuales de Boedo - considérese las ediciones baratas de la editorial Claridad-, se encuentra el segundo de los rasgos centrales que articulan la propuesta teatral de Barletta: educar al pueblo, organizar un teatro para "elevar el nivel de cultura del pueblo" y fomentar un arte popular. En este cometido Barletta se enfrenta a los dramaturgos del momento, a los escritores de sainetes y "comedietas de bajo fondo", a los empresarios que "tendían su malla de acero para atrapar dinero, sin advertir lo que al país se lastimaba" ${ }^{21}$ y funda, precisamente, "el Teatro del Pueblo para contrarrestar los efectos de un teatro sin arte":

En nuestra América, el teatro no ha salido todavía de sus pañales. En todas las ramas del arte se ha avanzado en uno u otro sentido. [...] Hay en el continente un buen número de poetas, cuentistas, novelistas, músicos y pintores, media docena de los cuales puede figurar sin desmedro entre los más grandes del mundo, pero no contamos con dramaturgos que puedan imponerse a la consideración mundial.

El teatro es, entre nosotros, una manifestación sin mayor trascendencia artística, sin valor social, ni emoción humana. ${ }^{22}$

Y también afirma en otro lugar:

Nosotros nos habíamos propuesto emprender sin impaciencias ni apuros el largo y penoso esfuerzo de devolver a nuestro teatro toda su dignidad y toda su belleza [...]

Después de siete años de ininterrumpido trabajo [...] refirmamos nuestro inquebrantable propósito de no lucrar con nuestro arte, de no mezclar a la cosa espiritual el cálculo de lo que nos corresponde por el esfuerzo realizado. [...]

No queremos ni dineros del estado, ni puestos, queremos el respeto que deben merecer quienes cumplen con un propósito recto $\mathrm{y}$ de interés público. ${ }^{23}$

\footnotetext{
favor de ella [la cultura] será siempre una mínima parte del esfuerzo colectivo que debería llevarse a cabo para inundar el vastísimo panorama argentino de esa semilla dorada e irreducible que es el conocimiento y la civilización." Conducta, n 3, octubre de 1938, p. 3.

${ }^{21}$ Véase el número 2 de Conducta, Op. Cit.

${ }^{22}$ Barletta, Leónidas. Viejo y nuevo teatro, Op. Cit. p. 14.

${ }^{23}$ Conducta, $\mathrm{n}^{\circ} 2$, Op. Cit.
} 
De los fragmentos citados, en los que se destacan las carencias de un teatro "sin arte", sin "valor social” y sin "emoción humana", se desprende que Barletta percibe el género dramático como un lugar vacío en el campo intelectual argentino de la década del treinta que, por lo tanto, es posible ocupar por los intelectuales de izquierda que se proponen renovar la escena y fundar un "arte nuevo". Asimismo, puede verse el modo en que se articula y piensa su lugar en la sociedad esa empresa cultural que es el Teatro del Pueblo de Barletta y las distintas formas en que procura diferenciarse en el campo de las letras. Así, si en su proyecto teatral, Barletta continúa en cierto sentido el afán difusionista de Boedo y su slogan parece ser "arte para todos", el Teatro del Pueblo se distancia de las propuestas de los años veinte afines al denominado grupo de Boedo, porque su arte, su literatura, su teatro, no se venden, no se cobra por ello, y manifiestan un claro desinterés y oposición al mercado: se trata de no lucrar con el arte, de no contaminar con "el cálculo" del dinero "la cosa espiritual” que está pensada únicamente para ayudar a cultivar "la nobleza de los pensamientos y de las ideas".

Ahora bien, si la propuesta de Barletta asume el "teatro de arte" para salvar las “carencias morales" y para "elevar el nivel" de la cultura popular, cabe preguntarse, por una parte, cuál es, en términos más precisos, ese pueblo tan reiteradamente mentado por Barletta y qué sujeto se supone o imagina como el destinatario de sus prácticas. Un recorrido por las páginas de Conducta permite rastrear al menos dos aspectos en que Barletta y estos intelectuales piensan el pueblo. Por una parte, el pueblo atañe a los nuevos sectores que las políticas de alfabetización constituyeron como un nuevo público, pero también a "la población que trabaja", la multitud a la que "por toda educación se le había brindado el teatro, el cinematógrafo y la radiotelefonía", "la plebe que no tenía discernimiento cívico, desbordando de bajas pasiones [...] sin ningún sentido del respeto, de la disciplina y de la dignidad"; ${ }^{24}$ es decir, el vulgo y la masa, los marginados de la cultura y de la civilización. ${ }^{25}$ Todos aquellos a quienes Barletta se ${ }^{24}$ Barletta, Leónidas. "Crónica del teatro" en Conducta, n 2, Op. Cit.

${ }^{25}$ Fischer y Ogás Puga refieren el hecho de que Osvaldo Pellettieri sostiene, a este respecto, que si bien el público al que aspiraba Barletta era el proletariado, el que efectivamente asiste al Teatro del Pueblo y el que se originó de su práctica teatral surge más bien de los sectores medios y la burguesía, preparados para el tipo de discusión que en ese ámbito se planteaba. Véase: Fischer, Patricia y Ogás Puga, Grisby. "El Teatro del Pueblo: período de culturización", Op. Cit., p. 168; el análisis de Pellettieri citado es: Pellettieri, Osvaldo. Clases de la materia "Historia del teatro latinoamericano y argentino", Facultad de Filosofía y Letras, UBA, 2000. Estas autoras analizan, además, las fotos que se publican en Conducta y señalan que el público que allí aparece es "distinto al 'vulgo', es decir, al espectador que ellos creían mayoritario de 
propone elevar, siguiendo quizás a Heine, "al nivel del hombre culto". ${ }^{26}$ Pero, en otros momentos y si nos atenemos al contexto de la crítica situación mundial y de la posible guerra, la referencia al pueblo indica una preocupación más general por el hombre y es por ello que Conducta interpela a "Dar lo mejor de nosotros en la más humilde servidumbre de la humanidad". ${ }^{27}$ En este sentido debe leerse el saludo que abre el primero de sus números:

Amigo lector: salud. En este apretón de manos inicial, va contenido todo nuestro desembozado esfuerzo de ganarte, de persuadirte, de hacer de usted también un disciplinado defensor de la cultura.

En medio de las tribulaciones espantosas de los hombres del mundo, hemos visto que toda iniquidad, parte de la incomprensión, engendrada a su vez por la ignorancia. Ignorancia del poderoso y del oprimido.

$\mathrm{Y}$ hemos descubierto que nuestro oficio tiene esa única finalidad, aventar la oscuridad del cerebro del hombre, excitar su sensibilidad, promover la vida del espíritu. Pues si el artista es el primer gozador de su creación, en realidad ella no existe para el mundo, sino en el momento en que se dirige al prójimo y toma contacto con él, vinculándose a través del tiempo y del espacio. [...]

Mucho agua ha debido correr para que comprendiéramos que no siendo la cultura un adorno del hombre, ni un arma para agredir, sino su propia capacitación para la vida, debíamos aprender bien nuestro oficio, aunque no fuese de los que se cotizan en el día y aunque se perdiera toda apariencia de heroicidad, en estos días en que es más fácil destacarse con un gesto que con la labor silenciosa de toda una vida. Invitamos pues a los amigos y adversarios, a trabajar por la cultura del pueblo...

$\mathrm{Y}$ esta es nuestra conducta. ${ }^{28}$

Como se ve, la redacción saluda a un lector que construye y presupone como un público de pares y lo invita a sumarse a lo que ellos llaman su "conducta": se trata de sus puestas" (p. 200).

${ }^{26}$ Montenegro, Ernesto. "El teatro del Pueblo de Buenos Aires", en Conducta, $\mathrm{n}^{\circ}$ 2, septiembre de 1938. Véase, también, en el número 23 de Conducta el modo en que se promueve su empresa: "Ha hecho Barletta por el teatro y por la cultura popular, lo que no ha sido dable hacer en ciudades con más tradición en atisbos escénicos: la conquista del pueblo para el teatro de jerarquía", [...] "Ha logrado poner en escena obras de específicos valores al alcance de las posibilidades del pueblo, de ese pueblo auténtico que trabaja, que se afana en la áspera brega diaria, pero que también se desvela por lo que demás digno tienen las apetencias del espíritu": Véase: "La obra", en Conducta, $\mathrm{n}^{\circ} 23$, abril de 1943.

${ }^{27}$ Véase: Conducta, $\mathrm{n}^{\circ} 1$, agosto de 1938, página inicial.

${ }^{28}$ Véase: “Al día...", en Conducta, agosto de 1938, p. 2. 
una empresa por la cual es deber de los artistas y escritores iluminar y servir al resto de los hombres. Esta minoría constituida por quienes participan en la revista y por todos aquellos que se suman en su misión, es quien tiene una capacidad tal que puede “orientar espiritualmente a la humanidad". De esta manera, Conducta invoca los poderes de la razón y la inteligencia para el engrandecimiento de los espíritus y marca una separación contundente entre la comunidad de intelectuales y el individuo corriente.

En el proyecto de Barletta entonces se inscriben dos modulaciones en relación con el pueblo y la misión de la cultura. La primera, que se vincula con ese lectorespectador plebeyo que el teatro de Barletta busca educar, imprime en sus notas una actitud paternalista cuya voz autorizada para hablar en la sociedad, se encamina en una misión pedagógica y homogeneizadora que sigue, en cierto sentido, la impronta que la crítica ha leído en Claridad. ${ }^{29}$ La segunda, que surge de la preocupación por el hombre en esa "etapa dramática del mundo" en que a ellos les "tocaba vivir" 30 asume una defensa, promoción y búsqueda de la cultura, de la razón y de la inteligencia como formas de oposición al irracionalismo de los años treinta, y aparece en cierta sintonía con las inquietudes que, como dijimos más arriba, se manifestaban asimismo en otros sectores del campo intelectual, como en la revista $\mathrm{Sur} .{ }^{31}$ Sólo la razón y el camino que indican las luces de la inteligencia y la cultura permiten contrarrestar los malos sentimientos, las malas ideas y lo negativo que hay en la conciencia del hombre, reorientándolo a un ideal de vida superior. De este modo se explica la función del teatro para Barletta: "la única escuela de vida de la mayoría de la población" y el "sanatorio del espíritu".

Por todo ello es que estos artistas e intelectuales piensan su labor como una "misión redentora" 32 e imaginan su valor en la cultura y en la literatura gracias a la

${ }_{29}$ Montaldo, Graciela. "Literatura de izquierda: humanismo y pedagogía", en Montaldo, Graciela y colaboradores. Yrigoyen, entre Borges y Arlt (1916-1930), Historia social de la literatura argentina, dirigida por David Viñas, tomo VII, Buenos Aires, Contrapunto, 1989.

${ }^{30}$ Conducta, $\mathrm{n}^{\circ} 1$, Op. Cit., p. 1.

${ }^{31}$ En este mismo sentido Borges, por ejemplo, propone la racionalidad del policial como una respuesta al irracionalismo totalitario

32 En el número 27 de Conducta, de diciembre de 1943, aparece un texto al principio de la revista publicado a doble página y en letra tamaño mural donde la revista agradece a los artistas y escritores que sin distinción de matices le ofrecieron su apoyo: "Nuestra gratitud no nos impide pensar, una vez más" [...] "que ser honrado es siempre un buen negocio". El breve manifiesto se inicia con un epígrafe del Evangelio de San Marcos, "Os envío como ovejas en medio de lobos". Estas referencias muestran que ellos asumen para sí mismos una misión redentora: su actividad es como la de las ovejas de Jesucristo que deben luchar en medio de 
acción desinteresada que su tarea reviste en el mundo social. Su arte se fundamenta en la educación del pueblo y su utilidad se justifica por estar al servicio de la humanidad en la nueva sociedad en crisis. Así lo define Barletta en el número 27 de Conducta:

Nosotros hacemos arte, por vocación ardiente y hemos adquirido la exacta conciencia de ser útiles a nuestro prójimo, y la seguridad de que cumplimos un deber ineludible.

Y sabemos ya que el arte es la manifestación más elevada de lo más puro y elevado que cabe en el alma del hombre.

El arte nos procura los goces y alegrías más intensos de la vida, nos hace la vida comprensible y nos enseña a amarla, nos pone en íntimo contacto con el hombre y nos induce a comprenderlo y estimarlo

En estas horas de angustia para la humanidad, cuando todos los valores hacen crisis y el desaliento cunde, el arte tiene la suprema misión de orientar espiritualmente al hombre.

La cultura artística salvará a la humanidad del caos moral, filosófico, político y social en que está sumida.

De este modo, con una visión sumamente optimista de la acción positiva de la cultura (y del teatro) en un momento de crisis moral, Barletta asume una empresa para la cual el arte sólo puede definirse como aquél que cumple con esa "misión redentora", como el que por sus fines positivos "educa al pueblo" y consigue, —como también deseaba Romain Rolland y esto es, a nuestro juicio, lo que toma Barletta puntualmente del autor francés de El teatro del pueblo- "elevar su capacidad intelectual"; 33 todo lo demás, queda, en su opinión fuera de la esfera de lo artístico.

Ahora bien, cabe destacar, asimismo, que el proyecto de Barletta se separa de las propuestas estéticas de un "arte por el arte" y en sus escritos reiteradamente se afirma que "No se puede ya considerar al arte como un pasatiempo o simple recreación", y que "hay que rechazar indignados el arte sin pretensiones, que nada dice a la mente o al corazón" 34 , pues, en el caso de Barletta se trata de un arte y una cultura que, como afirma Graciela Montaldo a propósito de Boedo, "no pueden entenderse sino desde un punto de vista moral", ${ }^{35}$ y también político; aunque no es, claro está, la política partidaria lo que está en juego, sino el "engrandecimiento espiritual e intelectual del lobos para salvar a la humanidad.

${ }^{33}$ Barletta, Leónidas. Viejo y nuevo teatro, Op. Cit., p. 20.

${ }^{34}$ Barletta, Leónidas. Viejo y Nuevo teatro, Op. Cit., p. 13.

${ }^{35}$ Montaldo, Graciela. "Literatura de izquierda: humanismo y pedagogía", Op. Cit. 
hombre", ${ }^{36}$ como sostiene Barletta en el número 27 de Conducta: "No podemos entender, pues el /arte por el arte/, ni el /arte de clases/, entendemos el /arte por el hombre/. ${ }^{37}$ En este sentido, tampoco su propuesta se resuelve, como afirma Osvaldo Pellettieri, en un proyecto de teatro vanguardista; ${ }^{38}$ aunque podría decirse que con Barletta -y también más claramente con otros escritores como Raúl González Tuñón quien, en los treinta, aúna la revolución estética y la política- la izquierda asume la voluntad de constituir un arte de experimentación; en tal sentido, un nuevo tono separa a este grupo de intelectuales como los de Boedo, que en los veinte proclamaban una vanguardia sólo en lo social. De hecho, como antes se señaló, es objetivo del Teatro del Pueblo "hacer experiencias de teatro moderno para renovar el envilecido arte teatral" y hay menciones en las notas publicadas por Barletta y artículos completos en Conducta donde su teatro se muestra como continuación de los experimentales europeos. No obstante, su propuesta puede considerarse indecisa entre la vanguardia y el realismo, y no se encuentran definiciones claras en el campo de la experimentación artística. Cuando de cuestiones estéticas se trata, las proclamas de Barletta apuntan somera y casi exclusivamente a una oposición al teatro comercial de la época y se mantiene en sus escritos una confusa valoración de lo verosímil a la vez que, contradictoriamente, se juzga y promueve su teatro en sus vínculos con los ensayos europeos de teatro experimental. ${ }^{39}$ Por todo ello puede entonces afirmarse, como sostiene José Marial, ${ }^{40}$ que lo que prevalece finalmente es el realismo, a lo que se suma una figura fuerte del

\footnotetext{
${ }^{36}$ Afirma Barletta en Viejo y Nuevo teatro: "El arte es para el pueblo, para todos, para elevar la capacidad intelectual y sentimental del hombre y conducirlo finalmente a su máxima perfección.” (p. 20)

${ }^{37}$ Barletta, Leónidas. "Avanzar sin prisa y sin pasusa como la estrella", Conducta $n^{\circ}$ 27, Op. Cit. ${ }^{38}$ Pellettieri, Osvaldo, “Algunos aspectos del 'teatro de arte' en Buenos Aires”, Op. Cit.

${ }^{39}$ Por lo demás, y si consideramos una serie de artículos aparecidos en Conducta, redactados por sus colaboradores más habituales, podría decirse que es un objetivo de Barletta y de su Teatro del Pueblo la instauración de lo que se denomina en las páginas de la revista "un nuevo realismo"; esto es, un arte propio que se ocupe de revelar la esencia y la "autenticidad" del hombre argentino. En estos artículos se valoriza la figura de Carriego, como en Borges. Pueden verse aquí las apropiaciones, cruces y préstamos entre diferentes zonas del campo intelectual.

${ }^{40}$ Marial, José. "Boedo antiguo", en Teatro XXI, año II, n 3, primavera de 1996. Cabe citar además, "Experiencia y público en la escena independiente", un artículo de este autor que aparecerá en el volumen III de la Historia del Teatro Argentino en Buenos Aires que está en preparación, dirigido por Osvaldo Pellettieri.
} 
director que en las puestas en escena busca enfatizar el mensaje y la tesis realistasocial. $^{41}$

Así, el Teatro del Pueblo de Barletta, con una mirada sumamente optimista que postula un teatro "de arte" que "salvará" a las masas del envilecimiento espiritual, ${ }^{42}$ constituye un intento de modernización y vanguardia en la escena nacional. En ese intento que es más bien una empresa cultural, priman el interés de divulgación artística, la idea de educación del pueblo y el énfasis la tesis realista, todo ello en una "misión redentora" que en el "engrandecimiento del hombre" encuentra su lugar en la literatura, en el arte y en la sociedad.

\section{En torno al proyecto teatral de Roberto Arlt}

Un público compacto, sorprendido, miraba... ${ }^{43}$

Roberto Arlt

Aunque Arlt representa casi todas sus obras en el Teatro del Pueblo, y sólo una, El fabricante de fantasmas, en la escena profesional y en sus piezas pueden verse muchos rasgos afines a la propuesta de Barletta, no obstante existían desacuerdos porque ambos sostenían "diferencias en cuanto al teatro que había que hacer". ${ }^{44}$

${ }^{41}$ Pellettieri trabaja esta cuestión en varios de sus artículos. Véase, entre los más significativos: "Algunos aspectos del 'teatro de arte' en Buenos Aires", Op. Cit., y "El Teatro del pueblo y sus puestas de los textos de Roberto Arlt", Op. Cit.

${ }^{42}$ Fischer y Ogás Puga sostienen, en este sentido que en Barletta hay un optimismo progresista con respecto al teatro: "Barletta creía efectivamente que Teatro del Pueblo no sólo podía salvar a la cultura, sino también al país. Además, Barletta defendía la noción de progreso. [...] Esta es otra idea adaptada y reformulada por Barletta que aparece en los intelectuales de la generación del '37: servir al país con la inteligencia, educando al pueblo, [...] este servicio sería el comienzo de un progreso indefinido". Véase: Fischer, Patricia y Ogás Puga, Grisby. "El Teatro del Pueblo: período de culturización", Op. Cit., pp. 169-170.

${ }^{43}$ Arlt, Roberto. "El Teatro del Pueblo va al teatro Corrientes", en El Mundo, 21 de mayo de 1937. Recopilada en Arlt, Roberto. Aguafuertes porteñas: cultura y política, Op. Cit. pp. 119.

${ }^{44}$ Osvaldo Pellettieri en "El Teatro del pueblo y sus puestas de los textos de Roberto Arlt", (Op. Cit) ha mostrado, por ejemplo, testimonios que evidencian cómo las puestas de Barletta de las obras de Arlt -Pellettieri se refiere puntualmente a La isla desierta- tienden a intensificar la claridad de la tesis social y a cristalizar o saturar el mensaje que puede extraerse del texto de un modo en que éste no lo suponía. También Pellettieri analiza en su libro sobre el Teatro del Pueblo la imagen fuerte del director, en cuya responsabilidad estaba hacer visible en la representación la "tesis" o la "idea" de cada autor que el texto dramático proponía. Véase: 
Por lo tanto, en este apartado se analizan los vínculos del teatro de Arlt con El Teatro del Pueblo, se especifican algunas de esas diferencias y también los modos en los que Arlt define su proyecto dramático. Así, en primer lugar, se estudian las propuestas estéticas de un teatro que busca sacudir al espectador, pero que no se piensa fundamentalmente como didáctico: el proyecto teatral de Arlt, si bien se constituye en el contexto del Teatro del Pueblo, se distancia del acento en lo pedagógico tal como en ese ámbito era considerado e intenta más bien provocar un efecto de "simpatía" en el espectador que lo introduzca y asimile a la "emoción" de lo representado. Además, hay una pregunta que recorre casi todas sus obras y que discute los alcances de lo didáctico a la vez que se contrapone al optimismo de Barletta: se trata del interrogante siempre abierto sobre la posibilidad de que el mundo de la representación, de la ficción y de la irrealidad pueda actuar positivamente en el orden real. En segundo lugar, se indaga la búsqueda literaria en el teatro de Arlt, la elección de poéticas de la irrealidad y, especialmente, el alejamiento estético en las piezas de contenido ideológico o de crítica política y los modos en que este alejamiento, que en muchos casos se orienta hacia lo fantástico, cuestiona algunas de las formas de la representación realista y abre en los textos otra dimensión de lectura posible más allá de la condicionada por la clave ideológica.

En principio, cabe destacar la forma en que Arlt, en sintonía con las propuestas de Barletta, se enfrenta a los saineteros, a los autores comerciales y sus modos de representación, ${ }^{45} \mathrm{y}$, en algunas de sus aguafuertes, inscribe su teatro dentro de los postulados y finalidades del Teatro del Pueblo, en una forma de exposición que se asimila, en algunos momentos, a los giros y expresiones del propio Barletta:

\begin{abstract}
"Nosotros queremos hacer teatro de arte", decía Barletta [...] La cueva de la calle Corrientes, "veinte centavos la entrada" fue siendo conocida por el público. La gente, con excepción de ciertos intelectuales, observaba con simpatía el esfuerzo de este grupo de artistas en semilla. [...]
\end{abstract}

Pellettieri, Osvaldo. "Algunos aspectos del 'teatro de arte' en Buenos Aires”, Op. Cit., pp. 69157. Patricia Fischer y Grisby Ogás Puga reiteran estas consideraciones: Fischer, Patricia y Ogás Puga, Grisby. "El Teatro del Pueblo: período de culturización”, Op. Cit., pp. 159-212.

${ }^{45}$ Como analiza Saítta, también en las aguafuertes teatrales Arlt ataca el teatro comercial "desde sus actores a sus técnicas de actuación, desde los dramaturgos a sus escenografías"; critica "los bodrios" y acusa a las comedias en uso de "engatuzar al público". Véase: Saítta, Sylvia. "Desde la butaca: Roberto Arlt, crítico teatral”, Op. Cit., p. 119. 
"Iremos a buscar a la gente a sus casas, a la escuela, a los barrios" decía Leónidas Barletta. Y por primera vez, Shakespeare y Calderón de la Barca y los entremeses de Cervantes fueron puestos en la plaza pública, en el arrabal, en Mataderos, en Parque Patricios, en las ferias. Un público compacto, sorprendido, miraba y se hacía cruces frente a este teatro desconocido, el teatro madre de la humanidad. $[\ldots]$

¿A qué se debe el éxito de Barletta? Sencillamente, no considerar el teatro como un negocio del cual hay que sacar dinero. [...] El Teatro del Pueblo será el refugio del teatro conceptual no comercial. Su finalidad cultural... formará la base de una nueva generación de hombres de teatro en este país. ${ }^{46}$

Como puede verse en la cita, del mismo modo que Barletta y con una retórica similar, Arlt invoca un "teatro de arte" "madre de la humanidad" y se opone a la labor de los "comiduchos", los "sainetones burdos" 47 y el interés comercial, algo que lo distancia, asimismo de sus concepciones previas: se propone una literatura o un teatro que no se fundamente en el dinero. Por otra parte, si la literatura de Arlt se había desarrollado en los comienzos y en sus primeras obras, en oposición a los mecanismos canónicos de legitimación literaria, y por ejemplo, en 1920, con "Las ciencias ocultas en la ciudad de Buenos aires", Arlt enfrenta al modernismo (el modelo de la literatura de la época) y define su escritura por diferencia para ganar un lugar en las letras argentinas, ${ }^{48}$ ahora con el teatro y también con las obras que circunscribimos en el último tramo, ocurre algo que en alguna medida, es contrario de aquello que sucedía antes: los textos ya no disputan con los procedimientos de la más alta literatura, sino con aquello que, aunque descalificado por los patrones de consagración del momento y con escasa legitimidad artística, constituye una amenaza contra una dramática nueva que trae lo estético y lo novedoso a las escenas de Buenos Aires.

\footnotetext{
${ }^{46}$ Arlt, Roberto. "El Teatro del Pueblo va al teatro Corrientes", Op. Cit., pp. 117-119. El subrayado es nuestro.

47 "Comiduchos" y "sainetotes burdos" son palabras que Arlt utiliza en una "Pequeña historia del Teatro del Pueblo" aparecida en Conducta, donde Arlt lee, elogiosamente, el empeño del teatro del pueblo en torno a valores que había utilizado para pensar su obra, como la prepotencia del trabajo, la idea de nueva generación y el juvenilismo. Arlt, Roberto. "Pequeña historia del Teatro del Pueblo", en Conducta, Julio/Agosto de 1942.

48 "Las ciencias ocultas en la ciudad de Buenos Aires", un ensayo ficcional que Arlt publica en 1920 puede ser considerado el comienzo literario de Arlt y el gesto fundador de su literatura. Véase: Juárez, Laura, "Arlt, el ocultismo y el comienzo de una escritura", en Orbis Tertius. Revista de Teoría y Crítica literaria, Universidad Nacional de La Plata, n 6, 1998, p. 67-87. Se retomará la cuestión en el capítulo tres.
} 
En este sentido, también en sus obras representadas, Arlt entabla la polémica antes mencionada. Allí se resaltan los peligros que, para el "verdadero teatro", encierra la escena comercial, preocupada únicamente por perseguir los intereses materiales del autor y la empresa. Esta crítica se organiza fundamentalmente en Trescientos millones y El fabricante de fantasmas, pero sobre todo en esta última que constituye una provocación al teatro comercial en el seno mismo del teatro comercial, pues se trata, como se dijo, de la única pieza de Arlt que se pone en escena en ese ámbito, fuera del teatro independiente. ${ }^{49} \mathrm{El}$ fabricante de fantasmas, obra teatral que dramatiza los problemas de Pedro, autor de teatro y personaje propuesto como alter ego de Arlt —si nos atenemos a los modos en que algunos de los protagonistas de la obra remiten directamente a conocidos personajes de las novelas de Arlt (la Coja, el Jorobado, la Prostituta) $-{ }^{50}$ desarrolla una teorización acerca de las formas en que debe representarse, y por ello llega a ser una oposición elocuente del autor a los convencionalizados espectáculos de ese entonces, sus clichés y su reiteración estereotipada. En los siguientes fragmentos puede observarse la crítica de Arlt al interés económico y diferentes formas por las que el texto procura sutilmente la captación y concientización del público que concurría al teatro comercial, al evidenciar los mecanismos que los autores empleaban para conseguir el éxito de las puestas en escena del momento:

JOROBADO. -Deberías recibirnos con banda de música. ¿No hace acaso siete años que lo mantenemos? ¿Que costeamos sus más mínimos caprichos? [...]

PROSTITUTA ( A Pedro)._...para que el maldito golpe de efecto final tuviera éxito, me transformaste en una basura de la calle. Lloraba el público en el teatro. (Dirigiéndose a los fantasmas) ¿Y saben lo que hacía él? ...restregándose las manos exclamaba: "Qué estúpido es el público, qué estúpido!"51

\footnotetext{
${ }^{49}$ En 1941 Arlt reflexiona sobre los autores independientes en los teatros comerciales y afirma: "Cuando más fielmente trate el autor independiente de expresar la realidad teatral, más lejos se sitúa del teatro comercial". Véase: Arlt, Roberto. "Los autores independientes en los teatros comerciales", en La Hora, 2 de diciembre de 1941.

${ }^{50}$ Volveremos sobre los modos en que en la obra se busca la cercanía entre Pedro, el autor teatral y Arlt escritor.

${ }^{51}$ Arlt, Roberto. El fabricante de fantasmas, en Obras completas, Buenos Aires. Carlos Lohlé, 1981, tomo 2, pp. 525 y 524 respectivamente.
} 
En otro lugar, el autor alecciona a sus personajes:

PEDRO. -Fantasmas modelados por mi mente, escúchenme: Necesito que expresen un amor ardiente e inverosímil, con palabras que jamás seres humanos utilizan en la comunicación de sus deseos. Yo no creo en la eficacia de esos ramilletes de doradas mentiras, pero la gente que acude a los teatros va en busca de lo que no existe en sus vidas. ${ }^{52}$

Obras creadas para satisfacer un interés comercial, distancia "inverosímil” de lo real en la expresión amorosa y "doradas mentiras" con que se engañan las expectativas del público, los pasajes constituyen una crítica respecto de los vulgarizados códigos expresivos del teatro comercial. En el último caso, además, lo expresado sirve de introducción a un diálogo en el que por medio de la distancia paródica, se impugna la retórica modernista y melodramática del teatro comercial y sus personajes tipo - el galán y la primera actriz- como formas posibles de identificación del espectador. ${ }^{53}$ Este mecanismo es similar al que aparece en la escena III del Galán y la Sirvienta en Trescientos Millones, cuando la Sirvienta le reprocha al Galán su modo de hacer la “comedia amorosa” y le dice: “¡No se enoje, hombre!...Pero, usted es bastante estúpido como galán. ¿A quién se le ocurre decirle a una mujer: ¡Te amo! Eso se dice en el teatro; en la realidad se procede de otra manera. ${ }^{, 54}$ De este modo, a la vez que se critican los lugares comunes del teatro, se muestra la insatisfacción del personaje (y, por lo tanto, su imposible felicidad ante las potencialidades de lo real) frente a una declaración amorosa (la del Galán) que no se inscribe en sus expectativas (reductivas y reductoras), moldeadas por su bovarismo de lectora de folletín. ${ }^{55}$

${ }_{52}$ Arlt, Roberto. El fabricante de fantasmas, Op. Cit., p. 495. El subrayado es nuestro.

${ }^{53}$ En un momento Pedro se dirige a Sustituto y le da indicaciones para sus diálogos con Martina que ponen en evidencia los procedimientos típicos de la figura del galán. Como puede verse en el siguiente fragmento: "Pedro ([...] al SUSTITUTO). — Engáñala atrevidamente. No ahorres promesas. Júrale que ansías ser su esclavo, simula durante un tiempo que obedeces a sus más íntimos caprichos, como si fueras un hombre sin carácter. La mujer ha sido siempre una esclava, por consiguiente, su secreto y fundamental deseo es tiranizar al amo. Emborracha su vanidad. La más tonta entre las tontas toca la luna con su pretensión. Sé duro, hipócrita, dulce e implacable. Guantes de terciopelo, pero el látigo bajo el brazo." Arlt, Roberto. El fabricante de fantasmas, Op. Cit., pp. 496-497.

${ }_{54}^{54}$ Arlt, Roberto. Trescientos millones, en Obras completas, Op. Cit., p. 414.

${ }^{55}$ Esto es evidente en el siguiente fragmento:

"GALÁN (de pie junto a la mecedora). — Señorita..., señorita...

SIRVIENTA. - ¡Ah! ¿Es usted? 
De todas maneras, Arlt no se asimila del todo a la propuesta de Barletta, como puede verse muy claramente en el caso de África, uno de los dramas más ficcionales de Arlt aunque, paradójicamente es, a la vez, el que tiene, junto con Trescientos millones, su punto de partida en sucesos reales: ambos nacen de la experiencia del cronista, en un caso como cronista policial del diario Crítica y en otro como cronista de viajes. ${ }^{56}$ En una nota previa a su estreno puede leerse muy claramente cómo Arlt postula, defiende y promueve un plan para su obra que se separa de la propuesta de Barletta a favor de un teatro pedagógico. Allí expresa:

Evidentemente, todo autor que escribe una obra en seis actos se propone demostrar algo, pero yo, aparte de la conclusión de carácter psicológico que permite desprender de África el final de la anécdota

GALÁN (lentamente). —Sí, soy yo..., soy yo...

La SIRVIENTA lo mira un instante y luego resuelve seguir el juego de la comedia amorosa.

SIRVIENTA. - ¡Ah! ¿Es usted..., es usted...?

GALÁN. - ¿Me permite decirle que la amo?

SIRVIENTA (con dulzura irónica). — ¿No podría decírmelo de otra manera?

GALÁN (sorprendido). — ¿Por qué?

SIRVIENTA (siempre con su modito irónico). - Porque de esa manera se me han declarado varios dependientes de tienda, farmacia y panadería.

GALÁN. — ¡Oh, no me compare!...Usted desea que yo sea un escogido.

SIRVIENTA. - Sí...un poco más expresivo. [...]

GALÁN. - ¡Oh! Entonces lo que usted me pide es un procedimiento de novela alemana...

SIRVIENTA (terminante). - No he leído nunca novelas alemanas. He leído "Rocambole", que es bien largo..., cuarenta tomos..., y nada más... [...]" Y sigue la obra, después de otros desaciertos del Galán:

"GALÁN. - La amo desde que la vi en el comedor. Y me juré interiormente que si usted me daba su mano la haría mi esposa ante Dios y los hombres.

SIRVIENTA. - ¿Por qué no habla de otra manera? Si yo fuera hombre me declararía de otra forma...

GALÁN (malhumorado). — ¿Puede decirme qué papel hago yo aquí? ¿Soy yo o es usted la que se tiene que declarar?

SIRVIENTA. - ¡No se enoje, hombre!... Pero usted es bastante estúpido como galán. ¿A quién se le ocurre decirle a una mujer: ¡Te amo!? Eso se dice en el teatro; en la realidad se procede de otra manera. En la realidad, cuando un hombre desea a una mujer, trata de engañarla. Lo creía más inteligente. A nosotras las mujeres nos gustan los desfachatados...”. Véase: Arlt, Roberto. Trescientos millones, Op. Cit., pp. 413-414.

${ }^{56}$ En el caso de Trescientos millones Arlt enfatiza esa adscripción al periodismo porque publica la obra con un prólogo, "A modo de explicación", donde aclara la procedencia "real" de su drama teatral: "Siendo reportero policial del diario Crítica, en el año 1927, una mañana del mes de septiembre tuve que hacer una crónica del suicidio de una sirvienta española, soltera, de veinte años de edad, que se mató arrojándose bajo las ruedas de un tranvía que pasaba frente a la puerta de la casa donde trabajaba... [...] De esa obsesión, que llegó a tener caracteres dolorosos, nació esta obra, que posiblemente no hubiera escrito de no haber mediado Leónidas Barletta." Véase: Arlt, Roberto. Trescientos millones, Op. Cit., p. 393. 
entretejida en ella, lo que he querido es exaltar la maravillosa fiesta de colorido que deslumbra al turista cuando pone los pies en Marruecos. ${ }^{57}$

En este texto, Arlt se distancia del énfasis en lo pedagógico para exaltar, enérgicamente, el colorido del espacio africano. Pero la oposición a la idea del teatro de Barletta se da en la obra también en otros sentidos: África no sólo no presenta contenidos de preocupación y debate ideológicos ni se piensa con una finalidad didáctica sino que podría caracterizarse como "teatro de entretenimiento", "de evasión" y "fiesta de color", rasgos que, como vimos y tal como Barletta mismo afirma en su libro Viejo y Nuevo teatro, se contraponen a su proyecto dramático:

Hay quienes hacen, dicen o leen poesía y viven una vida miserable. ¡Como si el objetivo final fuese la poesía y no la vida! Hay quienes tiemblan por encontrar una consonante delicada y no tiemblan frente a la injusticia o la crueldad. [...]

No se puede ya considerar el arte como un pasatiempo o simple recreación. Hay que rechazar indignados el arte sin pretensiones, que nada dice a la mente o al corazón. [...]

Es misión del arte sensibilizar al hombre, haciendo imposibles las guerras, impulsando a los pueblos hacia la felicidad, excitando el espíritu de justicia, desvaneciendo la ignorancia, fomentando una vida superior. ${ }^{58}$

En efecto, la obra contradice las premisas de Barletta pues, en primer lugar, el acento en ella está puesto en los modos más o menos estéticos de su construcción. África es "fiesta de color" y el texto evidencia, en muchos momentos, una inquietud estética que prevalece reiteradamente sobre otras preocupaciones también presentes. ${ }^{59}$ Un ejemplo claro de esto se da cuando uno de sus personajes destaca la simetría de la pieza y afirma: "Él me entrega a su mujer y a mi vez yo lo entrego a él a Hussein [...] $N i$

\footnotetext{
${ }^{57}$ Nota publicada en vísperas del estreno de África, reproducida en Castagnino, Raúl. El teatro de Roberto Arlt, La Plata, UNLP, 1964.

${ }^{58}$ Barletta, Leónidas. Viejo y nuevo teatro, Op. Cit. p. 13.

${ }_{59}$ África comparte la preocupación estética con otras como la de representar una "sangrienta historia" y una "historia terrible", es decir con lo que remite a aquellos episodios que surgen de los prejuicios del imaginario occidental sobre Oriente
} 
un jefe de conversación podría imaginar una trama mejor", 60 fragmento que revela no sólo la importancia y el interés de Arlt sobre cómo representar, sino que además pone de manifiesto lo que se considera un hallazgo en la composición del texto y la importancia que tiene para Arlt una trama bien contada a fin de lograr un efecto en el espectador. ${ }^{61}$ En segundo lugar, África también se separa de los postulados de Barletta porque a partir de tres lugares comunes del imaginario orientalista - traición, venganza y crimenconstruye una historia de aventuras, policial, de suspenso ${ }^{62}$ y espionaje. Esta elección constructiva y temática de Arlt, por su parte, resulta novedosa para el teatro de la época ya que vincula su producción teatral con el clima de ideas y de conspiración internacional inmediatamente previo al conflicto bélico: África es de $1938 .{ }^{63}$ Es decir, no hay nada que permita leer aquí una motivación que acerque el texto a una finalidad pedagógica o de denuncia social —ni siquiera una interpretación que subraye la crítica de Arlt a algunas condiciones negativas de la vida en África, pues la fascinación ante lo representado socava tal crítica- Por otra parte, podemos decir que esta trama de espionaje, aventuras y policial puede asociarse, en el caso de Arlt, con la búsqueda de espectadores para su teatro. Esto es así porque para él, y tal como afirma en una de sus aguafuertes haciendo un diagnóstico sintomático de la literatura de circulación masiva del momento, el argumento policial es condición incuestionable de venta y asegura un

${ }^{60}$ En otro lugar también se afirma algo similar: "Es curioso cómo nos liga el destino. Tú me das la dirección de la persona a quien odio, yo te facilito el medio de llegar junto a la persona contra la que tienes que ejecutar tu venganza". Arlt, Roberto. África, Op. Cit.

${ }^{61}$ En una de sus crónicas de la "Vida teatral", Arlt critica, con un diálogo teatral, una de las piezas justamente por la incoherencia entre los distintos cuadros, como puede verse en el siguiente ejemplo: "Hombre del vestíbulo.- El primer cuadro no tiene nada que ver con el segundo ni el tercer cuadro. Sólo al final, para justificar el primer cuadro, se trae por los pelos y de tan mala manera, a los tres personajes del primer cuadro, que la gente se ríe de lo inusitado para no protestar pidiendo que le devuelvan la plata.

Hombre de la calle. - Es maravilloso, porque yo, a mi vez, observé que el tercer cuadro no tiene nada que ver con el segundo, ni el segundo con el primero.

Hombre del vestíbulo.- Un bodrio..." Véase: Arlt, Roberto. "La República de la Boca', en el Monumental. Tres cuadros de Florencia Chiarello", en El Mundo, 7 de junio de 1933. Aguafuertes teatrales escritas en la sección "Vida Teatral".

${ }^{62}$ En una de sus pocas críticas favorables como cronista en la columna de El Mundo "Vida teatral", a propósito de La llama sagrada, un drama de un autor extranjero, Sommerset Maughan, representado en el Teatro Corrientes, Arlt valora, justamente, como sostiene Sylvia Saítta, que se trata de "un melodrama perfectamente construido, tan interesante como una novela policial, cuya intriga se sostiene hasta el final produciendo emoción y suspenso." Véase: Saítta, Sylvia. "Desde la butaca: Roberto Arlt, crítico teatral", Op. Cit., p. 118. El artículo de Arlt en cuestión es: Arlt, Roberto. "La llama sagrada en el Teatro Corrientes", en El Mundo, 22 de abril de 1933.

${ }^{63}$ Volveremos más adelante sobre la cuestión del espionaje. 
público y un lugar en el mercado: "Torriglia, _afirma Arlt en la nota mencionada, a propósito de un criminal que compara con Edgar Wallace- que se pasó la vida embaucando y estafando, tiene la posibilidad de ganar dinero sin necesidad de meterse en tantos líos y cementerios, y su chance consiste en escribir novelas policiales". ${ }^{64}$ Es significativo, entonces, que África refiera una intriga policial y de espionaje y es posible conjeturar, además, que en esta elección Arlt apela a un público entrenado en literatura de evasión y entretenimiento (el folletín policial y la literatura detectivesca eran una lectura masiva en ese entonces, promovida también desde los espectáculos radiales y el cine, que asimismo llenaba la pantalla con aventuras de espías ${ }^{65}$ y también a los espectadores del teatro criticado por Barletta, "ávidos de sensaciones morbosas". ${ }^{66}$

Cabe destacar, en este punto, el modo en que Arlt promociona y presenta ante los lectores y el público dos de sus obras. En el primer caso se trata de la nota publicada en momentos preliminares al estreno de El fabricante de fantasmas. En un fragmento en el que explicita cuál es el "asunto del drama", Arlt promete a los lectores del diario que su pieza pondrá en escena lo que puede definirse como un cruce entre intriga policial, psicológica y sentimental: "un hombre asesina a su esposa, ignorando los procesos subterráneos que provocan esa terrible y oscura fuerza denominada Remordimientos. Pero pronto los Remordimientos van a buscar al criminal y bajo la forma de fantasmas lo atacan, lo persiguen [...] hasta obligarlo, después de una refinada tortura a matarse del mismo modo que asesinó a su mujer". ${ }^{67}$ En segundo lugar, interesa observar la nota explicativa que Arlt agrega cuando publica por primera vez Trescientos millones. Allí, además de anunciar, como dijimos, que esta obra parte de su experiencia como cronista policial en el diario Crítica, hace una descripción de la pieza que la asimila a una intriga policial: el sujeto de la enunciación de este breve excursus se presenta a sí mismo como si fuera el detective que pone frente a su público un acto delictivo cuya investigación referirá: "Llegué al lugar del hecho. [...] Posiblemente no hubiera dado ninguna importancia al suceso [...] si investigaciones que efectué posteriormente... [...] Un

\footnotetext{
${ }^{64}$ Arlt, Roberto. “Un protagonista de Edgar Wallace', en El Mundo, 23 de junio de 1937.

${ }^{65}$ Volveremos sobre estos temas en el capítulo 5: "Historias infames y ficciones criminales"

${ }^{66}$ Barletta, Leónidas. Viejo y nuevo teatro, Op. Cit., p. 22.

67 "Habla Roberto Arlt sobre la obra que estrenará mañana (El fabricante de fantasmas)", en El Mundo, 7 de octubre de 1936, reproducido en Castagnino, Raúl. El teatro de Roberto Arlt, Op. Cit.
} 
examen ocular permitió establecer...". ${ }^{68}$ Así, en las operaciones que atraviesan los dos textos anteriores, pueden leerse distintas formas por las que Arlt piensa y promueve un proyecto teatral que no se define precisamente desde lo pedagógico y que intenta procurar -igual que en el caso de África- un público de futuros espectadores o lectores.

De todo lo anterior puede verse, asimismo, el modo en que se presentan inquietudes formales - por ejemplo, cómo debe escribirse y estructurarse una obra teatral- (más bien ausentes en el periodo anterior de la literatura de Arlt) y búsquedas e intereses estéticos en la literatura, como se observa en la carta que Arlt escribe a su madre después de la representación de África, donde expresa que lo emociona "ver la gente aguantarse 2 horas de plantón en el paraíso", que la obra tiene "un color que tira de espaldas de tan bonito" y que "Además hay momentos en que se siente una música árabe lejana, lo cual crea una atmósfera poética seductora", ${ }^{69}$

Si tenemos en cuenta que en los años treinta, tal como bien observaba Barletta, era incipiente el teatro nacional y a excepción de unos pocos de los jóvenes pertenecientes a las vanguardias de los años veinte, nucleados ahora en torno a Barletta (como Nicolás Olivari, Raúl González Tuñón y el propio Arlt), los escritores reconocidos, o con cierto reconocimiento y visibilidad entre los autores del circuito alto de la época, no escribían obras de teatro, (como tampoco, por ejemplo, los escritores más representativos de Sur), ${ }^{70}$ es posible conjeturar que, en aquel entonces, este género podía funcionar (para Arlt, y también para Barletta y los que participaban del Teatro del Pueblo) como un lugar potencialmente viable en tanto espacio de producción nacional, para permitir el predominio en un sector de las letras argentinas. Podría pensarse entonces, que con el teatro, en tanto zona inexplorada y posición estética a ocupar, Arlt intente adoptar un proyecto por el cual procura acceder a un mayor caudal de capital simbólico, mayor que el que, por ejemplo, puede darle la cuentística. Si esto es así, ${ }^{68}$ Arlt, Roberto. Trescientos millones, Op. Cit.

${ }^{69}$ Carta reproducida en Borré, Omar. Arlt y la crítica, Op. Cit., pp. 157- 158. El subrayado es nuestro.

${ }^{70}$ María Teresa Gramuglio sostiene que Victoria Ocampo (que quería ser actriz de teatro) habría ayudado a financiar el Teatro del Pueblo de Barletta; pero en Sur, si bien eran acogidos con éxito dramaturgos que modernizaron el teatro a nivel mundial, sus escritores más representativos, Mallea, Borges, no incluían el teatro como práctica. Véase: Gramuglio, María Teresa. "Posiciones, transformaciones y debates en la literatura", en Crisis económica, avance del Estado e incertidumbre política (1930-1943), tomo VII de la Nueva Historia Argentina dirigido por Alejandro Cataruzza, Buenos Aires, Sudamericana, 2001. 
parece haber una contradicción cuando se considera la relación cercana que, gracias al teatro, Arlt pretende establecer con el público. No obstante, en la combinación de interés estético y preocupación por mantener un público amplio es donde se perfilan los modos de funcionamiento de la literatura de Arlt en la época; en otros términos, el drama es una instancia doblemente buscada, ya que, por favorecer una relación directa con el espectador, le permite mantener aquí el lugar que ya había conseguido entre el público con las aguafuertes - recepción que, por otra parte, no se había repetido en el caso de sus novelas ni lo estaba haciendo en sus cuentos- y, al mismo tiempo, es en potencia una zona estratégica y aprovechable en los intentos de procurar una posición más alta en el campo literario, pues implica la posibilidad, no explotada por muchos escritores, de enaltecer la escena nacional mediante la introducción de elementos de un verdadero y nuevo arte dramático. Eso explicaría los pasajes y la reescritura de la ficción por el teatro que Arlt lleva a cabo con los argumentos de sus cuentos "Rahutia la bailarina" (1937) y "La aventura de Baba en Dimisch esh Sham" (1937), en el caso de Africa (1938), pues si como narraciones eran pensadas para un destinatario, como obras de teatro le permiten, aunque más no sea imaginariamente, el alcance de un público mayor, ${ }^{71}$ o un público distinto, pues también Arlt publica como relato en El Hogar, posteriormente al estreno de su obra La isla desierta, un cuento (inédito en libro en la actualidad y absolutamente desconocido) que retoma y reitera las líneas principales de esa pieza teatral, como veremos. ${ }^{72}$

En una serie de pequeños ensayos que Arlt publica en el diario El Mundo alrededor de los años cuarenta, ${ }^{73}$ aparecen ciertas posturas que sugieren razones para vincular la pretensión de un público amplio y la elección del teatro como el espacio propicio para ello. Una justificación adecuada es su consideración de la acción como el

${ }^{71}$ Sobre este aspecto volveremos en el segundo capítulo, en el apartado sobre África.

${ }^{72}$ Véase: Arlt, Roberto. "El hombre del tatuaje", en El Hogar, 30 de septiembre de 1938. Este cuento, inédito en libro en la actualidad no se incorporó en la edición de Piglia y Omar Borré de Cuentos completos.

${ }^{73}$ Se desarrollará un análisis detenido de estos artículos en el capítulo 6, "Arlt y la polémica sobre la novela". Dentro del conjunto de estos textos, los más importantes son: "Vidas paralelas de Ponson de Terrail y Edgar Wallance" (El Mundo, 20 de agosto de 1940), "Aventura sin novela y novela sin aventura" (El Mundo, 13 de agosto de 1941), "Confusiones acerca de la novela" (El Mundo, 22 de agosto de 1941), "Galería de retratos" (El Mundo, 6 de septiembre de 1941), "Irresponsabilidad del novelista subjetivo" (El Mundo, 2 de octubre de 1941), "Acción, límite de lo humano y lo divino" (El Mundo, 7 de octubre de 1941), "Literatura sin héroes" (El Mundo, 13 de octubre de 1941). También recopiladas en Arlt, Roberto, Aguafuertes porteñas: cultura y política. Op Cit. pp. 238 y ss. 
principal elemento garantizador de lectores y espectadores atentos. Esto es fundamental en el caso del drama y le sirve de sustento, pues el teatro permite, por definición, la puesta en escena de la "acción pura". Por otra parte, la elección arltiana de "la acción" resulta aquello que mantiene el contacto entre escritor y receptor y evita que la literatura derive en una "Galería de retratos" que conducen al embotamiento del lector. Y si bien estas crónicas se refieren a los personajes novelescos, en ellas despuntan, de todas maneras, las preocupaciones del dramaturgo, y en la argumentación se confunden reiteradas veces, lector y espectador, dramas y novelas:

Los teóricos confunden, generalmente, la decadencia de la novela con la decadencia de la capacidad de reacción del personaje novelesco"; "Los teóricos de la novela [...] dijeron: 'En la novela moderna, el personaje actúa sobre el lector por simple presencia, sin necesidad de accionar'. Género estático de influencia denominado catálisis en química. Actualmente ciertos teóricos suponen que el personaje inmóvil actúa sobre el lector como un agente catalítico, acelerando el proceso de comprensión entre el hombre y la vida [...] En la novela, el procedimiento de catálisis por simple presencia es absurdo y antinovelístico. $^{74}$

Y en otra crónica, Arlt sostiene:

Es evidente que cuando un personaje no reacciona, no suscita contra sí la resistencia del medio, y la falta de acción y de reacción es lo que determina la ausencia del suceso dramático y sus secuelas, la conmoción nerviosa.

Hoy los autores tratan de justificar la omisión dramática, asegurando que la acción dramática ha quedado transferida al contenido filosófico o poético de un diálogo dado, pero lo evidente es que el lector se aburre y arroja la novela o se levanta de su butaca y se marcha maldiciendo.

Generalmente el autor, frente a este suceso, insiste que el carácter de su obra, pese a la actitud del espectador, tiene la acción del diálogo y la belleza del diálogo, asegurando además, mediante todos los vehículos de publicidad a su alcance, que el drama y la novela contemporáneos se caracterizan por la particularidad de la falta de acción.

Lo cual es cierto.

${ }^{74}$ Arlt, Roberto. "Confusiones acerca de la novela", Op. Cit., p. 245 y 248. 

negativa. $^{75}$

El drama y la novela contemporáneos ofrecen esta característica

Como puede verse en la cita, Arlt hace aquí una fuerte defensa del efecto, de la “acción” y "reacción” de los personajes como medio de captación de un público. Se busca, además, provocar "la emoción en el espectador" con esa "acción dramática"”, ${ }^{76}$ Eso garantiza, espectadores y lectores: “algún día se logrará definir matemáticamente la constante de acción de un personaje novelesco dividiendo el número de ediciones de los libros en que este personaje ha figurado, por el número de años que demoraron en venderse". ${ }^{77}$ En vísperas del estreno de La fiesta del hierro, Arlt escribe una nota en El Mundo donde puntualiza sus principales intereses, que, claramente, coinciden en muchos sentidos con los postulados anteriores: "Estoy satisfecho de haber estructurado una acción, cuya congénita dramaticidad es su más alta virtud. ¡Sorpresa curiosa para el autor! Argumentos hay que nacen completamente anémicos de sustancia dramática; otros, en cambio, aparecen pletóricos de vigor trágico." 78

Ahora bien, aunque en este recorrido se puedan ver distintos modos en que se define la dramaturgia de Arlt -interés en la construcción de la obra del teatro, preocupación por captar la atención del lector, búsqueda del entretenimiento y el color-, algunos de los cuales la distancian de la propuesta didáctica de Barletta, no queda claro aún cuál es la relación que el escritor pretende establecer con el espectador y de qué modo piensa su vínculo con el público. Una aguafuerte africana titulada "El narrador de cuentos" permite reflexionar sobre esta cuestión. El texto describe con deleite una escena que se suscita en las calles de Tánger entre el “xej-el clam”, es decir,

\footnotetext{
${ }^{75}$ Arlt, Roberto. "Acción, límite de lo humano y lo divino", Op. Cit., p. 257.

${ }^{76}$ Arlt, Roberto. "Acción, límite de lo humano y lo divino", Op. Cit. Si bien Arlt pone el énfasis en el efecto sobre el público y no tanto en lo pedagógico, esta búsqueda de la "emoción en el espectador" es paralela a algunas proposiciones expresadas por Barletta en Viejo y nuevo teatro. Allí, por ejemplo, Barletta afirmaba que el público del teatro de arte tenía la "ventaja de llevar consigo el instante de emoción que la cosa de arte le ha procurado". Véase, Barletta, Leónidas. Viejo y nuevo teatro, Op. Cit., p. 23.

77 Arlt, Roberto. "Confusiones acerca de la novela", Op. Cit., p. 248.

${ }^{78}$ Véase: Arlt, Roberto. "Habla Roberto Arlt sobre la obra que estrena el jueves", en El Mundo, 16 de julio de 1940. Allí, además expresa Arlt: "El mérito de mi nueva farsa dramática 'La fiesta del hierro' consiste en que aunque estuviera mejor o peor escrita, no por ello dejaría de cumplir con la estricta obligación de la obra teatral consistente: $1^{\circ}$, fijar con rapidez la atención del espectador en una situación a venir, provocada por los personajes. $2^{\circ}$, suscitar un creciente movimiento de curiosidad en su intelecto ante las posibles derivaciones de la intriga. $3^{\circ}$, en emocionarle por el destino que acecha a los protagonistas."
} 
el narrador de cuentos, y los espectadores que escuchan su relato. La fascinación que transmite el cronista por esta escena — de la que afirma, por otra parte, que remite al "nacimiento del teatro antiguo"-, se genera sobre todo a partir de la situación comunicativa allí presentada. El "xej" pronuncia su historia y una multitud atenta reacciona y se introduce de tal modo en la ficción que actúa frente al espectáculo como frente a la realidad:

En medio de este círculo de piedra, está el narrador de cuentos [...] Narra un cuento en idioma árabe. Pronuncia media docena de palabras y nuevamente golpea tres veces el fondo del tam-tam. [...] Toma la vara y señala un punto en el suelo de piedra. Los espectadores vuelven los ojos a ese punto y menean la cabeza afirmativamente como si vieran allí algo que confirma las palabras del narrador. [...]...vertiginosamente su mano se extiende al cielo, pronuncia unas palabras y rápidamente todos los espectadores se llevan los dedos de la mano derecha a los labios y a la frente. Ha pronunciado el nombre de Dios. [...]...ahora el narrador habla en voz baja, debe reproducir un diálogo al oído de alguien. [...] todos mueven la cabeza asintiendo a esa voz que murmura quedo [...] De pronto el narrador levanta la voz, pronuncia tres palabras y todos estallan en carcajadas. Algo aquí ha ocurrido; el xej se encorva, su cara llena de terror, su palo se mueve en el aire. Evidentemente, está combatiendo con un espiritu invisible; todos contemplan espantados al enemigo con el cual batalla el narrador. ${ }^{79}$

La admiración con que se describe cómo esa multitud entra en la ficción, explica, en buena medida, lo que pretende Arlt con su teatro. La aguafuerte revela que su interés está orientado por lo que las potencialidades de la representación favorecen: un contacto directo con el público y la participación del espectador en lo representado. Lo que se acentúa si se tiene en cuenta que Arlt-cronista no entiende el enunciado del narrador (que habla en árabe) y cuenta la escena como si ese problema lingüístico no existiera, porque lo único que le interesa es la situación preformativa. En otros términos, más que la potencia pedagógica a la que aspiraba Barletta (y la claridad del mensaje que cada obra debía procurar), es ese tipo de enunciación privilegiada lo que Arlt busca en

\footnotetext{
79 Arlt, Roberto. "El narrador de cuentos", en Aguafuertes españolas, Buenos Aires, Rosso, 1936, p. 92-93. Cursivas nuestras.
} 
el teatro y un tipo de efecto dramático que provoque la "reacción" del público y su activa participación.

De todos modos la cuestión de lo pedagógico es un tema no resuelto que recorre el teatro de Arlt. En casi todas sus piezas dramáticas, desde Saverio el cruel, El fabricante de fantasmas, Trescientos millones, a El desierto entra a la ciudad hay un interrogante que las atraviesa y que podría sintetizarse en la pregunta sobre cómo el orden de la ficción, la irrealidad, la fantasía, los sueños, la simulación, la literatura, actúan en el orden de lo real. Esa pregunta, que es fundamento del argumento de muchas de sus obras - lo es de Saverio el cruel, El fabricante de fantasmas, y de Trescientos millones - y tiene que ver con la potencia pedagógica del teatro y con la función del teatro y la literatura, en sus textos siempre queda abierta. Si se esboza una solución, —como en Trescientos millones y también, de algún modo en Saverio el cruel - esta parecería más bien demostrar que ese orden de la ficción, de la irrealidad y de la representación no tiene o difícilmente pueda tener consecuencias positivas en el orden de lo real. De esta manera, frente al optimismo social de Barletta respecto del mensaje que el teatro puede transmitir en el espectador, la visión de Arlt es, por momentos, ambigua y desencantada, y en sus obras se cuestiona, en un gesto vanguardista, la función del teatro "como institución", ${ }^{80}$ a diferencia de la postura tímida que, en este sentido, sostiene Barletta. ${ }^{81}$

Trescientos millones es una obra que responde a estos problemas. Aquí Arlt pone de manifiesto que el arte o, más precisamente, la literatura de folletín que lee la Sirvienta, es una alternativa al mundo real, tiene una función crítica frente a la realidad opresiva del personaje, y proporciona una opción, pero al mismo tiempo muestra esa opción como inútil y peligrosa: la Sirvienta no logra compensar con sus lecturas de Rocambole la situación en que vive, y se suicida. En una aguafuerte titulada "La inutilidad de los libros", parece proponerse la misma consideración y Arlt aconseja a su lector: “...ningún libro podrá enseñarle nada. [...] Lo que hacen los libros es desgraciarlo al hombre, créalo. No conozco un solo hombre feliz que lea. [...] Si hubiera un libro que

\footnotetext{
${ }^{80}$ Véase, a este respecto. Bürger, Peter. Teoría de la vanguardia, Barcelona, Península, 1997.

${ }^{81}$ Pelllettieri sostiene que el Teatro del Pueblo y la postura de Barletta no llegan a ser vanguardistas, entre otras cosas, porque no se cuestiona el teatro como institución; lo que sí se logra, para este autor es una modernización de la escena nacional. Véase: Pellettieri, Osvaldo. "Algunos aspectos del 'teatro de arte' en Buenos Aires", Op. Cit.
} 
enseñara [...] ese libro estaría en todas las manos". ${ }^{82}$ En este sentido, Trescientos millones es una obra que claramente cuestiona la función del arte y la literatura en la sociedad. En tanto que aquí se pone en duda el carácter positivo del "mensaje" que la literatura puede ofrecer -y también el teatro- se cuestiona su capacidad como mecanismo didáctico y su incidencia social. Si bien esto es verdad, hay otro modo posible de considerar este texto. Según este otro enfoque, que convive con el anterior y lo problematiza, es viable leer en Trescientos millones una intención pedagógica: la pieza pone en escena una tesis social que apunta a mostrar el sufrimiento de la sirvienta, su opresión en el mundo del trabajo, y el riesgo de la evasión por los sueños y la imaginación. Pero aún si consideramos la pieza como denuncia, es importante destacar que el modo en que la expresa se distancia marcadamente de las formas de representación realista y propone un interesante cruce entre ideología y estética, fantástico y tesis social. ${ }^{83}$ Es decir, aquí, lo fantástico, el sueño materializado de ganar trescientos millones, funciona en tanto que motivación de la crítica ideológica y de la denuncia social, y de ese modo la obra entabla una discusión con el realismo.

Es de esta manera que puede verse en el teatro cierta preferencia por las poéticas de la irrealidad, del extrañamiento y de las rupturas del verosímil realista, que se distancian de un modo más contundente, del realismo también poco convencional de sus textos previos, atravesados por situaciones alucinatorias, procedimientos expresionistas e imágenes futuristas en la construcción del espacio. ${ }^{84}$ Así, en Trescientos millones — pieza que se inaugura con la presencia escénica de "personajes de humo"- y en $E l$ fabricante de fantasmas no sólo aparecen protagonistas que discurren sobre su propia ficcionalidad y son sabedores de su ser de ficción en un sentido macedoniano, sino

${ }^{82}$ Arlt, Roberto. "La inutilidad de los libros", en El Mundo, 26 de febrero de 1930. Recopilada en Arlt, Roberto. Aguafuertes porteñas, Buenos Aires, Losada, 1958.

${ }^{83}$ Así, según José Amícola, Arlt “.....no quería dejar de señalar constantemente el peligro que resultaba del hecho de perder pie con lo concreto. Y la fantasía serviría en su obra como recurso para desenmascarar las implicaciones de la realidad." Amícola, José. Astrología y fascismo en la obra de Arlt, Buenos Aires, Weimar ediciones, 1984, p. 107.

84 Véanse, a este respecto: Renaud, Marise. "Los siete locos y Los Lanzallamas: audacia y candor del expresionismo", y Jitrik, Noé. "Un utópico país llamado Erar", en Arlt, Roberto. Los siete locos-Los Lanzallamas, Edición crítica, Colección Archivos, Mario Goloboff coordinador, Francia, ALLCA XX, Université Paris X, 2000. También pueden consultarse: Capdevila, Analía. "Las novelas de Arlt. Un realismo para la modernidad", en Gramuglio, María Teresa (directora). El imperio realista. Historia crítica de la literatura argentina (dirigida por Noé Jitrik), Op. Cit.; y Amícola, José. "Fritz Lang, Alfred Döblin y Roberto Arlt”, 2007, mimeo. 
también, caracteres que se independizan de su creador, se rebelan a sus designios y se muestran en su cualidad de "fantasmas" o en su irrealidad literaria, lo que también remite, ciertamente a Pirandello. En estas obras se da, entonces, un giro nuevo sobre algunos procedimientos y tópicos que aparecían en las novelas de Arlt (desdoblamientos, alucinaciones), más cercano a lo fantástico en tanto forma de cuestionamiento del orden de lo real. ${ }^{85}$ En El fabricante de fantasmas, por lo demás, aparece la conciencia del autor teatral, Pedro, hecha personaje, y esa conciencia corporiza los "terrores" de una mente "afiebrada". Esto se acentúa por la identificación, comentada más arriba, entre Pedro y Arlt escritor, que subraya y replantea en la pieza la confusión de los límites, que la obra manifiesta, entre mundo ficcional y realidad, como también aparece en las postulaciones de Macedonio Fernández y se inscribe, como es sabido, en la literatura de Borges.

A este respecto, interesa considerar, asimismo, el modo en que en La isla desierta se sobreimprime sobre la tesis social que las representaciones de Barletta en el Teatro del Pueblo trataban de enfatizar, ${ }^{86}$ una escena inquietante que quiebra, altera y cuestiona en la pieza el orden convencional y opresivo de lo real. Como es sabido, la obra se inicia con una escena caracterizada por una extrema luminosidad entre un grupo de empleados que trabajan como "reclutas" y "encorvados" en una oficina donde se ven a través de los ventanales los buques que pasan. La luz intensa incita a vislumbrar lo que estaba oculto cuando los oficinistas trabajaban en el subsuelo, y por ello inquieta a los que la ven: “¿Para qué queremos tanta luz?”, dice uno de los personajes, “el jefe” —que es quien no ve en la pieza - "usa anteojos negros". En un momento, y con Cipriano, "exquisito y brutal", personaje que ha viajado por islas desiertas, se introduce en el espacio "civilizado" de la oficina una legalidad ajena, "arcaica", simiesca, que cuestiona y desestabiliza las convenciones: los bárbaros no son los que viven en la selva sino los oficinistas, a quienes se caracteriza como "bestias". De tal modo, con la danza de Cipriano irrumpe en ese espacio convencional de la oficina un orden desconocido que se acerca a lo que Freud llama inquietante o siniestro (das unheimlich): es decir, aquello que, familiar en el pasado y susceptible de ser reprimido, irrumpe en lo

${ }^{85}$ Véase: Jackson, Rosemary. Fantasy: literatura y subversión, Buenos Aires, Catálogos editora, 1986.

${ }^{86}$ Véase: Pellettieri, Osvaldo. "El Teatro del Pueblo y sus puestas de los textos de Robeto Arlt", Op. Cit. 
cotidiano y le da forma al deseo inconsciente que, tal como sostiene Rosemary Jackson, es lo que se tematiza en el fantástico moderno: ${ }^{87}$

(El mulato toma la tapa de la máquina de escribir y comienza a batir el tam tam ancestral al mismo tiempo que oscila simiesco sobre sí mismo. Sugestionados por el ritmo, van entrando todos en la danza.)

MULATO (a tiempo que bate el tambor).- - Y también hay hermosas mujeres desnudas. [...] Y hermosos hombres desnudos. Que bailan bajo los árboles, como ahora nosotros bailamos aquí...

La hoja de la bananera

De verde ya se madura

Quien toma prenda de joven

Tiene la vida segura

(La danza se ha ido generalizando a medida que habla el Mulato, y los viejos, los empleados y las empleadas giran en torno de la mesa, donde, como un demonio gesticula, toca el tambor y habla el condenado negro) [...]

(Histéricamente todos los hombres se van quitando los sacos, los chalecos, las corbatas; las muchachas se recogen las faldas y arrojan los zapatos. El Mulato bate frenéticamente la tapa de la máquina de escribir y cantan un ritmo de rumba) ${ }^{88}$

De esta forma, cuando el grupo "histéricamente" se despoja de la ropa y deja las actividades en la máquina de escribir, (eso que los unía a la civilización y a la vida de "reclutas" de la oficina), impera otro orden, vinculado con el imaginario aventurero (“-Usted se ha convertido en Simbad el Marino", le dice Cipriano a Don Manuel), lo ancestral y el desierto, que también en El desierto entra a la ciudad se propone como una alternativa a la esclavitud del mundo urbano, el jefe y la oficina. Cabe destacar, finalmente que en "El hombre del tatuaje", la versión narrativa de esta pieza teatral, el orden de lo siniestro se acentúa cuando se sugiere que los barcos "traen brujería" ${ }^{89}$

\footnotetext{
${ }^{87}$ Es, por ejemplo, el tipo de relato fantástico que aparece en muchos de los textos de Viaje Olvidado (1937) de Silvina Ocampo y en las narraciones posteriores de Julio Cortázar.

${ }^{88}$ Arlt, Roberto. La isla desierta, en Obras Completas, Op. Cit.

${ }^{89}$ Véase. Arlt, Roberto. "El hombre del tatuaje", Op. Cit. Hay al menos tres rasgos fundamentales que diferencian La isla desierta de "El hombre del tatuaje" y que acentúan en la obra de teatro su crítica social: la indeterminación de los personajes, que en la pieza están numerados y en el cuento llevan nombre; la postura del Jefe, más dura en la obra; y los rasgos que definen a Manuel, uno de los protagonistas centrales, que en el cuento ya no es quien "le cuenta todo al Jefe".
} 
En un sentido similar, La fiesta del hierro, es, asimismo, un texto central para pensar el desplazamiento hacia lo fantástico y la búsqueda estética en las obras arltianas de contenido ideológico, en este caso de denuncia ante las monstruosidades que para la humanidad trae aparejada la guerra. ${ }^{90}$ En esta pieza, Arlt retoma algunos elementos del capítulo XIII de Salammbô, un episodio central en la novela de Flaubert. El capítulo se titula "Moloch" y desarrolla el momento del asedio de Cartago por los bárbaros mercenarios que atacan la ciudad descontentos por el pago de su desempeño en la primera Guerra Púnica. Cartago sitiada sufre el aislamiento que se transmuta sobre todo en la falta de víveres y agua; los sacerdotes y Aníbal deciden intervenir para apaciguar la furia de sus dioses, sobre todo la de Baal Moloch, el más temido:

Los dioses indignados contra la república iban sin duda a proseguir la venganza.

Todos eran insignificantes comparados con Moloch, el devorador. La vida, la carne misma de los hombres le pertenecían; así, pues, para salvarla, los cartagineses tenían la costumbre de

\footnotetext{
${ }^{90}$ Una de las crónicas "Al margen del cable" permite observar cómo "La fiesta del hierro" es para Arlt, sobre todo, la fiesta de la destrucción del hombre por el hombre. Según lo que aparece en este texto el monstruo actual es la usina de fundición de metales, o el trabajo sobre el hierro, que se ha actualizado desde los orígenes del hombre pero responde al mismo impulso primigenio y ancestral de destrucción que llevaba al humano primitivo a construir flechas. Como puede verse en el siguiente fragmento: "Los dragones cambian de nombre, de religión, de herejía. Pero el hierro primitivo, meteórico, rechinante, continúa cercenando cabezas, reventando ojos, escindiendo miembros.

Se transforman las geografías, los mitos, las dinastías; [...] pero allá donde se encamina el Dragón, le sigue dócil, inmortal, esclavo, dignificado y sombrío, el fundidor de hierro. [...] Fundidor de hierro, inmortal a través de las edades. [...] Sí. Le vemos otra vez en el año 1938 como al comienzo de los tiempos prehistóricos, recogido en cuclillas, desnudo, triste, motudo. [...] Trabajan en el año 1938 como en el comienzo de los tiempos prehistóricos, en las edades del hombre simio. Y funden hierro para fabricar cuchillos con que degollar a sus prójimos.

Funden hierro...

El mismo hierro que en Swindon (Inglaterra) forma la pendiente de una montaña. Una montaña de hierro viejo. Son sunchos elásticos, ejes quebrados, [...] bastidores, ruedas, monobloques, cunas de niño, patines, cacerolas, engranajes...

Es el hierro.

El hierro por el que disputan Musolini, Hitler, Inglaterra, Japón, Rusia. El hierro que permite fundir maquinarias destructoras de hombres. Cañones, ametralladoras, tanques, motores, obuses, bombas, espadas, puñales.

Los dragones de Europa no afilan sus dientes en las piedras de amolar, sino en las usinas. Véase: Arlt, Roberto. "Los dragones afilan sus dientes en las usinas", en El Mundo, 4 de abril de 1938. Al margen del cable. Sobre la enunciación poetizante de las notas "Al margen del cable", (que en este caso particular se acerca a algunos textos de Enrique González Tunón sobre la guerra, también publicados en El Mundo), volveremos en el capítulo 4.
} 
ofrecerle una porción de ella para calmar su furor. Se quemaba a los niños en la frente o en la nuca con mechas de lana. [...]

Pero esta vez se trataba de la república misma. [...]

...no había sacrificio demasiado exorbitante para el dios, [...] Era preciso, pues, saciarlo por completo. [...]...creían que una inmolación por el fuego purificaría Cartago. La ferocidad del pueblo se gozaba en aquel espectáculo por anticipado. Además, la elección debía recaer exclusivamente entre las familias más importantes.

Los ancianos se reunieron.[...] Y cuando el pontífice de Moloch les preguntó si consentirían en entregar a sus hijos [...]...todos aprobaron con una inclinación de cabeza. ${ }^{91}$

Es así que se decide sacrificar a los niños de las familias más importantes, entre ellos el hijo de Amílcar. Se lleva la estatua del dios al centro de la ciudad y se enciende el fuego del sacrificio en el que, luego de algunas ofrendas, se van introduciendo los niños. En la obra de Arlt también aparece el contexto de la guerra y un sacrificio a Baal Moloch. Baal Moloch es, en este caso, el ídolo que el jefe de publicidad de un poderoso industrial, el Sr. Gurt, ha mandado a construir para que se encienda, después de las ofrendas, en los festejos por el aniversario de la fábrica de cañones del industrial. Debido a un accidente que no se evita, el niño, hijo del Sr. Gurt, queda atrapado en el ídolo y muere calcinado.

A partir de estas referencias y de las equivalencias que se registran entre las dos obras puede verse de qué manera un claro texto de denuncia contra el fascismo como es La fiesta del hierro sobreimprime sobre ese carácter una segunda interpretación posible que refuerza la crítica al fascismo pero que introduce, a la vez, una dimensión diferente. La referencia culta a Moloch $-\mathrm{y}$ sus resonancias flaubertianas- abre, detrás de los hechos puntuales que se ponen en escena, un espacio de lectura que se corre hacia lo fantástico: es la potencia sobrenatural del dios pagano la que ha producido en su sed de venganza la muerte del hijo del Sr. Gurt, capturado en el interior del ídolo, y es ese sacrificio el que propicia y ocasiona la guerra: la pieza termina cuando se siente el grito del niño en llamas dentro del ídolo y un personaje anuncia al mismo fabricante de armas, la noticia esperada por él poco antes: “- ¡Victoria!, ¡Victoria, señores! ¡La guerra! Ha estallado la guerra! (Muestra un puñado de telegramas.) Pedidos de armas,

${ }^{91}$ Flaubert, Gustave. Salammbô, Barcelona, Edhasa, 1996, p. 249. 
miren. ¡Piden armas!”. ${ }^{92}$ De esta forma, la denuncia del fascismo se lleva a cabo por un texto que la manifiesta desde una poética no realista. La pieza plantea una apertura hacia lo fantástico y se distancia de los modos de representación que el realismo emplea para referir una cuestión social: es lo fantástico y es el saber literario o estético lo que potencia la denuncia ideológica y también, como en otras obras de Arlt, es ese saber y los elementos asimilables a la literatura culta, aquello que permite y vehiculiza una lectura más compleja, menos simple y directa de esas obras.

Interesa considerar, a este respecto, el conjunto de adscripciones literarias que aparecen delineadas en las obras de teatro y en declaraciones efectuadas por Arlt a propósito de ellas, porque en esas adscripciones Arlt se separa y cuestiona anteriores filiaciones a la vez que puede observarse cierta pretensión de jerarquizar, en relación con los valores reconocidos ente los grandes hitos del teatro y la literatura universal, su empresa teatral. Así, es reiteradamente citado el hecho de que el autor, en vísperas del estreno de El fabricante de fantasmas, niegue una asociación de su dramática a Pirandello e indique su germen en Flaubert, Anatole France, Goya, Durero, Bruheguel el Viejo, Calderón de la Barca, Shakespeare y Goethe, ${ }^{93}$ lo cual no puede pensarse sino como un intento de establecer una nueva genealogía para su obra (diferente de adscripciones previas como Dostoievski y el folletín, por ejemplo) y otorgarle un status que la inscriba en la historia de la literatura. Este procedimiento de establecer filiaciones prestigiosas se continúa en el interior de los textos dramáticos. Así, por un lado, se produce una distancia paródica sobre ciertos modelos que en los comienzos de Arlt eran

${ }^{92}$ En una de sus notas de 1939, "Los jóvenes de los tiempos viejos", contemporánea al estallido de la Segunda Guerra Mundial, Arlt sostiene siguiendo la opinión de un filósofo a quien no cita "que Europa se encamina hacia las quemantes fauces de Baal Molock". Véase: Arlt, Roberto. "Los jóvenes de los tiempos viejos", en El Mundo, 21 de septiembre de 1939. Al margen del cable. Recopilado en: Arlt Roberto. Aguafuertes porteñas: cultura y política, Op. Cit., pp. 220223.

${ }^{93}$ El 7 de octubre de 1936 en El Mundo dice Arlt: "Posiblemente, algún crítico excesivamente avisado sitúe mi creación dentro de la técnica pirandelliana (hoy se abusa del término); yo creo que nace de la lectura de Flaubert, en su novela Las tentaciones de San Antonio, de Anatole France.

Los espantables personajes que animan el drama, el jorobado, el Verdugo, la Ciega, el Leproso y la Coja, aparte de que en germen se encuentran en mis novelas Los siete locos y El jorobadito, son una reminiscencia de mi recorrido por los museos españoles. Goya, Durero y Bruheguel el Viejo, quienes con sus farsas de la Locura y de la Muerte reactivaron en mi sentido teatral la afición a lo maravilloso que hoy, insisto, nuevamente se atribuye con excesiva ligereza a la influencia de Pirandello, como si no existieran los previos antecedentes de la actuación de la fantasmagoría en Calderón de la Barca, Shakespeare y Goethe”. 
funcionales. Como ha dicho la crítica, ${ }^{94}$ tanto en El juguete rabioso como también en ciertos tramos de Los siete locos y Los lanzallamas, aparecen escenas que siguen de cerca las reglas del folletín y de la literatura popular. En Trescientos millones los sueños de la sirvienta derivan y reescriben saberes culturales aprendidos en revistas populares - La esfera-, ficciones ampliamente divulgadas en la cultura masiva, como las de Perrault, Grim (recuérdese que la hija con la que sueña la sirvienta se llama "Cenicienta"), o en el folletín -Ponson du Terrail, Luis de Val, Carolina Invernizzio-; tanto es así que el mismo Rocambole es uno de los "personajes de humo". Pero aunque hay reutilización y uso de estos esquemas, se ejerce sobre ellos un movimiento paródico que sirve para distanciar estos discursos del discurso que sostiene la enunciación de la obra teatral. ${ }^{95}$ Así, en el siguiente fragmento, se puede ver cómo Arlt parodia la típica escena folletinesca del reconocimiento:

ROCAMBOLE - Me estoy aburriendo. ¿De modo que la chiquilla te la dio la madre?

VULCANO.-Lo juro bajo mi honrada palabra.

ROCAMBOLE.- (a la Sirvienta) -Descúbrale la espalda señora

La SIRVIENTA le rasga el vestido y mirando a la criatura exclama SIRVIENTA.- Aquí tiene la crucecita que le hizo la partera al nacer! Hija mía!

CENICIENTA. - Madre mía, qué alegría! ${ }^{96}$

\footnotetext{
94 Véase al respecto: Prieto, Adolfo. "Silvio Astier, lector de folletines" en Revista Río de La Plata, $\mathrm{n}^{\circ}$ 4-5-6, 1987, Zubieta, Ana María. El discurso narrativo arltiano, Buenos Aires, Hachette, 1987 y Saítta, Sylvia. "Tradiciones desviadas, ensoñaciones imposibles: los usos del folletín en Roberto Arlt", Iberoamericana, Lateinamerika. Spaien. Portugal, n 76, XXIII, 4, 1999.

${ }^{95}$ A este respecto, Sylvia Saítta considera que, en el caso de Trescientos Millones, "el folletín no sólo provee el argumento de la ficción de Sofía, quien sólo puede soñar a partir del material que ha leído, sino también es el intertexto de toda la obra" y, con respecto a la distancia paródica afirma "A pesar de la distancia por momentos paródica con que los personajes de la ensoñación de la Sirvienta suelen reflexionar acerca de los pasos previsibles de la trama, esta distancia se anula en la estrecha cercanía de la obra teatral con su modelo". Véase: Saítta, Sylvia. "Tradiciones desviadas, ensoñaciones imposibles: los usos del folletín en Roberto Arlt", Op. Cit.

${ }^{96}$ Arlt, Roberto. Trescientos millones, Op. Cit., p. 431.
} 
Lo anterior se reafirma aún más, si se tiene en cuenta que son los sueños producidos por esa baja literatura y su contraposición extrema con los hechos de la realidad, los que llevan a la sirvienta a la muerte a través del suicidio. Todo esto permite establecer, por un lado, en el caso específico de Trescientos millones, una relectura o revisión crítica de esa literatura (y cultura) popular. En este sentido, es importante considerar una aguafuerte de 1940: "Vidas paralelas de Ponson du Terrail y Edgar Wallance", ${ }^{97}$ pues si bien hay allí elementos que marcan una continuidad en la producción de Arlt a lo largo de los años, también es posible leer un ajuste de cuentas y una justificación de sus primeras lecturas. En efecto, como ha afirmado Saítta, ${ }^{98}$ Arlt encuentra en Ponson du Terrail una imagen de escritor en la cual reconocerse tanto por "su capacidad de trabajo" como por esa cualidad que le permitió "sin grandes destrezas de estilo" inmortalizarse a través de sus héroes". Sin embargo, y aunque esto indique, efectivamente, algunas constantes que se mantienen en la figura que Arlt construye durante toda su producción, sobre todo en lo que respecta a la capacidad de trabajo, es posible identificar, paralelamente a este reconocimiento del autor de Rocambole, un movimiento de separación en la postura de la enunciación que ubica a Arlt en un tono evaluativo de sus lecturas del folletín. Puede pensarse, entonces, que esta perspectiva le permite replantear la pregunta por los valores que un escritor como él pudo hallar en esa literatura. El artículo comienza con una interrogación: “¿Leemos hoy a Ponson du Terrail?", que sugiere una justificación en el presente de lecturas realizadas en un tiempo anterior. Arlt responde trazando un paralelo entre el escritor del siglo pasado y el que, a su juicio, sería su continuador en el presente, Edgar Wallance. Más adelante, después de afirmar que aunque sin "técnica novelística" ellos son "rabiosamente novelistas" dice el cronista:

Sus personajes [...] viven por cierta misteriosa gracia novelística en los recovecos de nuestro recuerdo y aunque entre estos modestos frecuentadores de cuevas, cárceles y subterráneos y los personajes de un Stendhal, de un Flaubert, o de un Anatole France, media una distancia astronómica, [ellos] están vivos...y estar vivos es la primera

\footnotetext{
97 Arlt, Roberto. "Vidas paralelas de Ponson du Terrail y Edgar Wallance", en El Mundo, 20 de agosto de 1940. Reproducida en Arlt, Roberto. Aguafuertes porteñas: cultura y política, Op. Cit.

${ }_{98}^{98}$ Véase: Saítta, Sylvia. "Tradiciones desviadas, ensoñaciones imposibles: los usos del folletín en Roberto Arlt", Op. Cit.
} 
condición para aspirar a la inmortalidad [...] aunque su padre creador le haya fabricado con trozos tuertos, huecos o estúpidos....99

Estas afirmaciones explican las cualidades y valores que hacen que Arlt no olvide a esos escritores, pero, al mismo tiempo, expresan en la posición de la enunciación una distancia paternalmente crítica. Lo expuesto en esta nota puede leerse, entonces, como un esfuerzo por asimilar en el presente de la enunciación de la crónica (1940) estas lecturas tan controvertidas en la institución literaria y, también, como una forma de justificación de los rasgos de la obra de Arlt que se identifican y relacionan (tal como él señala) con la producción de Ponson du Terrail y Edgar Wallace.

Pero volviendo al teatro, si se consideran varias de las obras dramáticas, puede delimitarse otro movimiento paralelo que complementa el anterior en lo que puede considerarse un proceso por el cual los textos dramáticos de Arlt (aunque no sólo éstos) en los años treinta se revaloran y rejerarquizan. Así, en muchos casos, las obras de teatro se acercan a tradiciones prestigiosas y lo hacen por un mecanismo de filiación con autores de gran trayectoria o porque cuestionan y reescriben tópicos muy situados en la literatura y cultura occidentales. Esto es fundamental no sólo si se considera que el próximo proyecto teatral de Arlt era escribir un drama sobre Helena de Troya, sino también si se revisan obras como El desierto entra a la ciudad (representada después de la muerte de Arlt, en 1953 por "El Duende"), pues allí aparecen personajes -Cesar, Escipión- y situaciones - banquetes, fiestas desenfrenadas- que remiten a episodios históricos de la antigua Roma y a lugares comunes literarios reiterados en las obras de la cultura clásica. En este sentido, por ejemplo, El desierto entra a la ciudad comienza con la puesta en escena de una simulación (los personajes actúan de latinos) ${ }^{100}$ que se representa con el episodio de un banquete - en este caso ofrecido por César a sus contertulios, que también es simulado porque los manjares son, en realidad, falsos, de utilería-, un tópico que, después de "El Banquete" de Platón, atraviesa una serie de hitos en la literatura latina desde las sátiras de Horacio, hasta El Satiricom de Petronio y las obras de Juvenal y Macrobio.

\footnotetext{
${ }_{99}^{99}$ Arlt, Roberto. "Vidas paralelas de Ponson du Terrail y Edgar Wallance", Op. Cit., p. 242. El subrayado es nuestro.

${ }^{100}$ Volveremos sobre la cuestión de la simulación en el apartado siguiente.
} 
Castagnino $^{101}$ ha dicho, asimismo, que en esta etapa de su teatro Arlt seguía modelos estructurales de la tragedia clásica, y si bien resulta difícil demostrar que esa relación llegue a tal punto, sí parece acertado leer en esas menciones diferentes modos de elevar lo que está siendo representado al asociarlo con personajes y temáticas cultural y estéticamente canonizadas. También en Saverio el cruel se han marcado intertextualidades con El Quijote, y, es más, uno de sus personajes en momentos previos a la representación de la burla organizada contra Saverio dice que la escena que ellos están protagonizando le recuerda "El capítulo del Quijote donde Sancho Panza hace de gobernador de la ínsula de Barataria”, "el de duques locos”. De esta manera, la mención y la cita del Quijote permite construir la genealogía de esta obra de teatro e inscribirla nada menos que como reescritura y continuación de una de las cumbres de la literatura universal, lo cual es útil no sólo como ubicación en una tradición prestigiosa, sino también como toma de distancia respecto de los sectores hacia los que, en una etapa previa, Arlt había establecido la filiación de sus novelas, como Dostoievski y el folletín. ${ }^{102}$

En lo referente a lo anterior es posible pensar, entonces, que la obra de Arlt se inserta en los contextos de su emergencia de diferentes modos a lo largo de los años, distribuyendo y desplegando filiaciones y aproximaciones, polémicas y rechazos en distintos sectores y sentidos. Así, en los años treinta el teatro es una posibilidad abierta para la literatura de Arlt, un género que viabiliza varios propósitos y que, a la vez que cuestiona las reglas mismas de los textos anteriores, es escenario de diferentes procesos de jerarquización que intentan procurar a su escritura un lugar más alto en el interior del

\footnotetext{
${ }^{101}$ Véase, Castagnino, Raúl H. El teatro de Roberto Arlt, Op. Cit.

${ }^{102}$ Si bien en una de sus entrevistas Arlt se presenta a sí mismo como un escritor de síntesis ("leo [...] a Flaubert y a Dostoievski"), frente a los dos grupos de la vanguardia de los años veinte (Boedo y Florida) que en la "Epístola a los genios porteños" publicada en Don Goyo había descrito, tal como analiza Sylvia Saítta, cabe aclarar que en la primera etapa de su obra es evidente, sin embargo, la adscripción de Arlt y su voluntad de afiliarse a la poética de Dostoievski y a las lecturas del folletín. Esto se explicita elocuentemente en la aguafuerte "Cómo se escribe una novela". Véase: Arlt, Roberto. "Cómo se escribe una novela", en El Mundo, 14 de Octubre de 1931. Recopilada en Arlt, Roberto. Obra Completa, Tomo 2, Buenos Aires, Carlos Lolhé, 1981. Puede consultarse, además: Arlt, Roberto. "Autobiografía", en Crítica Magazine, no 16, 28 de febrero de 1927. Recopilada en Arlt, Mirta y Borré, Omar. Para leer a Roberto Arlt, Buenos Aires, Torres Agüero, 1984; y, Arlt, Roberto. "Epístola a los genios porteños”, en Don Goyo, 23 de febrero de 1926. Recopilado en Arlt, Roberto. El resorte secreto y otras páginas, prólogo de Guillermo García, Buenos Aires, Simurg, 1996.
} 
campo literario. Todo esto muestra de qué modo, el teatro de Arlt se distancia de las propuestas programáticas del Teatro del Pueblo. El proyecto arltiano, tal como puede leerse en un recorrido por sus distintos textos -intervenciones periódicas y piezas dramáticas- presenta, en primer lugar, una búsqueda estética; en segundo lugar, se separa de la idea del teatro didáctico sostenida por Barletta: frente a la propuesta de lo pedagógico, procura, por una parte, sacudir al espectador y hacerlo participar sin mucha distancia de los hechos del drama puesto en escena; por la otra, cuestiona las formas de incidencia del orden de la ficción, la literatura y el arte en el orden de lo real. Finalmente, en el caso de las obras de contenido ideológico y político, o, en aquellas donde es clara la tesis social, el teatro de Arlt entabla una discusión con el realismo y sus formas de representación: hay una apertura hacia lo fantástico y los textos combinan una búsqueda estética con una intención ideológica.

\section{La simulación de Arlt: una teoría del teatro desde Saverio el cruel}

De la simulación se alimenta el teatro y con ella suele tejer sus redes la novela. Si esas son las formas de producción intelectual que consiguen interesar a mayor número de personas, es precisamente, por la afinidad que existe entre la simulación artística y la simulación habitual del público en la vida ordinaria. Además, el teatro y la novela son útiles a todos los que luchan por la vida por cuanto constituyen una verdadera escuela de simulación, donde al mismo tiempo que se aprende a simular, apréndese a reconocer las simulaciones de los demás. ${ }^{103}$

José Ingenieros.

Un ejemplo paradigmático para pensar la propuesta teatral de Roberto Arlt lo constituye Saverio el cruel, pues allí, desde la idea de la simulación de José Ingenieros, Arlt delimita las formas de la representación y formula, en términos escénicos, una teoría dramática en 1936. En efecto, las teorizaciones que Ingenieros publica a

${ }^{103}$ Ingenieros, José. La simulación en la lucha por la vida, Buenos Aires, Editorial Rosso, 1930, p. 83. 
principios de siglo, ${ }^{104}$ donde propone y desarrolla la cuestión de la simulación, uno de los temas cruciales de la época en que se editaron, ${ }^{105}$ se retoman en la obra de teatro muy posterior de Roberto Arlt. Ciertamente, no sólo la burla del grupo de jóvenes de esta pieza contra el mantequero reenvía a La Syringa, esa "peña de cachadas" que "el difunto literato José Ingenieros organizó, con otros animales de su especie", ${ }^{106}$ tal como el texto mismo lo manifiesta; también se reiteran y ponen en funcionamiento en Saverio el cruel algunos de los conceptos expresados en los textos de Ingenieros: la simulación de la locura, su disimulación —o "sobresimulación" como llama Ingenieros al estado por el cual un "alienado verdadero" que comete un delito simula o disimula con algún propósito su condición-, el "simulador sugestionado" o "simulador de segunda mano", al que "el impulso para simular le viene de otros individuos", ${ }^{107}$ la simulación que se apodera del simulador $\mathrm{y}$, finalmente, los simuladores "fumistas", esos "sujetos intelectualmente superiores, hiperestésicos e hiperactivos a la vez, exuberantes de vida y de alegría, cuya ocupación característica es deleitarse en 'tomar el pelo' a sus semejantes, haciendo de ello un verdadero sport". ${ }^{108}$

En efecto, la crítica ya ha señalado simetrías entre Arlt e Ingenieros. En su artículo sobre El amor brujo Aníbal Jarkowski establece estos vínculos, ${ }^{109}$ como también Josefina Ludmer en su libro El cuerpo del delito. Para Ludmer, Ingenieros

\footnotetext{
${ }^{104}$ En 1903, el médico criminólogo José Ingenieros publica por primera vez su tesis doctoral de 1900, La simulación de la locura, precedida por un texto que amplía sus conceptos y le sirve de introducción, La simulación en la lucha por la vida.

${ }^{105}$ Véase: Salessi, Jorge. "La simulación de José Ingenieros", en Médicos maleantes y maricas, Rosario, Beatriz Viterbo Editora, 1995, pp. 133-147, y Terán Oscar. José Ingenieros: pensar la nación. Antología de textos, Buenos Aires, Alianza Editorial, 1986, pp. 7-104.

106 Arlt, Roberto. Saverio el cruel, en Obras completas, Buenos Aires. Carlos Lohlé, 1981, tomo 2, p. 476.

${ }^{107}$ Ingenieros, José. La simulación en la lucha por la vida, Op. Cit., p. 142.

${ }^{108}$ Ingenieros, José. La simulación en la lucha por la vida, Op. Cit. p. 129. En esas páginas agrega además Ingenieros: "Su derroche de actividad prueba que el fumista posee un superavit en la lucha por la vida. El inferior limítase a economizar, aprovechando útilmente lo que posee, para no ser vencido: el derroche revela superioridad. Esta última condición le permite gozar a los individuos que, no encontrándose en igual caso, luchan ineptamente por la vida; no le guía el propósito malsano de perjudicar a las víctimas de sus simulaciones: sólo busca el deleite mental de precipitar a otros en los despeñaderos de sus ficciones. [...] El fumista tiene, casi siempre, el orgullo de su propia superioridad; eso, en ciertos casos, le hace cruel para con inferiores vanidosos que elige como víctimas de sus fumisterías". La obra de Arlt revela, en este sentido y como oposición a Ingenieros, que el fumista es un loco: Susana, la organizadora de la burla, está en verdad loca.

${ }^{109}$ Jarkowski, Aníbal. "El amor brujo: la novela "mala" de Roberto Arlt", en Graciela Montaldo y colaboradores. Irigoyen, entre Borges y Arlt. (1916-1930), Op. Cit.
} 
presenta, en este sentido, "un campo común" "con el tratado de la simulación y el delito de los locos y monstruos de Arlt (con Los siete locos y Los lanzallamas, 1929 y 1931)". ${ }^{110}$ "En Arlt —afirma la autora más adelante- insiste la serie de Ingenieros (o los límites de la simulación y sus combinaciones): la locura se puede simular, y los simuladores se pueden enloquecer y pueden llegar al delito", ${ }^{111}$ aseveración que la lleva a considerar Saverio el cruel. En este sentido, Ludmer expone dos tesis sobre esta obra que se leen a partir de la cita arltiana de Ingenieros y de las continuidades entre la burla presentada en Saverio el cruel y los titeos de La Syringa. Se trata, en primer lugar, de cómo el drama de Arlt pone en juego una serie de torsiones por las que la representación da vuelta su lógica: "Todo depende de cuantas vueltas o torsiones se haga dar a 'la representación' o simulación, un fenómeno de varias caras o un arma de doble filo, siempre presente en Arlt. Y que decide o no si se la lee como máquina de exclusiones. La niña bien, loca y simuladora, mata al pobre mantequero en la estancia: allí la Syringa funciona como un mecanismo de exclusiones sociales, de arriba hacia abajo; [...] Pero si el mantequero 'es' lo que simula en su 'locura', si es Saverio el cruel [...] la representación se da vuelta" y "ejecuta otro tipo de exclusión, política." ${ }^{112}$ La segunda tesis, - un poco más difícil de comprobar si sólo se constata, como hace Ludmer, la preocupación de los personajes por que Saverio simule su papel de coronel a partir del cine-, considera la presencia del cine y del psicoanálisis en Arlt, o, más precisamente, los modos en que "La teoría de Arlt de la simulación-representación pasa por el cine y el psicoanálisis, o por el psicoanálisis del cine, y por eso se acerca a la teoría de Lacan y al cine de Hitchcok", en el sentido de "decir la verdad fingiendo". ${ }^{113}$

Ahora bien, al trazar estos vínculos entre los simuladores de Ingenieros y los de Arlt, Ludmer permite interrogar (aunque ella no desarrolle el problema) si a partir de esta idea de la simulación podría pensarse la representación y el teatro arltiano. También Horacio González, que sigue en muchos aspectos la interpretación de Ludmer y señala ${ }^{110}$ Ludmer, Josefina. El cuerpo del delito. Un manual, Buenos Aires, Libros Perfil, 1999, p. 126. Con respecto a Los siete locos y Los lanzallamas Ludmer señala a propósito de la relación con Ingenieros: "El mundo brechtiano y capitalista del Chicago de Ingenieros con la simulación de los mendigos, también está en Arlt, en los Espila como simuladores de mendigos 'víctimas de la ciencia" " (p. 127); en otro lugar, también afirma: "Arlt transforma la teoría de la simulación de Ingenieros de 1900 en una ficción politizada de los años veinte: la simulación, la locura y el delito con el dinero, el plan y 'la revolución"” (p. 128).

${ }^{111}$ Ludmer, Josefina. El cuerpo del delito. Un manual, Op. Cit., p. 126

${ }^{112}$ Ludmer, Josefina. El cuerpo del delito. Un manual, Op. Cit., p. 362.

${ }^{113}$ Ludmer, Josefina. El cuerpo del delito. Un manual, Op. Cit., p. 388. 
además que en Saverio el cruel la simulación produce y "es la forma misma” de la metamorfosis del yo en sus personajes, ${ }^{114}$ deja en suspenso esta cuestión cuando analiza la pieza teatral de Arlt.

Por lo tanto, en las páginas que siguen, se intenta dar cuenta del tema de la simulación considerando el hecho de que Saverio el cruel es una obra de teatro - género que consiste, por otra parte, en que unas personas reales, fingen que son otras, escritas por un autor-, para estudiar cómo en esta obra se conjugan las ideas acerca de la simulación de Ingenieros con una poética del teatro de Arlt o, para ser más precisos, los modos en que algunas ideas de Ingenieros retomadas por Arlt ponen de manifiesto, permiten leer e intervienen en la construcción de una poética del teatro y una teoría dramática en la obra de 1936. ¿De qué modo esta teoría dramática implícita sirve para pensar el funcionamiento del teatro de Arlt y también su interés por el teatro?, ¿cómo se simula en Saverio el cruel?, ¿de qué manera se establece la relación entre el espectáculo y el público?, ¿cuál es la reacción de los espectadores ante lo representado?, ¿cuál es la función de la simulación-representación de ese teatro montado dentro del teatro?, ¿qué ideas tiene Arlt de la función actor?, son algunas de las preguntas que guían este apartado.

En principio, podemos decir que el estatuto de la simulación adquiere en Arlt un énfasis que lo separa de Ingenieros, aún si en su origen la noción es la misma o parecida, y que en su obra se inscriben otras connotaciones que remiten a su propuesta dramática. Así, en primer lugar, Saverio el cruel destaca y acentúa las reacciones y los efectos que produce la simulación: la reacción de Saverio ante la primera representación de Susana cuando se entera de que está loca, el giro de su personalidad ante su propia simulación, el impacto que sufren los jóvenes organizadores de la farsa ante la actuación del mantequero convertido en Coronel, la simulación final de Susana -o "sobresimulación" como clasificaría Ingenieros a un alienado delincuente que simula o disimula esa condición - por la que ella, estando en verdad loca, "engañó a todos". Por otra parte, ya desde el comienzo los personajes se interrogan por esos efectos - “y ustedes no piensan como puede reaccionar el mantequero...” afirma Julia-, y la obra muestra cómo la simulación organizada por el grupo de jóvenes resulta una acción

${ }^{114}$ González, Horacio. "Simulación y metamorfosis en el teatro de Roberto Arlt" en Pellettieri, Osvaldo (Ed.). Roberto Arlt. Dramaturgia y Teatro Independiente, Op. Cit. 
orientada a producir una reacción - “yo pongo enormes esperanzas en la reacción que puede provocar esta farsa", afirma Pedro, otro de los personajes-. ${ }^{115}$ A partir de aquí, puede verse nuevamente que es justamente esa capacidad de "acción" y de "reacción" de personajes y espectadores que el teatro posibilita, -en cierta manera la metamorfosis de la que habla González a propósito de Saverio el Cruel- lo que Arlt encuentra útil en el drama para su proyecto teatral, como aparecía en las teorizaciones sobre la novela comentadas anteriormente. ${ }^{116}$ En esta pieza, es la acción representada en el primer acto, la primera simulación de Susana frente a Saverio, lo que insta al mantequero a participar de la farsa, lo que genera su reacción; también es la acción de figurarse un Coronel lo que transforma a este personaje de simple mantequero en un tirano de opereta. Saverio el cruel, por lo tanto, pone el énfasis en las "acciones" y "reacciones" que propicia la simulación. Es decir, en relación con Ingenieros, el teatro de Arlt presenta una puesta en extremo de la cuestión de la simulación en función de su capacidad para producir un efecto, tal como afirma Susana, antes de la escena preparada en la que planean cortarle la cabeza al Coronel: "No conviene que un autor hable de su obra antes de que el desenlace horripile a la concurrencia. Lo único que les digo es que el final les divertirá bárbaramente". ${ }^{117}$ Aquí nos encontramos nuevamente con la preocupación por generar un efecto en el espectador, que el final "horripile", “divierta". ${ }^{118}$ En el caso del verbo "divertir, hay que considerarlo en sus dos sentidos: en el sentido de "hacer reír" - pues una alienada puede suponer que un asesinato predispone para ello-, y en el otro sentido de "desviar la atención", "retener el interés". Esto último nos reenvía nuevamente al proyecto teatral de Arlt: aquí se describe muy bien la mecánica de los desenlaces sorpresivos de muchas de sus piezas dramáticas, con escenas que "desvían la atención” y "horripilan”, en muchos casos —recuérdese por ejemplo el final de Trescientos millones y el de La fiesta del Hierro, por ejemplo-.

Otro de los modos por los cuales en Arlt el estatuto de la simulación resulta diferente de la de Ingenieros y aparecen en su pieza otras connotaciones que, a la vez que muestran las preocupaciones del autor de teatro, se distancian del primero, tiene que

\footnotetext{
${ }^{115}$ Arlt, Roberto. Saverio el cruel, Op. Cit., p. 467.

116 Arlt, Roberto. "Confusiones acerca de la novela", Op. Cit.

117 Arlt, Roberto. Saverio el cruel, Op. Cit., p. 476-477

${ }^{118}$ En este sentido, también afirma Susana con respecto a los modos en que la simulación moviliza: "...quiero seguir siendo loca, porque siendo loca pongo en movimiento a los cuerdos, como muñecos”. Véase: Arlt, Roberto. Saverio el cruel, Op. Cit., p. 484.
} 
ver con el carácter peligroso de la simulación. Hay todo un campo en Saverio el cruel donde representar y simular se cruzan con soñar. En la escena VII de Saverio el cruel, Susana le dice a Saverio una vez que éste confiesa conocer la farsa y demuestra que es capaz de actuar y posesionarse del papel de coronel: "Usted sí que es capaz de soñar. Vea que mandar a fabricar una guillotina", con lo cual el soñar está homologado a esa aptitud de asumir como propio un papel que se representa, es decir, en ese sentido el sueño es también representación y simulación (en "El traje del fantasma" también hay simetrías entre sueño y simulación). Entonces, el paralelo que el propio texto formula entre representación, simulación y sueño, permite leer también en Trescientos millones una teoría dramática; es decir, esta pieza, también puede orientarnos acerca de la concepción de Arlt sobre el teatro.

En este sentido, en las dos obras teatrales puede rastrearse la idea del riesgo que es la contrapartida del sueño y la representación o simulación. Simular ser loco convierte, a quien simula, en loco. A Saverio, simular, soñar, lo lleva a la muerte, igual que a la Sirvienta de Trescientos millones. Simular-representar-soñar es peligroso porque se alteran o se confunden los órdenes de lo real y lo imaginario, de lo verdadero y de lo falso. "-No he valorado mi capacidad real para vivir lo irreal", ${ }^{119}$ afirma Saverio y ese conflicto y los riesgos de abrir con el teatro un mundo de sueños son tematizados aquí. Este matiz, que no está en Ingenieros (en el médico criminólogo el énfasis está puesto más bien en las ventajas de la simulación en la "lucha por la vida") se relaciona con una idea que está en Saverio el cruel: la del teatro como "fábrica de mentiras", como "engaño"; resuena así, nuevamente, la aguafuerte de Arlt sobre "La inutilidad de los libros".

De este modo, como también analizábamos en el apartado anterior, si el teatro y la representación pueden ser peligrosos porque se corre el riesgo de asumir como propio un papel que se inscribe en el orden de la ficción, si el énfasis de Arlt se coloca en el efecto o la "emoción" - hasta cierto punto catártica - que provoca en el público una obra donde se privilegia la representación de "acciones" y "reacciones", esto se diferencia del propósito de "educar al pueblo" por el teatro: el acento está en otro lado, no en la potencia pedagógica que propugnaba Barletta. Lo que sí se corresponde con la propuesta del teatro de Barletta en esta poética dramática que es Saverio el cruel, es la

${ }_{119}$ Arlt, Roberto. Saverio el cruel, Op. Cit., p. 478. 
idea sobre la función del actor. Una buena actuación es la que plantea una consustanciación del actor con lo representado. Susana - "una gran actriz que le pone frío el corazón a uno"- ${ }^{120}$ y Saverio, comediante trágico, ofrecen lo que sería en términos de Barletta una representación "sincera", y constituyen por ello "un carácter" que "interesa y emociona por la fuerza y sinceridad de su pasión...", "una interpretación" que produce "en el ánimo del espectador la impresión duradera que la genuina obra de arte causa". ${ }^{121}$

Pero volviendo a los vínculos entre Saverio el cruel y los textos de Ingenieros, cabe destacar que en Arlt la simulación es literaria, o, en otros términos, los locos y simuladores de Arlt lo hacen con un lenguaje literario y con materiales tomados de la literatura: lo que se representa surge de la literatura y de la cultura libresca. Este carácter de la simulación no está contemplado en las obras del médico criminólogo sobre el tema, pero sí en la cultura finisecular argentina y de principios de siglo, en el modernismo decadentista, por ejemplo, que propugna la pose del escritor decadente inaugurada con Oscar Wilde: que "la vida imite al arte".

Escenas de un grotesco, el boceto teatral que Arlt publica en la Gaceta de Buenos Aires, es una primera versión de Saverio el cruel; ${ }^{122}$ este texto representa una prueba más de la cita arltiana de Ingenieros, y a la vez muestra de modo evidente cómo los locos de Arlt simulan y encuentran su inspiración en retazos literarios. A diferencia de Saverio el cruel, esta pieza se desarrolla en un instituto de enfermos mentales. ${ }^{123} \mathrm{El}$ Director del Instituto presenta ante un grupo de periodistas "la obra colectiva en la que

\footnotetext{
${ }^{120}$ Esta cualidad y la autoría del drama planeado para el mantequero le confieren a Susana en la pieza atisbos de genialidad y de ella se afirma que tiene "temperamento artístico" como de los jóvenes que la secundan que "nos estamos haciendo célebres", frases donde resuenan otros temas finiseculares constantemente referidos por Ingenieros: el parentesco entre genio y locura, "la neurosis de los hombres célebres".

${ }^{121}$ Barletta, Leónidas, Viejo y nuevo teatro, Op. Cit., p. 30.

${ }_{122}$ Arlt, Roberto. Escenas de un grotesco, en Gaceta de Buenos Aires, I, n 2, 4 de agosto de 1934. Reeditado en Proa. En las Letras y en las Artes, n 30, julio/agosto 1997.

${ }^{123}$ Mirta Arlt (Arlt, Mirta. "La locura de la realidad en la ficción de Arlt", en Pellettieri, Osvaldo (Ed.) Roberto Arlt. Dramaturgia y Teatro Independiente, Op. Cit.) asegura que fue a instancias del teatro de Leónidas Barletta que Arlt cambió la situación del primer acto: "En esa fría noche de 1936 Arlt supo [...] que a Saverio el cruel le aguardaba el retorno a las exigencias del Teatro del Pueblo, que, en efecto, impuso la situación del primer acto, con personajes de la burguesía [...], en lugar de la celebración de un aniversario del manicomio donde los internados eran autores y actores del evento, tal como ocurría en el libro que fue la génesis de esa pieza. En efecto, a mi padre, que era un ser de izquierda sentimental, le molestaba profundamente la sujeción a una estética heterónoma y mensajista" (p. 23).
} 
culminan los experimentos psiquiátricos realizados por este instituto frenopático"; ${ }^{124}$ allí se pondrá en escena la "representación de una tragedia escrita por un demente", cuyos actores "han sido seleccionados entre los más conspicuos enfermos mentales que alberga el Instituto". En la Escena III, y en un episodio de teatro dentro del teatro que es el germen de la simulación de Susana en Saverio el cruel, asistimos a la obra de "los locos". En ella, el texto se aparta del orden del discurso cotidiano y del "lenguaje de la calle" que predominaba desde el comienzo (incluso hay un uso del "che" rioplatense en uno de los periodistas) y aparecen otras formas de enunciación:

Hutten.- ¡Contémplame, oh tú, Zeus, protector de Suplicantes!

Con palabras insidiosas y procedimientos bárbaros, me han despojado de mi reino un hombre de cruel corazón y astuto de pensamiento. Y ahora, en vez de pavonearme en mi manto de púrpura, me ilumino como un mendigo con un farolillo y cubro mi cabeza, más rapada que la de un esclavo, con un rústico casquete de piel de perro. $[\ldots]$

$\mathrm{Y}$ aun durmiendo pienso en el horror de recorrer los caminos, como Orestes matricida, perseguido por las Furias. Aun durmiendo, oh Zeus resplandeciente, me veo mendigando mi sustento a los pastores y escuchando en las puertas de las tabernas el canto de la plebe que se lleva a los labios cántaros de vino. ${ }^{125}$

En efecto, aquí aparece un lenguaje elevado y arcaizante que remeda las expresiones y formas de la tragedia clásica: hay en el texto alusiones a distintas obras griegas (La Orestíada, Las Suplicantes, por ejemplo) y a diferentes episodios y personajes míticos (las Furias, Zeus, y en otros fragmentos también se mencionan, las Erinnias y Filoctetes). Así, en la voz del otro, que es el loco en la cultura occidental, Arlt introduce una elaboración estética en el discurso de sus personajes y es a partir de la locura esta obra muestra un saber literario.

En Saverio el cruel también es clara la literaturización del discurso de los alienados y de los simuladores o de los simuladores que son también alienados por el mismo carácter de su simulación — tal como se afirma en el mismo texto por uno de los personajes: "todos somos locos", de modo que locura y simulación quedarían equiparadas- Esto puede comprobarse, en primer lugar, porque la representación que

${ }^{124}$ Arlt, Roberto. Escenas de un grotesco, Op. Cit., p. 41.

${ }^{125}$ Arlt, Roberto. Escenas de un grotesco, Op. Cit., pp. 44 y 46. 
se monta para engañar a Saverio no sólo es explícitamente paralela a la de los duques locos en Don Quijote, sino además, porque Pedro, en su simulación de médico justifica la locura de Susana ante Saverio como se explica la locura de Don Quijote: “exceso de lecturas...una gran anemia cerebral...”. ${ }^{26}$ También en el discurso de las representaciones de Saverio y de Susana hay un cambio de tono que contrasta, como afirma Eva Golluscio, con el lenguaje porteño de otras escenas. ${ }^{127}$ Los parlamentos de la simulación de la locura de Susana funcionan como una mezcla de retazos literarios y culturales: restos del modernismo, del cuento de hadas, de El Quijote, del Tarzán de la cultura popular, del cine, etc. Finalmente, dos coincidencias nos reenvían a Hamlet: el episodio de "teatro dentro del teatro" y el caso "más célebre de la historia del arte - como lo refiere Ingenieros- ${ }^{128}$ en quien se une la circunstancia de simular locura y de estar verdaderamente alienado". ${ }^{129}$

En síntesis, el teatro de Arlt, a la vez que asume la tesis realista que le imprime su participación en el Teatro del Pueblo, manifiesta su adscripción a "esa fábrica de mentiras que es la literatura", y de esta manera evidencia en cruce presente en sus obras ${ }^{126}$ Arlt, Roberto. Saverio el cruel, Op. Cit., p. 475.

${ }^{127}$ Golluscio, Eva. "Los personajes-memoria: dos Saverios para un organito", en Pellettieri, Osvaldo (Ed.). Roberto Arlt. Dramaturgia y Teatro Independiente, Op. Cit. En este sentido, Golluscio también afirma: “...cuando Susana deja de ser una "niña bien" y se mete en el papel de Reina Bragatiana y Saverio, antes modesto mantequero, entra en el suyo de Cruel Coronel Golpista, ambos cambian radicalmente de forma de hablar. Desdoblados en tanto personajes y como revistiendo una máscara lingüística, los dos abandonan el hablar porteño medio, señalado por el uso de "vos", de "che", del lunfardo y de giros coloquiales de Buenos Aires. Modifican profundamente la selección léxica, adoptan otro registro... (p. 142)

${ }_{128}$ Ingenieros, José. Ingenieros José. La simulación de la locura, Buenos Aires, Talleres Gráficos, 1918, p. 13.

${ }^{129}$ Esto es equivalente a lo que sucede en otros textos de Arlt en los que también aparecen simuladores y/o delincuentes semejantes a los descriptos por Ingenieros, es decir, que evaden el delito apelando a la locura: Gustavo Boer, el personaje de "El traje del fantasma", sería un prototipo en el esquema psicológico de "la simulación de la locura en los delincuentes". En ese relato hay algo de modernismo en esos sueños, alucinaciones, estados intermedios a partir de los cuales Boer simula estar loco para no ser culpado por un crimen cometido. Es decir, acá también la locura que se simula surge de la literatura, una forma, esa sí, que no contemplaba Ingenieros. También en Trescientos millones la simulación-sueño-representación de la sirvienta se organiza con materiales de la cultura libresca, como el folletín de Rocambole y ciertos restos modernistas. Finalmente, en El desierto entra a la ciudad, la última pieza teatral de Roberto Arlt, también aparecen simuladores. La obra comienza con una escena que muestra el modo en que una serie de personajes escapan del mundo burgués de la oficina y viven su existencia como representación, remedando escenas de la época romana: "Cuando ese tunante de Escipión me sugirió que para ser feliz viviera libremente como los hombres de la edad clásica, creí que iba a ser dichoso", afirma uno de los personajes; otro, que Escipión le metió en la cabeza a César "la fantasía de disfrazarse de Romano". Véase: Arlt, Roberto. El desierto entra a la ciudad, en Obras Completas, Op. Cit. 
entre mensaje social y materiales literarios. La tosca realidad no es servil a la dramaturgia, es a partir de la literatura que los locos se expresan y a partir de allí que también surgen la simulación y la representación. 


\section{Viaje y representación}

Señores... me voy a España

¡Y aún no puedo creerlo! Aunque a ustedes les parezca un disparate. Sí, no puedo creerlo, tan largamente, con tanto ardor de años e imposibilidades he deseado este viaje. [...] No me atrevo a escribir una palabra que pueda, con su referencia, dar una imagen de la arquitectura de este sueño. [...] Y Yunque les parezca pueril, a mi este viaje se me antoja extraordinario... [...] "Me marcho". Irse... Irse... En el horizonte, en la vuelta de una calle, en el muro de nuestro cuarto, súbitamente se ha corrido el telón gris. [...] ...la hoja seca del conocimiento libresco transformándose por magia, en pámpano jugoso

Veré con mis ojos. Meteré la nariz y la cabeza y los pies y las manos y todo el cuerpo dentro de aquello [...]. Estaré allí. Allí con mi persona.

Esto basta. ${ }^{1}$

Roberto Arlt

Con estas palabras, y con un entusiasmo que anuncia una perspectiva largamente esperada y describe la arquitectura de un sueño extraordinario modelado por el deseo, se inaugura la serie de las aguafuertes españolas. En efecto, Carlos Muzio Saénz Peña, el director del diario El Mundo, envía a Arlt como corresponsal a Europa. Se trata, como afirma Sylvia Saítta, de un nuevo tipo de viaje (diferente al de los hombres del ochenta y al de los escritores de clase alta) que, con el periodismo masivo y comercial

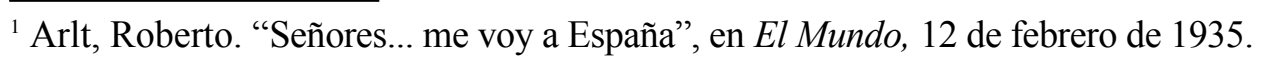


involucra a cronistas profesionales que responden con su trabajo a una demanda previa del diario que exige una escritura rápida y debe reconocer pautas muy precisas. ${ }^{2}$

En el texto del epígrafe, Arlt participa al público de El Mundo el "prodigio tan próximo", la "tamaña aventura" del viaje que se avecina para él, de un modo que se asimila y trata de establecer complicidad y cercanía con el imaginario de sus potenciales lectores. Con un punto de vista en el que el mismo Arlt pretende fusionarse hasta lo corporal $^{3}$ ("Veré con mis ojos. Meteré la nariz y la cabeza y los pies y las manos y todo el cuerpo dentro de aquello"), el periodista y escritor va a intentar confrontar, asimismo, su experiencia de viajero al "conocimiento libresco" y "La suma de páginas que [ha] leído". Así, desde una perspectiva exaltada, expectante y atravesada fundamentalmente por el optimismo y muchas veces por la fascinación, Arlt transitará durante un año por distintos puntos de España y África, desde febrero de 1935, momento en que emprende la partida. Su recorrido se inicia en Andalucía, continúa con un intervalo por el norte de África y algunas ciudades de Marruecos, como Tánger y Tetuán, regresa al Sur de la península y luego se concentra en el norte, en Galicia, Asturias y en el país Vasco. El itinerario sigue por Castilla la Nueva (Madrid y Toledo) y finalmente, Barcelona. En mayo de 1936, regresa a Buenos Aires.

El viaje a España y África marca sin duda un quiebre en su escritura que la distancia de los rasgos predominantes en sus novelas y relatos publicados hasta ese entonces; a partir de aquí aparecen en su obra nuevas maneras de narrar y puede decirse que se construye una espacialidad diferente en la literatura de Arlt, que a la vez que evidencia cierta búsqueda del estilo, le da consistencia a ciertos caracteres que su cuentística ya empezaba a desplegar desde "El traje del fantasma" y "La luna roja".

\footnotetext{
${ }^{2}$ Saítta, Sylvia. "Sueño del viaje", en El escritor en el bosque de ladrillos. Una biografía de Roberto Arlt, Buenos Aires, Sudamericana, 2000, pp. 136 y 145. Saítta afirma, además, con respecto al viaje de Arlt: "...Arlt viaja fundamentalmente para escribir mientras viaja; sus crónicas no son el resultado de quien busca hacer públicas unas percepciones de carácter privado: Arlt viaja porque su escritura es la condición de posibilidad de la existencia del viaje, su único pasaporte de escritor asalariado". (p. 145)

${ }^{3}$ Jorge Monteleone afirma que la experiencia del viaje siempre es una experiencia que se vive desde el cuerpo. Véase: Monteleone, Jorge. "Prólogo", en El relato de viaje. De Sarmiento a Humberto Eco, Buenos Aires, El Ateneo, 1999.
} 


\section{España: la mirada del viajero}

El 25 de febrero de 1935 Arlt se embarca para España, y desde allí enviará por avión, casi a diario, sus impresiones de viajero. Se trata de unas doscientas crónicas entre las cuales sólo elegirá algunas para su edición en 1936 de las Aguafuertes españolas. ${ }^{4}$ En vísperas de su partida, Arlt anuncia los propósitos del viaje y pretende inscribir las notas que aparecerán en el diario en el registro de las aguafuertes porteñas. De esta manera, sostiene que va a España a "convivir con el pueblo y las masas de sus ciudadanos" y a registrar las costumbres, tradiciones, tipos, cuadros y paisajes que interesarán a los españoles distantes de su terruño y a los argentinos "que así podrán conocer mejor la madre patria": "Recorreré aldeas y villorrios, a pie, en mulo o en camioneta", insiste, para equiparar ante su público al viajero turista que aparecerá en los próximos artículos con el cronista de Buenos Aires, paseante inmerso en el ajetreo de la ciudad. ${ }^{5}$ Como afirma Saítta, este objetivo de pintar cuadros y paisajes se desdibuja para Arlt cuando llega y toma contacto con la tensa situación política del país, y en más de una oportunidad afirma que no le interesa el color local ni la tarjeta postal: ${ }^{6}$ "Cada piedra, cada alféizar, sugieren infinidad de cosas. Pero no he venido aquí a recordar hechos históricos ni a vivir [...] en hoteles de primera clase. [...] Vivo entre el pueblo y con el pueblo", sostiene en una de sus primeras notas escritas ya desde Cádiz; ${ }^{7}$ y también le responde a un "parroquiano" que lo invita a descubrir la "bonita” Cádiz:

- Mi estimado amigo [...] Todo lo que usted me dice se encuentra en el tomo diez, página 320 de la Enciclopedia Espasa. Mis lectores, en la Argentina, esperan otra cosa. Están hartos de tarjetas postales bonitamente iluminadas. Hábleme usted de lo que hay de humano en este lugar, de lo triste y de lo alegre; del sufrir de las gentes. Allá en la Argentina, que es un pedazo de España, quieren saber de estas cosas. ${ }^{8}$

\footnotetext{
${ }^{4}$ En la bibliografía que aparece al final de la tesis se incluye la lista detallada de las aguafuertes consideradas para este capítulo.

${ }^{5}$ Arlt, Roberto. "Mañana me embarco", en El Mundo, 13 de febrero de 1935.

${ }^{6}$ Saítta, Sylvia. "Nuevos viajeros, otras miradas: Roberto Arlt en España", en Hispamérica. Revista de literatura, año XXVIII, $\mathrm{n}^{\circ}$ 82, 1999.

${ }^{7}$ Arlt, Roberto. "Carestía de la vida en España", en El Mundo, 14 de abril de 1935.

${ }^{8}$ Arlt, Roberto. "A Madrid, a pedir trabajo", en El Mundo, 16 de abril de 1935. Arlt ha consultado, efectivamente, la enciclopedia Espasa, porque en el tomo 10, página 320 de la edición de 1934 que él cita, aparece la referencia a Cádiz y el texto se centra en la descripción de las iglesias, en las particularidades de la arquitectura y en los lugares típicos de la ciudad.
} 
Este enfoque retoma, por lo demás, algunas ideas que el escritor había expresado en 1928 en una de sus aguafuertes, "Argentinos en Europa". Allí, Arlt se había distanciado de la perspectiva de otros viajeros argentinos como Manuel Gálvez, Lagorio o Rohde que, con una "miopía" de "vago hijo de estancieros" o de "argentinos con plata", se dedicaban a describir paisajes exóticos, ruinas, monumentos arquitectónicos y otras "pamplinas arqueológicas", olvidándose de que "en los países que visitan hay una mayoría que vive y trabaja, que en todos los territorios recorridos hay industriales y fábricas que nosotros ni sospechamos..."?

Si nos atenemos al corpus completo del viaje a España, sin considerar aquí las aguafuertes africanas, que analizaremos en el apartado siguiente, puede sostenerse, sin duda, que tal como la crítica ha estudiado recientemente, ${ }^{10}$ buena parte de sus notas responden a estas premisas. Arlt describe el mundo del trabajo y participa, por ejemplo, de la pesca de sardinas y visita una mina de carbón. Del mismo modo que escucha historias, se entusiasma y deja entrever el panorama político y económico, y la fuerte crisis social que estaba atravesando la península — son elocuentes en este sentido, las aguafuertes sobre el "problema agrario español", las que reproducen los avatares políticos de Madrid, el triunfo de las izquierdas y el vaticinio de la guerra civil, y los artículos sobre la situación del país Vasco, entre otros-. Pero, de todas maneras, si bien Arlt critica los modos de representación de la tarjeta postal, y sus notas indican en muchos casos una lectura en clave política e ideológica, también cabe considerar cómo, paralelamente y en crisis con el punto de vista del viajero testigo de acontecimientos políticos y el cronista veraz, sus aguafuertes españolas no sortean las trampas de lo exótico, lo típico y lo pintoresco y retoman algunas de las fórmulas por él rechazadas de la escritura de viajero.

\footnotetext{
${ }^{9}$ Arlt, Roberto. "Argentinos en Europa", en El Mundo, 18 de octubre de 1928. Recopilada en Arlt, Roberto. Nuevas aguafuertes, Buenos Aires, Losada, 1975, p. 76.

${ }^{10}$ Véase, a este respecto: Saítta, Sylvia. "Nuevos viajeros, otras miradas: Roberto Arlt en España", Op. Cit., y, de la misma autora, "Sueño del viaje", en El escritor en el bosque de ladrillos., Op. Cit. También, pueden consultarse los prólogos de Saítta de las ediciones de las aguafuertes gallegas y asturianas, madrileñas y vascas (Arlt, Roberto. Aguafuertes gallegas y asturianas, Compilación, prólogo y notas de Sylvia Saítta, Buenos Aires, Losada, 1999; Arlt, Roberto. Aguafuertes madrileñas. Presagios de una guerra civil, Prólogo compilación y notas de Sylvia Saítta, Buenos Aires, Losada, 2000; Arlt, Roberto. Aguafuertes vascas, Prólogo compilación y notas de Sylvia Saítta, Buenos Aires, Simurg, 2005)
} 
Se intenta reflexionar aquí sobre el viaje a España para analizar la fascinación de Arlt por lo nuevo -los escenarios, las costumbres, el paisaje urbano y natural- y estudiar sus modos de representación que, por momentos, apelan a los procedimientos de lo pintoresco y el color local. Pretendemos indagar, asimismo, las valoraciones, juicios y apreciaciones que asocian este orden con un mundo de ensueño, lugar de la aventura y sitio de lo ideal, y examinar, finalmente, los modos en que en las aguafuertes españolas, a diferencia de las porteñas y de lo que sucede en las novelas de Arlt, aparecen distintos modos de mirar los escenarios urbanos, suburbanos y el territorio natural. Si la mirada paisajística implica una perspectiva distanciada del todo ajena a una subjetividad en conflicto con el espacio del que surge y la rodea, ${ }^{11}$ el viaje también posibilita la construcción del paisaje en la literatura de Arlt.

\section{El color local y la tarjeta postal}

España es ante todo: color. $^{12}$

Roberto Arlt

Uno de los primeros puntos que surgen al considerar el uso arltiano del dispositivo del color local es la serie de artículos sobre la Semana Santa en Sevilla, publicados en El Mundo en 1935 y luego reeditados en conjunto por la Editorial Rosso en la selección que constituye las Aguafuertes españolas (1936). ${ }^{13}$ Textos escritos desde el elogio y la admiración, y organizados desde el goce y la experiencia "corporal" preferentemente visual- intentan describir la "tristeza alegre que todos los sentidos gozan y apetecen". Una de las crónicas en particular, del 30 de abril de 1935, ${ }^{14}$ arma un

${ }^{11}$ Tomo estas ideas, que se desarrollarán con mayor profundidad en la segunda parte del trabajo, de Silvestri, Graciela y Aliata, Fernando. El paisaje como cifra de armonía, Buenos Aires, Ediciones Nueva Visión, 2001.

${ }^{12}$ Arlt, Roberto. "Santander, muy moderno y muy antiguo. Recuerdos de África", en El Mundo, 15 de noviembre de 1935. Recopilada en Aguafuertes vascas, Op. Cit., p. 25.

${ }^{13}$ En efecto, Arlt publica en 1936 por la Editorial Rosso, y bajo el título Aguafuertes españolas, una breve selección de un reducido número de aguafuertes, que toma algunos de los itinerarios de su viaje (Sevilla, Cádiz, Marruecos, Granada). Véase, Arlt, Roberto. Aguafuertes españolas, Buenos Aires, Talleres Gráficos Argentinos L. J. Rosso, 1936.

${ }^{14}$ Arlt, Roberto. "El esplendor de Arabia: la opulencia del Asia; tal la Semana Santa en Sevilla", en El Mundo, 30 de abril de 1935. Reproducida en conjunto, con algunas variaciones, junto con toda la serie sobre el tema en: Arlt, Roberto. "Semana Santa en Sevilla", en su Aguafuertes 
cuadro de color y lee desde una perspectiva exotista y orientalista "la oriental magnificencia de la semana santa en Sevilla". Se trata de una aguafuerte que, lejos de las ironías de Oliverio Girondo al respecto, ${ }^{15}$ organiza con una impronta pictórica y una fusión del código lingüístico con el plástico, una exaltación del lujo (piedras preciosas, joyas) y del color; donde los violetas, los rojos, el dorado y el brillo de la pedrería y las tonalidades plata, escarlata y azul, circunscriben el panorama de la mirada en la visión de "el paso":

... a los costados de la multitud, los nazarenos de bonete rojo y veste blanca, forman dos filas. Monaguillos escarlatas avanzan hamacando incensarios de plata. [...] la Virgen, Jesús, los Apóstoles, Soldados y Judíos comparecen vestidos como ídolos asiáticos, tiesos en sus sayas y mantos de terciopelos recamados de oro y plata. Las vírgenes, rostros de adoloridas niñas andaluzas, muestran manos cuajadas de anillos resplandecientes. Llevan la cabeza coronada de nimbos de oro, florecidos de temblorosos lirios. A sus pies, gradinatas de cirios encendidos, cuyas luces temblequean y se reflejan en los palios de terciopelo escarlata, recamados de dragones de oro y ángeles verdes.

El sol centellea en las gemas de las colgaduras, entrechocando chispas lilas, violáceas, azules. Por el callejón que forman los bonetes rojos y las vestes blancas, avanzan banderas negras reticuladas de cruces moradas. [...]

¡Es magnífico y terrible! [...] [...]

¡El esplendor de Arabia en Sevilla, la opulencia de Asia en Europa!

¡Nada semejante puede verse en el mundo! ${ }^{16}$

Hipérbole en torno al lujo y el colorido de "el paso", el texto construye un espectáculo estético, un catálogo que entre todo lo visto da preeminencia al color y

españolas, Op. Cit.

${ }^{15}$ Si la mirada de Arlt sobre España en general y sobre la Semana Santa en Sevilla en particular podría decirse que, en muchos casos, es una mirada exotista que parte de lo propio y busca la diferencia y el atractivo de lo ajeno, la perspectiva cosmopolita de Oliverio Girondo, que iguala lo propio a lo ajeno, constituye una visión corrosiva totalmente distinta; pues se ocupa preferentemente de desenmascarar en "Semana Santa", con una ironía mordaz, la cualidad escenográfica y falsa de la celebración religiosa que se transforma en su punto de vista en una degradada fiesta popular. Véase: Girondo, Oliverio. "Semana Santa", en Calcomanías, Obra Completa, Edición crítica coordinada por Raúl Antelo, Buenos Aires, Editorial Sudamericana, 1999. Para la cuestión del cosmopolitismo en la obra de Girondo puede consultarse: Schwartz, Jorge. Vanguardia y cosmopolitismo en la década del veinte, Buenos Aires, Beatriz Viterbo, 1993. ${ }^{16}$ Arlt, Roberto. "El esplendor de Arabia: la opulencia del Asia; tal la Semana Santa en Sevilla”, Op. Cit. 
muestra la procesión como si fuera un cuadro. Predomina, asimismo, la fascinación de una mirada abarcadora, que no desestima los detalles del "esplendor" ("Todos los metales sobre los que se posa la vista son preciosos; las varas de las insignias son de plata, y de plata los incensarios y de plata los cálices y candelabros [...] y de oro los palios, y los trencellines, y los velos de las imágenes, y los lirios de los nimbos...), ${ }^{17}$ y una sintaxis enumerativa que, semejante a la enunciación caótica que aparecía, por ejemplo en "Corrientes por la noche", ${ }^{18}$ una de las aguafuertes porteñas, pero despojada de cualquier posible disyunción o contrasentido negativo, ${ }^{19}$ da el tono exaltado de la contemplación y remite al regocijo y a la multiplicidad del espectáculo que ciega los ojos en un torbellino de color. ${ }^{20}$ De esta manera, el reiterado uso de la enumeración que en los esbozos porteños, en algunos casos, como en la nota sobre la calle Corrientes, consignaba el entusiasmo y también el vértigo de la visión ante el espectáculo fugaz de la ciudad moderna ${ }^{21}$ en este y otros textos sobre España, como en las fiestas de Corpus Christi en

${ }_{17}$ Arlt, Roberto. "El esplendor de Arabia: la opulencia del Asia; tal la Semana Santa en Sevilla”, Op. Cit.

${ }^{18}$ Arlt, Roberto. "Corrientes por la noche", en Arlt, Roberto. Aguafuertes porteñas. Buenos Aires, vida cotidiana, Introducción, selección y notas de Sylvia Saítta, Buenos Aires, Alianza Editorial, 1993. Así, por ejemplo, aparece la mezcla enumerativa en este texto: "Vigilantes, canillitas, 'fiocas', actrices, porteros de teatros, mensajeros, revendedores, secretarios de compañías, cómicos, poetas, ladrones, hombres de negocios innombrables, autores, vagabundas, críticos teatrales, damas de medio mundo; una humanidad única, cosmopolita y extraña se da la mano en este único desaguadero que tiene la ciudad para su belleza y alegría. [...] Porque basta entrar en esta calle para sentir que la vida es otra y más fuerte y más animada. [...] Y libros, mujeres, bombones y cocaína, y cigarrillos verdosos y asesinos incógnitos; todos confraternizan en la estilización que modula una luz supereléctrica y una especie de estremecimiento sordo..." (pp. 32-33)

${ }^{19}$ Junto con el entusiasmo y la fascinación del cronista frente a la urbe moderna y el espectáculo fugaz de la vida nocturna, como se describe en "Corrientes por la noche", aparece también la idea de confusión y transmutación (por ejemplo, en la calle Corrientes, Arlt dice que "todo pierde su valor" y "todo se transforma"), y en muchas de sus aguafuertes porteñas —en "El desierto en la ciudad" o "Para qué sirve el progreso", por ejemplo- puede verse, como contrapartida de la visión entusiasta sobre la ciudad, una sensación de pérdida y una perspectiva nostálgica que muestra el anhelo de una sociedad más orgánica, y a partir de la cual Buenos Aires se representa como un desierto, un infierno y el lugar del artificio. Véase, a este respecto. Arlt, Roberto. Aguafuertes porteñas. Buenos Aires, vida cotidiana, Op. Cit., y también, el prólogo de Sylvia Saítta de esa edición.

${ }^{20}$ La cita textual dice: “...los ojos se ciegan en torbellino de colores”, Arlt, Roberto. "Semana Santa en Sevilla", en Aguafuertes españolas, Op. Cit., p. 23. En la versión publicada en El Mundo Arlt decía: “...los ojos se ciegan en una mar de colores”, Arlt, Roberto. "Qué son y cómo se organizan los 'Pasos' en la Semana Santa de Sevilla, en El Mundo, 29 de abril de 1935.

${ }^{21}$ Una perspectiva cercana, en el abuso de enumeración, a los modos enunciativos de las aguafuertes sobre España consideradas, (y que difiere de la que mencionamos sobre la calle Corrientes porque aquí no aparecería el vértigo de la mirada), es la nota sobre los sirio libaneses. En este caso el cronista consigna, desde algunos de los lugares comunes del 
Granada, contribuye a conferir el heterogéneo colorido, la diversidad y animación del espacio que el sujeto complacido observa. La retórica del goce de la mirada tiene, por lo tanto, una realización formal en la enumeración acumulativa, taxonómica y exacerbada:

Ningún escritor de la tierra podrá dar jamás la visión panorámica de esta mañana ardiente en las diez horas de la maravilla. [...] Estoy deslumbrado por el rayo de siete mil colores que centellea sobre Granada. [...] En el fondo de las habitaciones de los terceros pisos, familias de visitas, sombras calientes de chocolate en las esquinas, sombras de agua fría en las piedras, de acuarela en los frisos, chicos trepados en las verjas de la Catedral, en los faroles, en las rejas. Flujo y reflujo de voces humanas sobre las cabezas de la multitud. Desfile lento de cofradías, procesiones de niñas de blanco sosteniendo candelabros de plata, cruces de oro. Monagos escarlatas. Huérfanos con candelas encendidas bajo el sol. Suenan las trompetas y de las cabezas de los apóstoles de piedra que guardan los pórticos de la Catedral, se desprenden nubes de pájaros, baten las campanas y estallan los petardos [...] Sol, sol, murmullos de trompeta, niños sentados en las aceras, escalones de multitud oscura, cordones de guardias, océanos de cabezas, innumerable pantallear de abanicos en todos los ventanales, donde los tonos oscuros de las sombrillas claras festonean de siluetas los rostros de las muchachas reclinadas en los tapices escarlatas. ${ }^{22}$

Así, en un inventario acumulativo, que pretende la exhaustividad de todos los detalles de la fiesta que aparecen ante el ojo observador - "y se cierran los ojos y cuando se abren continúan desfilando los estandartes"- la enunciación enumerativa intenta dar cuenta de la variedad pictórica — sombras como acuarela, colorido, contrastes - del panorama de maravilla. Por lo demás, si en las notas porteñas puede aseverarse que en la perspectiva del cronista predominaba un cierto costumbrismo crítico y, por ejemplo, Arlt

orientalismo, la seducción que le produce "la calle de los mil colores", exótica y extranjera en Buenos Aires. Véase: Arlt, Roberto. "Sirio libaneses en el centro", en El Mundo, 23 de julio de 1933. Reproducida en Arlt, Roberto. Aguafuertes porteñas. Buenos Aires, vida cotidiana, Op. Cit.

${ }^{22}$ Arlt, Roberto. "Corpus Christi en Granada", en El Mundo, 21 de julio de 1935. Este modo de la enunciación enumerativa que intenta dar cuenta de "panoramas de maravilla", como en las fiestas de Granada, aparece reiteradas veces en el viaje de Arlt. Un caso particular se da en el viaje al norte de África, cuando hace referencia al colorido de algunas ciudades de Marruecos y a su diversidad, como veremos en el apartado siguiente. Asimismo, en las notas sobre el "Ferial de Betanzos", en muchos momentos la diversidad de la fiesta popular se describe con el uso de la enumeración. Véase al respecto: Arlt, Roberto. "El ferial de Betanzos- Hormiguea la multitud bajo el sol- Ruido y color", en El Mundo, 22 de octubre de 1935. Recopilada en Arlt, Roberto. Aguafuertes gallegas y asturianas, Op. Cit., pp. 111-115. 
cuestionaba, entre otras cosas, el carnaval como fiesta popular, ${ }^{23}$ lo que en estas aguafuertes aparece, en cambio, es una exaltación pintoresca de la celebración religiosa que busca y se deleita en la peculiaridad del color local. ${ }^{24}$

Por otra parte, también como una escena pictórica o un cuadro de color que parte de la tipificación, puede considerarse la estampa a partir de la cual Arlt representa a la "mujer sevillana" en su exhibición callejera del jueves santo. Después de estar "retenidas" en su casa durante el resto del año, en esta fecha y siguiendo, según Arlt, la "costumbre mozárabe, infiltrada en el tuétano andaluz", estas mujeres salen a la calle. Vestidas con peinetas, faldas de seda negra, rosarios de oro o coral, claveles rojos y "ataviadas con mantillas", las "jovencitas pálidas, cuyos ojos enormes, son almendras de azabache en córneas de porcelana" ofrecen para el cronista "un espectáculo cuya uniformidad estética exalta los sentidos hasta que la emoción revienta en piropos apasionados" y "...más que mujeres parecen cuadros para ser siempre contemplados". ${ }^{25}$ Cabe destacar, igualmente, a este respecto y a propósito de la Semana Santa en Sevilla, de qué manera los modos de la enunciación revelan, en muchos casos, una perspectiva musulmanizante y hacen hincapié en su singularidad oriental. Porque si, como dice Arlt, "es morisca la belleza de

${ }^{23}$ Fabiana Varela trabaja, a propósito de las aguafuertes porteñas, el contacto de Arlt con el costumbrismo crítico y ético social de origen inglés: Varela, Fabina, Inés. "Aguafuertes porteñas: Tradición y traición de un género", en Revista de Literaturas Modernas, Universidad Nacional de Cuyo, Facultad de Filosofía y Letras, Instituto de Literaturas Modernas, $n^{\circ} 32$, Mendoza, 2002.

${ }^{24}$ Cabe destacar al respecto que, si bien, por ejemplo, Arlt describe la Semana Santa como "fiesta religiosa" y "fiesta pagana", no se encuentra en su perspectiva una intención irónica ni crítica o corrosiva de las costumbres, como sí aparece claramente en Oliverio Girondo. Arlt destaca, por lo contrario, el "sentimiento" popular que le quita valor a las formalidades; como puede verse en el siguiente fragmento: "Semana Santa en Sevilla es fiesta religiosa y es fiesta pagana. En su cumplimiento se observan las anomalías más extraordinarias [...] Por la noche, [...] al regresar el "paso", después de diez o doce horas de trajín, los hermanos se quitan el bonete o levantan el barboquejo, metiéndose a la taberna que encuentran al paso... [...] Aquí la fiesta comienza de nuevo, porque las manzanillas recalientan la sangre de nazarenos y faquines; la gente les rodea, se pagan ruedas, y el más entusiasta comienza a cantarle saetas a la Virgen, que sola, con su carita de niña dolida, en la calle estrecha se inclina sobre los escalones de cirios que la iluminan con su temblorosa llama. Este espectáculo emociona a las sensibilidades más recias. [...]'Lo llevamos en la sangre', dicen los apasionados, con los cuales converso de estas anécdotas. Y es cierto. Lo sabroso del sentimiento, le quita valor a las formalidades que en otro país, escandalizarian al creyente. Y si alguien duda de lo que afirmo, piense que en este culto litúrgico, habitualmente popular, radica el éxito de la Semana Santa de Sevilla, en la cual participan indistintamente todas las clases sociales." Véase: Arlt, Roberto. "Pasos' y cofradíasRivalidades- El anecdotario de la Semana Santa", en El Mundo, 1 de mayo de 1935. El subrayado es nuestro.

${ }^{25}$ Arlt, Roberto. "El día de la mujer sevillana- Claveles y mantillas lucen en el jueves santo", en El Mundo, 4 de mayo de 1935. 
las sevillanas", ${ }^{26}$ y si la "virgen, Jesús, los apóstoles, Soldados y Judíos comparecen [en "el paso"] vestidos como ídolos asiáticos", y la luz vuelve "más morisca la figura del ajusticiado", también la procesión refleja "el esplendor de Arabia en Sevilla, la opulencia de Asia en Europa", o, más precisamente, "la oriental magnificencia de la semana santa en Sevilla". ${ }^{27}$ En efecto, como afirma el cronista en uno de los fragmentos que se agregan para la edición en libro, "El programa de festejos es vasto como corresponde a la liturgia católica, enraizada a través de la imaginación del moro cristianizado, pero en su sustancia, árabe hasta el tuétano"; ${ }^{28}$ lo que pone en evidencia de qué manera la mirada de Arlt sobre la celebración "popular" organiza el color y la tipicidad desde una perspectiva que subraya el exotismo árabe y orientalista. ${ }^{29}$ Lo mismo ocurre en muchas de sus aguafuertes sobre Andalucía, cuyos modos de representación constituyen frecuentemente una valoración de la región en su impronta musulmana.

Este énfasis contrasta con la perspectiva de escritores argentinos como Manuel Gálvez que negaban las marcas del mundo árabe en España y trataban de hacer prevalecer el "sello de la romanización”. Así, en 1913 Gálvez afirmaba que "no existe lo árabe en España sino como ruina arqueológica” y que [...] “...España, lejos de haberse arabizado, no dejó nunca de ser romana”. Es más, en un intento de acercar a Sevilla al “espíritu castizo" -y también a la Semana Santa que la piensa en relación con el mismo “espíritu de la raza”-, sostenía que "en Sevilla, que suele ser considerada una ciudad africana, lo árabe es insignificante". ${ }^{30}$ Por el contrario, en reiteradas oportunidades, Arlt

\footnotetext{
${ }^{26}$ Arlt dice que la belleza de la mujer Sevillana tiene que ver con la "...soldadura de razas orientales, por cuyas venas circula sangre morisca, árabe y berberisca". Y agrega: "Las ardorosas asechanzas de belleza, que nosotros los sudamericanos conocemos a través de los cuadros de Romero de Torres, no son creaciones de un imaginativo, sino reproducciones fieles de la mujer de la calle, de la mujer que aquí en Sevilla, en el recodo de cualquier callejuela, [...] podemos encontrar. [...] Junto a los caserones, allí, con un manojo de claveles o flores silvestres sobre una sien, tropezamos con esta locura de mujeres...". Véase: Arlt, Roberto. "Belleza morisca en las sevillanas", en El Mundo, 2 de junio de 1935.

${ }^{27}$ Arlt, Roberto. "El esplendor de Arabia: la opulencia del Asia; tal la Semana Santa en Sevilla", Op. Cit.

${ }^{28}$ Arlt, Roberto. Aguafuertes españolas, Op. Cit., p. 24.

${ }^{29}$ Esto relaciona la mirada de Arlt con la tradición de los franceses sobre España y con la serie de la literatura orientalista. Véase, con respecto a "la España pintoresca de los franceses": Colombi, Beatriz. "Retóricas del viaje a España", en Viaje intelectual. Migraciones y desplazamientos en América latina (1880-1915), Rosario, Beatriz Viterbo editora, 1994. Para la cuestión del orientalismo, véase: Said, Edward. Orientalismo, Madrid, Libertarias, 1990.

${ }^{30}$ Gálvez, Manuel. El solar de la raza, Buenos Aires, Sociedad Coop. "Nosotros", 1913, pp. 177-178.
} 
se fascina con las marcas de la España musulmana, valora las modalidades del arte y la arquitectura del tiempo "de la dominación mora", el espectáculo de color de los patios andaluces, por ejemplo, y la cerámica de Triana, admira las historias antiguas como la Jacobo Abu Juceph Alamazor, su ofrenda a Alá y la construcción La Giralda, y muestra, repetidamente, el imperio y primacía de lo pintoresco en lo árabe de España. ${ }^{31}$ También defiende los movimientos de la independencia musulmana y discute la "mentira" de la "indolencia andaluza". ${ }^{32}$ Asimismo, y, a diferencia de Gálvez, lo que para Arlt existe como resto arqueológico, no es "lo árabe en España" sino el mundo romano cuyas huellas encuentra, por ejemplo, en las "ruinas de Itálica” y en el espectáculo, muerto para él, de la Torre de Hércules. ${ }^{33}$ Es de esta manera, entonces, que las aguafuertes

${ }^{31}$ Para estas cuestiones, véase, entre otras notas: Arlt, Roberto. "La cerámica de Triana- El cristo llamado 'El cachorro'", en El Mundo, 4 de junio de 1935; Arlt, Roberto. "El jardín de Cerámica- Una fiesta permanente de color", en El Mundo, 14 de junio de 1935 y Arlt, Roberto. "La ofrenda de Almazor a Alá", en El Mundo, 10 de junio de 1935. Cabe destacar, que si bien prevalece en la mayoría de los casos, como venimos explicando, una perspectiva celebratoria y favorable hacia el mundo musulmán, en dos aguafuertes sobre la Alhambra que Arlt no publicó en el diario El Mundo, y que se agregan para la edición en libro, aparece una distancia crítica con respecto al "edificio muerto" y su arquitectura, que se separa, también, de los tópicos del viaje turístico. De esta manera, Arlt sostiene que algunas fuentes de cualquier "placeta ibérica" son "infinitamente más bonitas y artísticas" que el palacio de la Alhambra, y que para el ojo occidental ese arte "afeminado" y "voluptuoso" es, en algún punto, "repulsivo", si se compara con el arte que, en el mismo momento, llevaba a Occidente a construir templos y catedrales de piedra. Véase, a este respecto: Arlt, Roberto. "La Alhambra y el público" y, también "El amor propio en la Alhambra", en Aguafuertes españolas, Op. Cit.

${ }^{32}$ Véase, a este respecto. Arlt, Roberto. "La Andalucía Musulmanizante", en El Mundo, 12 de junio de 1935 y Arlt, Roberto. "La mentira de la indolencia andaluza", El Mundo, 13 de junio de 1935. En este segundo texto, Arlt afirma: "Es necesario quebrarle las piernas a la agraviante mentira de la indolencia andaluza. Por uno de esos prodigios, en que la mistificación resulta más corpulenta que la verdad, esta leyenda, perpetuándose a través de literatos chirles y falsos, ha dado vuelta al mundo presentando al pueblo andaluz, en la visión de un conglomerado de holgazanes, cuya exclusiva ocupación consistiría en lanzar coplas al aire y mayar el 'cante jondo'". Esta cuestión, que puede retrotraerse, por ejemplo, a Sarmiento, también la discute Manuel Gálvez, quien sostiene que probablemente los andaluces sean ociosos, pero no puede afirmarse esto de los españoles: "Sarmiento, —-sostiene Gálvez-, cuya audacia e ignorancia eran tan grandes como su espíritu, se empeñaba en ver al árabe en el español. 'El español de hoy, dice, es el árabe de ayer, frugal, desenvuelto, gracioso en la Andalucía, poeta y ocioso en todas partes'. [...] Quiero creer que Sarmiento se refiere solo al andaluz, porque ¿cómo atribuir al vasco y al catalán, por ejemplo, semejante idiosincrasia". Véase: Gálvez, Manuel. El solar de la raza, Op. Cit., p. 186.

${ }^{33}$ En la aguafuerte sobre las ruinas de Itálica Arlt describe con cierta perplejidad y admiración la permanencia de los restos del mundo romano en el Sur de España y el modo en que a partir de estos restos "la historia se hace verídica" y puede decirse que "los romanos existieron" (Arlt, Roberto. "Ante las ruinas de itálica", en El Mundo, 12 de junio de 1935). En cambio, una postura diferente aparece en la visión arltiana de la Torre de Hércules. En este caso y también, como dice David Viñas, en una oposición a viajeros como Manuel Gálvez, (Viñas, David. "Las 'Aguafuertes' como autobiografismo y colección”, en Arlt, Roberto. Aguafuertes, Tomo II, 
valoran la estampa árabe y orientalista en sus cuadros de color y manifiestan una postura contraria a algunas de las visiones de los apologistas de la vieja España, como la que comentamos de Manuel Gálvez en El solar de la raza, y también la perspectiva de Enrique Larreta, quien en La gloria de don Ramiro oponía el misticismo arcaizante y religioso, al peligro de los moros. ${ }^{34}$ La España "silenciosa" que aparece en estos autores, es la España de las iglesias, son las ciudades y pueblos "de piedra", que no le interesan a

Buenos Aires, Losada, 1998.), es evidente el fastidio arltiano y su irreverencia frente a las ruinas despojadas de individuos de La Torre de Hércules, que lo hacen distanciarse de sus lectura de los románticos: "Pienso que es necesario emocionarse frente a estas ruinas desabridas, pero permanezco indiferente [...]...a pesar de estas remembranzas a lo Walter Scott no consigo emocionarme. Envidio al señor Chateaubriand, que lloriqueaba frente a cada ruina. [...] Me marcho al tiempo que me digo: Al diablo con estas antigüedades" (Arlt, Roberto. "La Torre de Hércules'- Una atalaya del mar- Por el camino de las legiones de Julio César", en El Mundo, 1 de noviembre de 1935. Recopilada en: Arlt, Roberto. Aguafuertes gallegas y asturianas, Op. Cit., pp. 133-137.) En este caso, las ruinas, en tanto ofrecen algo monótono y unívoco, no se condicen con una perspectiva de viajero, como la que también se encuentra en Arlt, que desecha los espacios despojados de vida e individuos y muestra una propensión a la experiencia y los paisajes en los que intervienen lo cambiante y los sujetos. En este sentido, Todorov marca una diferencia sustancial entre dos categorías de viajeros: el antiguo viajero y el turista moderno, inventado, según su concepción, por Chateaubriand: "Chateaubriand inventó un personaje: en vez del antiguo viajero, en su libro aparece el turista moderno. El viajero tenía un prejuicio favorable hacia los pueblos de los rincones lejanos, y trataba de describírselos a sus compatriotas. 'Pero los años enteros resultan demasiado cortos para estudiar las costumbres de los hombres' (p. 41); y es que el hombre moderno tiene prisa. En consecuencia, el turista optará por otra elección: las cosas, y ya no los seres humanos serán objeto de su predilección. [...] Chateaubriand busca el colorido local para sus descripciones [...] y no experiencias intersubjetivas. Si por desgracia, se presentan seres humanos, se apresura a hacerlos huir". Véase: Todorov, Tzvetan. Nosotros y los otros, México, Siglo XXI, 1991, p. 347. Cabe destacar, al respecto, que esto es bastante diferente de los modos en que Arlt arma su perspectiva pintoresca y el color local, que en muchos casos se da sobre las fiestas populares y el paisaje con presencia de los sujetos.

${ }^{34}$ La gloria de Don Ramiro (Larreta, Enrique. La gloria de Don Ramiro, Buenos Aires, Kapelusz, 1972) es un texto que opone el misticismo, el orden y la razón de la Ávila católica o de la España católica, porque también aparecen otras ciudades como la emblemática Toledo, al desorden y el peligro del universo musulmán que, podría decirse, que aparece figurado como el invasor. De todas maneras, al mismo tiempo, el mundo moro se describe con cierta fascinación en su colorido y voluptuosidad (considérense las escenas de Ramiro con la seductora Aixa) y se repiten en Larreta una serie de tópicos modernistas de cuño orientalista, que también se inscriben en la literatura exotista de Arlt, como veremos, en sus cuentos y crónicas sobre África. Por ejemplo, en la aguafuerte donde refiere el viaje de regreso al sur de España (después de su recorrido por Marruecos), Arlt duda del embrujo de Rjmo, una mujer que había conocido en África. (Arlt, Roberto. "Salida de Tetuán - Hay que irse o enredarse - Rjmo, la de los ojos de miedo - La tristeza de la partida", en El Mundo, 21 de agosto de 1935"). Por otra parte, si bien en Larreta aparecen, reiteradamente, por ejemplo, vírgenes (o elementos que remiten a la España Católica) en el mundo musulmán, en la escenografía del barrio morisco, lo ruidoso, lo sucio y lo miserable están junto al color. Esto también se encuentra en Arlt, de un modo muy elocuente en 
Arlt, porque para él este tipo de ciudades están muertas: en ellas se muere de antigüedad. $^{35}$

En efecto, si nos atenemos a lo que las notas establecen como ciudades "de piedra", una de las más significativas a considerar es la representación de Toledo. Con una calificación inversa a la visión gozosa y laudatoria de la Semana Santa, de las fiestas en Granada y del espectáculo-cuadro de la mujer sevillana, pero también con una mirada que fusiona lo lingüístico y lo plástico y cierto empleo del color local, se presenta en las aguafuertes la "ciudad sacerdotal de otros tiempos". ${ }^{36}$ Uno de los puntos paradigmáticos de la España castiza, Toledo constituye, como se sabe, junto con otros centros de Castilla, como Ávila y Salamanca, un emblema del misticismo, modelo de espiritualidad y del imperio pasado de la religiosidad española. Así aparece nuevamente en El solar de la raza de Gálvez ${ }^{37}$ y también en tanto que exaltación de la España antigua, en La gloria de Don Ramiro, de Larreta, un libro no sólo muy leído en la década del veinte, sino reiteradamente citado por Arlt. ${ }^{38}$

A diferencia de estas imágenes y visiones cristalizadas en las letras argentinas, Toledo resulta para Arlt, una ciudad monacal y fría, que potencia la angustia que

sus notas africanas. Igualmente, puede decirse que la musulmana Cádiz es bulliciosa para Arlt, a diferencia de otras ciudades españolas, como las que encuentra en Galicia.

${ }^{35}$ Arlt dice esto a propósito de Santiago de Compostela y contraponiéndola a la alegre Betanzos. Véase, al respecto: Arlt, Roberto. "La alegría de Betanzos- Mitad América, mitad EspañaReminiscencias de la Argentina", en El Mundo, 30 de octubre de 1935. Recopilada en Arlt, Roberto. Aguafuertes gallegas y asturianas, Op. Cit., p. 127.

${ }^{36}$ La expresión es de Barrès, Maurice. Véase: Barrès, Maurice. El Greco ó el secreto de Toledo, Traducción y prólogo de Albeto Insúa, Madrid/Buenos Aires, Renacimiento, 1914, p. 161.

${ }^{37}$ Para Gálvez, Toledo constituye, justamente, un modelo de espiritualidad. En Toledo y otros lugares Castellanos como Segovia, Ávila, Sigüenza, Santillana del Mar "vive el pasado" y "la vida se detuvo [positivamente para él] hace tres siglos". Y agrega: " $¡ A h$ estas ciudades que nos extasían con su arte humano e inquietante, ciudades señoriales y místicas que hacen pensar en Dios, ciudades amigas a cuyo contacto nos hacemos más puros, más nobles, más buenos, más idealistas!. Barrès ha dicho de Toledo que es un verdadero hogar para el alma. Frase admirable y definitiva que debe aplicarse a todas las ciudades castellanas y que condensa, por modo genial, cuanto pudiera yo decir". Véase, Gálvez, Manuel. "El espiritualismo español", en $E l$ solar de la raza, Op. Cit., p. 25.

${ }_{38}$ Así, en la "Entrevista" realizada en 1929 a Roberto Arlt en La Literatura Argentina, él menciona reiteradamente, con elogios y también cierta toma de distancia, -perspectiva que, podría decirse, prevalece en toda la entrevista sobre los diferentes autores considerados- a Enrique Larreta y a La gloria de Don Ramiro como uno de los textos que marcan su generación. Véase, a este respecto. Arlt, Roberto. "Entrevista a Roberto Arlt", "Roberto Arlt sostiene que es de los escritores que van a quedar y hace una inexorable crítica sobre la poca consistencia de la obra de los otros", en La Literatura Argentina, n 12, agosto de 1929. 
prevalecía en otros sitios ya descriptos anteriormente en su viaje, como Jerez, ${ }^{39}$ Pontevedra $^{40}$ o Santiago de Compostela, otra "ciudad medieval", "de tedio" y "de penitencia”: 41 “¡Oh!...Ingenuo de mí cuando escribí que en Santiago de Compostela se enloquecía de angustia. Alegre es Santiago como el tintineo de una campana de plata y de oro, comparado con el sol bronco de esta alma de hierro fino que enfosca a Toledo" [...] La muerte y la penitencia donde se fija la mirada. La muerte. La agonía. El esqueleto". ${ }^{42}$

Si consideramos los modos de representar este espacio, cabe destacar al respecto, que en una conjunción de lo pictórico y lo literario, cierto empleo del pintoresquismo ${ }^{43} \mathrm{y}$ una reiteración de algunos lugares comunes en las "retóricas del viaje a España" sobre Toledo, - como ciertos tópicos del libro citado por Arlt de Maurice Barrès, El greco o

${ }_{39}$ Véase a este respecto, Arlt, Roberto. "Jerez es una evocación de pasadas glorias", en El Mundo, 15 de mayo de 1935. En esta aguafuerte Arlt opone a la "alegre" y "bulliciosa" Cádiz, la urbe "antigua", "triste" y "silenciosa", porque las "callejuelas antiguas [de Jerez] infunden ese pavor que es aureola natural de las cosas muertas". La crónica representa a Jerez, por lo demás, como ruina religiosa: "La hierba crece en la junta de los ciclópeos adoquines.[...] En patios fangosos se eleva a veces una columna de mármol, cuyos arcos de cimbra ostentan filigranas recamadas por un maravilloso cincel desconocido.[...] Silencio, penumbra, laberintos [...] Los templos roídos por los siglos, las batallas, la intemperie, muestran cúpulas de azulejos reventados, campanarios que se desmoronan, arcos que se abren vencidos por el peso de la carga. Y la cigüeña que se despioja o duerme al sol con la cabeza hundida entre los alones, da testimonio de un hundimiento definitivo e irreparable".

${ }^{40}$ Véase: Arlt, Roberto. "Pontevedra, la solitaria", en El Mundo, 30 de septiembre de 1935. Recopilada en: Arlt, Roberto. Aguafuertes gallegas y asturianas, Op. Cit.

${ }^{41}$ Arlt se refiere de este modo a Santiago de Compostela: "Galicia, la bucólica, se borra en los extramuros pétreos de Santiago de Compostela. La violenta presencia de la ciudad medieval es tan intensa, que de pronto se experimenta el terror de olvidar que aún existen ciudades alegres en la tierra [...] Monstruosos cubos de piedra, lisos, con altos ventanales enjaulados por cestones de hierro, puertas verdes, escudos de armas en las fachadas...oro muerto [...] Y el viento corre en este desierto de piedra, siniestro como si soplara en la ciudad de los espectros". Véase. Arlt, Roberto. "Santiago de Compostela- Ciudad triste, sin árboles, que se alegra en invierno bajo la lluvia, en El Mundo, 6 de octubre de 1935. Recopilada en Arlt, Roberto. Aguafuertes gallegas y asturianas, Op. Cit., p. 74.

${ }^{42}$ Arlt, Roberto. "Toledo la imperial", en El Mundo, 7 de abril de 1936. Recopilada en Arlt, Roberto. Aguafuertes madrileñas. Presagios de una guerra civil, Op. Cit., p.109.

${ }^{43}$ Según Pere Salavert, lo pintoresco se define como una relación entre la naturaleza y la cultura, y tiene dos caras. La primera — que remite a las ruinas románticas_, "es que las cosas del arte pueden presentarse en un punto tal de degradación o de dejadez que al espectador le sugiera la acción de una Naturaleza reapropiándose de la Cultura". [...] "La otra cara es que el propio paisaje natural sea capaz, bajo determinadas condiciones preceptivas, de sugerirnos una escondida obediencia de la Naturaleza a alguna intención o designio que nosotros atribuimos a la Cultura. En este caso se trata del paisaje digno de ser pintado, y es cuando aparece el viaje pintoresco' a la caza de cuadros en la Naturaleza." Véase: Salabert, Pere. Figuras del viaje. Tiempo, arte, identidad, Facultad de Humanidades y Artes, Universidad Nacional de Rosario, 1995, p. 58. 
el secreto de Toledo -,${ }^{44}$ la figuración arltiana se construye a partir de las imágenes de El Greco, o más precisamente, en diálogo con el cuadro donde el pintor pone en escena la vista de lejos de la ciudad amurallada:

Imagínense una roca cortada a pico sobre un río taciturno que traza en torno de ella un círculo de agua hervorosa. Esta roca, allá arriba, se muestra empenachada de murallas de bloques cenicientos, de torreones finos, de almenas, de puentes, de arcos, cada vez más elevados y más y las torres, las cúpulas, los cimborios, las agujas se eslabonan, ascienden...se mueven...suben...

Una fortaleza medioeval [sic] entre cielo y tierra.

En torno al eje calado, el paisaje volcánico, castigado por vientos humeantes. Ni llanura ni montaña; colinas, colinas rojizas, altozanos amarillos, ondulando tristemente hasta un próximo confín en el cual la tierra y el cielo se confunden en un desolado paño violeta.

Cuando las nubes pasan sobre la llanura montuosa, sus bordes blancos se recortan en sombras de tinta china en las tierras amarillas, y entonces se vuelve la cabeza para no mirar.

Al pie de la roca serpentea el Tajo. ${ }^{45}$

Igual que en la pintura (véase, en la página siguiente, la imagen de la "Vista de Toledo"), Arlt sitúa su mirada en un punto de vista frontal a la ciudad para describir el río Tajo a sus pies. ${ }^{46}$ Asimismo, la ubicación de las nubes, turbulentas y negruzcas, el panorama visto, la distribución de los planos y las tonalidades utilizadas (el río es negro, como "una balsa de alquitrán", los "altozanos amarillos", los "rojos de greda", "amarillos salitrosos" y "platas de ceniza"), ${ }^{47}$ semejantes, como se ve, a la obra

\footnotetext{
${ }^{44}$ Beatriz Colombi dice que Maurice Barrès es el responsable del mito de Toledo y figura central en esa versión de España que tanto eco tendría entre los escritores hispanoamericanos como Enrique Larreta o Amado Nervo. Véase: Colombi, Beatriz. "Retóricas del viaje a España”, Op. Cit., p. 128. En escritores como Pío Baroja, por ejemplo, también se reitera la representación de Toledo a partir de El Greco.

${ }^{45}$ Arlt, Roberto. "El paisaje de Toledo", en El Mundo, 6 de abril de 1936. Reproducida en: Arlt, Roberto. Aguafuertes madrileñas. Presagios de una guerra civil, Op. Cit., pp. 106-107.

${ }^{46}$ Oliverio Girondo elige el mismo punto de vista para representar la ciudad en la primera estrofa de su poema sobre Toledo: "Forjada en la 'Fábrica de Armas y Municiones',/La ciudad/ muerde con sus almenas/ un pedazo de cielo,/ mientras el Tajo,/alfanje que se funde en un molde de piedra,/atraviesa los puentes y la Vega... Véase: Girondo, Oliverio. "Toledo", en Calcomanías, Obra Completa, Edición crítica coordinada por Raúl Antelo, Buenos Aires, Editorial Sudamericana, 1999.

${ }^{47}$ Como dice más adelante el cronista, aparece aquí: "la misma gama de los colores que tiñen los ropajes de los profetas místicos, apóstoles y Cristos del Greco". Arlt, Roberto. "El paisaje de Toledo", Op. Cit., p. 108.
} 
mencionada, muestran que esta ciudad "muerta" y "de roca" ${ }^{8}$ está representada en la aguafuerte de Arlt en cruce con la imagen del conocido cuadro de El Greco y sus pinturas, tal como sucede en Barrès y otros escritores. "Y las nubes enlazan la ciudad y el cielo, — afirma Arlt—, con la misma técnica que los cuadros de El Greco, porque El Greco es Toledo, Toledo visto a través de la más extraordinaria sensibilidad de artista, que haya fijado en el planeta sus atentísimos ojos"; y repite al final de la aguafuerte: "El Greco es Toledo; Toledo es El Greco". ${ }^{9}$

Cabe destacar, por otra parte, que si bien estas aguafuertes retoman con la paleta de El Greco modos retóricos habituales de representar el lugar, la perspectiva de Arlt guarda cierta distancia de algunas de esas figuraciones cristalizadas. Y esto es así, porque en su visión se dejan de lado las imágenes celebratorias, las figuras del misticismo y de la religiosidad profunda que aparecen reiteradamente asociadas a la ciudad, $-\mathrm{y}$ que constituyen, por ejemplo, lo que a Maurice Barrès le revelaba "el secreto de Toledo" — ${ }^{50}$ y son los tintes de muerte y de angustia los que se construyen y acentúan a partir de los colores del pintor griego. De todos modos, una doble valoración atraviesa su mirada y el espectáculo percibido resulta un paisaje estético y, simultáneamente, una ciudad muerta, fría y distante. Si Toledo es, como dice el cronista citando textualmente al propio Barrès, "Asentada como diamante en preciosa montura", también resulta, como afirma siguiendo a Galdós, "ladronera miserable". "Ladronera y diamante simultáneamente", atravesada por un característico "encanto sombrío" que al

${ }^{48}$ Cabe aclarar que el calificativo de Toledo como ciudad de piedra utilizado por Arlt tiene que ver con la tipificación. Cuando Beatriz Colombi analiza los textos de Rubén Darío, sostiene que durante el siglo XIX se trabajó con algunos pares de oposiciones y ciertos tópicos sobre España que Darío revisaría y rearmaría: "Uno de los relatos peninsulares más constantes en el siglo XIX se articuló sobre un criterio de polaridad que dividía para representar (Granada y Toledo, sol y piedra, fiesta y procesión). Como puede verse, en Arlt, (a diferencia de Darío que, según Colombi, "fisura estas disociaciones"), se encuentran presentes esos contrastes y configuran los textos. Colombi, Beatriz. "Retóricas del viaje a España", Op. Cit., p. 127.

${ }^{49}$ Arlt, Roberto. "El paisaje de Toledo", Op. Cit., pp. 108-109.

${ }^{50}$ Dice Barrès: "El Greco me transmite, me revela el secreto de Toledo", pues la tarea del Greco consiste para Barrès en "haber hecho plástica una verdad de la religión". También afirma, en otro lugar: "Me seducirían menos los escombros de Toledo si no viera en ellos, gracias al Greco, los colores y las grandes líneas del misticismo que abrigaron": "Sus lienzos completan los tratados de las Santa Teresa y los poemas de los San Juan de la Cruz. Nos inician en la vida interior de los dignos castellanos. Libro alguno nos ha dado de esto una idea más nueva, más total. [...] El pintor nos lleva hasta el fondo nativo de los toledanos del siglo XVII. Vemos sus más nobles deseos alargándose hacia el cielo.[...] Sin él yo no sentiría tampoco alma ninguna en esta ciudad pronta a convertirse en polvo; ignoraría con qué estrella los toledanos se corresponden". Véase: Barrès, Maurice. El Greco ó el secreto de Toledo, Op. Cit., pp. 191, 193 y 192, respectivamente. 
escritor-viajero le cuesta precisar, "repulsiva y atrayente", con El Greco narra Arlt la desazón y la visión estética que, a la vez, le produce Toledo. ${ }^{51}$

Otro episodio paradigmático que interesa mostrar para la cuestión de la perspectiva de Arlt en torno a lo típico, el costumbrismo y el color local, es la puesta en escena de la corrida de toros. En efecto, poco antes de su partida hacia el norte de África, en su largo recorrido por el Sur de España, publica en julio de 1935 tres aguafuertes sobre su presencia en la efervescente fiesta popular. ${ }^{52} \mathrm{Si}$, como dice Jorge Monteleone, "El viaje es una experiencia corporal", lo que fascina a Arlt de la corrida es justamente el juego "emocionante" de agonía física y "pesadilla dolorosa" en que se sume al espectador, se lo "impresiona" e "hipnotiza", en una experiencia de catarsis sublime, intensa, deleitante y, a la vez, angustiosa: ${ }^{53}$ "No conozco angustia que más agote y quebrante el sistema nervioso que la emoción encendida en la sensibilidad, por un torero vacilante. A momentos su intensidad convierte al espectador en una agonía, pesadilla dolorosa que todo uno reclama, se termine para siempre"; y agrega más adelante: "Al salir de una plaza, después de presenciar varias lidias (cada una dura quince minutos) el físico del espectador tiene las coyunturas doloridas, los músculos relajados, la actividad mental ha quedado considerablemente reducida, el organismo dolorido de un trauma nervioso, reclama imperiosamente reposo". ${ }^{54}$

De esta manera, con el público así inmerso, y en una línea que continúa en algún punto la perspectiva del viaje de Sarmiento - con su visión de la corrida como un modo de lo sublime-, ${ }^{55}$ el toreo se transforma en episodio "salvaje", de "seductora y repugnante atracción” y en espectáculo estético:

\footnotetext{
${ }^{51}$ Agrega Arlt, además, “...ni Barrès ni Galdós ni Cossio, aún han dado la visión de Toledo. Semejante a una hecatombe cósmica, que se mantiene en equilibrio congelado, tal es la ciudadela que huele a magia negra, a pesar de que sus terribles sacerdotes visten en los cuadros dalmáticas catolicísimas, y a la vez tan repulsiva y atrayente, que cuando se escribe sobre ella, no se resuelve a poner punto final al tema". Arlt, Roberto. "Toledo la imperial", Op. Cit., p. 113.

${ }^{52}$ Las crónicas son: Arlt, Roberto. "¿Quítate de allí!, valiente”, en El Mundo, 13 de julio de 1935; Arlt, Roberto. "El toro y los toreros", en El Mundo, 14 de julio de 1935; Arlt, Roberto. “"El Niño de las Palmas' y las Banderillas", en El Mundo, 16 de julio de 1935.

${ }^{53}$ El deleite de lo sublime tiene que ver con la catarsis que provoca. Como escriben Silvestri y Aliata, siguiendo a Burke: "Lo Bello, para Burke, derivado del atractivo de un físico hermoso, se diferencia de lo sublime, que despierta en el espectador dosis moderadas de miedo que operarían de forma catártica, expurgando el alma de las pasiones. [...] El placer de lo sublime está provocado porque se ofrece una idea del peligro, del dolor o de la angustia, sin que uno esté realmente en estas circunstancias". Silvestri, Graciela y Aliata, Fernando. El paisaje como cifra de armonía, Op. Cit., p. 91.

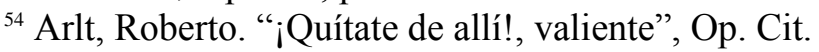


El que ha presenciado la corrida de toros... vuelve. ¡Volverá siempre! Inútil que el espectador sea un hombre culto, razonador, sensible. La lidia despierta en él instintos ancestrales, disloca su sensibilidad con un martirio de sobresalto y curiosidad feroz, tan violentas, que todas las nociones de civilidad se trastruecan. De allí que cuanto más salvaje sea la corrida, más profunda, torva, seductora y repugnante es la atracción. Hipnotiza su espectáculo. Después de una corrida, el organismo queda quebrantado, no se puede dormir. Durante varias noches, los ojos tienen fijos en la retina, el tremendo animal negro de agudas aspas, que por la arena color canela, avanza tardío, a lo largo de la circular barrera roja, vomitando sangre y babas por el morro; estirando tristemente el cuello como si estuviera sediento, hasta que cae sobre sus patas delanteras, moviendo los cuernos tal si estuviera sollozando.

Efectivamente, para Arlt, que en la nota siguiente se ocupará de describir la "estética de la corrida", y su carácter de estampa popular — la acometida de la fiera, la habilidad del picador, "el instante geométrico" en que el torero, "modelado de oro y escarlata" clava las dos últimas banderillas y en las "tribunas [blanquean] los pañuelos"-, el toreo "es un espectáculo de belleza prehistórica", y es por eso que su impresión perceptiva estetiza la atracción por la barbarie y la convierte en obra literaria: "El que acabo de describir es un espectáculo de arte, digno de la pluma de un escritor", afirma en la última de sus crónicas sobre el tema. ${ }^{56}$

Otra escena típica de color local que Arlt desestabiliza en su tipicidad escenográfica y fraudulenta, es el cuadro de las gitanas del Sacro Monte: ${ }^{57}$ “....vestidas a

\footnotetext{
${ }^{55}$ Para la cuestión del viaje a España de los latinoamericanos y, en particular el viaje de Sarmiento véase en el capítulo del libro de Beatriz Colombi, "Retóricas del viaje a España", el apartado titulado: "Sarmiento: orientalismo, españolada y prisma europeo", donde expone esta cuestión del toreo como un modo de lo sublime. Op. Cit., pp. 114-124.

${ }^{56}$ Arlt, Roberto. "El Niño de las Palmas' y las Banderillas", Op. Cit.

${ }^{57}$ Según Beatriz Colombi, uno de los libros que en "las retóricas del viaje a España" cristaliza gran parte de los tópicos sobre el color local español es el de Théophile Gautier, Voyage en Espagne. Afirma Colombi: "Si bien Gautier no es el primer productor de imágenes tipificadoras, es el responsable de numerosas cristalizaciones de la españolada y el orientalismo en su Voyage en Espagne (1843). Sus representaciones se vuelven la fuente autorizante de todo cuanto se diga sobre este espacio; el archivo y modelo estilístico al que acuden la mayoría de los escritores-viajeros, norma de la que no escapan los hispanoamericanos." También agrega en otro lugar, "Desde 1820, España se había vuelto la tierra privilegiada de la imaginación y la peregrinación estética francesa, convirtiéndose en un semillero del pintoresquismo y el color local." [...] "Los viajeros románticos franceses —Mérimée, Victor Hugo, Dumas y Gautier-", añade Colombi, "son los responsables de la representación de España a partir de cierto repertorio de color local: panderetas, manolas, bandidos en los caminos, pobreza, grotesco. El
} 
la usanza teatral; las cabezas radiando flores como el abanico de un pavo real; la vestimenta acampanada; rayas violetas con lunares blancos y faralaes escalonados. [...] De cerca son horribles [...] Abominablemente disfrazadas de gitanas". Porque, en efecto, en un primer encuentro con las gitanas, Arlt desestima el "colorido pirotécnico" que se arma a partir de una nota distintiva del lugar y desentraña su cualidad ilusoria y simulada: "Es mercadería falsa, para turistas. Estas gitanas son tan apócrifas como los apaches de París. Hojalata, yo no he venido a ver eso", afirma el cronista. ${ }^{58}$

Es así como se inicia, en un segundo momento, una larga serie de textos sobre su encuentro y relación con las gitanas del Sacro Monte. En este caso, la perspectiva centrada en las relaciones interpersonales y el encuentro con la individualidad de los sujetos, ${ }^{59}$ propone una visión "verdadera" y contraria a la de la gitanería teatral, que redefine, de esa forma, los rasgos del costumbrismo y el color local ${ }^{60}$. Así, mientras la

desarrollo del dispositivo del color local está ligado a tres órdenes de la descripción — tipismo, pintoresquismo y costumbrismo - aplicados a sujetos, espacios naturales y cuadros sociales, respectivamente" (Colombi, Beatriz., Op. Cit., pp. 113 y 116). Cabe destacar, a este respecto, que en las aguafuertes españolas de Arlt, coincidiendo con muchos de los tópicos que aparecen, por ejemplo, en el libro de Gautier, también se inscriben las gitanas, las corridas de toros, una aventura marítima muy desapacible en Cádiz (recordemos que Arlt asiste a la pesca de sardinas y vive un episodio en una trainera), los bosques de la Alhambra, la Alhambra, la pobreza de España y los mendigos, la ciudad de Toledo y una representación del Escorial con imágenes similares a las que se encuentran en Voyage en Espagne de Gautier.

${ }^{58}$ Arlt, Roberto. "Gitanas del Sacro monte- Pura escenografía para encandilar a los turistas- Lo falso y lo verdadero", en El Mundo, 5 de septiembre de 1935. Como con los gitanos, también en el caso de la Alhambra Arlt intenta desestabilizar su tipicidad pintoresca y se distancia del viaje turístico y de algunas visiones como la del "famoso libro de Washington Irving" y sus Cuentos de la Alhambra (texto que también cita Gautier pero en una mirada diametralmente contraria): "Creo que se dan pocos casos en los anales del turismo, que puedan igualar a la decepción que en el grueso del público, produce el palacio de la Alhambra. [...]...honestamente trato de comprender, en qué aspecto de este edificio muerto se ha fundamentado esa literatura de adjetivos sin sustantivos, que con tan alarmante abundancia, circula por la península". Arlt, Roberto. "La Alhambra y el público", Op. Cit., p. 84.

${ }^{59}$ En este caso la perspectiva de Arlt se acerca al tipo de viajero antiguo que caracteriza Todorov - ávido de experiencias intersubjetivas - diferenciándolo de Chauteubriand y el turista moderno. Véase nota 29.

${ }^{60}$ Se trata de las siguientes aguafuertes, publicadas por Arlt sucesivamente en El Mundo: "De cómo trabé amistad con los gitanos del Sacro Monte- Con La Golondrina y un éxito fotogénico se me abren las puertas", en El Mundo, 9 de septiembre de 1935; "Con los gitanos del Sacro Monte", en El Mundo, 10 de septiembre de 1935; "Vida de los gitanos del Sacro Monte", en El Mundo, 11 de septiembre de 1935; "Diálogo extraordinario con Lola la Chata", en El Mundo, 12 de septiembre de 1935; "La cueva de la gitana rica", en El Mundo, 14 de septiembre de 1935; "Historia de 'La Chata' - La gitana analfabeta que lee y hace cuentas- Se va a casar con un noble alemán arruinado", en El Mundo, 16 de septiembre de 1935; "Sensibilidad gitana", en El Mundo, 17 de septiembre de 1935. Reproducidas con algunas variaciones en Arlt, Roberto. Aguafuertes españolas, Op. Cit. 
gitanería escenográfica y para turistas era "abominable" y sus mujeres, "de piel erisipelada", "labios belfos", "jeta famélica", "mano pedigüeña", "nariz gótica", "la cara mordida por antiguas viruelas" y "la voz zalamera, cascada, [y] falsa", los gitanos con los que traba amistad son "fieras maravillosas" y "artistas", de una "sensibilidad prodigiosa" que aman la belleza y viven lo que imaginan. ${ }^{61}$ Ellos le acercan, por lo demás, un mundo de intrigas, celos y riñas, lleno de un encanto cercano a la literatura y plagado de sorpresas, que al cronista "apasiona y deleita". "Sólo con fotografías podrán admitir [en Buenos Aires] que esta novela es realidad", afirma el cronista, después de referir hechos concernientes a Lola La Chata, la "gitana burguesa" más rica del "Sacro Monte" que alterna sus vestidos con los modelos de la elegancia madrileña y está pronta a casarse con un ex Conde alemán. ${ }^{62}$ De esta manera, Arlt destaca en sus notas la cualidad ficcional de la vida de las gitanas y es así como las equipara al carácter novelesco, sorprendente y deleitoso de las narraciones inverosímiles de Ponson du Terrail: "Ya no me asombro de nada — sostiene con respecto a los episodios de que es testigo-, Creo en las novelas de Ponson du Terrail, creo en el disparate, creo en el absurdo", ${ }^{63}$ y también agrega, en otro lugar: "Yo sonrío. Me encuentro bien, cómodo y a gusto, escuchando chismes que desnudan la naturaleza humana. La luna asoma tras de la Alhambra, sobre los penachos de los cipreses. Y sonrío, gozando este pedazo de mi vida, que es un sueño". ${ }^{4}$

"Chico simpático [...] que has corrido mundo" — como le dice Lola La Chata— ${ }^{65}$ y cronista perspicaz, las aguafuertes describen paralelamente al mundo gitano y a sus naturalezas dramáticas e instintivas, los artilugios sutiles de que se vale el sujeto viajero para lograr su hospitalidad. Si la sociedad gitana es casi impenetrable, como le asegura el cónsul argentino al repórter viajero, la habilidad del cronista se pone en evidencia en estos textos y las aguafuertes refieren y destacan también esa habilidad. Arlt decide fotografiar a una jovencita, La golondrina, y de ese modo es que logra captar la simpatía de todas y el ingreso a sus cuevas. "¡El trabajo que me han dado estos malditos gitanos! —afirma Arlt—. Pero, al final me los he trajinado y estoy orgulloso" ${ }^{66}[\ldots]$ "No hago

${ }^{61}$ Arlt, Roberto. "Sensibilidad gitana", Op. Cit.

${ }^{62}$ Arlt, Roberto. "Diálogo extraordinario con Lola la Chata", Op. Cit.

${ }^{63}$ Arlt, Roberto. "La cueva de la gitana rica", Op. Cit.

${ }^{64}$ Arlt, Roberto. "Con los gitanos del Sacro Monte", Op. Cit.

${ }^{65}$ Véase: "Historia de 'La Chata'...", Op. cit.

${ }^{66}$ Arlt, Roberto. "De cómo trabé amistad con los gitanos del Sacro Monte- Con La Golondrina y un éxito fotogénico se me abren las puertas", Op. Cit. 
más que felicitarme y congratularme vanidosamente a mí mismo por haber acertado con el lado flaco de los gitanos. La envidia". ${ }^{67}$ De esta manera, las aguafuertes construyen para los lectores de El Mundo, en una continuidad con los textos porteños, la figura de un cronista ingenioso que gracias a su sagacidad y "simpatía" puede entrar en el mundo gitano y revelar lo que se escondía detrás de la falsedad escenográfica y del colorido de "utilería" teatral.

\title{
La construcción de "paisajes de la mirada"
}

\author{
El panorama es diversísimo y escrupuloso como el que adorna a casi toda España. Un \\ jardín parque.
}

...y a medida que se viaja se experimenta la desesperación de no poder vivir simultáneamente en cincuenta partes distintas, con cincuenta cuerpos y un solo cerebro. Más. Más. El hábito de viajar despierta una insaciabilidad de paisaje, necesidad compuesta de llegar y partir, y un solo miedo: quedarse. ${ }^{6}$

Roberto Arlt

Además de las escenas de color local, con el viaje ingresan, también, nuevos modos de representación: tanto los "agradables panoramas" 69 como los paisajes de la mirada sobre espacios naturales y urbanos, que son del todo inéditos en relación a lo que

\footnotetext{
${ }^{67}$ Arlt, Roberto. "Diálogo extraordinario con Lola la Chata", Op. Cit.

${ }^{68}$ Arlt, Roberto. "De Gijón a Santander. Alto en el pueblo de Llanes. Ríos que serpentean entre álamos", en El Mundo, 13 de noviembre de 1935. Reeditado en Arlt, Roberto. Aguafuertes gallegas y asturianas, Op. Cit., pp. 170 y 173.

${ }^{69} \mathrm{La}$ expresión es de Raymond Williams. El campo y la ciudad, Buenos Aires, Paidós, 2001. Sobre los panoramas de la mirada y el paisaje véase, también: Silvestri, Graciela y Aliata, Fernando. El paisaje como cifra de armonía, Op. Cit. Asimismo, puede consultarse sobre las vistas panorámicas: Barthes, Rolland. La torre Eiffel. Textos sobre la imagen, Barcelona, Paidós, 2001.
} 
Arlt ya había escrito, ${ }^{70}$ sobre todo en aquellos casos en que se convierten en cuadros típicos y vistas pintorescas o en los antes denostados escenarios de tarjeta postal.

"La quintaesencia de la mirada paisajística, que la historia ha fijado en la particular sensibilidad inglesa del siglo XVIII, — sostienen Silvestri y Aliata cuando analizan los orígenes de la idea de paisaje-, no partió de la tenue luz de la isla, sino de turistas entusiasmados que recorrían en Italia las huellas de los antiguos: partió [históricamente] del viaje y de la ausencia de raíces". ${ }^{71}$ Es más, para inteligir un espacio en tanto paisaje, afirman estos autores, no basta que exista un tipo de naturaleza: "es necesario un punto de vista y un espectador; es necesario, también, un relato que dé sentido a lo que se mira y experimenta; es consustancial al paisaje, por lo tanto, la separación entre el hombre y el mundo". Por ello, la "construcción paisajística", "es la mirada del exiliado, del que conoce su extrañeza radical con las cosas" y además "es siempre una mirada estética" que surge de una relación armónica $-\mathrm{y}$ de cierto dominio y "seguridad" - entre el ojo que observa y el mundo representado. ${ }^{72}$ Un espacio amenazante, inestable y de cambios que el yo no domina, domestica o controla, - como el que aparece en las novelas de Arlt y en muchas de sus crónicas porteñas-, difícilmente pueda ser paisaje. “¿Debemos recordar, —insisten Aliata y Silvestri- que el pintoresco Sur argentino, a fines del siglo XIX, emergió sólo después de la aniquilación indígena?" 73

Puede decirse, entonces, que con el viaje, aparece la mirada paisajística en la literatura de Arlt. Se trata de la experiencia de un nuevo sujeto y una perspectiva

\footnotetext{
${ }^{70}$ Cabe destacar que en las aguafuertes patagónicas, otras notas sobre viajes, también pueden encontrarse ciertas operaciones paralelas en relación con algunas vistas panorámicas y el paisaje. Véase: Arlt, Roberto. En el país del viento. Viaje a la patagonia (1934), Edición y prólogo de Silvia Saítta, Buenos Aires, Simurg, 1997. A este respecto, debe mencionarse el trabajo de Jens Andermann, quien analiza el viaje de Arlt en relación con las aguafuertes fluviales, las aguafuertes patagónicas y su columna sobre "El infierno santiagueño". Véase: Andermann, Jens. "Arlt: 'Lejos de las hermosas ciudades'”, en Mapas de poder. Una arqueología literaria del espacio argentino, Rosario, Beatriz Viterbo, 2000.

${ }^{71}$ Silvestri, Graciela y Aliata, Fernando. Op. Cit, p.10.

${ }^{72}$ La cita completa expresa lo siguiente: "La mirada paisajística es la mirada del exiliado, del que conoce su extrañeza radical con las cosas pero recuerda, o más bien construye, un pasado, una memoria, un sentido". Y luego afirman: "Aprendimos admirar la naturaleza guiados por el arte; la naturaleza contemplada es paisaje. [...] La mirada paisajística, en efecto, es siempre una mirada estética" y "la poetización del paisaje ignora los conflictos". Silvestri, Graciela y Aliata, Fernando. Op. Cit, p.10 y p. 177. Cabe agregar, además, que para ellos la ciudad también puede ser interpretada y construida como paisaje. Para esto, véase, en el mismo libro, "Representaciones de la ciudad como espectáculo paisajístico", pp. 143-149.

${ }^{73}$ Silvestri, Graciela y Aliata, Fernando. Op. Cit, p. 26.
} 
distanciada y ajena a la del hombre agobiado y en crisis con un mundo de cambios y tensiones de su obra previa. Es de esta manera que las aguafuertes españolas evidencian otros modos de enunciar que entran en disonancia con constantes típicas en su obra, y si bien, en muchos casos se mantienen similitudes en las formas de la representación caos, desorden, abuso de la enumeración, según aparecía en la Semana Santa en Sevilla, y también, formas geométricas y metáforas técnicas, como se verá mas adelantepueden detectarse modificaciones significativas y cambios en los juicios de valor y el sentido que se le otorga a la experiencia, por la diferente posición del sujeto en relación con el objeto de la descripción.

Un ejemplo paradigmático de este tipo de mirada es la vista desde lo alto (un panorama de la visión) de la ciudad de Bilbao que aparece en una de sus notas:

Bilbao está edificado a lo largo del montuoso pedestal de Archanda. [...] llegué a la cima del paseo agradable. La noche nos tomó arriba.

Bilbao, a doscientos cincuenta metros de profundidad, ofrecía un aspecto de mariposa negra con las dos alas manchadas de puntos luminosos, extendidas a lo largo del río Nervión.[...]

Sin embargo, el panorama visto desde Archanda, alcanza su intensidad máxima durante el crepúsculo. Entonces Bilbao adquiere la vidriosidad de una ciudad insepulta en una masa de bruma. A través de las humaredas de las fábricas, se distingue el río Nervión, semejante a una "ese" de plata batida. [...] Súbitamente se pierde la noción del lugar. Tres hileras de montes se extienden y sobreponen las masas de sus triángulos. Las colinas más próximas, revestidas de terciopelo verde; la segunda cadena de sierra muestra cumbres lilas que, por momentos, los juegos de luz pintan de vívida agua violeta; la última hilera de montañas corre sus masas inmensas de trapecios de papel de seda azul. [...] De pronto, el cielo se tiñe de cobre. Bilbao, cobra apariencia de inframundo. Se distingue inciertamente su techerio rojo montado en cubos de cartón. Las altas chimeneas como escarbadientes montados en caseríos fantasmales... [...] Una atmósfera brumosa que por momentos los rayos solares tiñen de plateadas yemas de vía láctea, patina el paisaje de una resplandeciente claridad cósmica. $^{74}$

Sin dicotomías marcadas entre campo y ciudad, el texto arma un paisaje de confluencia y contacto entre el espacio urbano y el natural. La escena muestra la

${ }^{74}$ Arlt, Roberto. "Archanda", en El Mundo, 18 de diciembre de 1935, Recopilado en Arlt, Roberto. Aguafuertes vascas, Op. Cit., p. 102. El subrayado es nuestro. 
industrial Bilbao, sus chimeneas y los efectos estéticos que el humo de las fábricas produce sobre la sierra, y una vista de las montañas y el caserío al pie del monte de Archanda. Como puede verse en la cita, la artificiosidad de la descripción se organiza según dos operaciones que son constantes en la escritura novelística de Arlt y que acá se retoman: la apelación a la metáfora tecnológica y técnica, y la mirada geométrica ${ }^{75}$. Pero en este caso, ese percibir bajo formas geométricas, que asociado en sus novelas a una imaginación vanguardista, es apoyo de psicologías tortuosas y configura espacios caóticos y apocalípticos, ${ }^{76}$ en las aguafuertes españolas adquiere otras connotaciones. Colinas de terciopelo, montañas que son "trapecios de papel de seda azul", "techerío rojo en cubos de cartón" y "chimeneas como escarbadientes", las formas se miniaturizan y, de un modo bastante peculiar, se retrotraen al terreno de lo íntimo y lo familiar, a un mundo infantil.

Otros pasajes, con imágenes que se reiteran en muchas aguafuertes, muestran, asimismo, tejados "de nieve" que rojean "como si los espolvorearan de canela", "cordones de montañas de papel azul", "felpudo verde manzana de los sembradíos", "caserío vasco" equivalente a dados desparramados en un abultamiento de paño verde, "retazos color papel madera, verde manzana" del sembradío, "torrecillas poligonales techadas de pizarra y tejas de cobre", "paños de montaña donde un halo lila abomba la atmósfera" como una "pompa de jabón", "colinas semejantes a tableros de ajedrez", "pequeños montes" que "recortan el cielo de porcelana celeste diferenciando manchas verdes", esquinas "pintadas de color rosa de calcetín"; ${ }^{77}$ todas ellas, imágenes candorosas de una mirada dichosa que paladea y torna

\footnotetext{
${ }^{75}$ Véase para estas cuestiones: Sarlo, Beatriz. "Arlt: la técnica en la ciudad", en La imaginación técnica, Buenos Aires, Nueva Visión, 1992 y, de la misma autora, "Arlt: ciudad real, ciudad imaginaria, ciudad reformada", en Punto de Vista, n 42, abril de 1992. También, Jitrik, Noé. "Ver bajo formas geométricas: el rencor cóncavo", en "Entre el dinero y el ser. Lectura de El juguete rabioso de Roberto Arlt", en La memoria compartida, Buenos Aires, CEAL, 1987

76 Véase: Renaud, Marise. "Los siete locos y Los Lanzallamas: audacia y candor del expresionismo", en Arlt, Roberto. Los siete locos-Los Lanzallamas, Edición crítica, Colección Archivos, Mario Goloboff coordinador, Francia, ALLCA XX, Université Paris X, 2000. Volveremos sobre este punto.

${ }^{77}$ Un fragmento que condensa mucha de estas imágenes y describe el encanto del paisaje en las vistas del camino entre Málaga y Granada, es el que aparece en la aguafuerte "Tortones de algarrobo contra el mareo- Cuestas y zigzags- El encanto del paisaje", en El Mundo, 23 de agosto de 1935. El fragmento es el siguiente: El camino describe curvas por lujo. Pasamos por trechos donde un pequeño barranco es rodeado por zig-zags de camino de un largo de más de cien metros [...] El paisaje abrumador de tan variado. Conos de montaña que surgen como surtidores de piedra de todos los costados, vereditas naturales a lo largo de los cerros, saliendo de los límites de la provincia de Málaga; el paisaje se dulcifica, parecen las colinas semejantes a tableros de ajedrez, cubiertas de paños de sembradío, retazos color papel madera, verde manzana. Las nubes que pasan
} 
perceptible lo extraño y lo acerca al orden de los objetos tangibles del mundo cotidiano - calcetín, papel, canela, felpudo, escarbadientes, dados, pompa de jabón, tablero de ajedrez, etc. $-{ }^{78}$

De esta manera, la imaginación geométrica de Arlt construye un paisaje que, opuesto a algunas de las figuraciones cristalizadas sobre el espacio del que parte el cronista como viajero, como por ejemplo, el territorio argentino y la idea de la extensión, ${ }^{79}$ se presenta a la mirada como limitado y aprensible. Esto se refuerza por el uso de los diminutivos y una reiterada apelación a la miniaturización que ayuda a conformar en muchas aguafuertes un mundo de cercanías, íntimo, fácilmente inteligible, casi de juguete o infantil. ${ }^{80}$ Como lo asevera en algunos momentos el propio Arlt, Girón tiene "un puertecito [...] que es una herradura de buey, con escaleras, limpio, diminuto, como si fuera de juguete [...] Estamos en una ciudad de intimidad de bazar. Sus calles cortas terminan en plazoletas diminutas, fantásticas...[...] ...levantando los brazos, se

producen sombras violáceas en los prados. A pesar de ser domingo, yuntas de toros arrastran arados; se ven entre las infinitas lanzas de los trigales, los campanudos sombreros de los labradores, los olivares tropean en la lejanía con sus líneas oblicuas a lo largo de los más altos montes; los graneros encalados, de piedra y ladrillo (en España no se sabe donde comienza el granero o empieza la vivienda) conmueven el entendimiento, con la pulcritud de su espectáculo. El tablero de ajedrez recostado en las colinas se tiñe de las anilinas más violentas y opuestas; las sombras siguen leyes singulares; hay trozos de hierba que rojea como si estuviera ensangrentada; paños de montaña donde un halo lila abomba la atmósfera, semejante a una prodigiosa pompa de jabón; [...] Uno termina por entrecerrar los ojos y decirse: - ¡Dichoso yo, que puedo viajar!”.

${ }^{78}$ El papel, la seda, el terciopelo, el paño, los cubos de carón, los escarbadientes, la porcelana, podrían sugerir también, cierta acumulación kitsch.

${ }^{79}$ En "La gloria del sol", una de las primeras aguafuertes sobre su estadía en Cádiz, Arlt compara, por ejemplo, las "calles-llanura" de la Argentina con las estrechas calles europeas, y explica cómo afecta ese confinamiento a "la mirada criolla, y a la perspectiva de los argentinos acostumbrados a "las calles-llanuras" (a "nosotros los argentinos, hombres de llanura y de calles anchas como otras llanuras", dice textualmente Arlt). Véase, Arlt, Roberto, "La gloria del sol", en El Mundo, 10 de abril de 1935. A este respecto, cabe agregar que, como bien explican Silvestri y Aliata, cuando se piensa un espacio o un paisaje propio o ajeno, no se lo puede considerar separado de las visiones previas y/o cristalizadas, y es por eso que las ideas de lo vacío y lo extenso aplicadas al territorio argentino y ciertas imágenes de los viajeros ingleses sobre nuestro suelo, siguen funcionando a la hora de pensar lo propio. En relación con algunos de los modos de figurar el territorio argentino, véase Prieto, Adolfo. Los viajeros ingleses y la emergencia de la literatura argentina, 1820-1850, Buenos Aires, Sudamericana, 1996. También puede consultarse: Pratt, Mary Louise. Ojos imperiales. Literatura de viajes y transculturación, Buenos Aires, Universidad Nacional de Quilmes, 1997.

${ }^{80}$ Las características de este mundo de cercanías que aparece en estos paisajes de la mirada de Arlt, la apelación a lo diminuto y lo ingenuo, el empleo de los colores pastel — verdes manzana, lilas, celeste, "seda azul", rosa de calcetín-y el tipo de texturas — porcelana, terciopelo, cartón - marcarían, de alguna manera, cierta coincidencia con algunas particularidades de la estética naïf. 
pueden tocar casi los balcones de los segundos pisos", ;1 y también, en otro lugar: "Callejuelas truncas con escaleritas de piedra, mujeres que pasan con un tonelillo de agua cargado a la cabeza [...] Cuando me asomo al balcón casi podría tocar con la punta de los dedos la torre de piedra de la iglesia, de tres pisos". ${ }^{82}$

Como en este último caso, y en la cita sobre Archanda, estas aguafuertes muestran, además, vistas a la distancia y desde lo alto, y en algunos momentos, panorámicas sobre lo representado que simulan y arman una especie de maqueta del lugar. Como sostiene Roland Barthes sobre las vistas panorámicas de Victor Hugo y Michelet, ${ }^{83}$ (una de París y otra de Francia), "ellos [Hugo y Michelet] comprendieron muy bien que al maravilloso alivio de la altura, la visión panorámica le añadía un poder incomparable de intelección: la vista de pájaro [...] [que] ofrece un mundo legible y no solamente perceptible, [y] por eso corresponde a una sensibilidad nueva de la visión”; "viajar, en otro tiempo - añade Barthes - suponía estar enterrado en la sensación y no percibir más que una especie de ras de las cosas". "La vista de pájaro", al contrario [...] "permite superar la sensación y ver las cosas en su estructura" ${ }^{84}$ Del mismo modo, las notas españolas de Arlt introducen, en muchos casos, la visión a la distancia y la "mirada del pájaro", una zona desde donde el paisaje se contempla como en un mapa. Así se inscriben escenas que construyen un cuadro desde arriba, un enfoque de perspectiva $\mathrm{y}$, ocasionalmente, arman un croquis perceptual de la estructura del sitio representado: ——Bilbao, a doscientos cincuenta metros de profundidad, ofrecía un aspecto de mariposa negra con las dos alas manchadas de puntos luminosos..."-. "La realidad aparece, [entonces] resumida en su totalidad en un solo golpe de vista". ${ }^{55}$ Como en la descripción del caserío vasco: "Tome usted un tapete verde, arrúguelo y sobre sus amontonados pliegues derrame los dados de un cubilete, y tendrá la más acabada visión del caserío vasco, en las faldas y valles de los Pirineos". ${ }^{86}$

\footnotetext{
${ }^{81}$ Arlt, Roberto. "Girón, preciosidad cantábrica- El palacio de Revillagigedo- Muchachas que sonríen", en El Mundo, 10 de noviembre de 1935. Recopilada en Arlt, Roberto. Aguafuertes gallegas y asturianas, Op. Cit., pp. 159 y 160.

${ }_{82}$ Arlt, Roberto. "La alegría de Betanzos. Mitad América, mitad España - Reminiscencias de la Argentina", en El Mundo, 30 de octubre de 1935. Reeditada en Arlt, Roberto. Aguafuertes gallegas y asturianas, Op. Cit., p. 129.

${ }_{83}$ Barthes considera que el comienzo de las vistas panorámicas se da en el romanticismo. Barthes, Roland. La Torre Eiffel. Textos sobre la imagen, Op. Cit.

${ }^{84}$ Barthes, Roland. La Torre Eiffel. Textos sobre la imagen, Op. Cit., p. 62.

${ }^{85}$ Silvestri, Graciela y Aliata, Fernando. Op. Cit, p. 77.

${ }^{86}$ Arlt, Roberto. "El caserío vasco. Viviendas en señorial aislamiento. Interiores severos y sombríos", en El Mundo, 26 de diciembre de 1935, Recopilado en Arlt, Roberto. Aguafuertes
} 
De esta manera, si en los paisajes españoles se da cabida a un ojo observador que, con frecuencia, organiza el paisaje urbano y natural a una distancia calculada, esto difiere de los modos principales de la figuración urbana (y natural) en las novelas, los relatos y algunas de las crónicas porteñas de Arlt. En este caso no se supera lo que Barthes denominaba el orden de la sensación o "la vista a ras de las cosas", y la percepción se sumerge, y a menudo se confunde con un mundo múltiple, cambiante y amenazador: una visión de "contigüidades" y "contacto", como la que describe César Aira, cuando formula lo que considera uno de los modos del expresionismo arltiano. ${ }^{87}$

En efecto, nada más alejado de esta geometría miniaturizante, de ese mundo "de juguete" y aprensible que el percibir bajo formas geométricas que aparece, por ejemplo, en novelas y ciertas ficciones arltianas. "Crestas puntiagudas de ciudades modernas, cemento hierro, cristal" que "enturbian la quietud de Erdosain", "prisiones de cemento más cargadas que condensadores de cargas eléctricas", ${ }^{88}$ "Distancia encajonada de altas fachadas entre las que parece flotar una neblina de carbón", 89 "tumultos monstruosos de la ciudad de Pórtland y de hierro", "diagonales oscuras a la oblicua sombra de los rascacielos bajo una amenazadora red de negros cables de alta tensión", 90 "rayo de sol" que penetra "por la entreabierta puerta de vidrios opacos" "como una barra de azufre" que cercena "en dos la atmósfera azulosa", 91 y "contramarcos fosforescentes, perpendiculares, azules, horizontales amarillas y oblicuas moradas", ${ }^{2}$ son algunos ejemplos elocuentes de ciertos modos predominantes de la figuración urbana en la narrativa de Arlt, anterior al giro que se produce en su literatura en 1932.

vascas, Op. Cit., p. 121. En este texto, la geometría miniaturizante de Arlt acerca la descripción, nuevamente, al universo aprensible de lo cotidiano y conocido: más precisamente, en este caso, al mundo de lo lúdico -dados, tapete, cubilete-, seguramente, muy familiar para los lectores de El Mundo.

${ }^{87}$ Aira César. "Arlt”, en Paradoxa. Literatura/Filosofia, n 7, Rosario, Beatriz Viterbo Editora, 1993. En las aguafuertes españolas aparece una representación espacial que tiene algunas líneas de contacto con la que se da en las aguafuertes africanas, como veremos en el apartado siguiente. Véase: Juárez, Laura. "La representación del espacio africano en la literatura arltiana de los años treinta", en Diez lecturas de Arlt, Premio Edenor 2000, Buenos Aires, Fundación El Libro, 2000, pp. 119-143.

${ }^{88}$ Arlt, Roberto. Los siete locos-Los Lanzallamas, Op. Cit., p. 524.

${ }^{89}$ Arlt, Roberto. "Noche terrible", en Cuentos completos, Edición a cargo de Ricardo Piglia y Omar Borré, Buenos Aires, Seix Barral, 1996, p. 117.

${ }^{90}$ Arlt, Roberto. Los siete locos-Los Lanzallamas, Op. Cit., p. 65.

${ }^{91}$ Arlt, Roberto. Los siete locos-Los Lanzallamas, Op. Cit., p. 200.

${ }^{92}$ Arlt, Roberto. "Noche terrible", Op. Cit., p. 117. 
Como puede verse, no sólo difieren los materiales (cemento, pórtland, hierro, azufre, carbón), que remiten a la ciudad moderna, cuyos caracteres Arlt no encuentra sino excepcionalmente en España. También aparece en sus novelas un uso de colores primarios y muy saturados y escenas de contrastes expresionistas, como "rectángulos anaranjados en fondos de tinieblas". De esta manera, las imágenes construyen una ciudad "violenta" y "monstruosa" que suscita, en el primer Arlt, el desamparo y el horror. ${ }^{93}$ Efectivamente, como afirma Marise Renaud, es a través de la percepción geométrica del mundo urbano, que Arlt expresa "el martirio del hombre moderno entregado al poder del entorno". Así, "gracias a una frenética proliferación de formas geométricas — paralelogramos, rectángulos, cuadrados, cubos y cilindros invasores-, a un brutal surgimiento de oblicuas incisivas, de amenazadores ángulos agudos, la agresividad y el poder destructor de la urbe van cobrando una dimensión realmente obsesiva". A esto se suma, añade Renaud, la violencia de los colores en un cromatismo de contrastes y tonalidades chillonas que consolida "un ambiente de pesadilla". No hay, por ello, para Renaud, una celebración futurista y exaltación vanguardista de la modernidad y, es de esta manera, que puede ligarse la literatura de Arlt a la visión sombría de los expresionistas alemanes ${ }^{94}$.

${ }^{93}$ Cabe aclarar que para Beatriz Sarlo, la representación de la ciudad moderna, además de caótica y apocalíptica, está atravesada por una "tensión estética", y que la idea de la "belleza ciudadana", según la autora, surge para Arlt, "de una crítica a la rutinización visual de la pequeña burguesía" y "de una fantasía cultural cuyos materiales provienen de la técnica, el cine y la fotografía." Sarlo, Beatriz. "Arlt: la técnica en la ciudad”, Op. Cit., pp. 51-52.

${ }_{94}$ Renaud, Marise. "Los siete locos y Los Lanzallamas: audacia y candor del expresionismo", Op. Cit., pp. 73-75. Si en el mundo expresionista de Arlt que se consolida preferentemente en las novelas, no aparecería, como señala Renaud, el tipo de exaltación vanguardista y futurista de la modernidad, podría decirse que en las aguafuertes españolas sí encontramos una gozosa celebración estética del industrialismo moderno, que es casi una encomiástica futurista, con la exaltación del monstruo-máquina (en este caso, el "tren bloming" que tiene brazos, manos, labios y mandíbulas), en la representación arltiana de los Altos Hornos de Baracaldo. "Espectáculo maravilloso" y "sinfonía" estética descripta como un juego de luces "pirotécnicas" y metáforas cósmicas y estelares (sol, meteoros, estrellas de oro), Arlt se encuentra "agobiado frente a tanta belleza". Ante ella, la naturaleza empalidece o se vuelve, por momentos, sombría, y el paisaje cobra mayor belleza al tornarse metálico: "Entrando a Bilbao por la noche, el turista se inmoviliza en la ventanilla del vagón, solicitado por el espectáculo pirotécnico que ofrecen las cúpulas de los altos hornos. Surtidores de chispas de oro alumbran con resplandores solares las negras torres de acero, agrupadas al pie de las montañas sombrías. Otras veces son llamaradas escarlatas, enormes; [...] A medida que se aproxima uno a Baracaldo, las casas son más negras, el follaje de los escasos sembradíos transparenta su verdor taciturno a través de una cutícula de carbón; [...] y la sorda emanación de esta Babel metaliza el paisaje, recubre sus contornos duros y geométricos, de un brillo particular, como de galvanoplastia" (Arlt, Roberto. "Altos hornos de Baracaldo. Montañas sombrías tras un fondo rojo y hombres y mujeres como hormigas en lo alto", en El Mundo, 5 de diciembre de 1935. Reproducido en Arlt, Roberto. 
Un caso interesante, que se separa de un modo peculiar de lo descrito anteriormente sobre las novelas y que introduce otros elementos sobre la figuración paisajística de Arlt en España, es el que aparece en "el prodigioso espectáculo" del pueblo de "Vejer de la frontera". ${ }^{95}$ Con una apelación a los contrastes de tonalidades brillantes y luminosas, y a los efectos de la luz solar sobre la piedra y la cal, aparecen "azules de cielo" que recortan planos blancos de luz y de sol. Pero en este caso, sin agresividad para el ojo que observa, "rebota el sol en tanta blancura sin ofender los ojos". También la arquitectura y el espacio natural, se reducen, como en otros textos y de un modo netamente tajante, a su simple forma geométrica, ${ }^{96}$ aunque la proliferación de cubos, rectángulos, pirámides, planos y triángulos, de modo diametralmente opuesto al que podía verse en las citas de sus novelas, contribuye, más bien, a consolidar, un paisaje onírico, universo alucinatorio y de ensueño infantil, que roza el orden de lo maravilloso, es sitio de lo placentero y deja, por ello, el corazón "extático de gozo":

Aguafuertes vascas, Op. Cit., pp. 61-62). Si como vimos, por lo demás, para el caso de "Archanda", no había confrontación entre el mundo urbano, el espacio verde y los atributos de la ciudad industrial, y la representación los incluía simultáneamente sin conflictos (las chimeneas en medio del paisaje de la montaña y de la ciudad), la celebración de los altos hornos tampoco pone en crisis el industrialismo moderno con el orden natural, que parecen colaborar mutuamente en la belleza del paisaje. En este sentido, interesa considerar cómo cuando Arlt se acerca a Bilbao, el cuadro de la naturaleza se mira a partir del sol que figuran las luces de la metrópolis industrial: "de pronto, — afirma Arlt mientras describe lo que ve desde el tren-, una llamarada azulenca cruza los aires; con tonos de oro se ilumina la torre de hierro negro. La humareda que nimba la lengua de llama azul revienta en lienzos de luz solar, que al soslayo revela la silueta de las montañas; estamos frente a los altos hornos y fundiciones de acero". (Arlt, Roberto. "De Santander a Bilbao. Luciérnagas inmóviles en un fondo negro. Se ha perdido una maleta", en El Mundo, 18 de noviembre de 1935. Reproducido en Arlt, Roberto. Aguafuertes vascas, Op. Cit., p. 31). De todas maneras, cabe destacar que lo que aparece en las aguafuertes sobre los altos hornos es casi excepcional en el corpus del viaje a España, y la imaginación tecnológica de Arlt que se expresa en estos textos deja lugar, más bien, casi siempre, a la geometría miniaturizante que se posa sobre el reino aprehensible del mundo urbano y natural.

${ }^{95}$ Arlt, Roberto. "Vejer de la frontera", en El Mundo, 25 de abril de 1935.

${ }^{96}$ Como puede verse en una cita más extensa, así aparece en la perspectiva de Arlt, la geometría de blancos del pueblo de Vejer de la frontera: "Quizá el prodigioso espectáculo que ofrece este pueblo, resida en que no existiendo diferencia de color en el baño blanco que le tiñe, la masa total de sus viviendas, semejante a una pirámide trunca, parece esculpida en un bloque cósmico de cal. [...] Cubos de casas blancas, sobreponiendo tejados verdinosos. [...] Una lluvia de leche de cal ha rociado las sobrepuestas masas de cubos y triángulos, desde las balaustradas hasta los cimientos. Rigurosamente. [...] El sol rebota en tanta blancura sin ofender los ojos. Diríase que el alma desde hace muchísimos años hubiera apetecido esta fantasmagórica creación cuyas líneas de planos blancos, cortándose en los azules del cielo, torna aéreos los bloques de piedra y tan puras las murallas, que el viajero no se atreve a encender una cerilla, raspándola en el muro. Arlt, Roberto. "Vejer de la frontera", Op. Cit. 
...y por momentos uno se pregunta si el cuadro que los ojos contemplan - torres, cubos triángulos - no es la creación de un sueño que será llorado cuando desaparezca como las hermosas fantasías de la niñez. [...] Si de pronto la puerta del Ayuntamiento se abriera y saliera de allí una procesión de reyes magos, con barbas hasta las rodillas y coronas sobre las cabezas, acompañados de un ángel moviendo las alas, parecería suceso tan natural como esta alucinación roquera, piramidal y blanca, de una albura como jamás se haya visto ni en el mármol ni en la leche ni en las más finas sábanas de lino. ${ }^{97}$

Un universo que presenta otra legalidad, el mundo de maravillas se hace patente de modo más contundente aún, en algunas representaciones del espacio verde y la naturaleza, como el caso de los bosques de la Alhambra y del paisaje gallego. Justamente, en el caso de la Alhambra se figura una zona de encanto y un viaje a un tiempo de ensueño, una "atmósfera de posibilidades", donde se revierten las leyes racionales, y lo imposible y lo irreal se vuelven verosímiles y "verdaderos": allí los árboles podrían comenzar a caminar, podría irrumpir un dragón con un cortejo de jovencitas, y, como en el caso de "Vejer de la frontera", dice el cronista, eso "nos parecería natural". ${ }^{98}$ Por otra parte, tal como lo define el propio Arlt, el "reino de lo maravilloso" "es complemento inevitable del paisaje gallego". ${ }^{99}$ En efecto, en Galicia Arlt queda fascinado por el encantamiento de las vistas que lo circundan. Allí encuentra un espacio "nigromántico" y de seres legendarios que remite a historias mitológicas y antiguas, y un mundo de magia y extrañas aventuras, que se supone poblado de espíritus, duendes, hadas y hechicerías. Y porque resulta al percibirlo un universo de embrujo y de ensueño, también en este caso se cuestionan los ordenes de la razón y la naturaleza; la descripción, entonces, se acerca a reino de lo prodigioso y lo sobrenatural. Si la irregularidad, lo quebrado y la variedad son, por lo demás, algunos de los rasgos principales que definen lo pintoresco, ${ }^{100}$ así se figura el cuadro "accidentado" pero no monstruoso, el territorio "roto, quebrado irregularísimo" del paisaje gallego, cuya

\footnotetext{
${ }^{97}$ Arlt, Roberto. "Vejer de la frontera", Op. Cit.

${ }^{98}$ Véase, a este respecto, Arlt, Roberto. "El bosque de la Alhambra- Ensueños y sugerencias", en El Mundo, 8 de septiembre de 1935.

${ }^{99}$ Arlt, Roberto. "El encanto del paisaje gallego- Montañas azules y bosques de terciopelo- Una escenografía mágica", en El Mundo, 24 de septiembre de 1935. Reproducida en Arlt, Roberto. Aguafuertes gallegas y asturianas, Op. Cit., p.53.

${ }_{100}$ Véase, a este respecto. Silvestri, Graciela y Aliata, Fernando. El paisaje como cifra de armonía. Op. Cit.
} 
"armonía plástica" "sólo puede ser rigurosamente verosímil — como lo expresa Arlt— en un teatro de magia". ${ }^{101}$

De tal manera, estas aguafuertes construyen una mirada fascinada que asocia con España cierto orden del ideal, del ensueño y lo imposible. Así, el caso de Arlt puede asimilarse a la perspectiva subjetiva de un sujeto aventurero que, semejante al yo poético del poema "Le voyage" de Baudelaire, busca y anhela "el azar de lo diverso", ${ }^{102}$ como en el epígrafe (“...y a medida que se viaja se experimenta la desesperación de no poder vivir simultáneamente en cincuenta partes distintas, con cincuenta cuerpos y un solo cerebro. Más. Más.”), ${ }^{103}$ y percibe el viaje en tanto que aventura: esto es, en términos de Georg Simmel, la experiencia de un/otro mundo alternativo que se recorta del orden cotidiano y se torna una totalidad autónoma, cerrada, con leyes propias. ${ }^{104}$ "Y sonrío gozando este pedazo de mi vida que es un sueño", "violenta sensación de encantamiento", "Atmósfera de posibilidades donde se hace posible la brujería y el endriago", "Impresión de salud tan violenta y agradable, que uno siente que renace", son términos que en las aguafuertes y en las descripciones numerosas veces asocian "lo otro" a un territorio onírico, paisaje de aventuras y asombro, sitio de lo deseado y otro mundo apetecible, lugar de lo heterogéneo.

\footnotetext{
${ }^{101}$ Arlt, Roberto. "El encanto del paisaje gallego- Montañas azules y bosques de terciopelo- Una escenografía mágica", Op. Cit., p. 54. También, véase: Arlt, Roberto. "Los fantasmas en el paisaje gallego- Supersticiones, leyendas y maleficios- El ensueño es inevitable". Cabe aclarar que Sylvia Saítta analiza muy bien de qué manera, en un primer momento, Arlt vincula el hombre a la naturaleza y explica el carácter del gallego por el paisaje. En un segundo momento, Saítta observa cómo "roto el hechizo del paisaje, Arlt discute con los escritores españoles, principalmente con Unamuno y con Valle Inclán, quienes explican la situación española a través de la vinculación entre el paisaje y el 'temperamento soñador' del español y difunden una literatura que no da cuenta de cuán ruda es la vida campesina gallega.[...] Arlt, en cambio, afirma Saítta - lee la naturaleza en clave económica y sostiene que, para captar el temperamento y la psicología del gallego, hay que explicarlo en términos de su economía regional" (Saítta, Sylvia. "Prólogo", en Arlt, Roberto. Aguafuertes gallegas y asturianas, Op. Cit., pp. 12-13).

${ }^{102}$ La expresión es de Jorge Monteleone, que analiza el poema de Baudelaire en el prólogo de su libro sobre los viajes. Véase: Monteleone, Jorge. Op. Cit., p. 13.

${ }^{103}$ Arlt, Roberto. "De Gijón a Santander. Alto en el pueblo de Llanes. Ríos que serpentean entre álamos", Op. Cit., p. 173. En "La ciudad de Betanzos" Arlt refiere cómo el encanto del paisaje está en razón de lo diverso, lo múltiple y la variedad. Así, sostiene refiriéndose a Betanzos: "Poco resta de su pasada gloria, pero la variedad que ofrece su paisaje, simultáneamente urbano, campesino y marítimo, es la razón de su encanto" (El Mundo, 20 de octubre de 1935. Recopilada en Aguafuertes gallegas y asturianas, Op. Cit., p. 103).

${ }^{104}$ Simmel, Georg. "La aventura" en su Sobre la aventura. Ensayos de estética, Barcelona, Península, 1988, p. 17-41.
} 
Es más, no sólo las aguafuertes españolas, como vimos más arriba, no sortean las trampas de lo exótico y lo pintoresco, organizan cuadros de la mirada y un universo de ensueños, también la construcción paisajística se lleva al mundo del trabajo. Arlt percibe, entonces, como paisaje, el costumbrismo de la labor de los animales de tiro, de los artesanos ${ }^{105} \mathrm{y}$ de los trabajos agrarios, que devienen así, en un "cuadro" estético para ser placenteramente contemplado:

Resulta espectáculo gustoso de ver el cuadro de los labradores, sentados en compañía de los molineros, a la sombra de la colmena blanca. Los borricos husmean la hierba, mientras aquellos tocados de campanudos sombreros de alas planas y la chaqueta abierta sobre la camisa, charlan lentamente, liando un cigarro y mirando la vera, extendida a doscientos metros de profundidad, en colinas donde el tono de los sembradíos semeja felpudos de distinto matiz verde". ${ }^{106}$

Asimismo, como puede verse en el final de la cita y también en otros pasajes, las marcas del trabajo agrícola y de la tierra cultivada se transforman, en su simetría geomética, en un patchword ornamental para el ojo que observa: “Cada vez son más altos los montes"; — expresa Arlt en su descripción del camino de Cádiz a Barbate“caen sobre los ojos sus masas violetas y verdes, onduladas llanuras donde la hoz ha

${ }^{105}$ En una de sus notas sobre Granada, el trabajo de los individuos y los animales forma parte del paisaje: "Moles blancas, calizas, salinas, de superficie rugosa, con cantos blancos, redondeados; gemas de cristal chispeando al sol. Pequeños montes en cuyo reborde las lanceadas hojas de las pencas y las espinosas de los cactus, recortan el cielo de porcelana celeste diferenciando manchas verdes. [...] Paisaje de ballet. Canturreo 'El amor brujo' y camino más despacio que un convaleciente. El tejado de nieve de la montaña rojea como si lo espolvorearan de canela. Mujeres enlutadas, pequeñas, avellanadas, cosen sus ropas a la sombra de los muros blancos; algunos artesanos baten tinajones de cobre; una yunta de toros pasa arrastrando una carreta, y en el recodo nuevos montecillos blancos, como de cal, de sal, muros rugosos, constelados de gemas áridas que deslumbran la vista. Arriba en el borde, manchas verdes de pencas y chumberas." Véase: Arlt, Roberto. "Trogloditas en Granada - Reminiscencias de "El amor brujo" - Visitas de cortesía a las casas cavernas - Una silla y agua fresca", en El Mundo, 28 de agosto de 1935. Reproducida en Arlt, Roberto. Aguafuertes españolas, Op. Cit.

106 Arlt, Roberto. "Molinos de viento en Vejer", en El Mundo, 23 de abril de 1935. En esta aguafuerte, además de referirse al mundo campesino como un cuadro para ser contemplado, Arlt se remonta a los molinos-gigantes de Cervantes y a Wells y sus guerreros marcianos: "Mas dejemos la crisis agraria para otro día y detengamos en los molinos de viento...los maravillosos molinos que el caballero cervantino confundió con los hoscos gigantes." [...] Los molinos de viento en Vejer, construidos en la época de la dominación mora [...] son confundibles con gigantes. $\mathrm{O}$ si ustedes lo permiten, con monstruos descomunales. Tan confundibles que estoy creyendo que Wells en su Guerra de los mundos tomó el modelo de los guerreros marcianos que invaden la tierra, de la novela de Cervantes...". De este modo, su viaje más allá de otras preocupaciones, es también un recorrido literario. 
dejado rectángulos oscuros en medio de tiernas alfombras lilas". ${ }^{107}$ En todos estos casos, apelar a la belleza de las tareas agrícolas significa, de esta manera, consignar un valor que se sobrepone y excede cualquier pretensión de registrar, como se proponía Arlt, lo que hay de humano en un lugar, lo triste y lo alegre, el sufrir de las gentes. ${ }^{108}$ Por ello, puede decirse que "la poetización elimina los conflictos"109 que se hacen patentes, en un contrapunto y de modo muy elocuente, en las notas sobre "El problema agrario español". ${ }^{110}$

\section{Más allá de las ciudades "nerviosas"}

Sanos. Impresión de salud tan violenta y agradable, que uno (y no me canso de repetirlo) siente que renace, que toda la mugre que le habian contagiado las ciudades nerviosas se le evapora del alma. ${ }^{111}$

Roberto Arlt

En este tipo de postales de la visión y de paisajes de la mirada que describe Arlt en sus aguafuertes españolas, lo representado se vincula, en la mayoría de los casos, con una valoración positiva y el ojo arltiano muestra reiteradas veces como ideales, a los sujetos y sus psicologías, asociados siempre al ámbito de lo extraño. “¿Qué diré del paisaje y del alma del hombre?" — afirma el cronista_, "En España, la belleza del paisaje la determina el alma del hombre". Porque, ciertamente, según Arlt, "Para el extranjero, vivir

${ }^{107}$ Arlt, Roberto. "De Cádiz a Barbate", en El Mundo, 17 de abril de 1935.

${ }^{108} \mathrm{Si}$ bien la mirada de Arlt se posa en la belleza de las campesinas gallegas, como en "Pontevedra, la solitaria" (El Mundo, 30 de septiembre de 1935. Reeditada en Arlt, Roberto. Aguafuertes gallegas y asturianas, Op. Cit.), y describe las tareas agrícolas, los sembradíos y el mundo del trabajo como paisaje, en una aguafuerte "La campesina gallega- Rudas jornadas en el campo- La tarea bajo la lluvia" (El Mundo, 11 de octubre de 1935. Reeditada en Arlt, Roberto. Aguafuertes gallegas y asturianas, Op. Cit.) se ofrece un contrapunto con esta visión estética del trabajo, y Arlt critica a algunos escritores españoles como Valle Inclán, que no nos permiten formarnos una idea de cuán ruda es la vida de las campesinas gallegas porque en sus obras "el elemento humano está condenado a un simple y humillante papel decorativo" (pp. 85-86).

${ }^{109}$ Véase: Silvestri, Graciela y Aliata, Fernando. Op. Cit, p. 177.

${ }^{110}$ Véase, a este respecto, Arlt, Roberto. "El problema agrario español (Primera parte)", en $E l$ Mundo, 27 de junio de 1935, Arlt, Roberto. "El problema agrario español (continuación)", en $E l$ Mundo, 1 de julio de 1935, y Arlt, Roberto. "El problema agrario español - Tercera parte", en El Mundo, 4 de julio de 1935.

111 "Psicología de la masa española", en El Mundo, 7 de septiembre de 1935. 
en España equivale a enamorarse de España": "Soy un apasionado de España, —añadedía a día voy paladeándola más profundamente en sus individuos, [...] se goza en el vivir de cada día, en el declive de cada hora, en la gratitud profunda que suscita en nuestros sentidos". ${ }^{112}$ España resulta, entonces, un territorio que se disfruta en distintos órdenes de la sensación, — se paladean sus individuos como un vino capitoso, ${ }^{113}$ se saborea el espectáculo de hombres y paisaje como un trozo de pan caliente, ${ }^{114}$ conmueve su cordialidad como "una descarga eléctrica", el aire tibio y el paisaje "escalofrían de satisfacción"-, ${ }^{115}$ y esta es la razón por la que España es "alegre", a diferencia de Buenos Aires, el lugar desde donde mira Arlt.

En efecto, una serie de oposiciones entre el sitio del viaje y el universo de origen atraviesa estos textos. Ellas contraponen un espacio idealizado, una sociedad armónica y feliz, a una civilización "epiléptica" y "nebulosa" que pone en crisis a los sujetos. Así se contrastan, entre otras cosas, la "viveza criolla" y la "sinceridad hispana", una "vida interior simple y profunda" y la "gente gastada; también aparecen enfrentados "benevolencia" y "engañifa", "pequeñas ciudades de España” y "grandes urbes americanas", "amabilidad" y "hostilidad", "predisposición festiva" y aburrimiento", "honradez" y "trampa". ${ }^{116}$ Un caso representativo en este juego de opuestos entre España y el mundo porteño, es la representación de un cuadro-paisaje citadino de Granada, donde se reiteran, además, los modos de la mirada paisajística comentados más arriba:

Estoy sentado en el café Royal frente al Ayuntamiento de Granada. Anochece. Instante en que el cielo español pasa misteriosamente del verde opalino al azul prodigioso del amanecer; hora extraña, más profunda que un decorado teatral. Los bloques de edificios iluminados internamente, adquieren el aspecto feérico de masas huecas de cartulina, cuyas cornisas tachonan bombonas de cartón. Las mesas del café, dispuestas en hilera hasta la mitad de las calzadas, están ocupadas por familias; hombres de edad y jóvenes,

\footnotetext{
${ }^{112}$ Arlt, Roberto. "El magnetismo de España", en El Mundo, 27 de agosto de 1935.

${ }^{113}$ Arlt, Roberto. "El magnetismo de España", Op. Cit.

${ }^{114}$ Arlt, Roberto. "Psicología de la masa española", Op. Cit.

${ }^{115}$ Arlt, Roberto. "El magnetismo de España", Op. Cit.

${ }^{116}$ Las aguafuertes donde aparece principalmente la construcción de esas oposiciones y que consideramos en este trabajo son: "El caso Porrita", en El Mundo, 13 de mayo de 1935, "Viveza criolla y sinceridad hispana", en El Mundo, 9 de junio de 1935, "La individualidad española", en $E l$ Mundo, 10 de julio de 1935, "El magnetismo de España", Op. Cit., "Psicología de la masa española", Op. Cit.
} 
muchachas y señoras. Conversan animadamente, a veces estallan a carcajadas $[\ldots]$

Yo miro y saboreo este espectáculo [...] Observo la conversación de los hombres con las mujeres, el natural desenvolvimiento de la charla, las risas espontáneas, las pupilas limpias, la cordialidad sana [...]

-Esta gente parece que hubiera sido lavada con agua lavandina. Brillan al modo de las cocinas antiguas, donde no hay lujo, pero el muro es de piedra, y el caldero de cobre. Y ello es suficiente para cocinar una sana comida.

Eso.

Sanos. Impresión de salud tan violenta y agradable, que uno (y no me canso de repetirlo) siente que renace, que toda la mugre que le habían contagiado las ciudades nerviosas se le evapora del alma. ${ }^{117}$

La nota describe un estado de armonía placentera entre los hombres y el paisaje de Granada, que contrapone las "existencias" "simétricas", "limpias”, “espontáneas” y "cabales", a las subjetividades negativas de las ciudades "nerviosas", como Buenos Aires. Asimismo, son estas "ciudades nerviosas" cuyos rasgos hacen productiva, según Arlt, la novela psicológica —y los dramas del tipo dostoievskianos, como "El Crimen y el Castigo", que se cita en este texto-, las que quedan caracterizadas, en oposición, por la "psicología mórbida" de sus habitantes, la "putrefacción de los sentimientos", la “descristalización del individuo", la mugre y la hipocresía: "Los personajes de las novelas psicológicas aquí en España morirían de consunción”, agrega el cronista. La sociedad y el paisaje urbano español son depositarios, entonces, de la percepción de un orden "incontaminado" de salud y bienestar que se separa de muchas de las leyes que regulan las urbes “epilépticas" y el mundo "civilizado". Así, las imágenes de incunditas, venustas, y salubritas, que pueden remontarse a la más larga tradición paisajística, ${ }^{118} \mathrm{se}$ asocian reiteradamente al territorio español y se repiten a lo largo de muchas aguafuertes. Como también en el caso del caserío vasco, que resulta un espacio recoleto, refugio de una "verdadera" civilización y un lugar donde "El alma se encoge despavorida en presencia" de la rectitud de estas vidas: ${ }^{119}$ "Habitar un tiempo entre esta

\footnotetext{
${ }^{117}$ Arlt, Roberto. Psicología de la masa española, Op. Cit.

${ }^{118}$ La incunditas, salubritas y venustas son caracteres que pueden retrotraerse a las primeras manifestaciones de la tradición paisajística. Véase, a este respecto: Silvestri, Graciela y Aliata, Fernando. Op. Cit.

119 Arlt, Roberto. "El caserío vasco. Viviendas en señorial aislamiento. Interiores severos y sombríos", en El Mundo, 26 de diciembre de 1935. Recopilado en Arlt, Roberto. Aguafuertes vascas, Op. Cit., p. 123. Dice Arlt allí: "Caserío vasco, dados desparramados en un
} 
gente de la montaña, — afirma Arlt en otro lugar, haciendo referencia, asimismo, al País Vasco-, es darse un baño de vida honesta, higienizarse el alma de toda la basura que amontonó en el continente ese torvo trapero que se denomina civilización". ${ }^{120}$

También la figuración de Madrid ofrece, en este sentido, aspectos singulares. Como afirma Saítta, después de casi un año transcurrido en el viaje lejos de Buenos Aires, cuando Arlt llega a Madrid lo fascina el reencuentro con la gran ciudad. Porque si bien Arlt había recorrido ciudades importantes como Sevilla, Oviedo, Granada o Bilbao, el ritmo de Madrid lo cautiva en pocos días. Entonces, "Arlt se entrega a la ciudad como un apasionado y recorre sus calles con la lenta parsimonia del enamorado que va descubriendo cada uno de los rasgos de la persona amada", ${ }^{121}$ y se hipnotiza con el "encanto brujo" y la alegría de Madrid.

Porque, en efecto, Madrid es alegre, y es alegre porque es populosa, ${ }^{122}$ pero también por el enlace de opuestos y la variedad, por la multiplicidad de un espacio que todo lo mezcla - individuos, arquitecturas, temporalidades - y que satisface, de este modo, la avidez por lo diverso del sujeto que, como comentamos más arriba, se perfila en estos textos: "Madrid se adorna de diferenciadas alegrías", [...] "Todo confabula para crear alegría en Madrid.[...] [la] diversidad de iluminaciones, de arquitecturas, simetrías, de urbanizaciones, compone la máscara sui géneris del Madrid inquietante, su personalidad fantástica, inexplicable, provinciana, grotesca, deliciosa, apasionante". ${ }^{123}$ Una capital donde se viven simultáneamente el enigma, el misterio, la sensación de la multitud y el éxtasis del desorden ${ }^{124}$ — "Dimana de este caos, afirma el cronista, la alegría de Madrid"-,${ }^{125}$ resulta para Arlt un caos alegre que "matiza los días" con su colorido. Así, a diferencia de Buenos Aires, que, por momentos, se transforma en las

abultamiento de paño verde. ¡En verdad eres el último refugio del año mil!” (p.124)

${ }_{120}$ Arlt, Roberto. "La naturaleza profesional", en El Mundo, 26 de noviembre de 1935. Recopilado en Arlt, Roberto. Aguafuertes vascas, Op. Cit., p. 45. También en la visión arltiana de África se reiteran estas ideas.

${ }^{121}$ Saítta, Sylvia. "Prólogo", en Arlt, Roberto. Aguafuertes madrileñas. Presagios de una guerra civil, Op. Cit., p. 8.

${ }^{122}$ Como afirma el cronista: "la casa de planta baja, el barrio solitario", ese barrio que Arlt desestima, no se encuentran allí; porque Madrid, si bien es más pequeña que Buenos Aires, parece más populosa. Arlt, Roberto. "La alegría de Madrid. Primera parte", en El Mundo, 26 de enero de 1936. Reeditado en Arlt, Roberto. Aguafuertes madrileñas. Presagios de una guerra civil, Op. Cit., p. 33.

${ }^{123}$ Arlt, Roberto. "La alegría de Madrid. Primera parte", Op. Cit., p. 34.

${ }^{124}$ Arlt, Roberto. "La alegría de Madrid. Primera parte.”, Op. Cit., p. 36

${ }^{125}$ Arlt, Roberto. "El color de Madrid (primera parte)", en El Mundo, 30 de enero de 1936. 
aguafuertes porteñas en un "emporio infernal", ${ }^{126}$ en la populosa Madrid no parece haber lugar, como en la urbe porteña, para la criminalidad, el delito, lo siniestro y lo monstruoso; el mundo "canalla" que Arlt vinculaba en ocasiones, a la gran ciudad.

De la heterogeneidad de ese espacio surge, entonces, una conjugación ideal entre presente y pasado que capta como un hechizo la percepción de Arlt. Porque en Madrid, "el tiempo ha espolvoreado la ciudad de pequeñas sorpresas [...] Los edificios altos penetran con sus rústicas boardillas en el cielo $[\ldots]$ y los faroles $[\ldots]$ con su caja poligonal, aprisionando un mechero de gas, en el que arde una chispa verde, nos sitúa [sic] en el siglo pasado!"127 "El español —afirma Arlt en otro lugar-, adorna su ciudad con rascacielos para que el extranjero no pueda reprocharle quietismo africano, pero en el fondo de su provinciana pereza ha descubierto que a la civilización se le pueden entresacar fórmulas para vivir bien. Y mientras tal orden de cosas dure, Madrid será feliz". ${ }^{28}$ Ciertamente, a diferencia de las ciudades antiguas y tristes que, como Pontevedra o Santiago de Compostela, aburrían con su apariencia pétrea la percepción de Arlt, la conjunción de esta doble temporalidad que permite una civilización particular (a la que se le puedan sacar "fórmulas para vivir bien"), se hace patente también, de modo tan elocuente en las normas de civilidad que hasta cambian los caracteres relacionados al mundo del trabajo. Así, el burócrata madrileño es feliz, a diferencia de su equivalente "el chupatintas" porteño, agobiado por el terror de "la cesantía", como

\footnotetext{
${ }^{126}$ Véase, a este respecto. Arlt, Roberto. "El placer de vagabundear", en El Mundo, 20 de septiembre de 1928. Recopilada en Arlt, Roberto. Aguafuertes porteñas, Buenos Aires, Losada, 1996. En esta aguafuerte el cronista describe su búsqueda de lo extraordinario, de las "historias crueles" y del mundo "canalla" en las calles de Buenos Aires, y el modo en que "la ciudad desaparece para convertirse en un emporio infernal”. Dice Arlt: “iCuántos dramas escondidos en las siniestras casas de departamentos! ¡Cuántas historias crueles en los semblantes de ciertas mujeres que pasan! ¡Cuánta canallada en otras caras! [...] Los extraordinarios encuentros de la calle. Las cosas que se ven. Las palabras que se escuchan. Las tragedias que se llegan a conocer. Y de pronto, la calle, la calle lisa y que parecía destinada a una arteria de tráfico con veredas para los hombres y calzada para las bestias y los carros, se convierte en un escaparate, mejor dicho, en un escenario grotesco y espantoso donde, como en los cartones de Goya, los endemoniados, los ahorcados, los embrujados, los enloquecidos, danzan su zarabanda infernal". (pp. 93-94)

${ }_{127}$ Arlt, Roberto. "La alegría de Madrid. Segunda parte", en El Mundo, 27 de enero de 1936. Reeditado en Arlt, Roberto. Aguafuertes madrileñas. Presagios de una guerra civil, Op. Cit., p. 38. En otra aguafuerte, dice Arlt que en Madrid, "una ciudad con subterráneos, rascacielos, tranvías", "los rascacielos de la Gran Vía no han conseguido eliminar" el pasado y las costumbres antiguas. (Arlt, Roberto. "La alegría de Madrid. Tercera parte", en El Mundo, 29 de enero de 1936. Reeditado en Arlt, Roberto. Aguafuertes madrileñas. Presagios de una guerra civil, Op. Cit., p. 44

${ }^{128}$ Arlt, Roberto. "La alegría de Madrid. Tercera parte", Op. Cit., p. 44.
} 
aparece retratado en muchos de los textos, y se expresa de modo contundente en La isla desierta, de 1936.

Si a Arlt le fascina, entonces, la conjugación ideal de presente y pasado que descubre en Madrid, también se sorprende con la temporalidad particular que encuentra en el País Vasco. Porque en algunas regiones de Euskadi, lo antiguo se incrusta en lo actual y la permanencia de tradiciones ancestrales provoca contrastes asombrosos:

Las viejas de abultada espalda y cabeza empañolada, pasan y se persignan devotamente, y por la noche, cuando el forastero se adentra a un cine y mira proyectada en la pantalla la silueta de los rascacielos de Nueva York, tiene que hacer un esfuerzo extraordinario para admitir que sobre el mismo planeta se encuentran la aldea vasca cuyas costumbres difieren poco de la del año 1000, y las ciudades donde trabajan con ametralladoras las series de gangsters arruinados por la derogación de la ley seca. Y uno por momentos vacila y se cree víctima de la deliciosa enfermedad mental del héroe de la plaza de Berkeley". ${ }^{29}$

Así, mientras la experiencia de la fugacidad es una de las que organiza la representación de lo urbano en las aguafuertes porteñas y también, en las novelas de Arlt donde se presenta, por ejemplo, en ocasiones la urbe en su fragmentario proceso de edificación, en la patria de los vascos, como puede apreciarse en la cita, Arlt percibe, en cambio, la sensación de lo inmutable. Es por ello que describe un contraste entre este territorio y su lugar de origen, que pasa a caracterizarse como un espacio sujeto a incesantes cambios: "Para nosotros — dice el cronista en la aguafuerte "El mayorazgo", donde relata la tradición familiar ligada a la casa y al terruño - inquietos inquilinos de ciudades donde vemos derribar viviendas que fueron construidas cuando éramos adolescentes", los problemas asociados a la casa y el nombre nos resultan extraños y difícilmente comprensibles. ${ }^{130}$ De esta manera, si en las notas porteñas se inscribe, por momentos, un cronista fascinado por la urbe moderna, que alterna su perspectiva con una visión nostálgica del pasado que es reclamo y anhelo, a la vez, de una sociedad más integrada cuyo orden se sabe que no volverá, ${ }^{131}$ la aparición de otra cronología en el país

\footnotetext{
${ }^{129}$ Arlt, Roberto. "Cruces monumentales", en El Mundo, 1 de enero de 1936. Recopilada en Aguafuertes vascas, Op. Cit., p. 144.

${ }_{130}$ Arlt, Roberto. "El Mayorazgo", en El Mundo, 27 de diciembre de 1935. Recopilada en Aguafuertes vascas, Op. Cit., p. 127.

${ }^{131}$ Dos aguafuertes bien significativas para ver la perspectiva nostálgica de Arlt son "Molinos de viento en Flores" (El Mundo, $1^{\circ}$ de septiembre de 1928. Recopilada en Aguafuertes porteñas,
} 
vasco y una coalición de presente y pasado en Madrid confiere, en los dos casos, el encanto y la nota distintiva, y en Madrid, particularmente, "el color" y "la alegría". Otras leyes de funcionamiento del mundo se hacen presentes, de esta forma, en España.

De todos modos, y volviendo al particular caso de Madrid, pareciera que lo que realmente fascina a Arlt de esa urbe es su "sinfonía de colores envejecidos", y podría decirse que en las aguafuertes madrileñas, la percepción "del enamorado"132 desdibuja el énfasis en los rascacielos, subterráneos y tranvías, y el universo representado acentúa la fascinación y el encuentro del cronista con el pasado:

Madrid es apasionante. A medida que más uno se calienta la planta de los pies en sus callejuelas, mejor se le van echando encima de los ojos estos cromos barnizados por el tiempo. Y es que a medida que la mirada se torna más experta y amorosa, más y mejor cata las franjas de su viejo colorido, el pastel de sus estampas, la mohosa viruela de sus cerrojos y aldabones, los agrietados cielorrasos de los zaguanes, la polvorienta jaula de arañas de los picos de gas...[...] Y es necesario amar sus plazuelas, con altos árboles de armazones peladas y faroles oxidados en un pañuelo de tierra entre portadas amarillas de antiguas imprentas y frentes de comercios de 1830, enlucidos de quebrados azulejos dorados y celestes.

Madrid es una sinfonía de colores envejecidos. [...] ¡Si uno se siente tentado a robarse la portada de la taberna! [...]

¿Dónde se halla el poeta madrileño que cante con justeza la belleza arcaica, rugosa, de esta ciudad caótica y antigua? ${ }^{133}$

La cita muestra la fascinación de Arlt por el exotismo madrileño que se descubre en las marcas del paso del tiempo y en la "belleza arcaica" de la ciudad "caótica y antigua". Efectivamente, tan exótica es Madrid que por momentos Arlt cree estar en África y mira la ciudad desde un aparato perceptual que se relaciona con su viaje a

Op. Cit.) y "Para qué sirve el progreso" (El Mundo, 23 de noviembre de 1929. Recopilada en Nuevas Aguafuertes, Buenos Aires, Losada, 1975). También puede considerarse, para esta cuestión, entre otros, textos como "Elogio de la ciudad de La Plata" (El Mundo, 27 de diciembre de 1928, recopilada en Arlt, Roberto. Aguafuertes porteñas. Buenos Aires, vida cotidiana, Op. Cit.) o "Pueblos de los alrededores" (El Mundo, 31 de marzo de 1929. Recopilada en Arlt, Roberto. Aguafuertes porteñas. Buenos Aires, vida cotidiana, Op. Cit.) donde se marca el contraste con la urbe porteña. Véase a este respecto, también, Saítta, Sylvia. "Introducción", en Arlt, Roberto. Aguafuertes porteñas. Buenos Aires, vida cotidiana, Op. Cit., pp. I-XVI.

${ }^{132}$ Saítta, Sylvia. "Prólogo", en Arlt, Roberto. Aguafuertes madrileñas. Presagios de una guerra civil, Op. Cit.

${ }^{133}$ Arlt, Roberto. "El color de Madrid", en El Mundo, 1 de febrero de 1936. Recopilada en Arlt, Roberto. Aguafuertes madrileñas. Presagios de una guerra civil, Op. Cit., pp. 44-45. El subrayado es nuestro. 
Marruecos. ${ }^{134} \mathrm{El}$ cronista encuentra, de esta manera, imágenes de cierto aire africano en lo arcaico de Madrid, ${ }^{135}$ que constituyen una de las zonas por las que la urbe despierta su atractivo y sensibilidad. Por otra parte, todo contribuye, además, a conformar una perspectiva pintoresquista sobre el Madrid antiguo. ${ }^{136}$ Las calles estrechas, ondulantes y "torcidas", los faroles de hierro oxidados y "sentimentalmente inclinados", el caos en la ciudad, donde se eliminan las simetrías y las líneas rectas, la acentuación de los contrastes, la "belleza rugosa", "los agrietados cielorrasos" y el barniz temporal. Se trata, en palabras de Arlt, del "Madrid tortuoso, populoso, de callejuelas curvas, zigzagueantes, con faroles de gas aún encendidos, con cúpulas de árboles tras de plazuelas tapiadas, sucias estaciones de Metro, recovas, tabernas del siglo XVIII con muros cubiertos de portadas de madera y braceros encendidos junto al cordón de la acera". ${ }^{137}$

Si un tono se impone en los pasajes comentados, es el tono del elogio, la fascinación por lo otro y la construcción de un mundo paralelo y diferente, alternativo al orden de la experiencia habitual y automatizada: "Y sonrío gozando este pedazo de mi

${ }^{134}$ Afirma Arlt, en este sentido: “...hoy, bajo una llovizna de las tres de la tarde, me perdí allá por la calle del Pez, cuando creía estar perfectamente orientado.[...] Y de pronto, en las tres de la tarde, a menos de mil metros de la Gran Vía, me encontré con una feria olvidada en medio de la calle...[...] Y mientras caminaba llevaba cuentas de las balanzas y platillos de bronce abandonados en el cruel pavimento de la callejuela [...] y la calle de Pelayo a las tres de la tarde resultaba maravillosa con las vereduelas emporcadas de haces de pasto, cáscaras de naranjas, esfolladuras de berzas, tronchos de plátanos y completaban el cromo sus ancianas detenidas en los pórticos de madera de las buñolerías o catando un jarro de leche caliente frente a sus puestos. [...] ...y yo no creía estar en Madrid a menos de mil metros de la Puerta del Sol, sino en el Zoco Grande de Tánger...". Arlt, Roberto. "El color de Madrid", Op. Cit., pp. 45-47.

${ }_{135}$ Sylvia Saítta observa muy acertadamente que "un eje que recorre estas notas es la confrontación entre dos temporalidades: una temporalidad moderna que vincula a Madrid con su presente europeo, y una temporalidad arcaica, que pareciera emparentarla con cierto aire africano". Saítta, Sylvia. "Prólogo", en Arlt, Roberto. Aguafuertes madrileñas. Presagios de una guerra civil, Op. Cit., p. 11.

136 Cabe destacar que el paradigma de lo pintoresco da primacía, en las formas de la representación, a la mezcla y la irregularidad, a la línea curva y lo variado, a los objetos, cuando su uso banal es suavizado por la historia o tamizado por el tiempo; e implica, asimismo, un acercamiento de lo figurado al mundo del arte y la cultura._Véase, para esta cuestión: Pere Salabert. Figuras del viaje, Op. Cit., p. 58, y, del libro de Silvestri y Aliata, especialmente, los capítulos "Bello, sublime y pintoresco" y "III. Ut pictura hortus: la arquitectura del jardín pintoresco" (en Silvestri, Graciela y Aliata, Fernando. El paisaje como cifra de armonía. Op. Cit., pp. 87-93 y 106-129, respectivamente). También, en la página 158 de se mismo libro se hace referencia a lo "pintoresco en la ciudad" como "una categoría que admite lo suavizado por la historia, lo íntimo, lo rústico, las perspectivas quebradas y los caminos serpenteantes".

${ }^{137}$ Arlt, Roberto. "La alegría de Madrid. Segunda parte", Op Cit., p. 37. 
vida que es un sueño". Narrador gozoso y viajero aventurero que se deleita en lo diverso, Roberto Arlt construye en estos textos un enunciador escindido en su carácter de testigo veraz y cronista político de los hechos. Así, y en contrapunto con sus propias afirmaciones, la tarjeta postal también se impone en las crónicas de España. Fiesta de color en Sevilla, frenesí estético en el toreo, pinturas del Greco en la representación de Toledo, panoramas de la mirada y descripciones de ilusión, estas notas ciertamente anuncian nuevos modos de representar en la literatura de Arlt que el impacto del viaje afianza y vehiculiza. Una nueva perspectiva y también un nuevo tipo de sujeto, las aguafuertes españolas introducen así postales "iluminadas" y cuadros de color, ciudades cordiales, mundos alternativos y paisajes de ensueño.

\section{2. África: el exotismo oriental}

Mi sensibilidad de occidental se descentra como en el panorama de un sueño de opio con estos laberintos encalados de legía azul... ${ }^{138}$

Roberto Arlt

Entre el 30 de julio y el 21 de agosto de 1935, el repórter viajero recorre distintas ciudades de Marruecos, como Tánger y Tetuán. Si bien su estadía en el norte de África es muy corta, a diferencia de lo que sucede con el paisaje español, el espacio africano reaparece como una obsesión inclusive algunos años después de finalizado el viaje, en cuentos, obras de teatro y en las crónicas periodísticas finales que Arlt redacta "Al margen del cable". ${ }^{139}$ Por lo tanto, a las aguafuertes escritas durante el viaje agrupadas bajo el subtítulo "Marruecos" en el volumen de Aguafuertes españolas que el

\footnotetext{
${ }_{138}$ Arlt, Roberto. "Tetuán, ciudad de doble personalidad", en "Marruecos", Aguafuertes españolas, Op. Cit., p. 133.

${ }^{139}$ Las crónicas "Al margen del cable" que Arlt publica en El Mundo, como veremos en el capítulo 4, no sólo retoman los modos de enunciación y el exotismo orientalista africano que remite a estos textos sino que, muchas de ellas, son la puesta en términos narrativos de noticias sobre África vinculadas con el clima de tensión mundial y la guerra, de modo que reaparecen, con otras motivaciones, los mismos espacios.
} 
mismo Arlt compila en 1936 - , se suma la pieza dramática África de $1938,{ }^{140}$ y los relatos publicados en 1941 bajo el título El criador de gorilas, libro de tema africano que reúne narraciones que habían sido editadas antes en las revistas El Hogar y Mundo Argentino.

Este conjunto de textos en los cuales prevalece la representación de escenarios exóticos inaugura una espacialidad desconocida en la obra anterior de Arlt. ${ }^{141}$ Porque en este corpus africano puede leerse tanto un recorte de las marcas de lo moderno y la representación de una temporalidad orientada hacia el pasado, como también el trazado de una visión casi desconocida en su producción sobre el paisaje y los objetos. A su vez, estos textos constituyen un ámbito en el que la literatura de Arlt dibuja un nuevo lugar, redefine posiciones y ensaya algunos modos de legitimación tendientes a dejar sin efecto, o a matizar, las críticas que el escritor había recibido a propósito del estilo.

Una de las aguafuertes que refieren el viaje de Arlt por Marruecos, "Tetuán, ciudad de doble personalidad", focaliza la atención en el modo particular de diagramación de la ciudad africana: en esa zona conviven dos espacios temporalmente distintos, el presente del cronista, y el pasado — como también sucedía en Madrid y en algunas ciudades españolas aunque, como veremos, en ciertos sentidos diferentes-. En principio, el texto registra el asombro y la desilusión del corresponsal viajero ante la visión del espacio "liso", "simétrico", iluminado, con "estructuras de cemento armado", con avenidas y letreros, de la "Tetuán moderna": "-Maldito sea el que me dijo que Tetuán era más característico que Tánger”, ${ }^{142}$ enunciado que, además, significa el reconocimiento de lo que se busca: los lugares exóticos deben ser exóticos. Luego, con fascinación, expectativa y gozo (que se reitera aquí como en algunos de los itinerarios de España) el cronista-viajero descubre la otra ciudad:

Y de pronto... inesperadamente aparece:

Aquí... aquí está Marruecos [...]

Me detengo estático a la entrada del barrio moro. Ahora comprendo.

La fotografía de la ciudad se diseña en mis ojos. Lo moderno es un

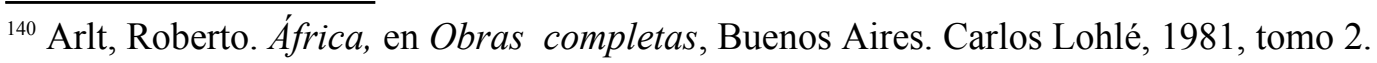

${ }^{141}$ Véase, a este respecto, además de nuestro trabajo previo sobre este tema (Juárez, Laura. "La representación del espacio africano en la literatura arltiana de los años treinta", Op. Cit.), el análisis de Axel Gasquet (Gasquet, Axel. "La ficción morisca y africana de Roberto Arlt", en Oriente al Sur. El orientalismo literario argentino de Esteban Echeverría a Roberto Arlt, Buenos Aires, Eudeba, 2007, pp. 269-290), que retoma, asimismo, este corpus.

${ }^{142}$ Arlt, Roberto. “Tetuán, ciudad de doble personalidad”, Op. Cit., p. 130.
} 
menor de edad, que recientemente ha cumplido quince años. [...] Tetuán moderna ocupa el centro de la herradura dentada que traza el semicírculo de montañas desde cuya punta se divisa la cinta azul del Mediterráneo. A diferencia de Tánger, donde lo moderno y lo antiguo se anudan como en la selva las raíces de las plantas distintas, Tetuán conserva una delimitación turística, natural, perfecta. La ciudad en el centro. La ciudad moderna, rodeada de una muralla encalada. Tras de esa muralla se encuentra el barrio moro cuyo fondo también lo cierra otra muralla almenada. [...]

Me interno en el Tetuán antiguo... [...] Vagabundeo por las catacumbas celestes del arrabal moruno. Mi sensibilidad de occidental se descentra como en el panorama de un sueño de opio con estos laberintos encalados de legía azul... [...]

...me quedo allí, sentado en el suelo, reposando de esa multitud de visiones estampadas en mi memoria, y que cuando esté lejos de África las recordaré como se recuerda la tenencia de un precioso tesoro que ahora paladeo con lentitud gozosa. ${ }^{143}$

El texto destaca la coexistencia de dos tiempos en la urbe africana y señala la atracción de ese lugar por ser una zona en la que el pasado se mantiene sin contaminar. En Tetuán es posible identificar un reservorio del pasado, un ámbito en el que la modernidad convive simultáneamente con una temporalidad anterior. No hay mezcla, no hay invasión, los dos tiempos funcionan paralelamente sin interferencias. Además de la convivencia, en la referencia que al pasar se hace de Tánger, podemos ver que la superposición de capas temporales es otro caso que no implica la fusión completa: la mezcla no es tal que no permita que lo "antiguo" y lo "moderno" puedan ser identificados. Estas dos temporalidades que también aparecen, como se dijo antes, en el recorrido por España, revelan, de este modo, el tipo de sujeto que mira: Arlt, un viajero del "nuevo mundo" que arriba por primera vez a un espacio donde las huellas del pasado conviven con las del presente. Y si en el caso de España hay una valoración negativa hacia el pasado castizo en las ciudades católicas de "piedra" y de "roca" que contrasta con el entusiasmo de Arlt por lo premoderno en Madrid y en el País Vasco (reservorio de lo pre-civilizatorio e incontaminado), es clave también la preferencia y la elección de ese tiempo-espacio anterior africano en el que el cronista desarrolla sus recorridos, como el lugar de la belleza, el escenario elegido para el deleite estético, para el vuelo y la evasión imaginativos, y también para el "goce" de lo primitivo que aquí es

${ }^{143}$ Arlt, Roberto. "Tetuán, ciudad de doble personalidad", Op. Cit., pp. 130-133. 
considerado positivamente, en tanto que primitivo, como puede verse en "El narrador de cuentos":

Gozo y paladeo el espesor de esta atmósfera tosca y brutal. [...]

El sol, tamizado por los sarmientos de una vid, deja en el suelo recortadas manchas de tinta china, y uno, a pesar de la mugre, de los parásitos, del hedor, está bien..., respira... Es como si se encontrara en un sanatorio de bestialidad profunda que le curara de esa larga y terrible enfermedad que se llama civilización. ${ }^{144}$

El espacio lejano, paradojal por los términos que entran en la descripción (exótico, primitivo, sucio, bestial, sano) resulta, entonces, el lugar del deseo, del goce también del goce estético a pesar de los elementos degradados de la descripción- y además el sitio que permite la percepción de otra temporalidad que es lo que conduce a un mundo primitivo de libertad y placer donde se inscriben distintas reglas de funcionamiento del mundo social: "Edad Media. Me encuentro en presencia de normas que mi ignorancia daba por muertas hacía muchos siglos. Todo es primitivo, antiquísimo, remoto", o, como expresa el cronista en otro lugar: "Camino de sueño en sueño" [...] "voy como se me da la gana. Podría andar descalzo y nadie me miraría mejor ni peor. Esta libertad infinita $[\ldots]$ es un regalo del cielo. ${ }^{145}$

Los rasgos que predominan en las aguafuertes africanas dan cuenta de las condiciones de su contexto de enunciación pues se espera que Arlt como corresponsal viajero no refiera lo habitual para su público (el paisaje y costumbres urbanas modernas) sino algo nuevo y desconocido. No obstante, estos mismos rasgos reaparecen, luego, en los relatos de El criador de gorilas, aunque el enunciado narrativo ficcional es menos declarativo y, a la vez, más radical en su separación del espaciotiempo de la modernidad. Las narraciones abandonan por completo la representación de la ciudad moderna y de los escenarios tecnológico-futuristas dominantes en las figuraciones de Buenos Aires en lo que consideramos la primera parte de la obra de Roberto Arlt. ${ }^{146}$ En estas ficciones africanas el traslado en el espacio significa también ${ }^{144}$ Arlt, Roberto. "El narrador de cuentos", en Aguafuertes españolas, Op. Cit., p. 94.

145 Arlt, Roberto. "Tetuán, ciudad de doble personalidad", Op. Cit. pp. 141 y 142 respectivamente. En relación con este punto se analizará más adelante cómo se desliza una crítica de la modernidad.

${ }^{146}$ Para estos aspectos véase Sarlo, Beatriz. "Arlt, la técnica en la ciudad", en La imaginación técnica, Op. Cit.; y también, el artículo "Arlt: ciudad real, ciudad imaginaria, ciudad 
un viaje en el tiempo: Arlt hace un recorte, borra las huellas de lo moderno y describe de África esas zonas que la vinculan con el pasado, como si lo pintoresco o lo exótico de los espacios en muchos casos fuera fundamentalmente la temporalidad. ${ }^{147}$

Esta operación se inscribe de diversos modos. En principio, entre las narraciones de El criador de gorilas pueden considerarse aquellas que omiten y no insertan en la ficción las marcas de lo moderno o las del tiempo real de la enunciación de esos textos, y a la vez se centran y/o privilegian los rasgos de un tiempo anterior, de modo que son relatos que remiten claramente al pasado. Es el caso, por ejemplo, de "Rahutia la bailarina" (1937) y "Acuérdate de Azerbaiján" (1938), cuentos que se desarrollan en una cronología donde no se manifiestan los rasgos del presente y se multiplican los caracteres que remiten a lo exótico y libresco en relación con Oriente: babuchas, alfombras, ajorcas, callejuelas zigzagueantes, etc. En segundo lugar, aparece otro grupo de ficciones donde se desdibuja el tiempo de la modernidad: las marcas y signos de lo moderno se recortan y se inscriben, o bien tangencialmente, o relegados al marco del relato. El encuadre resulta entonces el punto que permite el acceso a otros escenarios en los que se privilegian distintas figuraciones de la temporalidad, — muchas de las cuales cristalizan en un tiempo legendario, como veremos- y en los que los personajes se sumergen en una experiencia del pasado. En "Odio desde la otra vida" hay un pasaje de una dimensión espacio-temporal a otra. Desde el presente - que coincide con el de la enunciación- (hotel, barco) en que comienzan las peripecias de un turista argentino en África y en el que se ubica el relato, éste experimenta una entrada al "plano astral". Esta experiencia constituye el medio a través del cual se produce un salto en el tiempo y en el espacio: Fernando está "viviendo en otro siglo", aparecen los caracteres cúficos de la escritura árabe antigua, una ciudad amurallada, etc. ${ }^{148}$ Puede decirse que el personaje a la vez que ingresa en ese espacio fantástico y de ensueño que es el "plano astral" — tal como lo definíamos más arriba-, toma contacto con un tiempo legendario. Esto es así, por un lado, porque el texto construye un pasado poco situable, indefinido, remoto, y

reformada", Op. Cit.

${ }^{147}$ Hay excepciones en El criador de gorilas. Es el caso de algunas ficciones en las que está más definida la representación del presente del turista o el tiempo de la enunciación; en algunas oportunidades esto se da cuando se narran aventuras o hechos de espionaje, un tipo de textos que, como veremos en el capítulo 5, surgen en relación con el contexto bélico internacional. Véase, a este respecto, entre otros ejemplos: Arlt, Roberto. "La cadena del ancla" (1938) y "Ejercicio de artillería" (1939), en Cuentos completos, Op. Cit.

${ }^{148}$ Arlt, Roberto. "Odio desde la otra vida", en Cuentos completos, Op. Cit., pp. 440. 
por el otro, porque llega a ser un tiempo ejemplar, que permite interpretar el presente: la experiencia pseudopsicoanalítica explica el odio profundo que el personaje siente por su novia Lucía. También en "Accidentado paseo a Moka" las huellas de lo moderno aparecen relegadas al encuadre del texto, donde a bordo de un transatlántico el narrador es testigo del relato de una historia de aventuras acaecida en un tiempo anterior en que, según se dice, África era África. ${ }^{149}$ Es clave, finalmente, el caso de "Los bandidos de Uad Djuari” pues allí coexisten y se superponen dos temporalidades. Se trata de la historia de dos turistas que protagonizan en Fez una falsa aventura, pues, engañados por un niño que les promete lo extraordinario - conocer a la serpiente que devora todos los días un cabrito-, se dejan llevar a las afueras de la ciudad donde los capturan unos bandidos de ficción, que en realidad no eran bandidos. Como les dice a los turistas, antes de dejarlos en libertad, uno de ellos:

Lástima enorme que la civilización, la gendarmería, los jefes políticos, el protectorado y el ferrocarril hayan hecho desaparecer a los bandidos. Lástima enorme no vivir en una época en que uno se encontraba con una terrorífica aventura a la vuelta de cada zoco. ${ }^{150}$

En este relato conviven dos tiempos. Por un lado, el de "la civilización", el del progreso, el presente del turista; dentro de ese tiempo se abre una brecha y surge la máscara de una "época" que remite al pasado y en la que es posible vivir una aventura. Aquí, como en las aguafuertes, vuelve a dibujarse la idea de África como esa zona en la que, paralelamente, es posible tener la experiencia de otra dimensión temporal y el lugar en que el pasado se conserva aunque sea para la ficción, para el vuelo de la imaginación o para la aventura. Todo lo dicho, y sobre todo las valoraciones y asociaciones positivas que se vinculan con ese espacio-tiempo lejano, permiten pensar que también en los relatos aunque implícitamente $-\mathrm{y}$ no del modo declarativo de las aguafuertes - se inscribe la crítica de la modernidad, que en los textos de los años veinte, aparecía bajo las connotaciones ambiguas de la distancia y la fascinación. ${ }^{151}$ Es decir, si analizamos la

\footnotetext{
${ }^{149}$ Arlt, Roberto. "Accidentado paseo a Moka”, en Cuentos completos, Op. Cit., pp. 428.

${ }^{150}$ Arlt, Roberto. "Los bandidos de Uad Djuari", en Cuentos completos, Op. Cit., p. 426. El subrayado es nuestro.

${ }^{151}$ Véase: Sarlo, Beatriz. "Arlt: la técnica en la ciudad", Op. Cit. Considérese, asimismo las aguafuertes porteñas comentadas anteriormente, en el apartado sobre España, como "Corrientes por la noche" "Para qué sirve el progreso" y "El desierto e la ciudad", entre otras que cabe mencionar. Véase: a este respecto: Arlt, Roberto. Aguafuertes porteñas. Buenos Aires, vida
} 
ideología de estos textos, y el lugar que construyen a través de lo que legitiman y condenan se confirma un tipo de oposición por parte de Arlt a la civilización y a lo que genera diferente de los modos en que se ficcionalizaba una crítica de la modernidad en sus anteriores relatos.

Por otra parte, y en tanto estos escenarios africanos están sujetos a reglas ajenas al horizonte cultural del texto y sus lectores, surge la sorpresa, el azar, la incertidumbre, la extrañeza. De este modo, como veremos en el próximo capítulo, irrumpe lo fantástico, pero también se introduce la aventura como una acción no ordinaria (aunque no necesariamente fantástica), es decir, como aquello " que queda fuera del marco de la vida', en el sentido de la continuidad de la vida cotidiana, rutinaria", y lo que se constituye en una totalidad cerrada, autónoma, con leyes propias. ${ }^{152}$ En este nuevo universo ficcional ya no tienen cabida los personajes arltianos atrapados por el engranaje de la máquina infernal de la sociedad; hay una salida de la predestinación (o de la determinación social) y aparecen otras reglas de funcionamiento del mundo. A su vez, en este espacio y tiempo alejados los personajes tienen el poder de generar historias donde la "acción" funciona como un principio central para su construcción. Frente a las subjetividades exacerbadas que se plasman en la ciudad moderna, Arlt encuentra aquí relato, narración, tramas, "acción", es decir, los elementos privilegiados en sus intervenciones periódicas en El Mundo en los cuales se opone al psicologismo en la novela. ${ }^{153}$ Por lo tanto, estos textos remarcarían la complejidad y la pluralidad de una obra que, en muchos casos invierte sus normas precedentes pues incorpora otras temporalidades, pone en escena otros modos de representación, e introduce otros géneros, como el fantástico y el relato de aventuras.

Así, además de que dibujan una espacialidad diferente de la que aparecía en muchos textos precedentes (la ciudad moderna en la que se inscribía una exasperación

cotidiana, Op. Cit.

${ }^{152}$ Se sigue aquí el análisis acerca de la aventura que David Frisby hace respecto de las concepciones de Georg Simmel sobre la modernidad. David Frisby, Fragmentos de la modernidad, Madrid, Visor, 1992.

${ }^{153}$ En la serie de artículos de los años cuarenta que analizamos en detalle en el capítulo 6, Arlt menciona reiteradamente la "acción" como aquello que, opuesto al realismo, a la introspección y lo psicológico propicia un tipo de literatura donde es posible "la aventura". Véase, a este respecto: "Irresponsabilidad del novelista subjetivo", "Acción, límite de lo humano y lo divino", y "Aventura sin novela y novela sin aventura", en Arlt, Roberto. Aguafuertes porteñas: cultura y política, Op. Cit. 
de los "elementos de la modernidad arquitectónica y técnica", ${ }^{154}$ la ciudad de la "vida puerca"), los relatos africanos presentan un punto de vista distinto sobre los personajes y los escenarios de la representación. La crítica se ha referido al expresionismo arltiano y César Aira en un ensayo titulado "Arlt" describe la deformación expresionista provocada por la cercanía, por la "intromisión del autor en el mundo". La representación en este caso no toma perspectiva, no hay distancia, y por eso la "obra se llena de monstruos": "En Arlt el mundo expresionista, de contigüidades excesivas y deformaciones por falta de espacio en un ámbito limitado, un interior (su mundo es un interior) es una opción formal". ${ }^{155}$ Estas ficciones africanas introducen un movimiento, que si no puede definirse como exactamente opuesto es, en varios sentidos, muy diferente. Los escenarios son descriptos en planos y los distintos narradores de $E l$ criador de gorilas - aunque en muchos casos son orientales - relatan desde el punto de vista de un observador alejado (como en las crónicas españolas), un Oriente que se presenta a la visión como un espectáculo, como un cuadro que la mirada puede abarcar en su recorrido de las distintas escenas. De este modo comienza el relato del narrador de cuentos en "La aventura de Baba en Dimish esh Sham": 156

Había anochecido en Dimish esh Sham. La ciudadela amurallada y blanca parecía aplanarse a los pies del abultado monte. En su cresta, a mucha altura sobre el nivel de la arena, se arqueaba la desolación de las palmeras. Más próximo, recortando la acuidad verdosa del firmamento, se erguían los paralelepípedos de porcelana de los alminares de las mezquitas y las cúpulas de cobre en media naranja de los palacios señoriales. En los alminares, revestidos de mosaicos reproduciendo verticales tableros de ajedrez, la luna fijaba vértices de plata. Más allá, infinito, amarillento, oscureciéndose hacia el confín, se extendía el desierto. Y el horizonte, a pesar de la luna y las estrellas, parecía una muralla de betún, separando la tierra de los hombres de la tierra de los djins y de los targuis. ${ }^{157}$

\footnotetext{
${ }^{154}$ Sarlo, Beatriz. "Arlt, la técnica en la ciudad”, Op. Cit., p. 52.

${ }^{155}$ Aira, César. "Arlt", Op. Cit., p. 57.

${ }^{156}$ El hecho que "La aventura de Baba en Dimisch esh Sham" sea el primero de los relatos publicados por Arlt y el que da comienzo a la pieza dramática África como encuadre de todas las acciones que se suceden permitiría conjeturar que muchos de los cuentos tienen como marco el de esta ficción, dato que es imposible de cotejar sin tener presente cómo organizó el propio Arlt la edición que publicó en Chile.

${ }^{157}$ Arlt, Roberto. "La aventura de Baba en Dimisch esh Sham", en Cuentos completos, Op. Cit., p. 242
} 
La descripción se organiza aquí desde la mirada en un vaivén que va de lo lejano a lo cercano y a diferencia de lo que ocurría en las representaciones de sus textos anteriores, los espacios no resultan fragmentarios, no aparece una visión de contacto, deformada: ingresa la perspectiva a las narraciones de Arlt y se consolida un sujeto observador diferente. Este sujeto ya no se percibe a sí mismo, se aleja de su interior y de las psicologías exacerbadas, y se orienta al mundo, al exterior, con una mirada distanciada y con preponderancia de la visión. Por otra parte, este fragmento - y muchos otros- es el resultado de una búsqueda y selección de lo exótico y lo pintoresco: "ciudadela amurallada", "palmeras", "paralelepípedos de porcelana de los alminares", "desierto", "mezquitas". En otros textos esas elecciones se reiteran y aparecen además "elefantes", "músicos con tamboriles revestidos de pieles de serpiente y trompetas con forma de cuerno", "Una muchedumbre cubierta de verticales colores", "criada de color de chocolate, con luna y estrellas tatuadas"..., suelos esterillados, tapices, "calles tortuosas", etc. Esta operación es equivalente a la que Aira describe en sus ejemplos de exotismo: "La elección de datos es esteticista, irresponsable, jerarquizada". [...] "[se] habla de mobiliario, indumentaria, decoración, comidas, colores... Lo que sale de ahí es un[a] [...] estampa". ${ }^{158}$ Este mecanismo — acentuación de lo exótico — se escenifica también por los distintos modos de la enunciación. En primer lugar, en El criador de gorilas aparecen tanto relatos en los que el narrador es un extraño y un viajero que testifica lo raro y lo pictórico de las imágenes en que se resuelve la representación y la descripción de la topografía oriental, como otros en los que deja de existir este narrador viajero y la descripción de los hechos y los lugares se pone en boca de los personajes de la zona: lo exótico entonces se muestra y se narra a sí mismo y se propone una representación aparentemente sin mediaciones, ${ }^{159}$ lo que contribuye a crear una atmósfera de exotismo para el público occidental. Por otra parte, estos relatos construyen un narrador confiable, entendido (esto está especificado en algunas oportunidades: “Azerbaiján, con ojos de entendido, observaba...”), un narrador al

${ }_{158}$ Aira, César. "Exotismo", en Boletín/3, Centro de Estudios de Teoría y Crítica Literaria, Rosario, 1993.

${ }^{159} \mathrm{Al}$ mismo tiempo se puede observar la perspectiva orientalista con que se mira ese espacio y sus personajes. Los textos de Arlt arman, en este sentido una visión estereotipada de África, que resulta el escenario de la traición, la venganza, la astucia, el sitio de los usureros, los bandidos. No nos vamos a detener en estos aspectos, lo que sí nos interesa es cómo ciertos tópicos sobre lo oriental que se inscriben en el imaginario de la cultura son superados por las ficciones que encuentran en ellos lo que es apropiado -acción, lo extraordinario- para construir una nueva poética y redefinir el proyecto creador del escritor. Sobre el orientalismo véase: Said, Edward. Orientalismo, Op. Cit. 
que en muchos casos se ha delegado el contar la historia (“jefe de conversación”) y que es un conocedor, tiene autoridad para mirar, describir y para relatar las historias porque sabe. En segundo lugar, muchos cuentos funcionan como el cumplimiento de un refrán, la tematización de un proverbio árabe o de un fragmento del Corán y ponen en escena figuras retóricas - fundamentalmente metáforas y comparaciones - que juegan con los materiales pintorescos y raros del lugar como modos de buscar lo exótico: "Sus ojos blancos de cataratas semejantes a huevos de serpiente", "Mi narración es más sabrosa que la pata de camello hervida en leche agria", "Nariz más corva que un alfanje", "no te muestres reacio como un camello estúpido", "fina como camisa de mujer de sultán”, etc. De este modo, las ficciones de El criador de gorilas están atravesadas por la representación de un escenario oriental-exótico concebido como un espectáculo, casi como una obra de arte para ser observada por sus notas de color, construido por una mirada estilizada sobre los espacios, tanto arquitectónicos como naturales y sobre los individuos, sus ropajes, ocupaciones, rasgos, como partes de ese paisaje. Mirada que se deleita en la descripción y que articula las escenas remedando la composición de un cuadro.

Si consideramos estos modos de representación y el alejamiento o la evasión en el tiempo y en el espacio que los relatos ponen en escena, es preciso indagar qué conocimiento de otros textos y qué competencia retórica está en juego en estas figuraciones sobre África. En principio, cabe la hipótesis de que en los escenarios y sus descripciones $^{160}$ se exhibe y se ostenta un saber sobre la literatura ${ }^{161}$ que remite al modernismo o al imaginario decadente. ${ }^{162}$ De esta manera, cuando Arlt construye e imagina una serie de espacios exóticos recurre a ciertos modos y procedimientos estéticamente situados en la tradición literaria como formas de legitimar su literatura. Entonces, en relación con el modernismo-decadentismo, ${ }^{163}$ puede citarse en primer lugar y como complemento de lo que expresábamos más arriba, el trabajo con el color y el

${ }^{160}$ En este sentido dice Philippe Hamon: "Describir no es nunca describir lo real, es probar nuestros conocimientos retóricos, nuestras nociones de los modelos librescos". Ver su Introducción al análisis de lo descriptivo, Buenos Aires, Edicial, 1991.

${ }^{161}$ En las ficciones de El criador de gorilas y en los últimos textos arltianos está presente cierta representación espacial, a la que se hacía someramente referencia más arriba, que empalma con el cuento de horror y la narrativa de Edgar Poe, y es evidente que también se inscribe un saber sobre la novela de aventuras. En este punto se analizarán las figuraciones que se relacionan con el modernismo-decadentismo que serán estudiadas en detalle en el capítulo siguiente: "El modo fantástico".

${ }^{162}$ Véase: Pierrot, Jean. L'Imaginaire Décadent (1880-1900), Paris, Univ, de Paris, 1977.

${ }^{163}$ Para este aspecto en la obra de Arlt desde los comienzos, véase el capítulo que se desarrolla a continuación. 
brillo y el efecto de contraste que produce la correlación de verdes, amarillos, rojos, azules, dorados, plateados en los escenarios de la ciudad y en la vestimenta de los heterogéneos personajes. Estos últimos se presentan a la visión del narrador-espectador o del transeúnte que los observa, como estampas sugerentes para el vuelo de la imaginación: “...en cada callejuela de la milenaria ciudad africana encontrábamos ardientes motivos de ensueño"; ${ }^{164}$ África resulta un espectáculo para la vista, que se deleita ante el pasaje y la contemplación de lo diverso. En segundo lugar, además de la descripción plástica del colorido oriental, cabe destacar que, en dos ficciones dominadas por la figura de la femme fatale — "Ven, mi ama Zobeida quiere hablarte" y "Rahutia la bailarina" - se reescriben los interiores lujosos, saturados de objetos ornamentales, piedras preciosas y multiplicidad de texturas de la estética a la que nos referimos. En los textos mencionados y en una continuación de la línea que viene desde Flaubert, ${ }^{165}$ aparecen asociados esta figura femenina y los marcos suntuosos del decorado oriental. Así la habitación que se representa en el primero de los dos relatos introduce paradigmáticamente una escenografía sobrecargada de objetos lujosos, exóticos, ornamentales, cosméticos, aromáticos: "almohadones", "tapices”, "chucherías de bronce", “de plata", “mesitas laqueadas", “piedras preciosas", “cristales”, "gemas", “esencias misteriosas", “olor a jazmín”, “incienso". ${ }^{166}$ Es decir, objetos que aparecen más por su valor estético que por su funcionalidad y que contribuyen a crear esa atmósfera misteriosa, rara y estilizada en la que las mujeres fatales pueden llevar a cabo la misteriosa y perversa atracción que destruye y pierde a los hombres. En otros casos, además, como en "El cazador de orquídeas" y en "Accidentado paseo a Moka" aparece una flora misteriosa, hiperbólica, laberíntica, peligrosa, una selva con "genios malignos", "vapores venenosos", una naturaleza artificial.

De esta manera, los espacios tan situados en la tradición estética del modernismo-decadentismo ponen en escena y prueban una competencia literaria y retórica. ${ }^{167}$ Es en este sentido que pueden leerse los textos de la última etapa de Arlt como una búsqueda nueva por formas de legitimación que lo ubiquen en un lugar más alto en el campo literario y que superen o relativicen las críticas a su estilo de escritor.

\footnotetext{
${ }^{164}$ Arlt, Roberto. "Los bandidos de Uad-Djuari”, Op. Cit., p. 422.

${ }_{165}$ Pierrot, Jean. L'Imaginaire Décadent (1880-1900), Op. Cit., p. 52-57.

166 Arlt, Roberto. "Ven, mi ama Zobeida quiere hablarte", en Cuentos completos, Op. Cit., p. 556.

${ }^{167}$ Analizaremos estos aspectos en el capítulo siguiente.
} 
Las marcas y rasgos que Arlt incorpora en estos relatos no sólo difieren de los de sus textos anteriores redefiniendo su proyecto creador, sino que permiten pensar en la construcción —en el orden de lo imaginario — de un nuevo espacio para su literatura. El territorio exótico y ajeno le permite así tomar distancia del "edificio social que se desmorona"168 en sus novelas y realizar el deseo expresado en los preliminares de Los lanzallamas: el de componer un texto "de panorámicos lienzos" al modo flaubertiano, un texto donde se enfatice la preocupación por la belleza y por el estilo.

Esta operación se conjuga con la búsqueda de lo exótico y lo pintoresco a la que nos referíamos más arriba y, fundamentalmente, con el tipo se saber léxico y retórico que organizan las descripciones. Hay, en este sentido, dos operaciones en juego. Arlt por una parte abandona el repertorio anterior (por ejemplo, el tecnológico y el científico-técnico que todavía aparece en el viaje a España, aunque de diversos modos, como vimos) y acumula otro saber retórico y léxico. Esta nueva acumulación no sólo genera en los relatos cierta identificable ilusión de ilegibilidad que funda lo exótico — gracias a la mención de objetos raros, de nombres propios, al conocimiento sobre las palabras que se supone, a propósito del espacio y de lo que incluye, sin explicaciones - sino que, por otra parte pone en juego un saber de otro valor — donde se involucra una preocupación por el estilo-, para los códigos o las normas de la cultura y en las letras argentinas. Esto permite conjeturar que en esta zona de la producción de Arlt se inscribe una estrategia que permite o que intenta que el trabajo con la forma, con el estilo, pueda ser reconocido (o que el escritor imagina que pueda serlo) en el campo literario. De esta manera, la literatura de Arlt delata y hace visible una intención por manifestar las operaciones estéticas, lo que puede reconocerse, además, por dos mecanismos. Por un lado, por una ajuste y acomodamiento del discurso al espacio y a los materiales que describe; por el otro, por la ubicación de estos relatos en escenarios tradicionalmente asignados para lo exótico y lo bello. En las novelas y cuentos anteriores de Arlt - y esto constituía, quizá, una de las razones de su calidad estética superior-, en muchos casos se presentaba una inadecuación del lenguaje respecto del objeto representado; en este sentido, por ejemplo, las metáforas y descripciones técnicas estaban atravesadas, como sostiene Beatriz Sarlo, por una "tensión estética"; ${ }^{169}$ es decir que lo bello aparecía reiteradamente en relación con aquello un tanto alejado de lo convencionalmente asignado para la belleza. A diferencia de esos textos,

\footnotetext{
${ }^{168}$ Arlt, Roberto. "Palabras del autor", en Los siete locos/Los Lanzallamas, Op. Cit.

${ }^{169}$ Sarlo, Beatriz. “Arlt: la técnica en la ciudad”, en La imaginación técnica, Op. Cit.
} 
puede pensarse, entonces, que en El criador de gorilas hay una búsqueda — podríamos decir un tanto dócil- de ubicar ese trabajo en un sitio donde pueda ser reconocido como estético y alejarlo de materiales e imaginarios que impiden que eso sea identificado. Es más, si consideramos la imagen de escritor que construyen estas ficciones, cabe conjeturar que, en alguna medida, se solicita y reclama un reconocimiento de la habilidad estilística, pues oblicuamente los textos intentan que queden sin efecto o relativizados los motivos por los cuales tanto se había acusado a Arlt en su momento y a los que hace referencia, polémicamente, en las "Palabras del autor" de Los lanzallamas.

\section{Otras visiones, otras versiones de África}

Tal como antes se refirió, en un corto período — desde el viaje a Marruecos hasta la publicación de El criador de gorilas en Chile-, Arlt escribe más o menos simultáneamente narraciones, crónicas y una obra de teatro inspirados en el espacio africano. En algunos casos sucede además que las diferentes obras se imbrican y relacionan entre sí, pues el escritor efectúa con un mismo material el pasaje de un género a otro. Así, África es el resultado de la reescritura de los argumentos de dos relatos incluidos en El criador de gorilas, "Rahutia la bailarina" y "La aventura de Baba en Dimisch esh Sham" y de los episodios de un cuento que no seleccionó para ese volumen, "Hussein el Cojo y Axuxa la Hermosa". Si bien puede decirse que en los distintos textos aparecen elementos homólogos y complementarios, el hecho mencionado hace que convivan en su producción visiones y versiones un tanto diferentes - por sus distintos códigos, pactos narrativos, por las características propias de cada género- sobre el ámbito africano. A partir de aquí se intenta despejar los siguientes interrogantes: ¿qué dicen estos otros textos, que no digan ya los relatos, sobre el espacio exótico?, ¿qué indicios dan sobre la literatura de Arlt en los años treinta?, ¿qué otros sentidos activan en relación con los escenarios y cuáles dejan de lado?

\section{Aguafuertes sobre Marruecos}


Aunque en las aguafuertes africanas aparecen elementos y características que luego se continúan y retoman en los relatos que Arlt escribe a la vuelta del viaje, sin embargo también se inscriben algunas diferencias en las formas de la representación; efectivamente, del mismo modo que en las notas sobre España, en estos textos se constata la presencia del cronista testigo y veraz y la preocupación social, ${ }^{170}$ el interés por representar, en palabras de Arlt, el mundo del trabajo, "lo que hay de humano" en [el] lugar, "lo triste" y "el sufrir de las gentes". ${ }^{171}$ De esta manera, las aguafuertes africanas mantienen ciertas preocupaciones previas y despliegan mayores concesiones a la imagen que el público - masivo de El Mundo - se había formado del escritor. Esta situación hace de la cuentística la zona por la que ingresan más claramente en los textos de Arlt nuevos rasgos que remiten al proyecto creador que empieza a definirse en los años treinta.

Por una parte, hay una diferencia fundamental; los textos de El criador de gorilas presentan ficciones que surgen en Oriente y donde ese espacio exótico es el ámbito generador de las historias. En muchos casos, no hay excesivas concesiones al lector, -en el sentido de acercar y/o traducir lo que está siendo representado a los modos culturales y saberes del posible receptor, que era el que leía las revistas El Hogar y Mundo Argentino, donde los cuentos se publicaron por primera vez-. Asimismo, se ponen en escena esfuerzos formales para dar la apariencia de una ausencia de mediaciones, para que, digamos, África se narre a sí misma. Este procedimiento, además de reforzar lo exótico, desvincula los textos del presente y los sitúa, como se refirió, en un espacio y tiempos legendarios, al modo de los relatos de Las mil y una noches. Por el contrario, en las aguafuertes la voz del cronista opera como traductor y mediador; es la voz que explica lo exótico y lo ubica en los parámetros culturales e imaginarios de sus lectores. De allí que lo extraño, a través de comparaciones, vocabulario e imágenes, se familiariza a un esquema cultural apropiado a su destinatario, el lector de las aguafuertes porteñas. La cualidad de lo exótico se reduce: en las aguafuertes africanas - $\mathrm{a}$ diferencia de la ilegilibidad de algunos relatos- no existen vocablos árabes o referencias a lugares que dejen de ser comentadas o traducidas - “el Zoco Grande, mercado de los campesinos de las Kabilas que viven en

\footnotetext{
${ }^{170}$ Aspectos analizados a propósito de las aguafuertes españolas, como se citó con anterioridad por Sylvia Saítta.

${ }^{171}$ Arlt, Roberto. "A Madrid, a pedir trabajo”, Op. Cit.
} 
las montañas de Tánger" — ${ }^{172} \mathrm{y}$ aparecen permanentes referencias y términos que vinculan ese paisaje con las expresiones nativas — “chilaba de chocolate, esa vestidura parecida al hábito de un monje, que llega hasta los pies" -.${ }^{173}$

Por otra parte, también en otros sentidos una serie de artículos introducen diferentes representaciones de ese espacio oriental. En una aguafuerte titulada "El trabajo de los niños y las mujeres", el cronista refiere los "sentimientos contradictorios" que le suscita África: lugar que “...por momentos nos seduce con su color y en otros emana de su carnaza una bestialidad tan repulsiva que aterroriza". ${ }^{174}$ Cabe destacar que, más adelante, el sujeto de la enunciación se centra justamente en esa faceta de bestialidad negativa que no aparece representada en las ficciones - pues allí, lo primitivo está asociado siempre a connotaciones positivas, a la libertad, al misterio, a lo fantástico- y describe el "régimen espantoso de trabajo" de los niños y las campesinas. Este hecho, que aleja a las aguafuertes de lo que predominaba en los relatos, expresa además la posición evaluativa que ejerce un periodista occidental desde un conjunto de valores, normas, comunes en Occidente y que ese narrador-periodista comparte con el destinatario. ${ }^{175}$

Pero además de la preocupación por el trabajo en exceso y la crítica de sus condiciones sociales extremas, en dos aguafuertes, "Casamiento morisco" y "Noviazgo moro en Marruecos en el año 1935", el coleccionista de impresiones para El Mundo, hace intervenir nuevas imágenes de la mujer que se suman a la anterior de "bestia" para el trabajo. Con asombro y distancia el primer artículo registra la marcha de una procesión de bodas que, con un "doloroso quejido de trompetas" y un "tambor que truena siniestramente" se transmuta en cortejo fúnebre o "sacrificio" para la novia marroquí que pasa así, "encerrada" en esa jaula. Presenta entonces una versión de la mujer radicalmente diferente de la femme fatale que figuraba en las narraciones: aquí es, en palabras de Arlt "prisionera" y "mártir". ${ }^{176}$

\footnotetext{
${ }^{172}$ Arlt, Roberto. “Tánger”, en Aguafuertes españolas, Op. Cit., p. 83

${ }^{173}$ Arlt, Roberto. "Tánger”, Op. Cit., p. 87

${ }^{174}$ Arlt, Roberto. "El trabajo de los niños y las mujeres", en Aguafuertes españolas, Op. Cit., p. 99.

${ }^{175}$ En este sentido, es importante considerar el paso o la diferencia entre la ficción y el testimonio periodístico-etnográfico del viajero-corresponsal enviado por un diario. Pues en un caso se combina el encargo y la restricción genérica abocada a la tarea de referir lo que ve al viajar, y en el otro, la autonomía del autor y de la ficción.

${ }^{176}$ Axel Gasquet en su estudio sobre el orientalismo literario argentino, que incluye a Arlt se detiene en la crítica social del escritor en relación a este espacio. Véase: Gasquet, Axel. "La
} 
Interesan las anteriores calificaciones e intervenciones por dos motivos. En primer lugar, porque esta visión del cronista sobre África —que contradice en las mismas aguafuertes a la que en otros lugares prevalece - ${ }^{177}$ liga estos textos con los anteriores del escritor y se convierte en un espacio de concesiones donde, además, parece haber una búsqueda de adecuación a la imagen que Arlt se había formado entre los lectores. En los artículos se inscribe cierta preocupación por adecuarse a los parámetros de sus otras obras; en síntesis, por ser reconocido como Arlt. En segundo lugar, esas calificaciones son marcas que permitan leer mejor los relatos, en tanto que índices de las operaciones de representación, de la búsqueda estética y del saber literario que está en juego en las ficciones. Mientras en los cuentos aparecen mujeres fatales, aquí esclavas, mártires y prisioneras. Mientras que por un lado se privilegia lo exótico y lo pintoresco y la descripción es esteticista, irresponsable, por el otro hay un enunciador orientado por una preocupación sociológica y moral, y escindido en su carácter de viajero pintoresquista. Entonces es posible entender la ficción como la zona de la experimentación estética más clara en el Arlt de los treinta.

De esta manera, la visión contradictoria de los espacios obedece a dos propósitos que coexisten en las aguafuertes del viaje. Por un lado, la responsabilidad de un rol social y el compromiso como cronista "testigo". Por otro, el interés literario, territorio por el que la literatura de Arlt puede salir de sus reglas precedentes sin borrar por completo su imagen. Sin las marcas del aguafuertista, como resultado, el escenario que se dibuja en los relatos resulta libresco, ideal, extraordinario, saturado de elementos que indican un nuevo proyecto estético.

\section{Reescritura del viaje a África}

Esta unanimidad de colores violetas, té, café con leche, cacao, bronce, plata, va y viene, uno llora por dentro de no tener ojos en las sienes, en la nuca, dan ganas de correr tras ellos para decirles que vuelvan a pasar [...] y hay que apretar los dientes para no gritar de admiración. ${ }^{178}$

ficción morisca y africana de Roberto Arlt", Op. Cit.

${ }_{177}$ Arlt percibía esta contradicción. En "La vida campesina en la ficción y en la realidad", el cronista refiere en tono apologético: "Cuando en artículos anteriores describí el Zoco Grande de Tánger y sus campesinas, lo único que precisé fue un aspecto pintoresco de la cuestión”. 
Una clara estilización y voluntad estética se observa en la reescritura que Arlt realiza de las aguafuertes africanas publicadas en El Mundo entre julio y agosto de 1935, antes de incorporarlas, bajo el subtítulo "Marruecos", en su compilación de Aguafuertes españolas editada en 1936. Arlt retoma los testimonios del viaje, a los que modifica, reorganiza y en muchos casos, reescribe. Si bien anexa fragmentos o elimina otros, en varias ocasiones, excluye del libro aguafuertes completas. En esta reelaboración, donde prima cierta pretensión literaria, colorista y estética, Arlt retrotrae el imaginario de las aguafuertes al del orientalismo más o menos típico de la cultura occidental, disminuye el verismo periodístico y privilegia, mediante una búsqueda y selección de lo pintoresco, la perspectiva del exotismo. De este modo, las aguafuertes compiladas en "Marruecos" se constituyen en los primeros pasos de un proceso de estilización cuya culminación se da en El criador de gorilas.

En principio, es necesario considerar una nota aparecida en diario El Mundo en 1935 que Arlt elimina para la publicación en el volumen Aguafuertes españolas: “¿Dónde está la poesía oriental? - Las desdichadas mujeres del Islam - Mugre y hospitalidad". ${ }^{179}$ En este texto surge una representación de África que no sólo se separa de los lugares comunes e intenta salir de los estereotipos del orientalismo, sino que además contrasta notablemente con la construcción y los agregados de color local de las crónicas reescritas para el libro, como también con las ficciones posteriores de $E l$ criador de gorilas:

Una de dos, o yo soy la naturaleza más antipoética de la tierra, y de consiguiente, incapacitado para apreciar las delicadas bellezas del planeta, o de lo contrario, los que han escrito sobre la poesía de Oriente, han dejado actuar libremente su fantasía, olvidados totalmente de la realidad. [...]

Detengámonos ahora en la vida popular y en las causas de su evidente falta de poesía, derrochada en sus escritos, por muchos que probablemente jamás han visto Oriente. [...]

\footnotetext{
${ }^{178}$ Arlt, Roberto. "Tetuán, ciudad de doble personalidad”, en Aguafuertes españolas, Op. Cit., p. 88.

${ }^{179}$ Arlt, Roberto. “¿Dónde está la poesía oriental? - Las desdichadas mujeres del Islam - Mugre y hospitalidad", en El Mundo, 2 de agosto de 1935.
} 
Las mujeres a su vez, carecen de encantamiento y seducción femenina, provocador del sobresalto imaginativo o poético. Desfiguradas en el interior de sus mantas, la cabeza encapuchada, la frente vendada, el rostro cubierto [...], son menos atractivas que una monja tornera, cuyo aspecto reproducen con ostensible y superior deformidad. Leo no sé en qué revista, de un señor que encarece la poesía de Oriente, que "estas mujeres se pierden por las calles como fantasmas"; a mí más que fantasmas, me parecen bolsas ambulantes. Descalzas, mostrando los calcañares amarillentos por las babuchas aplastadas, desafío a nadie que pueda encontrar inspiración poética en fuentes tan bastas.

Dichas mujeres, en la intimidad producen una vivísima desilusión, pues carecen no sólo de la técnica de la coquetería, sino también del arte de agradar mediante la sociabilidad. [...] ... son pequeñas bestias junto a las cuales se pasa indiferentemente como ante un muro.

La ciudad africana es más sucia que un cajón de basura. Casi todas carecen de agua corriente, la gente se baña raramente, los moros huelen a manteca rancia. ${ }^{180}$

En principio, el texto presenta una oposición entre dos visiones sobre Oriente: una ilegítima y otra legítima. La primera es aquella que se aleja de la realidad por la fantasía y encuentra bellezas donde no las hay. La segunda, la perspectiva a la que adhiere el sujeto de la enunciación, autorizada además por el hecho de no pertenecer al grupo de los que "jamás han visto Oriente" — como se dice en la cita— resulta adecuada por ser testimonial, objetiva y verista. Es decir, se plantea una oposición entre fantasía literaria y verdad periodística. En segundo lugar, aquí, como en otros fragmentos que también fueron recortados o modificados en el libro para atenuar su dureza, ${ }^{181}$ aparece una representación, no sólo alejada de los cánones de la literatura sobre Oriente, sino además degradada del escenario africano y sus personajes. África se constituye, entonces, en un espacio despojado de cualidades y de los atributos

${ }^{180}$ Arlt, Roberto. “¿Dónde está la poesía oriental? - Las desdichadas mujeres del Islam - Mugre y hospitalidad", Op. Cit.

${ }^{181}$ Este es el caso de "El trabajo de los niños y las mujeres", texto en el que Arlt extrae un fragmento muy significativo del inicio y de ese modo atenúa la crítica de los lugares comunes y de las representaciones estereotipadas y coloristas de África. Dice el cronista:

"Hoy pensaba en las distintas versiones cinematográficas de Marruecos. Y me decía que aquella película dirigida por Von Stemberg [sic] es falsa y convencional a todas luces.

En cambio ahora sé que Jacques Feyder ha visto a Marruecos. También un film standard titulado Una noche en el Cairo de Ramón Novarro, refleja con sorprendente exactitud la psicología del guía árabe, así como La Atlántida y Baraud presentan paisajes africanos y personajes normalmente verídicos.

África es La Atlántida; Baraud, Le Grand Jeu, Una noche en el Cairo; pero nunca el Marruecos de Von Stemberg [sic] y de Marlene Dietrich." (El Mundo, 5 de agosto de 1935) 
necesarios para el vuelo de la imaginación, un lugar inadecuado para la producción literaria, construido por una mirada que no se compromete, que no se fascina con el espectáculo de lo otro, como en los textos y versiones posteriores. En este sentido, son fundamentales las apreciaciones sobre lo femenino y la imagen de la mujer que aquí se presenta, pues no sólo es radicalmente diferente de la que se desliza en otros lugares de las mismas aguafuertes publicadas en el diario, y de las mujeres que, en una serie de fragmentos agregados en 1936, fascinan al cronista - son como fantasmas que desaparecen por los recodos de la ciudad-, sino que, sobre todo, esta imagen se opone a la construcción saturada de saber libresco y de modernismo de la femme fatale que recorre la serie de relatos de El criador de gorilas, como "Rahutia la bailarina" y "Ven, mi ama Zobeida quiere hablarte".

Como se señaló, en las Aguafuertes españolas Arlt modifica sus modos de representación. Por ejemplo, reescribe dos notas publicadas en el diario en las que se describían los avatares del cronista en la ciudad africana de Tánger y sus impresiones de viajero, ${ }^{182}$ agrupándolas en una sola que se titula "Tánger", título que pone el acento en el espacio ciudadano que aglutina el contenido de las dos versiones anteriores y no en las peripecias del cronista. En "Tánger" no hay modificaciones muy significativas a lo largo de los fragmentos, pero hacia el final se agrega un largo párrafo que demuestra un claro interés estético, aparece una búsqueda y fascinación por lo exótico - fascinación que a lo largo de las versiones del diario prácticamente no se registra-, y el escenario oriental es concebido como un espectáculo para ser observado por sus notas de color, como en algunas de las aguafuertes sobre España. En este sentido puede leerse el comentario del cronista ante la visión de los extraños personajes y vestimentas que se le presentan a su mirada:

Cuando me fatigo del espectáculo, vuelvo al Zoco Chico. [...] Pasan viejos con perfiles de cabras y chilaba de chocolate, esa vestidura parecida al hábito de un monje, que llega hasta los pies, todos ellos descalzos, con los pies metidos en sandalias de cuero de cabra, amarillo; otros en vez de fez rojo, usan un turbante color de oro, moteado de guisantes escarlatas; [...] Desfilan mandaderos de

\footnotetext{
${ }^{182}$ Las dos aguafuertes son "El Tánger - Martirologio del turista - Plaga de guías - Persecución sistemática hasta el tercer día", en El Mundo, 31 de julio de 1935, y "En el Zoco Grande de Tánger - Mercaderes y campesinos - Uñas pintadas y tatuajes - "Flirt" sin trascendencia", en El Mundo, 1 de agosto de 1935.
} 
[...] bombachas verdes, casacas rosas [...]; desfilan turcos con bombachas hasta la rodilla, festoneada de franjas de oro, cabeza rapada bajo el fez morado; pasa un carabinero negro [...] tras él, fino, amarillo, un funcionario árabe, barba en punta, con turbante blanco arrollado a la cabeza y el turbante rematado por una calabaza de terciopelo escarlata en la que tiembla una larga pluma violeta. [...] Esta unanimidad de colores violetas, té, café con leche, cacao, bronce, plata, va y viene, uno llora por dentro de no tener ojos en las sienes, en la nuca, dan ganas de correr tras ellos para decirles que vuelvan a pasar [...] y hay que apretar los dientes para no gritar de admiración. ${ }^{183}$

Mirada abarcadora, enunciación enumerativa, reaparece aquí, como en las fiestas religiosas de Granada y Sevilla, un cronista fascinado frente al espectáculo de lo diverso que se presenta ante su ojo observador y que transforma a los hombres en color. De esta manera, la descripción acumulativa deja de lado aquí ciertos elementos degradados (el olor, la suciedad) que estaban presentes en las versiones previas, para acentuar y saturar la referencia a lo llamativo, lo típico y lo sobresaliente.

En la búsqueda de privilegiar una perspectiva exotista o de exacerbar el diluido pintoresquismo que aparecía en las versiones de 1935, se inscribe el largo fragmento (de ocho páginas en la primera edición) que Arlt anexa en "Tetuán, ciudad de doble personalidad", artículo que, del mismo modo que el anterior, agrupa dos aguafuertes que en el diario fueron publicadas sucesivamente. ${ }^{184}$ En este fragmento agregado, se relatan los recorridos del cronista por la ciudad y se hace una descripción de los distintos puestos del "arrabal moruno" que se presentan como cuadros a una mirada que capta distintas estampas, atrapada por el encanto de un paisaje de misterio. Es importante destacar, además, que la cartografía de Tetuán se transforma ahora en "laberinto", en lugar "extraterreno" y "ciudad lunar" donde los itinerarios semejan un peregrinar onírico: "Camino de sueño en sueño", dice Arlt, y donde, no sólo el espacio, también los objetos y las personas adquieren características maravillosas, al modo

\footnotetext{
${ }^{183}$ Arlt, Roberto. “Tetuán, ciudad de doble personalidad”, en Aguafuertes españolas, Op. Cit., p. 87-88. El subrayado es nuestro.

${ }^{184}$ Estas dos aguafuertes son "Tetuán, ciudad de doble personalidad - Me interno en el Barrio Moro - Reminiscencias cinematográficas", en El Mundo, 13 de agosto de 1935 y "El arrabal moruno - Mis amigos los tenderos - Saludos, genuflexiones y parásitos - Un refugio de paz y tranquilidad", en El Mundo, 18 de agosto de 1935.
} 
legendario de Las mil y una noches. ${ }^{185}$ Es decir, este ámbito no sólo extraña la visión, sino que también, instala una brecha en el tiempo y en el espacio, en la cual aparecen otras reglas de funcionamiento del mundo. Esto anticipa lo que va a suceder después en los relatos de El criador de gorilas, donde el quiebre de lo rutinario y la salida de la predestinación que se da en es orden espacio-temporal legendario resulta lo que abre la posibilidad para el surgimiento de la aventura y de lo maravilloso, como veremos. Finalmente, en el fragmento también se hacen presentes otros modos de sociedad, alejados de los convencionalismos burgueses y se define el escenario africano como el lugar del placer, de la libertad y de la paz: "Esta libertad infinita... es un regalo del cielo" [...] "y la paz, esa paz del saludo musulmán, la paz ritual que el creyente le desea al prójimo, está en mi corazón". ${ }^{186}$

Si se estudia el recorrido entre el material del diario y las enmiendas, agregados y modificaciones del libro, se verifica, entonces el comienzo de un proceso en la representación de los espacios africanos que culminará en el exotismo saturado de saber literario de los cuentos de El criador de gorilas; así, en estas ficciones finales se lleva a un límite lo que en el pasaje de las dos versiones consideradas de las aguafuertes está apenas iniciándose. Esto, por otra parte, es índice de los desplazamientos que, en los años treinta, se producen en la literatura de Arlt y de las formas en que su obra se aleja de los modos de representación precedentes.

Volviendo a las diferencias entre las aguafuertes de El Mundo y las publicadas posteriormente en libro, es importante considerar que en esta segunda versión, Arlt excluye, en su totalidad, un número considerable de crónicas. Las que deja de lado son, además de la que mencionamos al principio, las cinco primeras que publicó en el diario, ${ }^{187}$ que refieren los avatares del escritor y periodista para entrar a África, los

\footnotetext{
${ }^{185}$ Cabe señalar, en este sentido, la sensación de otro mundo que se presenta al cronista en su caminar por el laberinto que constituye para él la ciudad de Tetuán: "Camino, perdida la noción del rumbo. En este laberinto de pasadizos ignoro si marcho hacia el sur o el oeste. [...] La luz flota aquí, extraterrena, crepuscular. [...] Se tiene la impresión de vagar en una ciudad lunar [...] Las abejas se posan en mis manos, en mi rostro y no me pican". Véase: Arlt, Roberto. “Tetuán, ciudad de doble personalidad", Op. Cit., p. 132.

${ }^{186}$ Véase: Arlt, Roberto. "Tetuán, ciudad de doble personalidad”, Op. Cit., p. 144.

${ }^{187}$ Estas cinco aguafuertes son: "De Sevilla a Algeciras - Pasamos por Alcalá de los Gazules Circo, toros y gente dominguera", en El Mundo, 25 de julio de 1935; "Complicaciones a causa de mi apellido - La pesadilla de espionaje - El agente ${ }^{\circ} 80$ - "Puede embarcarse"", en El Mundo, 26 de julio de 1935; "El Peñón de Gibraltar - La ciudadela - Una ciudad sombría y limpia", en El Mundo, 27 de julio de 1935; "Policía política - Una cadena de agentes vigila a los viajeros - Imperialismo y comunismo", en El Mundo, 29 de julio de 1935; y "El agente No 80 y su
} 
conflictos y problemas con los espías del lugar. También elimina otra en donde se testimonia la visita del corresponsal viajero a la escuela musulmana y la violencia de la educación. ${ }^{188}$ En todos los casos, los textos excluidos son textos anecdóticos, que, o bien relatan experiencias y dificultades del cronista, o bien presentan un contenido de actualidad sociológica que no es funcional a la creación de un escenario exótico desconocido para un lector occidental; de esta manera, lo inadecuado para una representación pictórica y colorista empieza a ser dejado de lado.

Por otra parte, es importante notar que la versión de las Aguafuertes españolas reelabora los materiales previos en otros sentidos entre sí complementarios: primero, hay una alteración en el orden de los textos que descronologiza la trama narrativa; segundo, un borramiento de las marcas a través de las cuales en el diario se trataba de lograr, como en el folletín, un compromiso e interés en el espectador; tercero, se reducen los enlaces temáticos de una a otra aguafuerte y de este modo puede pensarse que cada texto está destinado a cubrir una parcela del tapiz oriental. Así, por ejemplo, Arlt suele agrupar en un solo artículo los contenidos que en la versión de El Mundo se describían en dos aguafuertes. Eso sucede en el caso de las crónicas que refieren los acontecimientos y testimonios sobre Tánger, sobre Tetuán, y también en la serie acerca del noviazgo y la sumisión social de la mujer. Este procedimiento estaría en correlación con el propósito de Arlt cuando estructura su obra teatral África, como analizamos en el apartado siguiente. De este modo, se organiza una estructura narrativa que, al romper la continuidad cronológica, y desligar los textos entre sí, no sólo tiende al estatismo y al espacialismo pictórico, sino que además remeda estampas y contribuye a armar cuadros de color.

substituto - Dos malandrines que se reverencian - Cada turista puede ser el mendrugo de un chivato", en El Mundo, 30 de julio de 1935.

188 Arlt, Roberto. "Visita a la escuela musulmana - Hay que saber el Corán de memoria - El palmetazo es en la planta de los pies - Indiferencia paternal por los conocimientos paternales", en El Mundo, 19 de agosto de 1935. 


\section{África, la pieza teatral}

El espacio oriental es fundamental en la composición de la pieza dramática África (1938); esto puede verse si se considera, por una parte, el amplio margen que la obra dedica a las indicaciones escénicas: la descripción de los ambientes sugiere detalles que, en su mayoría, son espaciales. ${ }^{189}$ La obra tiene como escenario y decorado la inexistente ciudad de Dimisch esh Sham, que en su diseño pone en evidencia la elección de los elementos necesarios para efectuar una condensación de los lugares más pintorescos del territorio de Marruecos; por otra parte, si seguimos lo que expresa Arlt en una carta que escribe a su madre después de la puesta en escena de África, puede decirse que esta pieza se estructura para representar espacios, se propone el muestreo del bello exotismo africano y es una excusa para la representación colorista de "lo otro" en todos sus escenarios típicos, “... pues el primer cuadro [...] es un mercado árabe, el segundo cuadro el interior de un harem, el tercero la joyería de un árabe y el cuarto el interior de una casa morisca". ${ }^{190}$ Más adelante, como se refirió en el capítulo anterior, el escritor manifiesta que lo emociona "ver la gente aguantarse 2 horas de plantón en el paraíso", que la obra tiene "un color que tira de espaldas de tan bonito" y que "Además hay momentos en que se siente una música árabe lejana, lo cual crea una atmósfera poética seductora". ${ }^{191}$ Es decir, una vez más los espacios exóticos están asociados, como en los textos ficcionales de El criador de gorilas, con lo bello y con la potencialidad estética y pintoresquista.

Pero lo hermoso de los cuadros se combina en esta obra con otros elementos. Como se señaló, la obra de teatro resulta una imbricación de los episodios de tres narraciones. Esta mezcla tiene dos objetivos principales: por un lado, permite el

\footnotetext{
${ }^{189}$ Un ejemplo que condensa muchas de esas indicaciones es el comienzo del Acto Tercero y el modo en que Arlt anota las características de la "Escena": "Sala de abluciones en la finca de HUSSEIN EL COJO. El recinto está cerrado por arcos lobulados con cancelas de hierro dorado, entre cuyas barras luce el jardín empenachado en la distancia de cipreses y encendido por rojeces de naranjos. En el centro de la sala, una fuente de mármol, en cuya vara de agua temblequea una magnolia de espuma. Los lienzos de muro estucado están recamados a la usanza musulmana en arabescos verdes, rojos, amarillos y azules. A los pies de los zócalos de azulejos, colchonetas de finas estofas recamadas. En las mesitas, que tienen la misma altura sobre el suelo que los cojines, narguiles, pipas turcas y cajetillas de cigarrillos. [...] El estrado está cubierto totalmente de esterilla y cojines." Arlt, Roberto. África, Op. Cit., p. 585.

${ }^{190}$ Carta reproducida en Borré, Omar. Arlt y la crítica (1926- 1990), Buenos Aires, Ediciones América Libre, 1996, p. 157.

${ }^{191}$ Carta reproducida en Borré, Omar. Arlt y la crítica, Op. Cit. pp. 157-158
} 
muestreo — que con los argumentos de una sola de las historias no sería posible- de distintos espacios típicos orientales, por el otro, manifiesta el interés de causar la sorpresa del lector mediante el relato de una "sangrienta historia" y de "una historia terrible". ${ }^{192}$ Es decir, lo bello se combina aquí, —en lo que el drama privilegia respecto de los relatos - con ciertos hechos sangrientos, extraordinarios, "terribles" - traiciones, venganzas, crímenes-, que surgen de los prejuicios o del imaginario occidental sobre Oriente.

En relación con las modificaciones que sufren las narraciones al ser traspasadas al teatro, es importante señalar aquellas que fundamentan la hipótesis de que es la cuentística el espacio donde se presenta el movimiento y las tendencias más alejadas de los lineamientos anteriores (fundamentalmente respecto del público amplio) y más sujetas a las preocupaciones que aparecen en la literatura de Arlt en los años treinta. Así, en primer lugar, cabe destacar las modificaciones que aparecen respecto de "Rahutia la bailarina". Aquí neutraliza los elementos tardomodernistas y desarticula el efecto final del relato. En el cuento ese efecto se producía por el dominio misterioso de una mujer fatal que hechizaba y mataba al hermano de El Mockri mediante el juego misterioso con sus ajorcas de oro. ${ }^{193}$ En África aparece una resolución trivial de los conflictos entre los personajes; por lo tanto, el final feliz pierde ese espacio de ambigüedad que, sumado al extraño poder de una femme fatale, contribuía a la producción de lo fantástico. A su vez, hay una degradación del personaje (“tenía olor"), entra lo grotesco y se busca el humor. En segundo lugar, en relación con otros relatos, África satura todos los significados y concluye explícitamente todas las líneas de la intriga de modo que no deja huecos para producir dudas y ambigüedad en el lector; todo queda resuelto. Además, la enunciación más o menos estilizada en los cuentos deja paso a formas grotescas - "podenco"- y bajas, y aparece en algunos casos una modificación de los pronombres personales - por ejemplo, en ciertos fragmentos donde en las ficciones un personaje se refiere a "vosotros" en el teatro se emplea el "ustedes", más familiar-. Finalmente, lo terrible está junto a lo hermoso porque se introducen personajes netamente grotescos, episodios escatológicos, y se representan

\footnotetext{
${ }^{192}$ Interesa destacar que mientras en el cuento "La aventura de Baba en Dimish esh Sham", que Arlt reescribe en la obra de teatro, como dijimos, el "Narrador de cuentos" llama a la multitud porque va a contar una "hermosa historia", en la pieza dramática ese personaje, en cambio, invoca a los oyentes a escuchar una "sangrienta historia" y una "historia terrible".

${ }^{193}$ Desarrollaremos esta cuestión en el capítulo siguiente.
} 
explícitamente crímenes y hechos de sangre, escenas sensacionalistas que no aparecían en los textos ficcionales. En otros términos, la obra de teatro colabora con el espectador, satura los significados y cierra las posibles interpretaciones. Dado que en los cuentos no hay esa saturación y el lector tiene a su disposición menos elementos, se podría suponer que a través de estos procedimientos Arlt busca inscribir esta obra de teatro en el marco de Teatro del Pueblo proporcionando claves acordes a su público:

Actualmente tengo en estudio el argumento de otra obra terrible. [...] El público del sábado a la noche, lo forman verdaderas multitudes incultas y groseras, pero esta gente inculta y grosera reacciona con toda justeza en los puntos de la obra en que el autor pensó que debían reaccionar mientras que la gente culta permanece impasible, lo que demuestra que el verdadero autor teatral debe trabajar su teatro teniendo en cuenta las reacciones de estas masas incultas no las minorías cultas, envidiosas, prevenidas y despojadas de ingenuidad y sensibilidad. ${ }^{194}$

Esto expresa la singularidad del teatro de Arlt en el contexto de la época. Por un lado, se manifiesta un interés esteticista ligado con el surgimiento de las nuevas tendencias de su literatura en los años treinta; por otro lado, y al mismo tiempo que este programa esteticista, aparece la pretensión de un público amplio y la preocupación por impresionar al lector, hecho que empalma con los procedimientos de su primer proyecto creador. Como se dijo más arriba, este movimiento un tanto contradictorio no aparece en los relatos que escribe después de 1932 - El criador de gorilas, Viaje terrible- y puede pensarse que Arlt imagina otro público para su literatura, un destinatario más culto y es por ello que reescribe con el argumento de sus cuentos la obra de teatro.

Así, desde el espacio africano y el exotismo oriental, se analizaron algunos de los avatares por los que pasaba la literatura de Roberto Arlt en ese tiempo. En El criador de gorilas se inaugura una espacialidad desconocida en la producción anterior de Arlt, se instituyen nuevas formas de representación y se manifiestan claramente algunas tendencias que dibujan una pretensión pintoresquista y exotista. Es en este sentido que aparece cierta búsqueda de la belleza, del estilo, una construcción

${ }^{194}$ Véase la carta reproducida en Borré, Omar. Arlt y la crítica, Op. Cit., pp. 157 y 158. 
escenográfica y colorista del sitio africano, una operación de borrado de las huellas de lo moderno. Por otra parte, las ficciones son también el ámbito en que se construye un nuevo lugar para la literatura de Arlt, se redefinen posiciones y se ensayan formas de legitimación: todo ello por el saber literario que está en juego, la búsqueda de lo exótico y los nuevos modos de la enunciación. Finalmente, puede verse en las distintas representaciones del espacio africano-exótico que construyen los textos —en la reescritura de la ficción por el teatro que se lleva a cabo con África, y en el análisis de las aguafuertes - cómo la cuentística resulta ser - a diferencia de lo que ocurre en las crónicas y en la obra dramática, que mantienen algunos de los lineamientos precedentes - la zona por la que ingresan claramente en los textos de Arlt las preocupaciones que remiten a su literatura en los años treinta. 


\section{El modo fantástico}

Si bien es sabida la preeminencia de las ficciones fantásticas en la literatura argentina y en la producción del Río de La Plata, una zona de la narrativa de Roberto Arlt no ha sido suficientemente analizada ni como corpus individual ni en relación a los contextos de su emergencia. Precisamente, la hipótesis de este capítulo sostiene que los relatos de Arlt de los años treinta y cuarenta deben situarse en el marco de las discusiones sobre cómo narrar, ${ }^{1}$ a lo largo de las cuales se consolida lo fantástico en oposición al realismo como una de las poéticas que empiezan a imponerse para la escritura de ficción. ${ }^{2}$

En efecto, entre los nuevos rasgos, géneros y procedimientos que aparecen en la literatura de Arlt en esos años, los modos de lo fantástico y lo maravilloso que recorren

${ }^{1}$ Para esta cuestión consúltese: Gramuglio, María Teresa. "Posiciones, transformaciones y debates en la literatura", en Crisis económica, avance del Estado e incertidumbre política (1930-1943), tomo VII de la Nueva Historia Argentina dirigido por Alejandro Cataruzza, Buenos Aires, Sudamericana, 2001. Véase también: Gramuglio, María Teresa. "Momentos del ensayo de interpretación nacional. 1910-1930", en Boletín/10. Del centro de Estudios de Teoría y Crítica literaria, Facultad de Humanidades y Artes, Universidad Nacional de Rosario, Rosario, Diciembre de 2002, pp. 37-50. En este artículo, Gramuglio cuestiona "la tesis, todavía vigente en muchos estudios tradicionales de literatura argentina, de que la crisis provocada por el golpe militar de 1930 había instalado el ensayo de interpretación nacional como el género literario paradigmático del período", y afirma, de un modo muy convincente, que "la centralidad del ensayo como género representativo o hegemónico resultaba opacada ante la evidencia de la formidable transformación que experimentaba la narrativa en los años que van aproximadamente de 1920 a 1940. Esa transformación de la narrativa puede sintetizarse en unos pocos nombres que muestran las diversas líneas por las que discurrió: Güiraldes, Arlt, Borges, Silvina Ocampo, Bioy Casares, Bianco, e incluso Macedonio Fernández. [...]... lo nuevo de los años treinta en el espacio de la cultura alta eran la aparición de una formación como Sur [...] y, en el plano de la vida de los géneros, la transformación de la narrativa" (pp. 38 y 43).

${ }^{2}$ Véase, para estas cuestiones los siguientes artículos publicados en Saítta, Sylvia. (directora). El oficio se afirma. Historia crítica de la literatura argentina (dirigida por Noé Jitrik), Buenos Aires, Emecé, 2004: Sarlo, Beatriz: "Una poética de la ficción", pp. 19-38; Stratta, Isabel. "Documentos para una poética del relato", pp 39-63; Gramuglio, María Teresa. "Posiciones de Sur en el espacio literario. Una política de la cultura", pp. 93- 122; Dámaso Martínez, Carlos. "La irrupción de la dimensión fantástica", pp. 171-194; y Balderston, Daniel. "De la Antología de la literatura fantástica y sus alrededores", 217-228. 
su cuentística son centrales para considerar un giro de su textualidad en los años treinta y las formas en que su obra se redefine, modifica y reestructura. En este sentido, El jorobadito, publicado en 1933 pero que reúne relatos previos, señala el quiebre entre dos estéticas en su producción. Allí se inscriben cuentos afines a las formas expresivas de sus novelas — como "Los hombres fieras"- o los relatos sobre el noviazgo y el matrimonio burgués - que también tiene su correlato en aguafuertes y en El amor brujo —, pero también se incluye por primera vez en libro "El Traje del fantasma" y "La luna roja", ${ }^{3}$ dos narraciones cercanas a lo fantástico que abren nuevas formas expresivas en su literatura. A su vez, en la década del treinta y los primeros cuarenta, Arlt publica en El Hogar y Mundo Argentino un número considerable de cuentos que se distancian acabadamente de las formas de la representación realista y se aproximan a los modos de lo fantástico, ${ }^{4}$ muchos de los cuales son recopilados en El criador de gorilas, cuando en 1941 edita casi el corpus completo de sus relatos de tema africano.

En las páginas que siguen consideramos, en principio, cómo lo fantástico que se inscribe en muchas de estas ficciones de Arlt se construye reiteradamente en relación con un saber literario que proviene del modernismo y del imaginario decadente, e indagamos de qué manera es a partir de los tópicos reescritos y retomados de esa estética que los cuentos se organizan, en un movimiento anacrónico que los acerca a relatos fantásticos de la literatura argentina bastante anteriores, como los de Leopoldo Lugones. Examinamos, también, el modo en que los rasgos decadentistas y modernistas se cruzan y conviven en los años treinta con otros elementos también presentes que remiten a las constantes más típicas de la ficción arltiana de la década del veinte: en este cruce de tendencias Arlt reestructura su obra a la vez que toma distancia y cuestiona algunas de las formas cristalizadas en la tradición literaria del modernismodecadentismo. Asimismo, y teniendo en cuenta que insistentemente es el escenario africano el ámbito donde se ubican las historias de estos relatos, y que lo fantástico se desarrolla preferentemente en un espacio exótico y alejado, analizaremos cómo la conjunción de exotismo y fantástico genera cierto tipo de narraciones que se acercan en

\footnotetext{
3 "El traje del fantasma", es un relato que Arlt había publicado por primera vez en La Nación, en 1930. "La luna roja", en El Hogar, el 16 de noviembre de 1932.

${ }^{4}$ Rosemary Jackson se refiere a "modos" de lo fantástico en el capítulo de su libro donde hace un deslinde terminológico y un acercamiento teórico sobre la cuestión. Véase, a este respecto: "El modo fantástico", en Jackson, Rosemary. Fantasy: literatura y subversión, Buenos Aires, Catálogos editora, 1986.
} 
muchos casos al orden de lo maravilloso. ${ }^{5}$ De esta manera, si en el campo literario se empezaban a imponer, como se verá, con Borges, Bioy Casares y Silvina Ocampo, los textos de aventuras, las narraciones policiales y los relatos fantásticos, como el tipo de ficciones que abrían un lugar en la literatura argentina, los cuentos de Arlt deben relacionarse y remiten indiscutiblemente a ese marco. No obstante, el anacronismo que aparece en muchos de sus textos y la apertura hacia lo maravilloso, hacen que su obra siempre se inscriba en los contextos de su emergencia de un modo conflictivo y problemático. Porque Arlt no sólo se aleja de la tradición modernista por la redefinición de sus rasgos: también sus cuentos fantásticos resultan extraños según los parámetros y las realizaciones que en los treinta y cuarenta empezaban a consolidarse para ese tipo de formas de la narración, bastante alejados, por cierto, de los tópicos modernistas o de algún acercamiento a lo maravilloso. ${ }^{6}$

${ }^{5}$ En este sentido, si las novelas de Arlt tampoco son "realistas", (aunque no por ello sean decididamente "fantásticas") y están atravesadas, como sostiene Analía Capdevila, por "fracturas y distanciamientos" de lo verosímil (o del realismo) que se promete al lector en las primeras páginas ("en la voz narrativa, en la construcción del personaje y en la figuración descriptiva de los espacios"), podría decirse que en estas obras se trataría, como analiza esta autora, de un tipo de textos que incorpora elementos de la vanguardia, tanto expresionista como futurista, cruzado con rasgos vinculables a los modos de lo fantástico tradicional (como las alucinaciones, las ensoñaciones, los dobles, por ejemplo, en la construcción de la subjetividad de Erdosain o del resto de los personajes) que también quiebran la narración realista, aunque no se resuelven en relatos fantásticos. En este sentido, a diferencia de las novelas, en los cuentos que aparecen en los años treinta se trataría, en cambio, de un fantasy que involuciona o que "atrasa" en relación a lo que el mismo Arlt ya había escrito, porque vuelve al modernismo, al decadentismo y al relato maravilloso. Véase, con respecto a las novelas: Capdevila, Analía. "Las novelas de Arlt. Un realismo para la modernidad", en Gramuglio, María Teresa. (directora). El imperio realista. Historia crítica de la literatura argentina (dirigida por Noé Jitrik), Buenos Aires, Emecé, 2002 p. 226

${ }^{6}$ En efecto, como señala Daniel Balderston cuando analiza la primera edición de la Antología de la literatura fantástica publicada por Borges, Silvina Ocampo y Bioy Casares en 1940, y la selección de los relatos que ella implica, el interés de estos autores está orientado en "privilegiar el cuento fantástico que tenga carácter metanarrativo", y ese juego "metanarrativo", en los textos de la antología "hace que lo fantástico se aleje del cuento maravilloso - y del cuento de horror- hacia otra cosa": "Son cuentos preocupados por una poética y una estética de lo fantástico"-. Y sostiene, además, en este sentido: “...la antología de 1940 se abre con `Enoch Soames', de Max Beerbohm, ese magistral cuento sobre un escritor fracasado [...] que viaja al fututo para ver cómo ha pasado a la posteridad y descubrir que la única mención que encuentra de su nombre [...] está en un texto satírico sobre él, 'Enoch Soames', de su falso amigo Max Beerbohm. [...] Al privilegiar este relato, los antólogos dejan claro que están interesados no en lo maravilloso en sí -el viaje en el tiempo-, sino en sus consecuencias narrativas: en este caso, la decepción que siente Soames, y el sentimiento de culpa que expresa Beerbohm, al verificar que la parodia ha podido más que la solemnidad literaria." Véase: Balderston, Daniel. "De la Antología de la literatura fantástica y sus alrededores", Op. Cit. pp. 221-222. Podría pensarse, a este respecto, algunos de los modos de lo fantástico de Arlt en relación con la "poética de lo extraordinario" a la que se refiere Isabel Stratta a propósito de Borges, vinculada, 


\section{Fantástico modernista e imaginario decadente}

\section{Un recorrido por los textos previos}

Un eje central para considerar las ficciones fantásticas de Arlt, más de una vez mencionado por la crítica pero poco profundizado, lo constituye el repertorio de elementos decadentes y modernistas que recorren la cuentística de los años treinta y, en menor medida, los dramas y aguafuertes de la época. ${ }^{7}$ Para abordarlo, es necesario remontarnos, en principio, a algunas de sus obras previas, porque allí aparecen rasgos, mecanismos y modos narrativos que permitirán analizar las formas de lo fantástico en los últimos textos de Arlt.

En el primer caso se trata de "Jehová", 8 el primer cuento que Arlt escribió, publicado en 1918 por Soiza Reilly en la Revista Popular, un texto muy epigonal que evidencia lecturas de fuerte matriz modernista. "Jehová" narra el momento en que Dios anuncia al universo que creará al hombre y, con una perspectiva que intenta asumir una mirada ultraterrena - lleva un epígrafe de Sinesio que dice: "Yo veo a Dios con el ojo que él me ve a mí" —, describe el ámbito donde reside la divinidad. ${ }^{9}$ Atravesado por una

en su caso, "con el espíritu del romance inglés". Véase: Stratta, Isabel. "Documentos para una poética del relato", Op. Cit. p. 42.

${ }^{7}$ Jorge Rivera, por ejemplo, cuando se refiere a "Las ciencias ocultas en la ciudad de Buenos Aires", señala, en este sentido, su asombro ante este texto tan cargado de "...citas cultas y referencias eruditas...", e indica que la mención de Baudelaire como el padre espiritual del emisor, introducida en esta obra primera, tiene, a su juicio, un valor "...indicial en la configuración del sistema arltiano, y que no es casual que años más tarde, en El juguete rabioso, Astier reparta su admiración entre Rocambole y Baudelaire". De modo que, varias elecciones de Arlt, como la de los desclazados y excéntricos, el dandismo de Barsut, su elección de la excepcionalidad, su invitación al viaje en lugares lejanos, parecerían apoyarse en una herencia simbolista (tamizada por Baudelaire). Véase: Rivera, Jorge. Roberto Arlt: Los siete locos, Buenos Aires, Biblioteca Crítica Hachette, 1986, pp. 24 a 27.

${ }^{8}$ El cuento entero no se encuentra, sólo contamos con una parte publicada en Cronicón de sí mismo, la compilación de Aguafuertes porteñas que publicó Edicom en 1969.

${ }^{9}$ Para apreciar la condensación y reiteración de elementos de la estética modernista, véase la siguiente cita: "Bajo los arcos de estrellas que coronaban a marmóreas cariátides ciclópeas, modeladas en las incandescencias solares por genios subterráneos, Jehová meditaba al resplandor de luminosísimos astrágalos, que derramaban sobre Él cataratas de perlas temblantes, cual los rotos cintillos de constelaciones desorbitadas. Apoteosis del esplendor: dijérase sobre la Celeste Ciudad sobrenadaba grávida la séptima y última Vía Láctea de los abismos, que un interminable plenilunio, inundaba plintos, arquitrabes, triglifos, metopas, y vacíos de una mística fluorescencia nocturna [...] $\mathrm{Y}$ en torno de los formidables pórticos nielados, [...] 
carga parnasiana fuerte (que puede vinculase con la impronta de lo parnasiano en el modernismo y con posibles lecturas de Leopoldo Lugones y Rubén Darío), un trabajo esmerado sobre las formas, el volumen y un interés por registrar los efectos de la luz, el cuento hace una descripción escultórica de un tema bíblico. Asimismo, el fragmento que se conserva de este relato, está saturado de esdrújulos y cultismos, apela a la sinestesia, y presenta, en un uso estético de la tradición cristiana, una proliferación de objetos lujosos, preciosos, joyas, construcciones opulentas y magníficas, como también algunos elementos que provienen del ocultismo: "esferas celestes", "rueda zodiacal" y "arcos astrales". De esta manera, en lo que podría considerarse casi un ejercicio de prosa modernista, la acumulación de recursos y tópicos marca, en esta obra inicial, un reconocimiento de cuáles son los modelos literarios para el joven escritor de dieciocho años poniendo de manifiesto qué es el arte y cuáles son sus concepciones sobre lo estético. Así, a diferencia de lo que sucede en mayor o menor medida en los textos futuros de Arlt, en "Jehová" se incorporan sin distancia y casi sin elaboración estos referentes culturales, aunque, por otra parte, también se inscribe claramente aquí lo que va a reiterarse en gran parte de su obra: la asociación permanente de un lenguaje estilizado que se aleja del orden del discurso cotidiano y los elementos del imaginario modernista. En otros términos, ya en "Jehová" aparece el modernismo cuando se constata una pretensión de estilo alto.

También merece consideración, en segundo lugar, "Las ciencias ocultas en la ciudad de Buenos Aires" (1920), un escrito de gran indefinición genérica, donde Arlt combina la ficción, el documento, la autobiografía, el ensayo y la denuncia periodística y que puede considerarse su comienzo literario. ${ }^{10}$ Este texto, si bien se propone

esplendentes centurias de ángeles, danzaban gráciles cual orientales abstracciones [...] Y era tal la euritmia de sus cambiantes aposturas, que un inagotable exordio amoroso, en cristalinos gorjeos de alegría musicalizaban las nítidas constelaciones vivas, cuyas escintilantes voces reflejaban en sus edénicos plumajes vagorosos, resplandores de metálicos tintes [...] Y severo, [...] Jehová permanecía de pie mirando fijamente los abismos caóticos con sus vastas pupilas que a instantes se posaban sobre el alado círculo de potestades y querubes que en luminosa rueda zodiacal gravitaban en torno de los colosales arcos astrales [...] Entonces majestático y terrible $[\ldots]$ se detuvo contemplando un instante al infinito, [...] donde como fabulosos lampanarios de argento eran las vertiginosas esferas, que se desplomaban serenas en las órbitas oblicuas [sic]. Entonces Jehová exclamó con tonante voz: [...] Universos, os he detenido para deciros que voy a crear al Hombre. Véase: Arlt, Roberto. "Jehová", en Cronicón de sí mismo, Op. Cit., p. 67-68. ${ }^{10}$ Arlt, Roberto. "Las ciencias ocultas en la ciudad de Buenos Aires", en Tribuna Libre, n ${ }^{\circ} 63$, Buenos Aires, 1920. Reeditado en Obras Completas, Tomo 2, Buenos Aires, Carlos Lohlé, 1981, pp. 9-35. Véase, a este respecto: Juárez, Laura.: "Arlt, el ocultismo y el comienzo de una escritura" en Orbis Tertius. Revista de Teoría y Crítica literaria, Universidad Nacional de La 
desenmascarar las mentiras en que se sustenta la teosofía, sus representantes e instituciones, no se circunscribe únicamente a una polémica con el ocultismo, sino que la excede y se desplaza a un orden donde la literatura y el escritor son los protagonistas. En este sentido, en varios puntos, las doctrinas ocultas dejan de ser el blanco principal y único de los juicios de valor negativos, y se vuelcan al campo literario y estético, para ejercer así una crítica de las formas establecidas, hegemónicas y automatizadas: el universo discursivo del modernismo-decadentismo, que con Lugones era el punto principal de referencia en el campo literario. De este modo, en una de las secciones del artículo - “Literatura teosófica" - Arlt desarrolla una evaluación crítica de la literatura que considera fundamentalmente basada en las doctrinas ocultas, ya que por medio de la influencia sugestiva que promueve, es la encargada de la propagación y el afianzamiento de esas creencias. Si se atiende a los autores allí citados (Bourget, Verlaine, Wilde, Valle Inclán) y al imaginario poético descrito, puede decirse que Arlt piensa en los textos de la estética decadente y modernista cuando se refiere a lo que llama "Literatura teosófica", la cual, aunque podría ser rescatada por “...la belleza de que están impregnadas sus obras", es fuertemente polemizada. Esta literatura, sostiene el joven Arlt, “...despojada(o) de crudas realidades”, no sólo privilegia el universo subjetivo y el intelecto sobre la vida, sosteniendo una visión pesimista de ésta, sino que también es amoral, perversa y lleva a la "degeneración". De esta manera, si el texto organiza un juego de contraposiciones entre "crudas realidades" y "vida", por una parte, y "subjetividad”, “intelecto", “imaginación”, "pesimismo”, “degeneración” y "lenguaje bello", por la otra, Arlt se declararía por el primero de esos términos en un intento de construir por oposición un lugar de enunciación y un lugar en la literatura: el arte debe estar unido a la vida y debe representar las "crudezas de la realidad", sería, en síntesis, la propuesta allí esbozada.

Si bien es cierto que el escritor se separa del ocultismo y del modernismodecadentismo en una ruptura que anticipa el proyecto de sus novelas y primeros relatos, también lo es que esa ruptura es ambigua pues oscila entre la admiración y el rechazo. Como bien ha notado Beatriz Sarlo, "la refutación participa del carácter imaginario del discurso que busca invalidar"; ${ }^{11}$ y a su vez, la propia argumentación, aunque intenta

Plata, $n^{\circ} 6,1998$, p. 67-87.

${ }^{11}$ Sarlo, Beatriz. La imaginación técnica, Buenos Aires, Nueva Visión, 1992, p. 55. Para un análisis de "Las ciencias ocultas en la ciudad de Buenos Aires" véase también, de la misma 
representar la ciencia autorizada y el positivismo, recibe las inflexiones de la teosofía, de un modo semejante a ciertos relatos de Las fuerzas extrañas que conjugan ciencia y ocultismo. El discurso ocultista es sometido a una estetización y una poetización que semeja los recursos de la prosa modernista-decadente y adjetivos como "bello", "hermoso", "dulce", son aplicados permanentemente a la teosofía y a su literatura. Así, el gesto de ostentación de saber literario que atraviesa el ensayo —además de la ostentación de los otros saberes—, muestra, una vez más, cómo ese pretendido, aunque polemizado, "estilo alto" se construye con los rasgos de la estética en cuestión.

Ahora bien, si en los comienzos Arlt escribe textos como "Jehová", saturado de modernismo y estilización, si en "Las ciencias ocultas en la ciudad de Buenos Aires" se separa de esa estética pero aún mantiene una tensión entre la admiración y el rechazo, entre la crítica y la recuperación estética, puede decirse que sus novelas y cuentos de los años veinte marcan, más o menos programáticamente, un corte con esas literaturas "de decadencia". Este corte se sostiene, por ejemplo, en el prólogo a Los lanzallamas y en algunas de las aguafuertes. En el caso del prólogo, no sólo Arlt defiende, aunque añora, ${ }^{12}$ una estética sin los cuidados del estilo, como la de Flaubert, sino que además, y en una demostración de que también puede escribir de otra manera aunque elige no hacerlo, emplea para sí la cita del final de las "Palabras liminares" de Rubén Darío a Prosas Profanas — "Y, la primera ley, creador: crear. Bufe el eunuco; cuando la musa te dé un hijo, queden las otras ocho encinta" — ${ }^{13}$ y la inscribe en una estética que, aunque continúa a Darío en la defensa de la fecundidad y la "prepotencia" del trabajo, es, en varios sentidos, antitética: "Crearemos nuestra literatura, no conversando continuamente de literatura, sino escribiendo en orgullosa soledad libros que encierran la violencia de un "cross" a la mandíbula. Sí, un libro tras otro, y "que los eunucos bufen'."14

autora "Guerra y conspiración de los saberes", en Una modernidad periférica: Buenos Aires 1920 y 1930, Buenos Aires, Nueva visión, 1988, p. 56.

${ }^{12}$ Véase: Drucaroff, Elsa. "El estilo, ese oscuro objeto de deseo", en Arlt. Profeta del miedo, Buenos Aires, Catálogos, 1998.

${ }^{13}$ Darío, Rubén. "Palabras liminares", en Prosas Profanas y otros poemas, Madrid, Castalia, 1987, p. 88.

${ }^{14}$ Arlt, Roberto. "Palabras del autor", en Los siete locos-Los lanzallamas, Edición crítica coordinada por Mario Goloboff, Colección Archivos, Francia, ALLCA XX, Université Paris X, 2000 , p. 286. Para enumerar algunas de las otras muchas diferencias que surgen solamente de la lectura de los dos textos considerados, cabe destacar, por ejemplo, que en su manifiesto estético, Darío afirma el valor de lo poético en un distanciamiento imaginario del presente, y dice "...he 
Por otra parte, en algunas de sus notas publicadas en El Mundo, como "El conventillo de nuestra literatura" (1928), ${ }^{15}$ Arlt construye una imagen de escritor que es afín a la propuesta del prólogo. Se trata de una aguafuerte en la que el cronista responde polémicamente a un ataque de Leopoldo Lugones quien, en una nota anterior, se ha puesto en contra de los escritores argentinos abocados a "describir la miseria" e "influenciados por el 'bolcheviquismo"”. Allí Arlt define su imagen de escritor por oposición a la figura del autor del Lunario sentimental, el poeta del estilo y las rimas, según lo que sugiere el propio texto. La reacción de Arlt surge, sobre todo, porque la intervención de Lugones amenaza desestabilizar su posición ganada entre el público lector: "Esto no tendría importancia si no desviara el criterio de los lectores, sobre todo el de aquellos lectores para quienes la letra de imprenta y una firma que ha hecho ruido en torno de sí, son artículo de fe.” Lugones es, a juicio del cronista, el escritor que sólo se interesa por el estilo, pues se ha dedicado casi exclusivamente a llenar "volúmenes de frases brillantes" y a cantar a "las ninfas, a las estrellas, al boj y al reloj", y que se ha olvidado de que ser escritor no es hacer "versos lindos", sino ocuparse de "la miseria y de la angustia de los hombres argentinos". Arlt ironiza sobre las frases y las rimas de Lugones, afirma que "con un poco de dificultad y otro poco de ingenio" las "constituye cualquier estudiante aventajado" y defiende su espacio ganado entre el público al proponerse, junto con otros escritores, como aquellos que sí se ocupan de "la miseria y de la angustia de los hombres argentinos" y no, como Lugones, de "inflar globos". ${ }^{16}$

Si bien Arlt se distancia de las tendencias del modernismo-decadentismo en sus novelas y primeros cuentos, aun perduran ciertos rasgos en las descripciones de situaciones, estados subjetivos o circunstancias vinculados a lo sublime, al ensueño y al

aquí que veréis en mis versos princesas, reyes, cosas imperiales, visiones de países lejanos o imposibles; ¡qué queréis!, yo detesto la vida y el tiempo en que me tocó nacer [...] (Si hay poesía en nuestra América ella está en las cosas viejas...". Véase: Darío, Rubén. "Palabras liminares" Op. Cit., pp. 86-87. En cambio, Arlt sitúa su literatura en el "hoy" y como bien señala Elsa Drucaroff, explica y justifica que no hace estilo porque la historia urge y no tiene tiempo: "Me atrae ardientemente la belleza. ¡Cuántas veces he deseado trabajar una novela que, como las de Flaubert, se compusiera de panorámicos lienzos...! Mas hoy, entre los ruidos de un edificio social que se desmorona inevitablemente, no es posible pensar en bordados". (Arlt, Roberto. "Palabras del autor", Op. Cit., p. 285. El subrayado es nuestro). Véase, también: Drucaroff, Elsa. "El estilo, ese oscuro objeto de deseo", Op. cit. p. 336.

${ }^{15}$ Véase a este respecto, por ejemplo, también "Un poco más sobre la sociedad de escritores", en El Mundo, 14 de enero de 1929. Recopilada en Arlt, Roberto. Aguafuertes porteñas: cultura y política, edición y prólogo de Sylvia Saítta, Buenos Aires, Losada, 1992, pp. 60-63.

${ }^{16}$ Arlt, Roberto. "El conventillo de nuestra literatura", en El Mundo, 21 de diciembre de 1928. Recopilada en Arlt, Roberto. Aguafuertes porteñas: cultura y política, Op. Cit., pp. 54-57. 
orden de las utopías imposibles que los personajes aspiran alcanzar. Por ejemplo, en Los siete locos se describe un ensueño de Erdosain quien imagina y modela con el recuerdo un mundo ideal y sublime:

El cielo verdea a lo lejos, mientras que la poca elevada oscuridad envuelve aún los troncos de los árboles. Erdosain frunce el seño. De su espíritu se desprenden vapores de recuerdos, neblinas doradas [...] Y el rostro de la criatura, una carita pálida, de ojos verdosos y rulos negros, escapando de un sombrerito de paño, se eleva de la superficie de su espíritu [...]. La dulce carita ocupa ahora, con su temperatura, un anochecido espacio de ensueño. ¡Se acuerda ahora de tantas cosas! Él estaba sentado a su lado, el viento movía sus rizos negros, de pronto extendió la mano y entre la yema de los dedos tomó la ardiente barbilla de la criatura. ${ }^{17}$

En efecto, aquí se registra un cambio de tono y un énfasis especial en diferenciarse del "lenguaje de la calle" y de las formas del habla cotidiana. El fragmento, construido con figuras, tópicos e imágenes que resuenan en la poética modernista — "neblinas doradas", "carita pálida", "ardiente barbilla de la criatura", "vapores de recuerdos"- introduce un estilo diferente que contrasta con otras partes del libro: hay una separación de los modos de enunciación de la fealdad y un "decorado de distanciamiento respecto de lo real". ${ }^{18}$ Lo mismo podría decirse de la zona "romántica" de El juguete rabioso, en que aparece la niña amada siempre recordada, pálida y de ojos tristes. De esta manera, cuando Arlt realiza descripciones vinculadas al ensueño, lo sublime y el ideal, ${ }^{19}$ o narra pasajes en los que prevalecen el lujo y la felicidad deseada ${ }^{20}$ reaparecen las marcas de otra estética en la literatura del "cross". Por ello,

${ }^{17}$ Arlt, Roberto. Los siete locos-Los lanzallamas, Op. Cit., pp. 100-101.

${ }^{18}$ Son palabras que Graciela Montaldo emplea en su libro para describir algunos resortes del imaginario modernista. Véase: Montaldo, Graciela. La sensibilidad amenazada. Fin de siglo y modernismo, Buenos Aires, Beatriz Viterbo ed, 1994, p. 76

${ }^{19}$ Sylvia Saítta (en "El jorobadito", material para las clases de Trabajos prácticos de Literatura Argentina II, mimeo) afirma, en este sentido, que en la dedicatoria de El jorobadito, construida con un estilo "intencionalmente poético", resuenan los ecos del modernismo en un movimiento ambiguo por el que, a la vez que se pretende inscribir este texto en "el modelo de una literatura bella, y dentro de la retórica amorosa", se cuestionan el noviazgo y el matrimonio y su función en la sociedad burguesa.

${ }^{20}$ Podrían citarse, en relación con el cambio de estilo que se emplea en Los siete locos para describir lo que se supone ideal o feliz, otros fragmentos como los siguientes: "Erdosain pensó: - Aunque tuviera una barca de plata con velas de oro y remos de marfil y el océano se volviera de siete colores liso, y desde la luna una millonaria con las manos me tirara besos, mi tristeza 
puede afirmarse que el impulso hacia lo utópico ${ }^{21}$ y a un orden alternativo al de la experiencia vital de los personajes, constituye una de las vías que imprime el estilo alto y la incorporación del tema decadente-modernista en la primera parte de la obra de Arlt

Por otra parte, no podemos dejar de destacar en Los siete locos-Los lanzallamas, ciertos motivos que remiten al imaginario decadente: la rosa de cobre ideada por Erdosain y construida por los Espila $^{22}$ y algunos de los proyectos extravagantes del Erdosain inventor, como la tintorería de perros, "que lanzaría al mercado canes de pelambre teñida de azul eléctrico, bulldogs verdes, lebreles violetas, foxterriers lilas, falderos con fotografías de crepúsculos a tres tintas...". ${ }^{23}$ Ahora bien, aunque Arlt asume con la flor metálica y los proyectos de sus personajes —que hasta cierto punto continúan algunas de las ocupaciones del Des Essaintes de Huysmans- ${ }^{24}$ algunos

sería la misma..." (Arlt, Roberto. Los siete locos-Los lanzallamas, Op. Cit., p. 34) En otro lugar, y a través de una nota del comentador que transcribe las creencias de Erdosain, la novela también introduce algunos rasgos del lenguaje modernista, a propósito de lo que el personaje imagina feliz e ideal: "'Yo creía que el alma me había sido dada para gozar de las bellezas del mundo, la luz de la luna sobre la anaranjada cresta de una nube, y la gota de rocío temblando encima de una rosa. Mas cuando fui pequeño, creía siempre que la vida reservaba para mí un acontecimiento sublime y hermoso. Pero a medida que examinaba la vida de los otros hombres, descubrí que vivían aburridos, como si habitaran en un país siempre lluvioso [...]. Y comprendí que las almas se movían en la tierra como los peces prisioneros en un acuario. Al otro lado de los verdinosos muros de vidrio estaba la hermosa vida cantante y altísima, donde todo sería distinto, fuerte y múltiple, y donde los seres nuevos de una creación más perfecta, con sus bellos cuerpos saltarían en una atmósfera elástica. Entonces me decía: 'Es inútil, tengo que escaparme de la tierra'"; Véase: Arlt, Roberto. Los siete locos-Los lanzallamas, Op. Cit., pp. 105-106. Cursivas nuestras).

${ }^{21}$ Más adelante veremos cómo en textos posteriores, como "La luna roja", también ligados a lo utópico, se introducen los tópicos del modernismo-decadentismo, pero de otra manera.

${ }^{22}$ La flor que, "cubierta de una finísima película metálica" y luego tratada "por el común procedimiento galvanoplástico del cobreado", "Tendría muchas aplicaciones", Arlt, Roberto. Los siete locos-Los lanzallamas, Op. cit. p. 57.

${ }^{23}$ Arlt, Roberto. Los siete locos-Los lanzallamas, Op. Cit., p. 106.

${ }^{24}$ Pensamos sobre todo en el episodio de $\grave{A}$ Rebours en el que Des Essaintes transforma una tortuga en una joya viviente. Cabe destacar, a propósito de Huysmans que Arlt lo había leído y que, en algunas oportunidades, lo cita elogiosamente en sus aguafuertes. Así, por ejemplo, tal como refiere Daniel Scroggins, en "Apología del pescador de caña" (El Mundo, 27 de octubre de 1928) lo llama "el cascarrabias más extraordinario que conoce la literatura" y en "Los gordos" (El Mundo, 15 de diciembre de 1928), "el escritor más delicioso de Europa". Véase: Scroggins, Daniel. "Lecturas de Roberto Arlt documentadas en las aguafuertes porteñas", en Las aguafuertes porteñas de Roberto Arlt, Buenos Aires, Ediciones culturales argentinas, 1981, p. 26. En los años cuarenta, cuando Arlt polemiza con el realismo y psicologismo de la novela, rescata del autor francés lo siguiente: “....sólo Huysmans, pésimo novelista y genial prosista, al exagerar la descripción de las cosas hasta su retorcimiento creó dentro del realismo un fenómeno de estilo esencialmente poético...”; puede consultarse, a este respecto: Arlt, Roberto. "Literatura sin héroes", en El Mundo, 13 de octubre de 1941. Recopilada en Arlt, Roberto. Aguafuertes porteñas: cultura y política, Op. Cit., p. 259. 
aspectos del gusto decadente de lo artificial, la búsqueda de lo raro y su oposición a la naturaleza, es preciso señalar que en sus novelas se introducen estos rasgos aisladamente y con otros matices que lo separan de esa sensibilidad. Por un lado, se plantea en ellas un cruce entre decadentismo y tecnologización: la rosa blindada une a las cualidades decadentes, un trabajo con lo nuevo y una fascinación por el saber hacer práctico y la tecnología: la imaginación técnica del "dandysmo de nuevo tipo", al que hace referencia Sarlo. ${ }^{25}$ Por otro, en las novelas aparece la pretensión de que el resultado del proyecto sea útil — “Tendría muchas aplicaciones", afirma Erdosain sobre la flor metalizada_- la preocupación por el mercado y la búsqueda de la industrialización, caracteres que inscriben, además, como cuestión de fondo el interés por el dinero: los Espila y Erdosain aspiran salir de la situación en la que viven por el éxito de su empresa y por la posible e imaginada comercialización de la flor ${ }^{26}$

\section{El giro de los años treinta}

Los rasgos decadentes y modernistas reaparecen en relatos de Arlt publicados entre 1937 y 1940. En esos años, Arlt vuelve a tópicos del modernismo y características del decadentismo para narrar cuentos fantásticos en los cuales abandona la ciencia y la tecnología de su novelística y se concentra en sus variadas y ricas posibilidades narrativas. La aparición reiterada de estos tópicos, pone en escena y prueba una competencia, un saber literario y retórico que supone una búsqueda literaria tendiente a la legitimación. No obstante, Arlt emplea esta retórica anacrónica pero para narrar lo nuevo: sus cuentos fantásticos se inscriben en los mismos géneros que Borges, Bioy Casares o Silvina Ocampo están promocionando en las páginas de Sur. Como sostiene Gramuglio, se trató de "una intervención polémica fuerte en el campo literario, encaminada a disputar un espacio a las tendencias realistas y psicológicas por entonces

\footnotetext{
${ }^{25}$ Sarlo, Beatriz. "Introducción”, en La imaginación técnica. Op. Cit., p. 10.

${ }^{26}$ Podrían destacarse también, el regodeo en el mal, la aparición de prostitutas, asesinos, y el mundo del vicio que aparece en las novelas arltianas como elementos y características que Arlt toma de esta estética, de la zona que viene de Baudelaire. Sin embargo, preferimos no detenernos en esta cuestión porque sin duda estos aspectos también se conectan con la lectura y la impronta en Arlt de Dostoievski.
} 
dominantes en la narrativa..."27 a través de las tramas elaboradas de los textos fantásticos, policiales y de aventuras.

La serie de artículos que Arlt publica en El Mundo en los años cuarenta también participa de los debates sobre la novela y el realismo en los que intervinieron los escritores de Sur. Si bien hay diferencias, también Arlt critica al realismo y la novela psicológica y se inclina por la acción en tanto elemento fundamental de la narración. ${ }^{28} \mathrm{~A}$ través de sus intervenciones críticas y del predominio del relato fantástico y maravilloso, las narraciones de viajes y aventuras, y el policial, Arlt intenta hacer más prestigiosa su obra aun cuando la reaparición del decadentismo y lo exótico maravilloso excede las reglas que se estaba consolidando, convirtiendo a su ficción, una vez más, en un caso peculiar y poco asimilable a las convenciones genéricas.

\section{Los relatos finales de Arlt y las formas "modernista- decadentes" de lo fantástico}

Una de las cuestiones más significativas que surgen al considerar los textos de Arlt de la década del treinta, es que en la vuelta a los tópicos del imaginario decadente y modernista se encuentra cierta búsqueda estética y un acercamiento al orden de lo fantástico en los modos de la narración, que separan estas obras de las novelas y primeros cuentos del escritor. Son significativos, a este respecto, "Rahutia la bailarina" y "Ven, mi ama Zobeida quiere hablarte", dos relatos de 1937 y 1941, respectivamente. Ambos cuentos, como se anticipó en el capítulo anterior, organizan ciertos núcleos que pueden vincularse a estas tendencias estéticas: la figura de la femme fatale, la presentación estilizada de una atmósfera exótica oriental y de espacios sobrecargados de objetos lujosos y raros, la acción de la "fatalidad", y la influencia de la "sugestión hipnótica" en el destino de los personajes. En los dos casos, es la ambigüedad que se configura a partir de los significados abiertos por tales tópicos lo que permite una lectura en clave fantástica. Por una parte, "Rahutia la bailarina", ya desde el inicio de la narración, presenta una imagen de mujer fatal que no sólo es caracterizada por el texto como una "sepulturera que ha hecho daño a muchos hombres", sino que además resulta

\footnotetext{
${ }^{27}$ Véase: "Posiciones, transformaciones y debates en la literatura", Op. Cit., p. 339.

${ }^{28}$ Esta cuestión se desarrolla en el capítulo 6.
} 
una nueva Salomé cuyas danzas "Presagia[n]ban la muerte y el zarpazo de la fiera." ${ }^{29} \mathrm{El}$ argumento gira en torno a la venganza que el hermano de El Mokri planea tomar sobre Rahutia, pues la considera responsable de la muerte de su hermano. En el momento en que esa venganza va a hacerse efectiva y se encuentran los dos personajes, ella aparece cubierta de ropajes lujosos y por un efecto extraño que el relato sugiere pero no termina de definir, aquieta la voluntad del hombre y le clava un puñal en el pecho:

Rahutia hizo jugar los alambres de oro que se arrollaban a sus muñecas; luego, cruzándose de piernas y mostrando sus pantalones de seda recamada de plata, apoyó el mentón en el puente de las manos entrelazadas. [...]

El hermano de El Mokri se sintió afectado por esa calma. La bailarina le [sic] dominaba a su pesar con aquella infinita serenidad.

-Mírame a los ojos [le dice Rahutia]

El hombre apartó los ojos de un versículo que en oro culebreaba en el tapiz y los fijó en la mujer. Aquel rostro largo, fino [...] lo perturbaba. ¿Mentiría ella o no?...Iría a caer en sus garras. Lo atraía. [...] Apelando a su voluntad, estranguló la ola de emoción que se le subía a los ojos, y, entristecido, fatigadísimo, habló como a través de un sueño, con palabras muy pesadas...

—ue Alá me condene si eres inocente [...]

Rahutia comprendió que no debía esperar más, y una ajorca de oro cayó de su mano y rodó por el esterillado. El hombre se levantó y corrió hasta la ajorca... [...]

El brazo de la mujer cortó el aire como la correa de un látigo, y el mozo tuvo en el corazón la sensación de la cornada de un becerro. El puñal de Rahutia se había clavado en su pecho, quiso gritar, pero únicamente pudo morder la palma de aquella mano ardiente $y$ perfumada... ${ }^{30}$

En efecto, la clave está en el modo en que el texto presenta esta escena: las referencias a la sensación "de sueño" que produce Rahutia en el Mockri, las sugerencias sobre su poder hipnótico - "Mírame a los ojos"-, y su cualidad de femme fatale, permitirían leer este cuento como fantástico. Es decir, son los tópicos modernistadecadentes que aquí se retoman los que organizan la ambigüedad del relato y los que desplazan hacia lo fantástico una trama y un desenlace que bien podrían entenderse provocados únicamente por el simple erotismo seductor de la bailarina. "Ven, mi ama

${ }^{29}$ Arlt, Roberto. "Rahutia la bailarina", en Arlt. Roberto. Cuentos completos. Edición a cargo de Ricardo Piglia y Omar Borré, Buenos Aires, Seix Barral, 1996, p. 282.

${ }^{30}$ Arlt, Roberto. "Rahutia la bailarina", Op. Cit., p. 285, el subrayado es nuestro. 
Zobeida quiere hablarte" funciona de un modo semejante. En este caso, el texto privilegia la representación, aún más estilizada que en el anterior, de los escenarios exóticos que, desde el Flaubert de "Herodías", La tentación de San Antonio y Salammbô en adelante, se asocian a la aparición de estas mujeres fatales. Así, como referíamos en el capítulo anterior, el cuento reescribe los interiores lujosos, saturados de objetos exóticos, ornamentales, cosméticos, aromáticos, piedras preciosas $\mathrm{y}$ multiplicidad de texturas de la estética a la que nos referimos ("almohadones", "tapices", "chucherías de bronce", "de plata", "mesitas laqueadas", "piedras preciosas", “cristales", "gemas", “esencias misteriosas", “olor a jazmín”, “incienso"). Es decir, objetos que aparecen sobre todo por su valor estético y que contribuyen, del mismo modo que el espacio exótico que se construye en "Rahutia la bailarina" a crear la atmósfera misteriosa, rara y estilizada en la que las mujeres fatales pueden llevar a cabo la misteriosa y perversa atracción que destruye y pierde a los hombres. En cuanto a lo fantástico, también queda abierta la interpretación sobre cómo pueden considerarse los sucesos narrados, pero una vez más el repertorio modernista acentúa la ambivalencia y perplejidad que generan los acontecimientos del relato: es imposible decidir si es el influjo hipnótico de Zobeida lo que ocasiona la muerte de su esposo jorobado, cuando el personaje a quien se le ha encomendado asesinarlo le dirige la mirada, o ésta se debe a la acción de la casualidad. ${ }^{31}$ La aparición del jorobado, una constante de los textos de Arlt desde los veinte, marca, por otra parte, cómo los decorados decadentes en este texto aparecen junto con rasgos que claramente remiten a su narrativa anterior. ${ }^{32}$

"Historia del señor Jefries y Nassin el Egipcio" (1938) y “Odio desde la otra vida" (1939) también constituyen la trama fantástica con los recursos del modernismodecadentismo: en el primer cuento, se narra un episodio de sugestión hipnótica provocado por un mago experto en ocultismo; en el segundo, una salida del cuerpo físico y una entrada al "plano astral" por la que uno de los personajes puede entrever el destino "fatal" que lo ata a su novia. Ambos relatos son la puesta en términos narrativos de temas espiritistas, y a diferencia de lo que ocurría en 1920, donde Arlt polemizaba abiertamente con las ideas del ocultismo y su literatura, estos textos parecen más bien desentenderse bastante de la preocupación por el "efecto nocivo" de esas creencias

${ }^{31}$ En este sentido, Todorov señala que cuando no puede decidirse entre una solución racional y una sobrenatural estamos en el terreno de lo fantástico. Todorov, Tzvetan. Introducción a la literatura fantástica, México, Ediciones de Coyoacán, 1994.

${ }^{32}$ Sobre este aspecto volveremos más adelante 
—que se mantiene sólo en la perspectiva crítica del narrador sobre los "doctores en magia" y otros "espiritistas" — ${ }^{33}$ y concentrarse en el desarrollo de sus ricas posibilidades narrativas. En "Odio desde la otra vida", por otra parte, la idea de "fatalidad" que en el modernismo estaba asociada, en muchos casos, con una inquietud "mística"34 y, podría decirse, también espiritual se despoja de esas orientaciones y termina funcionando únicamente como procedimiento que se beneficia de lo cristalizado del tópico para la constitución de un relato fantástico.

Todo esto vincula los textos de Arlt, con resoluciones del fantástico argentino de fines del siglo XIX y principios del XX, más precisamente, con los cuentos fantásticos de Leopoldo Lugones y Horacio Quiroga. Ciertas constantes y continuidades entre las ficciones fantásticas de Arlt y algunos relatos de Lugones son notables: "Odio desde la otra vida", por ejemplo, conjuga una historia amorosa con materiales ocultistas como $E l$ ángel de la sombra, de 1926, aunque sin la erótica sentimental que atraviesa el texto de Lugones. ${ }^{35}$ Fernando está "fatalmente" atado por un odio ancestral que atraviesa las sucesivas reencarnaciones y lo une y lo separa a la vez de su novia Lucía; la experiencia sobrenatural por la cual el personaje ingresa al "plano astral", le permite, en un viaje en el tiempo por el cual se introduce en un pasado más legendario que real, comprobar "la continuidad de su odio" con Lucía; Fernando, gracias a esta experiencia, huye de ella para siempre.

Si bien muchas de las ficciones fantásticas de Arlt, como las de Lugones, son la puesta en forma de hipótesis ocultistas y espiritistas, pseudocientíficas y/o sobrenaturales que se vinculan con las tendencias del modernismo y el decadentismo, el interés de Arlt no se centra en la teosofía, el espiritismo o la pseudociencia de la misma manera. Arlt no pretende probar estas hipótesis, ni discutirlas — cosa que sí hacía en

\footnotetext{
${ }^{33}$ Esto se da, sobre todo, en al caso de "Historia del señor Jefries y Nassin el Egipcio", cuando el narrador asesina al doctor en magia por miedo de "perderse para siempre". Por este motivo, según José Amícola, el cuento continúa la crítica a la que Arlt había sometido el ocultismo en 1920. Para más detalles, véase, Amícola, José. "Los magos del mal", en La Razón/Cultura, domingo 1 de septiembre de 1985, Buenos Aires, pp. 6-7.

${ }^{34}$ Henríquez Ureña la define en este sentido. Henríquez Ureña, Max. Breve historia del modernismo, México, FCE, 1954, p. 16.

${ }^{35}$ Para un análisis de El ángel de la sombra, véase: Gramuglio, María Teresa. "Estudio preliminar", en Lugones, Leopoldo. El ángel de la sombra, Buenos Aires, Losada, 1994. Véase, también: Dalmaroni, Miguel. "La espada y el puñal (sobre el penúltimo Lugones)", en Una república de las letras. Lugones, Rojas, Payró. Escritores argentinos y Estado, Rosario, Beatriz Viterbo editora, 2006, pp. 213-220.
} 
"Las ciencias ocultas en la ciudad de Buenos Aires"-, ni proponerlas en tanto que formas de imponer y sostener un sujeto de enunciación fuerte y poderoso, como sucede en el caso de Lugones, cuyos textos fantásticos sustentan una "jerarquía espiritual y social del poeta $[\ldots]$ que lo hace depositario y administrador de un saber superior, oculto o secreto...". ${ }^{36}$ En Arlt, las doctrinas teosóficas y los tópicos del fantástico modernista constituyen el argumento ficcional de sus narraciones fantásticas; el espiritismo, lo oculto y lo sobrenatural operan en tanto que tópico literario y procedimiento narrativo para la construcción del fantástico. La preocupación científica $-\mathrm{y}$ también esotérica-que ocupó en los veinte un espacio preferencial en sus relatos como estrategia de compensación de su lugar en la sociedad — de acuerdo a las hipótesis de Beatriz Sarlo- ${ }^{37}$ se transmuta en estos textos en la elección selectiva de una serie de tópicos narrativos ya convencionales que se toman para escribir un relato fantástico.

Esto puede verse, por ejemplo, si consideramos otros textos de Arlt que sugieren un acercamiento a la poética del fantástico de Lugones. Uno de los rasgos que Juan B. Ritvo describe, a propósito de esa poética y en relación con el imaginario decadente y la pasión por el ocultismo de Lugones, es la confusión de los órdenes allí presente —mineral, vegetal, animal_- y "la proliferación de mezclas aberrantes y de cascadas combinatorias que cercenan los límites”, las relaciones jerárquicas, causales, y de clase del aristotelismo. ${ }^{38}$ Para Ritvo, los relatos más notorios de Las fuerzas extrañas "describen con precisa fruición cataclismos y horrores cuya causa es la confusión indebida de los géneros, la sodomización de la naturaleza, el acercamiento trasgresor de extremos que deberían haber conservado su elegante equidistancia". ${ }^{39}$ Esto que, según Ritvo, está en la base de la composición de muchos de los textos de Lugones como "Los caballos de Abdera" — caballos humanizados_- "La lluvia de fuego" — "amores monstruosos de fieras:": lagartos con cisnes, monos y focas, etc. —, o "La estatua de sal", —vida y muerte conjugados—, también funciona en tanto que procedimiento para

\footnotetext{
${ }^{36}$ Dalmaroni, Miguel. "El fantástico de Lugones y Quiroga en el proceso de emergencia del "campo intelectual"”, 1996, mimeo.

${ }^{37}$ Véase, Sarlo, Beatriz. La imaginación técnica, Op. cit., p. 10

${ }^{38}$ Ritvo, Juan Bautista. "Lugones: el esplendor soberano", en Paradoxa, Universidad Nacional de Rosario, Año 5, n4/5, 1990, p. 43. Véase también para esta cuestión: Ritvo, Juan Bautista. "1885: La irrupción del decadentismo", en Paradoxa, Año X, nº 8, 1996, pp. 93-97

${ }^{39}$ Ritvo, Juan Bautista. "Lugones: el esplendor soberano", OP. Cit., p. 44.
} 
la constitución de algunos de los relatos fantásticos de Arlt. En efecto, "Los hombres fieras" (1940) configura su efecto fantástico a través de una serie de episodios de metamorfosis por los cuales los hombres se convierten en animales y asesinan inocentes en la noche de la selva. El cuento se preocupa casi exclusivamente por ficcionalizar y poner en escena el efecto narrativo de esa transformación: el tema de la metamorfosis, entonces, es un recurso para escribir lo fantástico y de esta manera se introduce algo totalmente novedoso en la literatura de Arlt. Por otra parte, además de que "Los hombres fieras" remite, en algún punto, a la pareja hombre-bestia que conjuga Lugones en cuentos como "Un fenómeno inexplicable", puede decirse que retoma a su vez, un tópico que, más allá de estar inscripto en la cultura popular a través de la imagen del hombre lobo, funda algunas de las primeras narraciones fantásticas de Horacio Quiroga. Pensamos, sobre todo, en "Episodio", texto que también relata la metamorfosis de hombres en bestias, y con recursos expresivos semejantes. ${ }^{40}$

En relación con estas cuestiones, cabe mencionar también "La luna roja", el cuento que Arlt publica en El Hogar en 1932 y luego reedita en el libro El jorobadito. Esta historia, si bien es bastante anterior a las que se han estudiado y se aleja de estos

40 "Los hombres fieras" pone en escena la metamorfosis de hombres en bestias de la siguiente manera: "Gan se retiró velozmente, y encogiendo el labio superior se quedó mostrándome los dientes como una fiera que quiere morder [...] recuerdo perfectamente que no sentí ningún desagrado por ese gesto bestial, sino, riéndome también, yo fruncí los labios, mostrándole los dientes al caníbal. Entonces Gan apoyó las manos en el suelo y comenzó a andar ágilmente a cuatro pies, rozándome las pantorrillas con el flanco; yo experimenté un sobresalto terrible, me precipité a la puerta, la cerré con llave, y apoyando las manos en el suelo, también me puse a caminar como una fiera. Y el niño lanzaba gruñidos y yo le imitaba y ambos parecíamos dos fieras que no se resuelven a reñir". Véase: Arlt, Roberto. "Los hombres fieras", en Cuentos completos, Op. Cit., p. 529. En "Episodio" (fechado entre 1899 y 1901), el relato de Quiroga, encontramos la narración de un suceso similar de un modo semejante: hay un progresivo abandono de la condición humana y un aprendizaje de la conducta salvaje y animal a partir de la imitación. Allí, leemos: "Y empecé a reírme mirándole y el me miraba y se reía sin quitarme la vista, y cada vez nos reíamos más fuerte, y sus uñas se ponían lívidas, y sus cabellos se erizaban y mis cabellos se erizaban, y su cuerpo se alargaba poco a poco, y mi cuerpo se alargaba poco a poco, y vi que se arrastraba sigilosamente por los rincones y sentí que me arrastraba torpemente por los rincones y la noche comenzó a entrar en el escritorio ya oscurecido, en el que nos replegábamos y nos extendíamos, aullando, mojando las paredes, babeando todo el piso por el que nos arrastrábamos entremezclados...". Puede consultarse: Quiroga, Horacio. "Episodio", en Cuentos completos, Volumen I, Edición al cuidado de Alfonso Llambías de Acevedo, Montevideo, Ediciones de la Plaza, 1979, p. 26. En relación con estos problemas y aunque la cuestión excede los límites del presente trabajo, podría indagarse también, de qué modo lo analizado por Ritvo para el caso de Lugones se aplica a ciertos cuentos de Horacio Quiroga. Así, además de "Episodio" podrían considerarse, entre otros, por ejemplo, "Para una noche de insomnio" (1899) que explora los límites entre la vida y la muerte, y textos de metamorfosis de hombres en bestia como "El lobisón" (1906). 
problemas al evidenciar como preocupación central el peligro inminente de la guerra, interesa porque pone en escena un episodio fantástico, el de la muerte del mundo, que es frecuente en los textos modernistas. En ese episodio, por el cual una multitud hipnotizada por la luna roja avanza adormecida ante el "extraño suceso", aparecen — del mismo modo que en los cuentos de Lugones - el desorden, la ruptura de los límites y de la individuación; los hombres, las mujeres y las bestias, confundidos, igualados y mezclados: "De pronto un hombre sintió que le tiraban de una manga insistentemente [...] encendió un fósforo y descubrió el achatado rostro de un mono grande que con ojos medrosos parecía interrogarlo acerca de lo que sucedía. Otro identificó varios tigres confundidos en la multitud. [...]...era difícil discernir los rostros femeninos de los masculinos. Todos aparecían igualados y ensombrecidos por la angustia del esfuerzo que realizaban...". ${ }^{41}$

"El cazador de orquídeas" (1939) es otro de los cuentos que puede leerse en este sentido y que además permite considerar de qué manera lo que podría denominarse para el caso de Arlt como un fantástico modernista y decadente, convive en algunos de los relatos de los años treinta con rasgos típicos de su literatura: "el hombre de Arlt" y sus problemas, el cuestionamiento de la sociedad burguesa, los deformes y jorobados, la traición, el dinero, la "literatura bandoleresca", etc. En este texto de aventuras, Guillermo, el cazador de orquídeas, emprende con el narrador una expedición en busca de la misteriosa "orquídea negra", "ese monstruo" "hermoso y repelente", esa "flor histérica y caprichosa, que la veréis bajo la forma de un andrajo gris permanecer muerta durante meses en el fondo de una caja, hasta que un día, bruscamente, se despierta, se despereza y comienza a reflorecer, coloreándose con las tintas más vivas". ${ }^{42}$ La empresa del personaje, aunque remite en algún punto a las ocupaciones raras y pasatiempos típicos del héroe decadente - Guillermo gasta sus días por el mundo en busca de los ejemplares más exóticos—, resulta más bien una aventura que lleva a cabo un ladrón desenfadado movido casi exclusivamente por el dinero: "Estábamos envenenados de codicia", dice el texto. Después de atravesar una selva misteriosa, hiperbólica y laberíntica, que tiene, como la flor buscada, todas las características que toma lo vegetal en el imaginario decadente, ${ }^{43}$ encuentran la lujosa y artificial orquídea negra: "una estrella de picos fruncidos, tallada en un tejido de terciopelo negro bordeado de un

${ }^{41}$ Arlt, Roberto. "La luna roja", en Cuentos completos, Op. Cit., pp. 184-185.

${ }^{42}$ Arlt, Roberto. "El cazador de orquídeas", en Cuentos completos, Op. Cit., p 467. 
festón de oro", de cuyo "cáliz lánguido, inmenso como una sombrilla de geisha", emerge "un bastón de plata...". ${ }^{44}$ En ese momento muere el niño tuerto que los guiaba y, —en una reiteración de lo que sucede desde los primeros textos de Arlt, por ejemplo en "El jorobadito", donde los "deformes" conducen a los personajes al infortunio- el amigo del narrador es obligado a comer, por una venganza que le impone el tío de la víctima, la preciada flor:

Cuando Guillermo terminó de comerse el último pedacito de terciopelo y oro, Taman salió del tabuco en silencio, y Guillermo se desmayó.

Estuvo dos meses enfermo del estómago, y cuando creyeron que se había curado, una peste curiosísima, manchas negras con borde bronceado, le comenzó a cubrir la piel en todas partes del cuerpo, y aunque varios médicos sospechan que es una afección nerviosa, ninguna autoridad sanitaria le permite al primo Guillermo abandonar la isla donde "se comió su fortuna". ${ }^{45}$

El fragmento muestra fundamentalmente dos cuestiones. En primer lugar, el efecto fantástico del relato se produce en torno a una cualidad decadente por la cual lo vegetal aparece con características humanas y se cubre de connotaciones inquietantes; la flor le transmite al primo del narrador una enfermedad que al cubrirle de manchas negras y doradas el cuerpo, la continúa en el tiempo. La venganza de la "flor histérica" sobre el profanador de lo vegetal — que nos lleva a una botánica fantástica y a la "flor

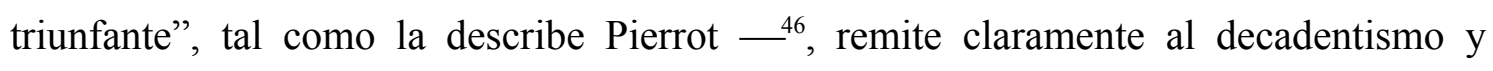
también, de cierta manera, a la Viola Acherontia de Lugones, ${ }^{47}$ marcando una clara distancia de la flor de cobre de Erdosain y los Espila, ligada al saber tecnológico. En

\footnotetext{
${ }^{43}$ Atraviesan una "planicie cristalina oscura", verde que es terciopelo, una nube de estaño, etc. En "Accidentado paseo a Moka" (1939) también aparece una flora misteriosa, hiperbólica, laberíntica, peligrosa, y lo vegetal como amenazante y macabro, lo que escapa a la restricción que las leyes naturales imponen.

${ }^{44}$ Arlt, Roberto. "El cazador de orquídeas", en Cuentos completos, Op. Cit., p. 472.

${ }^{45}$ Arlt, Roberto. "El cazador de orquídeas", en Cuentos completos, Op. Cit., p. 474.

${ }^{46}$ Pierrot, Jean. L'Imaginaire Décadent (1880-1900), Paris, P.U.F., 1977.

${ }^{47} \mathrm{Si}$ bien son textos muy diferentes, es necesario destacar, en este marco, que "El cazador de orquídeas" presenta una serie de cuestiones que se conectan con "Viola Acherontia" de Lugones. Así, está en los dos cuentos la búsqueda de la flor negra, la idea de desafiar los límites de la naturaleza y el castigo que supone esa trasgresión.
} 
segundo lugar, la cita enfatiza los cruces estéticos: el clímax final del cuento se constituye en torno a la cuestión del dinero, una de las preocupaciones centrales de Arlt desde sus primeros textos. De este modo, se mezclan y combinan aquí el tema decadente con elementos tan claros en la poética arltiana del "cross" como la preocupación por el dinero, la descripción estilizada de la flor con el lenguaje plebeyo y rústico del narrador, y todo esto en el marco de un relato de aventuras. ${ }^{48}$

El rasgo decadente de la naturaleza como amenaza y de lo vegetal inquietante y monstruoso, aparece, con otros matices, también en "La venganza de Tutankamón", relato publicado en Mundo Argentino. Este texto retoma muy tardíamente, en 1938, el mítico tema de la maldición de los faraones, trabajado ya por Lugones en los años veinte en los Cuentos fatales, pero sobre todo en uno de los relatos de ese libro, "El vaso de alabastro". En el caso de Arlt, es el viaje el que sirve de marco al suceso por el cual el señor Almstrong, ${ }^{49}$ violador de sepulturas y acompañante de Lord Carnavon en su empresa, hace partícipe al narrador del caso por el cual en poco tiempo y a causa de haber tenido contacto con un extraño hongo, su cuerpo se cubriría de manchas "color verdeazul con ligeras motas amarillas en la periferia" y "herviría de muerte vegetal". 50 El cuento también pone en escena una de esas mezclas y conjunciones de las que gusta el decadentismo: la simbiosis de hombre y vegetal, pareja trágica que lleva al señor Almstrong a la muerte. Como en "El cazador de orquídeas", es la cualidad decadente lo que organiza lo fantástico en este cuento, y de la misma manera que en el anterior, ese universo estético y la descripción estilizada del paisaje se combina aquí, con grotescas descripciones de los personajes y un tono desenfadado que —en todo sentido opuesto al spleen modernista - domina la narración.

"El aprendiz de brujo" (1939), finalmente, es otra de las ficciones que permiten mostrar la convivencia del modernismo-decadentismo con rasgos narrativos del Arlt de los veinte. El cuento escenifica, de modo semejante a "Odio desde la otra vida", una entrada al plano astral. Se trata de la historia que cuenta uno de los viajeros de un barco, testigo de los sucesos acaecidos. Borodin, individuo dedicado durante algún tiempo a

\footnotetext{
${ }^{48}$ Esta conjunción muestra, además, una zona de contacto entre el Arlt de los treinta y ciertas vertientes de la literatura popular y el folletín de aventuras.

${ }^{49}$ Especie de doble de Arlt que el relato sugiere cuando se refiere a la "curiosa coincidencia" que hace que Almstrong (aquel individuo que tiene un "maldito" y "complicado" nombre) le refiera al narrador-viajero, alter ego de Arlt, su suicidio ante la muerte inminente.

${ }^{50}$ Arlt, Roberto. "La venganza de Tutankamón”, en Cuentos completos, Op. Cit., p. 373.
} 
las prácticas de la magia negra con el objeto de dañar "a una mujer que lo había hecho sufrir", narra en lo que se transmuta en una historia de educación, su aprendizaje de brujo. Su maestro, Arsenio Anyelico, es quien "lo insta al maleficio", a realizarse cuando ambos, alumno y maestro, hayan ingresado en el mundo astral. Dicho maleficio consiste en torcerle para siempre la cara al hijo de la mujer de la que se quería vengar. El personaje prefiere morir antes de dejarse llevar por el "demonio" de Anyelico, y, en una prueba ficcional de la existencia del plano astral que funciona como la flor de Wells, el relato finaliza cuando ambos vuelven al cuerpo físico y Borodin comprueba que a Arsenio Anyélico se le ha deformado el rostro: una fuerza que se adjudica a la “justicia divina” y que, se asegura, toma revancha por sus maldades es la que ha provocado el prodigio. De este modo, el cuento presenta, por un lado, una distancia crítica del narrador sobre los magos y expertos en ocultismo, que, continúa, en algún punto, la polémica de Arlt en "Las ciencias ocultas en la ciudad de Buenos Aires", 51

${ }^{51}$ Cabe considerar que tanto en el caso de los relatos que reescriben temáticas de las ciencias ocultas, como en el de ciertos cuentos fantásticos surcados de elementos que pueden relacionarse con el imaginario decadente o modernista, se continúa el tratamiento - valoración estética y crítica, literaturización y poetización, y distancia- a que es sometida la teosofía en "Las ciencias ocultas en la ciudad de Buenos Aires". Un caso paradigmático, en este sentido, que inaugura esta perspectiva en los relatos, lo constituye "El traje del fantasma". Aquí, el narrador personaje Gustavo Boer describe la "memoria de los sucesos extraordinarios" (p. 68) que ha padecido, con el objeto de desvincularse de un delito cometido intentando pasar por demente, tal como nos asegura la nota final "del autor". La serie de sucesos fantásticos que son relatados, surge desde un narrador situado en un estado que oscila entre la vigilia, el sueño y el delirio. De este modo, a partir de esta visagra, realidad-alucinación o realidad-sueño, introduce al lector en el interior de su subjetividad, y a partir de ésta, en un viaje imaginario que facilita la evasión de un tiempo y un espacio reales. Es sabido que, en el imaginario decadente y modernista el sueño, las experiencias con estupefacientes, el refinamiento de las sensaciones, son los medios privilegiados para apartarse de lo inmediato y lo concreto, y los puentes que llevan al idealismo como reino de lo subjetivo. En el texto aparece la narración y descripción deleitosa de Boer de geografía, espacios, y seres imaginarios: la "ciudad de las orillas", la selva habitada por una flora fantástica, de dimensiones asombrosas y características antropomórficas (lo cual también es acorde a esa sensibilidad), los animales parlantes, etc. Con respecto a la perspectiva sobre lo representado que se perfila en este cuento, puede decirse que esta ficción en sí misma ejemplifica un doble movimiento, pues, si por un lado implica la puesta en escena de un gusto por lo fantástico, una preocupación estilística y un privilegio de lo subjetivo, también se presenta, a la vez, una distancia ideológica respecto de estos elementos representados. Esto puede verse, principalmente, en esa nota "del autor" que el texto introduce en el final, ya que con su presencia se atenúa y cuestiona lo fantástico y, sobre todo, se lo reduce a la lógica realista, moral y legal del policial: Gustavo Boer ha cometido un delito y los sucesos narrados intentan ser su justificación; además, porque los elementos representados aparecen no sólo en boca de un narrador que es un criminal que va a ser condenado (lo que indica distancia imaginaria respecto del narrador), sino que también constituyen la "mentira" que remedaría una falta, que por otra parte no consigue su objetivo. Véase: Arlt, Roberto. "El traje del fantasma", en Cuentos Completos, Op. Cit. 
aunque ya no se discutan las ideas y temas de la teosofía y se privilegie, sobre todo, su ficcionalización. Por otro lado, puede decirse que el argumento de este relato es la prueba ficcional y la puesta en términos narrativos de la tesis arltiana reiterada, de distintas maneras, en muchas de sus obras de los veinte: "Cuídate de los señalados por Dios". Se trata, como se sabe, de un refrán del saber popular que en El juguete rabioso entra en palabras de la madre de Silvio Astier, quien trasmite la doxa popular. Nuevamente podemos ver aquí la alta productividad que en Arlt tienen los saberes populares en todas sus formas. Así, la obra de Arlt en los treinta, a la vez que se orienta a lo fantástico y modifica de esta manera su proyecto creador, introduce algunas de las normas más cristalizadas de su literatura previa y en ese movimiento también transforma las tendencias situadas de la tradición modernista que retoma y reescribe.

\title{
2. Exotismo y fantástico-maravilloso en los cuentos africanos
}

\begin{abstract}
Nunca como hoy el sueño de los países exóticos ha sido tan intenso entre nuestros hombres. ${ }^{52}$
\end{abstract}

Roberto Arlt

Otro aspecto singular de lo fantástico en la literatura de Roberto Arlt puede leerse si se enfoca el exotismo de algunas de sus ficciones. Como se señaló en el capítulo anterior, después de su experiencia como cronista viajero en Marruecos, Arlt escribe una serie de textos africanos, muchos de los cuales recopiló en El criador de gorilas. Ya en los años treinta, en "El traje del fantasma", Arlt había incorporado ciertos espacios exóticos y remotos que se oponían a los escenarios ciudadanos, pequeño burgueses, tecnológicos y futuristas de sus novelas. Los cuentos africanos continúan lo iniciado con "El traje del fantasma" porque ponen en su centro la representación de un espacio exótico y ajeno que los aproxima al orden de lo maravilloso, y no siempre al de

${ }_{52}$ Arlt, Roberto. "Quieren huir de su propia sombra", en El Mundo, 1 de septiembre de 1938. Al margen del cable. 
lo fantástico. De alguna manera, esta oscilación entre lo fantástico y lo maravilloso pareciera ser la forma más apropiada para ficcionalizar África porque, como Arlt afirma en una de sus aguafuertes españolas, el orden de "la fantasía" de las historias orientales revela y es efecto de un tipo de cultura y de una clase de sociedad. La primacía de la "fantasía" en los cuentistas árabes - expresa el propio Arlt_ "refleja en la trama de sus hilos de oro y plata" el quietismo y "la vida casi inmóvil de sus creadores" y es por ello que "Las Mil y una Noches, es el calco perfecto de las actividades psíquicas de los pueblos de Oriente". 53

En este sentido, "Los bandidos de Uad Djuari” permite caracterizar los valores que, de un modo general, son atribuidos al espacio africano en los textos de El criador de gorilas. La historia narra la puesta en escena y producción de un evento ficccional en lo "real". El relato, como señalábamos en el capítulo anterior, refiere un secuestro apócrifo que sufren dos viajeros por unos bandidos de ficción que intentaban, con su disfraz, "emocionarles [los] y proporcionarles una aventura que gustosamente podrían narrar en su hogar". ${ }^{54}$ En sus formas de enunciación y en los juicios puestos en escena sobre lo representado, este texto condensa ciertas constantes que se reiteran a lo largo de todo el libro. Por una parte, entonces, tal como lo sugiere la narración de los hechos que viven los personajes, ese territorio es el lugar propicio y el que permite "explotar la emoción" de una aventura; una zona que genera tramas insólitas y es terreno adecuado para crear una literatura donde la acción - lo que privilegia Arlt en su intervención ensayística sobre la novela - sea el componente fundamental. Por otra parte, los espacios también activan otras valoraciones y sentidos:

53 Véase "El mercader oriental y las mil y una noches", en Arlt, Roberto. Aguafuertes españolas, Buenos Aires, Talleres Gráficos Argentinos L.J. Rosso, 1936. Allí, además, Arlt agrega, sobre Las mil y una noches: "En esta inactividad voluntaria, la imaginación del cuentista árabe se ha desarrollado escogiendo la línea de menor resistencia, es decir, la de la fantasía, a su antojo y capricho [y por ejemplo] se deleita imaginando que puede encontrarse en presencia de las riquezas más fabulosas, mediante el único, sencillísimo, cómodo y simple trabajo de pronunciar dos palabras: "Sésamo, ábrete" (pp. 107-110).

${ }^{54}$ La historia apócrifa del secuestro que pone en escena el relato, también acerca a los viajeros turistas protagonistas del cuento una experiencia cercana a la de muchos libros de viajes sobre África y también sobre España, donde se esperan, entre otras cosas, historias de aventuras y encuentros con bandidos. Esto aparece claramente, por ejemplo, en el libro de Théophile Gautier sobre su viaje a España y en los viajes de Sarmiento, quien, por lo demás, cuestiona esta tradición. Véase: Gautier, Théophile. Viaje por España, Madrid, Espasa calpe, 1934; y Sarmiento, Domingo Faustino. Viajes por Europa, áfrica y América, Madrid, Archivos, 1993. 
...ese rincón, a pesar de su extraordinaria suciedad, con su arco lobulado y un chorrito de agua escapando de la fuente bajo el farolón morisco, tenía tal fuerza poética, que muchas veces Arsenia y yo nos preguntábamos si al otro lado del arco tapiado no se encontraría el paraíso de Mahoma.

Y digo que teníamos tal impresión, porque Arsenia Spoil, estudiante de arquitectura, también estaba de acuerdo en que la belleza de aquel rincón estaba determinada por el farolón de bronce. [...]

...Fez nos entusiasmaba porque en cada callejuela de la milenaria ciudad africana encontrábamos ardientes motivos de ensueño. ${ }^{55}$

Así, el ámbito oriental, tal como lo construye este texto, es el lugar de la fuerza poética, de la belleza sutil, la zona de lo imaginario, del ensueño, del misterio y del placer; pero además, y si tenemos en cuenta lo que sucede en el relato unas líneas más adelante, cuando el niño ofrece a los dos viajeros ir a "la Casa de la Gran Serpiente" que devora todos los días un cabrito, el espacio exótico posee una potencialidad tal que suscita la aparición de un tipo de acontecimiento imposible de explicar, o que se escapa de las leyes del mundo familiar. Los personajes, aunque dudan sobre la realidad de la propuesta, asumen un pacto de creencia ante lo inverosímil, deciden aceptar otras reglas de funcionamiento del mundo y atendiendo a su inclinación por "las ideas románticas", se dejan llevar. Lo insólito y lo que nunca se hacía presente en otros lados, puede ocurrir en esos escenarios. Además, varios cuentos anuncian que van a relatar las "aventuras más extraordinarias". De modo que las leyes del territorio exótico y de la zona ajena y oriental, diferentes de las que en el imaginario construyen lo cercano, resultan las condiciones de posibilidad para la manifestación de lo maravilloso y lo sobrenatural y llegan a ser el ámbito que la literatura y la poética del escritor asignan para el advenimiento de lo fantástico. El suceso extraordinario que tanto esperan los personajes arltianos tiene su lugar en un mundo alejado, en el sitio donde, como en varias manifestaciones del exotismo, ${ }^{56}$ se proyectan los deseos e ideales que se contraponen a la realidad.

Es en este sentido, entonces, que "Los bandidos de Uad-Djuari" y otros textos de El criador de gorilas se alejan de lo que puede considerarse fantástico en términos

\footnotetext{
${ }^{55}$ Arlt, Roberto. "Los bandidos de Uad-Djuari”, en Cuentos completos, Op. Cit., p. 422. El subrayado es nuestro.

${ }^{56}$ Todorov, Tvetan. "Lo exótico", en Nosotros y los otros, México, Siglo XXI, 1991.
} 
estrictos $^{57}$ y constituyen un fantástico-maravilloso o un tipo de relatos que por introducir cierta forma de exotismo se aproximan más resueltamente a lo maravilloso. Porque, en efecto, como dice Rosemary Jackson "el mundo que lo fantástico representa es de una clase diferente del universo que imagina lo maravilloso". "El movimiento hacia un ámbito maravilloso transporta al lector o al espectador a un mundo alternativo", un "cosmos secundario" que es "relativamente autónomo y tiene una relación tangencial con lo 'real'": sus valores sólo se cuestionan en forma alegórica o retrospectiva; en el caso de lo fantástico, en cambio, es central ese cuestionamiento de lo 'real', porque "lo fantástico es un modo de escritura que introduce un diálogo con lo `real’ e incorpora ese diálogo como parte de su estructura esencial". ${ }^{58} \mathrm{O}$ como explica más adelante Jackson retomando las descripciones de S. Lewin en De otros mundos: hay un contraste marcado entre "visitar regiones extrañas en busca de belleza, asombro o terror, que no se pueden hallar en el mundo real" y "la irrupción más transgresiva del fantástico moderno en los escritos seculares que presentan la extrañeza y la otredad en este mundo". 59

Ciertamente, algunos relatos expresan puntualmente esa interconexión entre exotismo, fantástico y maravilloso, que hace que un espacio con esas características genere ficciones que se alejan de los modos de representación realistas. Así, en

\footnotetext{
${ }^{57}$ Rosemary Jakson prefiere considerar el fantasy no como un género sino como un modo literario que se desarrolla entre los modos de lo maravilloso y lo mimético, tomando elementos de ambos. Los rasgos específicos de lo fantástico estarían dados, entre otras cosas y fundamentalmente, por un tipo de textos que introduce en el centro de sus preocupaciones el cuestionamiento de los órdenes de verdad y realidad y cuyos efectos perturban: "La narrativa fantástica confunde elementos de lo maravilloso y de lo mimético. Afirma que es real lo que está contando - lo cual se apoya en todas las convenciones de la ficción realista- y entonces procede a romper ese supuesto de realismo, al introducir lo que - en esos términos - es manifiestamente irreal. Arranca al lector de la aparente comodidad y seguridad del mundo conocido y cotidiano, para meterlo en algo más extraño, en un mundo cuyas improbabilidades están más cerca del ámbito normalmente asociado con lo maravilloso. El narrador no entiende [...] Esta inestabilidad narrativa constituye el centro de lo fantástico como modo". Véase: Jackson, Rosemary. Fantasy: literatura y subversión, Op. Cit., p. 32. A este respecto, también afirmaba Todorov: "Sea como fuere, no es posible excluir de un análisis de lo fantástico, lo maravilloso y lo extraño, géneros a los cuales se superpone. Pero tampoco debemos olvidar que, como lo dice Louis Vax 'el arte fantástico ideal sabe mantenerse en la indecisión'”. Todorov, Tzvetan. Introducción a la literatura fantástica Op. Cit., p. 39. Es decir, para Todorov, cuando los hechos se alejan de las leyes del mundo familiar y reciben una explicación sobrenatural, caen en el terreno de lo maravilloso, si reciben, en cambio una explicación racional, en el de lo extraño; lo fantástico se da en el momento en que no puede optarse; se duda y el texto no se resuelve por ninguna de entre esas posibilidades.

${ }^{58}$ Jackson, Rosemary. Fantasy: literatura y subversión, Op. Cit., pp. 33, 39 y 40.

${ }^{59}$ Jakson, Rosemary. Fantasy: literatura y subversión, Op. Cit., p. 58
} 
“Accidentado paseo a Moka" (1939) se trabajan las connotaciones a la vez paradisíacas e inquietantes que tiene la selva. El escenario africano, como en el texto anterior, es el que permite que una aventura extraordinaria tenga lugar, y en ese sentido, es el motor de la narración y produce una historia que se resuelve en un viaje imaginario al pasado en el que un narrador testigo recibe de boca de un personaje la evocación de una aventura que ha sucedido en un momento en el que según su visión África era África; pero también aquí se inscribe uno de esos mundos de lo maravilloso que construyen realidades alternativas. La escena del cuento es un "paisaje" que extasía y también, entre otras cosas, "un paraíso de helechos, en cuyo centro una fuente de agua hirviente dejaba escapar vapores venenosos" y "emanaciones de óxido de carbono", un sitio proclive a la aparición de "genios malignos" y una zona que se corre de la restricción de las leyes de lo natural. ${ }^{60}$ Es decir, el lugar de lo bello y placentero, pero a la vez, de lo siniestro y de lo misterioso, de lo amenazante y macabro, de lo insólito y lo que roza el orden de lo irreal. En "El cazador de orquídeas", por lo demás, la selva en su cualidad de exótica, salvaje y artificial constituye, en este mismo sentido, el ámbito que genera y del que nace el prodigio: "la flor histérica", la bella y aterciopelada orquídea negra capaz de vengarse de su profanador y trasmitirle la inexplicable enfermedad que la continúa en el tiempo — recordemos que el primo del narrador ha debido devorar la flor y las manchas de su piel reiteran las particularidades del vegetal—. Por otra parte, este carácter antinatural del paisaje oriental africano — que ya aparecía en "El traje del fantasma" aunque esta narración no se sitúe en un sitio especificado geográficamente, pero sí en un escenario exótico y alejado-, puede verse claramente también en "El cazador de orquídeas" si se tiene en cuenta la exuberancia y lo hiperbólico de los espacios físicos y de la naturaleza botánica tal como son descriptos y representados en este relato.

A su vez, en "Los hombres fieras" (1940), el espacio hace posible y produce el surgimiento del suceso inverosímil y singular. Este texto se inicia cuando un "sacerdote negro" es interrogado por el doctor Denis, "un negro americano llegado hacía poco de Harlem a la Costa de Marfil" acerca de si debe ejecutar o no a un niño antropófago. De este marco surge un relato por parte del sacerdote donde se describen las metamorfosis en bestia que sufrió otro extranjero de color incitado por un niño "salvaje" al que

\footnotetext{
${ }^{60}$ Arlt, Roberto. “Accidentado paseo a Moka”, en Cuentos completos, Op. Cit., pp. 430-431.
} 
decidió no ahorcar. Esta es una historia maravillosa que se asume como ejemplar: intenta explicar la realidad e insinúa un tiempo cíclico y una circularidad en los acontecimientos; de este modo conduce a pensar que, sobre otras posibilidades, prevalece la de que esos hechos se reiteren en el tiempo, ya que un primitivismo asociado al espacio los genera. Así le dice el sacerdote al doctor:

\begin{abstract}
-Nosotros hemos conceptuado siempre un error nombrar negros nacidos en tierras extrañas para regir los destinos del país de una manera u otra...

-Yo he sostenido siempre que el hombre de color extranjero en este país, está desvinculado del clima de la selva y de la tierra. Y cuanto menos lo espera, se encuentra enganchado por el engranaje del misterio bestial que en todos nosotros ha puesto el demonio, siempre en acecho del alma animal de estos pobrecitos salvajes. ${ }^{61}$
\end{abstract}

La selva y la tierra son las que despiertan el misterio bestial que estos hombres de alma animal tienen dormido mientras residen en otros lugares. Es por eso que el espacio exótico con su clima, sus leyes diversas y su primitivismo no sólo es el ámbito en que suceden las metamorfosis, sino también el que introduce el misterio y lo extraordinario y el que, potencialmente, es capaz de originar hechos que se escapan de lo natural, de lo humano y de lo convencionalmente aceptado para el orden de lo real.

De esta manera, al mismo tiempo que estos escenarios suscitan por momentos una apertura a otro orden, en crisis con lo conocido, habitual y familiar, en muchos casos lo verosimilizan y eclipsan e impiden que se produzca ese "efecto perturbador" que las ficciones fantásticas son capaces de generar. Efectivamente, los textos vinculan toda una serie de suposiciones, asociaciones, ficciones extrañas y hechos insólitos —es decir, hechos que en otro escenario serían fantásticos, pero que en el espacio exótico son maravillosos - a los lugares que tienen que ver con lo otro y con lo que no es familiar por estar alejado de lo propio. También, porque muchas de las narraciones introducen cierto imaginario occidental sobre África que se asimila a lo esperado por el lector: en el orden de lo culturalmente inscripto esos territorios son, entre otras cosas, los sitios apropiados en los que se ha ubicado el primitivismo y el surgimiento del acontecimiento

${ }^{61}$ Arlt, Roberto. "Los hombres fieras", en Cuentos completos, Op. Cit., p. 526. El subrayado es nuestro. 
singular, imposible, extraño y perverso. Es decir, los espacios exóticos, más que otros, son los que en la cultura occidental - y también en la tradición o los comienzos del género- aparecen como propicios para la emergencia de este tipo de eventos y por eso neutralizan el efecto que esos hechos por sí mismos son capaces de producir. Esto hace que en los relatos se ponga en escena un mecanismo de aceptación de lo extraordinario que se distancia del que introducen las narraciones fantásticas en las que se consigue un verdadero giro en las expectativas del lector, ${ }^{62}$ y se presente en muchos casos, un "fantástico-maravilloso" que linda, por lo demás, con la tradición del cuento de horror, $\mathrm{y}$, tal como lo analizamos previamente, con algunas resoluciones del modernismo en la Argentina.

En este sentido, cabe considerar nuevamente "Historia del señor Jefries y Nassin el Egipcio" (1938), que relata, como vimos, un supuesto caso de sugestión hipnótica por el que Juan Jefries, el narrador protagonista, desentierra el cadáver de una jovencita, a instancias de una orden que él atribuye a la atracción sugestiva que ha ejercido sobre su "sensibilidad" el mago Nassin. Jefries, temiendo "perderse para siempre" bajo el dominio del otro, le hace estallar la cabeza al final de la historia. El cuento presenta, junto con los elementos del imaginario modernista y decadente comentados más arriba, la construcción imaginaria de una escenografía de terror y la introducción en ella de ciertos elementos que lindan y remiten indefectiblemente a lo gótico: una de las acciones principales se desarrolla en el cementerio, el personaje desentierra un ataúd con el cadáver de una muchacha, se describen "candelabros de tres brazos", "cirios negros", al egipcio con una "estola negra", una bola de cristal, etc. Asimismo, la atracción hipnótica que ejerce el mago sobre el personaje remite al imaginario del cuento de horror, además de vincularse, como vimos, a un fenómeno común dentro del conjunto de temas de las ciencias ocultas que era central en la estética modernista y en el fantástico argentino de autores como Lugones y Quiroga. Este texto es ejemplar para mostrar, por otra parte, una zona de la cuentística de Arlt donde se mantiene cierta oscilación entre lo fantástico y lo maravilloso. Porque si bien "la extraordinaria aventura" que acontece al sujeto de la narración se desarrolla en un espacio alternativo como es Tánger, el relato no resuelve si es el resultado de una mente afiebrada, o un suceso sobrenatural $-\mathrm{y}$, en este sentido se sostendría la "incertidumbre" propia de lo

${ }^{62}$ Ver: Rabkin, Erik S.. The Fantastic in Literature, (especialmente, Chapter 1) Princenton, Princenton University Press. 1977. 
fantástico o la duda a la que se refiere Todorov-. El principio del cuento abre, además, un diálogo entre lo que ha acaecido en el espacio exótico y es motivo del relato y lo que también podría irrumpir en el mundo familiar:

No exagero si afirmo que voy a narrar una de las aventuras más extraordinarias que pueden haberle acontecido a un ser humano, y ese ser humano soy yo, Juan Jefries. [...] Historia esta que ya había olvidado si no reactivara su recuerdo una película de Boris Karoff, titulada La momia, que una noche vimos y comentamos con varios amigos.

Se entabló una discusión en torno de Boris Karloff y de la inverosimilitud del asunto del film, y a ese propósito yo recordé una terrible historia que me enganchó en Tánger a un drama oscuro y les sostuve a mis amigos que el argumento de La Momia podía ser posible, y sin más, achacándosela a otro, les conté mi aventura... ${ }^{63}$

De esta manera, después de presentar un marco de la narración donde se enuncian las leyes supuestas de lo comúnmente aceptado como "real", el cuento discute los parámetros habituales de verosimilitud, realidad y verdad y afirma que esa historia “extraordinaria" bien "podría ser posible" y verdadera, y que podría acontecer, también, en el mundo cotidiano y familiar.

"Odio desde la otra vida" relata, igual que el texto anterior, una experiencia ocultista y, como veíamos antes, el efecto fantástico se produce por la apertura de un espacio: "una entrada en el plano astral". En este caso, aunque se duda sobre la naturaleza de los sucesos acaecidos, el cuento se resuelve en la narración de una historia que, elocuentemente, se acerca a los rasgos de lo maravilloso. El "plano astral", al cual Fernando puede acceder por la práctica ocultista, para comprobar el odio que lo ata a su novia Lucía a través de sucesivas reencarnaciones, resulta una zona que oscila entre el sueño, la vigilia y lo imaginario. Es, además, un espacio donde aparece otra temporalidad, una fatalidad misteriosa gobierna el azar y la incertidumbre, y el personaje que deviene en un oriental —a diferencia de lo que ocurría en el inicio del texto-, tiene una experiencia singular y sobrenatural semejante a las historias de Las mil y una noches. Todo ello permite pensar que el pasaje a esa zona astral es casi un recurso narrativo para generar un desplazamiento a otro orden cronológico y a un

\footnotetext{
${ }^{63}$ Arlt, Roberto. "Historia del señor Jefries y Nassin el Egipcio", Op. Cit., p. 163.
} 
mundo alternativo, para relatar una aventura que tiene su desarrollo en lo exótico y maravilloso de un Oriente legendario.

\title{
Arlt, lo maravilloso y Las mil y una noches. Un caso peculiar
}

\author{
La única aventura todavía se refugia en la geografía \\ Robert \\ o Arlt
}

Un caso específicamente revelador que muestra las particularidades de la oscilación entre lo maravilloso y lo fantástico en las ficciones de Arlt, puede observarse cuando sus relatos se acercan a Las mil y una noches y reiteran algunas de sus anécdotas y rasgos de. ${ }^{65}$ Muchos de estos cuentos se proponen como orientales, incorporan las mismas modulaciones en la narración, fórmulas de cortesías, permanentes invocaciones a Alá y críticas a los "perros cristianos", ${ }^{66}$ así como retoman el fraseo de muchos de sus

${ }^{64}$ Arlt, Roberto. "No por amor visitará Mac Donald a Mad Jadfi”, en El Mundo, 5 de enero de 1940. Al margen del cable.

${ }^{65}$ Es sabido que Arlt había leído Las mil y una noches. A este respecto, su hija Mirta sostiene: "Cuando estábamos juntos nuestro quehacer se vinculaba con el juego, el trabajo y el humor: estudiábamos inglés con una vieja inglesa que llegaba en los atardeceres... [...] Leíamos sentados ante una mesa cuadrada en el dormitorio-escritorio de mi padre. Nuestro libro de lectura era Las mil y una noches y se completaba con el Appleton's New Spanish Dictionary". Arlt, Mirta. "La locura de la realidad en la ficción de Arlt", en Pellettieri, Osvaldo (Ed.). Roberto Arlt. Dramaturgia y Teatro Independiente, Buenos Aires, Galerna/Fundación Roberto Arlt, 2000, p. 14. En un testimonio oral Mirta Arlt nos refiere, además, que la edición con que estudiaban inglés en 1936 era de tapas duras con ilustraciones en color y de unas 150 páginas. Seguramente, una selección de las historias árabes aunque no una edición infantil. Agradezco a Mirta Arlt por estos datos.

${ }^{66}$ Así, por ejemplo, en "El octavo viaje de Simbad el marino", aparecen afirmaciones como las siguientes: "Durante varios meses navegamos escrupulosamente todo el ancho mar que media entre las costas del país de los perros cristianos y el de los piadosos musulmanes, hasta que llegamos al gran océano donde el misterio es infinito y el temor del creyente grande y 
títulos: "Historia del señor Jefries y Nassin el Egipcio", "Historia de Nazra, Yamil y Farid", parecerían remedar el encabezamiento de los textos de Las mil y una noches, donde prevalece, entre otras formas, la estructura "Historia de", o un equivalente, seguido del nombre propio del personaje y algún atributo, gentilicio o cualidad. ${ }^{67}$ Entre múltiples ejemplos, pueden citarse: "Historia de Harún ar-Rashid y Alí el persa", "Historia de Zobeida, la mayor de las doncellas", "Historia del visir Nureddin, de su hermano el visir Chamseddin y de Hassán Badreddin”.

Un cuento clave es, en este sentido, "El octavo viaje de Simbad el marino", ${ }^{68}$ que narra una continuación de las aventuras de Simbad, una de las historias de Las mil y una noches que, junto con la de Aladino y Alí Babá (arquetipos de la aventura, la fantasía y el delito, respectivamente) alcanzaron más celebridad y popularidad en el mundo occidental, y cuyas figuras se incorporaron a la tradición narrativa de Occidente desde el siglo XVIII, a partir de la traducción de Antoine Galland. ${ }^{69}$ Arlt narra el octavo viaje aunque, como es sabido, las aventuras de Simbad terminan en el séptimo de sus viajes -; omite la presencia de Shehrezad ${ }^{70}$ y en las primeras líneas aparece un narrador que encabeza y da el marco a la historia y que luego, como en Las mil y una noches, deja la palabra a Simbad, para retomarla al final, después de que el marino cierre su relato.

El cuento mantiene el registro de Las mil y una noches estableciendo así la posibilidad de confundirse con el texto original. Particularmente, retoma muchos de los rasgos que se reiteran en las distintas variantes de las anécdotas que involucran los

duradero"; y, más adelante: "Nuestros remeros tuvieron harto trabajo en alejarse de los islotes, cuyos surtidores de chispas, gracias a la benevolencia de Alá, no alcanzaron nuestros velámenes". Arlt, Roberto. "El octavo viaje de Simbad el marino", Op. Cit., pp. 391 y 393. En muchos cuentos se repite, insistentemente, la fórmula: "En nombre de Alá el clemente, el Misericordioso" y también el saludo "La paz en ti", como en "Halid Majid el achicharrado", "La aventura de Baba en Dimish esh Sham", y "Rahutia la bailarina". Véase: Arlt, Roberto. Cuentos completos, Op. Cit.

${ }^{67}$ Esta estructura de los títulos se reitera en las distintas ediciones y versiones de Las mil y una noches, aunque en algunas es más reiterativa que en otras.

${ }^{68}$ El cuento se publica en El Hogar el 3 de junio de 1938 y nunca se editó en libro hasta la edición de Piglia y Omar Borré de Cuentos completos.

${ }^{69}$ Véase, a este respecto. Sagarzazu, María Elvira. "Introducción”, en Las mil y una noches, Traducción selección, notas e introducción María Elvira Sagarzazu, Buenos Aires, Colihue Clásica, 2006, pp. XV y XVI. Cabe destacar que en dos notas "Al margen del cable" al retoma a su vez estos personajes de Las mil y una noches. Se trata de "El novio y los cuarenta ladrones" (en El Mundo, 2 de octubre de 1937. Tiempos Presentes) y "Simbad el marino pero al revés" (en El Mundo, 24 de noviembre de 1937. Al margen del cable).

${ }^{70}$ Transcribimos así el nombre de Shehrezad atendiendo al hecho que señala Sagarzazu en su introducción a Las mil y una noches, de que ésta grafía acerca más el nombre a la pronunciación del árabe. Sagarzazu, María Elvira. "Introducción”, Op. Cit. 
viajes de Simbad. Porque, efectivamente, aunque pueden señalarse diferencias tangenciales entre las diversas ediciones y versiones de esa historia, ${ }^{71}$ hay algunas constantes, características y rasgos que pueden mencionarse en los distintos textos, muchos de los cuales también se encuentran en el resto de los cuentos del libro árabe. Uno de los caracteres que definen la estructura de la saga de "Simbad el marino", que se mantiene de versión en versión y que contribuye su configuración peculiar, es el modo en que se organizan las acciones y la forma en que con ellas se involucran los personajes. Se trata, la mayoría de las veces, de una sucesión de hechos con escaso encadenamiento causal, donde la fatalidad, el azar, la magia o "la voluntad de Alá" son los móviles que determinan la aparición de los conflictos o su solución. En este caso puntual un esquema simple —viaje marítimo, catástrofe, naufragio, aventura y conflictos, solución de los conflictos y regreso con riquezas - encadena los hechos que se repiten en cada caso y el acento está puesto en el modo en que el marino escapa a diferentas incidentes en distintos escenarios, o, dicho de otro modo, en las diversas experiencias del sujeto referidas a un espacio ajeno a lo real, maravilloso o ficcional. Las situaciones se modifican sin esfuerzo y hay cambios de suerte repentinos que sólo se explican por esas fuerzas como el azar, Alá, la magia, la casualidad o la fatalidad que, muchas veces, es la que gobierna los hechos; por ello hay poca responsabilidad e injerencia de los personajes en el curso de la acción. En este sentido, Todorov refiriéndose a Las mil y una noches, sostiene que en el texto no existe el desarrollo psicológico del héroe, que cada uno pasa por su historia "ya hecho", sin cambiar de principio a fin. ${ }^{72}$ De manera que, añade Sagarzazu, siguiendo a Todorov, si el personaje no determina necesariamente el curso de la acción, se crean arquetipos, personajes despersonalizados y la personalidad de los héroes de Las mil y una noches surge por un

\footnotetext{
${ }^{71}$ Para este punto del trabajo y por la diversidad que ofrecen las distintas ediciones de Las mil y una noches, y la historia de Simbad el marino en particular y sobre todo el séptimo de sus viajes, (que, como demuestra Richard Burton al incluir en su traducción dos versiones de ese viaje, es el que presenta mayor divergencia), hemos consultado las siguientes ediciones: Les Mille et Une Nuits. Contes Arabes. Traduits par Antoine Galland, édition électronique à partir du libre Les Mille et Une Nuits. Contes arabes traduits par Galland, Édition de Gaston Picard, Paris, Éditions Garnier fréres. Site web: http://clasiques.uqac.ca/ ; The Book of The Thousand Nights and a Night. A Plain and Literal Translation of The Arabian Nights Entertaiments. Translated and Annotated by Richard F Burton. Web edition: http://etext.library.adelaide.edu.ar; Las mil y una noches, Tradución directa literal del árabe por el Dr. J. C Mardrus, Versión en español de Vicente Blasco Ibáñez, Buenos Aires, MMVI; y Las mil y una noches, Traducción selección, notas e introducción María Elvira Sagarzazu, Buenos Aires, Colihue Clásica, 2006.

${ }^{72}$ Todorov, Tzvetan. Gramática del Decamerón, Madrid, Ediciones B, 1973, pp. 165187.
} 
mecanismo opuesto: surge de la acción. ${ }^{73}$ Otras constantes que se retoman en las distintas versiones de los viajes de Simbad son la aparición de animales monstruosos, la apelación a la hipérbole y al lujo como uno de los modos de la construcción de lo otro, escenas de reconocimiento, el final feliz, la fortuna y la riqueza como corolarios de cada viaje, el muestreo de distintos lugares, y la presencia de Alá. ${ }^{74}$

Si nos atenemos a la cercanía entre el cuento de Arlt y Las mil y una noches, lo cierto es que el relato acentúa los vínculos entre este octavo viaje y los demás, y numerosas afirmaciones del texto buscan esos enlaces. Espacio de la hipérbole como en las ficciones sobre los siete viajes de Simbad que aparecen en el libro árabe, la versión de Arlt introduce "monstruos marinos", "gigantescas ballenas", lujo y pedrería al final de la travesía, prodigios como una isla de papel y desenlaces inesperados. El desarrollo de la trama, por lo demás, sigue la misma secuencia — viaje marítimo, catástrofe, naufragio, aventura y conflictos, solución de los conflictos y regreso con riquezas- De esta manera, el cuento va de peripecia en peripecia, con una temporalidad acelerada, y si bien Arlt no introduce la magia como resolución de los problemas a los que se enfrenta Simbad — que primero es atrapado por unos navegantes, luego llevado a una isla donde está a punto de ser comido por un gobernante antropófago-, también el azar y la fatalidad, como en Las mil y una noches, operan sobre el destino de los personajes y determinan la sucesión de las acciones. Por ejemplo, en el climax del cuento, un terremoto repentino (verdadero deux ex machina) salva a Simbad de la isla donde estaban a punto de comerlo vivo y vuelve rico del viaje. Así, la poca injerencia del héroe en su accionar, mero nudo conductor de las acciones, como sostenía Todorov a propósito de las "noches árabes", se repite en el octavo viaje de Arlt y el texto no construye tampoco en este caso una subjetividad activa. De esto deriva en el relato, - pero también en otros del fantástico orientalista de Arlt y en sus ficciones policiales y de espionaje, como veremos- un tipo de personaje nuevo en su literatura, muy diferente al de sus novelas, apoyados en su psicología.

Aventura de viajeros, pues viajero por antonomasia es Simbad, con este cuento se actualiza la presencia del viaje en la obra de Arlt y la historia del marino le permite al

\footnotetext{
${ }^{73}$ Sagarzazu, María Elvira. "Introducción”, Op. Cit., p.XXVII.

${ }^{74}$ En la edición de Galland las invocaciones a Alá aparecen hechas a Dios. Se dice, por ejemplo en su texto: "Je me resigneu a la volonté de Dieu". En Burton, en cambio, reaparece Alá y las invocaciones se suceden en cada párrafo, como por ejemplo: "By Allah!", "There is no Majesty and there is no Might save in Allah, the Glorious, the Great", "Praised be Allah!".
} 
escritor narrar hazañas en el mar y en mundos maravillosos; el relato propone, de esta manera, una nueva experiencia espacial que permite conjurar mundos perdidos y lugares lejanos, sitios que garantizan y demarcan cierto alejamiento de la realidad. Efectivamente, si el libro árabe funcionó como un muestreo del mundo para los árabes ${ }^{75}$ donde se narraban historias curiosas y hechos prodigiosos, la versión de Arlt continúa en la misma búsqueda de lo exótico a partir de lo cual el entramado de Las mil y una noches surge como un mapa de excentricidades, estereotipado pero de todos modos curioso, para el lector occidental. Ciertamente, la sola presencia de Simbad invoca lo exótico como tópico y, como en Las mil y una noches y en los cuentos anteriormente analizados de Arlt, el relato garantiza una brecha temporoespacial con el orden de lo real donde se multiplica el límite de los posibles y aventuras y prodigios sorprendentes se suceden. Se instala, así, un acercamiento a lo maravilloso. Lo narrable resulta ser, entonces, ya no una historia capaz de vincularse de alguna manera con el presente crudo de la sociedad, como en las novelas de Arlt y sus primeras ficciones y crónicas, sino los avatares, las peripecias, y las aventuras extraordinarias que se suceden en la vida de un personaje en un tiempo recortado de la cronología y de la historia (un recorte en el entramado de lo real que orienta lo narrado a una zona cercana a lo maravilloso). Lo que es evidente finalmente, en el cuento de Simbad es el modo en que lo fantásticomaravilloso de Arlt se entreteje de una forma peculiar, como en las ficciones de $E l$ criador de gorilas, con el género aventuras.

Por otro lado, en la historia marco una voz autorizada presenta el espacio exótico que rodea la escena en que el personaje se dispone a narrar su historia, ${ }^{76} \mathrm{y}$ describe

\footnotetext{
${ }^{75}$ Véase el "Prólogo" a la edición de Colihue. En este texto, dice Sagarzazu: "En tiempos en que los viajes y la instrucción quedaban fuera del alcance de la gente común, los narradores de oficio constituyeron una perdurable institución del mundo arabizado", y, también, "...no todo es fantástico en las Noches, y para incontados orientales estos cuentos fueron una fuente de información, el único contacto con el mundo real que había más allá de su aldea; sólo a través de estas historias recibirían alguna noticia sobre asuntos ocurridos fuera de su entorno y escucharían hablar de comarcas que jamás conocerían por otro medio. Todo esto, condimentado con reflexiones, picardía, sordidez y sensualidad, hizo de esta colección un compendio informal y entrañable de la vida en una ancha franja del globo". Op. Cit.

${ }^{76}$ Así aparece constituida la escena en el cuento: "Estaba Simbad el Marino sentado a la cabecera de la mesa que, a muy poca altura del suelo, permitía a sus invitados comer sentados en cuclillas sobre las preciosas esteras que cubrían el mosaico. Venerable barba le bajaba hasta el ombligo y un turbante de razonable grandor rodeaba su cabeza. Daba testimonio de cuán grande señor era él y qué innumerables sus riquezas, un diamante prendido en la seda sobre su misma frente". Subrayamos las marcas de lo oriental y lo exótico. Arlt, Roberto. "El octavo viaje de Simbad el marino", Op. Cit., p. 390.
} 
cómo "los comensales, mirando el devastado rostro de Simbad, aguardaban a que el marino diera comienzo a otro de sus relatos, pues ninguno se consolaba que [sic] sus aventuras terminaran en aquel séptimo y famosísimo viaje, en el cual Simbad se dedicó a la caza de elefantes...". En una postura irreverente que se acerca al gesto borgeano de asumir un derecho propio sobre cualquier tradición, incluida la oriental, el narrador añade:

Comprendiéndolo así [que ninguno se consolaba en que sus aventuras terminaran en el séptimo viaje], el marino, después de recibir de un mancebillo que estaba de pie a sus espaldas un frasco de agua de rosas, y de salpicarse con ella la barba y también la barba de sus invitados, comenzó el relato de su octavo viaje, que no sé por qué razones ninguno de sus cronologistas ha insertado en "Las mil y una noches". Y lo hizo con estas mismas palabras:...

Y hacia el final del cuento sostiene:

Y así terminó la historia del octavo viaje de Simbad, que no es tampoco el último sino el anteúltimo. ${ }^{77}$

De esta manera, el cuento acerca el octavo viaje de Arlt, un episodio imaginario en la saga de Simbad, al registro de lo real cuando asegura que no sabe por qué los cronologistas no introdujeron esta anécdota en el texto árabe, y también equipara en esta afirmación, la historia inventada (y falsa), escrita por Arlt, a las ficciones sobre los viajes del marino efectivamente contenidos en el libro oriental. Arlt afirma, de esta manera, su derecho a reescribir Las mil y una noches y su reescritura del texto árabe se aproxima, a la postura borgeana de la literatura que propone un juego con la versión -o a la idea del cuento como derivación de una ficción previa y continuación de otro texto- y con los límites entre lo apócrifo y lo genuino, presente en Borges desde Historia Universal de la infamia. ${ }^{78}$

\footnotetext{
77 Arlt, Roberto. "El octavo viaje de Simbad el marino", Op. Cit., pp. 390 y 397 respectivamente.

${ }^{78}$ Para estas cuestiones véanse, entre otros, los trabajos de Beatriz Sarlo, Sylvia Molloy, Annick Louis e Isabel Stratta. (Sarlo Beatriz. Borges, un escritor en las orillas, Buenos Aires, Ariel, 1993, y de la misma autora: "Una poética de la ficción", Op. Cit.; Molloy, Sylvia. Las letras de Borges y otros ensayos, Rosario, Beatriz Viterbo Editora, 2000; Louis, Annick. Jorge Luis Borges: oeuvre et manoeuvre, Paris, L'harmattan, 1997; y Stratta, Isabel. "Documentos para una poética del relato", Op. Cit.
} 
En este sentido, cabe destacar que el interés Arlt por Las mil y una noches concuerda, en un punto, con el que despiertan en Borges las "noches árabes" quien, como se sabe escribió un ensayo al respecto en Historia de la eternidad, dos notas en la Revista Multicolor de los Sábados y artículos afines en otras publicaciones de la época como El Hogar. ${ }^{79} \mathrm{Y}$ si bien su esmerado acercamiento, su erudición y el tono de su reflexión están lejos de la reescritura arltiana, debe al menos observarse cierta coincidencia ente los dos escritores (en la lectura y apropiación del texto árabe); quizás, también una marca y tendencia de época en esta atención por Las mil y una noches, en el gusto por lo oriental y por las historias ajenas (y a su vez por lo variado y lo diverso), tal como se inscriben en el último Arlt, en sus narraciones africanas y textos "Al margen del cable", ${ }^{80}$ y aparecen claramente en Borges también en las ficciones de Historia universal de la infamia, publicadas por primera vez en el suplemento cultural del diario Crítica dirigido por el propio Borges y Ulyses Petit de Murat desde el 12 de agosto de 1933 al 6 de octubre de 1934, revista en la que también otros escritores abordaron temas orientales. $^{81}$

El cruce entre maravilloso y fantástico o el exotismo oriental constituyen sin

\footnotetext{
${ }^{79}$ Como es sabido, en 1936 aparece en Historia de la eternidad, "Los traductores de Las mil y una noches". (Borges, Jorge Luis. Historia de la eternidad, Emecé, Buenos Aires, 1989). Algunos de los textos de Borges sobre Las mil y una noches que aparecen en el período, entre otros que pueden mencionarse son: Borges, Jorge Luis. "El puntual Mardrus", en Crítica. Revista Multicolor de los Sábados, 3 de febrero de 1934, versión anterior a "El doctor Mardrus" que se publica en Historia de la eternidad; Borges, Jorge Luis. "Las 1001 noches", Crítica. Revista Multicolor de los Sábados, 3 de febrero de 1934; Borges, Jorge Luis. "The Arabian Knight, de Seton Dearden", en El Hogar, 8 de enero de 1937. Reproducido en Borges en El Hogar. 1935-1958, Buenos Aires, Emecé Editores, 2000; "Borges, Jorge Luis. "Una leyenda arábiga", en El Hogar, 16 de junio de 1939. Recopilado en: Textos cautivos. Obras Completas, Buenos Aires, Emecé, 1996. Entre los textos posteriores de Borges sobre Las mil y una noches, pueden mencionarse, entre otros: Borges, Jorge Luis. "Cansinos y las mil y una noches". Textos recobrados, 1976-1986 y también los prólogos a las traducciones al español de las versiones de Las mil y una noches de Richard Burton y Antoine Galland.

${ }^{80}$ Volveremos con más profundidad a estas cuestiones en los capítulos 4 y 5 .

${ }^{81}$ Para citar algunos ejemplos, pueden destacarse, entre otros artículos que se publican: "Rebelión de los leprosos", de Ulyses Petit de Murat (en Crítica. Revista Multicolor de los sábados, $\mathrm{n}^{\circ}$ 1, 12 de agosto de 1933, p.2), "Antiguas penas", de A.H. (en Crítica. Revista Multicolor de los sábados, n 5, 9 de septiembre de 1933, p. 5), "Relatos chinos" (Anónimo, en Crítica. Revista Multicolor de los sábados, n 10, 14 de octubre de 1933, p. 8), "El sabio califa", de Alberto Nin Frías (en Crítica. Revista Multicolor de los sábados, $\mathrm{n}^{\circ} 12,28 \mathrm{de}$ octubre de 1933, p. 6), "Los escalones ensangrentados" de Remy Saint-Maurice (en Crítica. Revista Multicolor de los sábados, $\mathrm{n}^{\circ}$ 13, 4 de noviembre de 1933, p. 2), "La leyenda de los duendes descabezados", de Lafcadio Eran (en Crítica. Revista Multicolor de los sábados, $\mathrm{n}^{\circ} 18$, 9 de diciembre de 1933, p. 6).
} 
duda zonas de la literatura de Arlt que cuestionan de modo más acabado sus reglas previas. Así, cuando estos cuentos rescriben algunos de los tópicos provenientes del modernismo y del imaginario decadente - ya incorporados hasta la saturación en "Jehová", ya discutidos con cierta distancia en "Las ciencias ocultas en la ciudad de Buenos Aires" e introducidos aisladamente en la literatura "del cross" — se produce un cambio en la trama narrativa que las tendencias del modernismo, con los sentidos que activan, orientan hacia lo fantástico, aunque también producen una tensión por la convivencia de estos elementos con rasgos anteriores de la poética del escritor. Se trata, sin duda, de un fantástico anómalo, ya que no sólo Arlt retoma anacrónicamente una estética con rasgos evidentes en la literatura argentina anterior y marcas que también aparecen, por ejemplo, en autores como Lugones, sino que además lo fantástico se acerca a lo maravilloso por su apelación a lo exótico del espacio oriental africano. Exotismo y fantástico, maravilloso modernista, viajes aventureros y prodigiosos, estos cuentos finales de Arlt a la vez que modifican de modo claro su proyecto creador, se vinculan, en forma compleja y problemática con los contextos de su emergencia y constituyen un espacio clave para pensar su textualidad en el período. 


\section{4}

\section{Ficción y crónica periodística}

Una figura en las letras argentinas cuya trayectoria está ligada desde los comienzos de su producción a su labor como periodista, Roberto Arlt desarrolló una parte muy importante de su obra y consiguió visibilidad y reconocimiento como escritor y entre el público lector, por su participación en diarios y revistas de la época. Como es bien sabido, en 1928 Arlt se incorpora al staff de redacción de El Mundo, un matutino renovador, de formato tabloid y destinado a la clase media, donde publica sus conocidas “aguafuertes porteñas". ${ }^{\mathrm{S}} \mathrm{Su}$ trabajo en El Mundo continúa hasta el momento de su muerte, no obstante lo cual su columna periodística va variando a lo largo de los años, como cuando Arlt publica textos sobre cine, cuando viaja a distintos puntos del país (el litoral argentino, la Patagonia, Santiago del Estero), de América latina (Uruguay, Chile, Brasil), de España y del norte de África, desde donde envía sus impresiones como corresponsal del diario.

Interesa considerar, en este punto, sus crónicas publicadas desde 1937 hasta 1942, un momento en el que ya no aparecen en El Mundo sus aguafuertes porteñas. Efectivamente, cuando Arlt vuelve en 1936 del viaje por España y Marruecos, su columna cambia de título y desde el 12 de marzo de 1937 empieza a denominarse “Tiempos presentes” y, a partir del 8 de octubre de ese mismo año, “Al margen del cable". 2 Una miscelánea que incluye curiosidades para los lectores del diario, excentricidades "novelescas" extraídas de los cables de noticias, breves relatos sobre el

\footnotetext{
${ }^{1}$ Véase para estas cuestiones, Saítta Sylvia. El escritor en el bosque de ladrillos. Una biografía de Roberto Arlt, Buenos Aires, Sudamericana, 2000, y los prólogos a sus ediciones de aguafuertes. También puede consultarse, entre otros, Scroggins, Daniel. Las aguafuertes porteñas de Roberto Arlt, Buenos Aires, Ediciones culturales argentinas, Secretaría de cultura de la Nación, 1981; y Varela, Fabina, Inés. "Aguafuertes porteñas: Tradición y traición de un género", en Revista de Literaturas Modernas, Universidad Nacional de Cuyo, Facultad de Filosofía y Letras, Instituto de Literaturas Modernas, n 32, Mendoza, 2002.
} 
mundo del hampa y de la criminalidad, despliegue de la noticia perdida y la nota marginal, interpretaciones (y breves ensayos, ocasionalmente) sobre los sucesos de la guerra y el clima bélico, narraciones desde el punto de vista de los protagonistas de los hechos que aparecen en la prensa, biografías de singulares personajes, estos textos se originan en la información internacional que Arlt lee en diversos periódicos de la época (The Times, United Press y también El Mundo, o publicaciones como Prensa Libre de San José de Costa Rica, entre otras y muchas fuentes que menciona) y en los sucesos más o menos relevantes de política u otros asuntos provenientes del exterior que llegaban a la dirección del diario en los cables de noticias. Las notas resultan, por lo demás, un nuevo género en su periodismo y difieren, ya desde el título, de las aguafuertes anteriores.

Este capítulo estudia los modos en que se constituyen estas crónicas, y analiza de qué manera, con qué procedimientos y recortes incorporan el registro del presente. Asimismo, considera cómo, a partir de la ficción que generan los cables y las noticias, Arlt reflexiona sobre la guerra inminente, sus implicancias, agentes y consecuencias, y los modos en que estos artículos se transmutan, reiteradamente, en textos de aventuras y relatos ligados al policial, a la trama de espionaje y a la criminalidad, es decir, a formas narrativas vinculadas con el tipo de cuentos que Arlt estaba publicando en ese momento, algunos de ellos recopilados en El criador de gorilas y otros editados póstumamente en El crimen casi perfecto. ${ }^{3}$ Por otra parte, en este capítulo se considera el modo en que, a partir de la noticia, Arlt despliega en muchos casos breves piezas teatrales con personajes, diálogo y notación dramática y se examina, por último, cómo se inscribe aquí un cruce particular entre ficción y crónica, periodismo y literatura.

\footnotetext{
${ }^{2}$ Cabe destacar que la sección "Al margen del cable" ya se había inaugurado en el diario $E l$ Mundo en un momento previo a la intervención de Arlt, y que, por ejemplo, el 23 de agosto de 1937 aparece una nota de José P. Sadi, "Barcos hundidos por submarinos", bajo el título "Al margen del cable". Las que Arlt publica en esta sección y en "Tiempos presentes" son más de 250 crónicas (que se han considerado en su totalidad para esta investigación), y más de 170 están inéditas en libro en la actualidad. En la bibliografía del final se introduce la lista completa de esos textos.

${ }^{3}$ Arlt, Roberto. El crimen casi perfecto, Selección y noticia de Omar Borré, Buenos Aires, Clarín/Aguilar, 1994.
} 


\section{Crónica arltiana y periodismo}

Los cablegramas cruzan el éter silenciosamente. A veces las informaciones ocupan una
línea dos líneas, tres líneas. Y quién da importancia a tres líneas? Pero. 4 línea, dos líneas, tres líneas. ¿Y quién da importancia a tres líneas? Pero... ${ }^{4}$

Roberto Arlt

Las notas de Arlt en "Tiempos presentes" y "Al margen del cable" surgen a partir de los cables de noticias y dan cabida, casi exclusivamente, a la información internacional. ${ }^{5}$ En la reelaboración y reescritura de la noticia periodística, los textos de Arlt muestran el enfrentamiento entre distintas formas de referir los sucesos y diferentes modos de enfrentarse e interpretar los hechos que se inscriben en la prensa del momento. ${ }^{6}$ Esto sucede, entre otras cosas, como también analiza Sylvia Saítta, ${ }^{7}$ cuando Arlt rescata lo perdido de las páginas de los diarios mediante el despliegue y, en muchos casos la literaturización de la noticia marginal. En efecto, uno de los rasgos más llamativos en la lectura de estas crónicas es su carácter de aleatoriedad, de reescritura de la información anecdótica y secundaria (la que incluso, a veces, ni siquiera se desarrolla

\footnotetext{
${ }^{4}$ Arlt, Roberto. "El subsuelo del diablo", en El Mundo, 15 de abril de 1937. Tiempos Presentes.

${ }^{5}$ Hay algunas crónicas sobre el ámbito local, pero lo evidente es que, como dice Sylvia Saítta, cuando Arlt vuelve del viaje a España "...un año transcurrido afuera del país, el contacto con otra cultura y otra realidad repercuten en su labor cotidiana [...] Todo pareciera suceder en otro lado y el anhelo de ser testigo, ya no de su ciudad, sino del mundo que parece derrumbarse irremediablemente" lo lleva a sus notas de "Tiempos Presentes" y "Al margen del cable". (Véase, a este respecto: Saítta, Sylvia. "La última pieza que faltaba del mecanismo", en El escritor en el bosque de ladrillos, Op. Cit., p. 185). Los textos sobre el ámbito local son los referidos a la sequía en Santiago del Estero, titulados "El infierno santiagueño", del 7 al 17 de diciembre de 1937; tres artículos (del 9,12 y 22 de agosto) sobre "El problema hospitalario" y las crónicas dedicadas a "Los problemas del Delta" del 2 al 10 de diciembre de 1941. Véase, asimismo, para una consideración de las crónicas "Al margen del cable": Corral, Rose. "Introducción", en Arlt, Roberto. Al margen del cable. Crónicas publicadas en El Nacional, México, 1937, 1941, Recopilación, introducción y notas de Rose Corral, Buenos Aires, Losada, 2001.

${ }^{6}$ En las primeras crónicas es reiterada la información de diarios y revistas en inglés y su interés está inclinado hacia los sucesos acaecidos en el ámbito estadounidense. Luego, el impacto de las noticias desvía su interés hacia Europa y los grandes y pequeños hechos que se vinculan, de alguna manera, con el clima previo a "la catástrofe" y el contexto bélico. Sylvia Saítta menciona en su biografía que Arlt estaba estudiando inglés tres veces por semana y esto parece influir en la elección de las noticias y en la cantidad de términos en esa lengua que desplazan a los del lunfardo. Saítta, Sylvia. El escritor en el bosque de ladrillos, Op. Cit.

${ }^{7}$ Saítta, Sylvia. "La última pieza que faltaba al mecanismo", Op. Cit., pp. 185-205.
} 
en $E l M u n d o$ ) y de los hechos curiosos, particularidad que liga en un punto estos textos arltianos a la tradición de la chronique periodística francesa de mediados del siglo XIX, especialmente el fait divers de Le Figaro, cuyos precursores habrían sido en América latina Manuel Gutiérrez Nájera y José Martí. ${ }^{8}$ Ciertamente, parte del objetivo de estas notas es explayarse sobre lo presumiblemente trivial, restituir y reponer para el público de El Mundo lo que en apariencia resulta irrelevante en las publicaciones de la época, desplegar y dar espacio a la información fortuita y circunstancial. De esta manera, además de las crónicas que discuten, ensayan, polemizan y narran a partir de cuestiones referidas a la Segunda Guerra o a su inminente estallido, es decir a partir de los grandes asuntos y tópicos de la política internacional, paralelamente con éstas, se encuentran artículos sobre los más variados temas. Porque, como puede leerse en uno de estos textos, "El Polo Norte no está más en el Polo Norte", 9 Arlt decide rescatar lo que se supone marginal del vértigo que en el periodismo significa "una noticia más", "cuatro líneas" y "una foto", vértigo que fomenta y acompaña, para él, "el horror de la presente civilización"; de ese modo se distancia de la perspectiva de la prensa de ese entonces:

¡Qué lejos estamos hoy de aquellos tiempos de Peary y Cook cuyo simultáneo descubrimiento del Polo Norte determinó querellas en los periódicos, de violencia tal, como pocos acontecimientos mundiales lo alcanzaron en la misma época. [...]

HOY

"Ayer, a las 11 y 35 de la mañana, después de volar sobre el Polo Norte, aterrizó a veinte kilómetros de allí el aviador soviético Vodopyanoff. Una expedición científica" [...] Bien. El conjunto de la noticia no ocupa más de diez centímetros en las columnas de cualquier periódico. [...]Una noticia más. Nada más. Una noticia más. [...] Hoy...un telegrama. Cuatro líneas. Cuatro nombres. Una fecha. "Stop". Han cambiado los tiempos. ¡Vaya si han cambiado! [...]

\footnotetext{
${ }^{8}$ La cronique, como el fait divers de Le Figaro de París, era el lugar de los hechos curiosos y de las variedades, de los asuntos sin la relevancia suficiente como para aparecer en las secciones "serias" del periódico, y destinada más al entretenimiento que a la búsqueda de información. Como retoma Susana Rotker, a propósito de la crónica latinoamericana, esta especie de "arqueología del presente" que se "dedica a los hechos menudos", tiene a Gutiérrez Nájera y a Martí como "sus precursores en América latina", quienes "no se conformaron con la escritura como mero entretenimiento sino que le imprimieron al espacio de la crónica un vuelco literario". Véase: Rotker, Susana. La invención de la crónica, Buenos Aires, Ediciones Letra Buena, 1992, p. 106. Puede consultarse, también, Histoire de la presse française, Paris, Presses Universitaires de France, 1969.

${ }^{9}$ Arlt, Roberto. "El Polo Norte no está más en el Polo Norte", en El Mundo, 5 de junio de 1937. Tiempos Presentes.
} 
Una noticia. Tres líneas. Una foto. Un nombre...y a otra cosa. Sí, a otra cosa

"Esa otra cosa" a pesar de su aparente ingenuidad, señala con precisión terrorífica el grado de nuestra progresiva insensibilización. No reaccionamos ante nada. 100.000 chinos se mueren de hambre en cualquier provincia. ¡Al diablo con la provincia de nombre impronunciable! (Lo que interesa es un nombre simplificado, cómodo, rápido, para escribir a máquina. Que no le provoque a uno líos con el corrector y líos con el director afanoso de la precisión). [...]

Si nosotros pudiéramos extraer con una pinza, de su sepultura, a un hombre del siglo pasado y situarlo en el medio de este vertiginoso remolino, donde nuestros ojos permanecen impasibles y nuestros oídos acondicionados a lo que nos conviene escuchar, al hombre así transportado a este caos, sentiría que el cerebro se le rajaba como una sandía frente a un horno. ${ }^{10}$

Mujeres que ganan la lotería, aventuras en el Polo, "ciudades debajo del mar", reminiscencias de La Atlántida, curiosidades sobre astrólogos y "adivinas embaucadoras", anécdotas como la del truco de la mujer cortada en pedazos y del hombre que escribió 72.431 cartas de amor, historias de aventuras, de buscadores de tesoros, exploradores, espías y contrabandistas, intrigas sobre el mundo del hampa y de la criminalidad, (como la serie de notas sobre Al Capone), ficciones sobre extraños y desconocidos personajes (a veces, infames, que recuerdan las de Borges), ${ }^{11}$ referencias sobre sitios paradisíacos, "sin ruido de automóviles", en muchos casos se trata de narrar (y mostrar) lo marginal, como en sus aguafuertes de los veinte, pero también lo exótico y lo ajeno. Si, como dice Saítta, “...uno de los movimientos de estas notas es precisamente otorgar densidad a cables de noticias despojados de todo tipo de dramaticidad" mediante

\footnotetext{
${ }^{10}$ Arlt, Roberto. "El Polo Norte no está más en el Polo Norte", Op. Cit.. Un caso curioso en este sentido, donde Arlt insiste nuevamente en el despliegue de la noticia marginal es "Regala diez millones de dólares y oculta su nombre" (en El Mundo, 28 de julio de 1937. Tiempos Presentes. Reproducida en: Arlt, Roberto. Al margen del cable. Crónicas publicadas en El Nacional, México, 1937, 1941, Recopilación, introducción y notas de Rose Corral, Buenos Aires, Losada, 2001, pp. 39-42). Allí Arlt reescribe la información de que un individuo anónimo ha donado diez millones de dólares a Yale para investigar el cáncer mediante un diálogo que imagina entre el "Doctor Angell", de Yale, y un "Desconocido". Antes de la escenificación del diálogo de los personajes se afirma, de un modo bastante similar al caso de "El Polo Norte no está más en el Polo Norte": "La noticia ocupa quince centímetros de columna. Nada más. En cualquier página de los periódicos norteamericanos del día 23 de junio [...] Pero lo más notable del caso es que los periódicos norteamericanos han recibido la noticia y la han publicado sin mayores comentarios. Es una noticia. ¡Nada más!”. (p. 39)

${ }^{11}$ Esta cuestión se analiza en el capítulo siguiente
} 
"la expansión narrativa del texto de la noticia", ${ }^{12}$ en reiteradas oportunidades Arlt selecciona, asimismo, aquella información cuyos rasgos permiten ese despliegue narrativo y ficcional. Abundan en este sentido los artículos en los que se asocian "las tres líneas del cable" a referencias literarias: "He recordado a Anderson y Kipling leyendo ayer una noticia perdida entre espesas columnas de tragedia internacional”, ${ }^{13}$ o crónicas que se desarrollan a partir del carácter "novelesco" que Arlt atribuye y encuentra en la información de la prensa, como "Un gitano ladrón y un caballo aprovechado". ${ }^{14}$ Este texto, de enunciación españolizada y arcaizante y una perspectiva jocosa sobre los gitanos y sus robos frecuentes, promete "contar la historia" "verísima como [su] [...] propia existencia" ya que "la calegrafió la United Press", del robo de un caballo de circo por unos gitanos. ${ }^{15}$ La noticia de que el caballo había sido finalmente recuperado por los dueños del circo cuando caminaba en dos patas, resulta para Arlt una "historia que merecía [sic] estar en un relato de Jack London", o que también "hubiera merecido figurar en un relato de Apuleyo", pues, como se dice al final del texto que se ha narrado, en una interpelación al lector, - $\mathrm{y}$ es insistente en esta y muchas de sus crónicas el uso de verbos como "narrar", "relatar", "contar" para referirse al asunto que está tratando-, "es digno de novela su relato".

Cabe referir, además, que en ciertos casos lo circunstancial y presumiblemente poco trascendente en que se detienen y explayan con frecuencia las notas, es utilizado para referirse a los sucesos más candentes del presente y exponerlos en su modo más brutal: entonces la información marginal que Arlt desarrolla lo es sólo de modo aparente. "Otro viaje milagroso de la Virgen Negra", ${ }^{16}$ por ejemplo, se centra en la descripción de los episodios que, a través de los siglos, muestran la devoción de los polacos por la Virgen Negra: el santuario que le construyen, la peregrinación a JasnaGora, la milagrería de la imagen que sus creyentes suponen tallada por el mismo José.

\footnotetext{
${ }^{12}$ Saítta, Sylvia. "La última pieza que faltaba al mecanismo", Op. Cit., pp. 189-190.

${ }^{13}$ Arlt, Roberto. "La ciudad sumergida en el bosque", en El Mundo, 18 de junio de 1937. Tiempos Presentes. Reproducida en Arlt, Roberto. Al margen del cable, Op. Cit., p. 27.

${ }^{14}$ Arlt, Roberto. "Un gitano ladrón y un caballo aprovechado", en El Mundo, 8 de octubre de 1937. Al margen del cable.

${ }^{15}$ Dice el cronista, exactamente, en este caso, con un tono españolizante: "Que esta historia que cuento es tan verísima como mi propia existencia y la calegrafió la United Press". Arlt, Roberto. "Un gitano ladrón y un caballo aprovechado", Op. Cit.

${ }^{16}$ Arlt, Roberto. "Otro viaje milagroso de la Virgen Negra", en El Mundo, 7 de septiembre de 1939. Al margen del cable. Este texto se reproduce en Arlt, Roberto. Al margen del cable, Op. Cit., pp. 198- 200 con el título de "El viaje de la Virgen Negra".
} 
Hacia el final del texto, se explica el "otro viaje milagroso del título" cuando Arlt refiere la noticia, nada anecdótica, por cierto, del telegrama del que parte su crónica: la "Virgen milagrosa" se ha trasladado a Varsovia, los soldados nazis entraron a caballo en el santuario. De esta manera, en un paralelismo que equipara las tropas de Hitler con los bárbaros de la historia de los cuales se había salvado la imagen — “siempre zarandeada por la barbarie de los siglos"-, Arlt expresa elocuentemente en la comparación, el terror del presente (los nazis son igualados en 1939 a los ejércitos de Herodes, Nerón, los verdugos bizantinos y los tártaros), pues es el momento en que, como se sabe, con la invasión de Hitler a Polonia, ha comenzado la Segunda Guerra Mundial. Como se expresa en la nota: "La imagen de la Virgen milagrosa de Jasna -Gora ha llegado a Varsovia y fue escondida por los monjes en un lugar seguro'. Otro viaje más [...] Otra aventura más. Una vez fue salvada de los mercenarios de Herodes, después de los legionarios de Nerón, más tarde de las garras de los verdugos bizantinos, después de entre los dientes de los tártaros. Otro viaje más. Otra aventura." Y añade hacia el final: "Los cables notifican que los soldados nazis entraron a caballo en el santuario, profanando con sus potros el altar..."; ${ }^{17}$ lo anecdótico del inicio del texto pasa a vincularse, de este modo, con un hecho candente y central en las preocupaciones del momento.

Además de detenerse en relatos auxiliares a los grandes sucesos de la conflagración internacional y de dar espacio, en otros casos, a la noticia explícitamente marginal, algunas de las crónicas presentan un tipo de enunciación literaturizada; como en "El subsuelo del diablo", una de las primeras notas de "Tiempos Presentes", donde aparece una descripción del espacio portuario cercana a lo poético, que apela al ritmo de la enumeración y la anáfora:

Dique 4 , dique 3 , dique $2 \ldots$

Barcos panzudos, sucios. Oficiales con cara de forajidos. En los entrepuertos, grumetes de rapada cabeza y sorprendida mirada. Cargan trigo.

Barcos de proa alta, afilada, la pintura arrugada, como la concha de un galápago, en el casco.

Hélices que aun conservan el fango de la rada. Cargan trigo.

${ }^{17}$ Arlt, Roberto. "Otro viaje milagroso de la Virgen Negra”, Op. Cit., p. 200. 
Lanchones, al pie de los gigantes, descargan trigo. Son grúas. Cargan trigo... ${ }^{18}$

Estas formas de expresión, como en muchos otros ejemplos que pueden mencionarse a propósito de las crónicas finales de Arlt, se contraponen a los modos enunciativos de las aguafuertes previas. Como es sabido, en las notas periodísticas de los primeros años, Arlt defiende "El hermoso idioma popular" por considerarlo, "verdadero" "vivo", "coloreado por matices extraños" y "comprensible para todos", y entabla una polémica con quienes lo acusan de "rebajar" sus artículos "al cieno de la calle". ${ }^{19}$ Esta operación se refuerza porque, no sólo introduce en las aguafuertes -y también por supuesto en las novelas y primeros cuentos- reiteradas expresiones del lunfardo o de la lengua coloquial, sino porque también, en muchos casos, lo hace de un modo provocativo, polémico e irrespetuoso de los lugares establecidos, como por ejemplo cuando en medio de un discurso "acorde a la gramática" aparece un paréntesis en el que se aclara: "me estoy portando bien, no uso términos del lunfardo ni meto la pata hasta el garrón". ${ }^{20}$ En el transcurso entre las primeras aguafuertes y las últimas notas que publica en El Mundo, y en un proceso que es índice de los cambios en las concepciones y en la estética de Arlt hacia el final de su producción, esto se modifica y se efectúa un borramiento de las marcas lingüísticas de lo que el escritor llamaba la lengua popular. Así, se encuentra un progresivo abandono del fuerte discurso polémico que defendía ese léxico y, además, en los textos "Al margen del cable" se suprimen las expresiones de la lengua "de la calle" y de la lengua popular, a la vez que se incrementan los intentos orientados a la elaboración de un discurso "más cuidado", y la incorporación de recursos literarios, como por ejemplo, el uso de la metáfora y del sistema comparativo, entre otros rasgos.

Por otra parte, interesa ver el modo en que estas crónicas finales cuestionan algunas de las formas de la escritura y la enunciación periodística que comentan; ciertamente, los artículos confrontan distintas maneras de referir los sucesos e informar,

\footnotetext{
${ }^{18}$ Arlt, Roberto. "El subsuelo del diablo", Op. Cit.

${ }_{19}$ Arlt, Roberto. “¿Cómo quieren que les escriba?”, en El Mundo, 3 de septiembre de 1929. Recopilada en Arlt, Roberto. Aguafuertes porteñas: cultura y política, Selección y prólogo de Sylvia Saítta, Buenos Aires, Losada, 1994, pp. 30-34.

${ }^{20}$ Arlt, Roberto. "Persianas metálicas y chapas de doctor", en El Mundo, 18 de octubre de 1930. Recopilada en: Arlt, Roberto. Aguafuertes porteñas, Buenos Aires, Losada, 1958.
} 
y variados modos de "certeza" y "realidad". En este sentido, también "El subsuelo del diablo" indaga acerca de los "cablegramas" e "informaciones" "que cruzan el éter silenciosamente" y sobre las " ¡Cuántas cosas que se escriben y pueden no ser verdad!". ${ }^{21}$ El texto, aparecido en abril de 1937, una época en la que Arlt ya comienza a señalar, con insistencia, cómo puede leerse en los avatares de ese presente la cercanía de otra posible devastadora y próxima guerra mundial, se inicia con la mencionada descripción enumerativa y estilizada del espacio del puerto de Buenos Aires en el momento en que los barcos cargan trigo para el extranjero. Luego de la descripción, inmediatamente, se plantea y desarrolla una pregunta: “¿Qué sucede en el planeta?”, interroga Arlt, cuando todos "los ojos se han vuelto hacia el campo argentino":

¡Cuántas palabras diversas se han escrito para explicar las razones porque la vieja Europa, compra frenéticamente nuestros cereales! Aquí una justificación: Australia cosechará trigo inferior al del año pasado [...] Allí se ha escrito: "el alza de nuestros cereales se debe a que la próxima cosecha de invierno en Canadá ha sufrido mucho a consecuencias de la humedad". Los canadienses, frente los encendidos troncos de sus estufas, meditarán leyendo la Biblia. ¡Cuántas cosas se escriben que pueden no ser verdad! [...]

¿Qué pasa? ¿Miedo a la guerra? [...] El signo de los tiempos: el pan se guardará en la caja de hierro.

Cierto es que en Canadá esto, que en Australia aquello...

Aparte de estas realidades un poco débiles, hay otra, la REALIDAD del presente: miedo a la guerra. Al Hambre de la Guerra. ${ }^{22}$

Como puede verse, el fragmento enuncia y contrapone dos versiones de los hechos y, por ello, dos versiones de "la realidad": la de los cablegramas que cruzan el éter y que escriben lo que aparentemente "es cierto", y la interpretación de Arlt de la información referencial. A partir de un trabajo con la cita de las justificaciones y explicaciones que a la pregunta de por qué se exporta tanto trigo se presentan como seguras — "las realidades un poco débiles", de las que se habla en la cita-, la perspectiva de la enunciación las enfrenta a lo que se señala como la "REALIDAD del presente" que clama: "miedo a la guerra. Al Hambre de la Guerra". Si como el propio

${ }^{21}$ Arlt, Roberto. "El subsuelo del diablo", Op. Cit.

${ }^{22}$ Arlt, Roberto. "El subsuelo del diablo", Op. Cit. 
Arlt expresa irónicamente en "El bacilo de la neutralidad en Escandinavia", 23 “...no se ha inventado expresión periodística de más infinita utilidad..." que "cierto es que", muchas de sus notas interrogan lo que presumiblemente "es cierto" en la prensa y lo transforman en aparente; se muestra entonces, otro modo de la verdad que desenmascara lo que expone superficialmente la rasa e "impersonal información cablegráfica" y algunas noticias. Como puede verse, asimismo, en esta crónica sobre "Escandinavia", — donde se pone en evidencia la forma en que estos países que aseguran tener deseos de paz y neutralidad, se "arman hasta los dientes"-, Arlt copia fragmentos extraídos de los diarios y de esta manera plantea dudas sobre lo que se presume certero: “Cierto es que... (no se ha inventado expresión periodística de más infinita utilidad que ésta), cierto es que muchos suecos ponen sus esperanzas en Noruega...pero cierto es que Noruega es un pastel teñido con diferente anilina", ${ }^{24}$ sostiene, por ejemplo, el cronista. Así, el "cierto es que" aparece como una verdad del lenguaje capaz de encubrir "otra realidad", una explicación que la escritura torna verosímil pero que se aleja, a veces, de lo que para Arlt constituye, más precisamente, la certeza y la verdad. ${ }^{25}$

Un caso curioso, en este sentido, en el que aparecen modos opuestos de referencialidad, es "El sepulcro de acero", ${ }^{26}$ un artículo sobre el hundimiento del submarino norteamericano "Squalus". En principio y luego del título, el cronista transcribe el breve cable de noticias fuente de la nota, sin indicar su procedencia — "En Portsmouth se hundió un submarino con sesenta hombres"- y luego diseña un texto que, por sus características, se opone a la objetividad periodística y taquigráfica de lo reproducido. De esta manera, al copiar el cable, como en muchas de sus crónicas, Arlt establece un diálogo con ese tipo de información y muestra, como se verá, una operación diferente con la noticia. Pero además, en la misma página de El Mundo en

${ }^{23}$ Arlt, Roberto. "El bacilo de la neutralidad en Escandinavia", en El Mundo, 9 de abril de 1937. Tiempos Presentes. Reeditado en Arlt, Roberto. Al margen del cable, Op. Cit., pp. 19-22.

${ }^{24}$ Arlt, Roberto. "El bacilo de la neutralidad en Escandinavia", Op. Cit., pp. 20-21.

${ }^{25}$ Otro artículo donde se retoma y polemiza acerca de una nota en la prensa de la época y se la muestra en su carácter de versión parcial de "la realidad" -el texto dice, explícitamente, "la realidad, es otra - es "El rompecabezas amarillo". Se trata de un diálogo sobre China y Japón que se desarrolla entre dos sujetos: el "Caballero escéptico" y el "Caballero respetable", y a través del cual la enunciación pareciera invitar y preparar a los lectores en el cuestionamiento de los editoriales y la discusión de la noticia. Arlt, Roberto. "El rompecabezas amarillo", en El Mundo, 3 de agosto de 1937. Tiempos Presentes.

${ }^{26}$ Arlt, Roberto. "El sepulcro de acero", en El Mundo, 24 de mayo de 1939. Al margen del cable. 
que se encuentra el texto de Arlt, también se desarrolla, en un lenguaje impersonal y descriptivo, una nota de la redacción sobre el mismo hecho, titulada: "Peligran 59 hombres encerrados en un submarino en el fondo del mar". ${ }^{27}$ Se inscribe, entonces, en las páginas de $E l M u n d o$, el enfrentamiento y contraposición entre diferentes modos de "contar lo real"; porque lo que en la enunciación periodística aparece en un registro someramente objetivo y centrado en la información sobre la cronología y el orden de los sucesos, (los datos, las cifras y las acciones de salvataje a realizar), en el caso de Arlt se literaturiza y la noticia adquiere otras connotaciones. Por ello su crónica marca una enfática diferencia tanto del cable que al principio reproducía, como de la información aparecida en la misma página del diario:

Es largo como una ballena el "Squalus". Largo como una ballena negra, fino y suave, los costados lacerados de ojos redondos, la torrecilla del periscopio gallarda como una hermosa doncella [...] y porque se parecía a una ballena negra, lustrosa y acerada, nunca el espectáculo de la muerte resultó más simétrico y posible...[...] Ahora [...] el "Squalus" reposa en el fondo del mar. [...] En un lecho de arena limpia. Los peces resbalan y ondulan en torno de él, tropiezan su hocico en la fría superficie del metal y el agua mece dulcemente el monstruo esbelto de acero. Adentro, en el vientre de la ballena de acero, sesenta hombres se miran a la cara mientras les crece la barba. $[\ldots]$

Ahora el hombre que pensaba en abrazar a su madre, ahora el hombre que pensaba recibir un beso apretado, ahora el hombre que pensaba en su "boy", ahora los sesenta hombres están en el fondo del mar, mirándose los unos a los otros a la cara...[...] Y los peces de tres hileras de dientes, y los peces que parecen cintas de plata y esmeralda, ondulan en torno del "Squalus" [...] No es conveniente dejar crecer el miedo dentro del alma, piensa cada uno, y todos se miran ligeramente pálidos... ${ }^{28}$

\footnotetext{
27 "Peligran 59 hombres encerrados en un submarino en el fondo del Mar", en El Mundo, 24 de mayo de 1939. La nota tiene un subtítulo que dice: "Hállase a 80 metros de profundidad y se hacen esfuerzos por salvarlos". Luego, se señala: "PORTSMOUTH (Nueva Hampshire), 23 (UP).- Debido a un desperfecto de una válvula de lastre que imposibilitó su achique, encuéntrase hundido en el mar, a unos ochenta metros de profundidad y a unos veinte kilómetros de distancia de este puerto, el submarino estadounidense 'Squalus', uno de los más modernos de la Armada, del mismo tipo que el 'Sargo', que visitó recientemente Buenos Aires y otros puertos sudamericanos". Los subtítulos que siguen desarrollan los siguientes temas: "Manifiestan plena confianza en la salvación", "Trabajará una docena de buzos", "Serán usadas cámaras de salvamento", "Localizan al 'Saqualus", "Capacidad de las cámaras", "Varios barcos acuden a su auxilio".

${ }^{28}$ Arlt, Roberto. "El sepulcro de acero", Op. Cit.
} 
Ciertamente, "El sepulcro de acero", a partir del cable sobre el hundimiento transcripto al comienzo, pone la noticia en términos literarios. El texto, construido con un lenguaje estilizado que enfoca la escena como un espectáculo estético que se produce en el fondo del mar, (por eso el submarino aparece como una ballena), también retoma tópicos del libro de Jonás, Melville, la literatura popular, infantil y de aventuras (como el estar atrapados en las fauces de un monstruo marino). En una reiteración anafórica que acentúa el dramatismo de la situación ("ahora el hombre", "ahora los sesenta hombres"), el cronista despliega los avatares posibles en torno a la angustiosa subjetividad y los diálogos que pueden imaginarse entre estos marinos encerrados en el fondo del mar. De esta manera, los sesenta hombres del "Squalus" se acercan a los personajes de una narración, aspectos, que, no dejan de enfatizar el carácter "novelesco", y si se quiere truculento de la reescritura del contenido de la información (puede suponerse que este texto resultaría afín a los gustos de un potencial lector popular, como el público del diario El Mundo, a quien Arlt tanto conocía).

\section{Crónica, ficción y representación}

¿Contesten si no es digno de novela el relato? ${ }^{29}$

Roberto Arlt

En algunas notas, Arlt retoma y pone en términos narrativos y literarios el contexto y los personajes que imagina a partir de la breve información cablegráfica y de las notas periodísticas. Como sostiene Saítta, son "tres las operaciones que Arlt realiza sobre el cable de noticias": expande narrativamente las líneas del cable, imagina la vida que se esconde detrás de un nombre y "describe algunas de las fotos que llegan a la redacción" para llenar "de contenido lo que la imagen sugiere". ${ }^{30}$ En esta expansión narrativa de la información internacional, Arlt incorpora los mismos procedimientos literarios, géneros y tópicos que caracterizan su narrativa de finales de los años treinta y

${ }^{29}$ Arlt, Roberto. "Un gitano ladrón y un caballo aprovechado", Op. Cit.

${ }^{30}$ Sylvia Saítta sostiene, además, que frecuentemente Arlt convierte “...un nombre propio desconocido en un personaje que bien podría haber sido protagonista de cualquiera de sus ficciones". Saítta Sylvia, "La última pieza que faltaba del mecanismo", Op. Cit., pp. 190-191 
comienzos de los cuarenta. Las crónicas devienen entonces en textos de aventuras, historias de espionaje y tramas ligadas al policial y a la criminalidad, así como también en breves piezas teatrales. En este sentido, estos escritos podrían pensarse como un lugar de experimentación literaria donde Arlt ensaya, por una parte, los modos de su narración, - ya que, por ejemplo, los cuentos de espionaje y los de aventuras son muy tardíos en su literatura ${ }^{31}$ - y también, como un espacio donde reaparece la mirada del dramaturgo y las inquietudes de la representación.

Se analizan en este apartado, entonces, distintos procedimientos de ficcionalización, y se estudia cómo a partir de estas formas literarias se reescriben las noticias. Asimismo, se indaga de qué manera se introducen aquí rasgos y constantes en la obra de Arlt, y el modo en que, en muchos casos, desde la narración o la puesta en términos dramáticos las crónicas exasperan y exponen críticamente al lector de $E l$ Mundo el presente cruento de la guerra.

"El cartero y el tigre", ${ }^{32}$ es un ejemplo muy elocuente para analizar algunos de estos aspectos. Arlt parte de las "dos líneas de linotipo", reproducidas textualmente al principio y al final de su nota, que informan en The Times el hecho de que "14.000 'runners' sirven a pie los caminos de la India, corriendo riesgos innumerables" ${ }^{33}$ y que "Ha sido despedazado por un tigre el 'runner' que hacía el servicio postal entre Delhi y Bombay". ${ }^{34} \mathrm{Si}$ bien la noticia transcripta tiene un carácter bastante indeterminado, vago y general, Arlt la particulariza en la descripción del espacio y en los variados incidentes que introduce en su texto y éste adquiere rasgos que lo acercan decididamente a un relato. De esta manera, la crónica de Arlt tiene un comienzo resueltamente ficcional que narra el encuentro del runner con un mendigo ciego, harapiento y musulmán: “...cierto horrible cadáver viviente, lívido como el yeso aún húmedo, con dos rayas negruzcas por ojos, las cejas repeladas por una eczema y todo arrebujado en un manto como un

${ }^{31}$ Los cuentos de espionaje y los relatos policiales de Arlt que remiten al modelo de las ficciones de enigma y al policial inglés, son textos que, como se verá en detalle en el capítulo siguiente, rondan los años cuarenta, del mismo modo que sus narraciones de aventuras.

${ }^{32}$ Arlt, Roberto. "El cartero y el tigre", en El Mundo, 12 de mayo de 1939. Al margen del cable. Reproducida en Arlt Roberto. Al margen del cable, Op. Cit., pp. 167-170.

${ }^{33}$ Arlt, Roberto. "El cartero y el tigre", Op. Cit., p. 167.

${ }^{34}$ Arlt, Roberto. "El cartero y el tigre", Op. Cit., p. 170. Dice el cronista sobre el cable de noticias, mostrando nuevamente su predilección por la información marginal: "El telegrama va de Delhi a Bombay; de Bombay a Londres; de Londres a la dirección de The Times. Dos líneas de linotipo. Nada más, y un nuevo cartero trotador en la línea que va de la ciudad antigua a la selva perpetua". Arlt, Roberto. "El cartero y el tigre", Op. Cit., p. 170. 
leproso, que suplicaba al pie de un baobab". ${ }^{35}$ El mendigo, ante la repulsión e indiferencia del cartero, le lanza una supuesta maldición y, según lo que la nota sugiere, esta sería la causa de su encuentro posterior con el tigre en el camino a Loheru. Atravesado por algunos de los tópicos del imaginario orientalista, venganza, hechizo y maldición, se relata el encuentro del cartero con el tigre y el modo en que el animal lo asecha y lo mata por el influjo del maleficio o del "mal demonio" al que se refiere el texto. ${ }^{36}$ A su vez, la nota reincorpora escenarios exóticos, extraños personajes y curiosidades que vislumbra el corredor en su viaje, las mujeres de "anillos de cobre en los dedos" y "uñas de gato engastadas en dijes de plata [...] para defenderse de los malos espíritus", misteriosas "callejuelas de un viejo poblado", "un buey sagrado", "pétreas mujeres desnudas terminadas en cola de pescado", "bueyes con tentáculos de pulpos" y "tigres cubiertos con conchas de caracol" de un templo en ruinas, que remiten al exotismo de sus cuentos orientales.

En estas crónicas se mantiene entonces el interés por "lo otro" y por "el entramado oriental", y las noticias de la guerra despuntan, frecuentemente, en ocasiones propicias para la representación de lo exótico y la construcción de lo ajeno. En estos casos, los artículos internacionales se detienen en la descripción de una urbe lejana, en la vestimenta de algunos individuos, en el costumbrismo localista y típico de los espacios que se focalizan. La percepción se concentra, así en el escenario oriental, africano, chino, árabe, japonés; el horizonte selvático y desconocido de los lugares ignotos, las ciudades y pintorescos paisajes de la "ardiente" Europa: París, los castillos góticos de Luxemburgo, Breslau, las callejuelas ondulantes del Viejo Continente, y, también en los mundos alejados, como el Polo Sur y la Isla Caimán, entre otros.

“¿De qué lado se pondría el profeta?”, ${ }^{37}$ es un texto que si bien parte del conflicto internacional —el enfrentamiento entre dos líderes del mundo musulmán—, es la excusa para describir lo exótico y detenerse en la representación del ambiente oriental:

\footnotetext{
${ }^{35}$ Arlt, Roberto. "El cartero y el tigre", Op. Cit., p. 167.

${ }^{36}$ Así se inscribe ese encuentro en el texto: "De pronto, el cartero -un mal demonio ha nublado sus ojos- vacila, quiere agarrarse a una rama y pesadamente se desmorona...[...] Un grito, una fiera encogida excavando en el vientre de un hombre y tres días después un telegrama: 'Ha sido despedazado por un tigre el 'runner' que hacía el servicio postal entre Delhi y Bombay'” Arlt, Roberto. "El cartero y el tigre", Op. Cit., p. 170.

${ }^{37}$ Arlt, Roberto. “¿De qué lado se pondría el profeta?”, en El Mundo, 7 de abril de 1939. Al margen del cable. Reproducida en Arlt, Roberto. Al margen del cable, Op. Cit., pp. 151-154.
} 
Finas alfombras cubren el suelo, sus flecos escarlatas ondulan por las gradas debajo de los soportes de un sillón americano. A un costado, un modesto escritorio de roble. [...] Más atrás, paredes encaladas y persianas, por donde el ardiente sol de Arabia filtra su resplandor enceguecedor y sus neblinas de arenilla.

Sobre el sillón americano, sentado un hombre descalzo. De la cabeza del hombre descalzo cae una especie de gran pañuelo a cuadros negros y blancos, sujeto a su cabeza por un ojal de oro. Este pañuelo recuadra un rostro largo y amarillento [...] El hombre está revestido de una chilaba. Su mirada es tierna y falsa, como la de una mujer. Su astucia infinita. Frente a él se inclina otro hombre descalzo. Un jefe del desierto. Los labios gruesos de ese hombre están entreabiertos, su mirada, con atenta expectativa, se fija en su interlocutor. Nadie al verle diría que este hombre, a comienzos del siglo, con menos de treinta ganapanes montados en menos de treinta camellos sarnosos, se apoderó de $\mathrm{Ar}$ Riyadh.

Hay quien afirma que este hombre [...] que es hoy rey de Arabia, es un político cándido e ingenuo. Debe serlo cuando sus admiradores lo afirman. Pero ¡Por Alá! que os juro que preferiríais encontraros con el mismo Diablo, antes que tropezar con su moralla de Juárez mercenarios fanáticos [...] que a bordo de los camellos sarnosos conquistaron $\mathrm{Ar}$ Riyadh.

...a través de Arabia, durante más de veinte años, Abdul Azis Abdur Raman Faisal Turki Abdulah Mohamed Ibn Saud, ha recorrido el país candente, y sus manos tintas de sangre hasta el codo impusieron la paz y la avenencia. ${ }^{38}$

El texto de la cita se refiere a uno de los dos líderes entre los cuáles, el título de la crónica se pregunta, "cuál elegirá el profeta" (el otro es Aga Khan). Se trata de un comienzo decididamente ficcional donde se describe detallada y minuciosamente la escena que rodea al sujeto en cuestión. Camellos, alfombras de "flecos escarlatas", chilaba, paredes encaladas, "ardiente sol de Arabia", "mercenarios fanáticos", las menciones recorren los lugares comunes del orientalismo asociados a ese espacio, como también la caracterización pormenorizada del personaje, vinculada a tópicos como la astucia y la traición (implícita en la falsedad de la mirada del árabe). Desde una enunciación que pretende confundirse con los modos de expresión del mundo figurado, __ “Por Alá! que os juro que preferiríais encontraros con el mismo Diablo, antes que tropezar con su moralla de mercenarios fanáticos [...] que a bordo de los camellos sarnosos conquistaron Ar Riyadh." - ingresa otro lenguaje en estas notas que se distancia sobremanera del habla de

${ }^{38}$ Arlt, Roberto. “¿De qué lado se pondría el profeta?”, Op. Cit., pp. 151-152. 
las aguafuertes porteñas y se acerca al de las ficciones africanas de los tardíos años treinta. Así, la crónica construye un narrador cercano que no sólo narra, sino que también, desde la mención del nombre (Abdul Azis Abdur Raman Faisal Turki Abdulah Mohamed Ibn Saud) satura de exótico lo representado. De esta manera, el marco de la guerra que da pie al relato/crónica de Arlt sobre los dos líderes del mundo árabe, resulta, en este caso, casi una excusa para contar lo otro y literaturizarlo.

Efectivamente, como en muchas otras notas, la información referencial se recorta en el interés de Arlt en los espacios extraños, las sociedades secretas, las historias de espías y aventuras y las cartografías imaginadas que se refieren como vistas. ${ }^{39}$ Un caso interesante, en este sentido, es "Dichoso aquel que tiene su casa a flote" ${ }^{40}$ porque además de poner en escena una geografía exótica y alejada, relata una aventura marítima que nos remite a sus narraciones posteriores — recuérdese que la última ficción que Arlt publicó es "Un viaje terrible" (1941), un texto inspirado en "Un descenso al Maelström" de Edgar Poe-. Así, la apelación a la aventura que es central en esta y otras crónicas "Al margen del cable", también aparece, con matices diferentes en "Un viaje terrible" y en los últimos cuentos de Arlt.

"Dichoso aquel que tiene su casa a flote" se abre con una descripción literariamente elaborada de un panorama de guerra que muestra a China en llamas. Enseguida, narra los avatares del viaje por el mar, de dos estadounidenses y dos chinos que se escapan de Shangai atravesando el Océano en una embarcación precaria, — “un junco fugitivo de masacres" - para llegar, luego, a California. Se trata, sin duda, de una aventura marítima, que le permite a Arlt, como proponía en uno de sus artículos publicados en 1941, la narración de acciones y el relato "con aventuras", ${ }^{41}$ en este caso la travesía de los cuatro fugitivos en el Pacífico. Es importante el cromatismo y la estilización sobre el lenguaje que aparece en algunas escenas. En principio, en la

\footnotetext{
${ }^{39}$ Entre los textos de Arlt que permiten estudiar esta cuestión pueden mencionarse, por ejemplo: "Dos fantasmas quieren luchar por Francia" (en El Mundo, 13 de septiembre de 1939. Al margen del cable), "Wan -Ching- Wei se frota alegremente las manos", (en El Mundo, 23 de septiembre de 1939. Al margen del cable), "La gran duquesa Carlota hace preparar sus baúles" (en El Mundo, 4 de octubre de 1939. Al margen del cable) y "Terror nazi entre los morochos de Liberia" (en $E l$ Mundo, 9 de diciembre de 1939. Al margen del cable).

${ }^{40}$ Arlt, Roberto. "Dichoso aquel que tiene su casa a flote", en El Mundo, 9 de octubre de 1938. Al margen del cable.

${ }^{41}$ Véase, a este respecto "Aventura sin novela y novela sin aventura", (en El Mundo, 13 de agosto de 1941. Reeditado en Arlt, Roberto. Aguafuertes porteñas: cultura y política, Op. Cit.) donde Arlt propone la vuelta a la aventura.
} 
descripción inicial del puerto de Shanghai, pues, desde la perspectiva de un narrador testigo, y de un modo semejante a algunas de las formas de representación expresionista del espacio que aparecen en sus novelas, se muestran los estertores y efectos de la guerra en la visión de la ciudad oriental. ${ }^{42}$ Entonces aparece una apelación a los contrastes de color - cielo azul que se opone al rojo de los dragones, a las máscaras rojas y negras de los diablos, al agua sucia y al humo espeso de las chimeneas que enturbian el aire-, y una simplificación de ciertas zonas del cuadro representado mediante la figuración geométrica y las formas singulares —en algunos casos, como en las novelas de Arlt, a las líneas rectas, "amenazadoras" e "incisivas" —: ${ }^{43}$ los hombres son nueve líneas de cascos de acero que se parapetan tras las franjas constituidas por las bolsas de arena, hay letreros verticales, los incendios son manchas. Entonces, el fuerte cromatismo de la escena que en otras notas se buscaba como muestra de exotismo y exaltación de lo típico y el color local, acá describe los contrastes violentos y el colorido funesto del puerto en llamas:

La ribera de la ciudad de siete mil colores con sus escalonados edificios de veinte pisos, con sus soldados de cantimplora a la cintura y las fachadas desprendiendo letreros verticales sembrados de alfabéticas cuñas doradas, pone en el crepúsculo la mancha de sus incendios. A lo largo de las grises naves de guerra, zampanes con chinos rapados y marineros blancos [...] A veces zumba un avión en el espacio, mientras con sus pajarracos dorados en la proa, con sus

\footnotetext{
${ }^{42}$ La cita completa del texto dice: "Puerto de Shangai. Rostros mongólicos enmarcados por cascos de acero levantan guardia en la pasarela gris de las naves de guerra. Las chimeneas ensucian el aire de rulos de humo espeso. En el fondo de las calles de bambú, multitudes de pies desnudos, con críos en los brazos y colchones sobre las cabezas. Nuevas líneas de cascos de acero, parapetados tras de franjas de bolsas de arena. Cielo azul, dragones rojos, agua sucia. La ribera de la ciudad de siete mil colores con sus escalonados edificios de veinte pisos, con sus soldados de cantimplora a la cintura y las fachadas desprendiendo letreros verticales sembrados de alfabéticas cuñas doradas, pone en el crepúsculo la mancha de sus incendios.

A lo largo de las grises naves de guerra, zampanes con chinos rapados y marineros blancos, cuyas gorras parece almidonados budines requintados. Custodian cajones de explosivos. A veces zumba un avión en el espacio, mientras con sus pajarracos dorados en la proa, con sus diablos enmascarados en rojo y negro, nacidos de las aguas, aplastados en las aguas, avanzan los juncos que vienen y parten de todos los puertos de Japón hacia China.

Muestran velámenes monstruosos, diez veces más altos en su mástil de bambú, que la carga que estiban a flor de agua. Véase: Arlt, Roberto. "Dichoso aquel que tiene su casa a flote", Op. Cit.

${ }^{43}$ Denominación de Marise Renaud, cuando analiza el espacio expresionista arltiano. Véase, Renaud, Marise. "Los siete locos y Los Lanzallamas: audacia y candor del expresionismo", en Arlt, Roberto. Los siete locos-Los Lanzallamas, Edición crítica, Colección Archivos, Mario Goloboff coordinador, Francia, ALLCA XX, Université Paris X, 2000, p. 73.
} 
diablos enmascarados en rojo y negro, nacidos de las aguas [...] avanzan los juncos...". ${ }^{44}$

Interesa, igualmente el modo en que Arlt describe el paisaje marítimo: "Nubes de masas de nácar", "relámpagos violáceos que iluminan la noche al soslayo", "cresta de leche de las olas verdosas". La enunciación revela un lenguaje estetizado que remite a las formas en que, con un acercamiento a rasgos del modernismo, aparece el estilo alto en otros textos de Arlt. ${ }^{45}$

Peripecias en el mar, intrigas sobre buscadores de tesoros, - como el texto que relata un conflicto en Costa Rica entre dos grupos que se disputan un botín—, ${ }^{46}$ barcos fantasmas, excursiones por los espacios selváticos y el Polo y conflictos de piratas, muchos artículos parten de la noticia internacional y retoman temas y motivos recurrentes en las obras de aventuras; otros, además, reflexionan con un tono cercano al del ensayo sobre los modos de construcción de este tipo de formas de la ficción. ${ }^{47}$ En reiteradas oportunidades, a su vez, las aventuras se vinculan al mundo del espionaje y de la criminalidad y, frecuentemente, en las notas previas a septiembre de 1939, el clima de la guerra o el de su inminente estallido constituye el ámbito del que surgen estas narraciones. Es el caso de historias como la de los "Soldados de cera", ${ }^{48}$ un texto que, originado en torno de a los conflictos más o menos marginales que suscita la próxima guerra, resulta muy cercano a los cuentos que Arlt publica por ese entonces y los que edita hacia los años cuarenta, como el relato posterior "El hombre del turbante verde". ${ }^{49}$ Ciertamente, "Soldados de cera", que presenta una trama de aventuras ligada al mundo del crimen por la cual un contrabandista de Breslau, Eric Müler, esconde los objetos que trafica en el interior de muñecos de cera que él mismo manda a fabricar con ese fin y cuyo aspecto simula el de soldados muertos, parecería el punto de partida desde el cual

${ }^{44}$ Arlt, Roberto. "Dichoso aquel que tiene su casa a flote", Op. Cit..

${ }^{45}$ Véase el capítulo: 3 "Los modos de lo fantástico".

${ }^{46}$ Arlt, Roberto. "Hay que ser millonario y chiflado", en El Mundo, 4 de abril de 1940. Al margen del cable.

47 Véase: Arlt, Roberto: "Hay que ser millonario y chiflado", Op. Cit. También, puede consultarse, entre otros, Arlt, Roberto. "La lógica diabólica de la tempestad", en El Mundo, 10 de diciembre de 1938. Reproducido en Arlt, Roberto. Al margen del cable, Op. Cit., y "El continente seductor", en El Mundo, 13 de noviembre de 1937. Tiempos Presentes. Sobre la modalidad ensayística en la escritura periodística de Arlt véase el capítulo 6.

${ }^{48}$ Arlt, Roberto. "Soldados de cera", en El Mundo, 15 de febrero de 1938. Al margen del cable. Reeditado en: Arlt, Roberto. Al margen del cable, Op. Cit., pp. 84-86.

${ }^{49}$ El 14 de abril de 1939 Arlt publica en El Hogar "El hombre del turbante verde", que se incluye, luego en El criador de gorilas, editado en Chile en 1941. 
Arlt construye "El hombre del turbante verde". Porque este texto, una narración de enigma policial clásico cuyo argumento reescribe "la carta robada" de Edgar Poe, pone en términos ficcionales cómo el hombre del turbante verde descifra el misterio que logra pasar inadvertido ante los ojos de todos, y mediante el cual se trafican armas en cadáveres disfrazados de pordioseros.

A este respecto, cabe referir que si bien las zonas del mundo del hampa y de la criminalidad son afines a la labor periodística de Arlt desde las aguafuertes porteñas, en el caso de las crónicas que nos ocupan encontramos nuevos matices que las separan de las anteriores y las vinculan con el tipo de relatos policiales y de espionaje que Arlt escribe hacia el final de su producción; y recordemos que Arlt es uno de los pocos escritores por los que las tramas de espionaje ingresan en la literatura argentina, otro es Borges. Porque si algunas de estas notas, como sus aguafuertes porteñas, se detienen en la descripción de la psicología del criminal, las aguafuertes de los veinte tienden a la delimitación de tipos sociales y conductas habituales, rasgos costumbristas que ya no aparecen en la intervención periodística de Arlt de finales de los treinta y los primeros cuarenta, ${ }^{50}$ además de que en esta oportunidad se hace fuerte hincapié, como vimos, en la narrativización y puesta en términos literarios de la información y los cables.

Un caso singular, en este sentido, son las notas que refieren narraciones de espías, textos bastante novedosos en las letras argentinas, y que aparecen en los últimos relatos publicadas por Arlt en El Hogar y Mundo Argentino. En efecto, los asuntos de espionaje y del crimen internacional ocupan una zona muy significativa en las crónicas "Al margen del cable" y redefinen, en este momento, algunos de los aspectos que habían sido centrales en la novelística de Arlt. Personajes que conspiran, sociedades secretas como la "Hermandad de la sangre", ${ }^{51}$ venganza, crimen y traición, son temas que, muy recurrentes en las novelas de Arlt, el contexto de la guerra reafirma, reorienta y vehiculiza en un cruce con los argumentos que le proveen las noticias. Ciertamente, Arlt encuentra en las historias "novelescas" que puede leer a partir de la información internacional, materiales propicios para la expansión narrativa que se aúnan con su preocupación por el conflicto europeo. Porque para Arlt, quien también observa y analiza la literatura (y la evolución literaria) desde el presente de la guerra, el clima

\footnotetext{
${ }^{50}$ Sobre estas cuestiones se indagará en detalle en el capítulo 5.

${ }^{51}$ Arlt, Roberto. "Hermandad de la sangre", en El Mundo, 9 de noviembre de 1939. Al margen del cable.
} 
bélico resulta el que origina y motiva estas historias y el que exige, además, nuevos modos de escritura y nuevas formas de narrar y novelar: ${ }^{52}$ “...cómo pintar hoy, sostiene en un artículo de los años cuarenta-, con la conveniente negrura de eclipse, con el conveniente tono rojizo de lluvia de sangre, el horror de este momento catastrófico". ${ }^{33} \mathrm{O}$, como afirma en "La vela encendida al sol", la guerra y el derrumbe económico y social de ese presente infortunado, es el contexto que exige una nueva definición del género novela, pues si la novela ya no es el lugar donde el hombre va a reconocerse, la aventura y la acción de los personajes son los recursos que, a su juicio, deben suplir esa carencia. ${ }^{54}$

De esta manera, si nos detenemos particularmente en las crónicas de espionaje (y en las de aventura, porque sus argumentos se cruzan), un ejemplo elocuente es "La eterna partida", ${ }^{55}$ una de las últimas notas publicadas por Arlt en El Mundo. Se trata de una historia que, si consideramos los procedimientos, el espacio africano representado y las formas de la narración, bien podría haber ingresado en su libro El criador de gorilas. El texto refiere el paso de una caravana de mercaderes afganos montados en camellos que, encomendados a "Alah" y atravesando exóticos parajes, se dirigen a Dakka. Enseguida relata el enfrentamiento de este grupo con unos soldados del rey de Afganistán, quienes los capturan y descubren que los mercaderes eran, en realidad, “espías del Servicio Secreto alemán”. Con un tono que enfatiza el exotismo del sitio representado y una trama que se organiza en procura de la intriga del lector en torno a los personajes, espías y aventureros, hacia el final del cuento, como en muchas de las notas de Arlt, la crónica se remite a la noticia de la que parte la ficción: "De allí que hoy en las desiertas zonas de Oriente, bajo el control del Eje, nada es más vigilado que los movimientos de las caravanas de mercaderes, cuyos bultos son constantemente revisados por las patrullas de soldados". ${ }^{56}$ A su vez, entre otros artículos que, a propósito de la cuestión, cabe considerar, Arlt refiere las intrigas sobre la presunta actividad pesquera en México, que resulta, en realidad, un ejercicio de espías ${ }^{57}$ y las "Vidas novelescas" del "general Doinahara, conocido por el apelativo del 'Lawrence de

\footnotetext{
${ }^{52}$ Como veremos en el capítulo 6.

${ }^{53}$ Arlt, Roberto. "La tintorería de las palabras", en El Mundo, 15 de junio de 1940. Recopilada en Arlt, Roberto. Aguafuertes porteñas: cultura y política, Op. Cit., p. 227.

${ }^{54}$ Arlt, Roberto. "La vela encendida al sol", en El Mundo, 13 de abril de 1941. Aparece en el diario sin título. Reproducida en Arlt, Roberto. Al margen del cable, Op. Cit.

${ }^{55}$ Arlt, Roberto. "La eterna partida", en El Mundo, 12 de julio de 1942. Al margen del cable.

${ }^{56}$ Arlt, Roberto. "La eterna partida", en El Mundo, Op. Cit.
} 
Manchuria' y la princesa Yisico Kawajima”, 'la Mata Hari japonesa': “aventureros japoneses" y "especialistas en espionaje", como se refiere en el texto. ${ }^{58}$

Pero además de los relatos de espionaje, de las historias de aventuras y de las narraciones sobre el mundo del delito y la criminalidad que se separan del impersonal e informativo registro periodístico, aparece una cantidad de textos como "Contrabandistas de su propia fortuna"59 que pone en términos dramáticos una trama también ligada, hasta cierto punto, al policial y a la aventura. El marco de la guerra es, nuevamente el detonante de los sucesos representados, pues el drama surge en la Italia de Mussolini y en la dificultad de un grupo de personajes para "resguardar su fortuna". El texto, dividido en dos partes (una que se desarrolla en Roma y otra en la frontera), describe, al comienzo, lo que se denomina el "Escenario"; es decir, un espacio del texto en el que, como en las obras de teatro, se dan las indicaciones escénicas anteriores al diálogo. ${ }^{60}$ Con un subterfugio por el cual la inteligencia de los que aparecen con vestimenta blanca supera la barbarie de los innominados "Camisas negras", el joven y el anciano vestidos de blanco logran atravesar la frontera ítalofrancesa con "dos millones de liras en los guardabarros de oro macizo". Aunque en este caso la dramatización refiere, sin duda, un hecho "novelesco" y circunstancial, seguramente imaginado por Arlt, se muestra en un cruce con el género teatral una situación que remite al presente cruento de la guerra. En otras crónicas, además, es sobremanera evidente la puesta en escena del contenido del cable o de la información internacional. Se trata, entonces, de la dramatización de la noticia, no sólo a través de la estructura del diálogo, sino a partir de la escritura de breves piezas de teatro, con detalladas indicaciones escénicas, notación dramática y separación en escenas (en algunas crónicas hay más de tres). Como en el caso de

\footnotetext{
${ }^{57}$ Arlt, Roberto. "Pesca y no de peces", en El Mundo, 25 de noviembre de 1938. Al margen del cable.

${ }^{58}$ Arlt, Roberto. "Vidas novelescas de aventureros japoneses", en El Mundo, 14 de enero de 1939. Al margen del cable. Reproducida en Arlt, Roberto. Al margen del cable, Op. Cit., pp. 136-138. Otros textos a considerar para el tema del espionaje, además de los mencionados son, por ejemplo: "Los persiguen... ipero los necesitan!", en El Mundo, 20 de marzo de 1938 y "Otro Londres para el mismo Carol", en El Mundo, 15 de noviembre de 1938.

${ }^{59}$ Arlt, Roberto. "Contrabandistas de su propia fortuna", en El Mundo, 15 de octubre de 1938. Reproducida en Arlt, Roberto. Al margen del cable, Op. Cit., pp. 109-112.

${ }^{60}$ Así se describe la escena: "Escenario: Una casa de campo de Roma. Confundido entre los árboles, un garage. El garage con su cortina metálica bajada. El interior, revestido de azulejos blancos, violentamente iluminados. Sobre una mesa rústica, un crisol eléctrico. [...] Sentado en la punta de la mesa, un caballero anciano con las mangas de la camisa arremangadas. Algunos pasos más allá, un joven, también de camisa blanca...". Véase: Arlt, Roberto. "Contrabandistas de su propia fortuna", Op. Cit., p. 109.
} 
“¿Quién fue el delator del sindicato de la muerte?”. ${ }^{61}$ Este texto, centrado en algunas de las peripecias que Arlt imagina a partir del crimen norteamericano, es una reelaboración de un cable sobre la captura de una "banda de Filadelfia que cometió doscientos asesinatos". Se trata de una breve pieza de teatro dividida en tres escenas (con descripciones escénicas precisas e indicaciones sobre los personajes), en la que Arlt representa, como en El juguete rabioso, la delación de un traidor; en este caso, Neumayer quien denuncia a Paul Petrillo, el italiano líder del grupo, ante el Departamento de Policía de Filadelfia. Con este texto, entonces y como había sucedido en su pieza dramática El fabricante de fantasmas (1936) en relación a otros personajes de su obra anterior (la Coja, el Jorobado), Arlt redefine en términos teatrales la figura del delator que, con Silvio Astier, aparecía en su primera novela.

Ciertamente, el teatro, el espionaje, los textos de aventuras y las ficciones ligadas al policial y a la criminalidad son géneros y temas que se disputan el interés de Arlt en estas notas y que, también, se inscriben en su literatura de ese entonces, pero interesa sobre todo la construcción de estas breves piezas teatrales porque, en algunos casos, el horror de la guerra presente o por venir se dramatiza para hacerlo más elocuente (en los dos sentidos del término, se hace dramático y se escribe en las formas del drama teatral). Es el caso de "Máscaras en el colegio de Eton", ${ }^{62}$ una crónica a partir de la cual Arlt nos hace espectadores de un diálogo entre dos ingleses (los innominados y por ello paradigmáticos "Él”, y "Ella) que deliberan sobre el hecho de que "se han reunido doce técnicos" para estudiar si los niños de Eton resistirán las máscaras de gases que se planean entregar si fueran necesarias, en una futura escena bélica. Se trata de un diálogo ficticio que se detiene en la descripción del horror y a la vez lo denuncia, pues la falta de asombro de los interlocutores y la apatía acerca de lo comentado no hacen más que evidenciar el espanto que estos personajes, individuos "anestesiados", no pueden ver frente a la catástrofe de una próxima guerra. ${ }^{63}$

${ }^{61}$ Arlt, Roberto. “¿Quién fue el delator del sindicato de la muerte?”, en El Mundo, 18 de junio de 1939. Al margen del cable. Reproducida en Arlt, Roberto. Al margen del cable, Op. Cit., pp. 187-190.

${ }^{62}$ Arlt, Roberto. "Máscaras en el colegio de Eton", en El Mundo, 26 de octubre de 1937. Al margen del cable. Reproducida en Arlt, Roberto. Al margen del cable, Op. Cit., pp. 57-60.

${ }^{63}$ En este sentido, afirma "Ella": "--He visto una fotografía [...] sumamente curiosa. [Un] niño con una careta de gases enchufada en el rostro, jugaba con un oso [...] Sentada junto a él estaba la criada y su perfil me recordaba el leonino perfil de una leprosa, desfigurada por la máscara [...]". Y más adelante, añade fríamente: “-iResistirán? [la careta]". Véase. Arlt, Roberto. "Máscaras en el colegio de Eton”, Op. Cit., p. 58. 
En otras ocasiones y en un procedimiento similar al utilizado con el género dramático, se pone en términos narrativos el horror y de esta manera se logra que aparezca más elocuente en tanto que intento de apelación al lector. Como en "Espíritu guerrero en los niños pequeños", ${ }^{64}$ una nota que, escrita en 1937, como la comentada sobre las "Máscaras en el colegio de Eton", augura y denuncia los desastres (morales, materiales, humanos) de una futura guerra. Los dos textos se focalizan, por lo demás, en los niños y el dramatismo de lo expresado resulta más cruento. En este caso, se parte de un hecho que se refiere sin detalles: "en un país, — no importa dónde [...] - el gobierno se ha propuesto" un plan de estudios cuyo preámbulo "gira constantemente en torno a la militarización infantil”. Enseguida la crónica relata lo que imagina un posible lector que, como Arlt, "deja abandonado el diario" ante esta noticia y "rueda en un torbellino gris". A partir de una división maniquea entre buenos y malos, una alteración de los órdenes de belleza y verdad, y una simplificación hacia lo concreto que también puede leerse en la sintaxis reiterativa de lo expresado, el texto narra cómo un maestro entrena a los niños "de ojos entornados, sin malicia" para despertar su espíritu guerrero: "Les explica qué hermosa es la guerra. Cuán hermosa es la guerra. Qué placer encuentra en ella un hombre que con una granada en la mano le arranca medio cuerpo a otro hombre. Es lo mismo que descuartizar vivo a un pajarito”. Y en la crónica se añade: “¿Y los aeroplanos? Nada hay más bonito que un aeroplano. [...] Los aeroplanos llevan también bombas, bombas grandes. Las bombas son como racimos de uvas. Las bombas se tiran sobre ciudades que están llenas de niños malos y malas mujeres y malos viejos y malos padres. Los niños buenos, en los aeroplanos tiran bombas sobre las ciudades y destruyen a los niños malos". ${ }^{65}$

En otras circunstancias, la posición de la enunciación que organiza, en muchos textos, la deriva escrituraria, es la que revela ese horror. Efectivamente, el punto de vista del cronista, cuando se mezcla y confunde con el orden de lo representado, resulta el que pone en evidencia el terror del presente y muestra el plan siniestro que rodea a los líderes del poder. Es el caso de "Señores: soy el Doble de Hitler"”, ${ }^{66}$ firmado en el diario, "Por la copia, Roberto Arlt". En el lugar donde habitualmente Arlt reproduce el

\footnotetext{
${ }^{64}$ Arlt, Roberto. "Espíritu guerrero en los niños pequeños", en El Mundo, 17 de octubre de 1937. Al margen del cable.

${ }^{65}$ Arlt, Roberto. "Espíritu guerrero en los niños pequeños", Op. Cit..

${ }^{6}$ Arlt, Roberto. "Señores: soy el doble de Hitler", en El Mundo, 4 de diciembre de 1939. Al margen del cable.
} 
cable de noticias se expresa, en cambio y, humorísticamente: "Carta escapada a la censura alemana". En efecto, se trata de una epístola que cruza el humor con el horror, y a partir de la cual Arlt crea la ilusión de presentar a Hitler desde la mirada de quien se halla realmente en el escenario y forma parte de él: en este caso, su doble:

Todos los que rodeamos al Führer, a corto o largo plazo nos sabemos condenados a muerte. [...] Después, o quizás antes de Kannenberg [el cocinero de Hitler], el primer condenado a muerte en el Reich soy yo, segundo "doble" de Hitler. [...]

...un día un compañero mío [...] me dijo:

-Vaya que te pareces al Führer [...]

Algunos días después me examinó un caballero cojo y flaco, de sonrisa perversa, en quien reconocí al señor Goebels. [...] y me dijo:

-De aquí en adelante trabajarás de "doble" de Hitler. Si te niegas, te suprimiremos.

Inmediatamente me nombraron un profesor de urbanidad; me enseñaron a comer [...] a inclinar la cabeza, a saludar al modo nazi, [...] a darles palmaditas en las mejillas a los niños que me traen un ramo de flores. [...] Mi profesor de urbanidad era un caballero con instrucciones precisas, de manera que en cuanto yo me equivocaba una vez más de lo normal, me condenaba a recibir quince azotes en las nalgas. Este sistema punitivo no tardó en surtir sus efectos y pronto aprendí a parodiar a nuestro Führer, que tiene un repertorio de setenta $\mathrm{y}$ cinco gestos $[\ldots]$

Por supuesto, los que me rodean, ignoran casi siempre que yo soy el "doble" de Hitler. Muchos de ellos no lo han visto jamás al Führer. Yo mismo, hablando francamente, no he estado nunca en presencia del Amo. Sé que él existe, que yo existo. ${ }^{67}$

Como puede verse en la cita, es la posición de la enunciación que se confunde con el referente expresado la que revela y da cuenta del horror del régimen nazi. De esta manera el nazismo aparece como una suerte de gestualidad monstruosa y una serie de conductas automáticas y aprendidas. Si por un lado es una "escuela de urbanidad", por el otro se transmuta en el "ejercicio del terror": "Mi profesor de urbanidad era un caballero con instrucciones precisas, de manera que en cuanto yo me equivocaba una vez más de lo normal, me condenaba a recibir quince azotes en las nalgas. Este sistema punitivo no tardó en surtir sus efectos y pronto aprendí a parodiar a nuestro Führer, que tiene un repertorio de setenta y cinco gestos". Asimismo, el texto refuerza y enfatiza la

${ }^{67}$ Arlt, Roberto. "Señores: soy el doble de Hitler", Op. Cit. Se corrigió en la cita la expresión "Führer", que no aparecía de modo homogéneo en El Mundo. 
relación "Amo" y esclavo y describe lo apócrifo y lo falso que rodea al nazismo y lo resguarda de sus enemigos: ni el propio Hitler es tal, Hitler no es uno sino varios, es evidente una proliferación y duplicación desprejuiciada en torno de la figura de Hitler.

Otro enfoque interesante respecto de la enunciación se presenta en "Podía haber preferido un cañoncito", ${ }^{68}$ porque aquí las noticias internacionales son leídas desde una hipotética mirada histórica que se pone en escena en un diálogo teatral. El texto presenta un juego con la perspectiva historiográfica a partir del cual se simula una distancia temporal que no existe y los hechos del presente son reconstruidos por una conversación entre dos personajes (Historiador $1^{\circ}$ e Historiador $2^{\circ}$, situados en el siglo XXIII), que estudian y analizan las "amarillentas páginas" de los diarios del pasado. ${ }^{69}$ Atravesado por un fuerte tono reflexivo, el diálogo imaginario que se transcribe gira en torno de la noticia de una subasta de libros que se ha realizado en París (en 1938, el momento de la enunciación de la crónica), para demostrar el descreimiento del hombre de ese entonces "ante la catástrofe que se avecina" y la fuerza de la literatura en medio del temblor y la sangre de las muchedumbres. De esta manera la perspectiva explicativa (lúcida y reconstructiva) de los dos historiadores que, figurativamente aparecen distanciados del año 1938 para analizarlo, se confunde con la del cronista y coincide con lo que Arlt expresaba en muchas de sus notas. La ficción vuelve elocuente, entonces, ese presente:

HISTORIADOR $1^{\circ}$. - Es toda una civilización que se precipita hacia el suicidio; pero con una particularidad notable. [...]...nadie cree en la próxima catástrofe, a pesar de que la auguran todos los días.

HISTORIADOR $2^{\circ}$. - $-\mathrm{Su}$ afirmación podría resultar audaz a muchos estudiosos.

HISTORIADOR $1^{\circ}$. - Mire; la fotografía de este suelto del año 1938 aparecida en diversos periódicos demostraría que mi tesis es menos audaz de lo que usted piensa. [...] Se combate en diversos países, mueren millares y millares de personas todos los días; en las cárceles se ejecutan a hombres culpables de ser honestos y amar a sus prójimos; las elementales normas de piedad han desaparecido entre los partidos, sexos, clases, razas. [...] Y en estos momentos, en que el suelo de Europa tiembla y sangra y muchedumbres [...] emprenden

\footnotetext{
${ }^{68}$ Arlt, Roberto. "Podía haber preferido un cañoncito", en El Mundo, 23 de marzo de 1938. Al margen del cable. Reproducida en Arlt, Roberto. Al margen del cable, Op. Cit., pp. 87-90.

${ }^{69}$ A este respecto, el cronista, antes de poner en escena la voz parlante de los historiadores, sostiene "Los nietos de nuestros biznietos revisarán los archivos de las bibliotecas [...] y se les verá menear desconcertados la cabeza y fruncir las narices en alarde de pintoresca perplejidad. Hasta me parece [...] escuchar un diálogo que podría desenvolverse de esta manera...”. Arlt, Roberto. "Podía haber preferido un cañoncito", Op. Cit., p. 88.
} 
terroríficos éxodos, en estos momentos, el señor Paul Voute, remata algunos librejos... [...] y los libros no sólo encuentran comprador sino que su costo alcanza proporciones de pequeñas fortunas. Un libro de poemas de Carlos Baudelaire... [...]

HISTORIADOR $2^{\circ}$. - Estos hombres ostensiblemente se habían acostumbrado a la catástrofe y en consecuencia no la percibían.

HISTORIADOR $1^{\circ}$. - Sin embargo debemos admirarnos y felicitarnos de que en un minuto del reloj de los tiempos, el libro de Carlos Baudelaire haya costado en una subasta tanto como un pequeño cañón de campaña... ${ }^{70}$

A propósito de la perspectiva histórica, un caso curioso, aunque en un sentido contrario al anterior, se presenta en la crónica titulada "Cómo se lo comieron a Orlando", de julio de $1939 .{ }^{71}$ En esta oportunidad, la amenaza de Hitler a Polonia y el apoyo de Gran Bretaña a los polacos (en abril del '39 Polonia y Gran Bretaña habían firmado un pacto de ayuda mutua) se evalúa desde una narración histórica por la que Arlt ficcionaliza sobre el momento en que "los Cuatro Grandes" firmaron en 1919 el Tratado de Versalles. Una vez más, entonces, Arlt se refiere al presente de modo sesgado, y es a partir de esa relectura del pasado que se interpretan los sucesos internacionales más candentes del momento, porque, como es sabido, en septiembre de 1939, con la invasión de Hitler a Polonia comienza la Segunda Guerra Mundial. El texto parte de la mirada irrespetuosa de un narrador-cronista-testigo que describe como una puesta escenográfica el "cuadro plástico" que componían los "Cuatro Grandes", Lloyd George, Orlando, Clemenceau y Wilson: “Juro que era un espectáculo gustoso de ver. ¡Vaya si lo era!”, afirma irónicamente la perspectiva del cronista. Si como sostiene Fernando Aínsa, refiriéndose a la "nueva novela histórica latinoamericana", el relato histórico supone muchas veces una postura irreverente frente al pasado donde la historia se relee en función de las necesidades del presente, en la breve nota arltiana, muy anterior a los textos considerados por Aínsa, encontramos procedimientos similares a estos señalados. ${ }^{72}$ De esta manera, la construcción de los personajes históricos revela

\footnotetext{
${ }^{70}$ Arlt, Roberto. "Podía haber preferido un cañoncito", Op. Cit., pp. 89-90.

${ }^{71}$ Arlt, Roberto. "Cómo se lo comieron a Orlando", en El Mundo, 19 de julio de 1939. Aparece sin título en el diario.

${ }^{72}$ Véase: Aínsa, Fernando. "La reescritura de la historia en la nueva narrativa latinamericana" (Cuadernos Americanos, Nueva Época n. 28, México, UNAM). Aínsa, sostiene, en este sentido y refiriéndose a la "nueva novela histórica" surgida en las últimas décadas del siglo viente, que allí la historia se relee en función de las necesidades del presente y que en estos textos se ha eliminado la "distancia histórica" gracias a diversos recursos como la narración en primera
} 
una distancia de la enunciación que los acerca al mundo de la marginalidad y el delito, y evidencia los intereses particulares que desprejuiciadamente y calculadamente sostenían. Se dice de ellos, entre otras cosas, que son "forajidos", "optimistas sobre los dividendos de la masacre", que George tiene "ojitos de boxeador ventajero", Clemenceau "facha de buen vividor", que Wilson es "pudoroso como una institutriz anglosajona" y posee "una estremecedora pudibundez de rigurosa virgen de cincuenta años", y que "el benemérito Orlando" es "alegre, caviloso y sombrío, como un tratante de quesos". También Arlt lee en este episodio, (lo que el discurso de la historia luego ha analizado) el modo en que la salida de la catástrofe de la Primera Guerra Mundial signó las tensiones para el comienzo de una nueva escena bélica; o, más precisamente, cómo de los pretendidos esfuerzos de paz surgen las guerras. Porque no sólo el reparto de tierras dejó descontento a Orlando y a Italia, y de eso nació el fascismo, según Arlt; las discusiones sobre el "corredor polaco" que este texto refiere entre George y Clemenceau, el interés de George de dejar a Alemania esta tierra para que se recupere económicamente, (y es sabido que Alemania era cliente importante para los productos británicos), ${ }^{73}$ la negativa de Clemenceau quien sostiene que el territorio debe ser para Polonia (como finalmente sucedió), muestra no sólo el descreimiento de Arlt sobre los tratados de paz, sino también, la inconsistencia y fragilidad de las alianzas y propuestas de quienes detentan el poder, como sostiene la crónica al final, en un puente con la situación de la actualidad: "Lloyd George sacó, lentamente, la pipa del bolsillo de su saco: miró, sonriendo cachazudamente a Clemenceau, y comenzó a cargarla de tabaco. Había perdido la partida [sobre el corredor polaco], que la Inglaterra del año 1939 defendería como si la hubiera ganado". ${ }^{74}$

persona entre otros que menciona: "La nueva novela histótica ha abolido la 'distancia épica' (Mijail Bajtin) de la novela histórica tradicional [...] En las descripciones de la intimidad de los héroes se los hace bajar de su pedestal", sostiene, entre otras cosas que analiza y que pueden pensarse en relación con Arlt.

${ }^{73}$ Véase, para estas cuestiones: Hobsbawn, Eric. Historia del siglo veinte, Londres, Routledge, 1994; también, Sharp, Alan. The Versailles Settlement: Peacemaking in Paris, 1919, New York, St. Martin's Press, 1991.

${ }^{74}$ Arlt, Roberto. "Cómo se lo comieron a Orlando", Op. Cit.. El texto completo de la discusión sobre el corredor polaco entre George y Clemenceau dice: "Los dos forajidos se reunieron, como dejé contado, en la casa de Clemenceau. [...] Perfectamente. Volvamos a nuestra historia, que quedó anclada en la biblioteca.

Felicitó Lloyd George a su compinche por la hermosa tierra que tenía. Luego sentóse junto a una entrante de la ondulada mesa, y clavando sus ojillos celestes de boxeador ventajero en la cínica facha del otro viejo dijo a boca de jarro:

— ¿Qué hacemos con Polonia? 
De esta manera, las notas de Arlt en "Tiempos Presentes" y "Al margen del cable" no sólo parten de las noticias internacionales y los cables de noticias y enfrentan la enunciación periodística al desplegar otras formas de referencialidad, y cuestionar, así, algunos de los modos de la certeza y la verdad de la prensa; también construyen textos que se acercan, en sus temas, géneros y tópicos a la literatura de Arlt del momento. Porque en estas notas, las narraciones de aventuras, los textos de espionaje y las ficciones del mundo de la criminalidad se reparten el interés arltiano con breves piezas de teatro. Relatos marginales, circunstanciales, fortuitos, en algunos casos; en otros, la ficcionalización o la puesta en términos dramáticos de los grandes sucesos de la política internacional, permiten una lectura del presente donde el horror de la guerra se revela en su elocuencia y se expone de modo evidente, monstruoso y brutal. Periodista escritor, literato cronista, estas notas manifiestan dos zonas de la producción de Arlt cuyo entramado se entreteje con los mismos géneros, rasgos y procedimientos en los años finales de la década del treinta y los primeros cuarenta.

Clemenceau carraspeó, escupió a la chimenea, y se quedó mirando al otro, que continuó:

- Mi gobierno cree que vamos a tener dificultades futuras si desposeemos a los alemanes de su ruta terrestre hasta Prusia del Este.

Clemenceau dejó vagar una sonrisa burlesca por su facha de buen vividor, y dijo:

— ¿De manera que para Inglaterra son importantes el millón y medio de alemanes que viven en la Prusia del Este?

El otro contestó:

- Sí, lo son.

- Pues no olvide, el señor ministro, que más importante es para los 30 millones de polacos que viven en Polonia tener libre acceso al mar Báltico, que para un millón y medio de alemanes de la Prusia del Este, tener una continuidad territorial al territorio nacional alemán.

- ¿Y las explotaciones de madera de los alemanes?

Si Lloyd George era brutal, Clemenceau no lo era menos. Estalló furibundo:

- Al diablo las explotaciones de madera. Los alemanes de la Prusia del Este transportarán su madera por el mar. ¿Para qué Satanás necesitan el corredor? El corredor pertenece a Polonia, y, además, los alemanes no podrán construir ningún 'corredor' a través del 'corredor' polaco.

Lloyd George sacó, lentamente, la pipa del bolsillo de su saco: miró, sonriendo cachazudamente a Clemenceau, y comenzó a cargarla de tabaco. Había perdido la partida, que la Inglaterra del año 1939 defendería como si la hubiera ganado". Arlt, Roberto. "Cómo se lo comieron a Orlando", Op. Cit. 


\section{Historias infames y ficciones criminales}

Desde fines del siglo XIX hasta los años treinta puede decirse que en la Argentina la cuestión de la criminalidad aparece en diferentes discursos como tema (literario, ensayístico, periodístico, de conocimiento científico y legal) y como problema. A las teorías de la ciencia y a las prácticas jurídicas que, con fuerte impronta y hegemonía positivista, tratan de explicar y controlar el sentimiento de inseguridad provocado por la inmigración y el vertiginoso aumento de la población, ${ }^{1}$ se suma el éxito de las historias de bandidos y las crónicas policiales de los diarios. Como analiza Lila Caimari, el fin de siglo "es el momento de florecimiento de un periodismo del crimen cuyos rasgos venían perfilándose desde hacía al menos dos décadas”. Es más, en los años veinte, cuando se inicia la "era de la prensa popular urbana", las potencialidades del periodismo sensacionalista alcanzaron su máxima realización. En este sentido, "el diario que emblematiza esa era es Crítica", una publicación de fuerte tono amarillista y popular, que "hizo del crimen y del delito uno de los ejes centrales en la construcción de un nuevo modelo de crónica periodística". ${ }^{3}$ También desde la prensa, diferentes escritores y periodistas inscriben distintas representaciones del delincuente en

\footnotetext{
${ }^{1}$ Pensamos, entre otros ejemplos que pueden mencionarse, en libros de José Ingenieros como Criminología, La simulación de la locura, La simulación en la lucha por la vida; también, La neurosis de los hombres célebres, Las multitudes argentinas, La locura en la historia y Los simuladores de talento de José María Ramos Mejía, y textos como Locura y crimen de Alejandro Korn.

${ }^{2}$ Véase: Caimari, Lila. "Pasiones punitivas y denuncias justicieras. La prensa y el castigo del delito en Buenos Aires (1890-1910), ponencia presentada en el Simposio "Construcciones impresas. Diarios, periódicos y revistas en la formación de los Estados nacionales en América Latina y Estados Unidos (1820-1920)", organizado por la Universidad de San Andrés, el 16 y 17 de mayo de 2002, p. 2; y, de la misma autora: Apenas un delincuente. Crimen, castigo y cultura en la Argentina, 1880-1955, Buenos Aires, Siglo XXI editores, 2004, p. 199. Sobre el diario Crítica y la presencia del delito en sus páginas, véase, Saítta, Sylvia. "Por el mundo del crimen", en Regueros de tinta. El diario Crítica en la década de 1920, Buenos Aires, Editorial Sudamericana, 1998, pp. 189-209.
} 
la sociedad, como por ejemplo, los textos de Fray Mocho (pseudónimo de José S. Álvarez), antecedentes, en muchos sentidos, de las aguafuertes de Arlt. En este marco, las respuestas al problema de la delincuencia difieren y también las estrategias discursivas y literarias que ensayan los diferentes actores de ese proceso.

El mundo del delito es propio a la literatura de Roberto Arlt desde los comienzos de su producción. Tiene un precedente en el trabajo que Arlt realiza durante 1927 como cronista de la página de policiales de Crítica. Se trataba, como Arlt afirmará después de un tiempo, de redactar para una sección de policiales "la nota carnicera y truculenta": “Crimen, fractura, robo, asalto, violación, venganza, incendio, estafa y hurto que se cometía, y allí estaba yo. Incluso estaba obligado a hacer un drama de un simple e inocuo choque de colectivos. ¡A lo que obliga a uno la necesidad del puchero!”. ${ }^{4}$ Desde 1928, con su ingreso al diario El Mundo, toda una zona de las aguafuertes porteñas se concentra en torno a algunas de las conductas sociales ligadas a la delincuencia urbana en Buenos Aires: estafadores, "coimeros", "pungistas", facinerosos, son tipos identificables que recorren los textos. ${ }^{5}$ En esta oportunidad, es a partir de una exploración y derivación del cuadro de costumbres como género que las crónicas bosquejan el mapa ciudadano y social y efectúan, al mismo tiempo, una crítica de esa misma sociedad que se diseña. Finalmente, debe mencionarse que también en las novelas, y ya desde El juguete rabioso, la primera de ellas, se manifiesta, como se sabe, una tendencia similar hacia la representación del mundo del delito, de la criminalidad y la marginalidad; sus personajes, asimismo, (Erdosain, Astier, el Astrólogo, el Rufián Melancólico, Haffner), individuos "excéntricos", locos, revolucionarios, fascistas, conspiradores, farsantes, torturados, traidores, asesinos, delirantes, inventores, están en muchas oportunidades al margen de la sociedad, contra la sociedad y en los límites borrosos de una ley que los cuestiona $\mathrm{y}$, frecuentemente, ellos mismos buscan cuestionar. A esto se debe, en ciertos casos, la potencia de la literatura de Arlt, una literatura del delito. ${ }^{6}$

\footnotetext{
${ }^{3}$ Saítta, Sylvia. "Los trabajos y los días", en El escritor en el bosque de ladrillos. Una biografía de Roberto Arlt, Buenos Aires, Sudamericana, 2000, p. 53.

${ }^{4}$ Arlt, Roberto. "Manía fotográfica", en El Mundo, 25 de agosto de 1930. Reeditado en: Arlt, Roberto. Aguafuertes porteñas: cultura y política, Buenos Aires, Losada, 1992, pp. 94-98.

${ }^{5}$ Una serie de notas muy significativas al respecto son las recopiladas en: Arlt, Roberto. Tratado de la delincuencia. Aguafuertes inéditas. Recopilación y prólogo de Sylvia Saítta, Buenos Aires, Biblioteca Página/12, 1996.
} 
Este capítulo describe una serie de pasajes en su prosa (periodística y ficcional) en torno a la delincuencia ya que, si bien el mundo del delito ha sido una constante de la ficción de Arlt, en los años treinta se reformulan sus modos de representación en las notas de "Tiempos Presentes" y "Al margen del cable" y en los relatos policiales y de espionaje que aparecen hacia el final de su producción. No se trata, ciertamente, de textos cuya presencia, como los cuentos fantásticos, resuena en abierta divergencia con su literatura anterior a 1932, pero sí de nuevos rasgos y modalidades que en el período que nos ocupa introducen una forma inédita en el tratamiento de esos temas y materiales.

En efecto, dentro del extenso corpus de las crónicas “Al margen del cable”, en ese subgrupo que constituye las notas ligadas al policial, al espionaje y a la criminalidad al que nos referimos someramente en el capítulo anterior, interesa reflexionar sobre las que podrían considerarse en muchos sentidos historias infames; es decir, crónicas narrativas sobre delincuentes singulares, personajes del delito, que curiosamente se acercan a las biografías de la Historia universal de la infamia de Borges. ${ }^{7}$ En las revistas El Hogar y Mundo Argentino, en cambio, Arlt publica cuentos de criminales y de espías, más cercanos al policial y a la literatura de espionaje desde el punto de vista de los modos de narrar y de los rasgos genéricos, inéditos en su producción anterior, que

${ }^{6}$ Véanse, para la cuestión de la excentricidad en Arlt: Sarlo, Beatriz. "Roberto Arlt, excéntrico". Liminar de Arlt, Roberto. Los siete locos-Los lanzallamas, edición crítica coordinada por Mario Goloboff, México, FCE, Colección Archivos, 2000. Sobre el fascismo en la obra de Arlt: Amícola, José. Astrología y fascismo en la obra de Arlt, Buenos Aires, Weimar ediciones, 1984. También puede consultarse el trabajo de Elsa Drucaroff, quien considera que algunos textos de Arlt sostienen el orden de clases y el orden de género impuesto por la sociedad: Drucaroff, Elsa. Arlt, profeta del miedo, Buenos Aires, Catálogos, 1998. Para otros de estos aspectos en las novelas de Arlt: Masotta, Oscar. Sexo y traición en Roberto Arlt, Buenos Aires, Corregidor, 1998; Guerrero, Diana. Arlt. El habitante solitario, Buenos Aires, Catálogos Editora, 1986; Aira, César. "Arlt", en Paradoxa. Literatura/Filosofía, n 7, Rosario, Beatriz Viterbo Editora, 1993; y, finalmente, las apreciaciones de Josefina Ludmer en su libro El cuerpo del delito. Un manual, Buenos Aires, Libros Perfil, 1999.

7 Es bien sabido que los cuentos que integran Historia universal de la infamia se editan primero en la Revista Multicolor de los Sábados, el suplemento cultural del diario Crítica que dirigían Borges y Ulyses Petit de Murat y que, con ciertas diferencias, aparecen en libro en 1935, en la colección Megáfono (una colección de biografías), de la popularísima editorial Tor, un sello cuyo desprestigio se basaba en la mala calidad de sus ediciones. En 1954, con motivo de sus obras completas, Borges publica nuevamente el libro con algunas variantes. Sobre el pasaje y le reelaboración de estos textos de un "soporte a otro", véase el cuidadoso estudio de Annick Louis: Louis, Annick. Jorge Luis Borges: oeuvre et manoeuvre, Paris, L'harmattan, 1997.Véase, asimismo, la edición en CD de esta revista: Crítica. Revista Multicolor de los Sábados. 1933-1934, Edición a cargo de Nicolás Helft, Buenos Aires, Fondo Nacional de las Artes, 1999. 
ponen en juego nuevas formas del relato. ${ }^{8}$ En el capítulo se indaga, entonces, este desplazamiento en el Arlt de los treinta, sus diferencias con los textos previos y los modos de representación del crimen y la delincuencia en la época.

\section{Historias infames}

Leedme con atención. Voy a narrar una sabrosa historia ${ }^{9}$ Roberto Arlt

Si un rasgo diferencia ya desde la primera lectura las "aguafuertes de la delincuencia" y algunas de las crónicas de "Tiempos presentes" y "Al margen del cable" vinculadas con el crimen y con la infamia, es que en el internacionalismo de estas últimas no aparecen, como en las notas sobre Buenos Aires, tipos urbanos y sociales identificables definidos desde una crítica irónica, incisiva, desenfadada y mordaz. Es el "costumbrismo crítico" de las crónicas porteñas, ${ }^{10}$ el que se desvanece en estos nuevos artículos arltianos; una clase de textos en los que los tipos descriptos del submundo del delito en la ciudad incitaban, además, una lectura cuestionadora de la sociedad en general. ${ }^{11}$ Ciertamente, a diferencia de las aguafuertes, toda una zona de las notas de "Tiempos Presentes" y "Al margen del cable", se explaya en "historias sabrosas" en torno al delito que se construyen a partir del cable de noticias; la materia a narrar por la crónica resulta, entonces, un asunto inesperado y sorprendente sobre el mundo del crimen que se desvincula, ya que el referente deja de ser Buenos Aires, del

\footnotetext{
${ }^{8}$ Algunos de estos cuentos fueron recopilados en 1994 en el libro titulado con el nombre de uno de los relatos: El crimen casi perfecto, donde se recogen textos que van desde 1937 a 1940. Arlt, Roberto. El crimen casi perfecto, Edición de Omar Borré, Buenos Aires, Clarín-Aguilar, 1994.

9 Arlt, Roberto. "Batallita naval por un cabaret florante", en El Mundo, 28 de septiembre de 1939. Al margen del cable.

${ }^{10}$ Véase, a este respecto: Varela, Fabina, Inés. "Aguafuertes porteñas: Tradición y traición de un género", en Revista de Literaturas Modernas, Universidad Nacional de Cuyo, Facultad de Filosofía y Letras, ${ }^{\circ} 32$, Mendoza, 2002

${ }^{11}$ Como sostiene Sylvia Saítta, esa lectura que cuestiona a la sociedad en su conjunto en muchos casos tiende a desdibujar el límite (lábil para Arlt) que separa a los "pilletes" y "malandras" de las "personas honradas". Véase: Saítta, Sylvia. "Prólogo", en Arlt, Roberto. Escuela de la delincuencia, Selección y prólogo de Sylvia Saítta, Montevideo, Ediciones de la Banda Oriental, pp. 7-10.
} 
localismo de la crítica social — que no tiene sentido cuando las anécdotas trascurren en otros escenarios-, y cuyo anclaje temporal es, en muchos casos, sólo el punto de partida de la expansión ficcional. Son historias de impostores, asesinos profesionales, contrabandistas, estafadores, traidores, conspiradores que se cuentan con algún sensacionalismo y sin truculencia; casos-relatos donde el hecho delictivo, "llamativo o curioso" y, muchas veces, anecdótico y circunstancial les da carácter de pertenencia (en la perspectiva que asume el cronista) para ser historias a contar.

El parentesco con Historia universal de la infamia es claro. Por una parte, porque como Borges, Arlt escribe un tipo de textos cercano al fait divers, y Borges también roza, aunque excede el fait divers desmontándolo y desplegándolo hacia la historia $^{12}$ (una historia peculiar la que se propone, por cierto, de hombres infames, y de ahí su ruptura, que lo distancia sobremanera en este punto de Arlt). Es claro, asimismo, el parentesco temático: simuladores e impostores, traidores, gangsters norteamericanos y orientales, asesinos a sangre fría, los infames recorren los textos de Arlt, y sus crónicas también internacionales o universales (en Arlt porque muchos de sus asuntos despuntan del conflicto bélico mundial) aparecen, reiteradamente, cercanas a la biografía: se trata de sucintas y caricaturescas biografías narradas, una vida en pocos trazos.

De todas maneras cabe aclarar que la biografía y, especialmente, la biografía y los escritos histórico ficcionales o de curiosidades sobre criminales, parece ser un tipo de texto de cierto interés en la época. ${ }^{13}$ Así puede verse, por ejemplo, en un recorrido por la Revista Multicolor de los Sábados, el suplemento cultural del diario Crítica; aunque, claro está, esto también puede ser atribuible a las inclinaciones y gustos personales de Jorge Luis Borges, uno de los directores de la publicación. En sus páginas no sólo se encuentran las biografías de las Vidas imaginarias de Marcel Schowb, que el

${ }^{12}$ Como analiza Annick Louis, los textos de Historia Universal de la infamia, publicados en Crítica rozan, aunque exceden, el fait divers. Véase: Louis, Annick. Jorge Luis Borges: oeuvre et manoeuvre, Op. Cit. Puede consultarse, también: Sarlo, Beatriz. Borges, un escritor en las orillas, Buenos Aires, Ariel, 1993: y, de la misma autora, "Borges: crítica y teoría cultural" y "La literatura de crímenes", en Escritos sobre literatura argentina, Buenos Aires, Siglo XXI editores, 2007.

${ }^{13}$ Como sostiene Lila Caimari, ya desde fines del siglo XIX es frecuente la aparición en el periodismo argentino del "caso célebre", género de larga tradición en Francia que opera en ese entonces como difusor de maneras modernas de representar al criminal Véase: Caimari, Lila. "Malhechores ocultos y perseguidores modernos" (1880-1910), en Apenas un delincuente, Op. Cit. 
propio Borges y la crítica acusaron como fuente de sus relatos infames, ${ }^{14}$ sino que esta especie genérica también es muy recurrente en los artículos, cuentos y demás intervenciones aparecidos allí. Historias de criminales, gángsters norteamericanos, asesinos, delitos excepcionales y temas sorprendentes, muchos relatos de este tipo se inscriben en los distintos números en términos de biografías narradas $\mathrm{y}$, en reiteradas oportunidades, con un tono semejante al de los cuentos de Borges. Es el caso de algunos textos donde se cruza la ficción y la historia, como en "Rebelión de los leprosos" de Ulyses Petit de Murat, (centrado en el clima de conspiración y vandalismo de Bakú, previo al comunismo), un escrito anónimo sobre "Un auto de fe", $\mathrm{y}$, entre otros, por ejemplo, "Espías en la Roma imperial”, de José Tuntar, ficción que enfoca el Imperio Romano desde la delación y el espionaje. ${ }^{15}$ También es el caso de aquellos que se detienen en personajes del delito internacional o local (pero sobre todo internacional), que se destacan por alguna particularidad infrecuente (bandidos, contrabandistas, asesinos, impostores), ${ }^{16}$ narraciones biográficas entre las que pueden mencionarse las “Aventuras de Morgan el viejo" de Raúl González Tuñón, "Siete generaciones de canallas" y "Fuga de dos graves sotanas", de Carlos Pérez Ruiz; "El Borbón aventurero" de Héctor Delcobre, "N.N. El artillero", de Miche Jacoby y algunos textos que, fácilmente asimilables a los gustos impulsados por el diario Crítica, aparecen atravesados por un fuerte tono sensacionalista, como el referido "al criminal más famoso de los últimos cincuenta años", Jack el destripador, y el dedicado a "Baker, el ambicioso de la silla eléctrica", entre otros que pueden destacarse. ${ }^{17}$

\footnotetext{
${ }^{14}$ Los textos de Marcel Schowb que se publican en la Revista Multicolor de los Sábados son los siguientes: "Los Señores Burke y Hare (Asesinos)" (n 4, 2 de septiembre de 1933, p. 1), "El capitán Kid" ( $n^{\circ} 12,28$ de octubre de 1933, p. 5), "La muerta que escuchó la queja de la hermana enamorada" ( $\mathrm{n}^{\circ} 21,30$ de diciembre de 1933, p. 7), "El incendiario" ( $\mathrm{n}^{\circ} 25,27$ de enero de 1934, p. 8) y "Petronio no se abrió las venas" (n 33, 24 de marzo de 1934, p. 7). Para un análisis de las operaciones que en la introducción de estos textos se realizan en la Revista Multicolor de los Sábados, Véase: Louis, Annick. "La destruction d'un recueil", en Jorge Luis Borges: oeuvre et manoeuvres, Op. Cit., pp. 131-140.

${ }^{15}$ Véase: Petit de Murat, Ulyses. "Rebelión de los leprosos", en Crítica. Revista Multicolor de los Sábados, n 1, 12 de agosto de 1933, p. 2; Anónimo. "Un auto de fe", en Crítica. Revista Multicolor de los Sábados, n 8, 30 de septiembre de 1933, p. 2; y Tuntar, José. "Espías en la Roma imperial", en Crítica. Revista Multicolor de los Sábados, ${ }^{\circ}$ 15, 18 de noviembre de 1933, p. 3.

${ }^{16}$ Baker, "el ambicioso de la silla eléctrica", se destaca, por ejemplo, por participar de un "puesto de honor en el templo del crimen"; véase: Larsen, Luis W. "Baker, el ambicioso de la silla eléctrica", en Crítica. Revista Multicolor de los Sábados, n 14, 11 de noviembre de 1933, p. 1.
} 
Volviendo a Arlt, ya desde las primeras notas de la sección "Tiempos Presentes", y en coincidencia con los textos de Borges de su "historia universal", puede leerse cierto interés en las singularidades y en la "capacidad de inventiva" en torno al delito. Se trata de "El chantaje en los restaurantes norteamericanos" y "Cazadores de ambulancias", dos artículos vinculados con el crimen en Estados Unidos, un tema al que las crónicas vuelven una y otra vez. En efecto, Arlt escribe sobre Al Capone, su captura, su liberación, sobre el fiscal Thomas Dewey, el "Ángel Bueno", y sobre las distintas bandas de criminales de Nueva York y sus cabecillas, muchos vinculados, en mayor o menor medida, con los "asuntos" de Capone: Míster James J. Hines, Tony Stralla, Arthur Flegenheimer "Diamond", en "pequeño Augie", Dutch Schultz y Louis Bouchalter, entre otros. ${ }^{18}$ Toda esta serie de textos, que recuerda, en algunos casos, y tiene un vínculo temático con "El proveedor de iniquidades Monk Eastman", el relato borgeano sobre "las pandillas de Nueva York", ${ }^{19}$ se inicia con "El chantaje en los

${ }^{17}$ Las notas en cuestión son: Gónzález Tunón, Raúl. "Aventuras de Morgan el viejo”, en Crítica. Revista Multicolor de los Sábados, n 1, 12 de agosto de 1933, p. 2; Pérez Ruiz, Carlos. "Siete generaciones de canallas", en Crítica. Revista Multicolor de los Sábados, n², 19 de agosto de 1933, p. 2; Pérez Ruiz, Carlos. "Fuga de dos graves sotanas", en Crítica. Revista Multicolor de los Sábados, n 3 3, 26 de agosto de 1933, p. 2; Delcobre, Héctor. "El Borbón aventurero", en Crítica. Revista Multicolor de los Sábados, n 8, 30 de septiembre de 1933, p. 6; Jacoby, Miche. "N.N. El artillero", en Crítica. Revista Multicolor de los Sábados, n 55, 23 de agosto de 1934, p. 4; Preston, Juan B. "Jack el destripador", en Crítica. Revista Multicolor de los Sábados, $\mathrm{n}^{\circ}$ 11, 21 de octubre de 1933, p. 8; y Larsen, Luis W. "Baker, el ambicioso de la silla eléctrica", Op. Cit. Cabe destacar que en la Revista Multicolor de los Sábados, también aparecen biografías de escritores, de directores de cine y de variados personajes no vinculados a la infamia. Pueden mencionarse, entre otros ejemplos: "Jack Dempsey íntimo" de Jim Tully ( ${ }^{\circ}$ 5, 9 de septiembre de 1933, p. 8) y los textos de Ulyses Petit de Murat "El frío delirio de Lautreamont" ( $\mathrm{n}^{\circ}$ 7, 23 de septiembre de 1933, p. 5), "La muerte de Poe" ( $\mathrm{n}^{\circ} 12,28$ de octubre de 1933, p. 3), "La muerte de Proust" (n 18, 9 de diciembre de 1933, p. 8) y "La muerte de Baudelaire" ( $\mathrm{n}^{\circ}$ 24, 20 de enero de 1934, p. 2). Para un estudio sobre la revista véase: Saítta, Sylvia. "Recorrido", en Crítica. Revista Multicolor de los Sábados, Edición completa con CDRom, Op. Cit.

${ }^{18}$ Las crónicas a las que nos referimos son: "Del imperio del crimen" (en El Mundo, 20 de noviembre de 1937. Al margen del cable), "Está loco o se hace el loco Al Capone" (en El Mundo, 12 de febrero de 1938. Al margen del cable), "Los defendidos de Mister Clarence" (en El Mundo, 17 de marzo de 1938. Al margen del cable), "A que no se le escapa" (en El Mundo, 4 de septiembre de 1938. Al margen del cable), “¿Qué vas a hacer ahora, Al Capone?”, (en $E l$ Mundo, 31 de marzo de 1939. Al margen del cable. Reeditada en: Arlt, Roberto. Al margen del cable. Crónicas publicadas en El Nacional, México, 1937, 1941, Recopilación, introducción y notas de Rose Corral, Buenos Aires, Losada, 2001, pp. 147-150), "Batallita naval por un cabaret flotante” (Op. Cit.), ¿Dónde comprará los tomates Louis Bouchalter?” (en El Mundo, 13 de octubre de 1939. Al margen del cable), "Reunión familiar en casa de Al Capone" (en El Mundo, 17 de noviembre de 1939. Al margen del cable). Volveremos sobre algunas de estas notas.

${ }^{19}$ Borges, Jorge Luis. "El proveedor de iniquidades Monk Eastman", en Historia universal de la infamia, Buenos Aires, Emecé, 1954. 
restaurantes norteamericanos". ${ }^{20}$ Aunque cabe aclarar que, si bien hay un parentesco temático en el interés de Borges y Arlt por el crimen norteamericano (y en el gusto por las biografías infames, como decíamos antes), la cronología en los dos autores es diferente. Mientras que en Borges se retrotrae al pasado, y de allí la historia se construye, en Arlt tiene que ver con el registro del presente. Tampoco al narrador borgeano lo entusiasma Al Capone, como puede leerse en "El atroz redentor Lazarus Morell”, cuando lo opone a su excepcional personaje: “Al Capone y Bugs Moran operan con ilustres capitales y con ametralladoras serviles en una gran ciudad, pero su negocio es vulgar. Se disputan un monopolio, eso es todo...". ${ }^{21}$

En "El chantaje a los restaurantes norteamericanos", entonces, la primera de las dos crónicas que interesa considerar aquí, Arlt se propone describir la "redonda perfección" "geométrica" que alcanza "la industria del crimen y derivados" en "el territorio de la Unión". El artículo, que pone el énfasis en el cuidado y la "originalidad" del procedimiento y la "invención" delictiva, relata, luego, en un arco temporal que va desde 1929 (cuando ese acto fue cometido por primera vez por un "caballero de honorable aspecto") hasta 1937 (el presente de Arlt), los modos en que opera la estafa de los "claims racket"; es decir, los estafadores de los restaurantes, esa "fauna rozagante" que para recibir una compensación económica, inventa, en "original[es] formas de actividad criminal" haber descubierto "en las sopas, en las tortas, en los guisos, en las cremas y en las verduras de los restaurantes toda clase de objetos extraños: tachuelas, pedazos de vidrio, trozos de cuero, ratones y cucarachas". Algo similar aparece en "Cazadores de ambulancias":

Días pasados, ojeando el "Esquire", correspondiente al mes de marzo de 1937 [...] encontré una caricatura genial. Esta caricatura representa una cáfila de bribonazos cuarentones de caras de blisteca, el sempiterno cigarro colgando del vértice de los labios y la galera requintada sobre la frente. [...] Todos yacen apretujados y orondos en el interior de una ambulancia. [...]

He aquí frente a una banda de "ambulante chasers", es decir, de cazadores de ambulancias, título tan extraño y nuevo, que me impulsó a estudiar el asunto y tratar de reducirlo a una especie de artículo en el

\footnotetext{
${ }^{20}$ Arlt, Roberto. "El chantage en los restaurantes norteamericanos", en El Mundo, 15 de marzo de 1937. Tiempos Presentes.

${ }^{21}$ Borges, Jorge Luis. "El atroz redentor Lazarus Morell”, Op. Cit.
} 
cual historiar uno de los más recientes aspectos de la criminalidad judicial de los Estados Unidos. ${ }^{22}$

Pícaros que orondos yacen en la ambulancia, tema sorprendente a "estudiar" e "historiar", este artículo, como el anterior sobre los restaurantes, se refiere a una estafa inusual que es materia y tema para la crónica-narración de Arlt; en este caso, el engaño que grupos de abogados "a la caza" de accidentes en la calle infligen a las compañías aseguradoras por daños inexistentes. De esta manera, los dos textos ponen el acento en el procedimiento delictivo y su originalidad: es la capacidad de inventiva y la "perfección geométrica" de la actividad criminal lo que seduce a un cronista bastante complaciente con la picardía y la suspicacia de los estafadores retratados. Cabe destacar, asimismo, que la elección arltiana de la curiosidad en torno al delito, como tema o asunto de una historia sabrosa a contar, se acerca de alguna manera al gesto de Borges en "El espantoso Redentor Lázarus Morell” y en sus otros textos infames. Porque, como sostiene el narrador en el relato borgeano, lo que vuelve al "espantoso Redentor" digno de figurar en una historia universal es su método singular, su inteligencia del delito: "Los caballos robados en un Estado y vendidos en otro fueron apenas una digresión en la carrera delincuente de Morell, pero prefiguraron el método que ahora le aseguraba su buen lugar en una Historia Universal de la infamia. Este método es único". ${ }^{23}$ En este sentido, Annick Louis sostiene, a propósito de los cuentos de Borges: "Il ne s'agit pas d 'une revendication morale ou esthétique du crimen, son intérêt porte sur ce qui est susceptible de devenir poétique, ou plutôt, ce qui peut devenir sujet de récit". ${ }^{24}$ Esto último que Louis encuentra en los cuentos de Borges, es decir, el interés en lo que puede volverse tema de un relato, es pertinente, asimismo, para el caso de Arlt.

Ciertamente, y además, Arlt promete, como veíamos en el epígrafe, "historias sabrosas". En "Batallita naval por un cabaret flotante", ${ }^{25}$ un cronista exhortativo — "Leedme con atención" - interpela a su lector, con un uso curioso del vosotros que ya no utilizaba en sus aguafuertes porteñas, ${ }^{26} \mathrm{e}$ instala en las primeras líneas la

${ }^{22}$ Arlt, Roberto. "Cazadores de ambulancias", en El Mundo, 18 de marzo de 1937. Tiempos Presentes.

${ }^{23}$ Borges, Jorge Luis. "El atroz redentos Lázarus Morell”, Op. Cit., p. 23.

${ }^{24}$ Louis, Annick. Jorge Luis Borges: oeuvre et manoeuvre, Op. Cit., p. 48.

${ }^{25}$ Arlt, Roberto. "Batallita naval por un cabaret flotante", Op. Cit.

${ }^{26}$ En este uso del vosotros, como en la reutilización del modernismo en la literatura de Arlt en los treinta, su poética parece volver hacia atrás o retroceder en relación con lo que el propio Arlt 
expectativa de un relato que promete deleitar: "Voy a narrar una sabrosa historia". Inmediatamente, el texto se refiere a Tony Cordero Stralla, "flor del hampa neoyorquina"; de modo que lo sabroso de la historia a narrar, se resuelve en la biografía y el relato sobre este villano singular: ex contrabandista de alcohol, jugador profesional, prohombre de la escuela de Capone", que "se crió poco menos que en un muladar y entre tachos de basura transcurrió su tierna infancia" (semejante al Billy de Kid borgeano). El sujeto, refugiado ahora (en el presente de la crónica) en las "doradas arenas de Santa Mónica", ha instalado en el mar un cabaret flotante y rechaza de modos inusitados "los asaltos" de la intervención de la autoridad judicial ("piojosa pandilla de piratas", según Stralla) que lo mueve a retirarse de allí y "ha sitiado" su buque. Este es el anclaje del texto en la noticia que Arlt reescribe a partir de una nota leída en Life, y la escena cómico-picaresca (y "sabrosa") que el cronista presenta como una "batallita naval", lo es por la inadecuación entre la situación referida y la perspectiva de la enunciación que la equipara (humorísticamente) a una acción bélica.

Si una historia resulta sabrosa es "La vida extraña de Lilian Valerie Smith que simulaba ser un coronel británico". ${ }^{27}$ Se trata de una de las primeras biografías que aparecen en la columna de "Tiempos Presentes" y una de las más significativas en relación con las historias infames; es la vida de una impostora. El texto se remonta a un pasado cercano y comienza con la descripción de una foto del coronel Leslie Bligh Barker en medio de la alta sociedad: un "gentleman" que luce en su traje "las condecoraciones de dos órdenes del imperio británico" y que participa en la cacería del zorro. "Nadie sospechaba -agrega el cronista- que el coronel Barker no es coronel y tampoco hombre". Luego de la trascripción narrativa de la imagen fotográfica, referida como vista ("Yo he visto una foto del coronel"), única descripción, indirecta y metonímica, del personaje, ${ }^{28}$ la nota se centra casi exclusivamente en el relato de las sucesivas escenas de la impostura y sólo al final aparece una referencia del texto al presente del cronista: el coronel ha sido nuevamente encarcelado. De este modo el artículo construye, como el anterior sobre Tony Cordero Stralla, una presentación

ya había hecho como cronista y narrador.

${ }_{27}$ Arlt, Roberto. "La vida extraña de Lilian Valerie Smith que simulaba ser un coronel británico", en El Mundo, 29 de marzo de 1937. Tiempos Presentes.

${ }^{28}$ Son palabras de Silvia Molloy quien sostiene que en las historias infames de Borges la descripción de los personajes es "indirecta y metonímica" y que por eso sus héroes siempre son máscaras de sí mismos. Véase: Molloy, Sylvia. Las letras de Borges y otros ensayos, Rosario, Beatriz Viterbo Editora, 2000, p. 34. 
externa del personaje que desconoce y deja de lado la psicología; importan, sobre todo, los distintos momentos de la simulación de Barker o de Smith. Es la historia de una vida aglutinada en pocos rasgos y en circunstancias similares que se repiten en el tiempo. Asimismo, lejos de cualquier crítica social, y muy lejos, por cierto, de alguna representación realista, cómo las primeras aguafuertes de Arlt, este texto, de impacto sensacionalista, pareciera construirse en torno al interés por relatar una historia que seduzca. "Curioso destino el suyo y repetido" refiere el cronista hacia el final del artículo, a propósito del coronel Barker o Leslie Smith, y, para explicar tal repetición, su relato se desplaza, reescribe e intercala una narración (otra biografía breve) sobre una nueva mujer, también simuladora: se trata en esta ocasión del personaje "que la historia conoce bajo el nombre de 'El alférez Doña Catalina de Erauso'”. Y si bien su vida es, según Arlt, "más rica en episodios de bravura", la crónica equipara y nivela en la impostura y en la simulación, los dos casos: la anécdota "extraña" y "curiosa" de la Smith y las aventuras lejanas en el tiempo de un alférez-mujer que vivió por el $1600 .^{29}$

Otro personaje que el cronista presenta como un impostor se encuentra en una historia situada en Oriente, un espacio privilegiado por Arlt para la aparición de conspiradores, espías, ${ }^{30}$ traidores $^{31}$ y simuladores, como lo muestra su recurrencia en las crónicas "Al margen del cable". Se trata del sujeto "de conducta inquietante" que se piensa "ascenderá al trono" como el nuevo Dalai-Lama de Tibet, "el peligrosísimo aventurero húngaro Ignacio Timoteo Trebistch Lincoln (el Lincoln es agregado") -dice

\footnotetext{
${ }^{29}$ Cabe destacar que Thomas De Quincey escribió una versión de la vida de la llamada "Monja Alférez Catalina de Erauso" (1592-1650) de quien se publican sus memorias en París mucho tiempo después de su muerte, en 1829.

${ }^{30}$ Véase, a este respecto, entre otros textos: Arlt, Roberto. "Vidas novelescas de aventureros japoneses", en El Mundo, 14 de enero de 1939. Al margen del cable. Reeditada en: Arlt, Roberto. Al margen del cable, Op. Cit., pp. 136-138.

${ }^{31}$ Véase: Arlt, Roberto. "El enemigo número uno de Chiang-Kai Shek", en El Mundo, 16 de mayo de 1939. Al margen del cable. En este caso Arlt apela a la ficción biográfica para hacer patente algunos aspectos de la situación internacional: la traición de unos a otros ("traición y contratraición"), las intrigas, secretas, las luchas de poder, el enfrentamiento entre Wang Ching'-Wei y Chiang Kai-Shek. El biografiado es Wang Ching-Wei, el ex ministro chino que el texto presenta como "uno de los más conspicuos traidores de China" en la red de alianzas que se tejen en relación con el conflicto mundial. En pocos rasgos, como en el caso de "la Smith", se condensa su vida. Wang Ching-Wei, que "se educó en el Japón" y participó de las pandillas de terroristas chinos, se "inició en la carrera política intentando, en el año 1909, asesinar al príncipe regente de China; aventurero, revolucionario, "guerrillero general de bandidos", en el presente, "fascista notorio, decidido partidario del Japón, amigo de Alemania, "resueltamente" está decidido "a entregar China a Japón".
} 
Arlt-, "que vive hoy bajo el nombre de abate Chao-Chung". ${ }^{32}$ La noticia despunta, de este modo, en la biografía sucinta de este "pícaro" que la crónica presenta como un simulador: Ignacio Timoteo Trebisth, "Un pillastre de siete suelas" que en "el Tibet misterioso" ha hecho conspicuo su nombre", es un "judío converso al catolicismo" que "ha hecho un viaje rotario por casi todas las religiones hasta terminar fundando un centro budista en Shangai". Así, también en este caso, Arlt lee en los "insólitos" hechos del presente la semejanza con un capítulo de novela donde se ocultan intereses de poder. Un juego de conspiraciones y maniobras políticas que se teje en el Tibet colocaría a "Timoteo" en ese espacio estratégico en el marco de la conflagración mundial. “Cerremos éste que parece y no es un capítulo de novela", sostiene al final el cronista.

Más allá del símil temático a propósito de los textos sobre impostores y simuladores (que reenvía a "El impostor inverosímil Tom Castro" y "El tintorero enmascarado Hákim de Merv", de Borges), de los gánsters norteamericanos y orientales y de los "asesinos desinteresados", que también recorren las notas "Al margen del cable", como se verá, los artículos de Arlt comparten varios rasgos con las ficciones borgeanas, y puede leerse alguna simetría en ciertos aspectos de la narración. Relatos despersonalizados y "sin interés psicológico", los textos de Borges presentan caricaturas de personajes, escenas emblemáticas y pictóricas que privilegian una historia a narrar y "condensan una vida" en pocos rasgos, como sostiene el prologuista;"33 ajenos al realismo, asimismo, los cuentos de Borges toman distancia, según sostiene Annick Louis, de dos formas de la relación entre delincuencia y literatura en la época: el relato como delación que implica una condena implícita o explicita del delincuente, y el estudio psicológico. ${ }^{34} \mathrm{Si}$ consideramos, finalmente, la perspectiva de la enunciación sobre los personajes, por momentos paródica, como bien analiza Sylvia Molloy; ${ }^{35}$ en otros, el registro irónico y la instauración de una distancia literaria ante lo real, ${ }^{36}$ la resuelve en un gesto de humor y cierta simpatía hacia los criminales de su historia

${ }^{32}$ Arlt, Roberto. "El Tibet tiene un nuevo Lama", en El Mundo, 21 de febrero de 1940. Al margen del cable.

${ }^{33}$ Borges, Jorge Luis. "Prólogo la primera edición", en Historia universal de la infamia, Op. Cit. Para Daniel Balderston esta condensación y perspectiva pictórica tiene que ver con el influjo de la literatura de Stevenson en la obra de Borges. Véase: Balderston, Daniel. "El cuento breve. Selección, exageración, caricatura”, en El precursor velado: R.L. Stevenson en la obra de Borges, Buenos Aires, Sudamericana, 1985.

${ }^{34}$ Louis, Annick. Jorge Luis Borges: oeuvre et manoeuvre, Op. Cit., p. 144.

${ }^{35}$ Molloy, Sylvia. Las letras de Borges, Op. Cit.

${ }^{36}$ Alonso, Amado. "Borges narrador", en Sur, n 14, Buenos Aires, noviembre de 1935. 
universal que también se reencuentra en las crónicas arltianas, pocos años posteriores. Borges cuestiona así los límites del delito, y esto también, con otros matices, se retoma en Arlt. ${ }^{37}$

Además de pícaros a los que se les atribuye la inteligencia en el crimen (de "pillastres" “interesantísimos", esa "fauna rozagante" 38 en la que se admira el procedimiento criminal), interesa indagar la perspectiva del cronista de las notas "Al margen del cable" en relación con la representación de los personajes del delito. En "Dónde comprará los tomates Louis Bouchalter"39 el enfoque es claro. El texto, centrado en el caso de Bouchalter, realiza, en el comienzo, un recorrido por todos los cabecillas del crimen norteamericano y su vida efímera como tales, desde "el bueno de Al" y su "relumbrante efigie" (por Al Capone) "que había matado a dos compinches suyos después de haber cenado con ellos", y mister Hines:

Lo encarcelaron a Capone y sobrevino el reino de los cielos hasta que el "pequeño" Augie comenzó a trabajar por su cuenta en Brooklyn. Feneció el "pequeño" y sobre el cielo rojo de Nueva York brilló efímeramente la estrella del piernudo Diamond, largo y elegante. Tan elegante que en su banda contaba con un joven de buena familia.

Arthur Flegenheimer "Diamond", no solo aspiraba a comercializar el contrabando de seda, alcohol y cocaína, sino que soñaba con imponer en su banda una especie de espíritu monástico, como el que se podía descubrir en la hermandad de los Caballeros Teutones en los añejos tiempos del medioevo. Como era lógico, el piernudo Diamond feneció también, como la blanca margarita.

\footnotetext{
${ }^{37}$ Como se sabe, los cuentos de Historia universal de la infamia, en tanto que reescritura de historias ajenas también ponen en escena el problema de la creación literaria, la cuestión de la originalidad, el juego con la versión, la lectura como reescritura, el cruce de géneros y sus límites porosos, aspectos no desarrollados aquí porque no se vinculan directamente con las hipótesis de este trabajo. Véase, a este respecto, además de la bibliografía mencionada: Sarlo, Beatriz: "Una poética de la ficción", en Saítta, Sylvia. (directora). El oficio se afirma. Historia crítica de la literatura argentina (dirigida por Noé Jitrik), Buenos Aires, Emecé, 2004; y, de la misma autora: Borges, un escritor en las orillas, Op. Cit. Asimismo, también puede analizarse en este libro de Borges el cruce entre la cultura universal y la criolla, o, más precisamente, el acriollamiento de la tradición universal en las historias de bandidos internacionales, y la universalización de lo criollo en "Hombre de la esquina rosada". Para ello, puede consultarse: Olea Franco, Rafael. "Hacia una nueva estética", en El otro Borges. El primer Borges, Buenos Aires, FCE, 1993.

${ }^{38}$ Arlt, Roberto. "El chantaje a los restaurantes norteamericanos", Op. Cit.

${ }^{39}$ Arlt, Roberto. “¿Dónde comprará los tomates Louis Bouchalter?”, Op. Cit.
} 
Después de Diamond apareció en el mercado Dutch Schultz. Dutch Schultz lo dejó tuerto a Joe Rock y para indemnizarlo del ojo perdido le dejó a Rock el renglón del contrabando de aguardiente, mientras él se reservaba el de la cerveza". ${ }^{40}$

Un recorrido por nombres que proliferan (Arthur Flegenheimer "Diamond") como prolifera el delito, ${ }^{41}$ el fragmento citado, que Arlt compara con una "historia" "de los patriarcas de un Nuevo testamento" ("Bueno, -sostiene-, parece que uno estuviera historiando el orden de todos los patriarcas de un Nuevo testamento") está atravesado por la ironía y se despega en múltiples connotaciones, sugerencias y guiños al lector atento: Al es bueno, pero su cualidad está en matar, la vida efímera de un maleante se compara como una flor blanca, el éxito del bandido "Diamond" lo hace brillar como una estrella en el cielo rojo de Nueva York. Enseguida la crónica se concentra en el sujeto-tema de la noticia que origina este artículo, de la que sólo se dan los datos al final: la policía de los Estados Unidos busca a Louis Bouchalter, prófugo desde hace dos años:

Después de Schultz [...] vinieron muchos hombres...

En esos mismos tiempos hubo un hombre que personalmente iba al mercado de su barrio casi todas las mañanas y escogía sus tomates y "spaguettis". Muchas veces le acompañaba su esposa, que también era prudente en la selección de la mercadería con que ornamentaba su mesa. Él era un hombre serio, al que probablemente Dios debía mirar con buenos ojos, porque no perdía sus noches en dancings, ni se embriagaba, y en cuanto a hablar, se mordía la lengua antes de pronunciar una palabra inútil. Era tan persuasivo, sin embargo, que en Nueva York, entre el gremio de los panaderos y fabricantes de ropa, hubiera sido dificultoso encontrar, a partir del año 1926, un audaz artesano que se atreviera a no pagarle un impuesto misterioso a nuestro ciudadano embellecido con el sonoro nombre de Louis Bouchalter.

Eliminado el piernudo y monástico Diamond, Louis, el casero y doméstico ciudadano, se interesó por el contrabando de narcóticos [...] Hubo muchos hombres que quisieron dedicarse a este honorable comercio, pero todos perecieron violentamente. ${ }^{42}$

\footnotetext{
${ }^{40}$ Arlt, Roberto. “¿Dónde comprará los tomates Louis Bouchalter?”, Op. Cit.

${ }^{41}$ También proliferan otros nombres en las crónicas "Al margen del cable" como el de Ignacio Timoteo Trebitch Lincoln, que también vive bajo el nombre de "abate Chao- Cheng".

${ }^{42}$ Arlt, Roberto. “¿Dónde comprará los tomates Louis Bouchalter?”, Op. Cit. Énfasis nuestro.
} 
La cita está atravesada por la ironía, y es por lo que el discurso irónico insinúa pero no dice acerca de Bouchalter que el texto refiere su carácter de criminal y de asesino. Asimismo, lo no dicho, pero sugerido con humor irónico, instala y mantiene en la perspectiva de la enunciación cierta simpatía hacia el personaje, enfoque que se repite en muchas de estas notas. Louis Bouchalter, un "ciudadano" que se dedica a un "honorable comercio", resulta un sujeto "muy persuasivo", tanto que no hay quien se niegue a su "impuesto misterioso"; todas estas, expresiones sujetas, como se ve claramente, a una doble valoración. Hombre "serio", asimismo, la crónica también introduce en su discurso (y parodia) la voz del otro: "probablemente Dios debía mirar[lo] con buenos ojos, porque no perdía sus noches en dancings, ni se embriagaba, y en cuanto a hablar, se mordía la lengua antes de pronunciar una palabra inútil." Pero si un rasgo sobresale en esta presentación del delincuente es su vinculación con el aspecto inusitado que da título a la nota y desdibuja, al mismo tiempo, en tanto que cualificación insólita e inesperada, su imagen de criminal: Louis Bouchalter, casero y doméstico, el hombre que selecciona cuidadosamente los tomates y los spaguettis.

En efecto, en casi todas las "sabrosas historias" del mundo criminal, la enunciación oscila entre dos movimientos: por una parte, una visión irónica hacia el maleante y su actividad delictiva (el "bueno de Al" es quien había matado a dos compinches, ${ }^{43}$ el "amigo y comprensivo Tony" se "sacrifica" por sus semejantes instalando un cabaret al que asiste una "distinguida clientela" donde se ofrece droga, mujeres, alcohol y juegos clandestinos, ${ }^{44}$ una "honorable matrona" estafa a un restaurante, ${ }^{45}$ Deibler y Elliot, "excelentes tipos de pequeños burgueses, afectos a la

\footnotetext{
43 “Arlt, Roberto. “¿Dónde comprará los tomates Louis Bouchalter?”, Op. Cit.

${ }^{44}$ Dice el cronista, al respecto: "Para trasladarse al REX, una lancha a motor, 'Juanita', por módica tarifa los conducía hasta el cabaret flotante [...] en cuya entrada podía leerse este pitagórico aforismo: 'Pay your dollar ald take your choice'.

En el interior del salón se descubrían hasta cuarenta mesas para jugar a la ruleta y a los dados y si usted no era aficionado a despilfarrarse los dólares podía arriesgar unos euproniqueles al juego de 'el bandido con un brazo' u otras inocentes desplumaderías. Sólidos malandrinos con visera de hule verde, cuidaban del orden y la armonía.

Pero allí no se jugaba sólo. ¡Admiremos al comprensivo Tony! Si a su cliente no le gusta el juego, Tony le ofrece muchachas eficientes, si al cliente no le gustan las muchachas, Tony le ofrece licor, y si finalmente, no le gusta el licor, le ofrece cocaína. De manera que hay que ser muy exigente o sumamente inmoral para no encontrarse a gusto a bordo del "REX". Arlt, Roberto. "Batallita naval por un cabaret flotante", Op. Cit.

${ }^{45}$ Arlt, Roberto. ““El chantaje en los restaurantes norteamericanos”, Op. Cit.
} 
sacrosanta costumbre del ahorro", son temibles verdugos y asesinos, ${ }^{46}$ etc); por otra parte, $\mathrm{y}$, paralelamente, un enfoque que desestabiliza y desarticula una imagen coherente del delincuente y su condición criminal al vincularlo con una actividad o un aspecto inusual, extraño e inesperado de su biografía. Tony Stralla que instala un cabaret flotante y resiste a la autoridad quijotescamente (según la enunciación de la nota, como hemos visto), Bouchalter "doméstico" interesado en la selección de sus tomates y spaguettis, los verdugos Monsieur Deibler, "profesional de la guillotina" y míster Elliot, "técnico de la silla eléctrica", ambos conspicuos asesinos y "abastecedores del infierno" que, con "gustos semejantes" eran aficionados igualmente a la floricultura y cultivadores "concienzudos" de su jardín. ${ }^{47}$

Es claro, en este sentido, "El bandido y la mariposa", ${ }^{48}$ pues el sujeto de la nota, además de ser un asesino fugitivo de la Isla del Diablo, caracterizado por su aspecto monstruoso y semi-lombrosiano (acá reaparece otro de los monstruos de Arlt) se distingue por cazar mariposas y este es el rasgo inusitado que lo singulariza y entra en tensión con su cualidad de monstruo-bandido en tanto que representación inicial del personaje que el texto retoma, expone y desarticula. Como en muchos otros casos que se reiteran en las notas “Al margen del cable”, la crónica biográfica comienza con la

${ }^{46}$ Arlt, Roberto. "Se necesita un par de verdugos", en El Mundo, 3 de enero de 1940. Al margen del cable. Esta nota biográfica es escrita por Arlt a partir de la noticia de la muerte de Monsieur Deibler y Míster Elliot, dos famosos verdugos, y también está atravesada por la ironía, como se ve en los siguientes fragmentos: "Evidentemente, tenían gustos semejantes. [...] Ambos eran verdugos oficiales de dos grandes países; ambos, paralelamente, podrían ser propuestos como ejemplos de costumbres morigeradas. A pesar de que la literatura picaresca situó siempre a los verdugos en los más ínfimos cuchitriles y codeándose con la más rufianesca de las sociedades, los caballeros de quienes me ocupo, monsieur Deibler y mister Elliot constituían excelentes tipos de pequeños burgueses, afectos a la sacrosanta costumbre del ahorro. [...]

La única diferencia que existía entre Deibler profesional de la guillotina, y Elliot, técnico de la silla eléctrica, consistía en que Elliot jamás veía al condenado. 'Soy un electricista', alegaba el buen hombre al embolsar en su faltriquera los ciento cincuenta dólares que le reportaba cada ejecución. [...] Sus módicas entradas se vieron aumentadas con los ingresos que le proporcionaban otros Estados donde era invitado a ejercer su profesión, pues se le reconocía su eficiente mano. [...]

A más simpático se llevaba la ventaja monsieur Deibler. [...] tenía más estampa de conferenciante de la Sorbona que de cortador de cabezas...[...]

Mister Elliot, criado desde jovencito en el temor de Dios, pertenecía a la congregación religiosa de su parroquia. El conocimiento de las ciencias físicas, a través de la electricidad, no había llegado a convencerlo al punto de considerar letra muerta la palabra de los profetas. Y aunque diferente del secretamente soberbio monsieur Deibler, ambos se encontraban en una pasión: el amor a las flores". Véase: Arlt. Roberto. "Se necesita un par de verdugos", Op. Cit.

${ }^{47}$ Arlt, Roberto. "Se necesita un par de verdugos", Op. Cit.

${ }^{48}$ Arlt, Roberto. "El bandido y la mariposa", en El Mundo, 30 de marzo de 1938. Al margen del cable. 
descripción de una fotografía de René Belbenoit, quien después de permanecer días en el territorio de "la Unión", ha reunido dinero con la venta de sus "maravillosos insectos" $\mathrm{y}$, como un aventurero, se ha escapado. Este es el vínculo del texto con el presente de la noticia. En la fotografía, el bandido resulta un monstruo cercano a la imagen cinematográfica de Frankenstein: “observándole, se le encontraba cierto siniestro parecido con Boris Karloff, el Boris Karloff de 'Frankenstein', la misma cara larga y populosa, con el mentón terminado en punta de higo, y el pelo alto sobre la frente ancha y la boca diezmada y como sumida en un silencio contagiado por las sepulturas"; y el retrato de este hombre, "el penado 46.635", que un fotógrafo aventajado tomó "enmarcado" con un fondo de biblioteca, es equiparada por el cronista a un cuadro "modernista" de su admiración: "El bandido y la paloma".

El resto de la nota, atravesada por oposiciones (monstruo-biblioteca, "finas manos del entomólogo"-garras violentas del asesino", bandido-mariposa, asesinato y “oficio dulce y pinturero"), tiende a desestabilizar esta primera caracterización del monstruo-delincuente y a asimilar la noticia con el cuadro que el cronista recuerda del bandido y la paloma. ${ }^{49} \mathrm{Si}$ tenemos en cuenta que desde fines del siglo XIX y de la mano de teorías positivistas como la de Lombroso, que circularon en la Argentina, se tiende a identificar al criminal con una fisonomía particular, ${ }^{50}$ y que la utilización periodística

${ }^{49}$ Arlt establece la comparación entre el cuadro sobre el bandido y la paloma y el caso de René Belbenoit, como puede verse en el siguiente fragmento: "Un fotógrafo aventajado retrató el busto de este hombre, denominado el número 46.635, sobre un fondo de biblioteca; y la revista parisiense "VU" le [sic] presentó como el primer bandido que consiguió fugarse de la Isla del Diablo. Un bandido cuya cabeza se recorta sobre el lomo redondo y cuadrado de libros diferentes, es un cuadro singular. Tan singular que me recuerda otro cuadro que admiré en un álbum de pintores modernistas titulado: 'El bandido y la paloma'. Era sobre un fondo cavernario de cemento armado, un presidio titánico. En un fondo rectangular, una cabeza mongólica, dos manos tremendas y asesinas, musculosas y vastas como las raíces de un árbol. Pertenecen al asesino. Y las manos del asesino, nudosas, inmensas, acarician con ternura la curva de cobalto del cuello de una paloma. El espectador se queda cavilando. También esta cabeza del penado 46.635 de boca desdentada, de frente alta, de pelo renegrido sobre unas orejas saltonas, y un pañuelo de cuadros escoceses cruzado sobre el pescuezo flaco, esta cabeza de asesino condenado a 75 años de presidio, enmarcada por una biblioteca y con una reminiscencia de Frankenstein, le deja a uno barajando pensamientos. Véase: Arlt, Roberto. "El bandido y la mariposa", Op. Cit.

${ }^{50}$ En la Argentina, el discurso científico de fines del siglo XIX y principios de los años veinte se propone una descripción y clasificación del criminal y tiene incidencia en la literatura de la época. En este sentido, sostiene Oscar Terán: "Sobre bases positivistas y darwinianas, y en la encrucijada de la frenología y la psiquiatría, el lombrosismo había creado en el último cuarto del siglo XIX una "naturaleza delictiva" como criterio preventivo contra la delincuencia. La teoría se refería a la existencia de caracteres físicos, morfológicos y somáticos que permitirían definir el tipo clásico del criminal nato, constituido por un individuo cuyos estigmas aparecerían 
del lombrosismo (que estaba desacreditada en el mundo académico), aunque se volvió más permisiva, sobrevivió en la prensa de los años 1920 y $1930,{ }^{51}$ es interesante destacar que este tipo de representación, que se reitera en la figuración de Arlt, se muestra allí como insuficiente. La descripción física del monstruo se combina con otra cosa; el hecho de cazar y ofrecer mariposas, es la acción extraordinaria del delincuente que lo convierte en sujeto del comentario-relato-biografía de Arlt: René Belbenoit "con la delicadeza de un gorila tuberculoso" "abría las tapas de su caja mágica" y ofrecía algo "precioso" y "fantástico”, “iMariposas! Mariposas extrañas de los trópicos. Mariposas que él, durante meses y meses, de su fuga por la selva ecuatorial, coleccionó para vender en la ciudad". De esta manera, si bien su fisonomía es la de un criminal, el énfasis de la crónica en su acción inesperada apunta a desdibujar o parcializar esa condición delictiva (de la cual el texto sostiene un curioso silencio, luego de la primera descripción) y, también cuestiona, así, indirectamente, algunos de los parámetros físicos, culturales y periodísticos para referirse al criminal: ${ }^{52}$ René Belvenoir, aventurero en tierras lejanas, el bandido que está junto a la mariposa se define en el texto por ese "oficio dulce y pinturero".

De esta manera, por sobre cualquier crítica irónica, se impone cierta complacencia de la enunciación sobre los sujetos del enunciado, un acercamiento a lo pintoresco de los antihéroes y sus particularidades extraordinarias. Esto marca una

cristalizados en rasgos antropomórficos y fisiognómicos. 'El delincuente -había escrito Lombroso- ofrece frecuentes asimetrías craneales y faciales, sobre todo en los violadores y en los ladrones [...]; y comparado con los locos y los seres sanos, tiene la cara más larga, un mayor desarrollo de los apófisis zigomáticos y de la mandíbula, la mirada sombría, el cabello espeso y negro, sobre todo en los salteadores de caminos'". Terán, Oscar. "Estudio preliminar", en José ingenieros: pensar la nación. Antología de textos, Buenos Aires, Alianza bolsillo, 1986, p. 51. El texto de Lombroso citado por Terán es: Lombroso, C. L'Homme criminel, Paris, 1895, pp. 260-261.

${ }^{51}$ Véase: Caimari, Lila. "Ladrones y policías, 1920 y 1930", en Apenas un delincuente, Op. Cit. En este trabajo sostiene, además Caimari: "a diferencia de la crónica roja de 1890, las notas del período son mucho más policiales que criminológicas. Pero de vez en cuando [...] el periodista apelaba al latente sentido común lombrosiano del lector. [...] Es que la hipótesis del rostro humano como clave interpretativa sobrevivió en la prensa mejor que ninguna otra idea científica sobre la especificidad del delincuente. [...] Justamente porque la idea del rostro y del cráneo era cuestionada y había perdido respetabilidad en el mundo científico, su utilización periodística se volvió más permisiva”. (p. 205)

${ }^{52}$ A este respecto, cabe destacar que en "Los defendidos de Míster Clarence", un texto sobre un abogado que defiende a terribles delincuentes y, entre ellos, a Al Capone, el que se describe desde el aspecto fisonómico como un criminal es el abogado. Este resulta así, el infame que con apariencia de honesto e hipocresía se atreve a afirmar que "lo importante es la moral". Véase, Arlt, Roberto. "Los defendidos de Míster Clarence", Op. Cit. 
diferencia con las aguafuertes porteñas, también socarronas e irónicas; porque si bien por momentos el humor y la ironía sugieren cierta simpatía con los tipos retratados, las notas sobre Buenos Aires se vuelven siempre una crítica aguda del espacio social del que surgen. ${ }^{53}$ Asimismo, y, en tanto cuadros de costumbres que tienden a la delimitación y a la identificación de la actividad delictiva en la ciudad, funcionan, en un punto, indirecta o directamente, como instrumentos de delación, lo que implica cierta condena (implícita o explícita) del delincuente y de la sociedad; hay allí, entonces, en las aguafuertes, una veta realista en Arlt. Ni crítica realista, ni psicología: como en Borges, son los "sabrosos" delitos internacionales los que se elige narrar en las notas "Al margen del cable", son los sujetos-criminales descriptos sucintamente y en pocos rasgos, en cuya simpatía recae la enunciación, los que, por un rasgo excéntrico que los particulariza resultan dignos de una crónica ficcional o de una sucinta biografía. ${ }^{54}$

\footnotetext{
${ }^{53}$ Una aguafuerte significativa, a este respecto es "El crimen en el barrio". En este texto el crimen "diluye el aburrimiento de esas almas sin distracciones", y por ello, es un hecho extraordinario que saca a los sujetos de la ciudad del lugar en donde están. Suceso movilizador, el crimen le permite al cronista caracterizar la psicología de distintos individuos de Buenos Aires, en tanto se muestran los efectos, las reacciones y las miserias de estos personajes del barrio ante el hecho "excepcional". Véase: Arlt, Roberto. "El crimen en el barrio", en El Mundo, 25 de enero de 1929. Recopilada en: Arlt, Roberto. Tratado de la delincuencia, Op. Cit., pp. 22-24.

${ }^{54}$ Cabe destacar, que en el marco de las notas internacionales de Arlt, hay una serie de biografías y biografiados donde el vínculo crónica, relato y delincuencia implica una fuerte delación, aunque ya no referida a ciudadanos porteños sino a los grandes sucesos de la conflagración mundial. Son los textos sobre los "Violentos personajes de hoy". En este caso las historias no son "sabrosas" ni la enunciación simpatiza con los personajes. Efectivamente, estas biografías distan de la complicidad del cronista-narrador $\mathrm{y}$, por su temática vinculada a la violencia de los sucesos de la conflagración mundial, no se relacionan con las borgeanas. Se trata del delito en relación con la guerra y el espionaje internacional. De este modo, para Arlt, en este momento, el sujeto criminal y la destrucción, aparecen, sobre todo, ligados a la guerra. Cabe destacar como las más significativas: una crónica sobre el creador del Lanzallamas, "La muerte de Gabriel Szakatch" (en El Mundo, 25 de Julio de 1937. Tiempos Presentes. Reeditada en Arlt, Roberto. Al margen del cable, Op. Cit.) y "El Doctor Pavelitch emulo de Rocambole" (en El Mundo, 22 de julio de 1942. Al margen del cable), un texto donde la política internacional y el presente son leídos a través del biografiado, sujeto de la nota (Pavelitch) como una intriga folletinesca, inverosímil, al estilo de Rocambole. También vinculadas con estas crónicas, pueden mencionarse: "Violentos personajes de hoy" (en El Mundo, 7 de julio de 1942. Al margen del cable), "Este es otro Rashid" (en El Mundo, 9 de enero de 1942. Al margen del cable), "El pesador de monedas" (en El Mundo, 13 de marzo de 1937. Tiempos presentes), "Se necesita un par de verdugos" (en El Mundo, 3 de enero de 1940. Al margen del cable), "Monsieur Deibler, el verdugo galante" (en El Mundo, 11 de noviembre de 1937. Al margen del cable), "Qué hacemos con tanto poder y tanta plata" (en El Mundo, 10 de abril de 1940. Al margen del cable).
} 


\section{Ficciones criminales}

\section{El policial de Arlt en los años treinta}

En la década del cincuenta, Rodolfo Walsh fija el inicio de la narrativa policial en la Argentina en 1942, con Seis problemas para don Isidro Parodi.$^{55}$ Diez años antes, Alfonso Reyes, en una reseña sobre el mismo libro, anticipaba esta periodización y situaba ese inicio también hacia $1940 .{ }^{56}$ En estudios más recientes, Jorge Lafforgue y Jorge Rivera parten de esta datación pero para recuperar "otras instancias anteriores y posteriores", también configuradoras en el caso de la Argentina, en un trabajo que rastrea cuidadosamente publicaciones y testimonios vinculados al policial. ${ }^{57}$ En efecto, si bien es en la década del cuarenta cuando aparecen cuentos como "La muerte y la brújula" y "El jardín de senderos que se bifurcan", es decir los textos ficcionales más representativos de Jorge Luis Borges ${ }^{58}$ Seis problemas para don Isidro Parodi, de Borges y Adolfo Bioy Casares en colaboración, los relatos de Manuel Peyrou, la novela policial de Adolfo Bioy Casares y Silvina Ocampo, Los que aman, odian, y las colecciones "prestigiosas" del "El séptimo círculo", entre otros hitos que es preciso

\footnotetext{
${ }^{55}$ Walsh, Rodolfo. "Noticia sobre cuentos policiales argentinos", en Diez cuentos policiales argentinos, Buenos Aires, Hachette, 1953. Reproducido en, Lafforgue, Jorge y Rivera, Jorge B. Asesinos de papel. Ensayos sobre narrativa policial, Buenos Aires, Colihue, 1996, pp. 247-248.

${ }^{56}$ En la reseña sobre Seis problemas para don Isidro Parodi, Reyes escribe: "Con este libro, la literatura detectivesca irrumpe definitivamente en Hispanoamérica, y se presenta ataviada en el dialecto porteño". Véase: Reyes, Alfonso. "El argentino Jorge Luis Borges", en Obras completas, México, FCE, 1959, tomo IX, p. 308. El artículo de Reyes apareció por primera vez en un periódico en 1943. (Para más datos véase: Fernández Vega, José. "Una campaña estética. Borges y la narrativa policial", en Variaciones Borges, $\mathrm{n}^{\circ} 1$, 1996. Reproducido en http://borges.uiow.edu/ftp/ub1/policial.pdf. Cabe destacar que también Donald Yates coincide en la periodización de Reyes y de Walsh. Véase: Yates, Donald. "The Spanish American Detective Story", Modern Lenguaje Journal, May 1956.

${ }^{57}$ Véase: Lafforgue, Jorge y Rivera, Jorge B. Asesinos de papel. Ensayos sobre narrativa policial, Buenos Aires, Colihue, 1996. Puede consultarse, asimismo: Lafforgue, Jorge. "Prólogo", en Cuentos policiales argentinos, Selección y prólogo de Jorge Lafforgue, Buenos Aires, Alfaguara, 1997, pp. 11-22.

${ }^{58}$ En contra de los que dicen que la incursión borgeana en el género es esporádica, Sergio Pastormerlo sostiene que lo verdaderamente importante es la operación crítica (y de la crítica) de Borges sobre el policial, que se desarrolló durante dos décadas y que sus ficciones son un dato más. Véase, a este respecto: Pastormerlo, Sergio. "Dos concepciones del género policial. Una introducción a la narrativa policial borgeana", en Literatura policial en la Argentina. Waleis, Borges, Saer, Serie Estudios e investigaciones, $\mathrm{n}^{\circ} 32$, Facultad de Humanidades y Ciencias de la Educación, UNLP, 1997.
} 
mencionar, es en los años previos cuando se preparan y establecen las condiciones para ese advenimiento, y por ello el período resulta, además, un momento que cobra relevancia para el estudio del género en la Argentina: en los treinta el policial se constituye en una zona donde confluyen y se intersectan de un modo peculiar el circuito popular masivo, las lecturas e intereses de la clase popular y del nuevo público ampliado y, ciertas operaciones sobre el género que, de la mano de Borges, se inscriben también en la alta cultura literaria y tienen en el período una función central. Porque ciertamente, es en este momento que Borges lee y reseña cuentos policiales, escribe notas sobre el género en las revistas Sur y, con profusa asiduidad, en El Hogar, dirige el suplemento del diario Crítica, con fuerte impronta de relatos policiales, como se verá, y publica en 1936 "El acercamiento a Almotásim", —el que ha sido considerado su primer texto policial一; todas ellas, intervenciones que no pueden desvincularse de lo que sucede en su obra y en su crítica en los años cuarenta. ${ }^{59}$ Inscripto entonces entre dos circuitos de circulación, promoción y difusión que en ese tiempo aparecen más o menos imbricados entre sí, el culto y el popular, ${ }^{60}$ el policial en los años treinta debe pensarse en sus vínculos y relaciones con distintas zonas y contextos que intentaremos delimitar de modo somero para analizar las ficciones policiales de Roberto Arlt.

Porque justamente, como otros autores nacionales que también incursionan en el género, ${ }^{61}$ entre los años 1937 y 1942, Arlt publica en las revistas El Hogar y Mundo Argentino una serie muy variada de relatos policiales que describen un pasaje o un arco

\footnotetext{
${ }^{59}$ En efecto, como sostiene Sergio Pastormerlo, es muy fuerte el gesto de ruptura borgeano al pasar del más prestigioso de los géneros, la poesía, que había ejercido en sus primeros libros, a uno sin prestigio literario: "Cuando Borges se introdujo en el policial en los primeros años de la década del 30 estaba entrando en un género cuyo prestigio literario en la Argentina no era dudoso: era evidentemente nulo". Y añade: "Borges abandonó la más legítima de las prácticas literarias para entrar en un género que estaba ubicado, según las creencias y los valores literarios de la época, en una especie de subsuelo de la legitimidad literaria -el infierno de la "subliteratura", sólo que "ejerció la ruptura" "como si no hubiera ruptura". Pastormerlo, Sergio. Borges crítico, Buenos Aires, FCE, 2007, pp. 69-77.

${ }^{60}$ Podría decirse que gracias a la intervención borgeana, esos circuitos, en los cuarenta, aparecen separados.

${ }^{61} \mathrm{Si}$ nos atenemos a la producción nacional deben señalarse, además de los textos de Roberto Arlt y de las "reivindicaciones borgeanas del género", de los que nos ocuparemos más adelante, El enigma de la calle arcos, la "primera gran novela argentina de carácter policial" que aparece publicada como folletín en el diario Crítica, bajo el pseudónimo de Sauli Lostal, los cuentos de Enrique Anderson Imbert y Leonardo Castellani en La Nación, las ficciones de Víctor Guillot, Manuel Peyrou y Nicolás Olivari, y los textos paródicos de Conrado Nalé Roxlo. Véase: Lafforgue, Jorge y Rivera Jorge. Asesinos de papel. Op. Cit. Asimismo, para un estudio de El enigma de la calle arcos, puede consultarse: Saítta, Sylvia. "Informe sobre El enigma de la calle Arcos", en Asesinos de papel, Op. Cit., pp. 235-246.
} 
entre dos modos de narrar; desde ficciones asociadas, en un principio, a la representación de una hipótesis psicológica que se organiza alrededor de los múltiples interrogantes generados por un delito, como "La pista de los dientes de oro" (1937) o “El resorte secreto" (1937), ${ }^{62}$ se pasa, luego, en los textos más cercanos a la década del cuarenta, a una tendencia donde predomina la narración de las peripecias, aventuras y acontecimientos generados en torno a un acto delictivo (trama policial y de aventuras), y la puesta en términos ficcionales de la investigación, al modo de la novela problema y del policial inglés clásico, como en "El crimen casi perfecto" (1940), "El enigma de las tres cartas" (1939) y dos cuentos que retoman tópicos clásicos del género: "Jabulgot el farsante" (1940) que trabaja el enigma del cuarto cerrado y "El hombre del turbante verde" (1939) que reescribe "La carta robada" de Edgar Poe. También en este período, y en esos mismos circuitos de publicación, aparecen sus cuentos de espionaje: "La doble trampa mortal" (1937), "La cadena del ancla" (1938) y "Espionaje" (1938), para mencionar los más significativos. Este corpus enfrenta a la crítica con una zona tangencial en la producción de Roberto Arlt, cruzada por constantes que se inscriben desde el comienzo de su obra y, a la vez, atravesada por características que se vinculan con los procesos que aparecen en su literatura después de 1932, como se analiza en las sucesivas páginas.

Los años treinta son, por lo demás, un momento de auge y difusión del policial en la Argentina. Luis Alberto Romero afirma, en este sentido, que después de la primera guerra mundial comienza una época que va hasta mediados de los años cuarenta en que en las colecciones populares se va a privilegiar el entretenimiento y la evasión. ${ }^{63}$ Es más, como sostienen Lafforgue y Rivera en la Argentina del período, el policial y los textos de aventuras son géneros que se venden en puestos de revistas y periódicos, porque es durante esos años el momento en que "se afianza y consolida en nuestro

\footnotetext{
${ }^{62}$ Así "La pista de los dientes de oro" (1937) o "El resorte secreto" (1937), funcionan en este sentido y son textos que además de centrarse en la figura del criminal, pueden pensarse como la puesta en narración de una conjetura acerca los móviles subjetivos de la acción criminal o delictuosa. En "El resorte secreto" observamos también una separación de la idea de buscar lo positivo en la mente de un delincuente, es decir, una separación de algo que recorre muchos de los primeros textos de Arlt - como las aguafuertes de la delincuencia y algunos relatos previos, "El gran Guillermito" (1933), por ejemplo-. En el cuento se constata una distancia irónica del discurso del personaje y de su psicología, que se evidencia como monstruosa.

${ }^{63}$ Romero, Luis Alberto. "Una empresa cultural: los libros baratos", en Leandro H. Gutierrez y Luis Alberto Romero. Sectores populares cultura y política. Buenos Aires en la entreguerra, Buenos Aires, Sudamericana, 1995.
} 
medio un vasto público afecto tanto a la lectura de relatos detectivescos como a los novelones de acción y de intriga". ${ }^{64}$ En relación con estos semanarios y colecciones populares de venta en los kioscos que se lanzan al mercado por esos años, deben mencionarse, entonces, entre los más significativos, el Magazine Sexton Blake, una publicación quincenal impulsada a partir de 1929 por la popularísima editorial Tor, de Juan Carlos Torrendel, que combina la trama de aventuras y la intriga policial; y, también, la célebre colección "Misterio", de J. C Rovira Editor, (que distribuyó igualmente la Editorial Tor), donde se publican las novelas del "veterano y talentoso Edgar Wallace", modelo y paradigma del tipo de escritores en que se centraba esa colección y que "tuvieron un éxito notable en nuestro medio". ${ }^{65}$ Jaime Rest señala, además, que la guerra española desplazó hacia Buenos Aires la actividad de la editorial El Molino, donde se inició a finales de la década, la publicación de "Hombres audaces" y la "Biblioteca de Oro", dos colecciones que divulgan los modelos de la ficciones de aventuras, la primera, y de los maestros de la novela problema, como Agatha Christie y Earl Derr Biggers, la última. Aunque la inscripción del policial en sus páginas no es central en la década del treinta, cabe mencionar, asimismo, Leoplán, el "plan de lectura" que surge en $1934 .^{66}$

\footnotetext{
${ }^{64}$ Véase: Lafforgue, Jorge y Rivera Jorge. Asesinos de papel, Op. Cit., p. 107. Podría suponerse que hacia fines de la década del treinta ese público ya se encuentra del todo constituido. Esta suposición está basada en el hecho de que las publicidades sobre los programas radiales o los filmes cinematográficos que aparecen en los diarios de la época, se apoyan en el presupuesto de que el público es "propenso a los temas de acción, intriga policial y aventuras". Esto es claro en muchos avisos que aparecen, por ejemplo en el diario El Mundo durante el año 1939, donde se inscriben, reiteradamente, apelaciones a un lector-espectador de este tipo.

${ }^{65}$ Lafforgue, Jorge y Rivera Jorge. Asesinos de papel. Op. Cit., p. 15. En este sentido, sostiene Jaime Rest: "tal como observó alguna vez Borges, el público argentino tendía a confundir el género detectivesco con el western, que disfrutaba por aquel entonces de su apogeo cinematográfico. Tal vez, la conciencia de que este tipo de relato poseía sus propios lectores y sus propias convenciones y, por ende, que era un fenómeno literario autónomo, sólo llega a afianzarse a partir de 1930, cuando la Editorial Tor lanza su Colección misterio, serie de volúmenes semanales que se vendían en los puestos de revistas y periódicos al precio de treinta centavos el ejemplar y tenían inconfundibles cubiertas en colores dibujadas por Luis Macaya. El puntal de la Colección Misterio fue Edgar Wallace, cuya copiosísima producción se alternaba con relatos de J. S Fletcher, Rufus King, y S. S Van Dine. El éxito de esta colección estimuló a los imitadores y durante algunos años proliferaron las empresas análogas. Véase: Rest, Jaime. "Diagnóstico de la novela policial", en Crisis, n 15, Buenos Aires, Julio de 1974, p. 39.

${ }^{66}$ Como sostienen Laffforgue y Rivera, Leoplán es la primera revista que incorporó en cada entrega una novela completa, entre las que se contaron las de Ellery Queen, aunque en sus primeros años brinda "Una atención fragmentaria a los relatos detectivescos" y desde 1946 "los irá incorporando con creciente asiduidad": Laffforgue y Rivera. Asesinos de papel, Op. Cit., p. 19.
} 
Ciertamente, si el policial en este período debe pensarse, entonces, en correlación con este sector popular de los lectores de la época que consumía literatura de evasión, criminal, de aventuras detectivescas y de entretenimiento en ediciones baratas de kiosco, entre las que se destacan los "novelones" de Edgar Wallace, los relatos policiales de Arlt indudablemente deben vincularse, por una parte, con este circuito. En los textos reaparece, entonces, como en el teatro, la preocupación persistente del escritor por el mercado y su manifiesto interés -que ya se inscribe en las primeras obras como El juguete rabioso- en mantener un público amplio. Si consideramos algunas intervenciones de Arlt en las notas de El Mundo, son sus propias afirmaciones las que lo relacionan, en un principio, con algunas de esas versiones populares de la literatura que circulaban en la Argentina, más explícitamente, con Edgar Wallace. En una aguafuerte publicada en 1937, donde Arlt compara un personaje real, Torriglia, un antihéroe del delito, con los "protagonistas de Edgar Wallace", el cronista expresa:

Hay gente que se avergüenza de confesar que lee al novelista policial Edgar Wallace. Creen que constituye un signo de inferioridad mental o, cuanto menos, de puerilidad. Ignoro si se ha escrito algún estudio sobre el hombre que se jactaba de "tener una mente criminal". Por mi parte, creo que es uno de los novelistas más extraordinarios que ha producido la humanidad. Su ciencia y estilo de construcción no han sido igualados por ningún escritor del género. Conocía, como pocos hombres, los caracteres humanos, sus reacciones, y efectivamente, no dudo que poseyera una mente criminal. Había en él una indulgencia festiva hacia los violadores de la ley en determinadas direcciones, $\mathrm{y}$ jamás ningún hombre, imaginariamente, se atrevió a tanto, como lo hizo Wallace. Imprime un giro nuevo a la novela policial, humaniza sus personajes. ${ }^{67}$

"Reencarnación de Ponson du Terrail, el creador de Rocambole" (alter ego de Arlt, por su parte, porque "producía como una coneja", y como Arlt, "un libro tras otro"), ${ }^{68}$ Wallace es defendido en su literatura policial frente a las acusaciones de

${ }^{67}$ Arlt, Roberto. "Un protagonista de Edgar Wallace", en El Mundo, 23 de julio de 1937. Recopilada en: Arlt, Roberto. Aguafuertes porteñas: cultura y política, Prólogo y selección de Sylvia Saítta, Buenos Aires, Losada, 1992, pp. 205-208.

${ }^{68}$ Véase, al respecto: Arlt, Roberto. "Vidas paralelas de Ponson du Terrail y Edgar Wallace", en El Mundo, 20 de agosto de 1940. Recopilada en: Arlt, Roberto. Aguafuertes porteñas: cultura y política, Op. Cit., pp. 240-242. 
"puerilidad" a las que se somete su lectura. Como puede verse en el fragmento, Arlt se enfrenta a estos prejuicios y, en un gesto de impudor intelectual y de defensa del gusto de ese público lector al que se dirigían las obras de Wallace, no muy alejado, seguramente, del lector de las aguafuertes de Arlt, elogia su insolencia "criminal" ("el mérito de Wallace -insiste más adelante- fue haberse atrevido a imaginar cantidades prodigiosas de delitos que hubieran hecho retroceder a otro novelista"), su "ciencia" y su "estilo de construcción". Y si bien la narrativa de Arlt empieza a separarse, como veremos, de la introspección psicológica en la construcción de sus héroes del delito, ${ }^{69}$ la crónica valora igual y paradójicamente, la composición y el tipo de caracteres de Wallace, la exploración de la "mente criminal" y la "humanidad" de sus personajes. Esta admiración manifiesta por Wallace, contrasta con la crítica de Borges en las páginas de El Hogar y Sur, aunque en uno de sus escritos muy tempranos sobre el policial, Borges se había referido elogiosamente a Wallace:

\begin{abstract}
Ambas pasiones -la de las aventuras singulares, la de la inmaculada legalidad- hallan satisfacción en la narración policial. Edgar Wallace, tengo entendido, era uno de los más conocidos artífices de ese género literario. No he leído su obra. Lamento esa omisión y tengo el propósito de corregirla, porque no soy de los que misteriosamente desdeñan las tramas misteriosas. Creo, al contrario, que la organización y la aclaración, siquiera mediocre, de un suculento asesinato o de un doble robo, exigen un trabajo intelectual que es muy superior a la fétida emanación de sonetos sentimentales o de diálogos entre personajes de nombre griego o de poesías en forma de Carlos Marx o de ensayos siniestros sobre el centenario de Goethe o de meritorios estudios sobre el problema de la mujer, Oriente y Occidente, la ética sexual, el alma del tango, y otras inclinaciones de la ignominia. Espero que nuestra literatura argentina merecerá tener, algún improbable día, su Edgar Wallace. ${ }^{70}$
\end{abstract}

\footnotetext{
${ }^{69}$ También Arlt se separa, como analizamos en el capítulo 1, de sus lecturas del folletín

70 "Edgar Wallace", en Edgar Wallace, Buenos Aires, Rovira, Colección Misterio, no 75, 1932. Recogido en Textos recobrados 1931-1955, Buenos Aires, Emecé, 2001. Cabe aclarar que este texto de Borges sobre el policial aparece en el volumen 75 de la colección Misterio, que contiene la autobiografía de Wallace. Las dos páginas finales de ese volumen dedican un espacio donde diversos escritores argentinos opinan sobre el autor inglés, y uno de ellos es Borges. A diferencia de esta nota, en textos posteriores, aparecidos en El Hogar y Sur, Borges critica enfáticamente las narraciones de Wallace.
} 
De todas maneras, Arlt toma de Wallace cierta combinación particular del policial con los sucesos de aventuras; en lo demás, sus relatos no entran en sintonía y difieren diametralmente de los modos de la narración detectivesca del autor inglés y de la resolución de sus enigmas, lo que diferencia, en este caso, el gusto de Arlt como lector y su reelaboración o utilización posterior de los materiales que leyó. ${ }^{71}$ En primer lugar, porque Arlt escribe cuentos y Wallace largas novelas; luego, porque en las novelas de Wallace, a diferencia de las ficciones de Arlt, lo dominante es la tensión de la intriga y del misterio, la aventura que se teje a su alrededor y la siempre dilatada y poco creíble resolución de un enigma que se difiere y retarda en múltiples e innumerables episodios resueltos bastante poco ingeniosamente en el final. Modelo de narración hiperbólica y acumulativa, las historias policiales de Wallace no nos reenvían sino muy lateralmente a las esquemáticas anécdotas de los cuentos de Arlt, y es sólo la combinación de narración detectivesca y rasgos de aventuras lo que permite pensar en cierta sintonía con estas publicaciones de venta masiva en la cultura popular, según lo que puede constatarse acerca de la popularidad de Wallace en los años treinta. Lo que sí se comprueba es la permanente asociación de Arlt entre el policial, el público y el mercado. Así, en "Un protagonista de Edgar Wallace", Torriglia, el ladrón de cadáveres con los que estafaba a las compañías de seguros y que tiene una "imaginación novelesca" semejante a la de Wallace, debería escribir novelas policiales, según el cronista, como forma de prosperidad económica e intelectual:

Torriglia, que se pasó la vida embaucando y estafando, tiene la posibilidad de ganar dinero sin necesidad de meterse en tantos líos y cementerios, y su chance consiste en escribir novelas policiales.

Torriglia cuenta con una experiencia delictuosa que puede constituir un capital literario. Si en vez de poner en práctica los proyectos que le sugiere su exuberante imaginación y mentalidad criminal, se limita a escribirlos y publicarlos, entretendríanse así los innumerables desocupados de vida tranquila y espíritu apocado que aman las emociones violentas. ${ }^{72}$

\footnotetext{
${ }^{71}$ Cabe destacar, no obstante, que en los cuentos de Arlt resuenan, por momentos, los episodios y procedimientos de algunas obras de Wallace. Por ejemplo, en "La cadena del ancla" (1938) aparece un suceso similar al que se presenta en El arquero verde, novela en la que, del mismo modo que en el relato de espionaje de Arlt, una mujer es escondida y atrapada en la cadena del ancla de un trasatlántico.

${ }^{72}$ Arlt, Roberto. "Un protagonista de Edgar Wallace", Op. Cit.
} 
Obras de entretenimiento, de impacto emocional y violento sobre el espectador, el policial aparece aquí como un género de mercado para Arlt cuyo interés se vincula en tanto que posibilidad, atractiva y segura, de obtener un capital económico y literario. Asociado con el dinero, insiste, de este modo, en la narrativa de los años treinta, con una de las obsesiones más persistentes de Arlt: la literatura como mercancía, el arte que se funda en el beneficio del intercambio monetario.

"Un argentino entre los gangsters" (1937), uno de los primeros relatos policiales de Arlt, en tanto que escritura orientada a una demanda preexistente, apela, justamente, a la satisfacción de las expectativas y deseos de ese público lector y consumidor de “entretenimientos", tan agudamente descrito y detectado por el cronista en la aguafuerte sobre Torriglia. El texto relata la historia de un argentino excepcional, Humberto Lacava, ingeniero a quien "los gentleman de la automática", un grupo de gangsters norteamericanos bastante cercanos a cualquiera de los monstruos de Arlt, ${ }^{73}$ habían secuestrado para que se ocupara del invento de una ruleta "con trampa", un dispositivo que fuera capaz de detenerse en cualquiera de los números que pudieran ser solicitados al azar. Con Lacava reaparece aquí, por lo tanto, otro de los temas y tópicos arltianos: la invención científico técnica y el personaje inventor; ${ }^{74}$ aunque en este caso no se trata, desde ya, del invento del aficionado, sino de un argentino ingeniero al que se le presenta la "oportunidad" que tanto esperan los primeros personajes de Arlt. Lacava, a diferencia de lo que sucede en las novelas, ${ }^{75}$ cumple el sueño arltiano de encontrarse ante un suceso excepcional. : "Hay muchos hombres que se lamentan de que nunca les ha sido concedida una oportunidad. [...] Nosotros le ofrecemos la oportunidad", le dice al argentino uno de los gangsters. A su vez, el relato está orientado a provocar la identificación y complicidad de ese lector ávido de "emociones violentas" que, en la aguafuerte, Arlt delineaba, y refiere, entonces, la aventura en la que este sudamericano

${ }^{73}$ Por ejemplo, Frank Lombardo, "especialista en acciones violentísimas" tiene una "rojiza cara de bull-terrier", y Tony es un homicida de pie desnivelado, un cojo, un deforme como muchos personajes de Arlt. Véase: Arlt, Roberto. "Un argentino entre los gangsters", en Cuentos completos, Edición a cargo de Ricardo Piglia y Omar Borré, Buenos Aires, Seix Barral, 1996, p. 250.

${ }^{74}$ Véase: Sarlo, Beatriz. La imaginación técnica, Buenos Aires, Nueva Visión, 1992.

${ }^{75}$ Masotta sostiene que los personajes de Arlt son hombres determinados por la sociedad en que viven y no hay cambio posible; lo real es lo inmutable y los hombres están condenados a ser lo que son: humillados. Por eso, para Masotta, si Arlt hace luchar a los personajes y los hace esperar un acontecimiento maravilloso que nunca se concreta, es para que terminen frustrados e instauren, de ese modo, un desacomodo entre lo que quieren ser y lo que pueden ser. Masotta, Oscar. Sexo y traición en Roberto Arlt, Op. Cit. 
de Palermo, del que Tony Berman (uno de los gangsters) "no podía esperar ningún daño", prepara astutamente un plan que se sostiene en la astucia y en la inteligencia aprendida en Buenos Aires y (por el que logra desembarazarse de los gangsters):

Humberto Lacava no hablaba. Se acordaba de Buenos Aires, el barrio de Palermo, al tiempo que observaba a los tres hombres entre sus párpados medio cerrados. Tony Berman jamás debió secuestrar a hombre semejante para lograr sus propósitos. Pero Tony no era perfecto. Además, ¿qué daño podían esperar de este sudamericano, delgado, de cinco pies de estatura, que entre las yemas de los dedos se esturaba pensativamente el labio inferior? [...]

Recordaba su casa de Palermo, sus hermanas. ¿Se imaginarían que estaba en esos momentos secuestrado por una banda de gangsters?... Una rabia fría se desenroscó en su corazón. [...]

No tenía prisa. Aguardaba su oportunidad. Cuando la ruleta funcionara correctamente, ellos le [sic] matarían. [...] Con la ruleta eléctrica emprenderían una estafa a gran escala, y únicamente un ingenuo podía soñar en su próxima liberación. Y él no estaba acostumbrado a trazar cálculos sobre buenas intenciones. Su infancia, transcurrida en los arrabales porteños, le había cargado de una socarronería fría y vigilante; no sería el humorismo de Tony "el Paticorto"; pero sí otro humor que probablemente les pondría a ellos los pelos de punta. $^{76}$

El narrador invoca los conocimientos sociales y geográficos de su lector ("la socarronería fría y vigilante" de un habitante de los suburbios porteños), y sugiere, en complicidad, las claves para el desarrollo de la aventura y la intriga policial en la que un argentino se impone a los gangsters: el cuento termina con el asesinato que Lacava ha planeado fríamente para sus captores, que mueren electrocutados alrededor de la ruleta mientras él escapa con el dinero. De esta manera "el humorismo" mencionado en la cita que, en un guiño al lector, anticipa que "probablemente les pondría a ellos [a los gangsters] los pelos de punta", hace que, efectivamente, en el final y por efecto de la corriente eléctrica los "atléticos asesinos", "paralizados" y con "ojos aterrorizados" no puedan "despegarse de la mesa y sus cabellos se ericen[erizaban] bajo la creciente ola de la quemadura que los echaba hacia atrás.” En esta instancia el inventor y aventurero

\footnotetext{
${ }^{76}$ Arlt, Roberto. "Un argentino entre los gangsters", en Cuentos completos, Op. Cit., pp. 252253.
} 
argentino Lacava "les soslayó una rápida mirada; subió corriendo a su dormitorio. Tomó la maleta con los veinte mil dólares y salió". ${ }^{77}$

Si puede señalarse, entonces, una preocupación por el mercado y suponerse que ciertas zonas del policial de Arlt se inscriben en torno a un interés comercial y apelan al público lector de policiales de circulación masiva en Buenos Aires, sus ficciones, que reiteradamente ponen en evidencia sus intertextos, intervienen, además, como los textos de Borges, sobre los modelos genéricos y tipificados y reformulan algunas de sus reglas. Así, en muchas oportunidades los cuentos presentan una distancia paródica sobre lo narrado y también cuestionan la figura del detective razonador. Un relato curioso, en este sentido es "La pista de los dientes de oro". Texto sensacionalista, policial y melodramático, retoma ciertos lugares comunes de la literatura criminal y la retórica sentimental $^{78}$ y los lleva al extremo de la crítica, la caricatura y la parodia. El cuento narra el crimen de Lauro Spronzini y el modo en que el asesino ha burlado a la prensa y a la policía con el recurso de una pista falsa: los dientes de oro que no han sido sino una película metálica colocada sobre su dentadura. En este caso, y en una reiteración de rasgos tradicionales del género - que ya aparecen en Poe-, el discurso periodístico entra en la ficción y la narración se distancia del sensacionalismo de sus modos de representación: "La primera plana de los diarios reproduce el cuarto del hotel en el espantoso desorden que lo ha encontrado la policía. El respaldar de la silla apoyado en la tabla de una puerta; el ahorcado colgando del aire por el cuello, y la sábana anudada en dos partes, amarrada al picaporte de la puerta. Es el crimen bárbaro que ansía la mentalidad de los lectores de dramones espeluznantes". ${ }^{79} \mathrm{Y}$ si bien el asesino no es descubierto nunca por la policía, Diana Lucerna, una odontóloga que encuentra un partícula metálica en el diente de Spronzini, transmutada en una especie de heroína sentimental, decide no delatar al asesino, en un final que cristaliza hasta la parodia la resolución policial en cruce con la intriga amorosa en el que se resuelve el relato:

\footnotetext{
${ }^{77}$ Arlt, Roberto. "Un argentino entre los gangsters", en Cuentos completos, Op. Cit., p. 256. Lila Caimari señala que el impacto del cine era tan fuerte que, en muchas oportunidades las crónicas de los diarios en los años veinte y treinta trataban de asimilar los sucesos acaecidos en Buenos Aires, con episodios de gangsters y ametralladoras tal como se veían en el cine. Esto permite pensar que el cuento de Arlt entronca de este modo con fantasías populares de aventuras en torno al crimen norteamericano que también se registran en la prensa. Caimari, Lila. Op. Cit.

${ }^{78}$ Véase, a este respecto: Sarlo, Beatriz. El imperio de los sentimientos, Buenos Aires, Norma, 2000.

${ }^{79}$ Arlt, Roberto. "La pista de los dientes de oro", en Cuentos completos, Op. Cit., p. 237. Énfasis nuestro.
} 
Lauro sale y Diana se queda sola en su consultorio, frío de cristales y níqueles, mirando abstraída por los visillos de una ventana las techumbres de las casas de los alrededores. Luego, bruscamente inspirada, va y busca los diarios de la mañana. Los elementales datos de la filiación externa coinciden con ciertos aspectos físicos de su cliente. [...] Si en este mismo momento se revisara la dentadura de todos los habitantes de la ciudad no se encontraría en los dientes de ninguno de ellos ese sospechosísimo trozo de película. No le queda duda: él es el asesino: él es el asesino y ella debe denunciarlo. Debe...

Una congoja dulce se desenrosca sobre el corazón de Diana, con tal frenesí hambriento de protección y curiosidad, que derrota toda la fuerza estacionada en su voluntad moral.

Debe denunciar al asesino...Pero el asesino es un hombre que le gusta. Le gusta ahora con un deseo tan violentamente dirigido, que su corazón palpita con más violencia que si él tratara de asesinarla. Y se aprieta el pecho con las manos. ${ }^{80}$

Otros textos de Arlt desarticulan ciertas constantes y estereotipos del género, como "El misterio de los tres sobretodos" que pone en cuestión los modos de la deducción y el razonamiento policial. El cuento se sitúa en un ambiente pequeño burgués muy afín a muchos de los relatos de Arlt (sobre todo a la serie del noviazgo que aparece en El jorobadito). De esta manera, el "enigma de la oficina" por el que se trata de descubrir al ladrón de tres sobretodos, un cinturón sin hebilla, un retazo de seda, "bagatela[s] que, como asume el narrador, "termina[n] por revestir un contorno cruento", sucede en la casa Xenius, "una ropería de hombres y mujeres" y en el círculo de los empleados de una tienda. En este misterio, "intrascendente" para la policía y que por ello no se ha llegado a descifrar, se ponen en juego las deducciones de Ernestina —un personaje también cercano a los estereotipos de insatisfacción pequeño burguesa de las mujeres en Arlt - cuyo razonamiento de novela y cine policial (recordemos que Ernestina es una mujer asidua al cine, como las heroínas de Manuel Puig) se muestra en el relato como impreciso, peligroso (porque son las deducciones las que la llevan al crimen) y falaz:

Casi todas las empleadas llevaban a la tienda el café con leche en un termo. Ernestina había observado que cuando no tenía ganas de

${ }^{80}$ Arlt, Roberto. "La pista de los dientes de oro", en Cuentos completos, Op. Cit., p. 239. 
comerse las "medialunas" y las dejaba en el cajón de su escritorio, para comerlas al día siguiente, una mano misteriosa que había revisado el cajón, se había llevado las "medialunas".

Ahora bien: aunque Ernestina no hizo ningún comentario al respecto, dedujo:

$1^{\circ}$ El ladrón de la tienda no era ni empleado ni empleada, porque ningún empleado ni empleada se quedaba después de la hora de la salida y, además, ninguno de ellos le hubiera robado a su compañero una o dos "medialunas" para tomar con el café con leche.

$2^{\circ}$ Por lo tanto, el ladrón de las "medialunas" era un hombre que merodeaba por las oficinas después que ellos salían.

$3^{\circ}$ Un hombre que es capaz de revisar un cajón y robarse una "medialuna" es un ser humano sin sensibiblidad, con la justa mentalidad para robarse un cinturón sin hebilla, un metro de seda o los tres sobretodos

$4^{\circ}$ En consecuencia, el ladrón de las "medialunas" era el ladrón de las prendas anteriores, y actuaba en el comercio exclusivamente por la noche. ${ }^{81}$

Si en el policial, como sostiene Pierre Boileau, ${ }^{82}$ el razonamiento es falaz y no responde a la lógica porque parte de premisas falsas, Arlt lleva al extremo esta consigna y la desmonta en tanto que procedimiento engañoso, peligroso y subjetivo: Ernestina una mujer que juega a deducir como un detective de policial, movida por la "indignación” pequeño burguesa de quien se siente robada en sus narices (siendo "mas pobres que las ratas"), envenena una medialuna para comprobar si la hipótesis sostenida en su razonamiento resulta certera. Así se descubre, con su muerte, que el sereno era el culpable. De esta manera, son las deducciones de Ernestina, las que movidas por la subjetividad y la indignación, no sólo se muestran como insuficientes e imprecisas sino que además la llevan a la justificación de la acción criminal que es la que, en definitiva, permite identificar que el sereno era el culpable, y no el efecto del razonamiento como en muchos textos policiales. En este sentido, otro cuento de Arlt, "El enigma de las tres cartas" es muy elocuente. El texto cuestiona la figura del detective razonador y muestra el carácter dudoso, equívoco y engañoso de ese mecanismo: el que cumple ese papel y que finge ser un investigador privado es un estafador ${ }^{83}$ Con la representación de este

${ }^{81}$ Arlt, Roberto. "El misterio de los tres sobretodos", en Cuentos completos, 339-340.

${ }^{82}$ Véase: Boileau-Narcejac (Pierre Boileau y Thomas Narcejac). La novela policial, Buenos Aires, Paidós, 1968.

${ }^{83}$ Otros cuentos, como "El crimen casi perfecto", discurren en torno a la poca verosimilitud de los problemas y soluciones que plantea el policial. En este caso, también se discute el enigma de un asesinato en un cuarto cerrado por dentro, y uno de los personajes dice: “...y si alguien había 
estafador, entonces, cuyo razonar de detective en un principio maravilla a Perolet, otro de los personajes, - “El señor Perolet movía la cara asintiendo embobado. Tenía la impresión de encontrarse frente al más lógico de los hombres. Qué simple y profundo era todo!"- ${ }^{84}$, el cuento pone en evidencia y problematiza esos personajes razonadores tan afines a la narrativa policial. ${ }^{85}$

Este hecho, indudablemente, nos reenvía nuevamente a Borges y a sus ficciones, y a las obras de Borges y Bioy Casares en colaboración que, como es sabido, también cuestionan la figura del detective razonador en las humorísticas deducciones del parodiado Parodi. ${ }^{86}$ Pero además nos reenvía a otros textos de la Revista Multicolor de los Sábados que, seleccionados seguramente a partir de las preferencias del propio

entrado en el departamento de la viuda rompiendo un vidrio de la ventana, y colocando otro después que colocó el veneno en el vaso? Era una fantasía de novela policial, pero convenía verificar la hipótesis". Véase: Arlt, Roberto. "El crimen casi perfecto", en Cuentos completos, Op. Cit., p. 545.

${ }^{84}$ Arlt, Roberto. "El enigma de las tres cartas", en Cuentos completos, Op. Cit., pp. 515-516.

${ }^{85}$ El texto atravesado por la ironía y la parodia, refiere el caso por el cual Perolet, personaje temeroso, que solamente "se sentía peligroso en el interior de su casa", es acusado de ser un espía y recibe tres cartas con amenazas de muerte. En una de ellas, una aparente bomba que no resulta ser sino una "bomba de chocolate"; lo que establece un guiño humorístico al lector y propone un alejamiento de los terribles crímenes que se narran en el policial. Así, lo que en un principio se supone como una broma que logra, en su insistencia, aterrorizar a Perolet, se resuelve como un engaño organizado por un estafador que, razonador eficaz, se abusa del miedo que las misivas generan en sus víctimas, propensas a los ataques cardíacos, para obtener el beneficio económico de los servicios de investigador que él ofrece. Como explica, en el final del relato, el inspector: "-Señor Perolet: tengo el gusto de comunicarle que hemos descubierto a su misterioso enemigo y a uno de los géneros de estafa más hábiles que pueda imaginarse. Este hombre, Girolamo Lenescu, rumano de nacimiento y vagabundo internacional, estuvo empleado durante cierto tiempo en una compañía de seguros. En dicha compañía tuvo oportunidad de informarse de todas las solicitudes que eran rechazadas por estar los candidatos enfermos del corazón. Entonces inventó el ardid de la persecución y de la 'agresión indirecta', ofreciendo sus servicios de detective privado a las mismas personas a quienes previamente atemorizaba con sus seudoatentados. Claro está que sus víctimas, al escuchar las interpretaciones lógicas que este hombre hacia de los seudoatentados, creian encontrarse frente a un extraordinario investigador, y no tenían inconveniente de abonarle su servicio que en el fondo era una estafa". Arlt, Roberto. "El enigma de las tres cartas", en Cuentos completos, Op. Cit., pp. 516-517. Énfasis nuestro.

${ }^{86}$ En 1942 aparece Seis problemas para don Isidro Parodi. Véase, a este respecto, entre otros trabajos, además de las apreciaciones de Lafforque y Rivera y de los artículos ya citados: Avellaneda, Andrés. "Jorge Luis Borges y Adolfo Bioy Casares. Un modelo para descifrar", en El habla de la ideología, Buenos Aires, Sudamericana, 1983, pp. 57-69; "Dossier Seis problemas para don Isidro Parodi de H. Bustos Domecq", Variaciones Borges, $\mathrm{n}^{\circ}$ 6, Aahus, 1998; Lafon, Michel. "Algunos ejercicios de escritura en colaboración", en Saítta, Sylvia. (directora). El oficio se afirma. Historia crítica de la literatura argentina (dirigida por Noé Jitrik), Buenos Aires, Emecé, 2004 
Borges sobre el policial, fueron publicados allí y circulaban en la época. ${ }^{87}$ En este sentido, interesa detenerse en las páginas de esta publicación, ya que resulta un punto de confluencia, préstamos (futuros) e intersección entre el circuito culto que Borges impulsa en ese momento y el popular. ${ }^{88}$ A este respecto, si en el diario Crítica, como analiza Saítta, ${ }^{89}$ el relato del crimen ocupa un lugar central, es curioso observar el modo en que el policial ingresa a las páginas de la revista.

En efecto, en relación con los textos ficcionales que allí se publican, además de los asuntos orientales y de los cuentos fantásticos "que pueden ser leídos como intertexto de la literatura borgeana", ${ }^{90}$ hay dos líneas muy marcadas en la Revista Multicolor desde el comienzo; una, que se da en torno a los relatos criollistas y de temas localistas; otra que, intensificándose a mediada que se suceden los números, se organiza en torno del policial. Ciertamente, si ya desde el principio aparecen textos de sangre, ficciones vinculadas al delito, biografías (infames), historias sobre crímenes y criminales más o menos célebres y textos de delincuentes cercanos al fait divers, como los que describimos en las páginas anteriores -y que, en algunos casos, se corresponden con una inclinación del diario que la revista retoma y reorganiza-, desde el número diecisiete la inclusión del policial como un género que se identifica como tal es contundente. En este caso, junto con "El mensaje en el reloj de sol" de J. Bell, ${ }^{11}$ aparece un recuadro editorial que promete al lector que "Todos los números Crítica Revista Multicolor publicará un gran cuento policial". Desde este momento (primeramente en la página 2, y luego, alternativamente, en otras) se editan en las sucesivas apariciones aportes "notables en el género", con un rótulo en el margen superior izquierdo (en letras rojas o algún carácter llamativo o de fácil

\footnotetext{
${ }^{87}$ Se ha discutido bastante acerca de la mayor o menor injerencia de Borges en la revista. Así, mientras Rivera considera tímida la participación de Borges en la publicación, sujeta a un grupo de nombres y géneros de su predilección, Annick Louis discute estas y otras apreciaciones y analiza de qué manera se ven las marcas de Borges como director. Veáse: Rivera, Jorge B. "Los juegos de un tímido. Borges en Crítica", en Crisis, n 38, mayo-junio de 1976; y Louis, Annick. "Instructions pour apprendre à trouver Borges dans la "Revista Multicolor de los Sábados"”, en Jorge Luis Borges: oeuvre et manoeuvre, Op. Cit., pp. 69-120.

${ }^{88}$ La revista constituye una zona que permite detenerse, también, y analizar las primeras aproximaciones borgeanas al género.

${ }^{89}$ Saítta, Sylvia. "Por el mundo del crimen", Op. Cit.

${ }^{90}$ Saítta, Sylvia. "Recorrido", Op. Cit. A este respecto, puede decirse que la tendencia a lo fantástico se intensifica con los sucesivos números. Cabe destacar, asimismo, que en la revista se da cierto espacio a la representación de la miseria.

${ }^{91}$ Bell, J. J., "El mensaje en el reloj de sol”, en Crítica. Revista Multicolor de los Sábados, $\mathrm{n}^{\circ}$ 17, 2 de diciembre de 1933, p. 4.
} 
individualización) para la rápida identificación del lector. De esta manera, a la vez que se discrimina este espacio del resto de lo publicado en la revista - gesto que sólo se repite muy ocasionalmente el caso de "Cuentos de ambiente argentino"-, se marca, de este modo, la presencia enfática de "UN CUENTO POLICIAL". Entre los textos que allí aparecen, pueden mencionarse: “Jervison, el millonario que murió de hambre", de Ronald Knox, "El muerto de la casa del pavo real" y "La profecía del perro" de G. K. Chesterton, "El envenenador de Sir. William", de Anthony Berkeley, "Ha desaparecido una perla" de Juan Erfjord, "Las muertes eslabonadas" de Jack London, "El señor Leggalt deja su tarjeta" de John Fletcher y "El viernes a las seis, un ahorcado" de Hanns Ewers Heinz..$^{2}$ Entre los autores nacionales, cabe destacar: "Los dos balazos", "El robo en la sala III", "Muerte encerrada" y "A treinta pasos" de Carlos Pérez Ruiz, "El misterio de los tres suicidas" de Víctor Guillot y "El crimen de la Safo de terracota" de Ferrari Amores. ${ }^{93}$ En 1943, algunos de estos relatos serán reeditados por Borges y Bioy Casares en la selección de los mejores cuentos policiales que sale a la venta por Emecé ${ }^{94}$ lo que pone en evidencia, de modo cabal, la presencia e intervención de las preferencias de Borges en esta selección de autores y títulos.

${ }_{92}$ Véase, a este respecto: Knox, Ronald. "Jervison, el millonario que murió de hambre", en Crítica. Revista Multicolor de los Sábados, n 18, 9 de diciembre de 1933, p. 2; Chesterton, GK. "El muerto en la casa del pavo real", en Crítica. Revista Multicolor de los Sábados, n² 21, 30 de diciembre de 1933, pp. 1-2; y, "La profecía del perro", en Crítica. Revista Multicolor de los Sábados, n 40, 12 de mayo de 1934, p. 2; Berkeley, Anthony. "El envenenador de Sir. William", en Crítica. Revista Multicolor de los Sábados, n 20, 23 de diciembre de 1933, p. 2; Erfjord, Juan. "Ha desaparecido una perla", en Crítica. Revista Multicolor de los Sábados, $\mathrm{n}^{\circ}$ 37, 21 de abril de 1934, p.1; London, Jack. "Las muertes eslabonadas", en Crítica. Revista Multicolor de los Sábados, n 38, 28 de abril de 1934, p. 4; Fletcher, John S. "El señor Leggalt deja su tarjeta", en Crítica. Revista Multicolor de los Sábados, n 43, 2 de junio de 1934, p. 2; y Heinz Ewers, Hanns. "El viernes a las seis, un ahorcado", en Crítica. Revista Multicolor de los Sábados, n 45, 16 de junio de 1934, p. 4.

${ }^{93}$ Pérez Ruiz, Carlos. "Los dos balazos", en Crítica. Revista Multicolor de los Sábados, $\mathrm{n}^{\circ} 43,2$ de junio de 1934), "El robo en la sala III", en Crítica. Revista Multicolor de los Sábados, $\mathrm{n}^{\circ}$ 48, 7 de julio de 1934, p. 2, "Muerte encerrada", en Crítica. Revista Multicolor de los Sábados, $\mathrm{n}^{\circ}$ 52, 4 de agosto de 1934, p. 6, y "A treinta pasos", en Crítica. Revista Multicolor de los Sábados, n 56, 1 de septiembre de 1934, p. 5; Guillot, Víctor. "El misterio de los tres suicidas", en Crítica. Revista Multicolor de los Sábados, n 19, 16 de diciembre de 1933, p. 2; y Ferrari Amores. "El crimen de la Safo de terracota", en Crítica. Revista Multicolor de los Sábados, $\mathrm{n}^{\circ}$ 30, 3 de Marzo De 1934, p. 3.

${ }^{94}$ Borges, Jorge Luis y Bioy Casares, Adolfo. Los mejores cuentos policiales, Buenos Aires, Emecé, 1943. Los textos reeditados son: "Jervison, el millonario que murió de hambre" de Ronald Knox (Op. Cit.), "El envenenador de Sir William", de Anthony Berkeley (Op. Cit.), "Las muertes eslabonadas", de Jack London (Op. Cit.), y el texto del argentino Carlos Pérez Ruiz, "A treinta pasos" (Op. Cit.) 
Si se consideran estos textos y el marco de su publicación, es preciso atender al modo en que las notas editoriales que los acompañan (en recuadro y en color llamativo, rojo o negrita, la mayoría de las veces) interpelan al público lector de distintas formas (que no resultan muy alejadas de las que se promovían en el diario Crítica), y buscan su colaboración activa en la resolución de los enigmas. También se promociona el cuento o los autores que se publicarán en el número siguiente $\mathrm{y}$, en reiteradas ocasiones, se destaca su singularidad, su originalidad (la nota sobre Chesterton, por ejemplo, es de las más extensas $)^{95}$ y se anticipan algunas de las claves para la resolución del problema que cada texto plantea. ${ }^{96}$ En algunos casos, como por ejemplo, en el número 47 donde se publica "Matando de sobremesa", de Oscar Peyrou, ese procedimiento se lleva a un extremo cercano a la parodia. ${ }^{97}$ Aquí, a partir del dibujo esquemático de diez personajes (diez sospechosos) la nota editorial impele al lector a elegir al asesino y solicita, como en un juego de niños, su diligente participación en el desarrollo del cuento: "Elija Ud. su asesino. Es uno de estos diez personajes". Juegos de la inteligencia, literatura como juego, relatos problemas, reiteradamente en la intervención editorial se promueve un diálogo que suscita la colaboración y la complicidad del lector, en un gesto también vanguardista $\mathrm{y}$, por momentos paródico en tanto lleva al extremo y cristaliza modos de participación cercanos a los que procuraba Crítica. ${ }^{98}$

\footnotetext{
${ }^{95}$ El texto editorial sobre Chesterton dice: "Gilbert K. Chesterton, ha renovado la técnica del cuento policial. Primero hizo célebre a su personaje, el sacerdote católico padre Brown, siempre incrédulo de la explicación sobrenatural de los crímenes y descubridor de una explicación racional aún más maravillosa. Ahora ha creado un nuevo detective, el distraído Gabriel Gale, héroe de la espléndida novela corta que hoy aparece por primera vez en castellano en Crítica, Revista Multicolor. Véase: Crítica. Revista Multicolor de los Sábados, ${ }^{\circ}$ 21, 30 de diciembre de 1933, p 2.

${ }^{96}$ En el número diecisiete aparece en recuadro: “Todos los números Crítica Revista Multicolor publicará un gran cuento policial. ¿Se suicidó o fue asesinado el millonario Jervison? Lea en el próximo número el relato de este caso misterioso por Ronald Knox" (en Crítica. Revista Multicolor de los Sábados, $\mathrm{n}^{\circ}$ 17, 2 de diciembre de 1933, p. 4). O, en otra oportunidad, puede leerse: "El próximo número de Crítica Revista Multicolor publicará un gran cuento policial de Antonio Berkeley. Un detalle imprevisto aclara el asesinato perfecto" (en Crítica. Revista Multicolor de los Sábados, n 19, 16 de diciembre de 1933, p. 2)

${ }^{97}$ Según Anick Louis, "[Borges] Il a probablement une idée du public qui achète le journal, dans la mesure où ceci est possible à l'époque; en tout cas, il ne peut ignorer que celui-ci s'adresse à un public large; un public dont la caractéristique la plus importante est qu'il est habitué à un certain type de journalisme. Les directeurs du supplément connaissaient les caractéristiques du Crítica et cette connaissance leur a permis de transformer l'espace du supplément en un lieu de reflexión sur les pratiques du journal, qui va jusqu'à la parodie. Louis, Annick. Jorge Luis Borges: oeuvre et manoeuvre, Op. Cit., pp. 93-94.

${ }^{98}$ Véase, a este respecto. Saítta, Sylvia. Regueros de tinta, Op. Cit.
} 
Pueden observarse, asimismo, en un recorrido por la revista, ciertas particularidades en torno al policial. Además de alguna presencia de textos sensacionalistas que apelan a la efusión de sangre y al impacto dramático y espeluznante sobre el público, ${ }^{99}$ — que reaparece en algunos textos de espionaje de Arlt, que se detienen, igualmente, en el derramamiento de sangre-, en sintonía con las tendencias del diario, puede decirse que prevalecen los relatos del tipo del policial inglés, $y$, por ejemplo, el enigma del cuarto cerrado, o intrigas similares a la de "La carta robada" de Edgar Allan Poe se rescriben una y otra vez. En algunas oportunidades, asimismo, los relatos cuestionan los estereotipos y cristalizaciones del género y discurren en torno a las formas tipificadas y sus modos de operar. Es el caso de "El crimen en la casa del pavo real", de Chesterton y "El detective magnífico" de Víctor Guillot, que narra, de un modo crítico semejante al que aparece en el relato de Arlt sobre el enigma de las tres cartas, la historia del fracaso de un detective razonador, el momento en el que a su "mentalidad ultrapotente" se le niega el éxito con su deducción, la primera equivocación de quien era una "especie de sobrenatural demiurgo, misteriosamente oculto en un sitio velado y recóndito, desde donde su mentalidad [...] desentrañaba los más complicados problemas de la delincuencia con sólo eslabonar en su cerebro la serie vertiginosa de sus razonamientos, partiendo del trapecio que le armaban los datos concretos". 100

Por lo demás, si el policial, los cuentos criollistas (campesinos y localistas) y los relatos fantásticos son muy frecuentes en la publicación, sugestivamente, en la revista se combinan esas líneas y aparecen textos que (como "Hombres de las orillas",

de Borges, versión previa, como se sabe, de "Hombre de la esquina rosada") constituyen su originalidad en torno a esa confluencia. Un caso singular, a este respecto, lo constituye el "El misterio de los tres suicidas", porque aquí, a la vez que se problematizan los estereotipos habituales, y aparece el "ambiente argentino" en un

${ }^{99}$ Como ejemplo, pueden mencionarse, entre otros. "Baker, el ambicioso de la silla eléctrica" (O. Cit.), "Jack el destripador" de Juan Preston (Op. Cit.) y "El bárbaro crimen del tren n 624", de Emmanuel Courter (Courter, Emmanuel, "El bárbaro crimen del tren $\mathrm{n}^{\circ} 624$ ", en Crítica. Revista Multicolor de los Sábados, $\mathrm{n}^{\circ}$ 22, 6 de enero de 1934, p. 2). Puede decirse que el carácter sensacional de algunas historias se somete a discusión en uno de los últimos números, porque se promociona un relato policial cuya peculiaridad y virtud está, justamente, en no mostrar el derramamiento de sangre. Se trata del cuento de John Fletcher, texto que se anuncia como "un policial sin efusión de sangre". Véase: Fletcher, John S. "El señor Leggalt deja su tarjeta", Op. Cit., p. 2.

${ }^{100}$ Guillot, Víctor. "El detective magnífico", Op. Cit. 
relato policial, ${ }^{101}$ se construye una intriga cuya resolución sugiere lo sobrenatural, aunque no se agota en lo sobrenatural: un caso de hipnosis habría producido los tres suicidios y, como sostiene uno de los personajes: "Por mucho que se haga para interpretar racionalmente los hechos, siempre queda flotando un trágico ambiente de misterio alrededor de aquello". ${ }^{102}$ De manera tal, este cuento y otros que allí se publican, —en un gesto que podría muy fácilmente vincularse a los interesen borgeanos, pero también a algunos relatos de Arlt, que, como veremos, combinan el hipnotismo y el policial一, desdibujan los límites genéricos (entre el policial y el fantástico, en los casos más reiterados; entre el policial, lo fantástico y las tramas de ambiente local, en el asunto puntual de Guillot) y deshacen las fronteras lábiles entre ellos. Entre los más significativos a este respecto, también pueden mencionarse, "El enigma de los ojos en la pared" de Ricardo Setaro, ${ }^{103}$ y "El viernes a las 6 un ahorcado", de Hanns Heinz Ewers, un texto cuyos rasgos puede decirse que se retoman en la poética de Silvina Ocampo.

De un modo semejante a lo que aparece en la revista y en confluencia o continuación con los intereses de Borges como director, estos caracteres nos reenvían directamente al policial borgeano, a sus intervenciones críticas y a sus textos en colaboración. En efecto, las notas de Borges en El Hogar y algunos artículos de la revista Sur están atravesados por el cuestionamiento sobre los modos adecuados para presentar el problema, o el enigma, policial, y sobre los mecanismos apropiados para su solución. También se discute la posible confluencia del policial y el fantástico: como sostiene Pastormerlo, "cuando a principios de la década del 30 Borges se inicia en la narrativa y se introduce en el género policial (estos dos comienzos son, en realidad, uno solo), recurre a la figura tutelar de Chesterton justamente por la mezcla de policial y fantástico que proponían sus relatos. Borges y Bioy Casares prefirieron atender a las similitudes ente estos géneros y olvidarse de las diferencias" ${ }^{104}$, y mucho de su poética,

101 El texto completo del recuadro de la editorial que aparecen en el número anterior promocionando este cuento policial que aparecerá en el siguiente dice: "Todos los números Crítica Revista Multicolor publicará un cuento policial. Lea el próximo sábado el caso de la sospechosa conexión de tres misteriosos suicidios, en un relato de ambiente argentino que firma Víctor Guillot", en Crítica. Revista Multicolor de los Sábados, n 18, 9 de diciembre de 1933, p. 2.

${ }^{102}$ Guillot, Víctor. "El misterio de los tres suicidas", Op. Cit., p. 2.

${ }^{103}$ Setaro, Ricardo. "El enigma de los ojos en la pared", en Crítica. Revista Multicolor de los sábados, $\mathrm{n}^{\circ} 13,4$ de noviembre de 1933, p. 1.

${ }^{104}$ Afirma, además, en este sentido Sergio Pastormerlo: “...esta fecunda confusión de géneros (el policial y el fantástico, el policial y la ciencia ficción) es la que define la narrativa del cuarenta de Bioy Casares: La invención de morel, Plan de evasión, "El perjurio de la nieve". 
de la poética de ambos, se basa en ese cruce. "Edgar Allan Poe -afirma Borgesescribió cuentos de puro horror fantástico o de pura bizarrerie; Edgar Allan Poe fue inventor del cuento policial. Ello no es menos indudable que el hecho de que no combinó jamás los dos géneros. [...] Chesterton, [...] ejecuta, siempre, ese tour de force. Presenta un misterio, propone una aclaración sobrenatural y la reemplaza luego, sin pérdida, con otra de este mundo. ${ }^{105}$ Esta es, a juicio de Borges la solución adecuada, pues lo sobrenatural no debe estar en la solución del problema o del enigma policial, sino en su desarrollo. Como afirma en una de sus notas publicada en El Hogar:

Puedo recomendar a los amateurs de la novela policial [...] este último libro de Ellery Queen. Puedo afirmar que cumple con los primeros requisitos del género: declaración de todos los términos del problema, economía de personajes y de recursos, primacía del cómo sobre el quién, solución necesaria y maravillosa, pero no sobrenatural. (En los relatos policiales, el hipnotismo, las alucinaciones telepáticas, los elixires de maléfica operación, las brujas y los brujos, la magia verdadera y la física recreativa, son una estafa.) Ellery Queen juega con lo sobrenatural, como Chesterton, pero de un modo lícito: lo insinúa para mayor misterio en el planteo del problema, lo olvida o lo desmiente en la solución ${ }^{106}$.

Las ficciones policiales de Borges responden más o menos a estas consignas, como también algunas de las que escribe en colaboración con Adolfo Bioy Casares, los relatos del parodiado razonador Parodi. Cabe señalar, sobre todo, en "Las doce figuras del mundo" (1941), donde el mecanismo racional desentraña y proporciona una explicación de lo que, en un principio, se atribuía a la magia y lo sobrenatural. ${ }^{107}$

Pastormerlo, Sergio. "Dos concepciones del género policial. Una introducción a la narrativa policial borgeana", Op. Cit.

${ }^{105}$ Borges, Jorge Luis. "Sobre Chesterton", en Otras Inquisiciones, Obras Completas, Buenos Aires, Emecé, 1996, p. 72.

106 Borges, Jorge Luis. "Half-Way House, de Ellery Queen", en Textos Cautivos, Obras Completas, Buenos Aires, Emecé, 1996, p. 216.

${ }^{107}$ De todas maneras las ficciones policiales de Borges van más allá, ciertamente, de cualquier decálogo o caracterización esquemática y se centran, sobre todo, en la resolución de un problema intelectual y se constituyen como una propuesta narrativa. Porque, como sostiene Daniel Baldeston Borges ve al policial más allá de sus convenciones: 'El 'código' que Borges propone para el cuento policial es interesante, entonces, por el énfasis que pone en la creación de un problema riguroso y económico para el intelecto, y por sus omisiones". Y añade: "el relato policial no es para él un género convencional sujeto a fórmulas, sino un experimento constante con toda la gama de lo posible, en que un relato deberá siempre ser juzgado por el 
Puede decirse entonces, que la intervención de Arlt sobre los modelos del policial y las formas de la distancia crítica que aparecen en sus textos se acercan, en algunos sentidos, a las lecturas, revisiones, y operaciones realizadas por Borges, a sus realizaciones ficcionales y a la labor de Bioy Casares y Borges en colaboración, y también es equivalente a algunas de las reelaboraciones del policial como las que aparecen en la Revista Multicolor. En este sentido, si la mezcla y confusión de los géneros, como el policial y el fantástico, caracteriza, según se refirió, algunas de esas zonas del policial — se inscribe en algunas ficciones de la revista, en las teorizaciones y relatos de escritores como Borges y también Bioy Casares-, los cuentos de Arlt coinciden con estos problemas.

Efectivamente, aunque de modo diferente al que se presenta, por ejemplo en la estética borgeana — con sus enigmas filosóficos y el carácter abstracto de los problemas que se proponen en ese juego de la razón y del intelecto que plantean sus textos-, ${ }^{108}$ en reiteradas ocasiones, también se desdibujan en Arlt los límites de los géneros (el policial y el fantástico) y sus cuentos se constituyen en la intersección fluctuante del enigma

rigor y la economía de los problemas que plantea." Antirrealismo, rigor intelectual, mezcla de géneros, parodia y carácter abstracto son algunos de los rasgos que pueden verse, entonces, en el policial borgeano en tanto que poética de la narración. Balderston, Daniel. "El asesinato considerado como una de las bellas artes", en El precursor velado: R.L. Stevenson en la obra de Borges, Op. Cit. En un sentido similar, Sergio Pastormerlo opone a una concepción "restricta del policial", preocupada por la "uniformidad" de los textos que se incluyen en el género, una concepción amplia (la de Borges y Bioy Casares), que es aquella que "se interesa en el género como abstracción, como matriz de posibilidades". Véase: Pastormerlo, Sergio. "Dos concepciones del género policial", Op. Cit., pp. 26-27. Para un estudio detallado sobre Borges y el policial, véase, además de los textos mencionados a lo largo del trabajo, el artículo de José Fernández Vega, "Una campaña estética. Borges y la narrativa policial", Op. Cit. También puede consultarse el artículo de Analía Capdevila referido a la polémica entre Borges y Caillois en torno al policial. Véase: Capdevila, Analía. "Una polémica olvidada. Borges contra Caillois sobre el policial", en Borges ocho ensayos, Rosario, Beatriz Viterbo, 1995.

108 "El jardín de senderos que se bifurcan", presenta, como es sabido, dos enigmas. La historia de espionaje, que es una narración de perseguidor y perseguido por la que se tiene que indicar el nombre de un lugar, constituye la primera incógnita que el texto plantea hasta el final y se sitúa en un tiempo cronológico preciso; en segundo lugar, el enigma del laberinto/libro de Ts'ui Pên, que en su concepción infinita y circular del tiempo, termina por involucrar a la aventura policial y de espionaje. Es, de esta manera, entonces, que las dos historias se imbrican y se cruzan en una trama que combina el espionaje y policial con el relato fantástico: la anécdota del espía Yu Tsun está contenida en el tiempo circular del libro/laberinto de su antepasado Ts'ui Pên, como puede verse en la cita: "En la obra de Ts'ui Pen — sostiene el sinólogo Albert-, todos los desenlaces ocurren; cada uno esel punto de partida de nuevas bifurcaciones. Alguna vez, los senderos de ese laberinto convergen; por ejemplo, usted llega a esta casa, pero en uno de los pasados posibles usted es mi enemigo, en otro mi amigo". Borges, Jorge Luis. Ficciones, en Obras completas, Buenos Aires, Emecé, 1989, p. 478. 
policial con algunas resoluciones cercanas al fantástico, al fantástico científico ${ }^{109} \mathrm{y}$ al fantástico técnico. De esta manera, tanto estos escritores vinculados a Sur, como Arlt, que escribe desde otro lado, presentan en sus distintos textos una propuesta que se basa en la indeterminación y en la mezcla de géneros. "Jabulgot el farsante" (1940), uno de los últimos relatos que Arlt publicó, es útil para esta cuestión. El cuento retoma el enigma del cuarto cerrado que, desde "Los crímenes de la calle Morgue" de Edgar Poe, es parte de la tradición de la literatura policial, sucesivamente reescrito. En este caso, y con los comienzos más típicos del género, la historia se inicia cuando Ernestina Brauning acude a la casa del detective con la sospecha de que han "asesinado a su tío" pues, encontrándose en su dormitorio con la "puerta cerrada por dentro", nadie contesta. La sospecha se confirma. Su tío es encontrado muerto, y si bien el investigador lo atribuye en principio a un suicidio, las deducciones de Ernestina - que es quien en verdad razona en este cuento-, terminan revelando un sofisticado y también fantástico mecanismo por el que se ha perpetrado el crimen en una habitación cerrada: un "poderoso electroimán" que su primo Jabulgot, estudiante de ingeniería, habría ideado para encubrir su delito. De esta manera, el texto de Arlt opta, entre otras soluciones, por una solución que apela a la fantasía científica o técnica: el electroimán del que descreería Borges, y es así que introduce para la resolución del enigma elementos cercanos al fantástico en un trama policial, de un modo que, en buena medida, se distancia de las prescripciones borgeanas. Debemos destacar, por lo demás, que el relato se muestra consciente de sus intertextos: cuando se discuten las posibles respuestas al misterio del cuarto cerrado, aparece una cita de Wallace y se caracteriza su solución como imposible: "Era aquella una operación embarazosa. Nadie se hubiera arriesgado a cometer un asesinato fiado en esa imposible treta"; ${ }^{110}$ también, en alusión a Poe y en una operación por la cual Arlt muestra no desconocer los antecedentes más prestigiosos del género, se atribuyen hipotéticamente las causas del hecho a un mono - “¿y si el asesino hubiera traído un mono domesticado? -¿Por dónde salió el mono? Aquí no hay conducto de chimenea"-, y, nuevamente se descarta esa solución, de la misma manera que la de Wallace, por considerársela impropia. Pero además de esto, cabe referir que también en esta historia se cuestiona el modo de razonamiento de Ernestina, una verdadera

\footnotetext{
${ }^{109}$ En La invención de Morel, por ejemplo, se inscribe la imprecisión y el juego con una solución científica técnica o de ciencia fícción, como se ha trabajado, repetidamente.

${ }^{110}$ Arlt, Roberto. "Jabulgot el farsante", en Cuentos completos, Op. Cit., p. 534.
} 
razonadora como en las más típicas novelas de enigma. Al final del cuento nos encontramos con que el asesino es la propia Ernestina, quien con su revelación de los mecanismos del crimen, intentaba inculpar a Jabulgot; sus deducciones, por tanto, no sirven para revelar al culpable, sino para encubrirlo.

Otro cuento de Arlt que muestra la confluencia del policial y el fantástico es "La venganza del mono" (1937). Leído de atrás para adelante, el cuento devela un enigma que se plantea al final: “'Se busca al cómplice que después del robo mató a Fligtebaud, pues se ha encontrado su galera arañada y mordida. La particularidad de este doble homicidio preocupa a los investigadores". ${ }^{111}$ En efecto, el cuento refiere, en las primeras páginas, los pormenores y el misterio de ese interrogante. Fligtebaud es "casi" un "perfecto asesino" que roba y mata a un anciano que tenía un mono a su cuidado. Cuando va a dar por terminado su delito y ya tiene en su poder los objetos robados, el mono se apodera de su galera y huye:

El mono parecía un demonio que se burlaba del asesino [...] Con la cola tiesa como la de un gato, avanzaba ahora a lo largo de un pequeño muro. El asesino, poseído de la misma fatiga que experimenta un durmiente en el transcurso de una pesadilla, trepó a la pared. [...] Aquello era una persecución fantástica y dolorosa [...] El hombre no experimentaba el más mínimo vértigo. Hubiera podido correr a lo largo de una cornisa, porque ya accionaba como un sonámbulo. Se diría que la maldita bestezuela le había hipnotizado, porque involuntariamente él repetía sus movimientos, apresurándolos o retardándolos, según el ritmo con que el mono avanzaba por las alturas

De pronto el animalito se detuvo [...] dejó la galera [...] y a grandes saltos desapareció en las tinieblas.[...] Fligtebaud ansiosamente entró en la sombra profunda que proyectaba un rascacielo. [...] Un crujido estalló a sus pies, y diez puntas de cristales rotos le desgarraron los muslos, y por el agujero que su cuerpo abrió en una claraboya de vidrio se desplomó en el vacío. ${ }^{112}$

A partir de este fragmento, del sonambulismo del perseguidor, de la supuesta hipnosis provocada en el ladrón asesino por la "bestezuela", el texto no resuelve y deja abierta la posibilidad - reafirmada por el título- de que sea el hechizo del mono lo que produce la muerte de Fligtebaud y, por lo tanto el segundo asesinato que los

${ }_{111}$ Arlt, Roberto. "La venganza del mono", en Cuentos completos, Op. Cit., p. 277.
${ }_{112}$ Arlt, Roberto. "La venganza del mono", en Cuentos completos, Op. Cit., p. 276. 
investigadores no "pudieron hallar jamás". Así, el relato conduce la lectura para el lado de lo fantástico y con este episodio que remite en algún punto a "El gato negro" de Poe, el enigma de los dos asesinatos se explica, entonces, por un argumento que cruza y entrelaza el policial con una trama más o menos asimilable a las costumbres más habituales de los siempre difícilmente encasillables aspectos de lo fantástico.

Es de esta manera cómo, en los cuentos de Arlt, a la vez que resuenan los ecos del que, junto con Ponson du Terrail era, para el escritor, uno de los "hombreadores de la literatura", es decir, algunos de los rasgos de la poética de Edgar Wallace, también se marca en ellos una confluencia con los problemas que, en los treinta y los primeros cuarenta Borges y otros escritores ligados a Sur, estaban discutiendo y promoviendo: los cruces entre el policial y el fantástico, las coexistencia de ambos géneros, sus posibilidades narrativas y también sus límites, sus caricaturas, sus convenciones más cristalizadas.

\section{Narración policial y aventuras sobre espías:}

En fin, parodiando a Quevedo, es cosa de decir que la mitad de Europa vigila a la otra mitad. El padre espía al hijo y el esposo denuncia a la esposa. Los ciudadanos conspicuos no saben jamás si el pariente afectuoso que les trata es un judas que le apuñalará por la espalda. Y que conste que estos no son conceptos frivolos "113

Roberto Arlt

Aunque Arlt confirma en el policial y en las ficciones de espionaje su persistente preocupación por el mercado y por un público amplio, sus textos inscriben de una forma bastante contundente una narrativa diferente de la que aparece en las novelas y relatos

${ }_{113}$ Arlt, Roberto. "Imprudencia del Vizconde o quién espía a quién”, en El Mundo, 26 de septiembre de 1939. 
iniciales. En principio, puede decirse que estos cuentos modifican algunos aspectos de la idea sobre la literatura y de la imagen de escritor que había definido en sus primeros textos. En los años veinte, el personaje de sí mismo construido por Arlt se caracterizaba por ser un "autor instintivo", un improvisado en las letras argentinas que escribía "así nomás" ${ }^{114}$ y que aborrecía cualquier método de trabajo, no trazaba un plan estricto para su obra, al modo de Dostoievski. Se trataba de una imagen que partía de la idea de una literatura improvisada, organizada alrededor de instintos e impulsos siempre espontáneos, azarosos, fortuitos y desordenados del escritor y de los requerimientos de sus héroes, antes que de los de la trama. ${ }^{115}$ Esta concepción de escritor y del trabajo literario —que se corresponde más o menos acertadamente con los modos de la narración efectivos de las novelas - se desdibuja en el giro a la cuentística policial: las ficciones policiales no sólo no se proponen como una literatura violenta sobre lo social (o, en términos de Arlt, con la violencia de un cross a la mandíbula); tampoco se presentan como una escritura "así nomás" porque el género impone reglas y convenciones que, en más de un sentido, el "anárquico" Roberto Arlt esta vez acata. Como se sabe, el policial exige una construcción rigurosa, que implica que el autor, desde la primera línea del relato, conozca su final; es "un producto de laboratorio" que requiere "un escritor capaz de escribir una historia al revés, capaz de imaginar el final

${ }_{114}$ Arlt, Roberto. “¿Cómo quieren que les escriba?”, en El Mundo, 3 de septiembre de 1929. Recopilada en Arlt, Roberto. Aguafuertes porteñas. Cultura y política, compilación, notas y prólogo de Sylvia Saítta, Buenos Aires, Losada, 1992.

115 Arlt, Roberto. "Cómo se escribe una novela", en El Mundo, 14 de Octubre de 1931. Recopilada en Arlt, Roberto. Obra Completa, Tomo 2, Buenos aires, Carlos Lolhé, 1981. En esta nota, bajo el subtítulo "Modos de escribir una novela", Arlt decía: "Hay autores que trazan un plan estricto y no se apartan de él ni por broma.

Ejemplo: Flaubert. Otros nunca pueden establecer si su novela terminará en una carnicería o en un casamiento. Ejemplo: Pirandello. Unos son tan ordenados que, fijan en su plan datos de esta categoría:

'El personaje estornudará en la página 92, renglón 7'; y otros ignoran todo lo que harán. Es lo que le pasó a Dostoievski, cuya novela El crimen y el castigo fue en principio un cuento para una revista. Insensiblemente el cuento se transformó en una novela [...] El novelista 'pur sang' aborrece cordialmente el método (aunque lo acepte), los planes y todo aquello que signifique sujeción a una determinada conducta.

Escribe de cualquier manera lo que lleva adentro...".Y más adelante, afirma cuáles son los "Problemas de autor": "En el novelista instintivo, los personajes proporcionan sorpresas de seres vivientes. [...] A mí me pasó un caso curioso en Los lanzallamas [....] Problemas así, se presentan a montones en el autor instintivo. En vez de autor debía ser denominado secretario de personajes invisibles. Hace lo que ellos le mandan." (Op. Cit., pp 256-257, énfasis nuestro). En el fragmento anterior Arlt opone y divide a los novelistas entre aquellos que tienen un plan estricto, y lo cumplen y aquellos que, como él, autor de Los Lanzallamas, ignoran todo lo que harán y que son sorprendidos por el destino de sus personajes. 
antes que el comienzo. No sentir los acontecimientos a través de los personajes; configurar a los personajes de acuerdo a los acontecimientos". ${ }^{116} \mathrm{~A}$ su vez, en estos textos se inscriben otro tipo de personajes en su literatura. En una aguafuerte aparecida a propósito de su novela Los siete locos, Arlt sostenía en 1929: "Para mí no tienen ningún interés las acciones de un delincuente, si estas acciones no van acompañadas de una vida interior dislocada, intensa, angustiosa", ${ }^{117}$ afirmación que propone, como se ve, la primacía de lo subjetivo sobre las acciones. Los relatos policiales y los textos de espionaje contradicen este tipo de proposiciones $\mathrm{y}$, también, los modos de representación de los héroes del delito en las novelas de Arlt. En este caso, por el contrario, se privilegia la acción por sobre la introspección de los personajes y las narraciones dejan poco margen o casi ninguno para la indagación del plano interior y subjetivo. Efectivamente, la incursión arltiana "por el mundo del crimen" muestra un desplazamiento que se corrobora en la distancia entre sus primeros cuentos, aguafuertes aparecidas en la prensa sobre el mundo de la delincuencia, y sus novelas, por un lado, y los modos en que en las ficciones posteriores se presenta el "caso delictivo". Así, si en las novelas, su perspectiva estaba centrada en los impulsos, cavilaciones, especulaciones y delirios de la "mente criminal" (o de los locos/monstruos de Arlt, subjetividades en conflicto que en algunos casos se proponían, además, "ser a través del crimen") y, en las aguafuertes el acento se ponía en los tipos urbanos identificables en la época - los "coimeros", facinerosos, "punguistas", estafadores-, los relatos policiales y las narraciones de espionaje empiezan a privilegiar en tanto que móviles principales de una historia a narrar, el accionar de los personajes, el ejercicio del delito o la actividad conspirativa, y las aventuras de los héroes cuyo modo de figuración y cuyo desenvolvimiento efectivo constituyen las formas principales en torno a las que gira la trama narrativa. En todos estos casos, Arlt no construye ficciones psicologistas del criminal, ni subjetividades cuya tensión es el centro de la historia; hay una preocupación por la trama y narra historias situadas en un espacio-tiempo poco identificable, importan los hechos, la acción, la actividad de los personajes en función de la trama, no los

\footnotetext{
${ }^{116}$ Boileau- Narcejac. La novela policial, Op. Cit.

${ }_{117}$ Arlt, Roberto. "Los siete locos", en El Mundo, 27 de noviembre de 1929. Recopilada en: Arlt, Roberto. Obras Completas, Op. Cit.
} 
personajes como espacio de exploración del sujeto, ni la indagación del plano interior. 118

Los cuentos de espionaje llevan a un extremo la caracterización anterior. Personajes función, en estas ficciones cada héroe parece tener su lugar asignado según el espacio que ocupará en los móviles de la narración; relatos sin psicología y sin "intensidad descriptiva" en cuanto a la representación de los protagonistas, su participación consiste en desempeñar simplemente uno de los resortes de la acción en la historia de espías. Personajes sin personalidad, piezas anónimas y fichas de la "Gran Partida", con ellos Arlt desmonta algunos de los mecanismos de la política mundial y la escenifica:

¿Cómo se llaman? ¿Para quiénes trabajan? ¿De dónde salen? ¿A donde van? ¿De dónde vienen?

No importa. Son peones, piezas de la Gran Partida que el demonio del dinero y de la política juega sobre los continenetes del planeta. Audaces, fríos, resueltos, la vida suspendida de un hilo, especializados, sabios, inexorables, asesinos, intelectuales.

Al servicio del espionaje. Al servicio del contraespionaje. Fríos, eruditos, educados, organizados, sabiendo que les aguardan tormentos horribles en celdas oscuras, misteriosos, creados por el ritmo del dínamo y el avión cada vez asoman con más frecuencia a los horizontes de los pequeños países infernales europeos. Son figuras de una fiereza que estremecería aun hombre fabricado con piezas de acero. Nunca Europa les ha necesitado tanto como ahora. Y nunca Europa se ha defendido de ellos tanto como ahora. ${ }^{119}$

Efectivamente, si hay un tenor político y de denuncia en los relatos finales de Arlt esto se da en torno de la situación internacional, e indefectiblemente los textos responden al horizonte de expectativas del público de entreguerras. En este sentido, si, como dice Arlt en la crónica "Al margen del cable" que transcribimos en el epígrafe, — "la mitad de Europa vigila a la otra mitad"-, las narraciones reelaboran, desde el clima de tensión mundial (que está presente en todos los cuentos de espionaje de Arlt) un tópico de su obra como es la traición, que se reviste, de esta manera, de nuevas connotaciones. El conflicto bélico, en tanto que marco de enunciación del que los

\footnotetext{
${ }^{118}$ Este par acción/introspección, se vincula con las teorizaciones de Arlt a propósito de la novela que analizamos en el capítulo siguiente.

${ }_{119}$ Arlt, Roberto. “Los persiguen....Pero los necesitan!”, en El Mundo, 20 de marzo de 1938. Al margen del cable.
} 
cuentos parten y que reelaboran en distintos sentidos, despunta, entonces en un tipo de narraciones que pone en evidencia la inestabilidad y la mutación de la identidad de los sujetos y la ambigüedad de las apariencias (nada es lo que parece); la traición, de esta manera, le da forma a los vínculos de los personajes. Historias de la guerra, de hombres en guerra o de tensiones mundiales que implican (y anuncian) la guerra, cada personaje se transforma en su contracara, su máscara y su contrario, y, en muchas oportunidades los relatos se refieren a la trama secreta que se oculta detrás de la imagen externa. Falsas identidades, identidad oscilante e inaprensible, Roberto Arlt, —como también Borges en cuentos más o menos cercanos cronológicamente como son "La forma de la espada", "El jardín de senderos que se bifurcan" y "Tema del traidor y del héroe", para nombrar los más significativos- ${ }^{120}$ muestra las máscaras que revelan que nadie es quien parece, que cada individuo es también su opuesto. Un relato paradigmático, en este sentido es "Espionaje". El texto, enmarcado en una situación bélica que no se llega a precisar, relata el modo en que cada personaje es la contracara de sí mismo: el hijo traiciona al padre, y la mejor espía (una bella y seductora muchacha muy cercana al estereotipo de las historias de espionaje), se transmuta en la que lleva a cabo la delación: los sujetos se confunden y los protagonistas "no saben jamás si el pariente afectuoso que les trata es un judas que le apuñalará por la espalda...". De esta manera, en la inestabilidad del yo representado, donde los sujetos son funciones a la acción que los incluye y supera, las ficciones de espionaje ponen el foco en las tensiones de la guerra próxima, cercana, y manifiesta.

Historias de aventuras y con cierto interés comercial, asimismo, los relatos de espionaje son narraciones que también nos enfrentan con cierta dosis de sensacionalismo y fatalidad (muchas son narraciones sangrientas, como la que aparece en "La cadena del ancla" y "Espionaje", que no escatiman los detalles truculentos). ${ }^{121}$

\footnotetext{
${ }^{120}$ Véase, a este respecto: Louise, Annick. "Borges va a la guerra", en Borges ante el fascismo, en prensa. Agradezco a Annick Louise por permitirme consultar su trabajo antes de que éste sea publicado.

${ }^{121}$ Así, por ejemplo, en "Espionaje" se describe con detalles truculentos una escena de tortura por la cual el personaje se confiesa como espía y se "vuelven blancos sus cabellos". Véase: Arlt, Roberto. "Espionaje", en Cuentos completos, Op. Cit. En "La cadena del ancla", asimismo, se narra, con apelación a lo sangriento, el modo en que una espía escondida en el hueco donde se repliega la cadena del ancla en desuso, muere cuando el capitán del barco decide utilizar esa cadena que no se empleaba desde hacía tiempo, como puede verse en la cita: "Rechinaron las palancas, una columnita de humo se escapó de los cilindros oxidados, comenzó a girar un tambor, y de pronto un grito agudísimo cruzó los aires sobre la superficie del mar; todos se miraron al rostro sin poder especificar de dónde partía aquel grito; luego estalló otro más agudo
} 
Relatos estereotipados, como el policial, las aventuras de espías — por ejemplo, "La doble trampa mortal" y "Espionaje" - presentan figuras y funciones tipificadas que responden a los modelos genéricos: el detestable traidor, la bella espía, la imagen (maquiavélica, a veces), del espía jefe o del viejo espía ${ }^{122}$ y, también, el sujeto corriente o ajeno a las actividades secretas que se ve inmerso en una aventura conspirativa. ${ }^{123}$ Efectivamente, si hay un tópico de la literatura de espionaje retomado muy insistentemente, es el del ciudadano honesto y común que se ve arrastrado en un episodio de espías, tema que, en un cruce con el exotismo de los relatos africanos aparece en "La aventura de Baba en Dimish esh Sham". Es el caso de la "historia hermosa" que ha protagonizado el "desarrapado deshilachoso" Baba el ciego, un "jefe de conversación", quien narra sus anécdotas ante un auditorio admirado en la puerta del Zoco. En el relato, Marbruk ben Hassan, "el hombre de la limosna" para Baba, un sujeto que "pertenecía a las sociedades secretas que reactivan el movimientos musulmán” y había traicionado a su familia y al sultán de Fez - la traición filial, del hijo contra el padre, tema del epígrafe sobre el que Arlt vuelve una y otra vez en sus cuentos de espionaje-, involucra a Baba el Ciego en una trama de conspiraciones, asesinato, traición y delaciones, al intentar escapar de sus perseguidores mediante el artilugio de confundirse con el mendigo, un yo opuesto a su yo en la percepción de los demás para Marbruk ben Hassan. ${ }^{124}$

y cargado de horror, las cadenas rechinaban en los escobetes y no volvió a escucharse nada.

'Las anclas entraron en el agua agitada; de pronto, un pescador [...] exclamó:

- ¡Una pierna sale por el escobén!...[...]

'Del ojo de acero, por donde se había deslizado la cadena, colgaba una pierna de mujer. Hilos de sangre se coagulaban en el acero del casco'". Arlt, Roberto. "La cadena del ancla", en Cuentos completos, Op. Cit, pp. 381-382.

${ }^{122}$ En este sentido, por ejemplo, en "La doble trampa mortal", ya desde el primer párrafo se presentan los típicos personajes de las historias de espías y, a su vez, el ambiente europeo de tensa confrontación donde se suceden los hechos: "- He aquí el asunto, teniente Ferrain: usted tendrá que matar una mujer bonita.

El rostro del otro permaneció impasible. Sus ojos desteñidos, a través de las vidrieras, miraban el tráfico que subía por el bulevar Grenelle hacia el bulevar Garibaldi. Eran las cinco de la tarde, y ya las luces comenzaban a esconderse en los escaparates. El jefe del Servicio de Contraespionaje observó el ceniciento perfil de Ferrain...". Arlt, Roberto. "La doble trampa mortal", en Cuentos completos, Op. Cit.

${ }^{123}$ Véase, para la descripción de algunos de estos rasgos: Veraldi, Gabriel. La novela de espionaje, México, FCE, 1983, p. 20.

${ }^{124}$ Interesa en el cuento, a su vez, el modo en que la admiración de la concurrencia que rodea a Baba el Ciego y escucha su historia se implica (como sucede en el teatro) en el desarrollo los hechos que sobrevendrán en la narración (en el "qué pasó", o en las acciones) y solicitan al narrador que no se detenga en la descripción del plano interior: "Yo estaba atemorizado. ¿Qué iría a ocurrirme? Pensaba que siempre había cumplido mis deberes para con el Profeta...' [...] 
Si como decíamos en el segundo capítulo, la experiencia del viaje a España y África en 1935 le proporciona a Arlt materiales útiles para una reformulación de su proyecto creador y muchos de los aspectos por los que su literatura cambia se relacionan con ella, los textos de espionaje (y sobre todo los que se llevan a cabo en el espacio de Marruecos) se constituyen también en relación con el saber adquirido en esa experiencia —que no es ni documental, ni científico- técnico como en las obras anteriores-. ${ }^{125}$ Ya desde la entrada a África, el cronista viajero que aparece en las aguafuertes de El Mundo describe "la pesadilla de espionaje", las complicaciones que supone su entrada en Tánger y, en Algeciras, con la policía internacional, y el "ambiente traidor, turbio desagradable", donde en cada personaje parece encubrirse un espía. ${ }^{126}$ Efectivamente, el viaje hace depositario a Arlt, o más precisamente, a la enunciación de los relatos de espionaje de Arlt, de un saber oculto, secreto y clandestino y muchos de los textos

-Abrevia - gritó una voz-: No nos cuentes la historia de tus deberes religiosos sino lo que ocurrió dentro de la casa". Arlt, Roberto. "La aventura de Baba en Dimish esh Sham", en Cuentos completos, Op. Cit., p. 247.

${ }^{125}$ Cabe destacar que el exotismo está en la tradición de los textos de espionaje, ya desde Ruyard Kipling. Véase, para más datos: Veraldi, Gabriel. "Folklore oriental de la gran novela de espionaje inglés, desde Kipling a Buchan", en La novela de espionaje, Op. Cit.

${ }^{126}$ Véase: Arlt, Roberto. "Complicaciones a causa de mi apellido - La pesadilla de espionaje - El agente $n^{\circ} 80$ - "Puede embarcarse", en El Mundo, 26 de julio de 1935. Allí, Arlt refiere: "Oficialmente, la entrada a Tánger es factible para cualquier ciudadano del mundo, cuyos papeles estén en orden; pero, prácticamente, no llega a Tánger sino aquel a quien la policía internacional de la zona permite entrar. Vigilancia extrema controla a los viajeros; mi apellido alemán resulta sospechoso, y en la Compañía de Navegación Trasmediterránea, cuando quiero comprar el pasaje, me indican la conveniencia de conversar previamente con el agente de la policía internacional, número 80, que hace el servicio de vigilancia entre Algeciras y Tánger.

En una nota próxima narraré el episodio que me ocurrió con un agente, también de policía, no sé si al servicio de Inglaterra, Francia o España, al volver de Gibraltar. Pero volvamos ahora a Algeciras.

Algeciras es España, pero una España cuyas características se nos aparecen completamente trastocadas.

Sus hoteleros ofrecen aquí una catadura enigmática, sospechosa. Los hombres serviciales y bondadosos que nos acogen cordialmente en las ciudades españolas, y que encienden una vela a la Virgen en los vestíbulos de sus hospedajes han desaparecido. Aquí, cada hotelero, tiene la prestancia de un agente de investigaciones; mirada en la que chispea la incredulidad; palabras donde se bifurca lo capcioso de la pregunta. Casi todos ellos son ex agentes de policía internacional, y aun dentro de la piel del posadero deben prestar sus pequeños servicios a la policía y recibir remuneraciones y propinas. El ambiente es traidor, turbio, desagradable; la zona internacional revela su proximidad equívoca. La Línea, pueblo de contrabandistas de sedas y tabacos, se encuentra a un paso de Algeciras. Los tiroteos son frecuentes entre contrabandistas y polizontes del Monopolio de Tabaco. La policía política no se queda atrás en el meneo de riñones. Africa es trabajada intensamente por los agitadores profesionales de diversas tendencias políticas. Los alemanes, fascistas o antifascistas no pueden entrar a Marruecos. Además, se trata de evitar la infiltración del comunismo, que le interesa a los jóvenes árabes. La vigilancia es intensa, reiterada." 
ficcionalizan ese conocimiento adquirido por el viaje y porque se viaja. En este sentido, en algunos cuentos se hace presente un narrador que propone una confusión con el cronista-viajero (y con Arlt) y que cuenta la historia como testigo directo de lo que refieren los protagonistas de los hechos (como en la historia de "La cadena del ancla"), o que delega el relato de los hechos en la voz de un sujeto ficticio oriental (como en el caso de Baba el Ciego). En este sentido, si muchas de las obras de espionaje suponen un enunciador y un autor que conoce el funcionamiento de lo servicios secretos, o ha tenido algún contacto con ellos, ${ }^{127}$ con el viaje Arlt torna creíble su enunciación, su conocimiento y la expresión de lo presumiblemente oculto y secreto. ${ }^{128}$ La pretendida verosimilitud de este narrador que se acerca a Arlt cronista y viajero es evidente en "La cadena del ancla":

Cuando a fines del año 1935 visité Marruecos, el tema general de las conversaciones giraba en torno a las actividades de los espías de las potencias extranjeras. Tánger se había convertido en una especie de cuartel general de los diversos Servicios Secretos. En Algeciras comenzaba ya esa atmósfera de turbia vigilancia y contravigilancia que se extiende por toda África costera al Mediterráneo.

Entre las verídicas historias y aventuras de espías que me fueron narradas, ésta que se titula "La cadena del ancla" es la que conceptúo la más terrible. ${ }^{129}$

Un narrador que se confunde con el cronista que había referido hechos similares en el diario, el yo de la enunciación se acerca a Arlt y de este modo construye, con el viaje, cierto fundamento de verdad y verosimilitud genérica para la historia de espionaje que se narra: la aventura por la cual una espía que viajaba escondida en la cadena del ancla de La Nuit muere despedazada cuando el capitán del barco decide bajar las dos anclas.

\footnotetext{
${ }^{127}$ Como refiere Gabriel Veraldi, el nacimiento de la novela de espionaje es una historia de espionaje en sí misma, y muchos de los autores que participaron en el género formaron parte, por ejemplo de los servicios secretos. Véase, Veraldi, Gabriel: La novela de espionaje, Op. Cit. ${ }^{128}$ Para la cuestión del espionaje en los textos de Leopoldo Lugones, véase: Dalmaroni, Miguel. "La espada y el puñal (sobre el penúltimo Lugones)", en Una república de las letras. Lugones, Rojas, Payró. Escritores argentinos y Estado, Rosario, Beatriz Viterbo editora, 2006, pp. 213220.

${ }^{129}$ Arlt, Roberto. "La cadena del ancla", en Cuentos completos, Op. Cit., p. 375
} 
De esta manera puede verse cómo el cronista de curiosidades "sabrosas" sobre el crimen, el cuentista policial y el escritor de aventuras de espionaje internacional, introduce en sus textos finales sobre el delito las preocupaciones y problemáticas que asume la literatura de Arlt en los años treinta, a la vez que reinscribe ciertas preocupaciones que aparecen desde los comienzos de su obra. Así, una serie de pasajes en su prosa (periodística y ficcional) pueden describirse en torno a la delincuencia que había sido una constante en su literatura y en los años treinta se reformulan sus modos de representación. Dentro del extenso corpus de las crónicas “Al margen del cable”, en ese subgrupo que constituye las notas ligadas al policial, al espionaje y a la criminalidad, se examinaron las que podrían considerarse en muchos sentidos historias infames; es decir, crónicas narrativas sobre delincuentes singulares, personajes del delito, que se acercan a las biografías de la Historia universal de la infamia de Borges. Por otra parte, en los cuentos de criminales y de espías que Arlt publica en El Hogar y Mundo Argentino, más cercanos al policial y a la literatura de espionaje desde el punto de vista de los modos de narrar y de los rasgos genéricos, se ponen en juego nuevas formas del relato. En este caso, además de cierta adscripción de Arlt a las vertientes de circulación masiva en la época cuyo paradigma era Edgar Wallace, puede leerse en sus ficciones criminales un cuestionamiento de los moldes genéricos en torno a la narrativa detectivesca y un cruce del policial con tramas fantásticas que nos reenvía nuevamente a los textos de Borges y Bioy Casares, a sus obras en colaboración y a algunos de los relatos que se publicaron en la Revista Multicolor de los sábados. 


\section{Arlt y el ensayo sobre la novela ${ }^{1}$}

Una de las preguntas fuertes que recorren la segunda mitad de los años treinta y el comienzo de la década del cuarenta en la literatura argentina es la de pregunta acerca de cómo narrar y es en los debates e intervenciones publicados en diarios y revistas que escritores e intelectuales dan cuenta de los cambios que revolucionan las formas narrativas ensayadas hasta entonces. ${ }^{2}$ Como una de las tantas respuestas y aproximaciones a esa pregunta — pero también como una de las más importantes contribuciones al debate y a la transformación de la narrativa-, a principios de la década del cuarenta y con la presencia de su autor en la Argentina, ${ }^{3}$ se discuten las "Ideas sobre la novela" que José Ortega y Gasset había publicado en su libro La deshumanización del arte en $1925 .^{4}$ El más conocido oponente de Ortega es, como se

\footnotetext{
${ }^{1}$ Este capítulo surgió después de un debate desarrollado en el seminario de doctorado dictado en la UNLP por el Dr. José Amícola en torno al ensayo en la literatura argentina, a quien agradezco sus comentarios oportunos y sus sugerencias.

${ }^{2}$ Para esta cuestión consúltese: Gramuglio, María Teresa. "Posiciones, transformaciones y debates en la literatura" en Crisis económica, avance del Estado e incertidumbre política (19301943), tomo VII de la Nueva Historia Argentina dirigido por Alejandro Cattaruzza, Buenos Aires, Sudamericana, 2001. Véase también: Gramuglio, María Teresa. "Momentos del ensayo de interpretación nacional. 1910-1930", en Boletín/10. Del centro de Estudios de Teoría y Crítica literaria, Facultad de Humanidades y Artes, Universidad Nacional de Rosario, Rosario, Diciembre de 2002, pp. 37-50. Véase, asimismo, la nota $\mathrm{n}^{\circ} 1$ del capítulo 3 de la presente tesis.

${ }^{3}$ José Ortega y Gasset realizó tres viajes a la Argentina y el tercero de ellos, desde 1939 a 1942. Véase, a este respecto: Aguilar, Gonzalo y Siskind, Mariano. "Viajeros culturales en la Argentina (1928-1942)", en Gramuglio, María Teresa (directora), El imperio realista. Historia crítica de la literatura argentina (dirigida por Noé Jitrik), Buenos Aires, Emecé, 2002, pp. 367391.

${ }^{4}$ Cabe destacar que esta polémica sobre la novela que se produce en la Argentina es eco del debate sobre el género que se estaba realizando en Europa desde la década del veinte y al que responde, entre otras cosas, el texto de Ortega. También son de los años treinta, por ejemplo, y para citar algunos casos, la mayoría de los ensayos de Georg Lukács sobre el realismo y el naturalismo, cuyas repercusiones, como se verá, pueden rastrearse en algunos de los autores locales.
} 
sabe, Jorge Luis Borges, que expone su posición en el citado prólogo a La invención de Morel de Adolfo Bioy Casares, libro editado en 1940. Además de Borges y con respuestas disímiles pero igualmente enfrentadas a las ideas de Ortega, también intervienen Roger Caillois, el joven sociólogo francés vinculado a Sur, el intelectual comunista Héctor Agosti y Roberto Arlt, quien dedica al tema una serie de artículos publicados en El Mundo.

La respuesta de Arlt reviste particular interés. Se trata de un conjunto de notas aparecidas en 1941, sin título, que ocupan el espacio dedicado a su columna "Al margen el cable". Consideramos que estas notas — que se analizarán a continuación — se inscriben bajo ciertas "formas del ensayo" "que, como tal, las convierte en el lugar de una búsqueda y en el espacio donde definir una nueva poética de la narración y una propuesta sobre el arte dramático. A su vez, estudiaremos los modos en que Arlt polemiza y discute algunas de las definiciones e ideas sobre la novela sostenidas por Ortega, acercándose así a otras opiniones contemporáneas.

\section{Arlt ensayista.}

En El cuarto en el recoveco, uno de los libros que estudian los alcances y manifestaciones del ensayo en la Argentina, Jaime Rest dedica un capítulo al análisis de las aguafuertes porteñas de Roberto Arlt. La intención del texto es clara: el autor parte de la tesis de que es el periodismo uno de los "vehículos naturales" de la "difusión" y "proliferación" del ensayo, e incluye, siguiendo a Bonamy Dobrée y Harold Merriam, el artículo de costumbres como una de las formas en que, con el avance de la prensa moderna y la alfabetización, se generalizaron y se diversificaron las características de

\footnotetext{
${ }^{5}$ Los artículos de Arlt a considerar son: "La vela encendida al sol”, en El Mundo, 13 de abril de 1941; "Aventura sin novela y novela sin aventura", en El Mundo, 13 de agosto de 1941; "Confusiones acerca de la novela", en El Mundo, 22 de agosto de 1941; "Galería de retratos", en El Mundo, 6 de septiembre de 1941; "Necesidad de un diccionario de lugares comunes", en El Mundo, 15 de septiembre de 1941; "Irresponsabilidad del novelista subjetivo", en El Mundo, 2 de octubre; "Acción, límite de lo humano y lo divino", en El Mundo, 7 de octubre de 1941; "Literatura sin héroes", en El Mundo, 13 de octubre de 1941; "Hace falta una escuela para novelistas", en El Mundo, 1 de noviembre de 1941. A excepción de "Hace falta una escuela para novelistas" y "La vela encendida al sol", las restantes están publicadas en Arlt, Roberto. Aguafuertes porteñas: cultura y política, Selección y prólogo de Sylvia Saítta, Buenos Aires, Losada, 1994.
} 
este género. ${ }^{6}$ Esto le permite a Rest considerar “...la función del artículo periodístico en el cuadro general de nuestro ensayo...” y determinar “...a través de la obra de Arlt, la importancia que poseía en su intento de indagar las manifestaciones de la vida urbana..." ${ }^{7}$ De este modo, en la prensa periódica, el género se inscribe también en los medios de circulación masiva y la consideración de Arlt posibilita al autor leer las aguafuertes porteñas como el testimonio de Buenos Aires convertida en ciudad cosmopolita, pues "en el ejercicio de esta forma particular del ensayo que es el artículo periodístico, Arlt logró trazar un intrincado y minucioso cuadro de la realidad porteña en un período clave de nuestra evolución contemporánea". ${ }^{8}$

Si bien la admisión de las aguafuertes en el contexto del ensayo podría justificarse para un número limitado de sus esbozos porteños — preferentemente textos como "El idioma de los argentinos", los que defienden la lengua "de la calle", o aquellos en que se sostiene una tesis sobre las conductas habituales y se delinean características del ciudadano de Buenos Aires, ${ }^{9}$ para mencionar algunos casos — resulta por lo menos problemática y bastante discutible esta caracterización para el resto de las aguafuertes. Y esto es así, en principio, porque el ensayo si bien supone una aproximación preliminar y un saber de carácter inacabado y tentativo que ofrece, como en Montaigne "una experiencia inconclusa" $\mathrm{y}$ subjetiva, ${ }^{10}$ implica asimismo y necesariamente la exposición de ideas y goza de una determinada propensión intelectual. O, tal como lo afirma el propio Rest, un ensayo no puede ser meramente informativo, descriptivo o anecdótico, sino que a partir de "tales ingredientes tiende hacia una meta en la que finalmente debe resplandecer cierta idea acerca de algo, acerca de alguien". [...] "su intención es persuadirnos de la validez de cierta noción. Es, en definitiva, una vía literaria de aproximación a [...] [un] conocimiento de índole conceptual". ${ }^{11}$ Por lo demás, cabe destacar que en la perspectiva de Theodor Adorno, el ensayo, en tanto ensamble conceptual, también supone alguna pretensión de verdad y

${ }^{6}$ Rest, Jaime. El cuarto en el recoveco, Buenos Aires, CEAL, 1982, pp. 19-20.

${ }^{7}$ Rest, Jaime. El cuarto en el recoveco, Op. Cit., p. 73.

${ }^{8}$ Rest, Jaime. El cuarto en el recoveco, Op. Cit., p. 68.

${ }^{9}$ Esta es una zona de las aguafuertes de Arlt que, aunque con algunas diferencias, podría relacionarse con los ensayos de Scalabrini Ortiz de El hombre que está solo y espera, texto de 1931.

${ }^{10}$ Para la cuestión de los orígenes del término ensayo y sus alcances en Montaigne, véase, Starobinsky, Jean. “¿Es posible definir el ensayo?”, en Cuadernos Hispanoamericanos, $\mathrm{n}^{\circ}$ 575, mayo de 1998.

${ }^{11}$ Rest, Jaime. El cuarto en el recoveco, Op. Cit., p. 17. 
este es el rasgo que marca su separación del mundo del arte. "El ensayo se diferencia por su medio, los conceptos, y por su aspiración a la verdad", ${ }^{12}$ sostiene, en el ya clásico trabajo sobre el tema y en oposición a la visión de Lukács, ${ }^{13}$ quien percibía el ensayo como "forma artística"; Adorno, en cambio, se centra en los alcances del territorio intermedio y fronterizo que la "forma" ensayo ocupa a mitad de camino, para él, entre la ciencia y el arte. ${ }^{14}$

Si bien algunas de las crónicas estudiadas por Rest responderían parcialmente a las consideraciones señaladas, parecería poco admisible sostener el común denominador de ensayo para todos los casos o para la mayoría de las aguafuertes porteñas de Arlt, publicadas por el autor en el diario El Mundo desde 1928 hasta 1935, momento en que viaja a España y escribe desde allí sus artículos de viajero. ${ }^{15}$ Porque las aguafuertes porteñas, como lo dice Arlt en reiteradas oportunidades, son textos bien coyunturales, surgidos en muchos casos de la premura de la columna cotidiana:

Veo que estoy macaneando, y en grande...Y todo porque debo escribir esta nota en veinticinco minutos $[\ldots]$ ¿No es trágico esto de tenerse que escribir una nota en veinticinco minutos? [...] ¿Dará el sujeto del trombón tema de nota para ochocientas palabras? ¡Maldito sea el trombón! Podría haber tomado el argumento de otro asunto; por ejemplo, ¿qué ejemplo? ... [...] En verdad que a mí hoy me importa un ardite el hombre del trombón. Escribo sobre eso como podría escribir

\footnotetext{
${ }^{12}$ Adorno, Theodor. "El ensayo como forma", en Notas de literatura, Barcelona, Ariel, 1962, p. 13.

${ }^{13}$ Véase: Georg Lukács, "Esencia y forma del ensayo", en Eco. Revista de la Cultura de Occidente, Brechholz, Bogotá, Enero de 1967. Sobre la cuestión del ensayo y del ensayo argentino, en particular, puede consultarse: Arias Saravia, Leonor, La Argentina en clave metafórica. Un itinerario a través del ensayo, Buenos Aires, Corregidor, 2000; Boletín / 10 del Centro de Estudios de Teoría y Crítica literaria, número dedicado a "Políticas del ensayo", diciembre de 2002; Borello, Rodolfo, "El ensayo. 1930-1970" en Capítulo, Historia de la literatura argentina, tomo 4, Buenos Aires, CEAL, 1980/1986; Flawiá de Fernández, Nilda, El ensayo argentino, 1900-1950, Tucumán, Instituto de Investigaciones Lingüísticas y Literarias Hispanoamericanas, 1988; Giordano, Alberto. Modos del ensayo. De Borges a Piglia, Rosario, Beatriz Viterbo, 1991; González, Horacio, Restos pampeanos. Ciencia, ensayo y política en la cultura argentina del siglo XX, Buenos Aires, Colihue, 1999; Rosa, Nicolás (editor), Historia del ensayo argentino. Intervenciones, coaliciones, interferencias, Buenos Aires, Alianza, 2003.

${ }^{14}$ Cabe aclarar que el propio Rest ubica el ensayo en "la mansión de la literatura", en ese "cuarto en el recoveco" que permanece casi "olvidado y en penumbras". Rest, Jaime. Op. Cit., p. 13.

${ }^{15}$ En la bibliografía sobre las aguafuertes predomina lo incierto sobre su denominación. En muchos casos también se las denomina ensayos y se intercambia el término alternativamente con el de artículos de costumbres. Este hecho puede relacionarse con las imprecisiones que rodean la utilización del concepto de ensayo.
} 
sobre cualquier otra cosa, pero el tiempo urge; el dibujante reclama la nota para ilustrarla. ${ }^{16}$

De esta manera, así como el contexto de enunciación de estos textos resulta en muchos casos bastante alejado de una presunta pretensión de verdad, también su contenido es muy distante, en reiteradas ocasiones, del ensamble conceptual y el desarrollo de ideas, y es por ello problemática la denominación de ensayos para el conjunto de estas crónicas.

Otro es el caso de los artículos que Arlt publica en El Mundo entre abril y noviembre de 1941 para participar de la polémica sobre la novela que se estaba desarrollando en el campo intelectual argentino. Cuando Arlt discute sobre la novela también lo hace sobre las distintas maneras de narrar y representar, asumiendo así las "formas del ensayo" de un modo considerablemente más claro y convincente. En principio, se parte de una situación de enunciación bastante diferente, porque es indudable que estas notas no se originan en el abatimiento y la premura de la columna cotidiana. Arlt, que en ese momento no publicaba en El Mundo un artículo diario, como hasta entonces, sino que sus colaboraciones se limitaban casi exclusivamente a los sábados, escribe las notas sobre la novela en su espacio del periódico, sucesiva e ininterrumpidamente desde agosto a noviembre de 1941, lo que evidencia, un claro interés del escritor en el tema. ${ }^{17}$ Además, los escritos en cuestión implican, a diferencia de las aguafuertes porteñas, una incuestionable discusión de ideas, pues parten, como en el ensayo, de un saber predeterminado que es reorganizado, revisado y resistematizado. ${ }^{18}$ En esa reformulación predomina el despliegue conceptual y la

${ }^{16}$ Arlt, Roberto. "Una excusa: el hombre del trombón", en El Mundo, 29 de enero de 1930. Recopilada en Arlt, Roberto. Aguafuertes porteñas, Buenos Aires, Losada, 1996, p.71.

${ }^{17}$ Hay sólo dos breves paréntesis. El primero, después del artículo publicado el 13 de abril de 1941, "La vela encendida al sol". Este texto, al mismo tiempo que marca una continuidad con las crónicas arltianas "Al margen del cable" porque su asunto es la guerra, inicia la discusión sobre la novela. Después de esta nota, Arlt publica algunas reflexiones sobre otros asuntos y la serie sobre la novela se retoma el 13 de agosto de 1941, cuando aparecen "Aventura sin novela y novela sin aventura" y, sucesivamente, las otras siete intervenciones sobre el tema (véase nota 5 de este capítulo). Sólo un artículo, intercalado entre estos textos mencionados, "Necesidad de un diccionario de lugares comunes" (del 15 de septiembre de 1941), se refiere a una cuestión ajena a la de la novela, pero se trata de una corta interrupción que no rompe la continuidad de los argumentos, pues, en la colaboración siguiente que se edita en El Mundo, se retoman nuevamente los términos planteados en la discusión del problema.

${ }_{18}$ Adorno y Lukács coinciden en que el ensayo es siempre revisión de algo ya dado y preformado culturalmente. En este sentido afirma Lukács muy elocuentemente: “...el ensayo 
discusión de otras nociones existentes sobre el tema que se vuelven a interpretar y ordenar en el mismo momento en que "el pensamiento se está haciendo". ${ }^{19}$ Porque en el ensayo, como afirma Beatriz Sarlo refiriéndose al ensayo de los escritores, los argumentos se dispersan y los textos "escriben y describen una búsqueda". O, más precisamente, el momento en que un texto "se piensa mientras se escribe". ${ }^{20}$ De allí viene el carácter indagatorio que tienen las reflexiones de Arlt: implican una exploración, donde a la vez que Arlt define y ensaya las vías posibles y los ingredientes que a su juicio "necesita" la novela, también procura delinear y proyectar los itinerarios y los lineamientos de su propia producción.

Es por ello que estos artículos tienen un innegable componente subjetivo. En efecto, si algo caracteriza al ensayo es la presencia del sujeto que enuncia y el carácter de experiencia de lo enunciado: "je sui moy-mesmes la matiere de mon livre", decía Montaigne. ${ }^{21}$ En este sentido, Silvio Mattoni sostiene que "el ensayo sería el género donde las pasiones se convierten en saber, donde lo intransmisible del estilo procura alcanzar la transmisibilidad de los conceptos y a través de ellos la verdad de un objeto, en cuya elección tal vez aparezca la verdad única de cada ensayista, su distinción, su especificidad, su enseñanza". ${ }^{22} \mathrm{O}$, como afirma el mismo autor siguiendo a Foucault, de manera particular para el caso de los escritores, “el ensayo, más que una simplificadora apropiación de otros para los fines de la comunicación, debe entenderse como 'un tanteo modificador de uno mismo en el juego de la verdad' [...] 'una ascesis, una ejercitación de uno mismo en el pensamiento'; vale decir, ascesis imprevisible donde el escritor se escribe a sí mismo, se modifica, se sopesa, se dispone a escribir". ${ }^{23} \mathrm{Y}$ es precisamente este interjuego entre lo subjetivo y lo objetivo ${ }^{24}$ el que puede leerse cuando Arlt

habla siempre de algo ya formado, o por lo menos de algo que en alguna otra ocasión ha sido; corresponde a su esencia no sacar de la nada nuevos objetos, sino solamente ordenar de nuevo los que en alguna ocasión tuvieron existencia. Y por limitarse a esta nueva ordenación, sin crear de lo informe nada nuevo, está obligado a expresar continuamente la 'verdad' sobre ellos, y a buscar la manera de exteriorizar su esencia". Lukács, George. "Esencia y forma del ensayo", Op. Cit., p. 267-268.

${ }^{19}$ Véase al respecto: Sarlo, Beatriz. "Del otro lado del horizonte", en Boletín/9. Del Centro de Estudios de Teoría y Crítica Literaria, Rosario, Diciembre de 2001.

${ }^{20}$ Sarlo, Beatriz. "Del otro lado del horizonte", Op. Cit., pp. 16-17.

${ }^{21}$ Véase: “Au lecteur”, en Montaigne. Essais, Tome I, Éditions Garnier Frères, Paris, 1962.

${ }^{22}$ Mattoni, Silvio. "El género", en Mattoni, Silvio. Las formas del ensayo en la Argentina de los años '50, Córdoba, Universitas, 2003, pp. 19-20.

${ }^{23}$ Mattoni, Silvio. Las formas del ensayo en la Argentina de los años '50, Op. Cit., p. 42.

${ }^{24}$ Véase. Mattoni, Silvio. Las formas del ensayo en la Argentina de los años '50, Op. Cit., pp. $39-40$. 
examina la novela para pensar las condiciones de su literatura y los caracteres singulares de su experiencia de escritor. Estos textos que persuasivamente argumentan desde el lugar del lector, ${ }^{25}$ están hablando al mismo tiempo de circunstancias concretas de su obra y de su práctica de autor teatral y narrador: Arlt discurre sobre novela, y ensaya y define los criterios de valor de su propia producción.

De esta manera, la presencia del ensayo $\longrightarrow$ de este conjunto de sus rasgos distintivos - en estas notas finales de Arlt, introduce en los años cuarenta algo bastante novedoso en su escritura periodística. Es más, esta intervención polémica sobre la novela, desplazada en la escritura hacia el registro ensayístico, se diferencia, por su aspecto programático y su entramado conceptual, de otros modos de la polémica que aparecían en textos como el prólogo a Los Lanzallamas o en su columna de El Mundo en años anteriores, y se constituyen en una zona muy elocuente para pensar su escritura. ${ }^{26}$ No es casual, por lo demás, que Arlt publique estos artículos en 1941, en un momento en que tiene una posición ganada en el campo literario y entre los lectores del diario: como afirma Liliana Weinberg, "el punto de encuentro entre un ensayista y su público se debe, en buena medida, a que el lector se reconoce y confia en quien escribe; el ensayista no es un descastado, un paria ni un recién llegado al sistema literario: ocupa ya un lugar estratégico en el campo intelectual". ${ }^{27}$ Es por eso muy significativo, en este caso, pensar el lugar del que enuncia y la construcción del nombre propio en relación con los enunciados expresados y en sus vínculos con el posible lector.

\section{Los términos de la polémica}

\footnotetext{
${ }^{25}$ Algunos aspectos relacionados con el carácter polémico del ensayo y su apelación al lector se desarrollarán en las páginas que siguen, cuando se estudie más precisamente el contenido de la intervención arltiana y los términos de su discusión.

${ }^{26}$ Estos rasgos pueden vincularse, asimismo, con los textos que Arlt escribe para otras publicaciones en los años treinta, como Bandera Roja o la revista Actualidad. De este modo, estos caracteres, inéditos dentro de su columna del diario El Mundo, no lo son en su trayectoria como periodista o intelectual.

${ }^{27}$ Son palabras de Saítta, Sylvia. "Modos de pensar lo social. Ensayo y sociedad en la Argentina (1930-1965), en Federico Neiburg y Mariano Plotkin (editores), Intelectuales y expertos. La constitución del conocimiento social en la Argentina, Buenos Aires, Paidós, 2004, pp. 107-146. El texto de Liliana Weinberg al que se hace referencia es: Weinberg, Liliana. En ensayo, entre el paraíso y el infierno, México, Fondo de Cultura Económica, 2001, p. 22.
} 
En 1939, y con motivo de la guerra civil española y la inminente guerra mundial, José Ortega y Gasset viaja por tercera vez a la Argentina y permanece en el país hasta 1942. En sus dos visitas anteriores, realizadas en 1916 y 1928, había pronunciado sus exitosas conferencias con las "impresiones" del viajero que gozaron de gran repercusión y réplicas en esos días. Si bien su obra era bien conocida y algunos de sus textos habían sido editados más de una vez en la Argentina, es sabido que en el tercer viaje empieza a tener ciertas diferencias con algunos círculos intelectuales argentinos, como es el caso de la revista Sur. $^{28}$ Este pensador español, que había inspirado con su Revista de Occidente ese proyecto editorial — tal como lo asegura la misma Victoria Ocampo, directora de la publicación, en el homenaje que Sur le hace en el momento de su muerte_- ${ }^{29}$ se aleja en 1939 del Comité de Colaboración. Como afirma María Teresa Gramuglio, su alejamiento "parece haber coincidido con un cierto acercamiento de Ortega a la derecha nacionalista" y, si bien sus relaciones con los totalitarismos y el franquismo todavía suscitan controversias, otras versiones aseguran que motivó esa separación su posición demasiado neutral y su indecoroso silencio en esos días ante Franco y la Guerra Mundial. ${ }^{30}$ Porque en ese momento en que el entramado político era el que decidía muchas de las adhesiones y rechazos, el caso de Ortega resultaba, por lo menos, bastante incómodo frente a la postura pacifista, antifascista y contraria a los regímenes totalitarios que explícitamente defendió Sur: “...nadie puede permanecer moralmente neutral. Nosotros no somos neutrales", decía Victoria Ocampo en el número editorial sobre la guerra titulado: "Nuestra actitud". ${ }^{31}$

\footnotetext{
${ }^{28}$ Según Tzvi Medin, Ortega regresó a la Argentina para su tercera visita con un reconocimiento mundial mayor del que tenía durante su viaje anterior, había publicado su libro más famoso, $L a$ rebelión de las masas, traducido al inglés, al francés, y al alemán, entre otros idiomas. Sin embargo, en Argentina, Ortega fue marginado por los núcleos académicos, profesionales e intelectuales — como es el caso de la revista Sur —, no se le otorgó ninguna cátedra en la Universidad y tuvo serias dificultades para poder mantenerse. Tzvi Medin. Ortega y Gasset en la cultura hispanoamericana, México, Fondo de Cultura Económica, 1994.

${ }^{29}$ Véase: Sur, ${ }^{\circ} 241$, julio y agosto de 1956.

${ }^{30}$ Gramuglio, María Teresa. "Posiciones, transformaciones y debates en la literatura", Op. Cit., p. 351-352. Con respecto al alejamiento de Sur, también se menciona como uno de los motivos determinantes, su desacuerdo con una nota muy incisiva e irónica titulada "Capricho español" en contra de Sol y Luna, la revista de la derecha nacionalista, que había aparecido en la sección "Calendario" de Sur y que aunque no estaba firmada se supone escrita por Borges. Según Tzvi Medin, cuando este incidente llegó a los oídos de Ortega, éste avisó de inmediato que retiraba su nombre del Comité de Colaboración de Sur.

${ }^{31}$ Victoria Ocampo, "Nuestra actitud", en Sur, nº 60, Buenos Aires, septiembre de 1939, p. 8.
} 
Es bastante sintomático por cierto, que en ese momento se discutan también sus ideas estéticas sobre la novela, escritas quince años antes, en La deshumanización del arte. Allí Ortega veía a la novela como un género que había caído en decadencia, del mismo modo que "una especie zoológica". 32 "Creo que el género novela, si no está irremediablemente agotado — expresaba en su trabajo de 1925-, se halla, de cierto, en su período último y padece de tal penuria de temas posibles, que el escritor necesita compensarla con la exquisita calidad de los demás ingredientes necesarios para integrar un cuerpo de novela". ${ }^{33}$ Ahora bien, esos "ingredientes" 0 , en otros términos, el entramado de elementos que determinaba cuál era una "buena novela" y no una que por reiterativa y previsible ocasionaba el aburrimiento y el "embotamiento de la facultad de impresionarse" del exigente lector en que pensaba Ortega, supone la elección indefectible de un "arte de figuras" frente a un "arte de aventuras" y el predominio de la “contemplación" sobre la "acción". "Más bien que inventar tramas por sí mismas interesantes" — cosa prácticamente imposible para Ortega, quien considera que lo estético del género no está dado por su trama y que no responde a una "sensibilidad superior" el interés por las acciones_- conviene a la novela "idear personas atractivas". Por otra parte, esto es lo que viene sucediendo, según la opinión del autor, en la evolución del género: la novela "actual", a diferencia de la "primitiva" y en oposición al folletín, el cuento o el melodrama tiene como fin "referirnos lo que el personaje es: hace falta que lo veamos con nuestros propios ojos"; 34 en ella prevalece, lo "descriptivo", lo "presentativo", y lo "directo", ${ }^{35}$ como en la obra de Proust que, de todos modos, implica, a su juicio, una puesta en extremo de ese método. ${ }^{36}$

\footnotetext{
${ }^{32}$ Ortega se opone a la idea de Croche que niega la existencia de los géneros artísticos, y sostiene que "Toda obra literaria pertenece a un género, como todo animal a una especie" [...] "Y lo mismo el género artístico que la especie zoológica significan un repertorio muy limitado de posibilidades". Ortega y Gasset, José. "Ideas sobre la novela", en Ortega y Gasset, José. Meditaciones del Quijote e Ideas sobre la novela, Revista de Occidente, Madrid, 1963, p. 143.

${ }^{33}$ Ortega y Gasset, José. "Ideas sobre la novela", Op. Cit., p. 145.

${ }^{34}$ Ortega y Gasset, José. "Ideas sobre la novela", Op. Cit., p. 147.

${ }^{35}$ Términos estos que describen a su juicio, los modos en que la novela procura apropiadamente una presencia inmediata del héroe y de su atmósfera, sin definiciones intermedias, ni el relato de acciones y sucesos que previamente lo revelen. (Ortega y Gasset, José. "Ideas sobre la novela", Op. Cit., p. 159)

${ }^{36}$ Si bien para Ortega la Obra de Proust indica el "camino a seguir por la novela", ella adolece de una falla que es la total ausencia de acción: "En Proust, la morosidad, la lentitud llega a su extremo... [...] La trama queda casi anulada y se borra el postrer resto de interés dramático. [...] Notamos que le falta el esqueleto, el sostén rígido y tenso, que son los alambres en el paraguas. [...] Por esta razón, he dicho antes que aunque la trama o acción posee un papel mínimo en la
} 
La novela, entonces, debe detenerse en el héroe, en su "atmósfera" y revelar su psicología, pues en eso consiste la "morosidad del personaje", tan afín al autor: "No en la invención de 'acciones', sino en la invención de almas interesantes veo yo el porvenir del género novelesco." ${ }^{37}$ Además, es preciso que sea "tupida" o que apele a una "plenitud de detalles". Es la descripción, por lo tanto, la que constituye un recurso ineludible en la construcción de este tipo de héroe pero también en la creación de un/otro mundo, paralelo al real, en la novela. Porque para Ortega, "al ser [ésta] un género 'realista' por excelencia resulta incompatible con la realidad exterior" y es por eso que debe crear un microcosmos "hermético", "Una cuasi realidad perfecta" [...], que no se la perciba como tal novela. ${ }^{38}$ Es decir, que no se evidencie su carácter de convención, artificial que es, por ejemplo, uno de los cuestionamientos que le hace el autor en este trabajo a la obra de Balzac. ${ }^{39}$ En síntesis, decadencia del género, ausencia de temas, centralidad de la psicología del personaje, escasez de trama que debe reducirse "a un simple esqueleto", y "plenitud de detalles", son los ejes principales sobre los que se basa y discurre la propuesta estética del ensayo de Ortega.

Borges discute algunas de estas ideas en el "Prólogo" a La invención de Morel, de 1940, y lo hace para rebatir los argumentos de Ortega Gasset y, a su vez, fijar su posición con respecto a la literatura de Eduardo Mallea, el escritor favorito de Sur en esos años. ${ }^{40}$ Se trata entonces de una más de las variadas operaciones con las que Borges $-\mathrm{y}$ otros escritores que formaban un subgrupo con Borges, como el propio Bioy

novela actual, en la novela posible no cabe eliminarla por completo y conserva la función, ciertamente no más que mecánica, del hilo en el collar de perlas, de los alambres en el paraguas". Ortega y Gasset, José. "Ideas sobre la novela", Op. Cit., p. 166.

${ }^{37}$ Ortega y Gasset, José. "Ideas sobre la novela", Op. Cit., pp. 191-192.

${ }^{38}$ Ortega y Gasset, José. "Ideas sobre la novela", Op. Cit., pp. 184 y 165.

${ }^{39}$ Dice Ortega, a propósito de Balzac: "Balzac, leído hoy, nos despierta de nuestro ensueño novelesco en cada página, porque nos golpeamos contra su andamiaje de novelista" (p. 165). Y, en otro lugar, afirma de un modo totalmente contrario a las perspectivas que sostendrán entre otros sobre todo Borges y Macedonio Fernández: "La verdad es que, salvo uno o dos de sus libros, el gran Balzac nos parece hoy irresistible. Nuestro aparato ocular, hecho a espectáculos más exactos y auténticos, descubre, al punto, el carácter convencional, falso, de à peu près, que domina el mundo de la Comedia humana" (Ortega y Gasset, José. "Ideas sobre la novela", Op. Cit., p. 146).

40 Seguimos aquí las consideraciones de María Teresa Gramuglio, "Posiciones, transformaciones y debates en la literatura", Op. Cit., p. 339. Véase también, para esta cuestión: John King, Sur. Estudio de la revista argentina y de su papel en el desarrollo de una cultura. 1931-1970, México, Fondo de Cultura Económica, 1990. Judith Podlubne trabaja la oposición de Borges a Mallea en esta polémica (Podlubne, Judith. "Capítulo II", Tesis doctoral, en preparación, mimeo"). 
Casares y Silvina Ocampo- promociona el relato fantástico y las tramas elaboradas de los textos de aventuras y el policial. Esta intervención de Borges crea un espacio para la lectura y la recepción tanto de su obra como de la de su grupo y se suma a sus notas publicadas en El Hogar — sobre todo las editadas entre 1936 y 1939 — $^{41}$ y a la tarea de director de la Revista Multicolor de los Sábados, en 1933 y 1934. Como se señaló en capítulos anteriores, en esta revista Borges efectúa una tarea de divulgación de obras y autores desconocidos para el público masivo del diario e imprime a la revista sus preferencias literarias en torno al policial y al relato fantástico.

Ahora bien, es entonces en el entramado de esta doble polémica — contra las ideas de Ortega y contra las tendencias realistas y psicológicas de la literatura argentina del momento-que el "Prólogo" de Borges define por oposición los criterios estéticos en los que debe basarse la ficción narrativa a principios de los años cuarenta. El primer movimiento de este breve texto es quitar autenticidad al pensamiento de Ortega y revelarle un origen anglosajón: "Stevenson, hacia 1882, anotó que los lectores británicos desdeñaban un poco las peripecias y opinaban que era muy hábil redactar una novela sin argumento, o de argumento infinitesimal, atrofiado. José Ortega y Gasset - La deshumanización del arte, 1925 - trata de razonar el desdén anotado por Stevenson y estatuye en la página 96, que 'es muy difícil que hoy quepa inventar una aventura capaz de interesar a nuestra sensibilidad superior'. Algunos escritores (entre los que me place contar a Adolfo Bioy Casares) creen razonable disentir". ${ }^{42}$ Borges se enfrenta entonces a la novela psicológica y se muestra a favor de los textos de aventuras. Tal prioridad se basa, en principio, en que este tipo de obras pone en evidencia su convencionalidad o "su carácter de artificio verbal", —-la novela psicológica quiere ser también novela realista [...] La novela de aventuras, en cambio, no se propone como una trascripción de la realidad: es un objeto artificial"- en el poder de la invención que ellas implican, y en el "intrínseco rigor de la novela de peripecias”. Estos argumentos justifican, por lo demás, la preferencia por las obras de "imaginación razonada", por la literatura fantástica y por las "ficciones de índole

${ }^{41}$ Ese período fue el que Borges estuvo a cargo de la sección "Libros y autores extranjeros". Véase: Borges, Jorge Luis. Borges en El Hogar. 1935-1958, Buenos Aires, Emecé, 2000.

${ }^{42}$ Borges, Jorge Luis. "Prólogo" en Bioy Casares, Adolfo. La invención de Morel, Buenos Aires, Emecé 1955, p. 11. 
policial". ${ }^{43}$ Asimismo, ante la ausencia de temas y la decadencia tan mentada del género anunciados por Ortega, también apela Borges a las ficciones científicas y fantásticas y, en un movimiento en el que ubica a Bioy Casares en la tradición universal, y arma una genealogía prestigiosa para su novela (donde además se menciona a Chesterton, Shakespeare y Cervantes) asegura "que ninguna otra época posee novelas de tan admirable argumento como The Turn of the Screw, como Der Prozess, como Le voyageur sur la Terre, como esta que ha logrado en Buenos Aires, Adolfo Bioy Casares. ${ }^{44}$ De este modo, más allá del pretendido dominio de todas las lenguas (inglés, alemán, francés) que le permite al prologuista, como sostiene Sarlo, apropiarse de la tradición de la literatura universal, ${ }^{45}$ se propone La invención de Morel como continuación en la lengua española de estas grandes obras y es de este modo, sobre todo, que el texto piensa su valor y su originalidad. ${ }^{46}$

Otra perspectiva es la que sostiene el ensayista y sociólogo francés Roger Caillois, uno de los colaboradores extranjeros de la revista Sur, que permanecía en esos días en la Argentina. En 1939 había viajado a Buenos Aires invitado por Victoria Ocampo para dar unas conferencias y el estallido de la Segunda Guerra Mundial

${ }^{43}$ En un sentido similar, Adolfo Bioy Casares, en la reseña de El jardín de senderos que se bifurcan, de Borges, también recalca "la importancia de la construcción" y el ideal de la invención como el aporte del género policial en la historia de la literatura. Véase, Bioy Casares, Adolfo. "Jorge Luis Borges, El jardín de senderos que se bifurcan", en Sur, n 92, mayo de 1942 .

${ }^{44}$ Borges, Jorge Luis. "Prólogo", Op. Cit., p. 13.

${ }^{45}$ Sarlo, Beatriz. Borges, un escritor en las orillas, Buenos Aires, Ariel, 1993.

${ }^{46}$ En este sentido, afirma el prologuista: "En español, son infrecuentes y aún rarísimas las obras de imaginación razonada. Los clásicos ejercieron la alegoría, las exageraciones de la sátira y, alguna vez, la mera incoherencia verbal; de fechas recientes no recuerdo sino algún cuento de La fuerzas extrañas y alguno de Santiago Dabove: olvidado con injusticia. La invención de Morel [...] traslada a nuestras tierras y a nuestro idioma un género nuevo." (Borges, Jorge Luis. "Prólogo", Op. Cit., pp.14-15). Así, Borges señala la necesidad de lo nuevo en "nuestras tierras" y "nuestro idioma" y plantea a la novela de Bioy Casares $\longrightarrow$ y a su modelo de la narracióncomo lo que viene a llenar un lugar vacío en el campo intelectual. La Invención de Morel, $\rightarrow \mathrm{y}$ la renovación que ella implica según lo que se asevera en el prólogo-cumpliría, por ello, una función inédita en las letras argentinas, que a diferencia de otras literaturas, es pobre en "obras de imaginación razonada". Es así como el breve ensayo borgeano al mismo tiempo que formula estas prescripciones generales para la narrativa, también define, el lugar de Borges como narrador y los juicios que autorizan y justifican su propia poética para la escritura de ficción. Para estas cuestiones puede consultarse, entre otros trabajos el artículo de Isabel Stratta, "Documentos para una poética del relato" en Sylvia Saítta (directora), El oficio se afirma, tomo 9 de la Historia crítica de la literatura argentina, Buenos Aires, Emecé, 2004; sobre la labor crítica y ensayística de Borges: Pastormerlo, Sergio. Borges crítico, Buenos Aires, FCE, 2007, especialmente, el apartado "Rupturas", pp. 69-77. 
impidió que regresara a Francia hasta $1945 .{ }^{47} \mathrm{Su}$ producción sobre el tema es bastante copiosa. En una de las cartas que asiduamente envía a Victoria Ocampo, fechada en abril de 1941, Caillois refiere las líneas generales del libro que está preparando sobre la novela. Este texto retoma sus ensayos anteriores al respecto y es editado al año siguiente por Sur con el título de Sociología de la novela. ${ }^{48}$ Ya había aparecido en 1941 en Lettres françaises "Le Roman Policier", el estudio sobre el policial que generó la famosa polémica con Borges, ${ }^{49}$ y el 17 de agosto de 1941 se publica en La Nación "El suicidio de la novela", un breve artículo que retoma algunos de los tópicos de la discusión del momento: el psicologismo actual del género, la introspección e individualismo, su "suicidio", antes que la decadencia.

Por lo demás, cabe decir que la posición de Caillois, y su explicación, también contraria a las ideas de Ortega, es la del sociólogo: "la novela nace en un verdadero vacío en la sociedad. Siempre impulsa al individuo a separarse de la sociedad y a volverse sobre sí mismo. Pero debilita la sociedad, acrecienta el "vacío". Pronto no hay más que vacío: sin moral, sin energía, sin nada: entonces la novela, para ser fiel a sí misma, debe proponer héroes que pretendan reconstruir la sociedad: esto llega y la novela desaparece [...] ...la novela es el arte individualizante. No renacerá sino cuando el "vacío" se haya introducido nuevamente en la sociedad". 50

Pero además de las teorizaciones de Caillois, también puede detectarse en las páginas de la revista Sur de ese entonces una preocupación marcada por la cuestión de

\footnotetext{
${ }^{47}$ En el exilio, dirigió una revista cultural, Lettres Fransaises, que era financiada por Sur y que apareció regularmente durante toda la guerra. También es conocido como el primer traductor de Borges al francés y por su tarea de difusión de la literatura latinoamericana como director de la colección "La croix du Sud", cuando volvió a Francia.

${ }^{48}$ Véase al respecto: Caillois Roger y Ocampo, Victoria. Correspondencias (1939-1978), Buenos Aires, Sudamericana, 1999. En una carta fechada el 30 de abril de 1941, Caillois describe a Ocampo el plan de su libro. Y en una carta fechada el 21 de abril de 1941, Caillois afirma: "Bianco ha creído conveniente pasarme las Ideas sobre la novela de Ortega: imposible no escribir entonces una pequeña nota para mostrar hasta qué punto las ideas susodichas están en desacuerdo con los hechos. La he redactado con la máxima cortesía posible." (p. 105). Es posible que aquí Caillois haga referencia al artículo publicado posteriormente en La Nación.

${ }^{49}$ Los textos de la polémica aparecidos ambos en el número 91 de Sur son el de Jorge Luis Borges en la Sección "Los Libros" (Borges, Jorge Luis. "Roger Caillois, Le roman policier", Sur, $\mathrm{n}^{\circ}$ 91, abril de 1942, pp. 56-57) y un artículo de Caillios ("Rectificación a una nota de Jorge Luis Borges", Sur, n 91, abril de 1942, pp. 71-72). Para la polémica ente Borges y Caillois véase: Capdevila, Analía. "Una polémica olvidada. Borges contra Caillois sobre el policial", en Borges ocho ensayos, Rosario, Beatriz Viterbo, 1995, y Pastormerlo, Sergio. "Rupturas", en Borges crítico, Op. Cit., pp. 69-77.

${ }^{50}$ Caillois, Roger y Ocampo, Victoria. Op. Cit., p. 108
} 
la novela, que coincide, de más está decirlo, con un debate sobre el tema que se da en otros puntos del planeta y del que Sur se hace eco. Así, por ejemplo, más allá del texto elogioso de Eduardo González Lanuza sobre Una novela que comienza de Macedonio Fernández, que es ya de por sí una toma de posición en torno del problema, ${ }^{51}$ cabe destacar dos artículos que aparecen en la sección "Calendario", sin firma de autor. El primero de ellos es una "Invitación a la novela" y reproduce reflexiones de Octavio Paz que, si bien se refieren a la situación en México, igualmente "Pueden aplicarse, en general, a $[. .$.$] todos los países sudamericanos". Para Paz, "Nuestro tiempo ha mutilado$ a la novela", que resulta, por ello, o bien un pretexto para opinar, o queda reducida a un monólogo interior. De esta manera, su destino es volver “...a lo que ha sido desde su nacimiento: épica pura". ${ }^{52}$ El segundo, titulado "La novela actual", reproduce un artículo de la revista inglesa "Purpose" e inscribe la preocupación de la guerra como el contexto que incita a reflexionar sobre el género. Del mismo modo que el anterior, aquí también se critica el psicologismo y se busca una vuelta a "la acción": "No veo ningún futuro para la novela que se mantiene en el pequeño cauce de la pequeñez individual, en esa larga y estancada corriente de la introspección. [...] La acción y la pasión tendrán que regir la novela". ${ }^{53}$ De más está decir que estos textos aparecidos en Sur coinciden en sus lineamientos con las posiciones de Borges y Bioy Casares comentadas anteriormente. ${ }^{54}$

Pero también desde otros sectores hay ecos y respuestas a esta polémica. Una mirada desde la izquierda intelectual y ligada al Partido Comunista Argentino es la de Héctor Agosti, discípulo de Aníbal Ponce. Entre 1938 y 1944, Agosti pronuncia una serie de conferencias y escritos sobre el tema, recopilados en 1945 en su Defensa del realismo. ${ }^{55}$ Una de esas conferencias, proferida en Rosario el 21 de septiembre de 1940 y titulada "Los problemas de la novela", es central para nuestro interés porque entabla

\footnotetext{
${ }^{51}$ Eduardo González Lanuza, "Macedonio Fernández: Una novela que comienza", en Sur, n 79, abril de 1941. Macedonio Fernández es, como se sabe, quien se opone a la novela realista, pretende y programa un tipo de texto donde el carácter convencional de la ficción es puesto en evidencia a cada momento.

52 "Invitación a la novela" (Calendario), en Sur, n 65, febrero de 1940, pp. 118-119.

53 "La novela actual" (Calendario), en Sur, n 68, mayo de 1940, pp. 82-84.

${ }^{54}$ Por el tono y los temas expuestos, podría suponerse que es Jorge Luis Borges el encargado de introducir estos artículos en la sección "Calendario" de Sur, quien por lo demás se sabe que había escrito algunas de las notas allí publicadas.

${ }^{55}$ Agosti, Héctor P. Defensa del realismo, Montevideo, Pueblos Unidos, 1945.
} 
una verdadera discusión con las ideas de Ortega. ${ }^{56}$ Para Agosti, el vaticinio pesimista de Ortega con respecto a la decadencia del género, es "insolvente" en los términos en que éste lo ha enunciado, y la "inteligencia está colocada ante dos posibilidades: o renunciar a sus funciones críticas, sometiéndose a la clase dominante", lo cual implica renegar del realismo y dejar paso "al análisis y a la descripción, como es, por ejemplo, el caso de Proust", que lleva a "una literatura de la decadencia social, sin trama, sin nervio, sin sangre, sin acción", [...] "o bien reasumir sus funciones críticas y revolucionarias". ${ }^{57}$ Para que esto segundo suceda, es necesario "reivindicar", según Agosti, un nuevo curso del realismo que sea superación del anterior. La novela debe ser, entonces, más que "reflejo" de su entorno, "instrumento de comprensión transformadora", y también debe ofrecer una poderosa "tonalidad romántica" en el sentido que Agosti toma de Gorki: "el romanticismo revolucionario 'es el seudónimo del realismo socialista, cuyo destino es, sobre todo, el de ayudar a consolidar lo que se ha obtenido revolucionariamente en el presente e iluminar los elevados fines del porvenir socialista'" ${ }^{58}$ De esta manera, con una argumentación actualizada que retoma las líneas del debate de la izquierda sobre el realismo socialista y las estéticas de la época —donde se apela por ejemplo a las teorizaciones de George Lukács, a quien el texto cita reiteradamente-, ${ }^{59}$ Agosti también responde a principio de los cuarenta a la polémica suscitada por el texto de Ortega.

\section{El ensayo arltiano sobre la novela}

\footnotetext{
${ }^{56}$ También aparece una polémica con las ideas expuestas por Roger Caillois en su Sociología de la novela. Como en este trabajo estudiamos el contexto de la discusión para pensar la propuesta de Arlt, no nos ocuparemos de textos posteriores a 1942.

${ }^{57}$ Agosti, Héctor P. Defensa del realismo, Op. Cit., p. 54.

${ }^{58}$ Agosti, Héctor P. Defensa del realismo, Op. Cit., p. 57.

${ }^{59}$ Agosti cita a Lukács sin referir explícitamente un texto en particular. Por lo que se ve, traducciones de Lukács parecen haber circulado por Buenos Aires. Lo que sí puede constatarse es que en el número 1 de la revista Dialéctica, publicación dirigida por Aníbal Ponce que sale en 1936, se edita un artículo suyo titulado "Zola y el realismo". Sylvia Saítta me pasó gentilmente este dato, a quien agradezco la información. Para las revistas de izquierda en el período, véase: Saítta, Sylvia. "Entre la cultura y la política: los escritores de izquierda" en Crisis económica, avance del Estado e incertidumbre política (1930-1943), Tomo VII de la Nueva Historia Argentina, dirigido por Alejandro Cattaruzza, Buenos Aires, Sudamericana, 2001.
} 
...la novela moderna ha tratado de determinar los más finos movimientos atómicos del alma de los personajes que permanecían casi inmóviles en el espacio de la vida novelesca. [...] La novela actual carece de aventuras porque el novelista profesional, aunque parece una paradoja, carece de profesión. [...] ...la aventura [...] realidad maravillosa desconocida hasta hoy por los fabricantes de sueños de aventuras. ${ }^{60}$

Roberto Arlt

María Teresa Gramuglio considera muy significativo pensar la actividad literaria de la década infame y hasta aproximadamente 1945, sobre todo en relación con la revista Sur, pues allí se encuentran "las grandes líneas que articularon la literatura culta en el período". ${ }^{1}$ Gramuglio se está refiriendo específicamente a las definiciones en torno a la narrativa que comentábamos más arriba, un contexto en que es preciso reflexionar los modos en que Arlt, al mismo tiempo que discute las ideas de Ortega y retoma los términos de una polémica instalada en el campo literario, también intenta hacerse un lugar en las letras argentinas. De esta manera, como se analiza en las páginas que siguen, parece atinado suponer que cuando Arlt se enfrenta al realismo tradicional, critica las realizaciones de la novela psicológica y propone una literatura en la que prime la acción y la "reacción" de los personajes, su intervención, a la vez que delimita, relee y proyecta los criterios de su propia obra — que en ese momento se centraba, como vimos, en el teatro, en el cuento de aventuras, el fantástico y el policial— se aproxima a las definiciones de Borges, Bioy Casares y este grupo de escritores argentinos que estaban prescribiendo con operaciones muy fuertes en el campo literario y desde Sur los nuevos moldes para la ficción narrativa.

Una de las primeras cuestiones que surgen en los artículos de Arlt, y que da marco a todas sus reflexiones, es el contexto de la guerra y la preocupación sobre cómo escribir cuando el mundo está en llamas: “...cómo pintar hoy, con la conveniente negrura de eclipse, con el conveniente tono rojizo de lluvia de sangre, el horror de este momento catastrófico". ${ }^{62}$ Arlt da inicio a su intervención con "Una vela encendida al

\footnotetext{
${ }^{60}$ Arlt, Roberto. "Aventura sin novela y novela sin aventura", Op. Cit., pp. 244-245.

${ }^{61}$ Gramuglio, María Teresa. "Posiciones, transformaciones y debates en la literatura", Op. Cit., p. 342.

${ }^{62}$ Arlt, Roberto. "La tintorería de las palabras", en El Mundo, 15 de junio de 1940. Recopilada en Arlt, Roberto. Aguafuertes porteñas: cultura y politica, Selección y prólogo de Sylvia Saítta, Buenos Aires, Losada, 1994, p. 227
} 
sol", un ensayo sobre la guerra y el derrumbe económico y social de ese presente infortunado que exige entonces una nueva definición del género novela. ${ }^{63}$ Para Arlt, en quien resuenan los ecos de algunos de los planteos del debate internacional de la izquierda intelectual, "la novela era una relación con un estado particular propio de la burguesía que se deslíe en el ácido nítrico de las economías catastróficas", ${ }^{64}$ incapaces de generar ya "verdaderos personajes":

El personaje [...] fue tal en un momento, que se llegó a considerarle como una de las formas intelectuales más perfectas para comprender la vida. Era la época en que la guerra entre continentes no pasaba de ser una fantasía verniana. [...] En esa feliz edad el Personaje sobrevivía a la miseria de las relaciones humanas, la novela su conductora, aspiraba a ser guía espiritual [...], el teatro tenía pretensiones de educativo [...] ...muchos vivieron una vida dentro de la piel del personaje

Sobrevinieron las catástrofes económicas. La burguesía aprendió sin titubeos que el personaje estaba constituido de aire y viento; y que el héroe más insigne en el mundo, podía ser aniquilado en un instante por el más miserable de los "squadristas".

Con este fenómeno básico de la destrucción del héroe la novela pierde su significación de guía espiritual. La intensidad de su acción dramática queda oscurecida bajo el sol como una vela encendida. ¡Tan candentes son las catástrofes que amontona la realidad!

Y nunca como ahora la novela se hizo más voluminosa en palabras y más vacía en acción. [...] ...el héroe degenera en un contemplativo. La novela languidece de anemia, se desvitaliza. ${ }^{65}$

El fragmento muestra el modo en que Arlt lee históricamente la evolución de la novela y explicita la forma en que los personajes son “...despojados de la fórmula de la vida magistral de la acción". La guerra y las economías catastróficas han desenmascarado la cualidad convencional del personaje que, revelado en tanto que "aire y viento", muestra su condición de artificio literario. Por ello ya no puede ser "arquetipo", ni modelo de conducta y es incapaz de confundirse con "las ensambladuras de un mundo cuyo andamiaje crujía ya". De esta manera, que evidencia la imposibilidad

\footnotetext{
${ }^{63}$ Luego de esta primera intervención y de un breve intervalo temporal, se publican ya sin título e ininterrumpidamente todos los demás artículos a los que nos referimos al comienzo del trabajo y que desarrollan en detalle la polémica sobre la novela.

${ }^{64}$ También Agosti afirma, siguiendo las teorizaciones de Georges Lukács, el hecho de que "la novela es el género inherente a la sociedad burguesa". Véase: Agosti, Héctor. Defensa del realismo, Op. Cit., p. 51.

${ }^{65}$ Arlt, Roberto. "La vela encendida al sol", Op. Cit., pp. 246-247.
} 
efectiva de algunas de las prescripciones sobre el género como la de Ortega, (para quien el personaje debía ser en la novela moderna, como en el teatro francés, un guía espiritual), Arlt insinúa y, de una manera solapada también propone otros estilos posibles de narrar para evitar la "decadencia".

$\mathrm{Y}$, en efecto, estas ideas son las que el escritor desarrolla en la serie de notas publicadas entre agosto y noviembre de 1941 donde entabla, sin mencionarlo de modo explícito, un diálogo y una discusión con las tesis de Ortega sobre la novela, y también con sus respuestas. ${ }^{66}$ A este respecto, Arlt se ocupa, preferentemente, de la tan deliberada cuestión de la decadencia del género y su supuesta ausencia de temas, del abuso de la introspección psicológica, el subjetivismo y la descripción "realista" de la "novela contemporánea" y del problema de la ausencia de "acción", de aventuras y peripecias.

Como afirma el escritor en "La vela encendida al sol", si la novela ya no es el lugar donde el hombre va a reconocerse, la aventura y la acción de los personajes son los recursos que, a su juicio, deben suplir esa carencia. Así, y de un modo equiparable en un punto a la idea borgeana de que algunos de los grandes argumentos del siglo son ficciones científicas y textos de aventuras, -en ese momento en que para Ortega, la novela carecía de argumentos-, Arlt encuentra en las "aventuras" que provee el mundo de la física y la ciencia moderna "una realidad maravillosa" y "desconocida" [..] que "ningún novelista ha conseguido describir aún, ni ha intentado novelar": "la aventura mediante la cual estos jóvenes inventaron aparatos para bombardear físicamente un átomo no ha sido descripta por ningún novelista". ${ }^{67}$ De esta manera, —en un gesto que lo separa de sus premisas anteriores para la ficción novelesca, ocupadas de "la sociedad que se desmorona"-, Arlt propone nuevos temas que dejan de lado la idea de una literatura cuyos referentes, personajes y conflictos deban servir necesariamente al reconocimiento del lector, y exige una novela en la que prime la acción: "Existen aún autores que se preguntan si la acción dramática puede coexistir en las actuales condiciones bajo una forma apasionadamente novelística" —expone Arlt retomando polémicamente la idea de Ortega—, “¡Claro que existe! Lo que ocurre es que el noventa

\footnotetext{
${ }^{66}$ Para la discusión de Arlt con Ortega véase: Capdevila, Analía. "Arlt contra Ortega (Una polémica sobre la novela)", en Boletín/8, Centro de Estudios de Teoría y Crítica Literaria, Rosario, 2000.

${ }^{67}$ Arlt, Roberto. "Aventura sin novela y novela sin aventura", Op. Cit., p. 244.
} 
y nueve por ciento de los novelistas contemporáneos carecen de sensibilidad expresiva para traducir dicha acción dramática, bifurcada en las diferentes corrientes de la vida actual" ${ }^{\prime \prime . . .] ~ " P e r o ~ t r a t e ~ a l g u i e n ~ d e ~ n a r r a r ~ c o ́ m o ~ s e ~ v i o l e n t a ~ u n a ~ c a j a ~ d e ~ h i e r r o, ~ c o ́ m o ~ s e ~}$ fabrica una fortuna especulando en la bolsa, cómo se fabrica una joya, cómo se escribe una novena sinfonía, y cuéntelo exactamente y con todas las tremendas dificultades que el suceso presupone; y entonces habrá hecho una novela". ${ }^{69}$

Y es por ello que se opone a la novela psicológica y a esos textos que, centrados en los procesos subjetivos, describen "los más finos movimientos atómicos del alma de los personajes que permanecen casi inmóviles en el espacio de la vida novelesca". Porque para Arlt (y aquí es presumiblemente clara la referencia a Ortega), "Los teóricos confunden, generalmente, la decadencia de la novela con la decadencia de la capacidad de reacción del personaje novelesco" y "lo que diferencia un personaje novelesco de otro personaje novelesco es la carga de acción puesta en juego, y" [...] "la carga de acción potencial de un personaje de Stendhal es completamente diferente a la carga potencial de un personaje de Proust". ${ }^{70}$ Para esclarecer esto Arlt utiliza uno de los frecuentes recursos retóricos del ensayo, como es el ejemplo, en términos de Sarlo, ${ }^{71}$ y acude a un paralelo con la química: el personaje medio de la novela subjetiva es como el helio, un gas inerte y "estúpido", que no actúa "ni reacciona en presencia de otros cuerpos". El carbono, en cambio, presente en todas las combinaciones de la química, ejemplifica "uno de los más activos y novelescos personajes que pudieran imaginar Manzoni o Kipling."72

Si bien esto es así, Arlt responde polémicamente otra vez y retomando las ideas de Ortega $\longrightarrow$ y la polémica es otro de los recursos retóricos del ensayo—, " teóricos suponen que 'él personaje actúa sobre el lector por simple presencia, sin necesidad de accionar'"; ${ }^{74}$ tesis que también es errónea para Arlt y que, nuevamente, intenta desestabilizar con la lógica del ejemplo:

${ }^{68}$ Arlt, Roberto. "Galería de retratos", Op. Cit., p. 250.

${ }^{69}$ Arlt, Roberto. "Literatura sin héroes", Op. Cit., pp. 260-261.

${ }^{70}$ Arlt, Roberto. "Confusiones acerca de la novela", Op. Cit..,pp. 245-246.

${ }^{71}$ Para Beatriz Sarlo, "No hay ensayo sin escritura, por eso se puede hablar de una retórica del ensayo, cuando sólo en un sentido débil conviene hablar de una retórica del tratado". Uno de esos recursos que menciona es el ejemplo. Véase: Sarlo, Beatriz. "Del otro lado del horizonte", Op., Cit., p. 19.

${ }_{72}$ Arlt, Roberto. "Confusiones acerca de la novela", Op. Cit., p. 246.

${ }^{73}$ Sarlo, Beatriz. "Del otro lado del horizonte", Op., Cit., p. 19.

${ }^{74}$ Arlt, Roberto. "Confusiones acerca de la novela", Op. Cit., p. 246. 
Supongamos que tenemos el poder de reunir a tres hombres famosos en un tablado. Hemos situado allí a Einstein, Ford y Stalin. Junto a ellos en el mismo tablado, ubicamos a otros tres señores absolutamente desconocidos. Ni el sabio, ni el político, ni el industrial, accionan de manera alguna; [...] De pronto, uno de los tres señores desconocidos, que permanecía sentado frente a Ford, Einstein y Stalin, se levanta y toma a bofetadas a otro de los caballeros desconocidos. [...]

Cuando Stalin, Ford y Einstein localizaban la atención de la masa en el tablado, actuaban por lo que eran capaces de hacer; cuando uno de los tres desconocidos le propinó un excelente par de bofetadas al otro desconocido, "la acción de presencia" quedó anulada por "la acción presente", y esto es perfectamente lógico, incluso desde el punto de vista mecánico, ya que la acción presente es cinemáticamente mucho más poderosa que la energía potencial, representada en aquellos momentos por los tres hombres famosos cruzados de brazos. ${ }^{75}$

El fragmento, que evidencia la mirada del dramaturgo, pone en escena un cuadro teatral que lee especialmente los mecanismos de la recepción del espectáculo y el impacto de los hechos sobre un posible espectador. Una vez más, Arlt toma un ejemplo constituido en paralelo con la ciencia (o la física mecánica, para ser más precisos) para graficar el efecto pragmático que una obra o un personaje son capaces de producir en el público lector o en un auditorio teatral. ${ }^{76}$ Esta preocupación por el público que el texto explicita, muestra, asimismo, una preferencia por la llamada "acción presente" frente a la "energía potencial"; o, en otros términos, la elección para la novela (y también para la dramaturgia y la ficción en general) de la representación de acciones concretas de los personajes frente a las múltiples y posibles actividades que un héroe novelesco puede ejecutar o conjetura y sueña realizar, pero no realiza. Esta opción, describe - como en todo ensayo donde la construcción del objeto revela al sujeto-, por lo demás, el propio pasaje y movimiento de su obra narrativa: desde una literatura dominada en un principio por las potencialidades de la acción y centrada en los procesos subjetivos y "proyectos extraordinarios" que, inscriptos en la imaginación de los héroes nunca se llegaban a concretar, — piénsese en Los siete locos-Los lanzallamas—, a una producción ahora ya propiamente centrada en la narración de "la acción"; como es el caso de sus ficciones

\footnotetext{
${ }^{75}$ Arlt, Roberto. "Confusiones acerca de la novela", Op. Cit., p. 247.

${ }^{76}$ Sobre este aspecto volveremos más adelante.
} 
policiales y de espionaje, los relatos fantástico-maravillosos y los textos de aventuras que aparecen hacia el final de su labor de escritor.

Una aguafuerte anterior - "Los siete locos", de 1929- muestra la diferencia entre el proyecto que Arlt esboza en 1940 y sus concepciones sobre la novela en los años veinte. En esa nota, Arlt reflexionaba sobre su propia novela caracterizándola por tres aspectos: "uno psicológico, otro policial, otro de fantasía". No obstante, en el curso de su crónica Arlt se ocupa del primero de los tres aspectos mencionados en el apartado acerca de la "Vida interior" de los personajes:

Para mí no ofrecen absolutamente ningún interés las acciones de un delincuente, si estas acciones no van acompañadas de una vida interior dislocada, intensa, angustiosa. [...] Hombres y mujeres, en el curso de la historia citada, viven el horror de su situación. De ahí la extensión de la novela: trescientas cincuenta páginas. Sacando cien páginas de acción el resto del libro no hace más que detallar lo que piensan estos anormales, lo que sienten, lo que sufren, lo que sueñan.

Aquí aparece una clara predilección por el componente psicológico frente a la acción; según el autor, el libro está destinado fundamentalmente y de un modo dostoievskiano, a reproducir las subjetividades exacerbadas de sus personajes; es por esta razón que, deliberada y explícitamente, el escritor deja poco margen para el accionar del héroe que en sí mismo no interesa y sólo importa casi como una excusa para poner en escena una "vida interior" "dislocada, intensa, [y] angustiosa". Estos personajes son, entonces, y para retomar los términos del ensayo de 1941, muy prolíficos en "energía potencial" pero escasos de acciones presentes, como los protagonistas de Dostoievski, a quien Ortega incluye, por lo demás, en la línea psicologizante de la novela. Por todo esto puede sostenerse que no sólo en sus teorizaciones cambia su énfasis sobre la acción que deben cumplir los personajes, también se modifica su funcionamiento efectivo en la ficción, al momento en que Arlt introduce desde 1932 otros géneros en su literatura y otros modos de representación.

\footnotetext{
${ }^{77}$ Arlt, Roberto. "Los siete locos", en El Mundo, 27 de noviembre de 1929. Reproducida en Arlt, Roberto. Las aguafuertes porteñas de Roberto Arlt, Selección y prólogo de Daniel Scroggins, Buenos Aires, ECA, 1981, p. 141. El subrayado es nuestro.
} 
Así, la actividad de los personajes que en muchas de sus primeras obras quedaba en el orden de lo imaginario o en los proyectos extraordinarios que ideaban Erdosain, el Astrólogo y los demás héroes novelescos, en sus cuentos policiales, de espionaje y en los textos fantásticos y de aventuras finales, es, en cambio, concreta y sobre esas acciones se construyen y giran los vericuetos de la narración.

Pero la crítica de Arlt a la novela contemporánea continúa. A su juicio, se ha convertido en una "galería de retratos", constituida por obras que, a falta de "asunto" sustituyen la acción por una sucesión de "procesos mentales críticos" y cuyos personajes nos "producen el efecto de una colección de fotografías", figuras aisladas carentes de "conflictos dramáticos" y sin hilo conductor. ${ }^{78}$ Huxley "nos obsequia por ello una novela fastidiosa" y Proust, que tan "desaforado aburrimiento le produjo", es el responsable de que no se salga de un "proceso mental", "Pienso y luego no obro parecería ser su consigna". ${ }^{79} \mathrm{Y}$ así como Borges decía en el "Prólogo" a La invención de Morel que “...hay capítulos de Proust que son inaceptables como invenciones a los que, sin saberlo, nos resignamos como a lo insípido y ocioso de cada día", ${ }^{80}$ Arlt acusa “...la frecuencia de este proceso" [...] en razón directa de la falta de imaginación del autor" ${ }^{81}$ Porque el novelista subjetivo es para él un "escritor irresponsable", "un profesional que carece de profesión" y que por desconocer la jurisdicción del héroe, es

\footnotetext{
${ }^{78}$ Arlt, Roberto. "Galería de retratos", Op. Cit., p. 248. La cita completa de este artículo de Arlt, es la siguiente: "En la novela contemporánea, salvo excepciones, los personajes nos producen el efecto de una colección de fotografías, colgadas en la galería. El autor llama novela a la galería; y acción dramática, al simple proceso de comunicar estos retratos con el hilo de sus diálogos. Esto nos haría suponer que los autores contemporáneos desprecian la acción dramática que dimana del conflicto...[...] En la novela contemporánea, la acción ha sido sustituida por sucesiones de procesos mentales críticos. [...] Otras veces se hace girar el paisaje en torno del protagonista, y lo que se busca entonces es producir una ilusión de acción dramática por el simple movimiento del marco." (pp. 248-249). Es interesante observar que George Lukács afirma, coincidentemente, en un trabajo de 1936, una imagen similar para describir la novela subjetiva y el estilo descriptivo de autores como Zola: "Desaparece en el estilo descriptivo toda conexión épica. [...] La conexión épica no consiste en la sucesión de distintos momentos. Si los cuadros o cuadritos individuales que se describen se disponen en una serie temporal, no se logra crear la conexión épica. [...] La sucesión de impresiones subjetivas [también] es insuficiente para proporcionar la conexión épica. [...] en ambos casos se obtienen cuadros que están ubicados uno junto al otro, aislados, desde el punto de vista artístico, como los cuadros de un museo”. Véase, Lukács, George. “¿Narrar o describir?, en Goldmann, Escarpit, Hauser y otros. Literatura y sociedad, Buenos Aires CEAL, 1977, pp. 56-57.

${ }^{79}$ En la novela clásica, sostiene Arlt, la consigna era pienso, luego obro, y el pensamiento "era el trampolín desde donde el protagonista se lanzaba a la acción". Véase, Arlt, Roberto."Galería de retratos", Op. Cit., p. 249.

${ }^{80}$ Borges, Jorge Luis. "Prólogo", Op. Cit., p. 12.

${ }^{81}$ Arlt, Roberto. "Galería de retratos", Op. Cit., p. 249.
} 
incapaz de "traducir la acción dramática según las distintas corrientes de la vida actual": "Como las complicaciones de los tiempos han diferenciado más y más las profesiones y la técnica para describirlas, los autores, con diferencia cultural y creadora, componen sus juegos con personajes híbridos, que suplen cualquier acción con discontinuas emisiones de procesos subjetivos" [..] "Al revés y mediante el auxilio de procesos subjetivos, es que la mayoría de los deficientes novelistas y dramaturgos modernos tratan de eludir la responsabilidad que implica analizar a un tipo a través de sus actuaciones, ya que es evidente que los actos (y no los pensamientos) están íntimamente ligados con la constante profesional". ${ }^{82}$

Arlt atribuye entonces al novelista y a su falta de idoneidad el estado de la novela del momento. Es por eso que Edgar Wallace en tanto es capaz de escribir según lo que él llama "la constante profesional" —o la cualidad que predetermina las acciones del héroe y su coherencia como en el caso del tigre, su profesión es matar y poco importa otra cosa—, ${ }^{83}$ resulta "uno de los novelistas más extraordinarios que ha producido la humanidad". Y si bien "hay gente que se avergüenza en confesar que lee al novelista policial Edgar Wallace", [...] su estilo no ha sido superado por otros cultores del género. ${ }^{84}$ Así, también Arlt, como Borges y Bioy Casares, encuentra en el género policial un ejemplo de los modos adecuados y exitosos en que la novela puede funcionar; aunque en su caso se trata, como veíamos en el capítulo anterior, del reconocimiento de uno de los autores más vendidos entre los que circulaban por ese entonces en el circuito de literatura popular y en las ediciones de kiosco. ${ }^{85}$

${ }^{82}$ Arlt, Roberto. "Irresponsabilidad del novelista subjetivo", Op. Cit., pp. 253-256.

${ }^{83}$ Dice Arlt, en relación con la constante profesional: "La profesión del tigre es matar. [...] Importa poco que el tigre sea grande o pequeño, que se aloje en una caverna o que se gane la carne en un circo.... [...] cuando nosotros examinamos a un tigre, en realidad remiramos al que mata. [...] Lo que el tigre piensa de las estrellas, no puede influir en el destino del ciervo en el momento en que el ciervo cae bajo las garras del tigre. Correctamente entonces, podemos definir que el carácter potencial de una bestia, de un hombre o de un personaje novelesco, es definible por su profesión. [...] En consecuencia, la profesión es anterior a la acción y la acción es una consecuencia de la profesión" en Arlt, Roberto. "Irresponsabilidad del novelista subjetivo", Op. Cit., pp. 253-254..

${ }^{84}$ Arlt, Roberto. "Un protagonista de Edgar Wallace". Recopilada en Arlt, Roberto. Aguafuertes porteñas: cultura y política, Selección y prólogo de Sylvia Saítta, Buenos Aires, Losada, 1994, p. 205.

${ }^{85}$ Véase: Lafforgue, Jorge y Rivera Jorge. Asesinos de papel. Ensayos sobre narrativa policial, Buenos Aires, Colihue, 1996.

, pp. 107 y 15 , respectivamente. 
Por todo ello, Arlt estima el porvenir de la novela, o de "las leyes que rigen la vivencia de un relato", en los nuevos temas que proveería, en parte, la ciencia, en la capacidad de imaginación del novelista y, sobre todo, en la narración de "acciones" y “conflictos presentes" que hagan de los héroes de la novela "personajes interesantes". Porque a diferencia de Ortega —que insistía en la "construcción de almas interesantes con la prescindencia y la casi nulidad de la trama—, Arlt sostiene que es la acción la que hace interesante al personaje y que "por lo general, no hay conflictos sin interés, sino personajes ininteresantes". ${ }^{86}$

Así, mientras Borges y Bioy Casares $\longrightarrow$ y los escritores que formaban con ellos un subgrupo en Sur-, reprochaban a la introspección psicológica su falta de rigurosidad, la debilidad de sus tramas y la escasez de invención, Arlt de un modo bastante equiparable, critica el subjetivismo de la novela de caracteres, la construcción de personajes estáticos e inmóviles y culpa al escritor —a su incapacidad, falta de idoneidad, escasez de imaginación y falta de profesión - por generar "cierto género de monstruo" [...] "de escasísimo interés vital". En suma, si bien el ensayo arltiano no apela a la rigurosidad de la trama, y la particularidad de su propuesta se aleja en varios aspectos de la que defendían los escritores de Sur (como veremos a continuación), es inexpugnable admitir simetrías en el modo en que se conciben los criterios pertinentes para la narración de ficciones. Porque para Arlt, poco importan también las diferencias genéricas. "Novela, relato, folletín", —dice en "Confusiones acerca de la novela"—, "a grosso modo' son definiciones de un solo género e informan más diferencias cuantitativas que cualitativas". ${ }^{87}$ Por lo demás, lo mismo sucede con el género dramático, pues Arlt mezcla alternativamente, novelista y dramaturgo, ficción y representación, público lector y espectador.

En relación al teatro, uno de los puntos clave en los que Arlt disiente con las tesis de Ortega — no mencionados por Borges, Bioy Casares o Roger Caillois pero también cuestionados por Héctor Agosti- es la respuesta a la pregunta sobre cuál es la causa de la desafección del lector en la novela contemporánea. Este tema, estrechamente emparentado con la preocupación por los efectos de lo narrado o lo representado, pone en evidencia la influencia del teatro en su perspectiva, o, en otros términos, los modos

${ }^{86}$ Arlt, Roberto. "Acción, límite de lo humano y lo divino", Op. Cit., p. 258.

${ }^{87}$ Arlt, Roberto. "Confusiones acerca de la novela", Op. Cit., p. 245. 
en que Arlt lee o piensa sobre todo como dramaturgo la cuestión de las relaciones y el impacto de las representaciones simbólicas sobre el receptor.

En la mirada de Ortega la decadencia del género era lo que ocasionaba "el embotamiento de la facultad de impresionarse del lector"; de ahí la exigencia cada vez mayor para el novelista, que debía evitar lo reiterativo y previsible, detenerse en los detalles en torno a la vida y "el alma" del personaje y construir un mundo imaginario, capaz de abolir la realidad circundante, motivos estos últimos que hacían esencial e imprescindible la descripción. Nada más ajeno, por cierto a la opinión de Arlt. Para él, del mismo modo que Héctor Agosti —aunque sin la "irresponsabilidad" social que le confiere este último— ${ }^{88}$ es el subjetivismo, el exceso de la descripción y la ausencia de conflictos y de acciones, lo que causa el hastío y también la ira del público lector y del espectador:

...lo importante de la acción dramática es la tensión nerviosa que origina. Es evidente que cuando un personaje no reacciona, no suscita contra sí la resistencia del medio, y la falta de acción y reacción es lo que determina la ausencia de suceso dramático y sus secuelas, la conmoción nerviosa.

Hoy, los autores tratan de justificar la omisión dramática,[...] pero lo evidente es que el lector se aburre y arroja la novela o se levanta de su butaca y se marcha maldiciendo. [...]

El drama y la novela contemporáneos ofrecen esta característica negativa. Si decimos que es una característica negativa, no lo hacemos en nombre de la estética ni de la moral, sino en nombre de una defraudación de que hemos sido víctimas en nuestro carácter de lectores o espectadores. [...]

El espectador ha ido a la novela o a la butaca para sufrir en un camino desconocido, la presión de una aventura que presupone inquietante. Si esa condición se cumple, el espectador deja de ser espectador para convertirse, mediante el procedimiento más inofensivo del mundo, en juez y parte. Este proceso subconsciente le proporcionará una emoción que será tanto más intensa cuanto que el espectador sienta que su propia existencia moral, política o económica está en juego de peligro. Es decir, que tanto en la novela como en el

\footnotetext{
${ }^{88}$ Héctor Agosti concuerda con Arlt en el hecho de que la falta de acción y el paso "al análisis y la descripción" es lo que genera el aburrimiento del lector, pero además agrega que "...gran parte de la novelística contemporánea es incapaz de dar respuesta a las angustiosas interrogaciones del presente.". La novela ha caído, por ello, "en un intrascendente juego de metáforas para huir de la 'peligrosa' realidad". Agosti, Héctor. Defensa del realismo,, Op. Cit., p. 54-55.
} 
drama, el conflicto cuando está correctamente delineado, se desarrolla al mismo tiempo en el escenario y en el espectador. ${ }^{89}$

La nota describe, más allá de las reminiscencias de la concepción de la catarsis aristotélica, una singular teoría de las relaciones entre arte y recepción y clarifica en qué sentido Arlt piensa los efectos de la literatura y el teatro sobre el lector y el espectador. Según esta teoría, es preciso el accionar del personaje, pues, sólo el despliegue de “acciones" y "reacciones", de "conflictos" y "sucesos dramáticos" es capaz de generar lo que él llama "conmoción nerviosa". Se trata, en definitiva, como se analizó a propósito del teatro en el primer capítulo, de que el espectáculo provoque una tensión, un efecto de simpatía, un juego "inquietante" de identificación, para permitir la participación "emocional" del receptor en los acontecimientos narrados o representados — su condolencia, su intervención, su juicio, etc.- - De esta manera, y si bien el texto surge de una polémica sobre la novela, el conjunto de los términos utilizados y los contenidos de la argumentación, sugieren que el fragmento puede leerse en sí mismo y, fundamentalmente, como una explicitación del proyecto del teatro arltiano o de los modos en que Arlt piensa toda su producción, en ese momento, preferentemente desde una óptica ubicada en el género dramático. Cabe destacar, además, que aquí se muestra la manera en que Arlt también argumenta persuasivamente como lector. Construido en la primera persona del plural, el artículo se ubica en la perspectiva del que se presume un destinatario de esas notas y se identifica con los posibles intereses y gustos promedio del supuesto público del diario, ya conocido y familiar para Arlt, en ese entonces. Se instaura así, un acercamiento y búsqueda de reconocimiento e identificación entre el nombre propio del que escribe y su potencial receptor.

Cuando estas notas se refieren al aburrimiento del lector, pueden leerse, además, dos aspectos singulares. El primero de ellos es el interés persistente de Arlt por el mercado, una preocupación que se reitera desde sus primeros textos: “... algún día se logrará definir matemáticamente la constante de acción de un personaje novelesco dividiendo el número de ediciones de los libros en que el personaje ha figurado, por el número de años que demoraron en venderse", afirma Arlt en uno de los artículos de

${ }^{89}$ Arlt, Roberto. "Acción, límite de lo humano y lo divino", Op. Cit., pp 257-258. El subrayado es nuestro. 
1941..$^{90}$ De esta manera, se mantiene un valor fuerte que el escritor defiende insistentemente desde los años veinte y a todo lo largo de su producción: la consagración o legitimación por el mercado, por el éxito y las ventas entre el público. Por otra parte, también es causa de la desafección del público, el realismo y sus excesos: "la medianía". En efecto, la medianía o, lo que es lo mismo, la profusión de los detalles y el abuso de la descripción -algo, recuérdese muy valorado por Ortega — “...constituyó $\mathrm{y}$ es la piedra angular del realismo, pero su frecuencia dentro de la novela contemporánea — sostiene Arlt-, es una peste que torna insoportable la lectura de los libros que hora tras hora invaden los escaparates.” Por ello, y en tanto “...el realismo no es un género sino una técnica que se limitó a describir lo que se hallaba debajo de sus narices con fidelidad de pantógrafo", ${ }^{91}$ la novela y el teatro contemporáneo han caído en manos de autores que, como "albañiles en disponibilidad. Saben manejar la cuchara, el nivel, la plomada, pero no tienen edificio que construir". ${ }^{92}$ De esta manera, lejos de ser recursos para la composición de una novela que intente asimilarla al orden múltiple y minucioso de lo real, lo subjetivo y la descripción sólo tienen sentido en la visión arltiana, - -y de un modo coincidente con algunas teorizaciones de esos días como las de George Lukács, ${ }^{93}$ a quien, como vimos, también cita Agosti-, si se los vincula con el “espectro magnético del héroe" y sus acciones y conflictos.

Ahora bien, en la discusión de Arlt sobre el realismo, lo primero que sorprende es la ausencia de referencias a la cuestión social. Efectivamente, si consideramos que a partir de 1932 Arlt colabora en publicaciones vinculadas a la izquierda como Bandera Roja y Actualidad, e interviene en algunos emprendimientos político-culturales ligados al Partido Comunista — como la formación de la Unión de Escritores Proletarios impulsada por él y Castelnuovo—, ${ }^{94}$ y si nos atenemos a lo que expresaba en muchas de

${ }^{90}$ Arlt, Roberto. "Confusiones acerca de la novela", Op. Cit., p. 246.

${ }^{91}$ Arlt, Roberto. "Literatura sin héroes", Op. Cit., p. 259.

${ }^{92}$ Arlt, Roberto. "Literatura sin héroes", Op. Cit., p. 261.

${ }^{93}$ Así, Lukács expone, en el mismo sentido: "En la literatura no existe una "poesía de las cosas" independiente del hombre y de las vicisitudes humanas. [...] Cada cosa que tenga una función efectiva en la acción de un hombre, que despierte en nosotros un interés poético, se vuelve significativa desde el punto de vista poético por su nexo con la acción. Lukács, George. Op. Cit., “¿Narrar o describir?, Op. Cit., p. 59. Y Arlt expresa en su texto de 1941: "Una fea lámpara humosa cobra valor estético cuando ilumina el rostro de un héroe. No importa que la existencia de este héroe determine un peligro dado. Su capacidad de acción, por profundidad, le presta a la lámpara un relieve desusado. Véase: "Literatura sin héroes", Op. Cit., p. 259.

${ }^{94}$ Saítta, Sylvia. "7. Ejercicio de artillería", en El escritor en el bosque de ladrillos. Una biografia de Roberto Arlt, Buenos Aires, Sudamericana, 2000, pp.105-135. 
sus aguafuertes, donde se definía como uno de esos escritores ocupados de "la miseria y de la angustia de los hombres argentinos" $" 95$ y a lo que exponía en sus conocidas palabras preliminares a Los Lanzallamas _ “....me atrae ardientemente la belleza... [...] Mas hoy, entre los ruidos de un edificio social que se desmorona inevitablemente, no es posible pensar en bordados"-,${ }^{96}$ llama la atención en este ataque al realismo, su silencio sobre las relaciones del arte y su compromiso con lo social.

A diferencia de la postura de Agosti, que criticaba la descripción y el subjetivismo por su desentendimiento de la realidad, Arlt obvia la discusión sobre el realismo socialista y, en contraposición a muchos de sus textos previos, no menciona en ningún momento la pretensión de que las obras de "contenido social", para él, en ese momento "pródig[as] en contradicciones", ${ }^{97}$ deban ser las que primen en la "novela actual". Y si bien Arlt sostiene en estas notas de 1940, que un conflicto situado fuera del presente ("nuestro tiempo" y "nuestro espacio" es la expresión que utiliza) puede adolecer de falta de interés, también afirma, en el mismo movimiento del ensayo, —que es, como dijimos, pensamiento que se va haciendo mientras se está pensando-, que "casi siempre cuando el asunto queda más allá del alcance del espectador, se debe a que el autor no domina la técnica de su especialización", ya que "no hay conflictos sin interés".

De esta manera, en los años cuarenta no sólo Arlt deja de lado en su intervención en El Mundo la idea según la cual el arte debe vincularse al presente crudo de la sociedad, sino que además propone una literatura y un teatro que no remita de modo imperioso a las preocupaciones del lector o espectador pero sí que suscite, ineludiblemente, su emoción catártica y lo vincule "emocionalmente" en tanto que representación.

Es más, en la última de sus intervenciones sobre la novela, "Hace falta una escuela para novelistas", también expresa una preocupación por la belleza que lo aleja,

\footnotetext{
${ }_{95}$ Arlt, Roberto. "El conventillo de nuestra literatura", en El Mundo, 21 de diciembre 1928. Recopilado en Arlt, Roberto. Aguafuertes porteñas: cultura y politica, Op. Cit., p. 50. Véase a este respecto, además, "Un poco más sobre la sociedad de escritores", El Mundo, 14 de enero de 1929, publicada en Arlt, Roberto. Aguafuertes porteñas: cultura y política, Op. Cit., p. 60.

${ }_{96}$ Arlt, Roberto. "Palabras del autor", en Arlt, Roberto. Los siete locos. Los lanzallamas, Edición crítica coordinada por Mario Goloboff, Colección Archivos, Francia, ALLCA XX, Université Paris X, 2000, p. 285.

${ }^{97}$ Véase al respecto: Arlt, Roberto. "Escritores jóvenes de la América hispana", en El Mundo, 22 de mayo de 1941.
} 
nuevamente, de algunas de las declaraciones más fuertes del prólogo a Los lanzallamas citadas con anterioridad: “...me ocurre que la creciente exigencia de material de lectura en la humanidad determinará la organización de una escuela para novelistas, donde el alumno estudiará científicamente los procedimientos para emplear con mayor provecho posible los elementos susceptibles de producir belleza al combinarse". ${ }^{98}$ Para ello, y a semejanza del teatro cuyas unidades, actos, escenas y tiempos son mensurables - hecho que prueba, además, que Arlt piensa la novelística y redefine los términos del debate desde su mirada como dramaturgo-, propone instaurar "límites" que no sean "la resultante del capricho de alguien", sino el resultado de un análisis matemático y estadístico que en "una serie de obras que el consenso humano ha calificado como maestras a través de todos los tiempos", sea capaz de establecer reglas. Estos criterios, como "tablas estadísticas" permitirán ilustrar sobre "la calidad de adjetivos y metáforas empleados" en el estilo, la "longitud de diálogos", el "número de conflictos, número de paisajes, etc.”. Así, además de que Arlt se muestra como un escritor conciente de su oficio, y desdibuja con esto la imagen, construida en muchos de sus textos previos, de un escritor improvisado y "así nomás", 99 también se evidencia una preocupación por el estilo, una valoración de los clásicos y del trabajo técnico de la escritura que, en tanto que "especialización racional", el genio, según sus palabras, de todas maneras, se apresurará a olvidar. ${ }^{100}$

${ }_{98}$ Arlt, Roberto. "Hace falta una escuela para novelistas", en El Mundo, 1 de noviembre de 1941. El subrayado es nuestro.

99 Arlt, Roberto. “¿Cómo quieren que les escriba?”, en El Mundo, 3 de septiembre de 1929. Reproducida en Arlt, Roberto. Aguafuertes porteñas: cultura y política, Op. Cit. Véase, además, Arlt, Roberto. "Cómo se escribe una novela", en El Mundo, 14 de Octubre de 1931. Recopilada en Arlt, Roberto. Obra Completa, Tomo 2, Buenos Aires, Carlos Lolhé, 1981. Estos aspectos han sido desarrollados en: Juárez, Laura. "Las aguafuertes de Roberto Arlt: el itinerario de un desplazamiento en la imagen de escritor y en la poética de la novela", en Vázquez, María Celia y Pastormerlo, Sergio (comp.) Literatura argentina. Perspectivas de fin de siglo, Actas del X Congreso Nacional de Literatura Argentina, Buenos Aires, Eudeba, 2001, pp. 283-292.

${ }^{100}$ Dice Arlt, más específicamente "Este trabajo [...] permitirá confeccionar índices curiosos pero sumamente instructivos. Sabremos el número de adjetivos que empleaba Flaubert, la longitud media del paisaje en la novela de D'Annunzio, el número de conflictos dramáticos que se producen cada cinco mil palabras en una obra de Dickens ó Dostoyewsky, la duración media del diálogo en Dreisser [sic] o Stendhal. [...] Entonces recién se podrá confeccionar un índice de proporciones, y en consecuencia bocetar una técnica para una especialización racional, de la que el genio se apresurará a olvidarse cuando abandone la escuela" Arlt Roberto. "Hace falta una escuela para novelistas", Op. Cit. 
Si, como dice Beatriz Sarlo "Hay algo de propagandístico en el ensayo, la decisión de defender o atacar una posición desde la escritura, haciendo de la escritura el argumento principal donde se articula toda otra argumentación", ${ }^{101}$ puede verse entonces, el modo en que estos artículos, a la vez que ensayan sobre la novela, están perfilando las líneas de validez de la labor literaria de Roberto Arlt. Las notas analizadas, a la vez que polemizan con las ideas que circulaban en el campo intelectual, se distancian de concepciones previas del autor y de los modos concretos de su ficción novelesca anteriores al giro de 1932, a la vez que se acercan a las posiciones prestigiosas de escritores como Borges y Bioy Casares e intentan delimitar, en ese movimiento, nuevos criterios para la narración.

${ }^{101}$ Sarlo, Beatriz. "Del otro lado del horizonte", Op. Cit., p. 19 


\section{Recapitulación y conclusiones}

Me atrae ardientemente la belleza. ¡Cuántas veces he deseado trabajar una novela que, como las de Flaubert, se compusiera de panorámicos lienzos! ${ }^{1}$

Roberto Arlt

Dos ideas inscriptas de modo más o menos solapado en el rutilante y agónico prólogo a Los lanzallamas, la admiración de Arlt por el estilo de Flaubert y su atracción enfática y "ardiente" por la "belleza", pueden ser repensadas si se enfocan sus obras de los años treinta; ideas eclipsadas, por otra parte, por las imágenes fuertes del "escritor torturado", que escribía mal, el "artista fracasado" e incomprendido y ocupado por "la sociedad que se desmorona". ${ }^{2}$ Porque efectivamente, en el período de diez años que se inicia en 1932, cuando Arlt deja de escribir novelas, se vuelca al teatro e introduce en sus obras nuevos modos de representación (lo fantástico, lo maravilloso, el relato de viajes y aventuras, el policial y las narraciones de espionaje), sus textos se redefinen y reestructuran, ensayan otras formas de legitimación y buscan ubicarse en posiciones más prestigiosas, que las que ofrecía el periodismo o el autodidactismo. En este sentido, la tesis indagó una zona de la historia crítica y literaria que no había sido explorada suficientemente: cómo cambia la literatura de Arlt en los años treinta y las distintas maneras en que puede verse un intento de jerarquización en las obras de esta época._

Por lo tanto, el primer capítulo estudió el proyecto dramático de Arlt y su inscripción en el Teatro del Pueblo de Leónidas Barletta que surge en Buenos Aires como una verdadera empresa cultural a través de la cual Barletta fundó un espacio

${ }^{1}$ Arlt, Roberto. "Palabras del autor", en Los siete locos-Los Lanzallamas, Edición crítica, Colección Archivos, Mario Goloboff coordinador, Francia, ALLCA XX, Université Paris X, 2000, p. 285.

${ }^{2}$ Muchas de estas conceptualizaciones en torno a la figura de Roberto Arlt, que el libro de Sylvia Saítta cuestiona y desestabiliza, aparecen cristalizadas en la biografía de Raúl Larra, Roberto Arlt, el torturado. Véase. Larra, Raúl. Larra, Raúl. Roberto Arlt, el torturado, Buenos Aires, Talleres gráficos Cadel, 1956. 
común que supo convocar a escritores que provenían de diferentes zonas del campo intelectual de la izquierda. Sus integrantes, en oposición al denominado en ese entonces "teatro comercial" o "teatro profesional", se propusieron realizar, según su acta de fundación, "experiencias de teatro moderno para salvar el envilecido arte teatral y llevar a las masas el arte en general, con el objeto de propender a la elevación de nuestro pueblo". ${ }^{3}$ En síntesis, teatro para el pueblo y teatro con contenido social, teatro de divulgación de los clásicos o "teatro de arte", desinterés económico y, fundamentalmente, educación popular, son los núcleos centrales de su propuesta cultural y artística. Si bien Arlt representa todas sus obras en el Teatro del Pueblo (a excepción de El fabricante de fantasmas), se inscribe en este ámbito con algunas disidencias pues sus piezas teatrales no buscan educar al espectador, como proponía el ideal pedagógico de Barletta, sino que procuran, más específicamente, la participación y la "simpatía" "emocional" del público y su "reacción" en relación con las acciones que se ponen en juego sobre el escenario. A su vez, a diferencia del optimismo de Barletta y su confianza en la dramaturgia como "escuela de la humanidad", en el teatro de Arlt se cuestiona la incidencia social del teatro, la literatura y el arte en general. Finalmente, en el caso de las obras de contenido ideológico y político, o aquellas en que es clara la tesis realista-social, el teatro de Arlt entabla una discusión con el realismo y sus formas de representación: hay una apertura hacia lo fantástico y los textos combinan una búsqueda estética con una intención ideológica.

El segundo capítulo analizó el viaje de Arlt a España y África, un viaje que marca sin duda un quiebre en su escritura y lo diferencia de los rasgos predominantes en sus novelas y relatos anteriores. Desde entonces, aparecen en su obra nuevas maneras de narrar, se construye otra espacialidad, se pone en evidencia cierta búsqueda por un estilo más elevado, características ya presentes en "El traje del fantasma" y "La luna roja". En su crónicas Arlt critica los modos de representación más típicos del relato de viajes y de la tarjeta postal no obstante lo cual sus aguafuertes españolas no sortean las trampas de lo exótico, lo típico y lo pintoresco y retoman algunas de las fórmulas convencionales de la escritura de viajero, como puede verse en la representación de la Semana Santa en Sevilla, en las vistas de Toledo, en las fiestas de Granada, en la gitanería andaluza, en el espectáculo-cuadro de la mujer sevillana y en las corridas de toros. Además de las

${ }^{3}$ Véase: Marial, José. "El Teatro del Pueblo" en El teatro independiente, Buenos Aires, Alpe, 1955 , p. 61. 
escenas de color local, con el viaje a España ingresa, también, la mirada paisajística en la literatura de Arlt ("la mirada del exiliado, del que conoce su extrañeza radical con las cosas" y además "es siempre una mirada estética" que surge de una relación armónica -y de cierto dominio y "seguridad" - entre el ojo que observa y el mundo representado). ${ }^{4}$ Se trata de la experiencia de un nuevo sujeto y una perspectiva distanciada y ajena a la del hombre agobiado y en crisis con un mundo de cambios y tensiones de su obra previa. De esta manera, puede decirse que si un tono se impone en los pasajes españoles ese tono es el elogio, la fascinación por lo otro y la construcción de un mundo paralelo y diferente, alternativo al orden de la experiencia vital: "Y sonrío gozando este pedazo de mi vida que es un sueño". Narrador gozoso y viajero aventurero que se deleita en lo diverso, Arlt se presenta en estos textos escindido entre el dejarse llevar que propone la aventura del viaje y el compromiso de ser un testigo veraz y un cronista político de los hechos. Una nueva perspectiva y también un nuevo tipo de sujeto, las aguafuertes españolas introducen así postales "iluminadas" y cuadros de color, ciudades cordiales, mundos alternativos y paisajes de ensueño.

Con respecto a la narración del viaje a África, se analizó el exotismo oriental que también incorpora formas narrativas novedosas en la literatura de Arlt. Esas nuevas formas desmienten, de alguna manera, las críticas que el escritor había recibido a propósito del estilo. Tanto en las aguafuertes africanas como en las ficciones de temática oriental que escribe después de su viaje, el traslado en el espacio significa también un viaje en el tiempo. Hay una separación enfática y contundente del espaciotiempo de la modernidad porque Arlt borra las huellas de lo moderno y sólo describe aquellas zonas africanas que la vinculan con el pasado, como si lo pintoresco o lo exótico de los espacios en muchos casos fuera fundamentalmente la temporalidad. De este modo, África no sólo resulta ser el lugar de la belleza y el deseo, el escenario elegido para el deleite estético y para el vuelo y la evasión imaginativos, sino sobre todo, el sitio que conduce a un mundo primitivo de libertad y placer, donde se hacen presentes distintas reglas de funcionamiento del mundo social. En este universo narrativo ya no tienen cabida los personajes anteriores, atrapados por el engranaje de la máquina infernal de la sociedad. Por otra parte, también aparece en los textos africanos una mirada diferente sobre los espacios: la perspectiva reemplaza a la visión de

${ }^{4}$ Silvestri, Graciela y Aliata, Fernando. El paisaje como cifra de armonía, Buenos Aires, Ediciones Nueva Visión, 2001, p. 10. 
contacto, fragmentaria y deformada de sus obras previas, y el colorismo oriental supone un cambio de estilo y una "estetización". Los textos inscriben así cierta búsqueda de la belleza, una construcción escenográfica del sitio africano y formas de enunciación que saturan de exótico lo representado e introducen un saber literario que remite al modernismo y al imaginario decadente. En conclusión, el espacio de lo ajeno hace posible que la literatura de Arlt se aleje del edificio social que se desmorona presente en sus primeras obras, para convertirse en la zona en que se puede pensar en bordados para realizar el deseo de componer un texto al estilo de Flaubert. 
Entre este conjunto de nuevos rasgos, géneros y procedimientos, el tercer capítulo se centró en la cuentística, por ser el ámbito en el que ingresan más claramente las preocupaciones de Arlt en los años treinta. En ese sentido, el análisis de los modos de lo fantástico y de lo maravilloso, son centrales para considerar cómo su obra se redefine, modifica y reestructura. Así, si bien es sabida la preeminencia de las ficciones fantásticas en la literatura argentina y en la producción del Río de la Plata, el fantástico en la narrativa de Arlt no había sido suficientemente analizado ni en sí mismo ni en relación a su contexto de emergencia. Los relatos que Arlt escribe a mediados de la década del treinta y en los primeros cuarenta coinciden con el momento de consolidación de ese género en la literatura argentina y se caracterizan por incorporar procedimientos y tópicos provenientes del modernismo y del imaginario decadente, que los acerca a relatos fantásticos de la literatura argentina bastante anteriores, como los de Leopoldo Lugones. Estos rasgos decadentistas y modernistas se cruzan y conviven en los años treinta con elementos que remiten a las constantes más típicas de la ficción de Arlt; en este cruce de tendencias Arlt reestructura su obra a la vez que toma distancia y cuestiona algunas de las formas cristalizadas en la tradición literaria del modernismodecadentismo. Asimismo, y teniendo en cuenta que insistentemente el escenario africano es el ámbito donde se ubican estos relatos, y que lo fantástico se desarrolla preferentemente en un espacio exótico y alejado, se analizó cómo la conjunción de exotismo y fantástico genera cierto tipo de narraciones que se arpoximan en muchos casos al orden de lo maravilloso. De esta manera, si bien el fantástico acerca los relatos de Arlt a las narraciones policiales, fantásticas y de aventuras de Borges, Bioy Casares y Silvina Ocampo, la reincorporación de tópicos y procedimientos modernistas torna conflictiva y problemática su inscripción en el contexto de emergencia.

El capítulo cuatro indagó la columna periodística de Roberto Arlt desde 1937 a 1942, período en el que las notas de "Tiempos Presentes" y "Al margen del cable" reemplazan el espacio que las “Aguafuertes Porteñas” tenían en El Mundo. Se trata de textos misceláneos que incluyen curiosidades para los lectores del diario, excentricidades "novelescas" extraídas de los cables de noticias, breves relatos sobre el mundo del hampa y de la criminalidad, despliegues de la noticia perdida y la nota marginal, interpretaciones de los sucesos de la guerra, biografías de singulares personajes. Cada uno de ellos, se origina en la información internacional que Arlt lee en 
diversos periódicos de la época y en los sucesos más o menos relevantes de política u otros asuntos provenientes del exterior que llegaban al diario en los cables de noticias. Por lo tanto, estas notas conforman un nuevo género periodístico que incorpora el registro del presente y reelabora la noticia mostrando, a su vez, distintas formas de referir los sucesos y diferentes modos de interpretar los hechos que se escriben en la prensa del momento. Así, además de detenerse en relatos auxiliares a los grandes sucesos de la conflagración internacional y dar espacio a la noticia explícitamente marginal, las crónicas cuestionan algunas de las formas de la escritura y la enunciación periodística y confrontan los distintos modos de construir la noticia. Arlt escribe en términos literarios el contexto y los personajes que imagina a partir de la breve información cablegráfica y de las notas periodísticas en una expansión narrativa de la información internacional que hace uso de los mismos procedimientos literarios, géneros y tópicos que caracterizan su narrativa de esos años. Las crónicas devienen entonces en textos de aventuras, historias de espionaje y tramas ligadas al policial y a la criminalidad, así como también en breves piezas teatrales.

El capítulo cinco se centró en cuentos y crónicas que hacen de la delincuencia su tema principal ya que, si bien el mundo del delito siempre estuvo presente en su obra, en los años treinta sus modos de representación son otros: Arlt incorpora tópicos y procedimientos del relato policial clásico, de la novela de espionaje y de las historias de hombres infames. Así, un conjunto importante de crónicas de "Al margen del cable" ligadas al policial, al espionaje y a la criminalidad, cuentan historias de delincuentes singulares y personajes del delito que se asemejan a las biografías de Historia universal de la infamia de Borges. Simuladores e impostores, traidores, gangsters (norteamericanos y orientales), asesinos a sangre fría, los infames aparecen en los cuentos y las crónicas internacionales de Arlt a través de sus biografías, sucintas y caricaturescas, que narran una vida en pocos trazos. Aunque el tiempo de la acción de las biografías de Borges y Arlt es diferente — Borges las ubica en el pasado mientras Arlt las registra en el presente-, en ambos puede leerse un interés en la singularidad y "capacidad de inventiva" en torno al mundo criminal y una perspectiva similar sobre los personajes que, a través de la ironía y la parodia desestabiliza los lugares establecidos y cuestiona los límites del delito. A su vez, los cuentos de criminales y de espías que Arlt publica en las revistas El Hogar y Mundo Argentino, incorporan rasgos del relato 
policial clásico y de la literatura de espionaje, inéditos en su producción anterior, que ponen en juego nuevas formas narrativas. En este caso, además de cierta adscripción de Arlt a las vertientes de circulación masiva en la época cuyo paradigma era Edgar Wallace, puede leerse en sus ficciones criminales un cuestionamiento de los moldes genéricos de la narración detectivesca y un cruce del policial con tramas fantásticas que nos reenvía nuevamente a los textos de Borges y Bioy Casares, a sus obras en colaboración y a algunos de los relatos que se publicaron en la Revista Multicolor de los Sábados. Con el espionaje, la literatura de Arlt le da nueva forma a la traición e introduce el conflicto bélico como motor narrativo de historias en las cuales predominan personajes función, sujetos despersonalizados, "resortes de la gran partida" que juegan las naciones “en llamas".

A partir de un saber aprendido en la propia práctica narrativa y teatral, Roberto Arlt comienza una reflexión más sistemática sobre el quehacer literario en una serie de notas que publica en El Mundo desde agosto a noviembre de 1941, y que se analizó en el último capítulo. Por su tono y su estructura, estas notas adscriben a ciertas "formas del ensayo" en tanto ensamble conceptual y desarrollo de ideas. En ellas, aunque sin mencionarlo de modo explícito, se entabla un diálogo y una discusión con las tesis de Ortega y Gasset sobre la novela, y también con las respuestas a esas apreciaciones que circulaban en los años cuarenta en la Argentina, entre las que se destacan la réplica de Borges en el "Prólogo" a La invención de Morel, y las apreciaciones de Roger Caillois y Héctor Agosti. Los artículos de Arlt se ocupan, en este sentido, de la tan deliberada cuestión de la decadencia del género novela y su supuesta ausencia de temas, del abuso de la introspección psicológica, el subjetivismo y la descripción "realista" de la "novela contemporánea" y del problema de la ausencia de "acción", de aventuras y peripecias. Mientras Arlt discute las ideas de Ortega y retoma los términos de una polémica instalada en el campo literario, también intenta hacerse un lugar en las letras argentinas y se distancia de sus concepciones sobre la novela que aparecían antes de 1932. De esta manera, cuando Arlt se enfrenta al realismo tradicional, critica las realizaciones de la novela psicológica y propone una literatura en la que prime la acción y la "reacción" de los personajes; su intervención, a la vez que delimita, relee y proyecta los criterios de su propia obra se aproxima, a su vez, podría decirse estratégicamente, a las definiciones de Borges, Bioy Casares y este grupo de escritores argentinos que estaban prescribiendo 
con operaciones muy fuertes en el campo literario y desde Sur los nuevos moldes para la ficción narrativa. Los textos sobre la novela manifiestan, en suma, los lineamientos principales de su propuesta dramática, su particular concepto de la prosa narrativa, los modos adecuados de la relación que Arlt buscaba entre el arte y el público lector o espectador y también, permiten leer los posibles argumentos para la legitimación de la tarea del escritor, que Arlt esboza, imagina y proyecta en estos breves ensayos periodísticos, en una reestructuración de su obra y consecuentemente con las nuevas modalidades y géneros que ingresan a su producción desde los años treinta.

De esta manera, se ha buscado que la tesis contribuya al debate de la crítica y la historia de la literatura argentina en su exploración de la etapa, los textos, los géneros literarios y discursivos menos transitados de la obra de Roberto Arlt y que permita repensar el lugar del teatro, lo fantástico, el policial y las historias criminales y de espionaje en el período, aspectos que en los estudios literarios y en las investigaciones históricas no se han examinado aún de modo definitivo. Escritor y periodista, cuentista y dramaturgo, sus textos de los años treinta permiten acercarnos a "otro Arlt" que se aleja del que suelen presentarnos algunas de las imágenes más cristalizadas sobre su obra y su figura. Colorismo oriental, paisajes de la mirada, imaginación exotista, relatos fantásticos, piezas teatrales, crónicas de delitos, ficciones criminales y asuntos de espías, son formas que, de distintos modos, dan curso a la literatura de Arlt en los años treinta, la redefinen y resignifican.

A la vez, y como se ha tratado de sugerir, parece razonable suponer que las conclusiones en torno de la obra y la carrera de Arlt a que aquí se ha arribado, conducen a revisar y posiblemente a completar el estudio crítico de algunos tópicos de la historia literaria argentina del siglo XX: las polémicas sobre la novela, y sobre las estéticas de juego o de "evasión"; la historia de algunos géneros clave en la literatura argentina, como el fantástico y el policial; las diversas y variadas posiciones de los escritores e intelectuales en torno de los desafíos que les planteaba la guerra europea; los contextos y voces parcialmente consonantes que -como la de Arlt- podían escucharse en los alrededores de Sur hablando en buena medida de los mismos temas; los años treinta como otro de esos territorios y momentos móviles y porosos en que las prácticas culturales concretas desdibujan las fronteras entre poéticas pedagógicas, aspiraciones 
artísticas de los escritores, alianzas y tensiones entre firmas fuertes y prensa periódica, literatura social, narrativas populares de mercado y formas distinguidas del gusto. 


\section{BIBLIOGRAFÍA}

\section{Obras de Roberto Arlt}

Arlt, Roberto. (Entrevista) "Roberto Arlt sostiene que es de los escritores que van a quedar y hace una inexorable crítica sobre la poca consistencia de la obra de los otros" en La Literatura Argentina, $\mathrm{n}^{\circ} 12$, agosto de 1929 .

Aguafuertes españolas, Buenos Aires, Talleres Gráficos Argentinos L.J. Rosso, 1936.

"El hombre del tatuaje", en El Hogar, 30 de septiembre de 1938.

1941.

"Los autores independientes en los teatros comerciales", en La Hora, 2 de diciembre de

"Pequeña historia del Teatro del Pueblo", en Conducta, Julio/Agosto de 1942.

Nuevas aguafuertes, Buenos Aires, Losada, 1975.

"Las ciencias ocultas en la ciudad de Buenos Aires", en Obras completas, Buenos Aires.

Carlos Lohlé, 1981, tomo II.

Trescientos millones, Saverio el cruel, El fabricante de fantasmas, África, La isla desierta, La fiesta de hierro, El desierto entra a la ciudad, en Obras completas, Buenos Aires. Carlos Lohlé, 1981, tomo II.

Aguafuertes porteñas, en Obras completas, Buenos Aires. Carlos Lohlé, 1981, tomo II.

Las aguafuertes porteñas de Roberto Arlt, Selección y prólogo de Daniel Scroggins, Buenos

Aires, ECA, 1981.

"Palabras del autor" en Arlt, Roberto. Los siete locos. Los lanzallamas, Buenos Aires, Biblioteca Ayacucho, 1986.

Aguafuertes porteñas: Buenos Aires, vida cotidiana, Selección y prólogo de Sylvia Saítta, Buenos Aires, Alianza, 1993.

Aguafuertes porteñas: cultura y política, Selección y prólogo de Sylvia Saítta, Buenos Aires,

Losada, 1994.

Aguafuertes porteñas, Buenos Aires, Corregidor, 1995.

Aguafuertes porteñas, Buenos Aires, Losada, 1996.

Cuentos Completos, Edición a cargo de Ricardo Piglia y Omar Borré, Buenos Aires, Seix

Barral, 1996.

Tratado de la delincuencia. Aguafuertes inéditas. Recopilación y prólogo de Sylvia Saítta, Buenos Aires, Biblioteca Página/12, 1996.

Notas sobre el cinematógrafo, Prólogo de Jorge B. Rivera, Edición de Sebastián M. Gallo, Buenos Aires, Simurg, 1997.

Escenas de un grotesco, en Gaceta de Buenos Aires, I, n 2, 4 de agosto de 1934. Reeditado en

Proa. En las Letras y en las Artes, ${ }^{\circ}$ 30, julio/agosto 1997.

En el país del viento. Viaje a la patagonia (1934), Edición y prólogo de Silvia Saítta, Buenos

Aires, Simurg, 1997. $\overline{1998 .}$

Obras. Aguafuertes. (Tomo II), Ensayo preliminar de David Viñas, Buenos Aires, Losada,

Aguafuertes gallegas y asturianas, Compilación y prólogo Sylvia Saítta, Buenos Aires, Losada, 1999.

Los siete locos-Los Lanzallamas, Edición crítica, Colección Archivos, Mario Goloboff coordinador, Francia, ALLCA XX, Université Paris X, 2000.

Aguafuertes madrileñas. Presagios de una guerra civil, prólogo, compilación y notas de Sylvia Saítta, Buenos Aires, Losada, 2000.

Al margen del cable. Crónicas publicadas en El Nacional, Méjico, 1937, 1941, recopilación, introducción y notas de Rose Corral, Buenos Aires, Losada, 2001.

Aguafuertes vascas. Aguafuertes vascas, Prólogo compilación y notas de Sylvia Saítta, Buenos 
Aires, Simurg, 2005.

Aguafuertes españolas y africanas consideradas

Se detallan aquí las aguafuertes españolas y africanas consultadas que no están editadas en libro

Arlt, Roberto. "Señores... me voy a España", en El Mundo, 12 de febrero de 1935. Aguafuertes españolas.

"Mañana me embarco", en El Mundo, 13 de febrero de 1935. Aguafuertes españolas.

"Ya estamos a bordo", en El Mundo, 25 de febrero de 1935. Aguafuertes españolas.

"Un vizcaíno en nuestra mesa", en El Mundo, 27 de febrero de 1935. Aguafuertes españolas. "Las islas Canarias, puertas de España", en El Mundo, 8 de abril de 1935. Aguafuertes

españolas.

"Llegada a Cádiz", en El Mundo, 9 de abril de 1935. Aguafuertes españolas.

"La gloria del sol", en El Mundo, 10 de abril de 1935. Aguafuertes españolas.

"La alegría de vivir", en El Mundo, 11 de abril de 1935. Aguafuertes españolas.

"La Catedral de Cádiz", en El Mundo, 12 de abril de 1935. Aguafuertes españolas.

"Carestía de la vida en España", en El Mundo, 14 de abril de 1935. Aguafuertes españolas.

"La institución y la universalidad del café", en El Mundo, 15 de abril de 1935. Aguafuertes

españolas.

"A Madrid, a pedir trabajo", en El Mundo, 16 de abril de 1935. Aguafuertes españolas.

"De Cádiz a Barbate", en El Mundo, 17 de abril de 1935. Aguafuertes españolas.

"En busca de un patrón de barco", en El Mundo, 18 de abril de 1935. Aguafuertes españolas.

"Pesca de la sardina", en El Mundo, 19 de abril de 1935. Aguafuertes españolas.

"Mar afuera en una trainera", en El Mundo, 20 de abril de 1935. Aguafuertes españolas.

"Vida de los pescadores de Barbate", en El Mundo, 21 de abril de 1935. Aguafuertes

españolas.

"Vida social en Barbate", en El Mundo, 22 de abril de 1935. Aguafuertes españolas.

"Molinos de viento de Vejer", en El Mundo, 23 de abril de 1935. Aguafuertes españolas.

"Vejer de la Frontera", en El Mundo, 25 de abril de 1935. Aguafuertes españolas.

"Semana Santa en Sevilla (Primera Parte)", en El Mundo, 28 de abril de 1935. Aguafuertes

españolas.

"Qué son y cómo se organizan los "Pasos" en la Semana Santa de Sevilla", en El Mundo, 29

de abril de 1935. Aguafuertes españolas.

"El esplendor de Arabia: la opulencia del Asia; tal la Semana Santa en Sevilla", en El Mundo,

$\overline{30 \text { de }}$ abril de 1935 . Aguafuertes españolas.

"'PasosŽ" y cofradías - Rivalidades - El anecdotario de la Semana Santa", en El Mundo, 1 de

mayo de 1935. Aguafuertes españolas.

"Pueblo y aristocracia en la Semana Santa de Sevilla", en El Mundo, 2 de mayo de 1935.

Aguafuertes españolas.

"El día de la mujer sevillana. Claveles y mantillas lucen en el Jueves Santo", en El Mundo, 4

de mayo de 1935. Aguafuertes españolas.

"Jueves Santo, a las diez de la noche, en la Catedral - Visiones medioevales", en El Mundo, 8

de mayo de 1935. Aguafuertes españolas.

"Último día - El Jesús del Gran Poder - Saetas y lamentaciones", en El Mundo, 12 de mayo de

$\overline{1935}$. Aguafuertes españolas.

"El caso Porrita", en El Mundo, 13 de mayo de 1935. Aguafuertes españolas.

"Jerez y sus bodegas", en El Mundo, 14 de mayo de 1935. Aguafuertes españolas.

"Jerez es una evocación de pasadas glorias", en El Mundo, 15 de mayo de 1935. Aguafuertes españolas.

"Las rejas y las súper rejas de Jerez", en El Mundo, 16 de mayo de 1935. Aguafuertes 
españolas.

"Casas y jardines de la vieja España", en El Mundo, 18 de mayo de 1935. Aguafuertes españolas.

"El Décimo Congreso de Federaciones de Autores", en El Mundo, 20 de mayo de 1935.

Aguafuertes españolas.

"La muralla en la ciudad española", en El Mundo, 30 de mayo de 1935. Aguafuertes

españolas.

"Belleza morisca en las sevillanas", en El Mundo, 2 de junio de 1935. Aguafuertes españolas.

"El color, consecuencia de la ciudad", en El Mundo, 3 de junio de 1935. Aguafuertes

españolas.

"La cerámica de Triana - El Cristo llamado `El CachorroŽ", en El Mundo, 4 de junio de 1935.

Aguafuertes españolas.

"Calle de la Muerte", en El Mundo, 6 de junio de 1935. Aguafuertes españolas.

"Viveza criolla y sinceridad hispana", en El Mundo, 9 de junio de 1935. Aguafuertes

españolas.

"La ofrenda de Almanzor a Alá", en El Mundo, 10 de junio de 1935. Aguafuertes españolas.

"La Andalucía Musulmanizante", en El Mundo, 12 de junio de 1935. Aguafuertes españolas.

"La mentira de la indolencia andaluza", en El Mundo, 13 de junio de 1935. Aguafuertes

españolas.

"El jardín de Cerámica - Una fiesta permanente de color", en El Mundo, 14 de junio de 1935.

Aguafuertes españolas.

"El Arenal es la Corte de los Milagros de Andalucía", en El Mundo, 15 de junio de 1935.

Aguafuertes españolas.

"La cabeza del Rey Don Pedro", en El Mundo, 17 de junio de 1935. Aguafuertes españolas.

"La Feria de Sevilla", en El Mundo, 18 de junio de 1935. Aguafuertes españolas.

"Ante las ruinas de Itálica", en El Mundo, 21 de junio de 1935. Aguafuertes españolas.

"El problema agrario español (Primera parte)", en El Mundo, 27 de junio de 1935.

Aguafuertes españolas.

"El problema agrario español (continuación)", en El Mundo, 1 de julio de 1935. Aguafuertes

españolas.

españolas.

"El problema agrario español $\mathrm{T}$ Tercera parte", en El Mundo, 4 de julio de 1935. Aguafuertes

" Los gitanos en la feria", en El Mundo, 5 de julio de 1935. Aguafuertes españolas.

"La individualidad española", en El Mundo, 10 de julio de 1935. Aguafuertes españolas.

"¡Quítate de allí!, Valiente", en El Mundo, 13 de julio de 1935. Aguafuertes españolas.

"El toro y los toreros", en El Mundo, 14 de julio de 1935. Aguafuertes españolas.

"El Niño de las Palmas" y las Banderillas", en El Mundo, 16 de julio de 1935. Aguafuertes

españolas.

"Fiestas de Corpus en Granada - Desgracia con suerte - Desencajonando los toros", en El

Mundo, 18 de julio de 1935. Aguafuertes españolas.

"Una fiesta de alegría - Evocaciones pintorescas de la antigua Granada", en El Mundo, 19 de

julio de 1935. Aguafuertes españolas.

"Corpus Christi en Granada", en El Mundo, 21 de julio de 1935. Aguafuertes españolas.

"El séptimo día de fiesta en Granada - La incontenible alegría del alma española", en El

Mundo, 22 de julio de 1935. Aguafuertes españolas.

"Con Blas Infante, líder del andalucismo - El sentido de la amistad en España - Visita de

despedida - Me voy al África", en El Mundo, 24 de julio de 1935. Aguafuertes españolas.

"De Sevilla a Algeciras - Pasamos por Alcalá de los Gazules - Circo, toros y gente

dominguera", en El Mundo, 25 de julio de 1935. Aguafuertes africanas.

"Complicaciones a causa de mi apellido - La pesadilla de espionaje - El agente $n^{\circ} 80$ - 'Puede

embarcarseŽ", en El Mundo, 26 de julio de 1935. Aguafuertes africanas.

"El Peñón de Gibraltar - La ciudadela - Una ciudad sombría y limpia", en El Mundo, 27 de 
julio de 1935. Aguafuertes africanas.

"Policía política - Una cadena de agentes vigila a los viajeros - Imperialismo y comunismo",

en El Mundo, 29 de julio de 1935. Aguafuertes africanas.

"El agente $\mathrm{N}^{\circ} 80$ y su substituto - Dos malandrines que se reverencian - Cada turista puede ser

el mendrugo de un chivato", en El Mundo, 30 de julio de 1935. Aguafuertes africanas.

"El Tánger - Martirologio del turista - Plaga de guías - Persecución sistemática hasta el tercer

día", en El Mundo, 31 de julio de 1935. Aguafuertes africanas.

"En el Zoco Grande de Tánger - Mercaderes y campesinos - Uñas pintadas y tatuajes - `FlirtŽ

sin trascendencia", en El Mundo, 1 de agosto de 1935. Aguafuertes africanas.

"¿Dónde está la poesía oriental? - Las desdichadas mujeres del Islam - Mugre y hospitalidad",

en El Mundo, 2 de agosto de 1935. Aguafuertes africanas.

"El narrador de cuentos - Abuso de ingenuos y piadosos - Precursores del teatro", en El

Mundo, 3 de agosto de 1935. Aguafuertes africanas.

"El trabajo de los niños y las mujeres", en El Mundo, 5 de agosto de 1935. Aguafuertes

africanas.

"Noviazgo moro en Marruecos en el año 1935", en El Mundo, 6 de agosto de 1935.

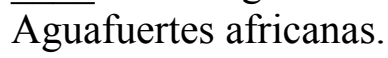

"Boda musulmana en Tánger - Me faltó coraje para usar el magnesio Tambores, trompetas y la

novia en la jaula - ¿Fiesta o sacrificio?", en El Mundo, 7 de agosto de 1935. Aguafuertes africanas.

"Esclavitud del matrimonio - Deseo y terror de la civilización europea", en El Mundo, 8 de

agosto de 1935. Aguafuertes africanas.

"La vida campesina en la ficción y en la realidad - Las mujeres, bestias de carga - Treinta kilos

por cincuenta kilómetros", en El Mundo, 12 de agosto de 1935. Aguafuertes africanas.

"Tetuán, ciudad de doble personalidad - Me interno en el Barrio Moro - Reminiscencias

cinematográficas", en El Mundo, 13 de agosto de 1935. Aguafuertes africanas.

"El arrabal moruno - Mis amigos los tenderos - Saludos, genuflexiones y parásitos - Un

refugio de paz y tranquilidad", en El Mundo, 18 de agosto de 1935. Aguafuertes africanas.

"Visita a la escuela musulmana - Hay que saber el Corán de memoria - El palmetazo es en la

planta de los pies - Indiferencia paternal por los conocimientos paternales", en El Mundo, 19 de

agosto de 1935. Aguafuertes africanas.

"Salida de Tetuán - Hay que irse o enredarse - Rjmo, la de los ojos de miedo - La tristeza de la partida", en El Mundo, 21 de agosto de 1935. Aguafuertes africanas.

"En el Zoco Grande de Tánger - Mercaderes y campesinos - Uñas pintadas y tatuajes - "Flirt"

sin trascendencia", en El Mundo, 1 de agosto de 1935. Aguafuertes españolas.

"¿Dónde está la poesía oriental? - Las desdichadas mujeres del Islam - Mugre y hospitalidad",

en El Mundo, 2 de agosto de 1935. Aguafuertes españolas.

"El narrador de cuentos - Abuso de ingenuos y piadosos - Precursores del teatro", en El

Mundo, 3 de agosto de 1935. Aguafuertes españolas.

"El trabajo de los niños y las mujeres", en El Mundo, 5 de agosto de 1935. Aguafuertes

españolas.

"Noviazgo moro en Marruecos en el año 1935", en El Mundo, 6 de agosto de 1935.

Aguafuertes españolas.

"Boda musulmana en Tánger - Me faltó coraje para usar el magnesio Tambores, trompetas y la

novia en la jaula - ¿Fiesta o sacrificio? ", en El Mundo, 7 de agosto de 1935. Aguafuertes españolas.

"Esclavitud del matrimonio - Deseo y terror de la civilización europea", en El Mundo, 8 de

agosto de 1935. Aguafuertes españolas.

"La vida campesina en la ficción y en la realidad - Las mujeres, bestias de carga - Treinta kilos

por cincuenta kilómetros", en El Mundo, 12 de agosto de 1935. Aguafuertes españolas.

"Tetuán, ciudad de doble personalidad - Me interno en el Barrio Moro - Reminiscencias

cinematográficas", en El Mundo, 13 de agosto de 1935. Aguafuertes españolas.

"El arrabal moruno - Mis amigos los tenderos - Saludos, genuflexiones y parásitos - Un

refugio de paz y tranquilidad", en El Mundo, 18 de agosto de 1935. Aguafuertes españolas. 
"Visita a la escuela musulmana - Hay que saber el Corán de memoria - El palmetazo es en la planta de los pies - Indiferencia paternal por los conocimientos paternales", en El Mundo, 19 de agosto de 1935. Aguafuertes españolas.

"Salida de Tetuán - Hay que irse o enredarse - Rjmo, la de los ojos de miedo - La tristeza de la partida", en El Mundo, 21 de agosto de 1935. Aguafuertes españolas.

"De Ceuta a Málaga - Noche de perros - No estoy para paisajes - Asalto al único turista", en El Mundo, 22 de agosto de 1935. Aguafuertes españolas.

"Tortones de algarrobo contra el mareo - Cuestas y zigzags - El encanto del paisaje", en El Mundo, 23 de agosto de 1935. Aguafuertes españolas.

"Anécdota de Almanzor - Hogares y graneros de la Vega Granadina - Se aprovechan de las bendiciones de la tierra", en El Mundo, 25 de agosto de 1935. Aguafuertes españolas. "El magnetismo de España", en El Mundo, 27 de agosto de 1935. Aguafuertes españolas.

"Trogloditas en Granada - Reminiscencias de `El amor brujoŽ" - Visitas de cortesía a las casas cavernas - Una silla y agua fresca", en El Mundo, 28 de agosto de 1935. Aguafuertes españolas. "Trato de visitar a Falla - Fortaleza inexpugnable - Un dragón, dos, tres dragones - 'Vuelva mañana y le recibiráŽ ", en El Mundo, 1 de setiembre de 1935. Aguafuertes españolas. "Con el maestro Falla - Convalecencia - El martirio de los ruidos molestos - El terror a los receptores de radio", en E1 Mundo, 2 de setiembre de 1935. Aguafuertes españolas. "Promesas imposibles de cumplir - María Carmen es más locuaz que el maestro - Detalles de la vida de un gran músico", en El Mundo, de setiembre de 1935. Aguafuertes españolas. "Turismo standard y `PatoŽ - Plática diaria con las bordadoras - Galanterías para Marín", en

$\overline{E l}$ Mundo, 4 de setiembre de 1935. Aguafuertes españolas. "Gitanas del Sacro Monte - Pura escenografía para encandilar a los turistas - Lo falso y lo verdadero", en El Mundo, 5 de setiembre de 1935. Aguafuertes españolas. "Lluvia de mendigos - Los hay de toda categoría - La 'mangaŽ no es palabra porteña - ¿Hay quienes comen yuyos? ", en E1 Mundo, 6 de setiembre de 1935. Aguafuertes españolas. "Psicología de la masa española", en El Mundo, 7 de setiembre de 1935. Aguafuertes españolas.

"El bosque de la Alhambra - Ensueños y sugerencias", en El Mundo, 8 de setiembre de 1935. Aguafuertes españolas. "De cómo trabé amistad con los gitanos del Sacro Monte - Con La Golondrina y un éxito fotogénico se me abren las puertas", en El Mundo, 9 de setiembre de 1935. Aguafuertes españolas. "Con los gitanos del Sacro Monte", en El Mundo, 10 de setiembre de 1935. Aguafuertes españolas. "Vida de los gitanos del Sacro Monte", en El Mundo, 11 de setiembre de 1935. Aguafuertes españolas. "Diálogo extraordinario con Lola la Chata", en El Mundo, 12 de setiembre de 1935.

Aguafuertes españolas. "La cueva de la gitana rica", en El Mundo, 14 de setiembre de 1935. Aguafuertes españolas. "Historia de 'La ChataŽ - La gitana analfabeta lee y hace cuentas - Se va a casar con un noble alemán arruinado", en El Mundo, 16 de setiembre de 1935. Aguafuertes españolas. "Sensibilidad gitana", en El Mundo, 17 de setiembre de 1935. Aguafuertes españolas. "Vigo, ciudad - Gente cordial, seria y reflexiva - Un contraste con Andalucía", en El Mundo, 19 de setiembre de 1935. Aguafuertes españolas. "A lo largo del Miño - Recuerdo a los gallegos de Buenos Aires - Paisajes puros, suaves y plácidos", en El Mundo, 20 de setiembre de 1935. Aguafuertes españolas.

Crónicas de "Tiempos presentes" y "Al margen del cable"

Se detallan aquí las crónicas de "Tiempos presentes" y "Al margen del cable" inéditas en libro. 
Arlt, Roberto. "Oro negro en Río Cuarto", en El Mundo, 12 de marzo de 1937. Tiempos presentes. "El pesador de monedas", en El Mundo, 13 de marzo de 1937. Tiempos presentes.

"El chantaje de los restaurantes norteamericanos", en El Mundo, 15 de marzo de 1937.

Tiempos presentes.

"Cazadores de ambulancias", en El Mundo, 18 de marzo de 1937. Tiempos presentes.

"Cuatro presidiarios a la deriva", en El Mundo, 20 de marzo de 1937. Tiempos presentes.

"No saben cómo resolver en Estados Unidos el problema de la neutralidad", en El Mundo, 24

de marzo de 1937. Tiempos presentes.

"La vida extraña de Lilian Valerie Smith que simulaba ser un coronel Británico", en El

Mundo, 29 de marzo de 1937. Tiempos presentes.

"Pobreza del escritor europeo", en El Mundo, 11 de abril de 1937. Tiempos presentes.

"¿Qué harán los dependientes de almacén?", en El Mundo, 13 de abril de 1937. Tiempos

presentes.

"El subsuelo del diablo", en El Mundo, 15 de abril de 1937. Tiempos presentes.

"Las madres del mundo miran y escuchan", en El Mundo, 28 de abril de 1937. Tiempos

presentes.

"No se quede en casa, señor", en El Mundo, 23 de mayo de 1937. Tiempos presentes.

"Roosvelt asegura la tranquilidad de 28 millones de ancianos", en El Mundo, 29 de mayo de

1937. Tiempos presentes.

"¿Por qué la intendencia no contrata un flautista?", en El Mundo, 31 de mayo de 1937.

Tiempos presentes.

"El Polo Norte no está más en el Polo Norte", en El Mundo, 5 de junio de 1937. Tiempos

presentes.

"100 años por cabeza", en El Mundo, 9 de junio de 1937. Tiempos presentes.

"Nada más que 970 fusilados", en El Mundo, 11 de junio de 1937. Tiempos presentes.

"En Kansas las mujeres se ponen los pantalones", en El Mundo, 14 de junio de 1937. Tiempos

presentes."

"Una adivina con 150.000 pesos", en El Mundo, 25 de junio de 1937. Tiempos presentes.

"Los reyes y sus rencillas domésticas", en El Mundo, 11 de julio de 1937. Tiempos presentes.

"La búsqueda de Amelisa Earhart", en El Mundo, 12 de julio de 1937. Tiempos presentes.

"Compre repuestos para su cerebro", en El Mundo, 16 de julio de 1937. Tiempos presentes.

"Un protagonista de Edgar Wallace", en El Mundo, 23 de julio de 1937. Tiempos presentes.

"El rompecabezas amarillo", en El Mundo, 3 de agosto de 1937. Tiempos presentes.

"La perrita madrileña", en El Mundo, 20 de agosto de 1937. Tiempos presentes.

"¿La guerra breve?...¿La guerra larga?...", en El Mundo, 2 de septiembre de 1937. Tiempos

presentes.

"La hora de lo `desconocidoŽ", en El Mundo, 13 de septiembre de 1937. Tiempos presentes.

"Cuando un hombre de números se apasiona", en El Mundo, 7 de octubre de 1937. Tiempos

presentes.

del cable.

"Un gitano ladrón y un caballo aprovechado", en El Mundo, 8 de octubre de 1937. Al margen

"No nos riamos de Luigi Gabbi", en El Mundo, 9 de octubre de 1937. Al margen del cable.

"¿Para qué irritaste a los Dioses, Susana Duvernois", en El Mundo, 14 de octubre de 1937. Al

margen del cable.

"Espíritu guerrero en los niños pequeños", en El Mundo, 17 de octubre de 1937. Al margen

del cable.

"El ladrón en el museo de Leipzig", en El Mundo, 18 de octubre de 1937. Al margen del cable.

"¡72431 cartas de amor!", en El Mundo, 20 de octubre de 1937. Al margen del cable.

"Huyendo del diablo a través del infierno", en El Mundo, 25 de octubre de 1937. Al margen 
del cable. cable.

"Augusto Jaeger, el Hombre de las rosas", en El Mundo, 27 de octubre de 1937. Al margen del

"Cascajos a su peso en oro", en El Mundo, 30 de octubre de 1937. Al margen del cable.

"Sueño de amor en Praga", en El Mundo, 3 de noviembre de 1937. Al margen del cable.

"Monsieur Deibler, el verdugo galante", en El Mundo, 11 de noviembre de 1937. Al margen

$\overline{\text { del cable. }}$

"El continente seductor", en El Mundo, 13 de noviembre de 1937. Tiempos presentes.

"Del imperio del crimen", en El Mundo, 20 de noviembre de 1937. Al margen del cable.

"Simbad el marino, pero al revés", en El Mundo, 24 de noviembre de 1937. Al margen del cable.

"¿No se imaginó así a Cuba?", en El Mundo, 6 de enero de 1938. Al margen del cable.

"Casualidades necesarias de la vida", en El Mundo, 18 de enero de 1938. Al margen del cable.

"La pata de palo del fondero", en El Mundo, 21 de enero de 1938. Al margen del cable.

"¿Por qué en la Nueca? -Wiedmann no lo explica", en El Mundo, 26 de enero de 1938. Al

margen del cable.

"¿Qué le traerá la cigüeña a la Princesa juliana?", en El Mundo, 9 de febrero de 1938. Al

margen del cable.

"La ballena prisionera", en El Mundo, 9 de febrero de 1938. Al margen del cable.

"¿Está loco o se hace el loco Al Capone?", en El Mundo, 12 de febrero de 1938. Al margen del cable. del cable.

"A la deriva- Cuatro hombres y un témpano", en El Mundo, 16 de febrero de 1938. Al margen

"Conversando con el tiempo", en El Mundo, 20 de febrero de 1938. Al margen del cable.

cable.

"El final de $\square$ Montaña de GongonzolaŽ", en El Mundo, 22 de febrero de 1938. Al margen del

"Emile...jSe te fue la mano!", en El Mundo, 23 de febrero de 1938. Al margen del cable.

" Una herencia y 7000 pleitantes", en El Mundo, 1 de marzo de 1938. Al margen del cable.

"Cuando Pardi vivía en el fondo del mar", en El Mundo, 4 de marzo de 1938. Al margen del cable.

"Otra vez el gas misterioso", en El Mundo, 8 de marzo de 1938. Al margen del cable.

"El simpático caballero Emil Blatz", en El Mundo, 11 de marzo de 1938. Al margen del cable.

"Los defendidos de Mister Clarence", en El Mundo, 17 de marzo de 1938. Al margen del cable. $\overline{\text { cable. }}$

"Los persiguen....pero los necesitan!", en El Mundo, 20 de marzo de 1938. Al margen del del cable.

"Cavilaciones del arzobispo de Chelmsford", en El Mundo, 28 de marzo de 1938. Al margen

"El bandido y la mariposa", en El Mundo, 30 de marzo de 1938. Al margen del cable.

"Los dragones afilan sus dientes en las Usinas", en El Mundo, 5 de abril de 1938. Al margen del cable. cable.

"¡Pobre señor Roosvelt! Lo compadezco", en El Mundo, 19 de agosto de 1938. Al margen del del cable.

"Ochenta años de abundancia ¿y después?", en El Mundo, 26 de agosto de 1938. Al margen cable.

"Quieren huir de su propia sombra", en El Mundo, 1 de septiembre de 1938. Al margen del

"¿A que no se le escapa...?", en El Mundo, 4 de septiembre de 1938. Al margen del cable.

"Al borde del gran misterio", en El Mundo, 12 de septiembre de 1938. Al margen del cable.

"¿Dónde se encuentra hoy el Barón de Von Popen?", en El Mundo, 24 de septiembre de 1938.

Al margen del cable.

"Preludios de movilización", en El Mundo, 29 de septiembre de 1938. Al margen del cable. 

$\overline{\text { cable. }}$

"Dichoso aquel que tiene su casa a flote", en El Mundo, 9 de octubre de 1938. Al margen del

"¿Ahora le toca a Schuschningg?", en El Mundo, 20 de octubre de 1938. Al margen del cable. cable.

"Para exorcizar a los malos espíritus...", en El Mundo, 28 de octubre de 1938. Al margen del

$\overline{\text { cable. }}$

"En el círculo de la blancura eterna", en El Mundo, 1 de noviembre de 1938. Al margen del

"Un mundo sin soñadores", en El Mundo, 9 de noviembre de 1938. Al margen del cable.

"Otro Londres para el mismo Carol", en El Mundo, 15 de noviembre de 1938. Al margen del cable.

"El truco de la mujer cortada en dos pedazos", en El Mundo, 23 de noviembre de 1938. Al margen del cable.

"Pesca y no de peces", en El Mundo, 25 de noviembre de 1938. Al margen del cable.

"El viejo tallador de diamantes", en El Mundo, 27 de noviembre de 1938. Al margen del cable.

"La sequía de Ceilán", en El Mundo, 2 de diciembre de 1938. Al margen del cable.

"Nueva edición de las pinturas de Goya", en El Mundo, 5 de diciembre de 1938. Al margen

$\overline{\text { del cable. }}$

"Termina un año terrible...¿¿y el que viene?", en El Mundo, 17 de diciembre de 1938. Al margen del cable.

$\overline{\text { cable. }}$

"La eterna actualidad del Greco", en El Mundo, 20 de diciembre de 1938. Al margen del

"El año 1938 a través de los astrólogos. ¿Y el 1939?", en El Mundo, 1 de enero de 1939. Al margen del cable.

"¡Feliz año nuevo!", en El Mundo, 22 de enero de 1939. Al margen del cable.

"Montaña despierta", en El Mundo, 1 de febrero de 1939. Al margen del cable.

$\overline{\text { cable. }}$.

"El suave morir de Monsieur Deibler", en El Mundo, 3 de febrero de 1939. Al margen del

"La personalidad del jefe del 'Intelligence ServiceŽ", en El Mundo, 12 de febrero de 1939. Al margen del cable. $\overline{\text { cable. }}$.

"Esperamos sus memorias, señora...", en El Mundo, 26 de febrero de 1939. Al margen del cable.

"Ocurre en San Diego de California", en El Mundo, 28 de febrero de 1939. Al margen del

"La culpa es del tocino, amada mía", en El Mundo, 26 de marzo de 1939. Al margen del cable.

"¿Qué le habrá contestado el tigre", en El Mundo, 12 de abril de 1939. Al margen del cable.

"Ocurrió en cuatro días", en El Mundo, 30 de abril de 1939. Al margen del cable.

"Íbamos a vivir en un laberinto", en El Mundo, 3 de mayo de 1939. Al margen del cable.

"Ocurrió en Samoa, bajo la lluvia", en El Mundo, 7 de mayo de 1939. Al margen del cable. $\overline{\text { del cable. }}$

"El enemigo número uno de Chiang-Kai-Shek", en El Mundo, 16 de mayo de 1939. Al margen

"El sepulcro de acero", en El Mundo, 24 de mayo de 1939. Al margen del cable.

"Los alegres congresos de Estocolmo", en El Mundo, 3 de junio de 1939. Al margen del cable.

"El hombre de la boca sellada", en El Mundo, 9 de junio de 1939. Al margen del cable.

"Probable candidato a Presidente de los Estados Unidos", en El Mundo, 24 de junio de 1939.

Al margen del cable.

"Los diabólicos submarinos", en El Mundo, 1 de julio de 1939. Al margen del cable.

"El astuto 7 Herr $\mathrm{G}$ Goering", en El Mundo, 14 de julio de 1939. Al margen del cable.

"Cómo se lo comieron a Orlando", en El Mundo, 19 de julio de 1939.

"¡Qué oportunidad $\square$ maitre $\square$ Guiafteri!", en El Mundo, 19 de septiembre de 1939. Al margen del cable. 
"Imprudencia del Vizconde o quién espía a quién", en El Mundo, 26 de septiembre de 1939. Al margen del cable. del cable.

"Batallita naval por un cabaret flotante", en El Mundo, 28 de septiembre de 1939. Al margen

"La gran duquesa Carlota hace preparar sus baúles", en El Mundo, 4 de octubre de 1939. Al margen del cable.

"¿Dónde comprará los tomates Louis Bouchalter?", en El Mundo, 13 de octubre de 1939. Al margen del cable.

"Se quedarán sin olimpíadas", en El Mundo, 15 de octubre de 1939. Al margen del cable.

"Coloquio entre Maquiavelo y Von Ribben Trop", en El Mundo, 25 de octubre de 1939. Al margen del cable.

"Dígale a la princesa Stirbey...", en El Mundo, 8 de noviembre de 1939. Al margen del cable.

"Hermandad de la sangre", en El Mundo, 9 de noviembre de 1939. Al margen del cable.

"Quieren matar los tulipanes", en El Mundo, 13 de noviembre de 1939. Al margen del cable.

"Reunión familiar en casa de Al Capone", en El Mundo, 17 de noviembre de 1939. Al margen del cable.

"Y entonces ¿qué le digo a mis muchachos?", en El Mundo, 19 de noviembre de 1939. Al margen del cable.

"Feliz historia de un fabricante de aplausos", en El Mundo, 23 de noviembre de 1939. Al margen del cable.

"Allí vive el crustáceo lunar", en El Mundo, 14 de julio de 1939. Al margen del cable.

"'Señores: soy el doble de HitlerŽ", en El Mundo, 4 de diciembre de 1939. Al margen del $\overline{\text { cable. }}$. $\overline{\text { cable. }}$

"Copetudos del nazismo en el destierro", en El Mundo, 6 de diciembre de 1939. Al margen del del cable.

"Terror nazi entre los morochos de Liberia", en El Mundo, 9 de diciembre de 1939. Al margen

"Ciudades debajo del mar", en El Mundo, 15 de diciembre de 1939. Al margen del cable.

"Vida de galeotes", en El Mundo, 20 de diciembre de 1939. Al margen del cable.

"Eróstato visita a un irresponsable", en El Mundo, 24 de diciembre de 1939. Al margen del cable. cable.

"Dos personajes de Noel Coward", en El Mundo, 26 de diciembre de 1939. Al margen del

"Se necesita un par de verdugos", en El Mundo, 3 de enero de 1940. Al margen del cable.

"No por amor visitará Mac Donald a Mad Jadfi", en El Mundo, 5 de enero de 1940. Al margen del cable.

"¿Volverá a ser reelegido el dinámico petiso?, en El Mundo, 17 de enero de 1940. Al margen

del cable.

"Programa Goering", en El Mundo, 24 de enero de 1940. Al margen del cable.

"Sin ruido de automóviles", en El Mundo, 2 de febrero de 1940. Al margen del cable.

"Cuando Creso se desploma", en El Mundo, 8 de febrero de 1940. Al margen del cable.

"Recordando el Eclesiastés", en El Mundo, 11 de febrero de 1940. Al margen del cable.

"El sueño de las balas perdidas", en El Mundo, 16 de febrero de 1940. Al margen del cable.

"El Tibet tiene un nuevo Lama", en El Mundo, 21 de febrero de 1940. Al margen del cable.

"Hace 4000 años", en El Mundo, 29 de febrero de 1940. Al margen del cable.

"Puede que sí...puede que no...", en El Mundo, 6 de marzo de 1940. Al margen del cable.

"El monstruo dolido", en El Mundo, 10 de marzo de 1940. Al margen del cable.

"Hitler le dijo...", en El Mundo, 18 de marzo de 1940. Al margen del cable.

"Nijinsky en la montaña mágica", en El Mundo, 24 de marzo de 1940. Al margen del cable.

"El único príncipe feliz", en El Mundo, 31 de marzo de 1940. Al margen del cable.

"Hay que ser millonario y chiflado", en El Mundo, 4 de abril de 1940. Al margen del cable.

"Agua, viento y silencio", en El Mundo, 16 de abril de 1940. Al margen del cable. 
"Joseph Tiso ¿por qué desoíste la voz de la Prudencia", en El Mundo, 11 de mayo de 1940. Al margen del cable.

"Weigand y la impaciencia", en El Mundo, 22 de mayo de 1940. La guerra frente a las pizarras.

"Una banana y la última guerra", en El Mundo, 20 de julio de 1940.

"Documentadas profecías de Toch", en El Mundo, 24 de julio de 1940.

"Inútil sacrificio de Toller", en El Mundo, 31 de julio de 1940.

"El rascacielo desalquilado", en El Mundo, 8 de agosto de 1940.

"Henry Ford" y el "Barco de la Paz", en El Mundo, 22 de agosto de 1940.

"Destierro y muerte del caballero del Verde Gabán", en El Mundo, 30 de agosto de 1940.

"El águila revolotea en torno de las tortugas", en El Mundo, 3 de septiembre de 1940.

"Ahí está el rabo, con la chispa en la Punta", en El Mundo, 19 de septiembre de 1940.

"Nerviosidad de la política chilena", en El Mundo, 9 de septiembre de 1940.

"Muñecos de aserrín", en El Mundo, 3 de mayo de 1941.

"El terrorista Hess aterrorizado", en El Mundo, 15 de mayo de 1941.

"Tierras fecundas para el ocultismo", en El Mundo, 26 de mayo de 1941.

"Seguirán jugando al truco", en El Mundo, 3 de junio de 1941.

"Hombres felices en 1960", en El Mundo, 25 de junio de 1941.

"Guerra de prehistoria y guerra científica", en El Mundo, 24 de diciembre de 1941.

"Anabaris o la reirada de los 10.000", en El Mundo, 1 de enero de 1942.

"Este es Otto Rashid", en El Mundo, 9 de enero de 1942. Al margen del cable.

"Europa, escuela de terrorismo", en El Mundo, 10 de enero de 1942. Al margen del cable.

"Goering también", en El Mundo, 11 de enero de 1942. Al margen del cable.

"Noche frente a Mozhaisk", en El Mundo, 14 de enero de 1942. Al margen del cable.

"Los buscadores de Wolfran", en El Mundo, 20 de enero de 1942. Al margen del cable.

"Explorarán Matto Grosso", en El Mundo, 24 de enero de 1942. Al margen del cable.

"Exterminio del parásito alegre", en El Mundo, 4 de febrero de 1942. Al margen del cable.

"Conspiran en Afganistán", en El Mundo, 14 de febrero de 1942. Al margen del cable.

"Caretas en soledad", en El Mundo, 18 de febrero de 1942. Al margen del cable.

"El museo melancólico", en El Mundo, 19 de febrero de 1942. Al margen del cable.

"Desaparición del último paraíso", en El Mundo, 25 de febrero de 1942. Al margen del cable.

"Época de las horas-vuelo", en El Mundo, 25 de marzo de 1942. Al margen del cable.

"Los desiertos se pueblan de mecánicos", en El Mundo, 25 de abril de 1942. Al margen del

cable.

"La esperanza de Serbia", en El Mundo, 29 de abril de 1942. Al margen del cable.

"Los aventureros de la caña", en El Mundo, 17 de junio de 1942. Al margen del cable.

"El drama de los refugiados", en El Mundo, 3 de julio de 1942. Al margen del cable.

"Violentos personajes de hoy", en El Mundo, 7 de julio de 1942. Al margen del cable.

"La eterna partida", en El Mundo, 12 de julio de 1942. Al margen del cable.

cable.

"El doctor Pawelith émulo de Rocambole", en El Mundo, 22 de julio de 1942. Al margen del

Bibliografía teórica

Acosta, Leonardo, Novela policial y medios masivos, La Habana, Letras cubanas, 1986.

Adams, Percy. Travel literature and the evolution of the novel, Kentucky, 1983.

Adorno, Theodor. "El ensayo como forma", en Notas de literatura, Barcelona, Ariel, 1962.

"La belleza natural", en Teoría estética, Madrid, Orbys-Hispamérica, 1983.

Aínsa, Fernando. "La reescritura de la historia en la nueva narrativa latinoamericana", Cuadernos

Americanos, Nueva Época $N^{\circ} 28$, México, UNAM.

Aira, César. "Exotismo" en Boletín/3, Centro de Estudios de Teoría y Crítica Literaria, Rosario, 
1993.

Alewyn, Richard, "The Origin of the Detective Novel", en Most, Glenn y Stowe, W., The Poetics of Murder: Detective Fiction and Literary Theory, San Diego, Harcourt Brace Jovanovich, 1983.

Amar Sánchez, Ana María. El relato de los hechos. Rodolfo Walsh: testimonio y escritura. Rosario, Beatriz Viterbo, 1992.

Bajarlía, Juan Jacobo, Estudio preliminar de Historia de crímenes y misterio, Buenos Aires, Fraterna, 1990.

Bajtín, Mijaíl. Esthétique et théorie du roman, Paris, Seuil, 1977.

Problemas de la poética de Dostoievski, México, FCE, 1987.

Barrenechea, Ana María. "Ensayo de una tipología de la literatura fantástica" en Textos

hispanoamericanos, De Sarmiento a Sarduy, Caracas, Monte Ávila, 1978.

"La literatura fantástica: función de los códigos socioculturales en la constitución de un

género" en Texto/Contexto en la Literatura Iberoamericana, Memoria del XIX Congreso del Instituto Internacional de L. I., Madrid, 1980.

Barthes, Roland. "El efecto de realidad", en Todorov, Tvetan. Lo verosímil, Buenos Aires, Tiempo contemporáneo, 1970.

S/Z, México, Siglo XXI, 1980.

La torre Eiffel. Textos sobre la imagen, Barcelona, Paidós, 2001.

Benjamin, Walter. "El narrador", en Sobre el programa de la filosofía futura y otros ensayos, Barcelona, Planeta $\square$ Agostini, 1986.

Imaginación y sociedad. Iluminaciones I, Madrid, Taurus, 1980.

Poesía y capitalismo. Iluminaciones II, Madrid, Taurus, 1980.

Bennett, D., "The Detective Novel: Towards a Definition of Genre", en PTL. Journal for

Descriptive Poetics and Theory of Literature, $\mathrm{N}^{\circ} 4,1979$.

Boileau-Narcejac (Pierre Boileau y Thomas Narcejac). La novela policial, Buenos Aires, Paidós, 1968.

Borrat, Héctor El periódico, actor político, Barcelona, Gustavo Gili, 1989.

Bourdieu, Pierre. "Campo intelectual y proyecto creador" en Pouillon, J. y otros, Problemas del

estructuralismo, México, Siglo XXI, 1967, pp. 135 y ss.

La distinction. Critique sociale du jugement, Paris, Minuit, 1979.

Las reglas del arte. Génesis y estructura del campo literario. Barcelona, Anagrama, 1995.

Braceras, Elena; Leytour, Cristina y Pitella, Susana, El cuento policial argentino, Buenos Aires, Plus Ultra, 1986.

Bürger, Peter. Teoría de la vanguardia, Barcelona, Península, 1997.

Caillois, Roger. Au coeur du fantastique, París, Gallimard, 1965.

Castex, P.G.. Le conte fantastique en France. París, José Corti, 1951.

Cawelti, John G. (1976) Adventure, Mistery and Romance, Chicago, The University of Chicago

Press, 1992.

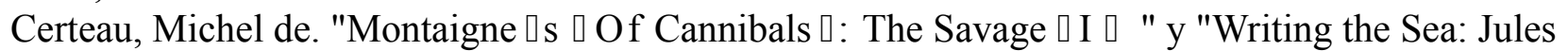

Verne" en Heterologies; Discourse on the Other, Minneapolis, University of Minnesota Press, 1985.

Chandler, R., Chandler por sí mismo, Madrid, Debate, 1990.

Christopher, J. R., "Poe and the Tradition of the Detective Story", en Nevins, Francis, The mystery writer's art, Bowling Green University Press, 1970.

Del Monte, Alberto, Breve historia de la novela policíaca, Madrid, Taurus, 1962.

Foucault, Michel. "La biblioteca fantástica" en Eco, Bogotá, septiembre 1974, nº 167.

Frisby, David. Fragmentos de la modernidad. Teorías de la modernidad de la obra de Simmel,

Kracauer y Benjamín, Madrid, Visor, 1992.

G. Simmel. Sobre la aventura. Ensayos filosóficos, Barcelona, Península, 1988.

Gramuglio, María Teresa. "La construcción de la imagen" en Tizón, Héctor y otros, La escritura argentina, Santa Fé, UNL y Ed. De la Cortada, 1992.

"Comienzos en fin de siglo: Leopoldo Lugones" en Orbis Tertius. Revista de Teoría y Crítica

Literaria, I, 2-3, segundo semestre 1996. 
Hamon, Philipe. Introducción al análisis de lo descriptivo, Buenos Aires, Edicial, 1991.

Hoveyda, Fereydoun. Historia de la novela policíaca, Madrid, Alianza, 1967.

Jackson, Rosemary. Fantasy: literatura y subversión, Buenos Aires, Catálogos Editora, 1986.

Juin, Hubert. "Les chemins du fantastique francais" en Magazine littéraire, París, Julio-Agosto de 1972, n 66, p. 9.

Link, Daniel (comp.). El juego de los cautos. La literatura policial: de Poe al caso Giubileo, Buenos Aires, La marca editora, 1992. (Incluye textos de Barthes, Benjamin, Brecht, Chandler, Deleuze, Foucault, Gramsci, Jameson, Lacan y otros).

Lovecraft, H. P. Supernatural Horror in Literature, Nueva York, Bern Abramson, 1945.

Lowndes, Robert. "The Contributions of Edgar Allan Poe", en Nevins, Francis, The mystery writer's art, Bowling Green University Press, 1970. Mabille, Pierre. Le miroir du merveilleux, París, Ed. De Minuit, 1962.

Ludmer, Josefina, Los procesos de construcción del relato, Buenos Aires, Sudamericana, 1977.

Lukács, George. "Esencia y forma del ensayo" en Eco. Revista de la Cultura de Occidente, Brechholz, Bogotá, Enero de 1967. "¿Narrar o describir?, en Goldmann, Escarpit, Hauser y otros. Literatura y sociedad, Buenos Aires CEAL, 1977.

Macdonald, Ross, "The Writer as Detective Hero", en Nevins, Francis, The mystery writer's art, Bowling Green University Press, 1970.

Marshal Berman. Todo lo sólido se desvanece en el aire. La experiencia de la modernidad, Buenos Aires, Siglo XXI, 1989.

Mattoni, Silvio. "El género", en Mattoni, Silvio. Las formas del ensayo en la Argentina de los años ૫ 50, Córdoba, Universitas, 2003.

Montaigne. Essais, Tome I, Éditions Garnier Frères, Paris, 1962.

Monteleone, Jorge. El relato de viaje. De Sarmiento a Humberto Eco, Buenos Aires, El Ateneo, 1999.

Most, G. y Stowe, W., The Poetics of Murder: Detective Fiction and Literary Theory, San Diego, Harcourt Brace Jovanovich, 1983. Penzoldt, P. The supernatural in Fiction, Londres, Peter Nevil, 1952.

Narcejac, T., Una máquina de leer: la novela policial, México, F.C.E., 1986.

Nevins, Francis. The mystery writer's art, Bowling Green University Press, 1970.

Palmer Jerry. Thrillers. La novela de misterio. Génesis y estructura de un género popular, México, FCE, 1983

Pate, Janet, El libro de los detectives, Buenos Aires, Crea, 1981.

Pavis, Patrice. Diccionario de teatro, Barcelona, Paidós, 1983.

Penzoldt, P. The supernatural in Fiction, Londres, Peter Nevil, 1952.

Piglia, Ricardo. "Los mayordomos siempre son sospechosos" entrevista de Sánchez, Matilde, en Revista Clarín, 30 de septiembre de 1990.

"Cuando el crimen paga", entrevista de Mariana Rapoport, en Revista Clarín, 23 de junio de 1991; pp. 8-9.

"La ficción paranoica", en Clarín, "Cultura y Nación", 10 de octubre de 1991; pp. 4-5.

Piglia, Ricardo, Prólogo a Arlt y otros, Las fieras, Buenos Aires, Clarín $\square$ Aguilar, 1993.

Piglia, Ricardo. "Sobre el género policial" en Crítica y ficción, Santa Fé. Universidad Nacional del Litoral. 1986.

Poe, E. A., Obras en prosa, San Juan, Ediciones de la Universidad de Puerto Rico, 1956

Pratt, Mary Louise. Ojos imperiales. Literatura de viajes y transculturación, Buenos Aires, Universidad Nacional de Quilmes, 1997.

Ojos imperiales. Literatura de viajes y transculturación. Buenos Aires, Universidad Nacional de Quilmes, 1997.

Prieto, Adolfo. Los viajeros ingleses y la emergencia de la literatura argentina, 1820-1850, Buenos Aires, Sudamericana, 1996. 
Rabkin, Erik S.. The Fantastic in Literature, Princenton, Princenton University Press. 1977.

Raymond Williams. El campo y la ciudad, Buenos Aires, Paidós, 2001.

Rest, Jaime. El cuarto en el recoveco, Buenos Aires, CEAL, 1982.

Rivera, Jorge. El folletín y la novela popular, Buenos Aires, CEAL, 1968.

Said, Edward. Beginnings: Intention and Method, New York, Basic Books, 1975. Orientalismo, Madrid, Libertarias, 1990.

Cultura e imperialismo, Barcelona, Anagrama, 1993.

Salabert, Pere. Figuras del viaje. Tiempo, arte, identidad, Facultad de Humanidades y Artes, Universidad Nacional de Rosario, 1995, p. 58.

Sarlo, Beatriz. "Del otro lado del horizonte", en Boletín/9. Del Centro de Estudios de Teoría y Crítica Literaria, Rosario, Diciembre de 2001.

Sartre, Jen-Paul. "Aminadab ou du fantastique considéré comme un langage" en Situations, I., París, Gallimard, 1947, pp. 117-118.

Segalem, Víctor. Ensayos sobre el exotismo. Una estética de lo diverso. México, FCE, 1989.

Silvestri, Graciela y Aliata, Fernando. El paisaje como cifra de armonía, Buenos Aires, Ediciones

Nueva Visión, 2001.

Simmel, Georg. "La aventura" en su Sobre la aventura. Ensayos de estética, Barcelona, Península, 1988, p. 17-41.

Starobinsky, Jean. "¿Es posible definir el ensayo?", en Cuadernos Hispanoamericanos, № 575, mayo de 1998.

Todorov, Tvetan. Introducción a la literatura fantástica. Buenos Aires, Tiempo Contemporáneo, 1972.

Gramática del Decamerón, Madrid, Ediciones B, 1973, pp. 165-187.

"Tipología de la novela policial" en Fausto, año III, N 4, Buenos Aires, marzo-abril de 1974. Nosotros y los otros, México, Siglo XXI, 1991.

Vásquez de Parga, Salvador. De la novela policíaca a la novela negra. Los mitos de la novela criminal, Barcelona, Plaza y Janés, 1986. Veraldi, Gabriel. La novela de espionaje, México, FCE, 1986.

Vax, L. El arte y la literatura fantástica, Buenos Aires, Eudeba, 1965.

Weinberg, Liliana En ensayo, entre el paraíso y el infierno, México, Fondo de Cultura Económica, 2001.

Williams, Raymond. Marxismo y literatura, Barcelona, Península, 1980.

Cultura. Sociología de la comunicación y el arte, Barcelona, Paidós, 1982.

La ciudad y el campo, Buenos Aires, Paidós, 2001.

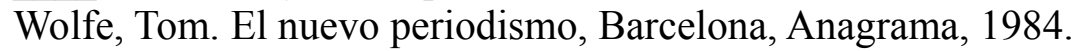

Bibliografía crítica sobre el período y problemas conexos.

AAVV. "Dossier: la revista Sur" en Punto de Vista, 17, abril-junio de 1983, pp. 7-14. (Artículos de María Teresa Gramuglio, Beatriz Sarlo, Jorge Warley).

1996.

TRAMAS para leer la literatura argentina. La década infame, $n^{\circ} 5$, Córdoba, Narvaja editor,

Agosti, Héctor P. Defensa del realismo. Montevideo, Pueblos Unidos, 1945. (Recopilación de conferencias).

Annick, Louis. Jorge Luis Borges: oeuvre et manoeuvre, Paris, L $\square$ harmattan, 1997.

Anónimo. "La novela actual" (Calendario), en Sur, nº 68, mayo de 1940, pp. 82-84.

"Invitación a la novela" (Calendario), en Sur, nº 65, febrero de 1940, pp. 118-119.

Avellaneda, Andrés. "Jorge Luis Borges y Adolfo Bioy Casares. Un modelo para descifrar", en El habla de la ideología, Buenos Aires, Sudamericana, 1983, pp. 57-69.

El habla de la ideología, Buenos Aires, Sudamericana, 1983.

Balderston, Daniel. "De la Antología de la literatura fantástica y sus alrededores", en Saítta, Sylvia. 
(directora). El oficio se afirma. Historia crítica de la literatura argentina (dirigida por Noé Jitrik), Buenos Aires, Emecé, 2004, pp. 217-228.

El precursor velado: R.L. Stevenson en la obra de Borges, Buenos Aires, Sudamericana, 1985. Barletta, Leónidas. Viejo y nuevo teatro, Buenos Aires, Futuro, 1960.

Barrenechea, A. M. y Speratti Piñero, E. S. La literatura fantástica en Argentina, México, Imprenta Universitaria, 1957.

Barrès, Maurice. El Greco ó el secreto de Toledo, Traducción y prólogo de Alberto Insúa, Madrid/Buenos Aires, Renacimiento, 1914.

Barthelemy, Edmundo. "Función social del teatro", en Claridad, n 175, enero de 1929.

Bastos, María Luisa. Borges ante la crítica literaria argentina: 1923-1960, Buenos Aires, Ediciones Hispamérica, 1974.

37-38.

"Imágenes de Sur" en Revista de la Universidad de México, XXXIII, 12, agosto de 1979, pp.

Bioy Casares, Adolfo "J.L. Borges: El jardín de senderos que se bifurcan" en Sur, 92, mayo de 1942, p.60.

"Prólogo"(1940) en Borges, J. L., Bioy Casares, A., Ocampo, S., Antología de la literatura fantástica, Buenos Aires, Sudamericana, 1965.

Blanco Amores de Pagella, A., Nuevos temas en el teatro argentino, Buenos Aires, Huemul, 1965. Boccanera, Jorge, "El viaje de González Tuñón" en Raúl González Tuñón, Juancito Caminador, Buenos Aires, Ameghino, 1998.

Borges, Jorge Luis. "El arte narrativo y la magia", en Sur, n 5, Buenos Aires, mayo de 1932 (recogido en Discusión).

"El puntual Mardrus", en Crítica. Revista Multicolor de los Sábados, 3 de febrero de 1934.

"Half-Way House, de Ellery Queen", en El Hogar, Buenos Aires, 30 de septiembre de 1936.

"Los laberintos policiales y Chesterton", en Sur, N 10 , Buenos Aires, julio de 1935.

"Modos de Chesterton", en Sur, n²2, Buenos Aires, julio de 1936.

"Murder off Miami, por Denis Wheatley, J. G. Links, etc", en El Hogar, Buenos Aires, 13 de

noviembre de 1936.

"Luis greve, muerto" en Sur, 39, diciembre de 1937, pp. 85-6.

"Roger Caillois: Le roman policier" en Sur, 91, abril de 1942.

"Prólogo"(1940) en Bioy Casares, Adolfo. La invención de Morel, Buenos Aires, Emecé,

1953.

Historia universal de la infamia, Buenos Aires, Emecé Editores, 1954.

Historia de la eternidad, Buenos Aires, Emecé Editores, 1989.

Textos cautivos. Obras Completas, Buenos Aires, Emecé Editores, 1996.

Borges en Sur, Buenos Aires, Emecé Editores, 1999.

Borges en El Hogar. 1935-1958, Buenos Aires, Emecé Editores, 2000.

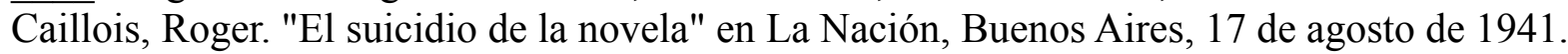

Sociología de la novela, Buenos aires, Sur, 1942.

y Ocampo, Victoria. Correspondencias (1939-1978), Buenos Aires, Sudamericana, 1999.

Caimari, Lila. "Pasiones punitivas y denuncias justicieras. La prensa y el castigo del delito en

Buenos Aires (1890-1910), ponencia presentada en el Simposio "Construcciones impresas. Diarios, periódicos y revistas en la formación de los Estados nacionales en América Latina y Estados Unidos (1820-1920)", organizado por la Universidad de San Andrés, el 16 y 17 de mayo de 2002.

Apenas un delincuente. Crimen, castigo y cultura en la Argentina, 1880-1955, Buenos Aires,

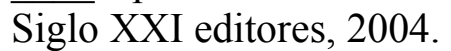

Capdevila, Analía. "Una polémica olvidada. Borges contra Caillois sobre el policial", en Borges ocho ensayos, Rosario, Beatriz Viterbo, 1995.

Castelnuovo, Elías. Yo vi...! en Rusia; impresiones de un viaje a través de la tierra de los

trabajadores, Buenos Aires, Actualidad, 1932.

Cattáneo, Liliana, La izquierda argentina y América Latina en los años treinta. El caso de Claridad, Tesis de Posgrado del Instituto Di Tella, Buenos Aires, 1992. 
Cattaruzza, Alejandro, Historia y política en los años treinta: comentarios en torno al caso radical, Buenos Aires, editorial Biblos, 1991.

Colombi, Beatriz, Viaje intelectual. Migraciones y desplazamientos en América latina (1880-1915), Rosario, Beatriz Viterbo editora, 1994.

Conducta, $\mathrm{N}^{\circ} 1$ al 27, desde agosto de 1938 a diciembre de 1943.

Crítica. Revista Multicolor de los Sábados, Edición completa con CD-ROM, Buenos Aires, Fondo Nacional de las Artes, 1999.

Dalmaroni, Miguel. "La espada y el puñal (sobre el penúltimo Lugones)", en Una república de las letras. Lugones, Rojas, Payró. Escritores argentinos y Estado, Rosario, Beatriz Viterbo editora, 2006, pp. 213-220.

Dámaso Martínez, Carlos. "La irrupción de la dimensión fantástica", en Saítta, Sylvia. (directora). El oficio se afirma. Historia crítica de la literatura argentina (dirigida por Noé Jitrik), Buenos Aires, Emecé, 2004, pp. 171-194.

de Diego, José Luis. "1938-1955. 'La época de oroŽ de la industria editorial", en de Diego, José Luis (director), Editores y políticas editoriales en Argentina, 1880-2000, México, FCE, 2006.

Delgado, Verónica y Espósito, Fabio. "1920-1937. La emergencia del editor moderno", en de Diego, José Luis (director), Editores y políticas editoriales en Argentina, 1880-2000, México, FCE, 2006. de Torre, Guillermo. "La novela contemporánea y sus personajes" en La Nación, Buenos Aires, 2 de agosto de 1942.

Díaz, Silvina y Sikora, Marina. "Notas sobre la recepción de la obra dramática de Arlt en su tiempo" en Pelletiere, Osvaldo (Ed.). Roberto Arlt. Dramaturgia y Teatro Independiente, Buenos Aires, Galerna/Fundación Roberto Arlt, 2000.

Fernández Vega, José. "Una campaña estética. Borges y la narrativa policial", en Variaciones Borges, $\mathrm{n}^{\circ} 1,1996$. Reproducido en .

Fischer, Patricia y Ogás Puga, Grisby. "El Teatro del Pueblo: período de culturización", en Osvaldo Pellettieri (dir). Teatro del Pueblo: una utopía concentrada, Buenos Aires, Galerna, 2006, pp. 159212.

Gálvez, Manuel. El solar de la raza, Buenos Aires, Sociedad Coop. "Nosotros", 1913.

Gautier, Théophile. Viaje por España, Madrid, Espasa Calpe, 1934.

Giordano, Alberto: Modos del ensayo. Jorge Luis Borges- Oscar Masotta, Rosario, Beatriz Viterbo Editora, 1991.

Girbal-Blacha, Noemí y Diana Quatrocchi-Woisson (directoras), Cuando opinar es actuar. Revistas argentinas del siglo XX, Buenos Aires, Academia Nacional de la Historia, 1999.

Girondo, Oliverio. Calcomanías, Obra Completa, Edición crítica coordinada por Raúl Antelo, Buenos Aires, Editorial Sudamericana, 1999.

Gorelik, Adrián, La grilla y el parque. Espacio público y cultura urbana en Buenos Aires, 18871936, Bernal, Universidad Nacional de Quilmes, 1998.

Gramuglio, María Teresa. "Sur en la década del treinta: una revista política" en Punto de Vista, 17, abril-junio de 1983.

"ŽSurŽ en la década del treinta: una revista política", en Punto de vista, Año IX, nº 28, noviembre de 1986.

"El campo literario en la década del 30: imágenes de escritor, proyectos literarios y espacios de legitimación", Informe de Investigación (mimeo), CIUNR, 1991.

"Estudio preliminar", en Lugones, Leopoldo. El ángel de la sombra, Buenos Aires, Losada, 1994.

"Las minorías y la defensa de la cultura. Proyecciones de un tópico de la crítica literaria inglesa en Sur", en Boletín/7, del Centro de Estudios de Teoría y Crítica Literaria, Facultad de Humanidades y Artes, Universidad Nacional de Rosario, octubre de 1999.

"Posiciones, transformaciones y debates en la literatura" en Crisis económica, avance del Estado e incertidumbre política (1930-1943), tomo VII de la Nueva Historia Argentina dirigido por Alejandro Cataruzza, Buenos Aires, Sudamericana, 2001.

(directora). El imperio realista. Historia crítica de la literatura argentina (dirigida por Noé 
Jitrik), Buenos Aires, Emecé, 2002.

"Introducción", en Gramuglio, María Teresa (directora). El imperio realista. Historia crítica de la literatura argentina (dirigida por Noé Jitrik), Buenos Aires, Emecé, 2002.

"Momentos del ensayo de interpretación nacional. 1910-1930", en Boletín/10. Del centro de

Estudios de Teoría y Crítica literaria, Facultad de Humanidades y Artes, Universidad Nacional de Rosario, Rosario, Diciembre de 2002, pp. 37-50.

"Posiciones de Sur en el espacio literario. Una política de la cultura", en Saítta, Sylvia.

(directora). El oficio se afirma. Historia crítica de la literatura argentina (dirigida por Noé Jitrik),

Buenos Aires, Emecé, 2004, pp. 93-122.

Green, Raquel Atena. Borges y la "Revista Multicolor de los Sábados": cómplices en la literatura y en la infamia, Disertación doctoral, Bryn Mawr, Pa., Bryn Mawr College, 1990.Gugliemini, H.. El teatro del disconformismo, Buenos Aires, Minor Nova, 1967.

Gutierrez, L. H. y Romero, L. A.. Sectores populares, cultura y política, Buenos Aires, Sudamericana, 1995.

Helft, Nicolás. Jorge Luis Borges; Bibliografía completa, Buenos Aires, FCE, 1997.

Ingenieros, José. La simulación en la lucha por la vida, Buenos Aires, Editorial Rosso, 1930.

King, John. Sur. Estudio de la revista argentina y de su papel en el desarrollo de una cultura 19311970, México, FCE., 1989.

Lafforgue, Jorge y Rivera Jorge. Asesinos de papel. Ensayos sobre narrativa policial, Buenos Aires, Colihue, 1996.

"Prólogo" en Cuentos policiales argentinos, Buenos Aires, Alfaguara, 1997.

"Prólogo", en Cuentos policiales argentinos, Selección y prólogo de Jorge Lafforgue, Buenos Aires, Alfaguara, 1997, pp. 11-22.

Lafleur, Héctor René, Sergio Provenzano y Fernando Alonso, Las revistas literarias argentinas, 1893-1967, Buenos Aires, Ceal, 1968.

Lafon, Michel. "Algunos ejercicios de escritura en colaboración", en Saítta, Sylvia. (directora). El oficio se afirma. Historia crítica de la literatura argentina (dirigida por Noé Jitrik), Buenos Aires, Emecé Editores, 2004.

Larra, Raúl. Leónidas Barletta. El hombre de la campana, Buenos Aires, Edición Homenaje de Amigos de Aníbal Ponce, 1987.

Larreta, Enrique. La gloria de Don Ramiro, Buenos Aires, Kapelusz, 1972.

Louis, Annick. Jorge Luis Borges: oeuvre et manoeuvre, Paris, LŽharmattan, 1997.

Ludmer, Josefina. El cuerpo del delito. Un manual, Buenos Aires, Libros Perfil, 1999.

Marial, José. El teatro independiente, Buenos Aires, Alpe, 1955. "Boedo antiguo", en Teatro XXI, año II, N 3, primavera de 1996.

"Experiencia y público en la escena independiente", en volumen III de la Historia del Teatro

Argentino en Buenos Aires, dirigido por Pellettieri, Osvaldo (en preparación).

Masiello, Francine. Lenguaje e ideología. Las escuelas argentinas de vanguardia, Buenos Aires, Hachette, 1986.

Matamoro, Blas. Oligarquía y literatura, Buenos Aires, Ediciones del sol, 1975

Medin, Tzvi. Ortega y Gasset en la cultura hispanoamericana, México, Fondo de Cultura

Económica, 1994.

Molloy, Sylvia. Las letras de Borges y otros ensayos, Rosario, Beatriz Viterbo Editora, 2000.

Montaldo, Graciela. "Los años veinte: un problema de historia literaria" en Filología, XXII, 2, 1987. y colaboradores. Yrigoyen, entre Borges y Arlt (1916-1930), Historia social de la literatura

argentina, dirigida por David Viñas, tomo VII, Buenos Aires, Contrapunto, 1989.

"Literatura de izquierda: humanismo y pedagogía", en Montaldo, Graciela y colaboradores.

Yrigoyen, entre Borges y Arlt (1916-1930), Historia social de la literatura argentina, dirigida por

David Viñas, tomo VII, Buenos Aires, Contrapunto, 1989.

La sensibilidad amenazada. Fin de siglo y modernismo, Buenos Aires, Beatriz Viterbo

Editora, 1994.

Neglia, E. G. Pirandello y la dramaturgia rioplatense, Firenze, Valmartina, 1970. 
Olea Franco, Rafael. "Hacia una nueva estética", en El otro Borges. El primer Borges, Buenos Aires, FCE, 1993.

Ordaz, Luis. El teatro en el Río de La Plata, Buenos Aires, Leviatán, Ediciones siglo veinte, 1957. Orgambide, Pedro, El hombre de la rosa blindada, Buenos Aires, Ameghino, 1998.

Ortega y Gasset, José. "Ideas sobre la novela", en La deshumanización del arte, Madrid, Revista de Occidente, 1925.

Pastormerlo, Sergio: "Borges crítico", en Cuadernos Angers-La Plata, N 1, La Plata, UNLP/Université d $\square$ Angers, 1996, pp. 93-108.

"Dos concepciones del género policial. Una introducción a la narrativa policial borgeana", en Literatura policial en la Argentina. Waleis, Borges, Saer, Serie Estudios e investigaciones, $\mathrm{n}^{\circ} 32$, Facultad de Humanidades y Ciencias de la Educación, UNLP, Año 1997.

"Dos concepciones del género policial. Una introducción a la narrativa policial borgeana", en Literatura policial en la Argentina. Waleis, Borges, Saer, Serie Estudios e investigaciones, $\mathrm{n}^{\circ} 32$, Facultad de Humanidades y Ciencias de la Educación, UNLP, Año 1997.

Borges crítico, Buenos Aires, FCE, 2007.

Paz Leston, Eduardo. "El proyecto de la revista Sur" en AAVV, Capítulo. Historia de la literatura argentina, Buenos Aires, CEAL, 1980. $2^{\mathrm{a}}$ ed.

Pelletieri, Osvaldo. Cien años de teatro argentino. De Moreira al teatro abierto, Buenos Aires, Galerna, 1990.

"El teatro independiente en la Argentina (1930-1965): intertexto europeo y norteamericano y realidad nacional", en F. de Toro (ed), Semiótica y teatro latinoamericano, Buenos Aires, Galerna, 1991.

"Algunos aspectos del `teatro de arteŽ en Buenos Aires", en Osvaldo Pellettieri (dir). Teatro del Pueblo: una utopía concentrada, Buenos Aires, Galerna, 2006, pp. 69-157.

Pereyra, Washington, La prensa literaria argentina, 1890-1974, Buenos Aires, Librería Colonial, 1993-1998. Cuatro volúmenes

Petit de Murat, Ulyses, Borges Buenos Aires, Municipalidad de la Ciudad de Buenos Aires,

Secretaría de Cultura, 1980.

Ramos, Julio. Desencuentros de la modernidad en América Latina. Literatura y política en el siglo XIX, México, FCE, 1989.

Rest, Jaime. "Diagnóstico de la novela policial", en Crisis, № 15, Buenos Aires, Julio de 1974, pp. 30-39.

Ritvo, Juan Bautista. "Lugones: el esplendor soberano", en Paradoxa, Universidad Nacional de Rosario, Año 5, N 4/5, 1990.

"1885: La irrupción del decadentismo", en Paradoxa, Año X, Nº 8, 1996, pp. 93-97.

Rivera, Jorge B. "Los juegos de un tímido. Borges en Crítica", en Crisis, N 38, mayo-junio de 1976.

Romano, Eduardo. "El cuento. 1930-1959" en AAVV, Capítulo. Historia de la literatura argentina, Buenos Aires, CEAL, 1980. $2^{\mathrm{a}}$ edición.

Romero, Luis Alberto. "Una empresa cultural: los libros baratos" en Leandro H. Gutiérrez y Luis Alberto Romero. Sectores populares cultura y política. Buenos Aires en la entreguerra, Buenos Aires, Sudamericana, 1995.

Rosa, Nicolás. "Sur o el espíritu y la letra" en Los libros, 15-16, enero-febrero de 1971, pp. 4-6.

Rotker, Susana. La invención de la crónica, Buenos Aires, Ediciones Letra Buena, 1992, p.106.

Sagarzazu, María Elvira. "Introducción", en Las mil y una noches, Traducción selección, notas e introducción María Elvira Sagarzazu, Buenos Aires, Colihue Clásica, 2006.

Sagaseta, Julia Helena. "Conducta, la revista del Teatro del Pueblo: una mirada a la modernidad", en Espacios de crítica y Producción, n 12, junio - julio, 1993.

Saítta, Sylvia. Regueros de tinta. El diario Crítica en la década de 1920, Buenos Aires, Editorial Sudamericana, 1998.

"Recorrido" en Crítica. Revista Multicolor de los Sábados, Edición completa con CD-Rom, Buenos Aires, Fondo Nacional de las Artes, 1999. 
"Entre la cultura y la política: los escritores de izquierda" en Crisis económica, avance del Estado e incertidumbre política (1930-1943), Tomo VII de la Nueva Historia Argentina, dirigido por Alejandro Cattaruzza, Buenos Aires, Sudamericana, 2001, pp. 383-428.

(directora). El oficio se afirma. Historia crítica de la literatura argentina (dirigida por Noé

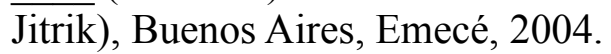

"Modos de pensar lo social. Ensayo y sociedad en la Argentina (1930-1965), en Federico

Neiburg y Mariano Plotkin (editores), Intelectuales y expertos. La constitución del conocimiento social en la Argentina, Buenos Aires, Paidós, 2004.

Salessi, Jorge. "La simulación de José Ingenieros", en Médicos maleantes y maricas, Rosario, Beatriz Viterbo Editora, 1995, pp. 133-147.

Sarlo, Beatriz, El imperio de los sentimientos. Narraciones de circulación periódica en la argentina (1917- 1927), Buenos Aires, Catálogos, 1985.

Una modernidad periférica: Buenos Aires 1920 y 1930, Buenos Aires, Nueva Visión, 1988.

La imaginación técnica, Buenos Aires, Nueva Visión, 1992.

Borges, un escritor en las orillas, Buenos Aires, Ariel, 1993.

"Una poética de la ficción", en Saítta, Sylvia. (directora). El oficio se afirma. Historia crítica

de la literatura argentina (dirigida por Noé Jitrik), Buenos Aires, Emecé, 2004, pp. 19-38.

"Borges: crítica y teoría cultural" y "La literatura de crímenes", en Escritos sobre literatura

argentina, Buenos Aires, Siglo XXI editores, 2007.

Escritos sobre literatura argentina, Buenos Aires, Siglo XXI editores, 2007.

Sarmiento, Domingo Faustino. Viajes por Europa, África y América, Madrid, Archivos, 1993.

Sosnowski, Saúl (editor), La cultura de un siglo. América latina en sus revistas, Buenos Aires, Alianza, 1999.

Stratta, Isabel. "Documentos para una poética del relato", en Saítta, Sylvia. (directora). El oficio se afirma. Historia crítica de la literatura argentina (dirigida por Noé Jitrik), Buenos Aires, Emecé, 2004, pp. 39-63.

Terán, Oscar, "Aníbal Ponce o el marxismo sin nación" en En busca de la ideología argentina, Buenos Aires, Catálogos, 1986.

"Estudio preliminar", en José ingenieros: pensar la nación. Antología de textos, Buenos Aires, Alianza bolsillo, 1986.

"El dispositivo hispanista", en Luis Martínez Cuitiño y Elida Lois (Eds.), Actas III Congreso

Argentino de Hispanistas. España en América y América en España, Buenos Aires, Facultad de

Filosofía y Letras, Instituto de Filología y Literatura Hispánica Dr. Amado Alonso, 1992, Tomo 1, pp. 129-237.

Trastoy, Beatriz. "El movimiento teatral independiente y la modernización de la escena argentina", en María Teresa Gramuglio (dir.), El imperio realista. Historia crítica de la literatura argentina, Vol.

6, Buenos Aires, Emecé Editores, 2002.

Verzero, Lorena. "Actividades y Estrenos I" y "Actividades y Estrenos II", en Osvaldo Pellettieri

(dir). Teatro del Pueblo: una utopía concentrada, Buenos Aires, Galerna, 2006, pp. 11-68.

Viñas, David. Literatura argentina y realidad política. De Sarmiento a Cortázar, Buenos Aires, Siglo Veinte, 1974.

Literatura argentina y política. De Lugones a Walsh, Buenos Aires, Sudamericana, 1996.

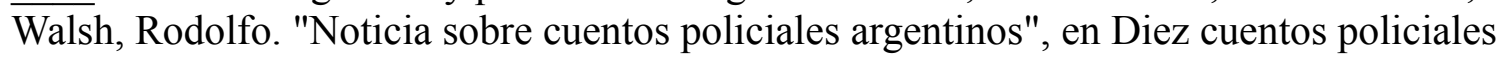
argentinos, Buenos Aires, Hachette, 1953. Reproducido en, Lafforgue, Jorge y Rivera, Jorge B. Asesinos de papel. Ensayos sobre narrativa policial, Buenos Aires, Colihue, 1996, pp. 247-248. Warley, Jorge. Vida intelectual en la década de 1930, Buenos Aires, CEAL, 1985.

Bibliografía crítica sobre Arlt

AAVV, Seminario sobre Roberto Arlt, Poitiers, Publications du Centre de Recherches LatinoAmericaines de 10Université de Poitiers, 1982. 
Cuadernos Hispanoamericanos, "Los complementarios", N 11, Madrid, Julio de 1993.

(Número especial dedicado a Roberto Arlt)

Aira, César. "Arlt" en Paradoxa. Literatura/Filosofía, N 7, Rosario, Beatriz Viterbo Editora, 1993.

Amícola, José. Astrología y fascismo en la obra de Arlt, Buenos Aires, Weimar ediciones, 1984.

$\overline{\text { pp. } 6-7 .}$

"Los magos del mal", en La Razón/Cultura, domingo 1 de septiembre de 1985, Buenos Aires,

"Elogio de la razón y la locura" en Arlt, Roberto. Los siete locos. Los lanzallamas, Edición crítica coordinada por Mario Goloboff, Colección Archivos, Francia, ALLCA XX, Université Paris X, 2000, pp. 676-686.

"Fritz Lang, Alfred Döblin y Roberto Arlt", 2007, mimeo.

Andermann, Jens. "Arlt: 'Lejos de las hermosas ciudadesŽ", en Mapas de poder. Una arqueología literaria del espacio argentino, Rosario, Beatriz Viterbo, 2000.

Aricó, José, "La polémica Arlt-Ghioldi. Arlt y los comunistas" en La Ciudad Futura, Nº 3 , diciembre de 1986.

Arlt, Mirta. "Prólogo" en Arlt, Roberto. Novelas completas y cuentos, Buenos Aires, Compañía General Fabril Editora, 1963.

Prólogos a la obra de mi padre, Buenos Aires, Torres Agüero, 1984.

y Borré, Omar. Para leer a Roberto Arlt. , Buenos Aires, Torres Agüero, 1984.

"La locura de la realidad en la ficción de Arlt", en Pellettieri, Osvaldo (Ed.) Roberto Arlt.

Dramaturgia y Teatro Independiente, Buenos Aires, Galerna/Fundación Roberto Arlt, 2000.

Borré, Omar. Arlt y la crítica. Buenos Aires, Ediciones América Libre, 1996.

Roberto Arlt. Su vida y su obra, Buenos aires, Planeta, 2000.

Caillois y Ocampo. Correspondencias, Bs As, Sudamericana, 1999.

Capdevila, Analía. "Sobre la teatralidad en la narrativa de Arlt", en Cuadernos Hispanoamericanos, $\mathrm{N}^{\circ} 11,1993$, pp. 53-57.

"Arlt: la ciudad expresionista", en Boletín/7, Rosario, Facultad de Humanidades y Artes,

Universidad Nacional de Rosario, Octubre de 1999, pp. 130-140.

"Arlt contra Ortega (Una polémica sobre la novela)" en Boletín/8, Centro de Estudios de

Teoría y Crítica Literaria, Rosario, 2000.

"Las novelas de Arlt. Un realismo para la modernidad", en Gramuglio, María Teresa

(directora). El imperio realista. Historia crítica de la literatura argentina (dirigida por Noé Jitrik),

Buenos Aires, Emecé, 2002.

Castagnino, Raúl. El teatro de Roberto Arlt, La Plata, UNLP, 1964.

Corral, Rose. "Ficción y crónica en Los siete locos y Los Lanzallamas" en Arlt, Roberto. Los siete locos. Los lanzallamas, Edición crítica coordinada por Mario Goloboff, Colección Archivos, Francia, ALLCA XX, Université Paris X, 2000, pp. 613-632.

"Introducción", en Arlt, Roberto. Al margen del cable. Crónicas publicadas en El Nacional, Méjico, 1937, 1941, recopilación, introducción y notas de Rose Corral, Buenos Aires, Losada, 2001.

Correas, Carlos. Arlt literato. Buenos Aires, Atuel, 1995.

de Diego, José Luis. "Arlt y los setentas", en Boletín/9. Del Centro de Estudios de Teoría y Crítica Literaria, Rosario, Diciembre de 2001.

Drucaroff, Elsa. Arlt, profeta del miedo, Buenos Aires, Catálogos, 1998.

Dubatti, Jorge. "Roberto Arlt: su relación con los dramaturgos expresionistas alemanes" en Actas de las Octavas Jornadas Universitarias de Literatura Alemana, Córdoba, Asociación Argentina de Germanistas, 1991.

"Roberto Arlt y la escritura de Trescientos millones" en Espacio, n $12,1992$.

Fernández, Graciela Beatriz. "La isla desierta: un espacio clausurado, una metáfora" en Estudios Filológicos, Valdivia, $\mathrm{n}^{\circ} 18,1983$.

Foster, David W. "Popular Culture as Mediating Sign Between Fantasy and Reality in Arlt $\square \mathrm{s}$ Trescientos millones" en The Argentine Teatro Independiente 1930-1935, York, South Carolina, Spanish Literature Publishing Company, 1986. 
García, Guillermo. "Arlt y las ciudades", en AAVV, Diez lecturas de Arlt, Premio Edenor 2000, Buenos Aires, Fundación El Libro, 2000.

Gasquet, Axel. "La ficción morisca y africana de Roberto Arlt", en Oriente al sur. El orientalismo literario argentino de Esteban Echeverría a Roberto Arlt, Buenos Aires, Eudeba, 2007.

Giordano, Enrique. La teatralización de la obra dramática: de Florencio Sánchez a Roberto Arlt, México, Red de Jonás, 1982.

Goldar, Ernesto. Proceso a Roberto Arlt, Buenos Aires, Plus Ultra, 1985.

Golluscio, Eva. "Los personajes-memoria: dos Saverios para un organito", en Pellettieri, Osvaldo (Ed.). Roberto Arlt. Dramaturgia y Teatro Independiente, Buenos Aires, Galerna/Fundación Roberto Arlt, 2000.

Goloboff, Mario. Genio y figura de Roberto Arlt. Buenos Aires, Eudeba, 1988.

González Lanuza, Eduardo. Roberto Arlt, Buenos Aires, CEAL, 1971.

González, Horacio. Arlt. Política y locura ,Buenos Aires, Colihue, 1996.

"Simulación y metamorfosis en el teatro de Roberto Arlt" en Pelletiere, Osvaldo (Ed.).

Roberto Arlt. Dramaturgia y Teatro Independiente, Buenos Aires, Galerna/Fundación Roberto Arlt, 2000.

Gorini, Juan José (seudónimo de David Viñas), "Arlt y los comunistas" en Contorno, № 2, mayo de 1954.

Guerrero, Diana. Arlt. El habitante solitario, Buenos Aires, Catálogos Editora, 1986.

Jarkowski, Aníbal. "El amor brujo: la novela $\square$ mala $\square$ de Roberto Arlt" en Montaldo, Graciela y colaboradores. Yrigoyen, entre Borges y Arlt (1916-1930), Historia social de la literatura argentina, dirigida por David Viñas, tomo VII, Buenos Aires, Contrapunto, 1989.

Jitrik, Noé. "1926, año decisivo para la narrativa argentina" en Escritores argentinos. Dependencia o libertad, Buenos Aires, Ediciones del Candil, 1967.

"Entre el dinero y el ser" en La memoria compartida, Buenos Aires, CEAL,1987.

"Presencia y vigencia de Roberto Arlt" en Roberto Arlt Antología, México, Siglo XXI, 1980;

reeditado en La vibración del presente, México, FCE, 1987, pp. 106-126.

"Un utópico país llamado Erar" en Arlt, Roberto. Los siete locos. Los lanzallamas, Edición

crítica coordinada por Mario Goloboff, Colección Archivos, Francia, ALLCA XX, Université Paris

X, 2000, pp. 659- 675.

Juárez, Laura. "La representación del espacio africano en la literatura arltiana de los años treinta", en Diez lecturas de Arlt, Buenos Aires, Fundación El Libro, 2000.

"Las aguafuertes de Roberto Arlt: el itinerario de un desplazamiento en la imagen de escritor y

en la poética de la novela" en Vázquez, María Celia y Pastormerlo, Sergio (comp.) Literatura

argentina. Perspectivas de fin de siglo, Actas del X Congreso Nacional de Literatura Argentina,

Buenos Aires, Eudeba, 2001.

Larra, Raúl. Roberto Arlt, el torturado, Buenos Aires, Talleres gráficos Cadel, 1956.

Luzurriaga, Gerardo. "Las máscaras de la crueldad en el teatro de Roberto Arlt", Textos críticos, ${ }^{\circ}$ $10,1978$.

Masotta, Oscar. Sexo y traición en Roberto Arlt , Buenos Aires, Jorge Alvarez Editor, 1965.

Matamoro, Blas. "Güiraldes, Arlt y la novela educativa" en Cuadernos Hispanoamericanos, 432, 1986, pp. 61-69.

Mattalia, Sonia, "Modernización y desjerarquización cultural: el caso Arlt (de La vida puerca a El amor brujo) en Revista Iberoamericana, $\mathrm{n}^{\circ}$ 159, abril-junio 1992.

Ordaz, Luis. "La dramática renovadora de Roberto Arlt" en Hispanorama, Universität Bremen, 1983. pp. 3-14.

"Las máscaras dramáticas de Roberto Arlt" en Revista de estudios de teatro, VI, N 15, 1987,

Pauls, Alan. "Arlt: la máquina literaria" en Montaldo, Graciela y colaboradores. Yrigoyen, entre Borges y Arlt (1916-1930), Historia social de la literatura argentina, dirigida por David Viñas, tomo VII, Buenos Aires, Contrapunto, 1989.

Pellettieri, Osvaldo (Ed.). Roberto Arlt. Dramaturgia y Teatro Independiente, Buenos Aires, 
Galerna/Fundación Roberto Arlt, 2000.

"Relaciones textuales entre el teatro de Pirandello y la obra de Arlt", en Espacio, $n^{\circ}$ 5, año 3, abril de 1989.

"Roberto Arlt: una dramática germinal y el Teatro Independiente", Clarín. Cultura y Nación, 5 de abril de 1990.

"Teatro latinoamericano de los veinte: una práctica teatral modernizadora" en Revista

Iberoamericana, $\mathrm{n}^{\circ}$ 156, Abril-Septiembre, 1991.

"El Teatro del pueblo y sus puestas de los textos de Roberto Arlt" en Pelletieri, Osvaldo (Ed.). Roberto Arlt. Dramaturgia y Teatro Independiente, Buenos Aires, Galerna/Fundación Roberto Arlt, 2000.

Pezzoni, Enrique. "Memoria, actuación y habla en un texto de Roberto Arlt" en El texto y sus voces, Buenos Aires, Sudamericana, 1986.

Piglia, Ricardo. "Roberto Arlt: una crítica de la economía literaria" en Los libros, Buenos Aires, ${ }^{\circ}$ 29, marzo-abril, 1973. de 1974.

"Literatura y Propiedad en la obra de Roberto Arlt" en La Opinión, Buenos Aires, 10 de abril

Respiración artificial, Buenos Aires, Sudamericana, 1980.

Preve, Pablo. "Arlt en África" en Diez lecturas de Arlt. Ensayos seleccionados en el concurso sobre su vida y obra, Buenos Aires, Fundación El libro, 2000.

Prieto, Adolfo. "La fantasía y lo fantástico en Roberto Arlt" en Boletín de literaturas hispánicas, Instituto de Letras de la Facultad de Filosofía y Letras de la Universidad del litoral, Rosario, 1963.

"Roberto Arlt. Los siete locos. Los lanzallamas" en Arlt Roberto. Los siete locos, Los

lanzallamas, Caracas, Biblioteca Ayacucho, 1978.

"Silvio Astier, lector de folletines" en Revista Río de La Plata, n 4-5-6, 1987.

Ramírez, Helios Jaime. "La estructuración de lo real y lo fantástico en la dramaturgia de Roberto Arlt", en AAVV, Reflexiones sobre el teatro latinoamericano del siglo veinte, Buenos Aires, Galerna, 1989.

Rela, Walter. "Argumentos renovadores de Roberto Arlt en el teatro argentino moderno" en Latin American Theatre Review, 13/2, Spring 1980, pp. 65-71.

Renaud, Marise. "Los siete locos y Los lanzallamas: audacia y candor del expresionismo" en Arlt, Roberto. Los siete locos. Los lanzallamas, Edición crítica coordinada por Mario Goloboff,

Colección Archivos, Francia, ALLCA XX, Université Paris X, 2000, pp. 687- 709.

Rest, Jaime. "Roberto Arlt y el descubrimiento de la ciudad" en El cuarto en el recoveco, Buenos Aires, CEAL, 1982.

Rivera, Jorge B. "El juguete rabioso" en Tiempo argentino. Cultura, Buenos Aires, 7 de octubre de 1984.

Roberto Arlt: Los siete locos, Buenos Aires, Biblioteca Crítica Hachette, 1986.

"Borges esquina Arlt. Trayectoria y confluencias de un entrañable tema de nuestra literatura" en Clarín, Buenos Aires, 28/3/1991, p. 8.

Borges y Arlt. Literatura y periodismo, Buenos Aires, Hipótesis y Discusiones/2, Facultad de Filosofía y Letras, Universidad de Buenos Aires, 1992.

Romano, Eduardo. "Arlt y la vanguardia argentina" en Cuadernos Hispanoamericanos, Madrid $\mathrm{n}^{\circ}$ 373, Julio 1981.

Rosa, Nicolás. "Sexo, traición, Masotta y Roberto Arlt" en David Viñas y Oscar Masotta. Ensayo literario y crítica sociológica, Rosario, Ediciones Paradoxa, 1989.

"La ilusión cómica" en Revista de Letras, N 5, Rosario, 1997. pp. 5-10.

Rubio de Zocchi, Mercedes y del Carril Sara Luisa. "Nota sobre El Hogar" en Borges en El HOGAR, 1935-1958, Buenos Aires, Emecé, 2000.

Russi, David P. "Metatheatre: Roberto Arlt Vehicle toward the Awareness of an Art Form", en Latin American Theatre Review, 24/1, Fall 1990.

Saítta, Sylvia. Aguafuertes porteñas: Buenos Aires, vida cotidiana, Selección y prólogo de Sylvia Saítta, Buenos Aires, Alianza, 1993. 

$\overline{1992 .}$

"Prólogo" en Arlt Roberto. Aguafuertes porteñas: cultura y política, Buenos Aires, Losada,

"Nuevos viajeros, otras miradas: Roberto Arlt en España", en Hispamérica. Revista de literatura, año XXVIII, nº 82, 1999.

"Desde la butaca: Roberto Arlt, crítico teatral" en Pelletiere, Osvaldo (Ed.). Roberto Arlt.

Dramaturgia y Teatro Independiente, Buenos Aires, Galerna/Fundación Roberto Arlt, 2000.

El escritor en el bosque de ladrillos. Una biografía de Roberto Arlt, Buenos Aires,

Sudamericana, 2000.

"Prólogo", en Arlt, Roberto. Escuela de la delincuencia, Selección y prólogo de Sylvia Saítta,

Montevideo, Ediciones de la Banda Oriental, 2000, pp. 7-10.

"Prólogo", en Arlt, Roberto. Aguafuertes vascas, Prólogo compilación y notas de Sylvia Saítta,

Buenos Aires, Simurg, 2005.

Salzman, Isidro. "Una lectura de la obra dramática de Roberto Arlt en el contexto de la década den treinta" en Pelletiere, Osvaldo (Ed.). Roberto Arlt. Dramaturgia y Teatro Independiente, Buenos Aires, Galerna/Fundación Roberto Arlt, 2000.

Sarlo, Beatriz. Una modernidad periférica: Buenos Aires 1920 y 1930, Buenos Aires, Nueva Visión, 1988.

1992.

"Arlt: ciudad real, ciudad imaginaria, ciudad reformada" en Punto de Vista, $\mathrm{N}^{\circ} 42$, abril de

"Arlt: la técnica en la ciudad" en La imaginación técnica, Buenos Aires, Nueva Visión, 1992.

"Lo maravilloso moderno: Arlt" en Humanidades, Año I, N 3, La Plata, octubre 1993.

"Roberto Arlt, excéntrico", en Arlt, Roberto. Los siete locos-Los Lanzallamas, Edición crítica,

Colección Archivos, Mario Goloboff coordinador, Francia, ALLCA XX, Université Paris X, 2000.

Scari, Robert. "Estructura y técnica de los ensayos costumbristas de Roberto Arlt". Revista de literatura hispanoamericana, $\mathrm{n}^{\circ} 10$ (enero-junio de 1976).

"El arte del ensayo costumbrista en Roberto Arlt" en Revista chilena de literatura, $\mathrm{N}^{\circ} 14$

(octubre de 1979).

Scroggins, Daniel. Las aguafuertes porteñas de Roberto Arlt, Buenos Aires, Ediciones culturales argentinas, Secretaría de cultura de la Nación, 1981.

Sillato de Gómez, María del Carmen. "Lo carnavalesco en Saverio el cruel", Latin American Theatre Review, 22/2, Spring 1989.

Sorrentino, Fernando. "Borges y Arlt: las paralelas que se tocan" en Anthropos, Barcelona, $\mathrm{n}^{\circ}$ 142/3, marzo-abril 1993, pp. 129ss.

Terán, Oscar. "Modernos intensos en los veintes" en Prismas, Buenos Aires, año 1, N 1, 1997.

Trastoy, Beatriz. "El fabricante de fantasmas de Roberto Arlt y su relación con el teatro de

Lenormand", en De Sarah Bernhardt a Lavelli, O. Pellettieri (ed). Cuaderno del GETEA N ${ }^{\circ} 3$,

Buenos Aires, Galerna/Revista Espacio, 1993.

Troiano, J.L.. "Pirandellism in the theatre of Roberto Arlt" en Latin American Theatre Review, 8/1, Fall 1974, pp. 37-44.

Varela, Fabiana Inés. "Aguafuertes porteñas: Tradición y traición de un género", en Revista de Literaturas Modernas, Universidad Nacional de Cuyo, Facultad de Filosofía y Letras, Instituto de Literaturas Modernas, $\mathrm{n}^{\circ}$ 32, Mendoza, 2002.

Viñas, David. "El escritor vacilante. Arlt, Boedo y Discépolo" en Literatura argentina y realidad política. De Sarmiento a Cortázar, Buenos Aires, Siglo Veinte, 1974.

"Trece recorridos con las novelas de Arlt" en Arlt, Roberto. Novelas. Edición y prólogo de

David Viñas, Buenos Aires, Losada, 1997.

"Las `Aguafuertes — como autobiografismo y colección", en Arlt, Roberto. Aguafuertes,

Buenos Aires, Losada, 1998.

Zaina, Alicia. "El proyecto teatral de Roberto Arlt", en El juguete rabioso, 1, N 1, 1990.

Zubieta, Ana María. El discurso narrativo arltiano, Buenos Aires, Hachette, 1987. 